5

Wh

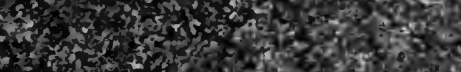

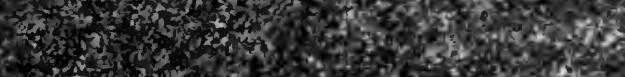

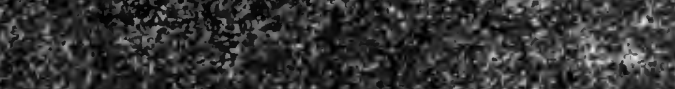

(2)

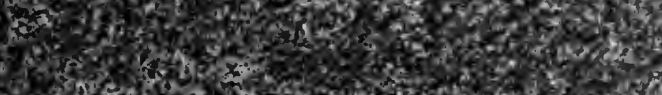
Hor. , 37 . (3) -

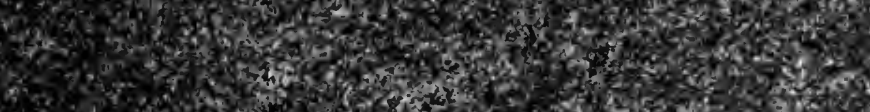

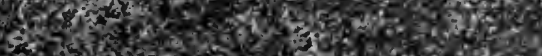
2. s.t. 6.

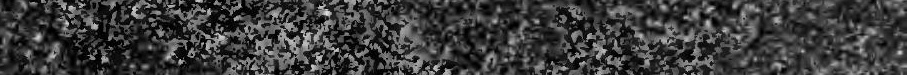
13.75 .

W 3. $x^{2}$.

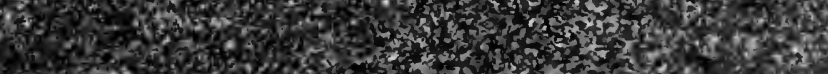

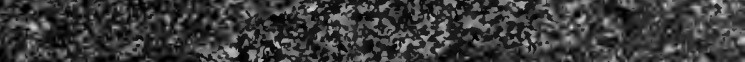

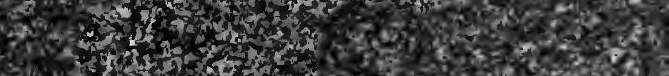

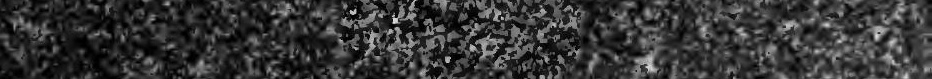
ofing

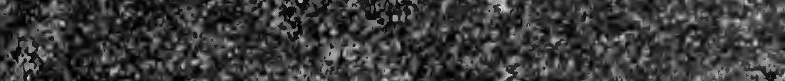

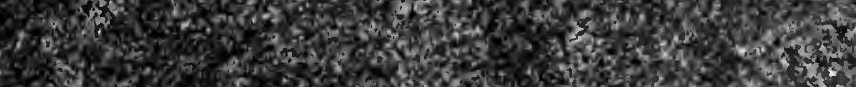

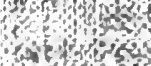


D

and copp

$p+b^{6}$

$p^{11 b^{5}}$ 


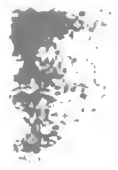

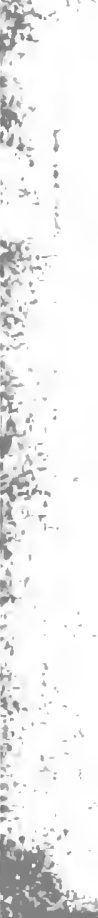

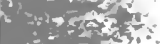
- trencti $(4)^{2}+x^{2}+4$

$\frac{3}{3}$

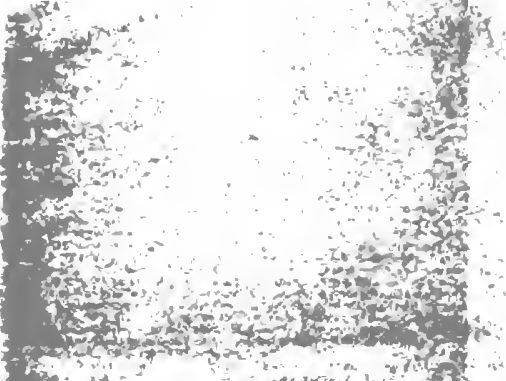
and on $\cdots$, t

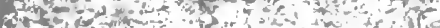
ST$t^{3}=56^{2}+2$ $4 x^{2}+250$ 3.

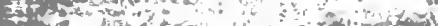
2.te pis ts of $-2 x+200$

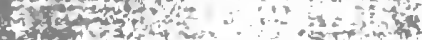
at $3 x^{3}+420$

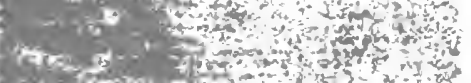

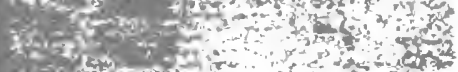

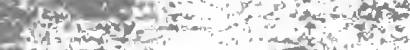

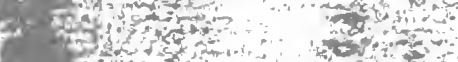
ros Ton fen

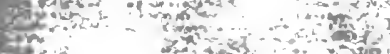
tox cons and on wa

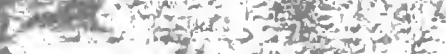
A $\quad$ -

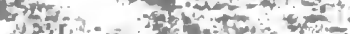
crom

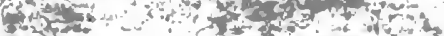

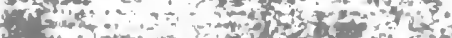

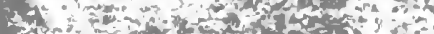

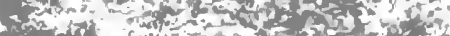

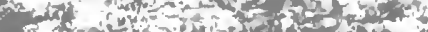
a
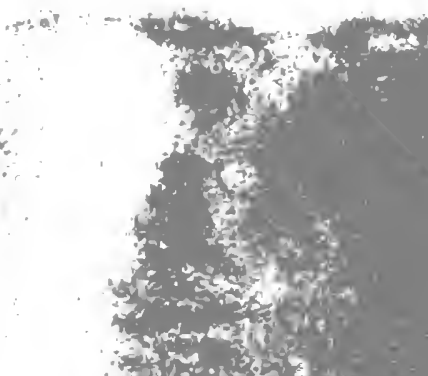

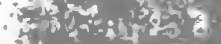
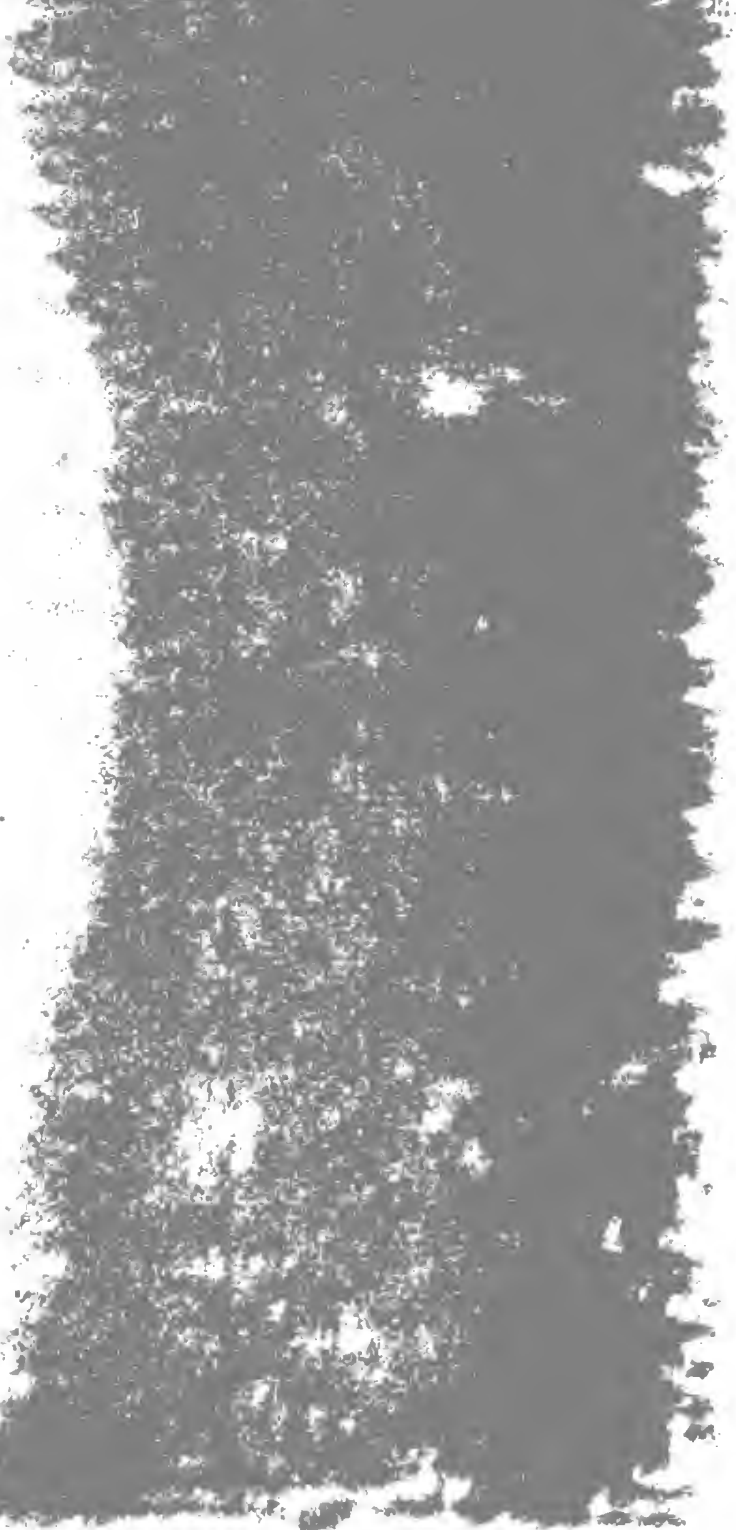
$$
x^{x}
$$ 
Digitized by the Internet Archive in 2007 with funding from Microsoft Corporation

http://www.archive.org/details/dictionaryofprin00plomiala 
• 


\section{A DICTIONARY OF THE PRINTERS AND BOOKSELLERS WHO WERE AT WORK IN ENGLAND, SCOTLAND AND IRELAND \\ FROM I668 TO I725.}





\section{A DICTIONARY OF THE}

\section{PRINTERS AND BOOKSELLERS}

\section{WHO WERE AT WORK IN ENGLAND, SCOTLAND AND IRELAND FROM I668 TO I725.}

HENRY R. PLOMER.

WITH THE HELP OF H. G. ALDIS, E. R. McC. DIX,

G. J. GRAY, AND R. B. McKERROW.

EDITED BY ARUNDELL ESDAILE.

PRINTED FOR THE BIBLIOGRAPHICAL SOCIETY,

AT THE OXFORD UNIVERSITY PRESS.

1922. 


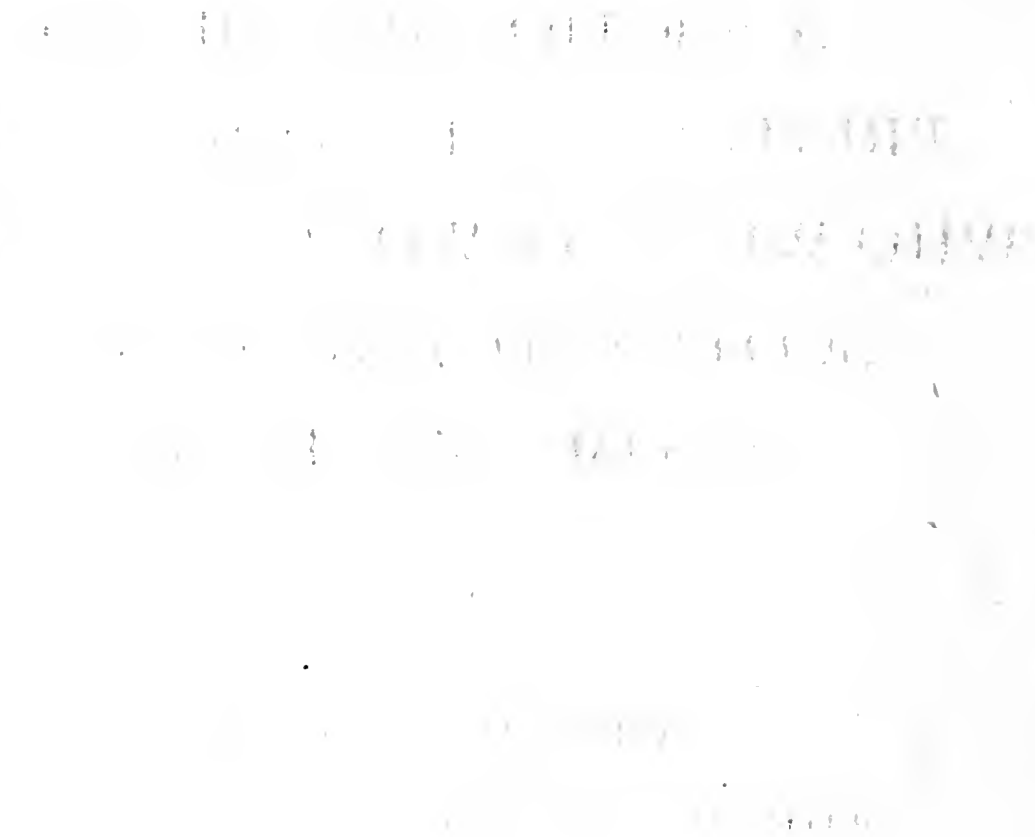




\section{INTRODUCTION.}

HREE important events in the history of the book-trade marked the
period covered by this Dictionary:

I. The expiration of the Licensing Act of 1662 in 1695 .

2. The paper and pamphlet duties of 1696 and $\times 7 \times 3$.

3. The Copyright Act of 1709 .

The result of the first was that during the closing years of the seventeenth century printing presses were established in many provincial towns, Bristol and Exeter in the West, Chester, York, Newcastle, and Gateshead in the North, Norwich and Ipswich in the East, and with every year their numbers increased until by 1725 all the important towns in the kingdom had their own printers. Almost the first thing these printers did, was to establish a local newspaper, which, though little else than mirrors of the London press, and containing scanty local news beyond a few advertisements and the trials of criminals at the local assizes, served the useful purpose of broadening the outlook of the people and keeping them in touch with the outside world.

The first of the paper duties was imposed by the 8-9 William III, c. 7, called “ An Act for granting to his Majesty several duties upon paper, vellum and parchment, to encourage the bringing of plate and hammered money into the Mints to be coined ". It imposed upon all paper, parchment, and books imported an ad valorem duty of 25 per cent., a similar duty of 20 per cent. on paper or parchment made, while all stock-in-trade was to pay $17 \frac{1}{2}$ per cent.

In I 711 another Act was passed (10 Anne, c. 18) combining duties on paper with a stamp duty on pamphlets and newspapers. The duties on paper took the form of a tax per ream which varied in the case of imported paper from Is. to $16 s$. per ream, and in the case of British-made paper from $4 d$. to $1 s .6 d$. per ream. Books, prints, and maps imported were charged $3 \circ$ per cent. ad 


\section{R E F E R E N C E S}

\section{ABBREVIATED IN THE TEXT.}

Allnutt. English Provincial Presses. By W. H. Allnutt. Pt. 3 (Bibliographica, ii. 276-308). C. J. Commons' Journals.

C.P.R. Common Plea Rolls (Record Office).

Cooke. Bibliotheca Cestriensis. By John H. Cooke. 1904.

Creswell. Collections towards the History of Printing in Nottinghamshire. By S. F. Creswell. 1863.

Davies. A Memoir of the York Press. By Robert Davies. 1868.

Dictionary, 1641-67. A Dictionary of the Booksellers and Printers who were at work in England, Scotland, and Ireland from 1641 to 1667 , by Henry R. Plomer. Bibliographical Sociely. 1907.

Dredge. Devon Booksellers and Printers in the seventeenth and eighteenth centuries. By J. I. Dredge. 3 pts. $1885-7$.

Dunton. The Life and Errors of John Dunton (written 1703, printed r705) edited, with other tracts by him, by J. Nichols. 1818 .

Gent. The Life of Thomas Gent, written by himself. 1832.

Hearne. Remarks and Collections of Thomas Hearne. 1705-22. ro vols. Oxford Historical Society, 1885-1915.

Hyett and Bazeley. The Bibliographer's Manual of Gloucestershire Literature. By F. A. Hyett and W. Bazeley. 5 vols. 1895-1915.

Lawler. Book Auctions in England in the seventeenth century. 1676-1700. By J. Lawler. 1898.

List of Printing Houses in London in 1675. State Papers Domestic. Charles II, 36n (97).

Liverpool Pr. \& Doc. Liverpool Free Public Library. Liverpool Prints and Documents. 1908. pp. 333 sq.

Madan. A Chart of Oxford Printing. Bibliographical Society. 1904.

Negus. A List of London printers, classified by their political parties, drawn up by Samuel Negus in 1724. Printed in Nichols' Literary Anecdotes, i. 288-312.

Reed. A History of the Old English Letter Foundries. By T. B. Reed. 1887.

Stationers Company Records. (Unprinted.)

Stat. Reg. (Roxb.). A Transcript of Registers of the Worshipful Company of Stationers from I640 to I 708. [Presented to the Roxburghe Club by G. E. Briscoe Eyre.] 3 vols. 1913-14.

T.C. The Term Catalogues, 1668-171x. Edited by E. Arber. 3 vols. 1903-6.

Times Handlist. The Times Tercentenary Handlist of English and Welsh Newspapers, \&c. 1920. 
Timperley. A Dictionary of Printers and Printing. By C. H. Timperley. r839. Second edition 1842 . The references serve for both editions.

Wallis. A Sketch of the Early History of the Printing Press in Derbyshire. By Alfred Wallis. (Journal of the Derbyshire Archaeological and Natural History Society, III, r37, \&c.) r88x.

Watson. History of the Art of Printing. By James Watson. r 713 .

Welford. Early Newcastle Typography. By Richard Welford. (Archaeologia Aeliana, $3^{\text {rd series, III.) }}$ rgo6.

Wood. The Life and Times of Anthony Wood, ed. A. C. Clark. Oxford Histortcal Society. 5 vols. $2889-92$. 


\section{A DICTIONARY OF THE PRINTERS AND BOOKSELLERS WHO WERE AT WORK IN ENGLAND, SCOTLAND AND IRELAND FROM I668 TO I725}

A. (т.), bookseller in Oxford, 1682. [Madan, p. 30.]

ABINGTON, or ABBINGTON (WILLIAM), bookseller in London, (I) Black Spread-Eagle at the West-end of Pauls ; (2) Three Silkworms, near the Wonder Tavern, Ludgate Street. 1679-1705. Succeeded Elizabeth Calvert at the first address. First entry in T.C., Trinity, 1679 [1. 359]. Dunton calls him "beauish Abington". He published in 1683 nos. I and 2 of Scotch Memoirs, by way of dialogue between John and Elymas. [Timperley, p. 565.]

ABREE (JAMES), printer and bookseller at Canterbury. Over against the Three Tuns, (a) Castle Street; (b) St. Margaret's Parish. 1717-68. Settled at Canterbury in $17 \mathrm{I} 7$, and began by printing a sheet, containing the names of the mayor, aldermen and common council, who had encouraged the revival of printing in the city. On October $23 \mathrm{rd}, \mathrm{I}_{71} \mathrm{7}$, appeared the first number of a newspaper called The Kentish Post or, The Canterbury News Letter. The early numbers were printed for the proprietors by Thomas Reeve, in quarto form with a cover. It was afterwards printed by James Abree in partnership with $\mathrm{W}$. Aylett and then by Abree alone, and it then took the ordinary form of a small folio, and appeared twice a week. The Kentish news in this sheet was confined to a few inches of space on the last page, and was of very little interest ; but many Kentish advertisements were inserted. In 1718 Abree printed Thomas Hardres's Panegyrical Poem on the Fair and Celebrated Beauties in and about the City of Canterbury, folio ; in $1726-7$ several quarto pamphlets in a quarrel between doctors Packe and Grey of 
Canterbury, and in 1740 Poems on Several Occasions, by an anonymous lady. Abree was also a bookseller and stationer, and sold wall papers and patent medicines. He circulated by his chapmen many books published in weekly or monthly parts, by London publishers. About 1764 he took into partnership George Kirkby, the son of a Canterbury clergyman, in favour of whom he retired in I768. Kirkby then dropped the publication of the Kentish Post, and entered into partnership with another Canterbury printer, James Simmons, who was then publishing a rival sheet, called The Kentish Gazette, or Canterbury Chronicle. James Abree died on August 2oth, r768, aged 77, administration of his effects being granted to his daughter.

ACTON (VAlentine), bookseller in London. Holy Lamb, St. Paul's Churchyard, 1678. T. James printed for him J. Nye's A Display of Divine Heraldry. [T.C. I. 319.]

ADAMS (JoHN), bookseller at Oxford, 1673. See Dictionary, 1641-67. Still in business in 1673, when he published Holyday's edition of Juvenal. [T.C. I. I35.]

ADAMS (ROGER), printer at Manchester and Chester. Manchester : At the lower end of Smithy-Door. 1719-33. Printer and publisher of the first Manchester newspaper, the Manchester Weekly Journal, first issued in January 1719. Believed to have come from Chester, whither he returned and conducted The Chester Courant from $173^{\circ}$ until his death. During his stay in Manchester he reprinted $A$ Catalogue of the Lords, Knights and Gentlemen that have com-

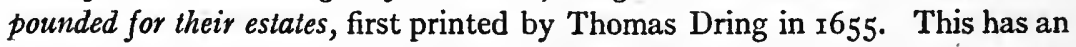
introduction signed by the printer and also the advertisement of another reprint, The Ordinance of Oliver Cromwell for ejecting scandalous ministers.

ADAMS (WILIIAM), junior, printer in Edinburgh, (I) opposite to the TroneChurch, I7I7 ; (2) in Carubber's Close, I720. I717-25. Adams printed The Caledonian Mercury from its beginning in April 1720 to the end of 1723 .

ADAMSON (JAMES), bookseller in London, Angel and Crown, St. Paul's Churchyard, 1686-94. First heard of in 1686, when he sold the edition of Reliquiae Wottonianae, published by Tooke and Sawbridge. In the same year he published a Latin edition of St. Clement's Epistles to the Corinthians. [T.C. II. I79.] From this time his name is of frequent occurrence in the Term Catalogues. 
Amongst other works of note he had a share in Thévenot's Travels, 1687; the Latin edition of The Life of Cardinal Pole, 1690; and Geo. Ashwell's De Socino et Socinianismo dissertatio, 1692. His last book-entry occurs in Michaelmas 1694. [T.C. II. 534.]

ADDERTON (WILLIAM), see Dictionary, 1641-67.

AINGE (JOHN), bookseller in Bristol. In Temple Street, during the Fair. 1693-97. Advertised in the Post Boy of January 6th-8th, 1697, as agent for Powel's History of Wales, a new edition by W. Wynne, A.M. An earlier reference to him has been found in some Chancery Proceedings of the year 1693 [Bridges, $\frac{108}{6}, \frac{109}{6}$ ] relating to property in Gloucester, and to business transactions with John Dowly of London, " a wholesale haberdasher of small wares", whose daughter Alice Ainge married. The will of a John Ainge of Lechlade is found in the Calendar of Gloucester Wills, proved in 1717 .

AITKEN (WILLIAM), bookbinder in Edinburgh, 1687. Named cautioner in the confirmation of Gideon Shaw's will. [Bann. Misc. II. 294.]

ALEXANDER (JAMES), bookseller in Edinburgh, 168r. A broadside entitled A true copy of the Indictment . . . against Archibald Earl of Argyle, bears the imprint, "Edinburgh, Printed for James Alexander, r68r." [Aldis, p. 107.]

ALEXANDER (Jo.), bookseller of Bristol, x682. Only known from a broadside entitled Sad and lamentable cry of oppression . . in . . Bristol, 1682, 4. [Haz. I. 53.]

ALKINS (J.), bookseller (?) in London, near Fleet Street, 1 704. Only known from a broadside entitled An account of a most horrid Plot and Conspiracy, \&c. " London, Printed for J. Alkins, near Fleet Street, 1 704." [Bibl. Lind. Catalogue of English Broadsides, no. 874.]

ALLAN (ROBERT), bookseller in Edinburgh, at his shop over foregainst the Court of Guard, 1695-6. One of several booksellers who in 1695 sold Sir T. Craig's Scotlands soveraignty asserted, and in the following year $A$ Letter to a Member of Parliament. [Aldis, p. 107.]

ALLDRIDGE (T.), bookseller in Southwark, 1697. Only known as the publisher in 1697 of a ballad entitled The True English Prophet. [Ouvry Catalogue, no. 76 ; Haz. II. 203.] 
ALLEN, MRS., bookseller in Sevenoaks, 1699. Her name appears in the advertisement in the Flying Post, December and, of the publication of the Rev. Edward Brown's Sermon preached on the occasion of the Kentish Feast on November I6th. It does not appear in the imprint to the Sermon.

ALLEN, or ALLIN (CHARLES), bookseller in Bristol, Broad Street, 1674-8r. In 1674 published Bristol Drollery, Poems and Songs by $M r . C$., printed in London, doubtless by Edward Horton, who entered it in Stat. Reg. [Roxb. II. 478]. Hazlitt says that the contents have no peculiar connexion with Bristol. [Hdbk., p. 169.] In Hilary 1679 he entered in T.C. [1. 342] Shortwriting, by Laurence Steel of Bristol. His last entry is S. Crossman's Sermons, 168r. [T.C. I. $43^{8}$.]

ALLEN (JоHN), bookseller in London, White Horse, Wentworth Street, near Bell Lane, r669-85. May be the John Allen who was in business in Little Britain in 1667 ; but if so there should be more notices of him in the Term Catalogues. His imprint is found on a poetical broadside entitled Character of London Village, r684. [B.M. 1872. a. I (28).]

ALLEN (ROBERT), bookseller in Norwich, St. Stephen's parish, 1702. Mentioned in a list of printers and booksellers contributed by C. J. W. W. to the East Anglian, I. 281.

ALLESTREE (HENRY), bookseller in Derby, Market Head, 1719-32. One of a distinguished Derby family of that name, and probably a son of William Allestree, formerly Recorder of the Borough. He was established in business by 1719 , when his name occurs in the imprint to the Nottingham Mercury. [Sketch of the early history of the Printing-press in Derbyshire, by Alfred Wallis, Journal of the Derbyshire Archaeol. and Nat. Hist. Soc., III. 137, \&c.]

ALLESTREE (J.). See Diclionary, 1641-67.

ALLIN, see Allen.

ALLPORT (BENJAMIN), bookseller in London, (I) White Horse, Little Britain ; (2) St. Botolph's, Bishopsgate. 1685-9. Married, October roth, 1685, Dorothy, daughter of Thomas Dawks, printer, and sister of Ichabod Dawks, printer. After Allport's death she married William Bowyer, printer, q. v. [Timperley, p. 660.] The only book that is connected with him is F. André's Chymical Disceptations, advertised Easter 1689. [T.C. 11. 252.] 
ALSOP (BENJAMMN), bookseller in London, Angel and Bible over against the Stocks Market [in the Poultry], 1679-85. Probably a descendant of Bernard Alsop (1616-1653). In 1679 he published John Gerhard's Divine Consolations, which was advertised in the Domestic Intelligence of October 21st. In I68I he was defendant in an action for assault brought by Bartholomew Sprint against a number of printers and booksellers in London and Oxford, the details of which are wanting. [C.P.R. Trinity 33, Charles II, Roll 2992, m. 256.] Dunton has this account of him: "He was a first-rate bookseller for some years. But see the rambling fate of some men; for, Ben being a wild sort of a Spark, he left his shop to get a commission in Monmouth's army, and, as Ben told me in Holland, had the Duke succeeded, he had been made an Earl, or a Baron at least : i. e. 'If the sky had fell, he had catched a lark.' I succeeded Captain Alsop in his shop in the Poultry." [Dunton, pp. 147, 214, 262.]

AMERY (JOHN), bookseller in London, (r) Peacock, Strand, over against St. Clement Danes Church ; (2) Peacock, near St. Dunstan's Church, in Fleetstreet. 1670-86. Dealer in law books. Described by Dunton as "thinking Amery." [Dunton, p. 292.] First entry in T.C., Easter 1670. [1. 39.] The $\mathrm{J}$. Amery who published the works of Machiavelli in 1695 [T.C. II. 54I] may have been a son. Amery moved to Fleet Street in 1673 . [T.C. 1. 1 36, 143.]

ANDERSON (ANDREW), printer, I653-†1676. At Edinburgh, 1653-7; at Glasgow, 1657-6r ; again at Edinburgh, 1661-76. See Dictionary, 1641-67.

ANDERSON (ANDREW) and his partners, printers in Edinburgh, $1671-75$. This is the copartnery of $\Lambda$ ndrew Anderson with G. Swintoun, J. Glen, T. Brown, and D. Trench, in the gift of King's printer, which Anderson obtained in ${ }_{1} 67 \mathrm{r}$. They printed under the style of "His Majesties Printers" 1672-5, and "Andrew Anderson and his partners "I675. Watson (p. 12) says that on Anderson's death $(1676)$, "After printing of one small Bible by the Widow and Partners in company, they disagreed; the booksellers apprehending themselves to be wrong'd . . . all of them sold off their shares of the house and gift to Mr. Anderson's widow, except George Swinton." [Aldis, p. 107.]

ANDERSON (HEIR OF ANDREW), Edinburgh, 1676-94.)

ANDERSON (HEIRS OF ANDREW), 1680-1700.

See Anderson (James).

ANDERSON (SUCCESSORS OF ANDREW), 1693-1722. 
ANDERSON (HEIRS AND SUCCESSORS OF ANDREW), r694-1717. Over against the north-side of the Cross ; at the printing House in Edinburgh College, r693. See Anderson (James).

ANDERSON (JAMES), printer in Edinburgh, $1676-(?)$. After the death of Anderson in 1676 his widow (see Anderson, Mrs.) conducted the business in conjunction with, or on behalf of, his son and heir James, under the above styles. They were printers to the town and college as well as King's printers. During the Revolution they dropped the latter title and printed by order of the Privy Council until June 1690 . Mrs. Anderson came into frequent conflict with the other printers and booksellers in her endeavours to enforce the monopoly conferred by the gift as King's printer. In I690 she made an unsuccessful attempt, in opposition to Mosman, to obtain the appointment of printer to the General Assembly, but in 17 I2 succeeded Mosman in his office, [Aldis, p. I07.]

ANDERSON (RELICT OF A.), printer in Edinburgh, I681. See Anderson, Mrs.

ANDERSON MRS., printer in Edinburgh, I676-1716. See above, Anderson (James). Agnes Campbell, wife of A. Anderson. After her husband's death in 1676 , she conducted the business. By November $168 \mathrm{r}$, she had married Patrick Telfair, a merchant in Edinburgh. Died July 24th, I 7 I6. Inventory [Bann. Misc. II. 284] names as one of the executors, "Mr. John Campbell, corrector of the said defunct her press". [Aldis, p. I08.]

ANDERSON (JAMES), stationer in Edinburgh, c. 1679. Will registered July Ist, I679. [Bann. Misc. II. 296; Aldis, p. ro8.]

ANDERTON (WILLIAM), printer in London, 1688-93. Said to have been a North Country man. He was apprenticed to Miles Flesher or Fletcher, and later (?) to one Snowden (see below). Became a corrector of the Press. At the Revolution he set up a private printing press. At the Sessions of June Ist-3rd, I693, he was tried for printing two pamphlets, Remarks upon the present confederacy and late Revolution in England and $A$ French Conquest neither desirable nor practicable. The principal evidence against him was given by Robert Stephens, the Messenger of the Press, who declared he had known the prisoner for upward of two years as a printer of seditious libels but never 
could tell where he worked. On May and he had tracked two journeymen printers to a house and there found William Anderton in a secret room in which were a printing press, letters, and all other materials for printing; and in the press was an Errata, as found in the Remarks. Amongst other broadsides found in the room were: A Caution to the Navy, An Historical Romance upon the Wars, A Second Letter to the Bishop of Salisbury, which were said to be in the same type as the Remarks. Two printers, $\mathrm{R}$. Roberts and one Snowden, a dissenter to whom Anderton was some time an apprentice, also gave evidence. In summing up the evidence everything was aggravated to the utmost, but it was a long time before the jury could be persuaded to find him guilty of high treason. He was sentenced to death and executed at Tyburn on June r6th, 1693. [Proceedings on the King and Queen's Commissions of the Peace, B.M. 5r5. 1. 2 (149).-An account of the Conversation, Behaviour and Execution of William Anderton, printer, B.M. 515. 1. 2 (150).-Howell's State Trials, xi1. 1240-67.]

ANDREW (JoHN), bookseller in Glasgow, s676. Named among the debtors in Andrew Anderson's inventory (1676). The "John Androw, in Glasgow", mentioned in G. Lithgow's inventory (1662) may be the same. The will of Bessie Sheills, his widow, was registered December 27th, I689. [Aldis, p. 108.]

ANDREWE (RICHARD), stationer of London, I683. Only known from his will, which was proved in the Prerogative Court of Canterbury on September inth, 1683. As he left bequests to the towns of Desborow and Thorpe in Northamptonshire, he was perhaps a native of that county. He also referred to his son-in-law John Bird, who may be the bookseller of that name who is found renting a stall in Westminster Hall in 1689. [P.C.C. 1or, Drax.]

ANDREWS (ROBERT), type-founder in London, Charterhouse Street, 1680-1 735. Born in 1650 . He served as Steward of the 69th Feast of the Masters and Workmen printers in 1680 and about 1683 succeeded to the foundry of Joseph Moxon, which he transferred to Charterhouse Street. His foundry, largely consisting of Moxon's matrices, was, next to Grover's, the most extensive of his day, and consisted of a large variety of Roman letters and titlings, 1 I Hebrew and 5 Rabbinical founts, \&c. He was Junior Warden of the Company of Stationers in $1702-3$ and $1703-4$, and Senior Warden in $1706-7$ and $1707-8$. Although he accumulated a large quantity of matrices, Andrews 
does not appear to have been a good workman. Humphrey Wanley describes him as a "blunderer" because he cut the punches for Elizabeth Elstob's Saxon Grammar so badly. According to Timperley Andrews died November 27th, I 735, aged 8o, but if that were so, it would make his age 85. His son Silvester carried on the business at Oxford. Thomas James subsequently purchased both foundries. [Reed, pp. 194-7; Timperley, p. 653.]

APPLEBEE (JOHN), printer and bookseller in London, (a) a little below Bridewell Bridge in Black-Fryers; (b) Fleet Ditch. I7I5-I724. Printer of pamphlets and broadsides. In I 7 I5 he printed the St. James's Evening Post, or Nightly Pacquet, "for Samuel Jackson, over against Bridewell-Bridge". He was also the printer of a Daily Journal and a Weekly Journal bearing his own name. [Timperley, p. 632.] His printing was very bad, and his type worn and old.

APPLEBY, MRS., bookseller at Gravesend, I7II. Only known from an advertisement of Seamans Speculum or complete schoolmaster, by John Davis, in the Post Man, March Ioth, $17 \frac{10}{1}$.

ARCHER (JOSEPH), bookseller in London, near the Playhouse in Great Russell Street, Covent Garden, I 7 I I. His name occurs in an advertisement of a sale of miscellaneous books by Sam. Illidge in the Daily Courant of January I9th, I 7 I I and in the following month he was mentioned as one of the booksellers receiving subscriptions for $\mathrm{R}$. Bradley's Treatise of succulent plants, advertised in the Post Man of February 3 rd.

ARCHER (THOMAS), bookseller in London, Fleet Street, under St. Dunstan's Church, I671-3. In partnership with Thomas Burrell he issued in 1671 E. Maynwaring's Praxis Medicorum [T.C. I. 7 I], and in 1672 was one of the publishers of the second edition of P. Heylyn's Aerius Redivious, or, the History of the Presbyterians. His last entry was, in Trinity, I673, A Pleasant Treatise of Witches. [T.C. I. I42 ; Haz. II. 654.]

ASHBURN (ROBERT), bookseller in York, I676. Sold The [or $A n$ ] Appeal from the Cabal, r676.

ASHWORTH ( ), bookseller in Durham, 1696. Only known from an advertisement of patent medicines in the London Gazette, February $25^{\text {th, }} 169 \frac{6}{7}$.

ASPERNE (Jo.), bookseller in London, c. 1700. Only known from the imprint to a broadside entitled Duke of Shoreditch; or Barlow's Ghost, London, Printed for J. Asperne [c. I700]. [Haz. II. 365.] 
ASTLEY (THOMAS), bookseller in London, Saint Paul's Churchyard, 1729. Publisher of the London Magasine. [Timperley, p. 657.]

ASTWOOD (JAMES), printer in London. Behind St. Christopher's Church in Threadneedle Street, the back-side of the Royal Exchange, 1691-1705. Dunton writes, "He was my near Neighbour and intimate Friend for many" years. He printed for me near Sixty books, and was constantly engaged in the 'Athenian Mercury'. . . . Since the death of his son (Mr. John Astwood) he seems no longer to have any commerce with the world and hath nothing so familiar as a life that is (by his retreat from London to a country village) as it were buried in death." [Dunton, p. 245.] As Dunton speaks of him as a "near neighbour" his printing house was probably that in which his son worked, as given above. His name is found in the imprint to T. Hales's Account of several nerv inventions, 1691. [B.M. 534. a. 27.]

ASTWOOD (JOHN), printer in London, behind St. Christopher's Church in Threadneedle Street, the back-side of the Royal Exchange, 1695-8. Son of James Astwood, q.v. He printed John Pointz's Present prospect of ... Tobago. Second edition, 1695, $4^{\text {to }}$, and $A$ Dialogue between a Country Gentleman and a Merchant, 1696, $12^{\circ}$. [Haz. I. 194; II. 491.] Amongst those for whom he printed was John Lawrence the bookseller. His address is given in full in an advertisement in the Post Boy of May roth, 1698 .

ATHERTON ( ), bookseller in London, c. 1700. Dunton [p. 292] mentions, among booksellers and publishers, "grave Atherton".

ATKINS (MAURICE), bookseller in London, (r) King's Head, Westminster Hall ; (2) Half Moon in St. Paul's Churchyard; (3) Golden Ball, in St. Paul's Churchyard. 1671-r715. First found in partnership with W. Hensman at the King's Head in Westminster Hall in $167 \mathrm{I}$, when they issued a small octavo entitled The Ancient rites and monuments of the ... Cathedral Church of Durham. [T.C. I. 89.] In 1673 he succeeded W. Gilbert at the Half Moon in St. Paul's Churchyard, publishing from there The Gentleman's Recreation ... Illustrated with sculptures and other books. [T.C. 1. 152, 157.] Then his name disappears from the Term Catalogues until 1707 , when he is found at the Golden Ball in St. Paul's Churchyard in partnership with M. Newborough, publishing Boyer's Wise and ingenious Companion, French and English and several other works. He was still in business in 1715 , when he issued the first edition of Ralph Thoresby's Ducatus. 
ATKINS, or ATKYNS (RICHARD), patentee of Law Books. See Dictionary, I64I-67, Atkyns.

ATKINS (WILLIAM), bookseller at Leicester, $x 684$. In that year he sold a sermon preached by the Rev. Joln Newton, then vicar of St. Martin's, Leicester, on the occasion of the execution of certain criminals at the recent assizes. [Haz. IV. I57.]

ATKINSON (ABRAHAM), bookseller at Cambridge or Peterborough (?), r680. His son Robert, born at Cambridge, educated at Peterborough School, was admitted sizar at St. John's College, Cambridge, February 24th, 16 $\frac{79}{80}$, aged 19, his father being apparently still alive. [St. John's Coll. Admissions, ed. Mayor, II. 76.]

ATKINSON (GEORGE), bookseller at Chester, I682. The only book associated with him is John Allen's Sermon preached at the Assizes held at Chester, April 24, 1682. [T.C. 1. 482.] He died during the year 1682, and in Hilary Term 168 $\frac{2}{3}$ Awnsham Churchill, the London bookseller, commenced an action against his widow, Mary Atkinson, in the Court of Common Pleas [C.P.R. 3009, m. II3 recto] probably for the recovery of a debt for books or stationery supplied to her husband.

ATKINSON (THOMAS), bookseller in London, White Swan, St. Paul's Churchyard, I704-7. Chiefly a publisher of divinity. His first and last entries in T.C. are in Easter I704 and Trinity r707. [T.C. III. 403-4, 556.]

ATKINSON (TROYLUS), bookseller in Cambridge, c. I626-75. Lived in Great St. Mary's parish from 1626 when he first appears as paying the Church Rate. He was a wealthy man and died possessed of freehold and leasehold properties as described in his will dated May 23rd and proved November 22nd, 1675 . [Gray and Palmer, pp. II 5-18.] He died July 2oth, I675. To his son William, q. $v$., he left the lease of his dwelling-house, book-debts, \&c.

ATKINSON (WILLIAM), bookseller at Cambridge, I675-94. Son of Troylus Atkinson, $q . v$. In 1684 he was defendant in a suit brought by the Sheriff of the County for a debt of $£ 30$ [C.P.R. 2994, m. I I5 I, Trinity 33, Charles II] and again in 4 James II he was defendant in a plea for trespass. [C.P.R. $3068, \mathrm{~m}$. 162 verso.] His will, dated March 7 th, 1693 , and proved May 28 th, I694, left all household goods and chattels to his wife Mary. [Gray and Palmer, p. I28.] 
AULD (wIlliaM), bookbinder in Edinburgh, I684. Named cautioner in the confirmation of the will of John Calderwood. [Bann. Misc. II. 292; Aldis, p. I08.]

AXE (THOMAS), bookseller, bookbinder, and book-auctioneer in London, (I) Holiday Yard in Creed Lane, near Ludgate Street, 1692 ; (2) Blue Ball in Duck Lane, 1696. 1692-1703. Dunton [p. 258] describes him as a man " of a great deal of wit and honesty. ... He was my chief binder for ten years; but honest Tom has met with losses . . . but, notwithstanding . . . I believe Mr. Axe will get money enough : for he is not only a good binder, but sells Books, Globes, Auctions". In 1692 he published an Epitome of the Whole Art of War. [T.C.11.394.] His last entry was in Trinity 1696 : Letters and Essays on several subjects... in Prose and Verse to John Dryden Esq. . . Mr. Congreve and other ingenious men of the age. By several Gentlemen and Ladies. [T.C. II. 592]. He was apparently still in business when Dunton wrote in 1703 .

AYLMER (BRABAZON) sen. and jun., booksellers in London, Three Pigeons over against (or near) the Royal Exchange, I670-I 709. Dealers in theological works. In the Term Catalogue of Hilary I670 Aylmer sen. advertised a small schoolbook called Formulae Oratoriae, but without giving any address. [T.C. 1. 27.] His first entry in the Stationers' Register was made on December 12 th, 1673 , when in partnership with Nath. Ranew and Jonathan Robinson he entered Dr. Bates's Harmony of the Divine Attributes [Stat. Reg., Roxb., vol. II, p. 474], and in 1674 Joannis Miltoni Angli Epistolarum familiarium liber unus [ibid., p. 48r]. He became the assignee of Samuel Simmons and so held the copyright of Paradise Lost, one half of which he sold to Jacob Tonson on August I 7 th, I683, and the other on March 24th, I69o. [Masson, Life of Milton, vI. 786.] Dunton [p. 206] speaks of him as " a very just and religious man. I was partner with him in Keith's Narrative of the proceedings at Turner's Hall, and so had an opportunity to know him. He is nicely exact in all his accounts and is well acquainted with the mysteries of his trade." In I 707 the names of Brabazon Aylmer sen. and jun. are found together in several entries in the Term Catalogues. [T.C. III. 533-54.] The few subsequent entries in 1708 and 1709 of plain Brabazon Aylmer, at the same address, may imply that the father was dead and the son carrying on the business.

AYSCOUGH (wILlam), printer in Nottingham, Bridlesmith Gate, I 7ro-r9. In 17 to he printed for Hildyard of York and Ryles of Hull Remarks on the 
several paragraphs of the Bishop of Salisbury's speech in relation to the first article of Dr. Sacheverell's impeachment [B.м. IIr. b. 28]. The second edition of Sir T. Parkyn's Imn-Play, I 7 I4 (also perhaps the first, I 7 I3), was printed for him and for Timothy Goodwin of London. In 17 I 7 he printed the Grammatical Commentaries, by R. Johnson, Head Master of the Free School in Nottingham ; and in I7 $18-19$, for Mrs. Hartshorn at Leicester, The Certainty ... of a future General Judgement. A sermon preached at Leicester . . Mar. 19th, 1718-19, n. d. Deering in his Nottinghamia Vetus et Nova, $175 \mathrm{I}, 4^{\text {to }}$, Sec. 2, p. 40, records the following inscription in St. Peter's Church, in the South aisle: "Here lye the bodies of William Ayscough, Printer and Bookseller of this Town; and Anne his wife, she was daughter of the Rev. Mr. Young, Rector of Catwick in the County of York. He died March 2, 1719: she died Dec. 16, r732."

B. (B.), printer in London, I696. Probably B. Beardwell of Swan Yard (q. v.). In partnership with J. M. They printed amongst other things Sir Samuel Morland's Urim of Conscience, published by A. Roper, E. Wilkinson, and R. Clavel in 1696.

B. (H.), printer in London, I682. Printed for J. Conyers a poetical broadside entitled Rome's Thunder Bolt, r682. [B.M. C. 40. M. I I (93).]

B. (J.), printer in London, r686. Printed for Dorman Newman and R. Bentley.

B. (J.), printer in Exeter, r688. Printed two broadsides entitled (I) The General Association of the Gentlemen of Devon to his Highness the P. of Orange, and (2) The Speech of the Prince of Orange to some principle Gentlemen of Somersetshire and Dorsetshire, on their coming to joyn his Highness at Exeter, the 15th of Nov. 1688. [B.M. T. 100*, 201, 202.]

B: (J.), see Baker (John), bookseller in London, r683.

B. (I.), printer in Edinburgh, I670. Printed an edition of the New Testament, I670, sold by James Miller.

B. (P.), see Bruce (Peter).

B. (R.), see Boulter (Robert).

BACK (JOHN), bookseller in London, Black Boy on London Bridge, near the Drawbridge, r682-r703. Son of John'Back of Hinxhill, co. Kent. Apprenticed on May 3 rd, 1675 , for seven years to Thomas Passenger ( $q . v$. Dict. 164I-67). 
On taking up his freedom Back set up for limself at the sign of the Black Boy, and, like other London Bridge booksellers, dealt chiefly in cheap popular literature, ballads, broadsides, chap-books and school-books. About 1696 he was appointed bookseller to the Society of Kentish Men, and in addition to selling tickets for the Annual Feast he published the sermons preached at it from 1697 to 1701. He died in the end of June 1703 , and was buried in St. Magnus Church on July $3^{\text {rd }}$ [Churchwardens' Accounts of St. Magnus.]

BADMAN (C.), see Bateman.

BAGFORD (JOHN), bookseller and printer in London, 1650-1716. Thomas Hearne, the antiquary, believed John Bagford to have been born in Fetter Lane; but other authorities state his birthplace to have been in the parish of St. Anne's, Blackfriars. It is probable that he was originally a shoemaker by trade, but afterwards became a collector of books on commission for booksellers and amateurs, more especially for Robert Harley, Earl of Oxford, Sir Hans Sloane, and John Moore, Bishop of Ely. He was also a bookseller, and during the great frost of January I 716 he had a printing press at work on the Thames. Bagford collected an immense amount of material, both manuscript and printed, for a history of printing, which was also to include bookbinding and paper-making; but it was never published. As a bookseller, he was frequently asked to make up imperfect books, and it was the custom of the book trade to collect title-pages and portions of books for this purpose. A great number of Bagford's title-pages and fragments are from books which could have been bought in his days for a few pence, while it is highly probable that some of them were salvage from the Great Fire of 1666, when immense quantities of books were burnt or damaged ; that Bagford wilfully destroyed books, in order to form his collections, is a slander on a man who was universally spoken of as "honest John Bagford" and who, according to Thomas Hearne, was a "despiser of Money". In fact, many of these titlepages show the source from which they were obtained, as they bear the name of the person from whom he received them. Without his industry, many books and editions of books would have perished entirely, being only known to us from the title-page in the Bagford collection. This collection comprises 129 volumes, including three of ballads. The manuscript pieces are contained in 36 volumes, the printed pieces in 63 . In addition to title-pages this collection 
contains much miscellaneous matter of interest, such as printers' devices, advertisements, and book-plates. In his old age Bagford was admitted to the Charterhouse, and on his death on May 5th, 1716, was buried in the Charterhouse graveyard. [Bibl. Soc. Trans., 1v. 185-201 ; vil. 123-160.]

BAGNALL (JOHN), printer in London, near Fleet Street, 1709, and at Ipswich, I 717-35. The only thing known from his London press is Sir John Packington's speech in the House of Commons relating to the Harbour of Dunkirk. [Bibl. Lind. Broadsides no. 966.] For his Ipswich press see Allnutt, p. 3or.

BAILEY, or BAYLY (JOHN), bookseller in London, Judge's Head, Chancery Lane, near Fleet Street, I708-9. At the latter end of 1708 or the beginning of 1709 he published $A$ Complete Course of Chemistry by George Wilson. [T.C. III. 629.] Possibly Dunton's " Grammatical Bayley" [p. 293].

BAILEY (WILLIAM), bookseller at Burton on Trent, Lichfield, Tamworth, and Wolverhampton, 1685. His name appears in a list of booksellers selling a patent medicine, given at the end of M. Bromfield's Brief discovery of the . . . Scurvy, I685. [N. \& Q., I I Ser., XI. 45.]

BAKER ( ), bookbinder in London, Warwick Lane, c. I703. Bound for Dunton, who speaks [p. 258] of the excellence of his work.

BAKER (G.), bookseller (?) in London, Bridge Row, north-east corner of the Royal Exchange, 1679. In this year he published a map of the world by Francis Lamb. [T.C. 1. 364, 372.]

BAKER (J.), bookseller in London, Black Boy, Paternoster Row, r680-1710. In the Post Man for January I 3 th, 1680 , he advertised The Political State of Great Britain, but advertised nothing in the Term Catalogues until I 709 , when he entered $A$ Vindication of the Church and Clergy of England from some late Reproaches. He dealt chiefly in theology. A J. Baker was senior warden of the Company of Stationers in 1686-7.

BAKER (JOHN), bookseller in London, ( $\mathrm{I}$ ) at Mercers' Chapel [i.e. in Mercers' Chapel Porch] at the lower end of Cheapside, r703-25 ; (2) Sun and Moon, Cornhill, 1707; (3) near the Bank, in the Poultry, r709. There was more than one bookseller of this name in London at the beginning of the eighteenth century, and it is possible that the addresses given above are those of two or perhaps three distinct men. First we find a John Baker issuing in 
1703 a devotional book from Mercers' Chapel, and Dunton [p. 226] refers to him as at this address. [T.C. I11. 366.] Then a gap of five years occurs during which no book was entered in the Term Catalogue by J. Baker of Mercers' Chapel, but in July 1707 several books of importance were issued by $J$. Baker in partnership with $R$. Burrough at the Sun and Moon [T.C. III. 556-8.] Then at the latter end of 1708 or the beginning of r $709 \mathrm{~J}$. Baker of Mercers' Chapel begins advertising again in the Term Catalogue [T.C. III. 606]. In I7I he issued A Full Account of the Rise... of Dr. Asheton's proposal, as managed by the Worshipful Company of Mercers, London, for the benefit of Widows. In 1722 he started Baker's News, or, the Whitehall Journal, "to be continued weekly", the first number of which was dated May 24th.

BAKER (s.), bookseller in London, 17 I 7 . Publisher of J. Arbuthnot's Present State of the Crown-Inn (2 edd.), I 7 17. [Esdaile, p. 154.]

BAKER (THOMAS), bookseller in London, Bible and Rose, Ludgate Street, near the West end of St. Paul's, I 708-9. Publisher of theological books and works on book-keeping. [T.C. III. 594, 609, 625, 639.]

BAKEWELL (THOMAS), map- and print-seller in London, next the Horn Tavern in Fleet Street, 1670. Publisher of John Ogilby's England Exactly Described ... In a compleat Sett of ... Mapps. [Haz. 111. 179.]

BALDWIN (ANN), bookseller in London, Oxford Arms, Warwick Lane, 1698I 7 I . Widow of Richard Baldwin. Dunton [p. 260] writes of her: "Mrs. A. Baldwin, in a literal sense was an help-meet and eased him of all his publishing work; and since she has been a widow, might vie with all the women in Europe for accuracy and justice in keeping accompts. . . .'

BALDWIN (RICHARD), bookseller, bookbinder and printer in London, (1) In Ball Court, near the Black Bull, Great Old Bailey ; (2) Oxford Arms, Warwick Lane. 1681-98. One of the best-known publishers of his day, his publications consisting largely of political pamphlets and broadsides, satires on social life and on current literature, as well as plays and romances. The newspapers of the last twenty years of the seventeenth century are full of his advertisements and it is surprising that no biography of him exists. Dunton says that Baldwin was a native of Wickham; but there is more than one Wickham in England, and Dunton does not specify the county. Nothing is 
known as to his parentage, his apprenticeship, or his commencement in business. His name is first met with in the Term Catalogue for Hilary Term I68I, when he advertised a political pamphlet of twenty folio pages entitled The Certain Way to save England. [T.C. I. 429.] At this time he was also carrying on the business of a bookbinder in Ball Court, near the Black Bull in the Old Bailey, and numbered John Dunton among his customers. In the same year he published a newspaper called Mercurius Anglicus, previously printed by Robert Harford. [Timperley, p. 558.] He was also erroneously believed to have been the printer and publisher of the first and second parts of a notorious pamphlet, No Protestant Plot. In Michaelmas Term he brought an action in the Court of Common Pleas against Thomas Newcombe, John Towse, Randall Taylor, and Michael Foster, three of whom were stationers, for assault ; but the particulars are wanting. [C.P.R. 2996, m. 256 recto.] In The Impartial Protestant Mercury of January roth, 168 $\frac{1}{2}$, is an account of an assault made on two of Baldwin's apprentices, which incidentally records that it was a long-established custom for bookbinders' servants on Saturday nights to post up the titles of such books as their masters had to bind which were to be published the following week. The title which led to the trouble was a political one, Rights of the Kingdom, or Customs of our Ancestors, the result being that one of the lads was forced to give security and a copy of the book was sent to one of the Secretaries of State. On May ist Baldwin began to issue another newspaper called The Protestant Courant, and a complaint was lodged with the Judges of the King's Bench that it reflected upon the Government; but there is no record of what followed. [London Mercury, May 15-18, 1682; Timperley, p. 563.] In 1691 he was summoned before the House of Commons for printing and being the author of The New Observator, but made his peace by declaring that Dr. Wellwood was the author of the paper. [C. J. X. 558, 562, 566]. During the year 1695 he published a paper called The Post-Man, which drew a protest from the editor of The Post-Boy, who declared that the author of The Post-Man was Monsieur de Fonvive. [Post-Boy, Oct. 26-9, 1695]. In 1697 he was sued by the King's Printers for printing speeches. Baldwin continued to publish The Post-Man until his death in $169 \frac{7}{8}$. Space forbids notice of the many satires published by Baldwin, but Dunton has the following notice of him : "He printed a great deal, but got as little by it as John Dunton. He bound for me and others when he lived in the Old Bailey; but, removing to Warwick Lane, 
his fame for publishing spread so fast, he grew too big to handle his small tools. Mr. Baldwin having got acquaintance with Persons of Quality, he was now for taking a shop in Fleet street; but Dick, soaring out of his element, had the honour of being a Bookseller but a few months. However to do Mr. Baldwin justice, his inclinations were to oblige all men, and only to neglect himself. He was a man of a generous temper.... His purse and his heart were open to all men that he thought were honest ; and his conversation was very diverting. He was a true lover of King William ; and, after he came on the Livery, always voted on the right side. ... He was as it were flattered into his grave by a long consumption; and now lies buried in Wickham parish his native place."

BALDWIN (T.), a misprint for T. Bassett (q.v.), in The honesty and true seal of the King's witnesses justified by Florence Weyer, Gent., 1681. [Haz. II. 637 ; B.M. T. 2* (I4). See T.C. I. 465, which gives Bassett's name.]

BALL ( ), printer in London, Fetter Lane, r 709. Referred to by J. How as a pirate printer. [Some Thoughts on the present state of Printing and Bookselling, 1709, p. 12.]

BALL (JOHN), stationer in Banbury, against the Shambles, 1685. Occurs in a list of booksellers and stationers who sold a patent medicine, given at the end of M. Bromfield's $A$ brief discovery of the ... scurvy. [N. $\& Q Q$. I Ser., XI. 45.]

BALLARD (J.), a misprint for S. Ballard (q.v.) in one of the editions of The Clergyman's Vade Mecum.

BALLARD (SAMUEL), bookseller in London, Blue Ball in Little Britain, I 70633. Issued in 1706 an edition of The History of George a Green [B.M. 1077. e. 32.], and also The Clergyman's Vade Mecum. [T.C. III. 494.] He was probably related to Thomas Ballard, who was carrying on business in the same street. Samuel was still in business in 1733 .

BALLARD (THOMAS), bookseller and book auctioneer in London, (1) Ring in Little Britain; (2) Rising Sun in Little Britain. 1698-1725. Believed to have been thefirst of an eminent firm of booksellers. He is first found associated with and sharing the premises of G. Conyers at the Ring in Little Britain in 1698, and his first advertised publication was Youth's Safety, or Advice to the 
Younger Sort. [T.C. III. 8I.] In I 700 he moved to the "Rising Sun", and Dunton [p. 222] briefly notices him as " a young bookseller in Little Britain ; but is grown man in body now but more in mind ". Soon after this he appears to have added to his business as a bookseller that of a book auctioneer. In the Daily Courant of January and, I 7 I I, he advertised for sale the libraries of Sir Thomas Browne and his son Dr. Edward Browne. Amongst other collections dispersed by him were that of Dr. William Salmon, I7I3-14, and the smaller library of Dr. Charles Oliphant, 1720. In March $17 \frac{20}{21}$ he issued a catalogue of miscellaneous books. He was succeeded in business by Edward Ballard.

BALLINGER (JOHN), bookseller in Cirencester, I723-42. Noticed by H. Norris in his Notes on Booksellers of Cirencester. [N. \& Q., II Ser., II. I4I.]

BANBURY (BENNET), bookseller in London, Blue Anchor in the New Exchange, I700. His name occurs in the imprint to Mrs. Centlivre's play, The Perjur'd Husband, ז700. [B.M. 644. g. 27.]

BANKS (A.), printer in Edinburgh, I706. Printed in 1706 a broadside entitled $A$ List of the Nobility and Gentry ... for and against the Union. [B.M. Harl. $\left.593^{8}(90).\right]$

BANKS (ALEXANDER), bookseller in London, Charing Cross, 1676-85. In an inquiry by a Committee of the House of Lords, February I9th, $167 \frac{5}{7}$, into the publication of certain libellous pamphlets, it was incidentally stated that Alexander Banks was one of the compositors of Nathaniel Thompson, one of the printers involved. [Hist. MSS. Comm., 9th Report, App.] Banks subsequently became a publisher of ballads and broadsides. At the time of the Oates conspiracy in I68I, he published The Hue and Cry after $\mathrm{Dr}$. T. Oates, and in 1684 he issued a broadside by Thomas Calvert, entitled $A$ Letter from the Chancellour of Maryland to Col. Henry Meese, concerning the late troubles in Maryland. His name does not appear in the Term Catalogues.

BANKS (ALLEN), bookseller in London, (I) Flower de Luce, next door to the Three Squirrels, Fleet Street, over against St. Dunstan's Church, I668-7I ; (2) St. Peter's Head, West End of St. Pauls, I672 ; (3) St. Peters Head, Whitefriars, I673; (4) Fetter Lane, 1673-82. I668-82. In I668 Charles Harper and Allen Banks entered in the Stationers' Registers as their joint 
copyright Lukin's Introduction to the Holy Scriptures [Trans. Roxb. II. 386], and in the same year they published the English version of Louis Fontaine's satire, $A$ Relation of the Country of lansenia. [B.M. 873. f. 7.] It is not until 1670 that his name appears in the Term Catalogues, and his last advertisement in that publication is in February, 1674. [T.C. I. 163.] In 1672 he dissolved partnership with Harper and set up for himself at the sign of St. Peter's Head in the Churchyard ; but in the following year he carried the sign into Whitefriars. On March I 3 th, I680, he issued a news sheet called Currant Intelligence. There was already one publication with this title, and its publisher, John Smith, in his issue of April 6th, I680, issued a warning to his readers : "This Intelligence having gained reputation as well by its truth as honesty, some persons have maliciously printed another with the very same title . . therefore we think fit to give notice, that the counterfeit 'Currant Intelligence' is printed for Allen Banks in Fetter Lane, but the true one for John Smith in Great Queen Street." Banks's news sheet was very short lived; four numbers can be traced ; but he continued publishing up to $\mathrm{I682}$, when he issued the works of Francis Osborn, beyond which he cannot be traced. He may be identical with the 'Faithful Bancks', mentioned by Dunton. [p. 292.]

BANKS (HAMMOND), bookseller in London, I714. Married Anne Rogers, sister of William Rogers of Clifford's Inn, London, Gent., and is mentioned in his will proved January I4th, I 7 I4. [P.C.C. I 5 Fagge.]

BANNISTER ( ), bookseller (?) in London, Queens Arms in the New Exchange in the Strand, $17 \mathrm{r}$.

BARBER (ABRAHAM), bookseller at Wakefield, Yorkshire, 1700-03. Compiler of a book of Psalm tunes, advertised in 1700 and 1703. [T.C. III. 214, 36r.]

BARBER (JOHN), printer in London, (I) Queen's Head Alley ; (2) Lambeth Hill. I700-40. Born in 1675 of poor parents, Dunton says [pp. 248, 250] that he was apprenticed to the elder Larkin and afterwards successfully managed the printing office of Henry Clark's widow. He set up for himself in Queen's Head Alley in I700. Dean Swift befriended him in many ways and makes frequent reference to him in his Letters to Stella. It was probably through Swift's influence that Barber was engaged as printer to the ministry of the day, and he printed for Pope, Prior, Dr. King, and Mrs. Manley. Through 
the patronage of Bolingbroke he obtained the contract for printing the votes of the House of Commons, and became printer of the London Gazette, the Examiner and Mercator. He was also printer to the City of London, and received the reversion of the Royal Printing House after Baskett, but relinquished the latter post for a sum of $£ \mathrm{I}, 500$. Elected an alderman of Baynard Castle Ward, Barber filled the office of Sheriff, and in 1733 became Lord Mayor. At the time of the South Sea scheme, Barber took large shares and is said to have amassed a considerable fortune. He died on January 22nd, I740.

BARKER (A.), bookseller in London, Unicorn, Fleet Street, next Sergeant's Inn Gate, 1708. In partnership with C. Smith, he published the Rev. John Harrison's Exposition of the Church Catechism, I708; a catalogue of their other publications is printed on the last page. [T.C. III. 567 ; B.M. 4257 . aaa. 47 (2).]

BARKER (BENJAMIN), bookseller in London, (I) White Hart, Westminster Hall ; (2) Judge's Head in Westminster Hall. I70I-14. Dealer in general literature. In r jor he advertised Advice to the Sceptick [T.C. III. 239]; and in I 702 he published Three discourses of Sir Walter Raleigh. He also held a share in Moll's Atlas Geographus, I709. At the end of J. A. Dubourdieu's sermon preached at Chelmsford Assizes, July I5th, I7I4, is a list of eight other books published by Barker and C. King at the Judge's Head.

BARKER (CHRISTOPHER) the Third, see Dictionary, 1641-67.

BARKSDALE (JOHN), bookseller and bookbinder in London and Cirencester, London: At (or over against) the Five Bells, New Street; between Fetter Lane and Shoe Lane. 1674-1719. Related in some way to Clement Barksdale, the Gloucestershire author. He is first mentioned in the Term Catalogues for Hilary 1674 as the publisher of a translation of Procopius. [T.C. I. I77.] Between 1675 and 1678 he published several of Clement Barksdale's translations from Hugo Grotius. Some time between this and 1680 he appears to have moved to Cirencester and set up as a bookseller, publishing in the latter year T. Beye's Epitaphia, and in 1681 Memorials of Alderman Whitmore, Bishop Wilkins $\delta^{\circ} \mathrm{c}$., and there appear to be two impressions of the latter, unless the edition was divided in half, one bearing the imprint of the London publisher, Sam. Lee, at the Feathers in Lumbard Street, $168 \mathrm{r}$, and the other 
that of John Barksdale, bookseller in Cirencester, I681. [Haz. II. 37.] Barksdale was still there in 1698 , when he published The Minister of Cirencester's Address to the Dissenters of his Parish. [B.M. T. 1047 (13).] There is no evidence to connect him with the John Barksdale, Gentleman, of MiddletonCheny in Northampton, who died in 1699 and whose funeral sermon was preached by the Rev. Thomas Hilton. [B.M. 4903. ee. 28.] Mr. Herbert Norris, in his Notes on the Booksellers of Cirencester, says that J. Barksdale died January Ioth $17 \frac{18}{19}$. [N. \& $Q$., II Ser., XI. 14I.]

BARNARD (HENRY), bookseller in London, the Bible in the Poultry, r693. There is no mention of this bookseller either in the Term Catalogues, in Dunton or in Hazlitt. He is known to have sold: (I) A Rejoynder to Mr. Daniel Williams his reply to the first part of Neonomianism Unmaskt, by Isaac Chauncy, M.A. "London, Printed for H. Barnard at the Bible in the Poultry. MDCXCIII." [B.M. T. I047 (8).] On the last leaf of this is given a list of books printed for Barnard. Briefly stated they are,(2) Examen Confectionis Pacificae... By Isaac Chauncy, M.A., (3) The Old Man's Legacy to his Daughters... Written by N. T. deceased, (4) The Banqueting House ... A Divine Poem . . . By Benjamin Keach, (5) Chirurgus Marinus ... By John Moyle senr.

BARNES (JOHN), bookseller in London, the Crown in Pall Mall, i688-i 7 II. In Easter Term, 3 James II (I688), Alexander Pope brought an action against John Barnes for trespass. [C.P.R. 3056, m. I20 r.] He is there described as stationer of Westminster. In 1696 he published $A$ New Year's Gift for Dr. Birch. [B.M. T. I047 (10).] In 1697 a small tract entitled Fasti Gulielmi Tertii was issued by him, and he was still in business in $\mathrm{r} 7 \mathrm{Ir}$.

BARNHAM (ROBERT), bookseller in London, the Goat in Little-Britain, I70I. Only known from his imprint being found on a scurrilous broadside against the Court published in 1 701. [B.M. C. 20. f. 2 (214).]

BARRETT (PHILIP), stationer in London (?) 1 702. Witnessed the will of Sir William Swann, Baronet, of Greenhithe, Kent, on November 28th, $x$ yo2. [P.C.C. I02, Barnes.]

BARRY (EDWARD), bookseller in London, 1681. Only known as the publisher of Jus Anglorum ab antiguo. [Haz. II. 203.] 
BARTLET (ROGER), bookbinder in Oxford, I674-82. In Anthony à Wood's Diary occurs the following : "Dec. 24, 1674, Th[ursday], to Bartlet, 45 . for binding 7 paper books with stained covers : to Mr. Bartlett for binding my book [i.e. Hist. et Antiq. Oxon] 7s. 6d. a piece 3 in number." [Wood, II. 299.] In a book belonging to Anthony à Wood is a note: " 7 Apr. I68I to Roger Bartlet of Oxon for binding of this book $6 d$." followed by the bookbinder's signature, "Rog. Bartlet", in evidence of receipt. [Ib. I. 249.] He was possibly a relative of T. Bartlett (q.v.)

BARTLETT (THOMAS), bookseller at Oxford, 1677. Advertised in 1677 A Philosophical Essay towards an Eviction of the Being and Attributes of God, by Seth [Ward], Lord Bishop of Salisbury. [T.C. 1. 277.] Possibly a relative of R. Bartlet $(q . v$.$) .$

BARTON (GEORGE), bookseller in Boston, Lincolnshire, I 7 Io. Sold E. Kelsall's Mistakes about moderation detected, London, I 7 Io. [B.M. 225. h. I2 (2).]

BARTON (HUMPHRY), see Burton.

BASKERVILLE (ANTHONY), bookseller in London, the Bible, against St. Clement's Church, 1688-9. His name occurs in the imprint to the Latin edition of Joseph Glanville's Saducismus Triumphatus, 1689. Mr. HiltonPrice, in his Signs of the old Houses in the Strand, notices him as being there in I688. [Middx. \& Hert. N. \& Q., II. 95.] There is no trace of him in the Stationers' Register, or in the Term Catalogues.

BASKERVILLE (LAURENCE), bookseller in London, at the Red Lion in Aldermanbury, 1688 . He and John Marsh sold The British Language in its Lustre, or a copious Dictionary of Welsh and English, by Thomas Jones, 1688, 8vo. [Haz. I. 240.]

BASKETT (JOHN), King's printer, London, Blackfriars, Oxford and Edinburgh, I709-42. Nothing seems to be certainly known of Baskett's antecedents. $\mathrm{He}$ is first heard of as purchasing the patent of King's printer for Bible printing from the executors of Thomas Newcombe and Henry Hills in 1709, and his name first appeared on a New Testament in I 712. In I7I3 he began to print the Book of Common Prayer. Four editions of the Bible appeared with his imprint in I7 5 . His next publication was an edition in two volumes imperial folio printed at Oxford (the Old Testament in I 7 I 7 and New Testament in 17 16). Dibdin called this the most magnificent of the Oxford Bibles; 
it has also been called " A Baskett-full of Printers errors"; but of its typographical beauty there could be no two opinions. In I718 Baskett mortgaged his printing materials to James Brooks, stationer, of London. It included "A very large fount of Double Pica, new, the largest in England". It seems possible that this was cut by Caslon I. In I7II Baskett acquired a third part of Robert Freebairn's gift as King's printer in Scotland, and in 1716 he obtained, in conjunction with the widow of Andrew Anderson, a fresh commission as King's printers in Scotland. Baskett appears to have allowed his share of these privileges to lie dormant until $\mathbf{2 7 2 5}$, when he set up a printinghouse in Edinburgh and produced some indifferent editions of the Bible during the next three or four years. [Lee (John), Memorial for the Bible Societies in Scotland, Edinburgh, 1824 (pp. I79-83 and App. XxxI); Additional Memorial, r826 (p. I53).] Baskett was frequently called upon to defend his title of King's printer in the courts of law, especially in Scotland, where it was stubbornly disputed by John Watson, a printer, and finally settled by a judgement of Lord Mansfield in favour of Baskett. At Cambridge he was seriously disturbed by the proposal of W. Ged to stereotype Bibles and Prayer-books, and succeeded by intrigues in damaging the success of Ged's innovation. In the year 1737 Baskett's printing office was burnt. He died on June 22nd, r742. He left three sons, Thomas, Robert, and John. His will was proved on the 23rd. Baskett desired that his body might be buried in St. Ann's, Blackfriars. To his son Thomas he left " the messuage or late dwelling house, lately rebuilt, adjoining to the King's Printing House in Blackfryers, the courtyard and other appurtenances .... also all that other piece of ground whereon part of my dwelling house stood before the fire in January 1737 and whereon part of the printing house now stands ". To his son John he left an annuity of $£ 200$. "To each of the compositors and pressmen which shall be at work in my printing house at the time of my death, ten shillings, and to each of the boys, five shillings." He directed that his patents were not to be sold but to remain in the family, "during the remainder of the several terms of years therein yet to come." His daughter Elizabeth married - Innys. [P.C.C. I76, Tremley.] Baskett was Master of the Stationers' Company in I7I4 and I7 15.

BASSET (J.), bookseller in London (?), 1693. Published an edition of the Counter-Scuffle, 1693. [Haz. II. 529.] 
BASSET (RICHARD), bookseller in London, ( $\mathrm{r}$ ) Mitre, Fleet Street, (a) near the Inner Temple Gate, $(b)$ over against Chancery Lane, $(c)$ within Temple Bar; (2) George, Fleet Street, over against Inner Temple Lane. 1697-1706. Dealer in all kinds of literature and publisher of plays and poems. In most of his publications his name appears jointly with that of Abel Roper, from which it may be inferred that there was some kind of partnership between them. His first and last entries in the Term Catalogues were in Michaelmas I697 and Trinity 1706. [T.C. III. 40, 512.]

BASSET (Thomas), see Dictionary, 1641-67; also Baldwin (T.)

BATEMAN (CHRISTOPHER), bookseller and book-auctioneer in London, (1) Bible and Crown, Middle Row, Holborn; (2) Bible and Crown, Paternoster Row, Corner shop. 1698-I 730. Probably no bookseller's shop in London was better known in the days of Swift and his contemporaries. Bateman had a large stock of new and second-hand books. He was in addition a book auctioneer of some repute, and the publisher of one or two notable works. $\mathrm{He}$ is first heard of as an auctioneer. In or about 1686 he sold a stock of philological and Greek books, and on February 18th, 1698, "the Mathematical and Physical parts of the famous library of Sir Charles Scarburgh, Kt., M.D." [Lawler, p. 183 ; B.M. 831. i. 5 (9).] Dunton says of him [p. 217]: "There are very few booksellers in England (if any) that understand books better than Mr. Bateman, nor does his diligence and industry come short of his knowledge. $\mathrm{He}$ is a man of great reputation and honesty, and is the son of that famous Bateman, who got an alderman's estate by bookselling." We have not been able to identify the father. The aldermen of the name were not booksellers. [Beaven, The Aldermen of the City of London.] But possibly " an alderman's estate " is a figurative phrase. Stephen or W. Bateman might be the man, for if they published little, they may have been large retail dealers. Christopher Bateman makes his first appearance as a publisher in Easter Term 1699, when with several other booksellers he issued a translation of $\mathrm{La}$ Bruyère's Characters. [T.C. III. 126.] Amongst other works of which he was the sole or joint publisher, may be noted Sir Hans Sloane's Voyage to the Islands Madera, Barbadoes, E.c., I 707 [T.C. III. 569], Maittaire's Historia Stephanorum insignium Gallia Typographorum, I709. [T.C.III.627] and the castrated sheets of Holinshed's Chronicle which he shared with Benj. Cowse in 1722-3, and which were the subject of some dispute. [Nichols, Lit. Anecd., I. 25r.] 
But it was chiefly as a dealer in second-hand books that he and his shop became famous. Dean Swift was among his customers. Writing to Stella in I 7 Io, he says, "I went to Bateman's the bookseller and laid out eight and forty shillings for books. I bought three little volumes of Lucian in French, for our Stella." Another of his customers about the same time was Zacharias Conrad von Uffenbach, who visited this country in 1710 and published an account of his travels in 1753-4. Extracts from this work have been given in J. E. B. Mayor's Cambridge under Queen Anne, I9II, from which the following paragraphs are taken: " i I June [I7Io] Wednesday-To Paternoster Row, the corner house, to Badman's [sic] store of old bound books, which is the best in England. Elsewhere you find few latin books, but here there were two shops full, and the floors piled up with books. The prices were however so high, that I only bought a few English historians, and Mabillon de re diplomatica, the last very cheap at 2 guineas." " I4th JulyI got out at Mr. Badman's [sic] in Paternoster Row, and asked the price of Mabillon ' de re diplomatica'. The good man asked only 30 s. supposing no doubt that the new edition had superseded the old." It is stated that Archbishop Sancroft's nephew sold his MS. papers for 80 guineas to Bateman the bookseller, from whom they were purchased by Bishop Tanner and presented to the Bodleian Library. [D'Oyly's Life of William Sancroft, vol. II. p. 90.] Gough says that the MSS. were in 300 vols., but does not give the source of his information. [Anecdotes, p. 58.] Finally Nichols [Lit. Anecd. I. 424] says : "It was said that Bateman never would suffer any person whatever to look into one book in his shop; and when asked a reason for it, would say, ' I suppose you may be a physician or an author, and want some recipe or quotation; and, if you buy it, I will engage it to be perfect before you leave me, but not after; as I have suffered by leaves being torn out, and the books returned to my very great loss and prejudice." Nichols also records [II. 6I6] that Bateman was holding book auctions as late as 1730 .

BATEMAN (STEPHEN), bookseller in London, 1686. Published Fleta Minor, the lazos of art and nature . . . with 44 sculptures, I686. [Haz. II. 470-I.]

BATEMAN (w.), bookseller in London, next the King's Head Inn, Old Change, 1684. Advertised Lucian's Dialogues in 1684 [T.C. II. 73], and in the same year published The Prerogative of the Monarchs of Great Britain asserted. [Ib. 87.] 
BATERSBY, see Battersby.

BATES (c.), bookseller in London, Sun and Bible in Giltspur Street, near Pye Corner, I709-I4. A dealer in ballads, broadsides, and all kinds of cheap and popular literature. Most of this was printed without any date, but Hazlitt [1. 436] states that The Adventures of Five Englishmen, published by Bates and others, has a date I7 I4. He is not noticed by either Dunton or Timperley, nor is his name found in the Term Catalogues. Sarah Bates was almost certainly his widow.

BATES (SARAH), bookseller in London, Sun and Bible, Giltspur Street near Pye Corner, I719-20. Almost certainly the widow of C. Bates. In I7I9 she published The Queen's Royal Cookery [Haz. III. 294], and in 1720, with Hannah Tracy, an abridged chap edition of Forde's Montelion. [B.M. 12403. a. 19.] She published an undated edition of the latter in partnership with A. Bettesworth and C. Hitch, J. Osborn, S. Birt, and J. Hodges, also other undated chap books.

BATLEY (JEREMIAH), bookseller in London, Dove in Paternoster Row, 171737. Published an edition of Quarles's Divine Poems, I7I7. [Haz. II. 506.] Batley was also the publisher of Aubrey's Miscellanies in I 221 , and shared with S. Chandler the publication of the Rev. P. Morant's Introduction to the reading of the New Testament in 725 [Nichols, Lit. Anecd. II. 204], and, with Thomas Cox, Stackhouse's History of the Bible, and also published several novels and romances. [Esdaile, pp. I89, \&c.] He died September IIth, I737. [Timperley, p. 684.]

BATTERSBY, or BATERSBY (ROBERT), printer in London, Staple Inn Gate, Holborn, 1670-1 705. On June 28th, r670, Robert Battersby entered Molière's Tartuffe in the Stationers' Register [Stat. Reg., Roxb., II. 4I3.] In February $167 \frac{6}{7}$ he was called as a witness before the Committee of the House of Lords, which was inquiring into the publication of certain libellous pamphlets, and deposed that he printed an unlicensed work called The Ladies Calling, and that he was warned by Randal Taylor that the Company were making a search on a certain day. Battersby's name does not appear in the Term Catalogue before Michaelmas I699, when an edition of Don Quixote was advertised as printed for several publishers, of whom he was one. In the following year he published a work on Primogeniture. [T.C. III. I54, I75.] 
Dunton has this record of him [p. 2I8]: "He printed The Infant's Lawyer, and Ars Clericalis, and has purchased other Copies that have sold well. He is scrupulously honest; he never abridged another mans Copy, or purchased his Author by out-bidding."

BATTERSBY (WIILIAM), sen., bookseller in London, Thames Inn Gate, Holborn, near St. Andrew's Church, 1671-r 7or. In Mich. 1671 he advertised Murtadi's Egyptian History. [T.C. I. 86.] He dealt also in maps, prints, and law books. Some time before the end of the year he took his son William into partnership and their names are jointly found in an advertisement of patent medicine in the City Mercury, June IIth, 1694. [B.M. Burney II 2 A.] The last entry made by W. Battersby sen. in the Term Catalogues was in Trin. I701. [T.C. III. 263.]

BATTERSBY (WILlLAM), jun., bookseller in London, near Holborn Bars, 1694. In partnership with his father, W. Battersby sen., q.v.

BAXTER (THOMAS), bookseller at York, 1697. Only known from the imprint to George Barker's Sermons upon several texts of Scripture, I697. [T.C. III. 23.]

BAYLY, see Bailey.

BEALE (WILLIAM), bookseller in London, Little Britain, 1690. Published His Grace the Duke of Schombergh's character, I690. [Haz. I. 373.]

BEARDWELL (B.), printer in London, in the Passage going into the Swan Yard next Newgate, 1697. Printer of The Post Boy from April 2oth, 1697. Dunton says [p. 25I]: "Mr. Beardwell and Mr. Moxon were partners all the time I employed them. The former is very generous and obliging."

BEARDWELL (L.), printer in London, next the Red Cross Tavern in Black Friars, r7r I-r2. He was the printer of The Post Boy in r 7 r.

BECHET, or BECKET (?) (w.), bookseller (?) in London, at the Royal Exchange, 1692. Sold W. Jordan's Copy Book. He was more probably a stationer only. [T.C. II. 404.] The name Bechet may be a misprint for Becket. BECKFORD ( ), widow, bookbinder (?) at Oxford, r68r. Probably widow of Ralph Beckford [Madan, p. 30.]

BECKFORD (RALPH), bookbinder at Oxford, I680 (?).

BEE (CORNELIUS), see Dictionary, $164 \mathrm{I}-67$. 
BEECHING (EDMuND), bookseller at Cambridge, 1655-89. Lived in St. Michael's parish certainly from 1655 to his death. His will, dated May 28th, was proved June I3th, I689. To his wife Elizabeth he left all his stock of books, goods, chattels, \&c., and debts. The inventory showed his stock of "Books bound \& Queres $£ 7$ ros." By Elizabeth Tillman, whom he married February 22nd, 1655 , he had nine children. This was his second marriage, as one of his other sons, John, was christened November 24 th, $16_{5}$. [Gray and Palmer, p. 127.]

BEIGLIE ( ), Mrs., bookseller in Edinburgh, in the Parliament Close, 1696. Sold John Holland's Short Discourse . . . Indian and African Company, 1696. [Aldis, pp. 94, I09.]

BELL (ANDREW), bookseller in London, (I) Pestle and Mortar over against the Horseshoe Tavern in Chancery Lane ; (2) Cross-Keys and Bible in Cornhill, near the Stocks Market. I694-I7 I5. First appears as publisher, in partnership with Jonas Luntley, of Sir George Mackenzie's The Institutions of the Laws of Scotland, I694. [Haz. II. 376.] His connexion with Luntley was brief, as in the following year he published alone Considerations on the Trade to Newfoundland. [Haz. III. I 74.] Bell's first entry in the Term Catalogues occurs in Hil. 1697 as one of the publishers of Tyrrell's History of England. [T.C. III. 4], and from that time until I 7 I h his name occurs frequently as a miscellaneous publisher. In I702 Dunton [p. I95] sold him the copyright of The Athenian Oracle, and in $\mathrm{I} 7 \mathrm{O}_{7}$ he started a monthly quarto of poems, songs, \&c., entitled The Muse's Mercury. Bell was also the publisher of the monthly critical journal, The Works of the Learned, and was agent for the Edinburgh booksellers, A. Sympson and R. Freebairn ; for the latter he entered in Stat. Reg., March 26th, I7 5, The Rudiments of the Latin Tongue, by T. Ruddiman. [Timperley, p. 607.]

BELL (E.), bookseller in London, Cheapside, at the corner of Bow Lane, r6981722. Advertised in 1698 An Historical Account of Russia [T.C. III. 64]; in 1722 his name occurs first in a list of publishers of a novel entitled The Adventures of the Prince of Clermont. [Esdaile, p. 189.]

BELL (JAMES), stationer in Edinburgh, 1676 . Named cautioner in confirmation of Andrew Anderson's will, r676. [Aldis, p. rog.]

BELLINGER (JонN), see Dictionary, 1641-67. 
BELLINGER (R.), bookseller (?) in London, Wych Street, near New Inn Gate, 1685. Only known as the publisher of a Book of Copies for learners of Round. Hand, a series of engraved plates. He may have been a print-seller rather than a bookseller. [T.C. II. 148, 158.$]$

BENBRIDGE (WILLIAM), bookseller in London, Half-Moon, Huggins Alley, Wood Street, $1683_{3}-4$. Advertised in Mich. 1683 The present state of Denmark, by G. Pierreville, and a translation of Lucian by Ferrand Spence. The last heard of him is in Mich. I684, when he advertised a sheet, probably engraved, A Description of Buda in its ancient and present state. [T.C. II. 43, 5I, 99.] Of the 5 vols. of the Lucian only $1-3,1684$, were published by Benbridge ; 4-5 bear J. Walthoe's name and are dated 1685 . [Esdaile, p. 93.]

BENCE (J.), bookseller at Wotton-under-Edge 1725 (?). A Dialogue between Honest John and Loving Kate, Part the First, n.d., was sold by him.

BENNET (F.), 1692. Hazlitt [II. 59] records an edition of N. Brady's tragedy The Rape as printed for F. Bennet in 1692 . This is a mistake for T. Bennet. [T.C. II. $4 \mathrm{Ir}$.]

BENNET (THOMAS), London agent for Oxford printers, x669. [Madan, p. 30.] BENNET (THOMAS), bookseller in London, Half-Moon in St. Paul's Churchyard ; Oxford. 1687-r 706. One of the most important booksellers of his time. He made his first entry in the Term Catalogues in Easter $x 687$ with an edition of Homer's Iliad by George Sylvanus. [T.C. II. 194.] Dunton was partner with him in the publication of Lecrose's Works of the Learned. Bennet had an extensive connexion amongst the clergy, and Bishop Atterbury, who was his friend and patron, has left this account of him: "I need not say how perfect a master he was of all the business of that useful profession wherein he had engaged himself. ... His natural abilities were very good and his industry exceeding great, and the evenness and probity of his temper not inferior to either of them. Besides he had one peculiar felicity ... that he was entirely contented and pleased with his lot, loving his employment for its own sake." He published the catalogues of Abp. Tenison's library and of Dugdale's bequest to the Ashmolean. Bennet married Elizabeth Whitewrong, daughter of James Whitewrong of Rothavestead, co. Hereford. He died on August 26th, I 706, and was buried in St. Faith's. His stock was afterwards bought by J. Nicholson, William Newton, Robert Knaplock, and Benjamin Tooke. [T.C. III. 563.] Possibly a son of the preceding. 
BENNETT (GEORGE), bookseller in Cork, I714-34. The earliest mentions of Geo. Bennett are in February I7I4, when he printed a small single-sheet periodical called The Idler, and in 1716 , when he was described as a "Bookseller in Cork". His second imprint extant is found in 1719 , on a schoolbook entitled shortly $A$ Tutor to Arithmetic. He was a member of the Cork Corporation and elected Mayor for I724. In 1734 he is described as "Alderman" and was appointed in that year to execute all printing that should be wanted for the Corporation. He also printed The Cork Neros Letter, I 723 to I 725 .

BENNETT (JAMES), bookseller in London, Paved Alley in St. James's Fields, I680. Mentioned as a disperser of unlicensed pamphlets. His wife's name was Grace. [Hist. MSS. Comm. Report XI. App. pt. i, p. 268.]

BENNETT (JOSEPH), printer in London, St. Giles, Bloomsbury, I675 (?)-9I A "Josias" Bennett, possibly the same, is mentioned in a list of printing houses drawn up in 1675 , as one who had "set up since the Act was in force". [S.P.D. Car. II. vol. 369, p. 97.] For Richard Bentley he printed in 1679 a novel entitled Fatal Prudence [Esdaile, p. $2 \mathrm{x} \mathrm{x}$ ], and in $\mathrm{x} 678$ was the printer of Huntington Divertisement. [Haz. II. 297.] In 1680 a Joseph Bennett, stationer of St. Giles, gave information against Sir Roger L'Estrange as being a Papist [House of Lords Journal, I680, p. 630], and in 1685 he printed for Charles Brome Dangerfield's Memoirs. [Haz. I1. 297.] In 169 I he was defendant in a suit brought by a certain John Smith for the recovery of a debt. [C.P.R. Mich. 3, W. \& M. 3roI, m. 372, verso.]

BENNETT (M.), printer in London, I70I-3. Printed Sir Thomas Craig's Right of Succession to the Kingdom of England, r703. [Haz. III. 50.]

BENSKIN (THOMAS), bookseller in London, (I) St. Bride's Churchyard ; (2) Green's Rents near Fleet Bridge; (3) Little Lincoln's Inn Fields. I68I-I 704. First heard of in $168 \frac{0}{1}$ as a publisher on the Protestant side during the Popish Plot. On March roth he issued the first number of The Protestant Oxford Intelligence, altered a month later to The Impartiall London Intelligence, or Occurrences Forraign and Domestick. On June 6th, I68I, the Earl of Danby moved the Court of King's Bench that Thomas Benskin, the publisher of The Phanatick Intelligence, might be ordered to find bail in $£ \mathrm{I}, 000$ to answer 
a charge of scandal against the Earl, but the bail was fixed by the Court at £500. In the same year he issued a broadside entitled The Vindication of ... James, Duke of Monmouth. [B.M. 8122. i. I. (35).] In Michaelmas Term his name first appears in the Term Catalogue as one of the publishers of a work entitled The History of the Life ... of Queen Mary. In 1684 he moved to Little Lincoln's Inn Fields, but between 1682 and 1704 he made little use of the Term Catalogues. He was the publisher of Mrs. A. Behn's comedies The Round-Heads and The City Heiress.

BENTLEY (F.), bookseller in Halifax, 1695. Publisher of The Doctrine of the Church of England concerning the Lord's Day. [T.C. II. 548.]

BENTLEY (M.), bookseller in London, 1698. Apparently no relation of Richard Bentley (q.v.) The Term Catalogue for Mich. 1697 has an advertisement of L. Hennepin's New discovery of a vast country in America . . . printed for M. Bentley, J. Tonson, \&c. [T.C. III. 39 ; B.M. (dated I698) 278. f. 36.]

BENTLEY (RICHARD), bookseller in London, Post House in Russell Street, Covent Garden, 1675-97. The well-known publisher of novels, plays, and romances, hence referred to by Dunton as " novel " Bentley. [Life E Errors, p. 292.] His name first appears in the Term Catalogue of Hilary 1675 in partnership with J. Magnes as joint publisher of a tragedy Andromeda [T.C. III. I97.] and in the following year they advertised and published the romance of Zelinda. [Esdaile, p. 329.] As J. Magnes's name appears first in all the imprints, Bentley was evidently the junior partner. In the latter part of 1678 the firm became R. Bentley and M. Magnes and so continued until 1682, when for a few months Bentley was publishing alone, but in the Term Catalogue for Michaelmas $168_{3}$ Dryden's Religio Laici was published by R. Bentley and S. Magnes [T.C. II. 50.] S. Magnes's name occurs for the last time in Mich. I688, after which Richard Bentley continued the business alone. Some time in 1688 he issued a broadside entitled The Commissioners' proposals to... the Prince of Orange, \& $c$. [B.M. 1850. c. 6(6).] In 1692 Bentley reissued some fifty novels of the preceding fifteen years, not all bearing his imprint, as Modern Novels, in xii volumes. [B.M. I2410. c. 18-29.] Letters of his in Sir H. Ellis's Original Letters of eminent Literary Men, I843, show that Bentley was both an enterprising and liberal man. Amongst other notable books published by him may be noticed John Evelyn's Sylva, and the author, writing to Dr. Richard Bentley in 1697, says that the latter's 
namesake " had sold off three impressions and was impatient for the fourth." But it is chiefly as a publisher of romances that Bentley is known, and in some "romans à clef" he adopted fictitious imprints. For example, Gabriel de Brémond's Hattige, or the Amours of the King of Tamaran, was published "For Simon the African, Amsterdam", 1680; again, The Secret History of the Duke of Alançon and Q. Elizabeth, published in $\mathrm{r} 69 \mathrm{I}$, bore the imprint "For Will with the Whisp, at the sign of the Moon in the Ecliptick", sometimes with the addition of "Cologne." [Esdaile, pp. 169, 21 5.] Bentley's name last appears in the Term Catalogue of Easter 1697 [T.C. III. 15] and he died between that date and July 6th, when his will was proved. He made his wife Katherine his sole executrix and he left a son Thomas. Among the witnesses to the will was Robert Everingham.

BENTLEY (THOMAS), bookseller in London, Crown in Little Britain, 1688-95. In 1688 , in partnership with $\mathrm{B}$. Walford, Thomas Bentley sold by auction the library of William Cecil, first Baron Burleigh, and the catalogue gives his place of business as above. After this nothing more is known of him until r695, when he married Mrs. Anne Ridley of Downham in the Isle of Ely. [Cambridge Parish Registers-Marriages-Knapwell, p. I45.] His name does not appear in the Term Catalogues.

BENTLEY (T.), stationer at Cambridge, 1679. Admitted by the Vice-Chancellor and Heads to the trade of stationer in Cambridge, 1679 , but on November Ist, 1679, he was "prohibited by the Vice-Chancellor and Heads from selling books in Cambridge till the determination of his controversy with Cambridge stationers".

BENTLEY (WILLIAM), bookseller in London, 1697. Hazlitt records The Picture of Quakerism drawn to the Life. . . By Francis Bugg, London, Printed for and are to be sold by W. Bentley ... I697. The only copy in the British Museum of that date does not give Bentley as one of the publishers. [Haz. II. 68.]

BERINGTON (E.), printer in London, Silver Street, Bloomsbury, 17 II-24. Only known as the printer of The Evening Post, I7Ir. Mentioned in Negus's List as printer for the Roman Catholics.

BERRY (E.), bookseller and engraver in London, Holborn Court, Gray's Inn, 1672-81. Dealer in maps, charts, prints, playing cards, and topographical 
works. In partnership with William Berry. In Michaelmas 1672 they announced An exact Survey of the United Provinces of the Netherlands. [T.C. I. II9.] In I68r E. Berry's name is found in the imprint of a work entitled Jus Anglorum ab Antiquo.

BERRY (WILLIAM), bookseller and engraver in London, ( $\mathrm{I}$ ) Blue Anchor, Middle Row, Holborn; (2) Globe, Strand, (a) near the New Exchange; (b) between York House and the New Exchange ; (3) Globe, between Charing Cross and Whitehall, near Charing Cross ; (4) in Cragg's Court, near Charing Cross. $1677^{-1} 703$. Dealer in maps, charts, prints, playing cards and topographical works, first heard of in I67I [T.C. 1. 80.] In the following year, in partnership with E. Berry, he announced An exact Survey of the United Provinces of the Netherlands. [T.C.1. I 19.] In 1673 he moved from Holborn to the Strand and in 1679 had moved still further west to Charing Cross. He made his last announcement in the Term Catalogues in Michaelmas, 1703. [T.C. III. 382.]

BERTRAM (WILLIAM), stationer in Cambridge, in St. Edward's parish, I693. On January 26th, 1693 the Vice-Chancellor licensed him to keep a "Common Alehouse or Tippling-house" within the Town of Cambridge. [Cooper's Annals of Cambridge, Iv. 25.]

BETTENHAM (JAMES), printer in London, St. John's Lane, $1712(?)-74$. Is believed to have been born in 1683 , but no particulars are obtainable as to his life before the year $\mathbf{1 7 1 2}$, when he married the step-daughter of William Bowyer the elder. This took place shortly before the fire which destroyed Bowyer's premises. Nichols [Lit. Anecd. 1. 65] furnishes almost all that is known about him. He refers to Bettenham as "a printer of no small eminence in his profession, which he pursued with unabated industry and reputation till the year 1766 , when he retired from business, and died Feb. 6, 1774, of a gradual decay, at the advanced age of 91 . To shew the uncertainty of human affairs, this worthy man, after carrying on a respectable and extensive business for more than 60 years, left behind him not quite $£ 400 . .$. His first wife died Dec. 8, 1716, aged 30 ; and he had a second who died July 9, 1735, aged 39." Amongst those who served their apprenticeship in his office was F. Kirkby, the successor of J. Abree the Canterbury printer and the partner of J. Simmons of that city. Bettenham will always be remembered as one of those who helped to finance William Caslon the First 
and set him up as a type founder. [Nichols, Lit. Anecd. Ir. 356, 720.] Negus in his list of printers in $\mathbf{7 2 4}$ described Bettenham as a Non-juror. Most of his work as a printer lies beyond the limit of this volume, but it may be noted that amongst other things he was the printer in $\mathrm{r} 72 \mathrm{I}$ of Vita Johannis Barwick. [Nichols, Lit. Anecd. I. 217.]

BETTESWORTH (ARTHUR), bookseller in London, Red Lion on London Bridge, I699-1737. Chiefly a publisher of divinity, though he published many novels, \&c., and, like all the booksellers on the Bridge, dealt in some questionable literature. [See Post Boy, January rith, I7Ir.] His daughter Elizabeth married Charles Hitch, bookseller of Paternoster Row, in partnership with whom her father had published many books. [Timperley, p. 7r3.]

BEVER (THOMAS), bookseller in London, Hand and Star, within Temple Bar ; (a) next the Middle Temple Gate, (b) by, (c) near, Temple Bar. r689-1712. Made his first entry in the Term Catalogues in Mich. 1689. [T.C. II. 283.] Publisher of books on a variety of subjects. Amongst others may be noticed, Alphonso, King of Naples, A Tragedy, by Geo. Powell, r69r, and England's Glory ; Or, The Great improvement of Trade in General, by H. M., I694. In 1713 he subscribed one guinea to the Bowyer relief fund. Dunton [p. 226] has this character of him: "Mr. Bever, in Fleet Street, had ever the character of being a very merciful, just, and peaceable man, never intermeddling with state matters. He is a constant hearer at St. Dunstan's church. . . . I shall only add, he has a large acquaintance amongst the lawyers, and is himself a very thriving bookseller." The premises he occupied were those once tenanted by Richard Tottell, and bore the same sign.

BiCKERTON (s.), see Bickerton (T.).

BICKERTON (THOMAS), bookseller in London, (I) Flower de Luce (or Golden Flower de Luce), St. Paul's Churchyard, I707; (2) Rose and Crown, Little Britain, I7II ; (3) Crown in Paternoster Row, 1719. I707-20. In partnership with S. Bickerton. Dealer in theological books, and book-auctioneer. On March 26th, I720 he took over the publication of The Weekly Packet, a newspaper issued by the Sun Fire Office, which had previously been published by E. Place.

BILL (CHARLES), printer (?) in London, King's Printing Office, r687-99. Son of John Bill the Second; held a share of the King's Printing Office by reversion, but he seems never to have exercised the art of printing. 
BILL (JonN) the Second, see Dictionary, 1641-67.

BILLING (R.), bookseller (?) in London, White Swan in St. Paul's Churchyard, 1703. Published, with G. Briant, W. Leybourn's Mathematical Institutions [T.C. III. 370]; but was perhaps a mathematical instrument maker and not a regular publisher.

BILLINGER (J.), see Bellinger ( J.)

BILLINGSLEY (BENJAMIN), bookseller in I.ondon, (I) Printing Press, at the entrance into Gresham College, Broad Street; over against the Church; (2) (a) within the South-west Piazza, (b) under the Piazza, of the Royal Exchange, Cornhill ; over against Pope's Head Alley. I669-1706. Although carrying on business at the sign of the "Printing Press", Benjamin Billingsley was not a printer but a bookseller. His first entry (with $\mathrm{O}$. Blagrave) in the Term Catalogues was The Epitome of the Art of Husbandry. [T.C. 1. 9.] According to Dunton [p. 230] he suffered for some years from a mental disorder during which time his wife and son managed the business. His name appears in the Term Catalogues for the last time in Trinity Term I698 [T.C. III. 83], but in 1706 he published the ninth edition of Nathaniel Strong's England's Perfect Schoolmaster. [Haz. III. 3II.] Amongst his numerous publications was A True Account of the Most Considerable Occurrences that have hapned in the Warre between the English and the Indians in Nerv England, 1676.

BIRCH (WILlIAM), bookseller in London, (r) Bible, New Cheapside, Moorfields ; (2) Blue Bible, at the Lower end of Cheapside, (a) at the corner of the Poultry, (b) at the corner of Bucklersbury ; (3) Peacock in the Poultry, (a) near Old Jewry, (b) at the lower end of Cheapside; (4) Black Swan, against St. Clement's Church, in the Strand; (5) St. Paul's Alley, over against the little North Door of St. Paul's. 1669-93. His first publication, a theological work, was entered in the Term Catalogue in Mich. 1669. [T.C.I. 18.] He was the publisher of J. Crowne's tragi-comedy, Juliana, or the Princess of Poland, $167 \mathrm{r}$, also of the Rev. Samuel Clarke's Marrow of Ecclesiastical History, 1675. In that year he issued a political broadside on the Royalist side, entitled The Triumph of Levy. [B.M. C. 40. m. Ir. (35.)] In I678 he either opened another shop or moved to the Black Swan, against St. Clement's Church in the Strand [Midd. E Herts. N. \& Q., vol. II, p. 95]. Birch is last heard of in Easter 1693 when he published Dr. Baldwin Hamey's Dissertatio Epistolaris De juramento medicorum, edited by Adam Littleton. [T.C. II. 455.] 
BIRCHALL(DANIEL), bookseller and printer in Liverpool, Castle Street, 17 I 2-22. In 1712 he published C. Owen's Hymns sacred to the Lord's Table, printed for him by S. Terry at Liverpool. By $\mathbf{r}^{22}$ he had set up a press of his own, for we find him then printing H. Wosterholme's Sermon ... for promoting the Charity School. [Liverpool Free Public Library, Liverpool Prints and Documents, 1908, pp. 333-4.]

BIRD (JOHN ?), bookseller in London, Sun in Westminster Hall, 1683-89. This bookseller is perhaps the John Bird, son-in-law to Richard Andrew, stationer, ( $q . v$.) who died in $\mathrm{r683}$. He had a stall in Westminster Hall during Easter Term r689. Two books were advertised by him in the Term Catalogue. [T.C. II. 243, 249.]

BISHOP (GEORGE), printer and bookseller in Exeter. In the Fore Street, opposite to St. Stephen's Church, 1718-20. Son of Philip Bishop, born on January Ist, 1697, and succeeded to his father's business about I718: but his careerwas a short one, as nothing more is heard of him after 1 720. [Dredge, ff. 19, \&c.]

BISHOP (M.), bookseller in Exeter, I7 7 . Widow of Philip Bishop? The Rev. W. Rayner's Sermon Preach'd in Ely Chappel at the Consecration of ... Lancelot Lord Bishop of Exeter, bears the imprint, "Exon : Printed for M. Bishop . . . г717." [Dredge, f. 45.]

BISHOP (PHILIP), printer and bookseller in Exeter, (I) Fore Street ; (2) High Street ; (3) St. Peter's Church Yard. r688-r7 16. Philip Bishop, stationer, was admitted a freeman of Exeter by apprenticeship r688-9. He appears to have lived in St. Martin's parish, as the Register has several entries of his family. [Dredge, f. ro.] The first book recorded by Dredge as published by him was a Sermon preached in the Cathedral Church of . . . Exon., by William Chilcot, M.A., on April 4th, 1697. [Ibid.] He appears to have died about 17 I6 and was succeeded by his widow (?) M. Bishop, and later by his son George, Dunton [p. 237] speaks of him as " a firm adherer to the Established Government, and a declared enemy to Popery and Slavery ... a man of strict justice, deals much and thrives of his trade".

BIXOU alias TABB (L.), printer in Limerick, 1722-23? Worked with Samuel Terry $(q . v$.) but nothing is known of him beyond the two imprints in which his name occurs, 
BLACK (J.), bookseller in London, Holborn, 1694 . Hazlitt records : Dr. Mason's Wonderful Vision. A Further. . . Relation of one Mr. Mason, minister of Water-Stafford, near Buckingham, who pretends Our Saviour appeared to him I6th April I694 . . . London, printed for J. Black in Holborn. [Haz. II. 68.] It is possible that $\mathrm{J}$. Black is a misprint for $\mathrm{J}$. Blackwell $(q . v$.) but see Blake.

BLACKBORNE (J.), bookseller in London, I68I. Only known from his imprint on a pamphlet entitled The Reformed Papist or High Church Man, I68I, Fol. [B.M. 1850. c. 6. $\left(43^{*}\right)$.]

BLACKBURY (HENRY), stationer in London, r686. Defendant in a plea of trespass brought by William Roberts in 1686. [Hilary 2-3 James II, C.P.R. 3052, m. 86.]

BLACKWELL (JAMES), bookseller in London, Bernard's Inn Gate, Holborn, 1690-4. In 1690 he published, with R. Taylor, W. Mountford's The Successful Strangers, A Tragi-Comedy ... [T.C. II. 301.] Hazlitt also records a poem by E. Ward, On the Death of the late Lieutenant General Talnach, 1694, printed for and sold by him. [Haz. III. 3I3.] The work recorded under J. Black may have been published by James Blackwell.

BLAGRAVE (OBADIAH), bookseller in London, (I) In Cornhill ; (2) Printing Press at the entrance into Gresham College, Broad Street ; over against the Church; (3) Printing Press, Little Britain; over against the Pump ; (4) (a) Bear, St. Paul's Churchyard ; near the little North Door of the Church, (b) Black Bear, or Bear and Star, St. Paul's Churchyard. 1669-9r. Probably a member of the family of Blagrave of Reading, as in 1671 he published Joseph Blagrave's Astrological Practice of Physick. He is first met with in Easter, 1669, when, with B. Billingsley, he advertised The Epitome of the Art of Husbandry [T.C. 1. 9]. In the following year he had moved to Little Britain, where he remained till 1677 when he is found at the Bear in St. Paul's Churchyard. He was the publisher of John Quarles's Fons Lachrymarum, in that year; but he dealt chiefly in works on divinity and mathematics. His last advertisement in the Term Catalogues was in Hilary Term I69r. [T.C.II. 352.] He was tersely described by Dunton [p. 292] as "plain Blagrave".

BLAGUE (DANIEL), bookseller and book auctioneer, 1691. Possibly a descendant of John Blague (see Dictionary, 1641-67.) He held a book auction on 
June I5th, I69I, at Mr. John Martin's at Guildhall Coffee House, a principal feature of which was " a number of Stitched Plays not expressed in the Catalogue" [B.M. 821. i. 9 (IO).]

BLAKE ( ), bookseller in London, 1705. Described by Dunton [p. 213] as the "father of the Company of Stationers for age and experience". See also Black ( $\mathrm{J}$.) who may be identical.

BLAND (THOMAS), printer in London, (I) near Ludgate Street; (2) near Fleet Street. I706-8. In the British Museum is a copy of the Postcript to the Post Man, of May 2oth, 1706. This was only printed on one side, but Bland secured copies of it and printed on the back, The Tryal and Examination of Dr. William Drake for writing Mercurius Politicus. Hazlitt records the following: Here is a full and true Relation of one Mr. Rich. Langley, a Glazier ... that lay in a trance, London, Printed for T. Bland near Fleet Street, $x$ 708. [Haz. IV. I52.]

BLARE (ELIZABETH), bookseller in London, The Looking Glass on London Bridge, I707. Widow of Josiah Blare. She carried on the business for a short time after his death in 1706 . In 1707 the Company of Stationers entered an action against her in Chancery, for the infringement of their patents in almanacs, \&c. [Chan. Proc. before I7I4, Bridges $\frac{270}{21}$.]

BLARE (JOSIAH or JOSEPH), bookseller in London, The Looking Glass on London Bridge, 1683-1706. Dealer in chap-books and miscellaneous literature. By his will, proved on December $3^{\text {rd, }}$ 1706, he left to his wife Elizabeth, his shop and house "known by the name or sign of the Looking Glass on the North East side of London Bridge". [P.C.C. 225 Eedes.] He was buried in St. Magnus Church.

BLISS (JOSEPH), printer at Exeter, (I) The Exchange, I705-10 ; (2) a little without the East Gate, I III-I9. I705-19. He printed, inter alia : (I) with S. Farley, A True and Impartial Account of what Occurred at the late Conference in Exon, I707 [Dredge, f. 14] ; (2) alone, for P. Bishop, Blackall's Sermon on Almsgiving, I708 [J. S. Attwood, Addenda to Dredge] ; (3) alone, J. Withers's Truth try'd or Mr. Agate's pretended Plain Truth, I 709. [T.C. III. 6ro.]

BLITH (FRANCIS), bookseller in Colchester, I702-II. In Michaelmas Term 1702 he advertised Serious Advice from a Minister to his Parishioner [T.C. III. 
318], and he also published Edward Cresfield's Duty of the subject to his prince .... In a sermon preached at the parish church of Witham in Essex on Tuesday the zoth January $17 \frac{1}{1} \frac{0}{1}$, which was advertised in The Post Boy, March 6th, $17 \frac{1}{1} \frac{0}{1}$.

BLOME (RICHARD), cartographer in London, at Mr. Kid's in the Corner of Lincoln's Inn Fields, near New [=Clare] Market, 1668-79. Perhaps a descendant or relative of Jacob Blome, q.v. Dictionary, 1641-67. On May 29th, 1663, one or the other of them entered in the register $A$ Geographicall Description of the World, written in French by Sanson, Geographer to ye King of France and translated into English, and at the same time, although the title was not entered, a translation of the works of Varenius. On the last day of July 1668 Richard Blome entered both these works again in the Register, and an advertisement of Sanson's work appeared in the Term Catalogue for Hilary 1670. Amongst his other publications was an atlas of England and Wales issued during 1673 and the fifth edition of Guillim's Heraldry in 1679.

BLOUNT, or BLUNT (CHARLES), bookseller in London; (I) Black-Raven between Worcester House and the Savoy, near the Bear Tavern, Strand; by the New Exchange ; (2) The Catherine Wheel, Charing Cross. 1678-84. Publisher of medical books, plays and novels. Amongst the latter may be noticed The Mock Clelia, advertised in Mercurius Civicus, April 22nd, 1680, and A. Oldys's Fair Extravagant, I68I [T.C. I. 46I]. In the same number he also advertised a translation of one of the novels of Cervantes, called The Jealous Gentleman of Estremadura. His last advertisement was in the issue of Michaelmas I684. [T.C.II. 97.] Blunt moved to the Catherine Wheel about I680.

BLOW (JAMES), printer in Belfast, 1 706-58. Succeeded Patrick Neill. His earliest extant imprint is dated 1706. While very largely of a religious character the output of his press included secular works. Blow was connected by marriage with Geo. Grierson who married his widowed sister. The allegation that Blow printed a Bible in $\mathbf{1 7 0 4}$ is now admitted as untenable. Blow did not claim to do so but he certainly did claim in an advertisement of works printed and sold by himself an edition of the Holy Bible in several vols. and the N.T., but no copy is extant or recorded elsewhere. The edition of I 757 commonly called "Blow's Bible" is the earliest one extant from his press. BLUNT, see Blount. 
BODDINGTON (M.), bookseller in London, Duck Lane, r7I1-25. Published in 1711 in partnership with N. Boddington, Thos. Lydal's Accomptant's Assistant. In 1722 the twentieth edition of the first part of Bunyan's Pilgrim's Progress was printed by A. Wilde for M. Bodington. [B.M. 44I4. de. 27.]

BODDINGTON (NICHOLAS), bookseller in London, Golden Ball, Duck Lane, 1687-1717. This bookseller was perhaps a descendant of George Boddington (1648). He began as a publisher in I687, when he advertised The Gentleman's new Jockey or Farrier's approved guide. [T.C. II. 188.] In 1693 he published the thirteenth edition of the First Part of Bunyan's Pilgrim's Progress for R. Ponder. In a law suit instituted in 1697 by Nathaniel Ponder, who held the copyright, against Thomas Braddyll, Boddington deposed that he bought ten thousand copies of this edition and paid Braddyll at the rate of five shillings per ream for them, although he had agreed with Ponder that he was to have them at four and sixpence a ream. Boddington gave his age as forty-five or thereabouts. Dunton [p. 209] has the following account of him: "By an industrious management he has gathered a good estate, and makes a considerable figure in the Parish where he lives. He deals much in Bibles, Testaments and Common Prayer Books. He purchased Mr. Keach's Travels of true Godliness of me, and deals much in the country." From I7II he was publishing in partnership with M. Boddington $(q . v$. ) who succeeded him.

BODVELL or BODRELL (PETER), see Dictionary, 1641-67.

BOLDERO (ARTHUR), bookseller in London, Mitre, Mitre Court, Fleet Street, near the Inner Temple, 1677. Only known by a little octavo called Poor Robin's Visions, which he published in 1677. [T.C. 1. 283 ; Haz. I. 36r.]

BOLTON (s.), bookseller in London (?) $17 \mathrm{I} 3$. Publisher of the sixth edition of J. Arbuthnot's Complete Key to Law is a Bottomless Pit, 17 13. [Esdaile, p. 152.]

BONNY (wILlIAM), printer in London and Bristol: Bristol, $(x)$ Tower Lane, 1695 ; (2) Near the Tolzey, 1699 ; (3) Small Street, 1703 ; (4) Corn Street. 1691-1714. Began business as a printer in London and was employed by John Dunton to print Baxter's Directions to the Unconverted, Cotton Mather's Tryals of several Witches, and Dunton's own Pleasant art of Money Catching. He is favourably mentioned for his just dealing by Dunton [pp. 247-8], who suggests 
that his migration to Bristol was due to money losses. This took place in the early part of 1695 , the Chamber of the City coming to the conclusion that a printing press might be useful in several respects, but not being disposed to allow a "foreigner" to compete with local booksellers in their special business, granted him the freedom on condition that he dwelt in the city and exercised no trade save that of a printer. His first book printed in Bristol was $A n$ Essay on the State of England in relation to its Trade, its Poor and its Taxes. "By John Cary, Merchant in Bristoll; Bristoll, Printed by W. Bonny for the author and are to be sold in London.... Also by Tho. Wall and Rich. Gravett near the Tolzey in Bristol, Novem. I695." In 1696 he printed (I) a broadside entitled, The Humble Presentment of the Grand Inquest at Mid-summer Sessions; (2) Mr. John Cary's Proposals for the better maintaining and Imploying the Poor of the City of Bristoll; and (3) The Banner of Corah, Dathan and Abiram displayed ... Sermons preach'd at Bristol, by John Moore. In 1702 he became the editor and publisher of a newspaper called The Bristol Post Boy which is believed to have appeared in November, but the earliest known copy of which is that of August I2th, 1704. In one of its issues he announced that he was ready to buy old rope and paper stuff, and to sell Bibles, Welsh Prayer Books, paper hangings, music, maps, blank ale licenses, and blank commissions for private men of war; and in May 1712 he had very good Bridgewater peas and excellent charcoal for sale. The Post Boy cannot be traced beyond May 1712. Another of his publications was the Rev. Arthur Bedford's Evil and Danger of Stage Plays, 1706. When Dunton wrote (1703) Bonny was "stark blind".

BONWICKE (HENRY), bookseller in London, Red Lion, St. Paul's Churchyard, 1677-1706. Son of the Rev. John Bonwicke and uncle of Ambrose Bonwicke the younger, whose life under the title of $A$ Pattern for Young Students, was published by Professor Mayor in 1870. Dunton writes of him [p. 216] "I do not think there is an honester man in London, or one that is more zealous for the church. He served his time with Mr. Benjamin Tooke." He dealt chiefly in works of divinity but published also medical books and books on music. He died in I706. [Nichols, Lit. Anecd. v. 119.] Two letters from him to Strype are printed in $N$. \& $Q$., August 29th, 1859, p. 343. Rebecca Bonwicke (q.v.) may have been his widow.

BONWICKE (JAMES), bookseller in London, ( $x$ ) Hat and Star, St. Paul's Churchyard; (2) Red Lion, St. Paul's Churchyard. 1699-1714 ? His relation- 
ship to Henry Bonwicke is not clear. His first entry was of a City sermon, in I699. [T.C. III. 134.] After the death of Henry Bonwicke he moved to the Red Lion and was in partnership with Rebecca Bonwicke. They were still publishing in I7II. In I7I4 James subscribed for Walker's Sufferings of the Clergy.

BONWICKE (REBECCA), bookseller in London, Red Lion, St. Paul's Churchyard, I 706-II ? Perhaps the widow of Henry Bonwicke. She was joined after his death by James Bonwicke, and they were still publishing in I 7 II and probably later.

BOOMER (T.), bookseller in London, White Horse in Ludgate Street, 1686. His name is found in the imprint to The Book of Bertram, priest and Monk of Corby. [T.C. II. I64.]

BOSVILLE (ALEXANDER), bookseller in London, The Dial in Fleet Street, $169 \frac{6}{7}$; (2) The Dial and Bible in Fleet Street, 1703. 1696-1709. Publisher, largely of broadsides. Identical with Dunton's "Mr. Boswill" [p. 210]. His first appearance in the Term Catalogue is in Mich. 1696. [T.C. II. 599.] In the same year he published Motteux's comedy Love's a Jest. [T.C. II. 602.] $\mathrm{He}$ is last met with in the Term Catalogues in Hil. r709. [T.C. III. 630.] His shop was taken by Edmund Curll in 1711 .

BOTHAM (w.), printer in London, Jewin Street, r 700-25. Printed Dampier's New Voyage round the World for James Knapton. In I $7 \mathbf{I}_{3}$ he contributed to Bowyer's relief fund, and in $\mathbf{1 7 2 4}$ is mentioned in Negus's List of Printers as "well affected to King George". [Nichols, Lit. Anecd. 1. 290.]

BOUGES(J.), bookseller(?) in London, Castle in Westminster Hall, r 700. Appears to have had a stall in Westminster Hall in Mich. 1700, when he advertised in the Term Catalogue $A$ new book, wherein is given the whole ... Account the Scriptures gives of the Deity, $\mathcal{E}^{\circ}$ c. [T.C. III. 212.] It seems doubtful if he was a bookseller.

BOULTER (ROBERT). See Dictionary, I64I-67. Still in business in 1679, when he published, or at least sold, Bedloe's Narrative of the Burning of London. In 1674-5 the widow of Thomas Underhill transferred to him all her late husband's copyrights, most of these being works of divinity. [Stat. Reg., Roxb., 11. 64.] His name appears in the Term Catalogues for the last time in Hil. 1683. [T.C. II. 4.] See Bowter (R.). 
BOURN (SAMUEL), bookbinder in London, c. 1 y00? Described by Dunton [pp. 258-9] as just to those who employed him, but of loose character, and as coming to an untimely end.

BOURNE (CHARLES), printer in York, within the Coffee House Yard, 1721-4. Successor to Grace White. Continued the publication of the York Mercury. On June 24th, I721 he married Alice Guy at St. Michael the Belfry, but he died in August 1724. His widow shortly afterwards married Thomas Gent (q. v.).

BOURNE (THOMAS), see Diclionary, 1641-67.

BOURNE (ZACHARIAH), bookseller and book auctioneer in London, 1678 . Is said by Lawler to have held the third book auction in England, when he sold the library of the Rev. William Greenhill, pastor of Stepney, in February 1677. [Lawler, Book Auctions in England, p. 117 ; B.M. 821. i. 1. (3).]

BOWEN (J.), bookseller in London, 1681. Hazlitt records A Poem (by way of Elegie) upon Mr. Stephen Colledge, 1681, printed for him. [Haz. II. 134.]

BOWERS (JOSEPH), bookseller in London, Crown in Long-Acre, $168 \frac{8}{9}$. His imprint is found in a pamphlet entitled, A Breviate for the Bishops, By a person of Honour. [B.M. T. 1702 (5).]

BOWIS (TH.), bookseller in London, 1683. Published a poetical broadside entitled The Sham Office, 1683. [B.M. 1875. d. 6 (68).]

BOWLES (JOHN), printseller in London, Black Horse, Cornhill; and [in the Strand] over against Devereux Court, without Temple Bar, 1709. Arber states [T.C. III. 70r, Index] that John and Thomas Bowles sold G. de l'Isle's map [Theatrum Historicum] ; the announcement referred to [111.647] mentions neither, but their names appear on the map itself [B.M. maps 100 (3).].

BOWLES (thomas), printseller in London, St. Paul's Churchyard, I 709. See Bowles (John).

BOWMAN (FRANCIS), see Diclionary, 1641-67.

BOWMAN (THOMAs), bookseller at Oxford, 1664-78. See Dictionary, 1641-67. In Trinity Term 1672 he published for R. Bohun, Fellow of New College, $A$ Discourse concerning the origin and properties of Wind [T.C. I. 112], and in 1678 a book of Songs, composed by H. Bowman, " Philo-Musicus ", possibly 
a relation. [T.C.I. 319.] His books were sold by auction at Oxford in February 1686. [Life and Times of Anthony Wood, Oxford Hist. Soc. vol. III, p. 213.]

BOWTELL (WILLIAM), printer in London, (I) Golden Key in Fleet Street, near Mitre Court ; (2) Star, Cheapside, near Mercers' Chapel, r675-9. Bowtell's name occurs in a List of Printing Houses in London, drawn up in March 1675, as one of those who had "set up since the Act was in force" [S.P.D. Car. II, vol. 369-97]. His name appears in the Term Catalogue of Trinity Term, 1676, as selling a medical work [T.C. I. 246]. Nothing is heard of him after 1679 [T.C.I.342]. Dunton [p. 293] calls him "generous Bowtel". He was possibly a descendant of Stephen Bowtell, 1643-64. [See Dictionary, 1641-67.]

BOWTER = BOULTER ? (ROBERT), stationer in London and Edinburgh, $\mathbf{x} 687$. Will registered in Edinburgh, July 22nd, 1687. [Aldis, p. 109.] See Boulter(R.).

BOWYER (EDWARD), stationer in London, 1686. His name occurs in a lawsuit in this year. [C.P.R. 3042. m. 511 , recto.]

BOWYER (JONAH or JONAS), bookseller in London, Rose, Ludgate Street, (a) the corner of St. Paul's Churchyard, $(b)$ near the West End of St. Paul's Churchyard, 1705-22. Nichols states that this bookseller was no relation to William Bowyer the printer. He succeeded W. Hawes at the Rose in 1705 , and his first publication was a divinity book [T.C. III. 436.] In 1713 he gave a subscription of two guineas to the Bowyer Fund. Lintot is said to have bought of him a half share in Lauderdale's Virgil for $£ 57 \mathrm{~s} .6 \mathrm{~d}$. [Nichols, Lit. Anecd. VIII. 294.] In September 1722 he gave Harley some papers. [Ib. I. 9.]

BOWYER (WILLIAM), the elder, printer in London, ( 1 ) White Horse in Little Britain ; (2) Dogwell Court, Whitefriars. 1699-1737. Son of John Bowyer, citizen and grocer of London, by Mary daughter of William King, citizen and vintner of London. Born in 1663, apprenticed to Miles Fletcher, printer, in I679, and made free of the Company of Stationers in 1686. By his first wife he had no issue. He married secondly Dorothy, daughter of Thomas Dawks, printer and widow of Benjamin Allport, bookseller. In 1699 he was in business as a printer at the White Horse in Little Britain. In the same year he removed to Dogwell Court, where on January 29th, $17 \frac{1}{1} \frac{2}{3}$ a fire destroyed his printing house with his plant and the MSS. and sheets of many important books. A subscription, amounting to $£ 2,539$, by Bowyer's fellow printers and the booksellers, was collected for his relief. Most of the finest books of the 
time are the work of the Bowyer press. Negus calls Bowyer a Non-juror. In 1722 he took his son William into partnership. Bowyer died December 27 th, 1737, and was buried in the church of Low Leyton, Essex. [Nichols, Lit. Anecd. ; D.N.B.]

BOWYER (WILLIAM), the younger, printer in London, ( $r$ ) Dogwell Court, White Friars, I 722-67 ; (2) Cicero's Head, Red Lion Passage, Fleet Street, 1767-77. 1722-77. Only son of William Bowyer the elder, q.v., by his second wife; born on December rgth, r699. Most of his career lies outside our period, but a brief account may be given of "the most learned printer of the eighteenth century." He entered St. John's College, Cambridge, as a sizar, in 17 16, and won a Roper Exhibition there, but did not take a degree. While still at Cambridge he began to assist his father in the work of reading for the press, and in $\mathbf{1 7 2 2}$ was taken in as a partner ; he continued as " corrector ", his father retaining the management. In 1728 he married Anne Prudom, his mother's niece. At the elder Bowyer's death in 1737 he carried on the office alone. In 1729 the firm had been appointed printers of the Commons' Votes, and in 1736 printers to the Society of Antiquaries. The younger Bowyer was soon elected a Fellow of the Antiquaries, and contributed many papers, which were collected and published in 1785 by John Nichols. In 1754 he entered into a partnership with a near relative, James Emonson, which lasted till I757, when John Nichols, then aged I2, was placed under him, and was soon entrusted with the management of the office, becoming his partner in 1766 . He died on November I8th, I777, aged 77. Nichols's Literary Anecdotes is an expansion of a memoir of the two Bowyers with an annotated list of their productions.

BRADDYLL (THOMAS), printer in London, r680-1704 (?) Braddyll is first heard of in 1680 , when he printed for Robert Clavell The Rights of Bishops to judge in Capital Cases in Parliament cleared, and in the following year for the same bookseller The Annals of King James and King Charles the First. [Haz II. 50, III. 87.] In r680 Nathaniel Ponder, in the fourth edition of Pilgrim's Progress, accused Braddyll of printing surreptitious and unauthorized editions of the book and spoke of him as a "land pirate". At the same time he appears to have subsequently employed Braddyll to print an edition for him, as appears by a series of documents in a law suit which Ponder brought against Braddyll in 1697. According to the story there told, he gave Braddyll an order to print an edition of ten thousand copies at four shillings and sixpence 
a ream, and he accused Braddyll of defrauding him, and further declared that he was the author and printer of the Third Part, in which by transporting a great part of the original work, especially the titles, he hindered the sale of the plaintiff's copies. Braddyll in reply gave a complete answer to these charges, and further stated that while Ponder was a prisoner for debt in the King's Bench Prison he (Braddyll) had spent a sum of $£$ I4 on behalf of Ponder's son. He denied having anything to do with the publication of the Third Part of The Pilgrim's Progress. Dunton [p. 25I] gives the following character of Braddyll : "Mr. Braddyll is a first rate printer and has always been a very active diligent man. $\mathrm{He}$ is religiously true to his word and faithful to the booksellers that employ him.... He was once a good friend to Sir R. L'Estrange when matters looked a little dark upon him." In I 704 Braddyll was the printer of the fourth edition of Plutarch's Morals for J. Taylor [T.C. III. 4I 7] after which nothing more is known of him.

BRADFORD (JоHN) printer in London, (I) Bible in Fetter Lane ; (2) Little Britain; (3) New Street, without Bishopsgate ; (4) Bible, in Westmoreland Court. I685-I709. There was more than one printer of this name in London in the latter part of the seventeenth century, and it is difficult to distinguish them. There was first John Bradford, brother of William Bradford the Quaker, and it seems probable that the work entitled, The Protestant Martyrs; or the Bloody Assizes, 1685, came from his press. John Bradford was present at his brother William's marriage to Elizabeth Sowle in February 1685, and he is believed to have subsequently gone to America. Another John Bradford is found between 1697 and 1709 printing theological books. [T.C. III. 36, 122.] In 1704 he printed Proceedings at the Old Bailey, in which his imprint is given as the "Bible in Westmoreland Court". J. How refers to John Bradford as a printer of other men's copies. [Some Thoughts on the present State of Printing and Bookselling, p. I2.]

BRADLEY (JOB), bookseller in Chesterfield, I725-98. In 1725 he sold Charles Cotton's Wonders of the Peak. [Haz. III. 49.] Later he became a printer as well as a bookseller, and served the office of Alderman of Chesterfield, where he died in February 1798. [Nichols, Lit. Anecd. 111. 672.]

BRADLEY (WILLIAM), bookseller in London, Three Bibles, Minories, I67o. Sold Grammaticus Analyticus, 1670, a Iatin Grammar composed for the use of the Free School in East Smithfield. [T.C. I. 43, 49.] 
BRADWELL (THOMAS), printer in London, 1681. Defendant in an action for assault brought by Bartholomew Sprint, bookseller, against several printers and booksellers of London and Oxford in I68I. Details are wanting. [C.P.R. Trinity 33 Chas. II. 2992. m. 265.]

BRAGG (BENJAMIN), printer and bookseller in London, (I) White Hart, Fleet Street, over against the end of Water Lane ; (2) Blue Ball, Ave Mary Lane, near Ludgate Street; (3) Black Raven in Paternoster Row, over against Ivy Lane End. 1694-1709? Began business as a bookseller in Fleet Street in 1694, amongst his publications in that year being Miscellaneous Letters and Essays on several subjects . . by several Ladies and Gentlemen. [T.C. II. 512.] He then disappears from the Term Catalogues for ten years, his next appearance being in Hilary 1704, when he published An Account of the Proceedings of the Parliament of Scotland, May 6th, I703. [T.C. IIr. 39r.] He was the printer of a broadside entitled $A$ New Express from Holland, July 12th, 1 703 , [Bibl. Lind., Broadsides, No. 840.] He had then moved to Ave Mary Lane. where he published several of Defoe's writings. In I 706 he moved again to Paternoster Row, and between that date and 1709 he published numerous books of all kinds. Dunton, whose Whipping Post he printed in 1706, has [p. 210] this character of Bragg: "He was formerly a Booksellerand is now a publisher in Ave Mary Lane. He has been unhappy ... yet . . . is of a soft, easy, affable temper .... and being just in his dealings is like to have constant employment." Hazlitt notices several books without dates, with Bragg's imprint. [I. I65, II. 282.]

BRAY (WILLIAM), bookseller in London, (I) in Exeter Court near Exeter Exchange in the Strand ; (2) Bell and Dragon, (a) at Charing Cross, $(b)$ between Charing Cross and Whitehall. r709-20? His name is first met with in the Term Catalogue for 1708-9 as the publisher of Reflections on men's prejudices against Religion. [T.C.IIr.6ro]. He may or may not have been related to the Rev. Thos. Bray, Minister of St. Botolph's, Aldgate, whose funeral sermon on a Mr. John Dent he published in 1709. [T.C. III. 637.] He also issued an undated reprint of Terra Australis Incognita, 16I7. [Haz. 1. 18.]

BREACH ( ), Mrs., see Dictionary, 1641-67.

BRENT (JOHN), printer in Dublin, (I) at the Post-Office-Coffee-House in Fishamble Street ; (2) at the back of Dick's Coffee-House (?) ; and in Cork. 
I69I-I700? Two imprints of this printer dated at Dublin in I69I are extant, then he is found in Cork in the same year, but in 1697 he is again in Dublin printing in partnership with J. Brocas $(q . v$.$) and S. Powell at the Post-Office-$ Coffee-House in Fishamble Street. In 1698 we find as an imprint " J. B. \& S. P." clearly indicating that either John Brent or John Brocas was in partnership with S. Powell in this year; but in 1699 each of these three printers has his own imprint separately as if they had severed all partnership. There occurs, however, one imprint of " J. B. \& S. P." in 1699, and the place of printing is given as " at the Back of Dick's Coffee-House ", and this place forms the place of imprint in 1700 without any printer's name and " J. B. \& S. P." also occurs in 1700 . So possibly John Brent was still at work in 1700 ;

BREWSTER (ANN), see Dictionary, 1641-67. Widow of Thomas Brewster. In the Proceedings in the House of Lords, $167 \frac{6}{7}$, about libellous pamphlets, she was said by Mearne to be of "Cocking's Conventicle", and was more than once in trouble for printing or causing to be printed books against Church and State.

BREWSTER (EDWARD), see Dictionary, 1641-67.

BRIANT (G.), bookseller (?) in London, King's Head, Cornhill, near the Royal Exchange, I703. Published, with R. Billing, W. Leybourn's Mathematical Institutions [T.C. III. 370]; but was perhaps a mathematical instrument maker and not a bookseller.

BRICE (ANDREW), printer in Exeter, Head of the Serge-Market, in South-gate Street; and in Truro. I7 $14-73$. Only the early part of the career of this well-known printer comes within the scope of this work : but it may be of interest to give an outline of his life as given in Timperley. Andrew Brice was born at Exeter in 1690 of parents neither low nor eminent, who designed him for a dissenting minister and gave him a grammatical education. But at the age of seventeen some other vocation had to be found for him and he was apprenticed to Joseph Bliss the Exeter printer $(q . v$.$) for five years.$ He ran away, married, and enlisted as a soldier; but friends procured his discharge, and in I7I4 he commenced business as a printer, having only a fount of Great Primer for everything, including a newspaper, called The Post-Master, or the Loyal Mercury, begun in $17 \mathrm{I} 8$, for which he carved the title in wood. Brice became involved in law suits and for seven years was 
confined to his own house as a debtor. He appears to have carried on his printing business nevertheless. He employed women in his printing office. At the time of his retirement from business, he was the oldest master printer in Fngland. He died November 14 th, 1773 , aged 83. At one time Brice had a press at Truro, Cornwall, but the business did not suceed and he removed the printing material to Exeter.

BRIDGE (D.), printer in London, 1706 , see Bridge (S.).

BRIDGE (s.), printer and bookseller in London, ( $\mathrm{I}$ ) in Austen Friars, near the Royal Exchange ; (2) Little Moor-Fields. 1699-I724. In Hil. 1699 F. Saunders and T. Bennet advertised the fourth part of the Rev. W. Nicholls's Conference with a Theist, pointing out at the same time that the third part, which bore the imprint, "Printed by S. Bridge, and sold by Flizabeth Whitlock," was a surreptitious edition. [T.C. III. ro6.] In I700 Bridge succeeded R. Janeway as printer of The English Post. At some date, not clearly specified, S. Bridge was joined by $\mathrm{D}$. Bridge, and together they printed, for John Lawrence, Isaac Watts's Horae Lyricae, 1706. Samuel Negus in his "List of Printing Houses", 1724, mentions among those well affected to King George, "Bridge, Little Moor-Fields" showing that one of the partners was still at work at that date.

BRIDGES, BRUGES, or BRUGIS (HENRY), see Dictionary, 164I-67.

BRIGGS (PHILIP), see Diclionary, $164 \mathrm{I}-67$.

BRIGS (в.), bookseller in London, near Paternoster Row, x707. His imprint occurs on Lord Haversham's Speech in the House of Peers . . Nov. I5th, I705, printed in 1707 .

BRINGHURST (JOHN), printer and bookseller in London, the Book in Gracechurch Street, near Cornhill, r680-4. Apprenticed to Andrew Sowle; set up a press for himself about I680. Became a printer of Quakers' books. Amongst the resolutions passed at their Monthly Meeting of February $\mathrm{I}$ ith, 1681, was the following: "A book entituled "the life of Christ magnified in his minister, by certaine testimonyes concerning his faithfull servant Giles Barnardiston ' read and given to John Bringhurst to print in octavo in pica." In 1682 he printed The Present State of Carolina, with advice to the Setlers, By R. F. [B.M. B. 670 (8)] ; also George Fox's The Devil was and is the old Informer against the Righteous, 1682 [B.M. T. 407 (10)]; in 1683, An Abstract 
of a Letter from Thomas Paskell in Pennsilvania [Bodl. Ashm. G. I3 (37)], and Francis Estlacke's Bermuda's Preacher proved a persecutor, Being a just Tryal of Sampson Bond's book entituled, A Publick Tryal of the Quakers. An edition of George Fox's Primer was printed by him in 1684. Bringhurst's name does not occur in the Term Catalogues.

BRISBANE (WILLIAM), printer in Edinburgh, 1670 . Will registered July 28, I670. [Aldis, p. rog.]

BRISCOE (SAMUEL), bookseller in London, Russell Street, Covent Garden, (a) over against Wills's Coffee House, $(b)$ at the corner shop of Charles Street. 169I-1705. First heard of in Mich. I69I, as one of the publishers of a translation of Suetonius. [T.C. II. 38r.] He published numerous plays and also two novels, The Siege of Mentz [B.M. 635. a. 5 (I)], and The Female Gallant, both issued in 1692. [T.C. II. 402.] His name appears in the Term Catalogues for the last time in Hil. I696. [T.C. II. 57x.] He was the publisher of the and ed. of Richard Blome's Art of Heraldry, 1693. Dunton [pp. 292-3] refers to him mysteriously as "revived Briscoe, who has printed for Dryden, Wycherley, Congreve, \&c., and by contracting a friendship with Tom Brown, will grow rich as fast as his author can write or hear from the Dead, so that honest Sam does, as it were, thrive by his misfortunes, and I hear has the satisfaction and goodness to forgive those enemies who are now starving, as a judgment upon them, for attempting his overthrow."

BRISSENDEN (MRS.) bookseller (?) or stationer at Chatham, 1699. Her name appears in an advertisement of Edward Brown's sermon preached on the occasion of the Kentish Feast on November I6, in the Flying Post of December and, as one of those from whom the book might be obtained. It does not appear in the imprint.

BRIXEY (JoshuA), stationer in London, Clement's Inn Gate, 1694-5. His name occurs in an advertisement of the sale of Blank Warrants of the Quarterly Poll Tax in the London Gazette, April 3oth-May 3rd, 1694. In Easter, 1695, his name appears amongst a number of publishers of The Law against Bankrupts. [T.C. II. 549.]

BROCAS (ABISHA), see Dictionary, 1641-67; also Dredge, pp. 8, 61, 93-4.

BROCAS (JOHN), printer in Dublin, (I) Fishamble Street; (2) Skinner Row ; (3) School House Lane. 1696-I 707. First met with in 1696 in partnership 
with Cornelius Carter in Fishamble Street. In 1697 he is found with J. Brent and S. Powell at the Post Office Coffee House in that street, and they executed some Parliamentary and Government printing. Dunton [p. 522] speaks of Brent, Powell and Brocas as partners, and says that " no man . . . better understands the Noble Art and Mystery of Printing than John Brocas in Skinner Row". He continued in business until 1707 .

BROME (CHARLES), bookseller in London, (a) Gun, St. Paul's Churchyard, (b) at the West End of St. Paul's Churchyard, $(c)$ at the West End of St. Paul's in Ludgate Street. 1684-I 7 I I. Possibly son of Henry Brome. He succeeded Joanna Brome, the widow of Henry, at the Gun, in I684. From this time until I7II, his name is constantly in the Term Catalogues, and he was a publisher of all kinds of literature. He is last heard of in the following advertisement in the Daily Courant of January and, I 7 I I [i.e. I $7 \frac{10}{11}$ ] : "The four following Books printed for C. Brome at the Gun, the West end of St. Paul's Church: (r) The Compleat Gamster; (2) Geographical Cards on Copper plates; (3) The Presbyterians, Anabaptists, Independants, Quakers, E'c., lively represented on a copper cutt ; (4) The Dissenters sayings in their own words."

BROME (HENRY), See Dictionary, I64I-67. Still publishing in 1681. [T.C. I. 434.] He appears to have died in that year, and was succeeded by his widow Joanna.

BROME (JOANNA), bookseller in London, Gun, St. Paul's Churchyard, 1681-3. Widow of Henry Brome. She occurs frequently in the Term Catalogues from Easter I681 to Trin. 1683. [II. 437, III. 32.] She was succeeded in 1684 by her son (?) Charles Brome.

BROMWICH (WILLIAM), bookseller in London, Three Bibles, Ludgate Street, 1677-80. In Trin. 1677, he advertised Richard Baxter's Poor Man's Family Book. [T.C. I. 285.] He published several astrological books for John Partridge in $1679-80$, one of which, Vox Lunaris, is not entered in the Term Catalogues, in which his name appears for the last time in Hil. 1680. [T.C. I. $3^{85}$.]

BROOKE or BROOKS (JAMES), bookseller in London, Anchor and Crown on London Bridge, 1702-50. In the English Post of August 14-17, 1702, this stationer's name occurs as agent for the sale of a remedy for toothache. In 1718 Baskett, the King's printer, mortgaged his letter-presses and other stock at Oxford to Brooke for a loan of $£ 4,000$. [Athenaeum, September 5 th, 
1885.] In the same year Brooke is found selling The Historical Register, published by the Sun Fire Office. He died December $5^{\text {th }}, 175^{\circ}$, leaving a sum of $£ 50$ to the poor of the Stationers' Company. [Timperley, p. 680.]

BROOKE (ЈOHN), bookseller at Coventry, I67I. In 1671, A Funeral Handkerchief by the Rev. Thomas Allestree, rector of Ashow, Warwick, was. advertised as "printed for J. Wright at the Globe in Little Britain and John Brooke in Coventry", but the imprint ran "London, Printed for the Author. Anno Dom. I671." [T.C. I. 79.]

BROOKE or BROOKS (JOHN), stationer in London, The Ship near the May Pole in the Strand, I697-I7II.

BROOKE (NATHANIEL), see Dictionary, 164I-67.

BROOKS (E.), bookseller in London, 1682. Published A True Account of the Last Speeches ... of Christopher Vrats, George Boriskie and John Sterne ... Guilty of the ... murther of Thomas Thinn Esq., I682. [Haz. I. 422.] Timperley also says that E. Brooks is found in the imprint to The Loyal Impartial Mercury. Dunton [p. 292] mentions " military Brooks".

BROOKSBY (ELIZABETH), bookseller in London, Golden Ball, Pye Corner, r 703 . Hazlitt [IIl. I96] records a copy of John Philips's English Fortune Tellers with the imprint, "London. Printed for E. Brooksby ... I703." She was probably the widow of P. Brooksby.

BROOKSBY (PHILIP), bookseller in London, ( $\mathrm{I}$ ) next door to the Ball, in West Smithfield, near to the Hospital Gate; (2) Golden Ball, West Smithfield, near the Hospital Gate; (3) Golden Harp and Ball near the Bore Tavern in Pye Corner. I672-96. Dealer in all kinds of popular and cheap literature such as ballads, chap-books, pamphlets, romances and song-books. He did not avail himself much of the Term Catalogues, where his first entry does not appear until Easter I673. [T.C. I. I34.] In the previous year he had published several pieces. [Haz. H. 3I7, I. I75, III. 30.] In I683 he had two shops, and amongst the ephemera to be found there were several illustrated poetical broadsides on the great frost and the fair held on the frozen Thames that winter. [B.M. C. 20. f. $2(160,161)$.] His last entry in the Term Catalogues was in Easter 1696. [T.C. II. 583.] He was succeeded by his widow Elizabeth. The Soldier's Fortune, "printed for T. Brooksby at the Golden Ball, Pye Corner ", n.d., is probably a misprint for P. Brooksby. [Haz. H. 566.] 
BROOKSBY (T.), see Brooksby (Philip).

BROTHERTON (JOHN), bookseller in London, Bible, Threadneedle Street, near the Royal Exchange, 1718-25. Began publishing about 1718, chiefly novels. [Esdaile, pp. 185, 198, 329.] In 1725 he issued $A$ Short Explication of such Foreign words as are made use of in Musick-Books. [Haz. II. 410.]

BROUN (ROBERT), see BROWN (R.), stationer at Edinburgh, r649-85? in Dictionary, $164 \mathrm{r}-67$.

BROWN, or BROWNE (CHARLES), printer and bookseller in London, 1682-1 707 . Printer of and dealer in popular literature, such as almanacs, ballads and chap-books. In 1682 he issued a ballad entitled The Cavalier's Lilany. [Haz. H. 79.] In 1707 he was defendant in an action brought by the Company of Stationers, to uphold their privilege of printing almanacs, \&c. [Chan. Proc. before 1714 . Bridges $\frac{270}{21}$. ]

BROWN, or BROWNE (DANIEL), bookseller in London, Black Swan and Bible, next door to the Queen's Head, without Temple Bar, 1672-I729. He made his first entry in the Term Catalogues in Easter Term 1672 , with a small theological book [T.C. I. ro4.], but quickly rose to an important position in the trade. He also sold books by auction. He was still publishing in 1729, when Bernard Lintot sold him a fourth part of a half share in Webb's Antiquities of Stonehenge. [Nichols, Lit. Anecd. viIr. 294.]

BROWN (GEORGE), bookseller in Glasgow, 1676 . Named among the debtors in Andrew Anderson's inventory ( 1676$)$. The "George Browne in Glasgow" mentioned in Lithgow's inventory (I662) may be the same person. [Aldis, p. rog.]

BROWN (HUGH), printer in Glasgow, I7 $12-30$. In I 7 I4 Brown got into trouble with the authorities for assuming, without authority, the title of printer to the University in The Jacobite Curse. [John McUre : History of Glasgon (1830), p. 370.]

BROWN (JAMES), bookseller in Glasgow, 1662 (?)-85. Named among the debtors in Andrew Anderson's inventory ( 1676 ). His name appears in the imprints of James Durham's The Law Unsealed (Edinburgh, r676), and James Paterson's The Scots Arithmetician (Edinburgh, 1685). The James Browne, Glasgow, in Lithgow's Inventory, x662, may be the same. [Aldis, pp. 69, rog.] 
BROWN, or BROUN (ROBERT), stationer in Edinburgh, 1649-85 (?). See Dictionary, I64I-67.

BROWN (ROBERT), printer in Edinburgh, in Forrester's Wynd, 1714-18. In I7I4 Brown printed several numbers of The Edinburgh Gazette, and James Clark's Memento mori (17 18 ) also bears his name.

BROWN (T.), bookseller in London, Green Dragon without Temple Bar, I682-1705. Published $A$ recital of the Act... respecting the power of the Croven over chattels, hereditaments, \&્c., I682. [Haz. II. II7.]

BROWN (THOMAS), printer and bookseller in Edinburgh, on the Plain-stones, over against the Stone-shop, $1671-99$ [-1722 ?] A Thomas Brown appears among the debtors in Lithgow's inventory (r662). Probably one of the booksellers who in $167 \mathrm{r}$ acquired the printing-house of the Society of Stationers. A partner in A. Anderson's gift as King's Printer, r67I. In virtue of this partnership Brown styled himself "one of His Majesties printers", and his name as printer appears alone in books from 1674 to 1678 , and in partnership with others from $167 \mathrm{I}$ to $168 \mathrm{x}$; but from 1687 books bearing his name are printed for, and not by, him. For books bought from him, 1673-7, see Fountainhall's Journals, App. I and 2. [Scot. Hist. Soc. Xxxvi.] In 1695 he sold Sir T. Craig's Scotland's soveraignty asserted, and in 1699 Sir George Mackenzie's Institutions of the Law of Scotland. The will of Thomas Brown of Eastfield, stationer, burgess of Edinburgh, was registered May 3oth, I722. [Aldis, pp. 9r, rog.]

BROWN (WILLIAM), printer and bookseller in Edinburgh, (I) on the north side of the High Street, a little above the Cross, I7I4; (2) in the Parliament Close, I 722. I714-31. Printed in partnership with John Mosman, c. I 7 17-29. In I724 Brown and Mosman succeeded as assigns of the deceased James Watson, and thereafter they assumed the title of King's Printers. [Lee (John) Additional Memorial, Edinburgh, 1826, pp. *105, 153.]

BROWNE (CHRISTOPHER), bookseller in London, Globe, St. Paul's Churchyard, r69I-1707. Dealer in maps and mathematical books. [Haz. II. 403, III. 256 ; T.C. II. 369.] Made his last entry in the Term Catalogues in Trin. 1707. [T.C. III. 555.]

BROWNE (ROBERT), bookbinder at Cambridge, in St. Mary's parish, I667 (?)81. His will dated August 8th, I68r, and the account of his widow, Rose, 
presented the same year, shows value of his stock, \&c., at $£ 433^{s .6 d}$. He may have been one of the valuers of several inventories, 1667 to 1680 . [Gray and Palmer, p. 122.] A Thomas Browne, bookbinder, was living, 1631-55, in one of the houses attached to the west end of Great St. Mary's Church, specially mentioned in a report to Archbishop Laud, September 23rd, 1636. [Gray's Shops at the West End of Great St. Mary's Church.]

BROWNE (w.), bookseller in Horsham, 17x2. Sold the Rev. Charles Bettesworth's Sermon preach'd at Petworth . . . on Wednesday, September 3rd, I712, at a Confirmation ... "London, Printed by H. Meere for A. Bettesworth ... and sold by ... W. Browne in Horsham, I7 12." [B.M. 4473. aaa. 46 (8).]

BROWNING (MERCY), bookseller in Amsterdam, (a) op de Beurs-sluys, (b) juxta Bursam. $1675-87$. Described as a widow. Published in $1675 A n$ English and Nether Dutch Dictionary, in 1680 The Practice of Piety, and in 1682 Increase Mather's tract on the signs and tokens of the coming of the Messiah. In 1678 she became agent for N. Ponder, the publisher of Bunyan's Pilgrim's Progress, and he consigned to her a stock of books for sale which became the subject of a law suit in Chancery; from this we learn that in 1687 she sold her business to Rest Fenner (q.v.), a London bookseller who afterwards moved to Canterbury. [Chan. Proc. before I714, Reynardson, Bundle 428, 132.]

BRUCE (PETER), printer in Edinburgh, Holy-Rood-House, I687-8. A foreigner who from 1674 onwards was engaged in engineering and other enterprises (including the manufacture of paper and playing cards) in Scotland. In October 1687 he took over James Watson's press in Holyrood Palace, and in December of the same year was appointed royal printer in succession to him. He styled himself " Enginier Printer to his most Excellent Majesty, for his Royal Household, Chapel and Colledge, Holy-Rood-House". His printing house was wrecked by the mob which broke into Holyrood on December Ioth, I688, and Bruce himself was imprisoned till June 1689. Watson says that his printing materials were sold to the Society of Stationers. His paper mill at Restalrig was acquired by James Hamilton in 1690 . Some of the Holyrood books of 1687 without printer's name were probably printed by him. [Aldis, p. rog.]

BRUDENELL( ), printer in London, c. 1 700. Mentioned by Dunton [p. 252] as a hot-tempered man but "a good Printer and truly honest". Probably 
a son of John Brudenell ; see Dictionary, r64r-67. He had a brother Moses Brudenell, a compositor.

BRUGIS (HENRY), see Bridges.

BRYAN (STEPHEN), printer in Worcester, next the Cross Keys in Sidbury, r 706 -48. Took up his freedom as a stationer on June 3 rd, r706. Three years later while still quite a young man he started The Worcester Posiman, (no. I, June I709); in 1722 the title was changed to The Worcester Post, or Western Journal. Bryan died in 1748 , but before his death he assigned his paper to H. Berrow, who then gave it the name it has ever since borne, that of Berrow's Worcester Journal. [Rev. J. R. Burton, Early Worcester- shire Printers and Books, I897.]

BRYSON (MARTIN), bookseller at Newcastle-upon-Tyne, c. I722-55. His name first occurs on Occasional Hymns, by Benj. Bennet, Newcastle r 722. He was admitted to the freedom of the Upholsterers', Tinplate Workers', and Stationers' Company of Newcastle July 25th, 1726. His shop was on Tyne Bridge on the west side and near the north end. It was destroyed by the fire of July 24 th, $175^{\circ}$, when ten houses and many warehouses adjoining the Bridge were burnt. In May I75 $\mathrm{I}$ he took into partnership his apprentice William Charnley, who succeeded to the business on Bryson's retirement in 1755. Bryson went to live at Stockton-on-Tees, where he died August I $_{5}$ th, r759. The business founded by him was in existence in Newcastle until the year $\mathrm{r} 88 \mathrm{r}$.

BUCK (PETER), bookseller in London, Temple, Fleet Street, near the Inner Temple Gate, r692-1 700. In r692 he published Congreve's Incognita [Esdaile, p. I90]; in r698 Oldmixon's Poem to the Earl of Portland; and in 1700 Dr. Herwig's Art of curing sympathetically. [T.C. III. 185.] He was possibly a descendant of the Cambridge Bucks.

BUCKLEY (SAMUEL), printer and bookseller in London, (I) Dolphin, Fleet Street, over against St. Dunstan's Church ; (2) Dolphin, St. Paul's Churchyard ; (3) Dolphin in Little Britain ; (4) In Amen Corner. r696-r741. Began as a bookseller; the first of his publications recorded in the Term Catalogues was The French Perfumer, announced in Trin. 1696. [T.C. II. 59r.] He was also the publisher of Le Comte's Memoires in 1697, and of an edition of Don Quixote in 1699 . But he is chiefly remembered as a printer. In $x 703$ he 


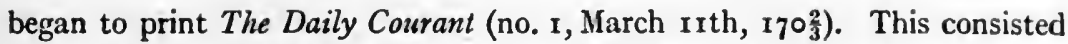
of a single sheet printed on one side only, and was the first daily newspaper. It was first printed by Edward Mallet, but a month afterwards it changed hands. Buckley's imprint appears on the issue of April 22nd, r7०3. Dunton [p. $3^{14}$ ] refers to him at this time and says: "He is an excellent linguist, understands the Latin, French, Dutch and Italian tongues ; and is master of a great deal of wit. He prints the Daily Courant and Monthly Register (which I hear he translates out of the foreign papers himself)." In I7I3 Steele's Englishman was printed by Buckley in Amen Corner. Nichols says that Buckley "was afterwards appointed writer of the Gazetteer, and was put into the commission of the peace for the County of Middlesex. He was a man of an excellent understanding and great learning, very sincere where he professed friendship; a pleasant companion and greatly esteemed by all who knew him ". He died on September 8th, r74r, in his 68th year and is buried in Hornsey Church. [Nichols, Lit. Anecd. II. 26, 27.]

BUCKRIDGE (JOHN), bookseller at Marlborough, 1704. Only known as the publisher of Courage and sincerity ... A Sermon, by Robert Wake, Vicar of Ogburn St. Andrew, Wilts., r704. [T.C. III. 422.]

BUDDEN (w.), (?) bookseller in London, near Fleet Bridge, r685. Only known as the publisher of a broadside : A strange and wonderful discovery newly made of Houses under ground, at Colton's Field in Gloucestershire. [Bibl. Lind., Broadsides, No. 396.]

BULKLEY, BULKELEY, or BUCKLEY (STEPHEN), see Dictionary, I641-67.

BULL ( ), bookseller at Ashford, Kent, r699. Mentioned in an advertisement in The Flying Post of December 2nd, 1699, of the Rev. Edward Brown's Sermon preached at the Kentish Feast. The names of this and other provincial booksellers who sold the work are not given in the imprint to the book.

BULL (SETH), stationer in London, The Minories, 7 13. He and his wife Elizabeth are mentioned in the will of Mary Hayes, proved in I7r3. [P.C.C. I36, Leeds.]

BULLOCK (J.), bookseller in London, Rose and Crown on Snow Hill, near Holborn Bridge, 1709. Publisher of a poem, Libertas Triumphans, in honour of the victory of Oudenarde [T.C. III. 620], and also of Calvin's Ghost [T.C. III. 642], both in 1709 . 
BULLORD (JOHN), bookseller and book-auctioneer in London, Old Black Bear in St. Paul's Churchyard, I689-r7or. Succeeded Obadiah Blagrave at the above address in r689. On May 8th of that year he began the sale of Bibliotheca Selectissima Generosi Angliae nuper defuncti at Sam's Coffee House in Ave Maria Lane [Lawler, Book Auctions, p. I75] and from that time until r7or he was one of the recognized book-auctioneers of London; amongst the libraries that he sold may be mentioned those of Peter Scott, prebendary of Windsor, Thomas Britton the "Small coal man", Dr. Adam Littleton, John Baron Stawel of Somerton, Robert Littlebury the bookseller, and the Rev. William Hopkins of Oxford. As a publisher he introduced Thomas Durfey to the public in Collin's Walk through London and Westminster, r69o, and in 1695 he was agent for the sale of Chauncy's Hertfordshire. [T.C. II. 544.] His last entry in the Term Catalogues was in Easter I700. [T.C. III. 189.] Bullord is sometimes confused with Thomas Ballard of Little Britain.

BUNCE (THomas), printer in London, 1706. Printed Baxter's Monthly Preparations for Holy Communion for T. Parkhurst in I706. [Haz. I. 22.]

BUNCHLEY (SAMUEL), bookseller in London, (I) Blue Ball, Ave Mary Lane; $(2)$ at the Publishing Office $(a)$ in Dove Court $(b)$ in $(c)$ near, Bearbinder Lane, near the Stocks Market. I707. Made his first entry in the Term Catalogues in Hil. I 707 with one of the pedlars' favourite books, Essays of Love and Marriage. [T.C. III. 537.] Amongst his other publications was Ned Ward's Humours of a Coffee House, issued in penny numbers every Wednesday morning; Bunchley's name did not appear in the advertisement of this, but only his address in Bearbinder Lane. [T.C. III. 558.]

BUREAU ( ), bookseller in London, in the Middle Exchange in the Strand, 1683. A lottery of wine was to be drawn for at his shop. [Lond. Gaz., February 4 th, I683.]

BURGES (FRANCIS), printer in Norwich near the Red Well, r7or-6. On September 2 th, r ror, there appeared Some Observations on the Use and Original of the Noble Art and Mystery of Printing, printed by F. Burges, and said to be the first book printed at Norwich since the sixteenth century. He also started in the same month a newspaper called the Norroich Post. Burges died in January I jo6, leaving the business to his widow. [Plomer, English Printing, r915, pp. 207-8.]

BURGES (HENRY), see Bridges (Henry). 
BURGIS (srMON), bookseller in London, 1689-91. Published A Full Answer to the depositions ... concerning the birth of the P. of Wales, 1689. [B.M. T. 100* (179).] In Hil. 1690 he advertised The Muses' Farewell to Popery and Slavery, and in 1691 Wit for Money; or Poet Stutter. [T.C. II. 30r, 360.]

BURLEIGH (FERDINAND), bookseller in London, Amen Corner, I713-15. Publisher of Steele's Englishman and also of $A$ Letter to a Member of Parliament, in I 7 14. Nichols records that Burleigh sold a periodical called The Balm of Gilead, which was printed by J. Mayo. [Lit. Anecd., viII. 494.]

BURNET (c.), bookseller in London, 1696. Published a ballad entitled The Boon Companion, 1696. [Haz. II. 587, from Ouvry Cat. no. 75.]

BURRELL (THOMAS), bookseller in London, Golden Ball in Fleet Street, under St. Dunstan's Church, 1670-9. In Mich. 1670 he advertised an edition of Henry Phillippes's Purchaser's Pattern [T.C. I. 5I], and in the following year was joint publisher with Thomas Archer of Maynwaring's Praxis Medicorum. In February $167 \frac{6}{7}$ he was examined before the committee of the House of Lords, then inquiring as to the publication of certain libels, and admitted that he had seen one of them, The Naked Truth, twentyfive copies of which he declared were "thrown into his shop but he delivered them to Mr. Sawbridge again", but he admitted having sold two or three copies of The Letler about the Test. [Hist. MSS. Comm., gth Report, p. 78.] Amongst Burrell's varied publications may be noted John Ray's Collection of English Words, 1673, and Sir H. Spelman's Villare Anglicum, 1677. He also published works on gardening. His name does not appear in the Term Catalogues after 1678 ; but he was the publisher of a sheet called The English Intelligence (no. 1, July 21st, 1679) written in the Protestant interest, and also of The English Currant (no. I, September 8th, 1679).

BURRIDGE (RICHARD), journeyman printer, I 7 I . Reader of Mist's Weekly Journal. On March $3^{\text {rd, }}$ I 7 I $_{7}$ he was convicted of uttering blasphemous words and sentenced to be whipped from the Church in the Strand to Charing Cross, to be fined twenty shillings, and to be imprisoned one month. [Timperley, p. 6r5.]

BURROUGH (R.), bookseller in London, Sun and Moon, Cornhill, r 705-8. Publisher of historical books; made his first entry in the Term Catalogues in Trin. 1705. [T.C. III. 464.] In 1708 he was joined by J. Baker. 
BURROWES (SAMUEL), bookseller in London, ( $\mathrm{r}$ ) Crown in Cornhill ; (2) Bible and Three Legs, Poultry ; (3) Little Britain. 1697-r707. Began as a publisher at the Crown in Cornhill in 1697 , when his namc appeared amongst those issuing Dr. Adam Littleton's True method of learning the Latine Tongue by the English. [T.C. III. 7.] His name does not appear again in the Catalogue until Easter, I702, when he was one of the publishers of John Moyle's Chirurgus Marinus. [T.C. III. 302.] Finally in 1707 he was one of the publishers of The Diverting Works of the Countess D'Anois. [Esdaile, p. 255.]

BURTON ( ), printer in London, St. John's Lane, r724. Only known from a mention of his name in Negus's list, as well affected to King George.

BURTON (HUMPHRY), bookseller in Tiverton, 1696-1701. Publisher of a sermon, The Lawfulnesse and use of Organs, preached by John Newte, Rector of Tiverton, on September I3th, 1696. [B.M. 226. h. 20 (28.)] He was also the local agent for The Country-mans Conductor in reading and writing, by John White, master of Chilcot's English Free School in Tiverton, Exeter, r7or. [B.M. I2983. a. 54.] His name is sometimes spelt Barton.

BURTON (PHILIP), bookseller at Preston, Lancashire, 1678. Publisher of Seth Bushell's The Believer's Groan for Heaven, A sermon . . preached at Preston, 1678. [T.C. 1. 308.]

BURTON (RICHARD), see Diclionary, I641-67.

BURTON or BUTTON (SARAH), bookseller at Newcastle-upon-Tyne, $1700-4$ (?). Local agent for R. Gilpin's Assize Sermon at Carlisle, preached in 1660, London, 1700. The author was " now minister . . . in Newcastle-upon-Tyne". [B.M. 4474. bb. 51.] Wife of Joseph Button (q.v.).

BUSH (EDMUND), bookseller in Oxford, r696-r705. [Madan, p. 3r.]

BUTLER (JOHN), bookseller in Worcester, r702-8. Publisher of Thos. Cooke's sermon, Workhouses the best Charity, r702. Noticed by Dunton [p. 237] as having been " a rising man for some time, has a brisk trade and pays well".

BUTLER (R.), bookseller in London, (a) next the Holy Lamb and Three Bowls in the Barbican, $(b)$ next door to the Lamb and Three Bowls, 1677-85. Publisher of divinity and books against the Quakers. His last entry in the Term Catalogues was the Rev. N. Taylor's Practical . . : Exposition of the Catechism, and ed., in Hil. r685. [T.C. It. rr8.] 
BUTLER (s.), bookseller in London, Bernard's [i.e. Barnard's] Inn Gate in Holborn, 1707-11. In Povey's General Remarks on Trade, July 4-7, 1707 [Burney 140], this bookseller is mentioned as selling "the True Golden Snuff". In the Term Catalogue, Mich. 1708-Hil. 1709, S. Butler's name occurs as publisher of The Gamester's Law. [T.C. III. 619.] Again in the London Gazette of February 8th, $17 \frac{10}{1} \frac{1}{1}$ he appears as one of those selling $A$ Help to History.

BUTT, or BUTS (RICHARD), bookseller in London, (r) Bear and Orange Tree in Princes Street, near Drury Lane; (2) Princess Street in Covent Garden [probably the same as (r)]. 168r-96. Publisher of novels and cheap literature. The only reference to him in the Term Catalogues is the entry of Cervantes' The Jealous Gentleman of Estremadura. [T.C. 1. 461; Esdaile, 33.] Timperley [p. 563] records that in 1683 he was publishing Scotch Memoirs, and in 1696 he published Letters written by Mrs. Manley. [T.C. II. 591; Esdaile, 266.]

BUTTER (THOMAS), bookseller in Exeter, near St. Martin's Lane, I 7 I4-20 (?). In a book printed in 1714, Mr. Dredge found the following advertisement: "Sold by Thomas Butter, Bookseller near St. Martin's-lane in Exon, where (besides Books and Stationary Wares of all sorts) is sold the best of Mathematical and Sea Instruments, several sorts of Physical Medicines, as Dr. Daff's Elixir Salutis, Stoughton's Elixir Stomachicum, Spirit of Scurvy-Grass Golden and Plain \&c. Also the famous Cephalick or Liquid-snuff, prepar'd for the Queen. With Japan Ink, Indian-Ink, Cake-Ink, Ink-powder, Common Ink ; Ink-Glasses, Pounce, shining sand; great variety of paper-hangings for rooms ; the best of Stampt-Parchment and Paper, Bonds, \&c., at reasonable rates, by Wholesale or Retail." After his death his widow Jane married Daniel Pring jun. by licence on August 3 Ist, 1723 ; but she continued to carry on the business as Jane Pring until her death sometime before $173 \mathrm{r}$. [Dredge, pp. 44, 67, 98-9.]

BUTTLER (EDWARD), printer in London, 1690. Indicted for printing a libel entitled, His Majesty's Most Gracious Declaration to all his loving subjects, a Jacobite broadside found scattered about the streets of London. William Newbolt (q.v.) was associated with him, and both were described as "printers". Their printing press was said to have been kept at one Douglas's at Westminster. [Harl. MS. 6846, fol. 371-9.] 
BUTTON (JOSEPH), bookseller at Newcastle-upon-Tyne, on the Bridge, 1704-14. In Hil. I704, he appears as the publisher of Christus in Coelo, by Thomas Bradbury. [T.C. III. 386.] Some time between this and 1714 he and his wife were parties to an action brought by the Company of Stationers for upholding their privileges. [Chan. Proc. before 1714 , Bridges $\frac{270}{21}$.] In 17 I4, Button published B. Bennet's Several Discourses against Popery. See Saywell (J.).

BUTTON (SARAH), bookseller at Newcastle-upon-Tyne, I704 (?). See Burton (Sarah).

C. (A.), see Clark (Andrew).

C. (E.), see Cotes (Ellen).

C. (F.), see Clark (Francis)

C. (L.), see Curtis (Langley).

C. (R.), see Clavell (Roger); also Cutler (Robert).

C. (w.), see Cooper (William).

CADE (JOHN), see Dictionary, $164 \mathrm{I}-67$.

CADMAN, or CADEMAN (WILIIAM), bookseller in London, (I) Pope's Head in the Lower Walk of the New Exchange, Strand; (2) Pope's Head in the New Exchange, and Middle Exchange, Strand. 1668-87. On November 9th, 1668 he entered Davenant's comedy The Rivalls [B.M. 643. d. 57 ; Stat. Reg., Roxb., II. 392], and in the Term Catalogue for Mich. I669 [T.C.I. 20] he advertised Frances Boothby's Marcelia . . A Tragi-Comedy, dated I670. [B.M. 644. g. 20.] He was the publisher of much good literature, and is found in business in 1684 , when he appears to have been succeeded at this address by G. Cownly; but his name is found in the Term Catalogues three years later as one of the publishers of Settle's Emperor of Morocco. [T.C.II. 203.] Dunton [p. 292] calls him "blunt Cademan".

CADIVELL (THOMAS), bookseller at Derby, 1685. His name occurs in a list of booksellers and stationers at the end of M. Bromfield's $A$ brief Discovery of the Scuroy, I685, as agent for a patent medicine. [N. \&。 Q., II S. XI. p. 45.]

CAIRNS (JOHN), printer and bookseller in Edinburgh, at the lower entry to the Parliament Yard, I67I-80? One of the six booksellers who petitioned the Privy Council against A. Anderson's monopoly in 167 I. Watson [p. 14] says that Cairns (who had now Mr. Hyslop's printing-house) was employed by 
Sir Thomas Murray to print his digest of the Acts of Parliament, and that he brought Dutch workmen (J. van Solingen and J. Colmar) and materials from Holland for that purpose. Shortly after this Cairns died (1680-1) and his printing house passed to David Lindsay and his partners. [Aldis, p. 110.] Quarles's Enchiridion was "printed by John Cairnes for Gideon Shaw " in 1680. [Haz. I. 347.]

CALDECOT ( ), bookseller in Stamford, Lincolnshire, 1690. Only known from the imprint to a sermon by G. Topham, entitled Pharisaism display'd, $\mathbf{1 6 9 0 .}$

CALDECOTT (THOMAS), bookseller in London (?), 1714. Mentioned in the will of his brother-in-law William Rogers of Clifford's Inn, Gent., dated January 14th, 17 14. [C.C. 15. Faggs.]

CALDERWOOD (JOHN), stationer in Edinburgh, 1676(?)-1682. His will and inventory, 1682, are printed in Bann. Misc. II. 289. The John Calderwood who appears among the debtors in A. Anderson's inventory 1676 may be the same. The imprint in Richard Simon's Opuscula critica adversus Isaacum Vossium, "Edinburgi, typis Joannis Calderwood, M.Dc.Lxxxv," is fictitious. The book was probably printed at Rotterdam. [Aldis, p. IIO.]

CALVERT (ELIZABETH), see Dictionary, 1641-67.

CALVERT (GEORGE), see Diclionary, 1641-6\%.

CAM (JOHN), stationer in London, 1688. Defendant in a plea of debt brought by William Johnson, Trin. 4 Jas. II [i. e. 1688]. [C.P.R. 3069. m. 693 verso.]

CAMPBELL (AGNES), see Anderson, Mrs., printer in Edinburgh.

CAMPBELL (PATRICK), bookseller in Ireland, Dublin, 1687-1720. Chiefly known from the account of him in The Dublin Scufle by Dunton, whom he opposed during the latter's visit to Dublin in I698. [Life and Errors, pp. 491639 passim.] In 1694 he shared with E. Dobson and M. Gun the publication of a religious work by J. Bayne, a Dissenting minister. His will was proved in the Prerog. Court in 1720.

CANNING (WILLIAM), printer and bookseller in London, Vine Court, $(a)$ in the Middle Temple, $(b)$ in (or under) the Temple Cloisters. 1686-90. Appears first in Hil. 1686 as a publisher of law books. [T.C. II. 160.] In 1687 he published Mrs. Behn's comedy The Lucky Chance [T.C. II. 188], and N. Tate's Island 
Princess [T.C. II. 200], and was chiefly a publisher of plays and poems. He was at one time a printer, and was arrested for his part in a Jacobite broadside entitled His Majesty's most gracious declaration to all his loving subjects [c. 1690]. He was stated to be a person "very famous for such work", who had been tried twice or thrice before for similar offences, and to have kept a private press in Grocers' Alley. [Harl. MS. 6846, fol. 375-9.]

CANTREL (WILliam), bookseller in Derby, 1718-27. Mr. Arthur Wallis, in his History of the Printing Press in Derby, 1881, says : "It is not unlikely that William Cantrel was the brother of the Rev. Thomas Cantrell, Head Master of Derby School, Lecturer of All Hallowes, and vicar of Elvaston, who dying in 1699, was succeeded by the Rev. Anthony Blackwall in all those offices." William Cantrel published Blackwall's Introduction to the Classics, I718, and also Charles Cotton's Wonders of the Peak, 1725. He was also the agent, with H. Allestree, of the Nottingham Mercury. As his business was put up to auction in 1727 he was probably then dead.

CARNAN (WILLIAM), printer at Reading, The Bible and Crown in the Market Place, 1723-37. Printer and publisher of The Reading Mercury, (No. I, July 8th, I723). After his death, his widow married John Newbery, who had worked under her husband and was appointed one of his executors. John Newbery soon afterwards moved to London, where he became famous as the publisher of "penny histories" for children. [C. Welch, A Bookseller of the last Century, pp. 6-7.]

CARR (JOHN), bookseller or musical instrument maker in London, (I) under the King's Head Tavern in Chancery Lane end ; (2) at the Middle Temple Gate. 1676-84. Sold Tho. Mace's Musick's Monument, 1676. In 1683 he joined J. Playford in the publication of music books. [T.C. II. 4.] In the London Gazette of October 23 rd-2 7 th, 1684 an advertisement of musical books appeared in which his address is given as " at John Carr's shop, at the Middle Temple Gate when built, but as yet under the King's Head Tavern in Chancery Lane end."

CARR (SAMUEL), bookseller in London, King's Head at the West End of St. Paul's Churchyard, 1675-85. His first advertisement in the Term Catalogues was in Trin. 1677 [T.C.1. 285], and his last in Mich. 1685, when he issued Catechismus ... secundum usum Coll. Regalis Etonensis. [T.C. II. I48.] 
CARRON (WILLIAM), printer in Edinburgh, I680. Joined William Hislop when he set up. He printed for J. Cairns an edition of Jas. Durham's The Dying Man's Testament, for G. Shaw, Funeral of the Mass, and also $A$ Discourse unto ... James Duke of Albany and York, all in r680. [Aldis, pp. 59, 110.]

CARRUTHERS (THOMAS), bookseller in Edinburgh, in the Parliament Close, 1695-1700. In 1695 he sold the Earl of Cromarty's Vindication of Robert III ; in 1696, A. Pitcairne's Dissertatio de legibus historiae naturalis; in 1699 Answer to the ... refutation of Dr. Olyphant's defence and a medical work; in I700 G. Dempster's The Prodigal Returned. In the Edinburgh Gazette, No. 50, August 14th-17th, I699, several books are advertised as printed for Thomas Carruthers. [Aldis, p. rro.]

CARSON (JAMES), printer in Dublin, I7I3-59. Printer and publisher of miscellaneous literature, including The Dublin Weekly Journal, 1725-30. He was styled "the facetious".

CARTER (CORNELIUS), printer in Dublin, Post Office Coffee House, Fishamble Street, 1696-1727. His name is first found, with John Brocas, in the imprint to a Latin book in 1696 , and they were partners in another book in the next year. In 1699 he appears alone as printer of The Flying Post, or the Postmaster, and in 1700 of a Dublin edition of the London Gazette. His address, given above, is found in these periodicals. In 17 ro he printed the Tatler and in I 7 I 3 the second edition of Bishop Browne's sermon on Drinking to the memory of the Dean.

CARTER (WILlIAM), bookseller in London, (I) Green Dragon, St. Paul's Churchyard : (2) Rose and Crown, St. Paul's Churchyard. ryo6-II. Publisher of anti-Quaker tracts. A list of some of these will be found at the end of the Rev. Edw. Cookson's Winding-sheet for Quakerism, I7II. [B.M. T. I8I6 (9).]

CARTERSON (Jorn), bookseller in London, r690. Published a political play, The Abdicated Prince, I69o, without giving an address. [B.м. 643. d. 40.]

CARVER ( ), widow, bookseller (?) in Melton, 1720. Her name occurs in the imprint to the Nottingham Mercury, as one of those from whom it might be obtained; but there is no other evidence that she was a bookseller.

CASTLE (EDWARD), bookseller in London, ( 1 ) Angel and Crown, St. Paul's Churchyard; (2) (a) near (or next) Scotland Yard-Gate, by Whitehall, 
(b) against Scotland Yard, near the Admiralty. 1695-17 17. In Easter 1695, he is named as selling The London Practice of Physick. [T.C. II. 552.] In 1697 he published John Aubrey's Miscellanies and shared with A. and J. Churchill an abridgement of John Locke's Essay on the Human Understanding. In June I 7 I 7 a patent was granted to William Churchill and Edward Castle for the sole furnishing of several offices of His Majesty's Revenue with stationery. [Timperley, p. 6r5.]

CAWDLE (EDWARD), bookseller in London, of the parish of St. Gregory next Paul's, r68r. Defendant in an action for assault brought against him and others by Israel Aylett, widow, in Mich. Term 33 Chas. II (r68r). [C.P.R. 2996. m. 260 recto.]

CHALKIN, see Chauklin.

CHALMERS (ANDREW), bookseller in Edinburgh, in the Parliament Close, r688-91. In June r688 he had in stock 22I copies of the Irish Psalm Book. In 1691 he was one of several booksellers who sold J. Cockburn's Eight Sermons, and in the same year Sir G. Mackenzie's Moral History of Frugality and the second edition of W. Sherlock's Case of Allegiance due to Sovereign Princes. [Aldis, p. III.]

CHAMBERLAIN (ABSOLOM), a running bookseller [hawker] in London, Red Bull Playhouse-yard, over against the Pound in St. John's Street, r684. Known from three broadsides of 1684. [Bodl. Ashm. G. I5 (170); Haz. H. 676, II. 423.]

CHAMBERLAIN (J.), bookseller at Bury St. Edmunds, 1685-90. His name occurs in the Term Catalogue for Easter 1685, as publishing New English Examples to be turned into Latine, and again in Trin. I69o as selling Edward Leeds's Methodus Graecam Linguam docendi, both for use in Bury school. [T.C. II. $128,322$.$] No copy of the first edition of either of these books is in$ the B.M.

CHANDLER (ABRAHAM), bookseller in London, Surgeon's Arms in Aldersgate Street, 1693. Dealt chiefly in theology. [T.C. II. 450, 474, 490.]

CHANDLER (SAMUEL), bookseller in London, in the Poultry, c. r72o. A wellknown Nonconformist divine; he was forced by the loss of his wife's fortune in the South Sea Bubble to open a bookshop: 
CHANDLER (IWLLIAM), bookseller in London, Peacock in the Poultry, 1696-9. Published N. Pullen's translation of Jean Mocquet's Travels into Africa, 1696, and Poems on Several Occasions, 1699, the work of a brother bookseller, Herbert Walwyn (q.v.). [T.C. Ir. 588.]

CHANTRY (JOHN), bookseller in London, (I) Pestle and Mortar, without Temple Bar; (2) at the sign of Lincoln's Inn Square, near Lincoln's Inn Fields, at Lincoln's Inn Back Gate. I693-r708 (?). In the S.P.D. William and Mary, iv. Ir. is a Petition to Parliament from William Fuller, dated February 23rd, 1692, complaining of libels written by William Pettis for Abel Roper and Chantry booksellers. Chantry's name first occurs in the Term Catalogues in I 703 as one of the publishers of John Brydall's Ars transferendi Dominium. [T.C. III. 285.] Amongst his other publications may be noticed Sedley's Miscellaneous Works, ed. 2, 1708. [T.C. III. 599.]

CHAPMAN (HENRY), bookseller in London, near Stanhope-Court at Charing Cross, 1685-94. In the Term Catalogue for Trin. 1685 An Historical Account of the late Troubles during the wars of Paris, and in Trin. I694 The Gentleman's Journal for the War are advertised as sold by him. [T.C. II. I37, 510.] There seems to be some confusion between this publisher and Thomas Chapman (q.v.) in the entry of Spencer Redivivus, 1687, in T.C. [II. 217.]

CHAPMAN (ROBERT), bookseller in Cambridge, I $7 \mathrm{II}$. Robert Green's Demonstration of the Truth and Divinity of the Christian Religion, I7II, was printed at the University Press for him. [Bowes, Calalogue of Cambridge Books, No. $3^{81}$.]

CHAPMAN (THOMAS), bookseller in London, (I) the Chirurgeons Arms over against the upper Meuse Gate near Charing Cross ; (2) The Golden Key over against the Meuse near Charing Cross ; (3) in Pall Mall over against St. James's Square ; (4) Angel in the Pall Mall. I687-1709. In 1687 he published Spencer Redivivus, a modernization of Book I of the Faerie Queene [B.M. 1346. g. I], the imprint being No. I above. In the advertisement in Hil. I688, not only is the title of this wrongly entered but the publisher's name is given as H. Chapman. [T.C. II. 2I7.] Thomas Chapman dealt largely in plays, and this fact is advertised in another of his publications The Rule of Behaviour, in which the Spenser is also mentioned. In 1692 , he either moved to another shop in Charing Cross or altered his sign to the "Golden Key" but 
two years later he moved to Pall Mall, where he was joined by W. Chapman. The last two pages of Le Maire's Voyage to the Canary Islands, published jointly by them in 1696, contain a list of plays sold by T. Chapman. [B.M. 1425. a. 4.] His last entry in the Term Catalogues was in r709. [T.C. III. 6r3.]

CHAPMAN (THOMAS), bookseller in Norwich, 1722. Only known from the occurrence of his name in an advertisement of a patent medicine in the Post-Man of February 26th-28th, I70 $\frac{2}{3}$.

CHAPMAN (WILliaM), bookseller in Iondon, Angel in the Pall Mall, I696. In partnership with Thomas Chapman (q.v.).

CHASE (WILlIAM), printer at Norwich, ( 1 ) in Dove Lane ; (2) at the Printing Press in the Market. I $7 I_{1-27}(?)$. In I 7 I I he printed, for Thomas Goddard, Josiah Chorley's Metrical Index to the Bible. [в.м. Ior7. k. I8 (2).] In I715-16 he changed his address, $A$ Form for the Consecration of the New Chapel at Yarmouth, I 7 5, being issued from Dove Lane, and the Norwich Visitation Articles of I7I6 from the Market. In I727 he founded The Norwich Mercury. The Mr. Chase who died March Ist, r78I [Timperley, p. 747] may have been his son.

CHAUKLIN, or CHALKIN (HENRY), bookseller at Taunton, I695-I70I. Published some of the sermons and writings of Matthew Hole, vicar of Stogursey, Somerset. His name did not always appear on the title-pages, but it is found on $A$ Correct Copy of some letters woritten to $J . M$., which has the imprint, "London. Printed for H. Chauklin, Bookseller in Taunton ... r698." [B.M. 472. a. 54.]

CHEESE (RICHARD) jun., printer (?) in London, 1690. A single sheet Elegy on the Death of His Grace, the Duke of Grafton, r690, bears the imprint, " London, Printed by Richard Cheese, junior." [B.м. C. 20. f. 2. (I9I).]

CHETWIND (PHILIP), see Dictionary, r641-67.

CHILDE (TIMothy), bookseller in London, $(\tau)$ White Hart in St. Paul's Churchyard, I690-I, I697-I7II ; (2) Unicorn, (a) St. Paul's Churchyard, (b) at the West end of St. Paul's, I69r-7. I690-I7II. Amongst his publications is a rare little book with engravings called An Accurate description of the United Netherlands ... with an exact Relation of the Entertainment of . . King William at the Hague, 1691. He made his first entry in the Term Catalogues in Mich. 1690. [T.C. II. 340.] Sometime in r69r he moved to the Unicorn and was in partner- 
ship with A. Swalle as publisher of classics and history. In 1697, they appear to have dissolved partnership and Childe returned to the White Hart. A list of books published for him is given on sig. $4^{b}$ of T. Hearne's Ductor Historicus, 1704. His last entry in the Term Catalogues was in Easter I 711 , when he shared with the Churchills the publication of Moll's Atlas. [T.C. III. 672.]

CHISWELL (RICHARD). See Dictionary, 164I-67. In a manuscript note, dated I66I, in a copy of A. Gölnitz, Ulysses Belgico-Gallicus, 1631, Chiswell describes himself as "servant to Mr. John Sherley", i.e. the bookseller of that name, $q . v$. in Dictionary, 1641-67. In Mich. 1681, Chiswell was defendant in a suit for debt brought by Richard Hughes. [C.P.R. 2996. m. 260 r.] On January 16th, 168I he began to publish Weekly Memorials for the Ingenious, or, an account of books lately set forth in several languages, $\mathbb{E}^{\circ} \mathrm{C}$.

CHOWN (ROBERT), bookseller in Northampton (?), 1684. Hazlitt records a single sheet: The Speech of Robert Clerk, Esq., Deputy Recorder of Northampton to the Mayor elect For ... I684. London, Printed for Rob. Chown, 1684. [Haz. II. p. 428.]

CHURCHILL (AWNSHAM), bookseller in London, (a) Black Swan, Ave Mary Lane ; $(b)$ at the lower end of Paternoster Row, near Amen Corner. 168 I-1 728. Son of William Churchill, bookseller of Dorchester. Apprenticed to George Sawbridge. His name first appears in the Term Catalogues in Mich. 1681, as the publisher of a law-book, The Touchstone of Precedents. [T.C. I. 460.] Another early publication of his was Dr. William Saywell's Evangelical and Catholick Unity, which bore the imprint, "Printed for Robert Scott and Awnsham Churchill, at the Black Swan, near Amen Corner, 1682." This Robert Scott was no doubt the bookseller of that name whose shop was in Little Britain. Churchill soon became one of the first publishers of the day, and in 1690 he took into partnership his brother John, the first work recorded under their joint names being $A$ second Letter concerning Toleration. [T.C. I1. 323.] Of their numerous publications, one or two only can be noted. In I69I they shared in the publication of Sir R. L'Estrange's Fables of Aesop. With Jacob Tonson they shared Selden's Table Talk in 1696, and in the same year they published alone John Locke's Several Papers relating to Money. In I704 they issued $A$ Collection of Voyages and Travels, 4 vols. fol., and between 1704 and I7I5 Rymer's Foedera, I6 vols. fol. Granger refers to Awnsham Churchill as the greatest bookseller and stationer of his time, 
while Dunton [p. 204] says of the brothers: "They were of an universal trade. I traded very considerably with them for several years, and must do them the justice to say that I was never concerned with any persons more exact in their accompts and more just in their payments." Awnsham Churchill amassed a considerable fortune and bought an estate in Dorset. He was M.P. for Dorchester between 1705 and 1710. He died unmarried on April 24th, I728, his will being proved on May IIth. It contains the following clauses: "I give and bequeath my books at Henbury and my bound books in London and Westminster to be divided equally between my three nephews Wm. Churchill, Awnsham Churchill and Joshua Churchill. I give and devise my shop in Dorchester now in possession of the widow Wentworth, to my nephew Wm. Churchill, Esq." He also left a bequest to Mrs. Mary Churchill, widow of his brother John Churchill. [P.C.C. I42. Brook.]

CHURCHILL (JOHN), bookseller in London, Black Swan in Paternoster Row, I690-I714. Brother of Awnsham Churchill, with whom he was in partnership from I690 till I714, soon after which he probably died, leaving three sons, two of them, Joshua and William, being booksellers.

CHURCHILL (JOSHUA), printer in London, I688-1 728. Son of John Churchill (?) Printed for his brother (?) William Churchill a broadside entitled, A Paper delivered to His Highness the Prince of Orange ... I688. [B.M. T. 100* (199).] $\mathrm{He}$ is mentioned in the will of his uncle Awnsham Churchill (q.v.), 1728 .

CHURCHILL (WILlAM), bookseller at Dorchester. See Dictionary, 1641-6;. Father of Awnsham and John Churchill.

CHURCHILL (WILLIAM), bookseller in London, I688-1736. Son of John Churchill. In I 7 I 7 a patent for furnishing stationery was granted to William Churchill and Edward Castle (q.v.). He died February 22nd, I736. [Timperley, pp. 6I5, 659.]

CLARK, or CLARKE ( ), bookseller at York and Kingston-upon-Hull, I68I-9I. His name occurs in an advertisement of the sale of Dr. W. Outram's library in the London Gazette of November I7th-2 Ist, I68I. In I69I "Clarke of York" was sued by Edward Darrell for payment for goods supplied. [C.P.R. Mich. 3 W. \& M. Roll 3IOr.] Probably same as Clarke (Thomas), q.v.

CLARK (ANDREW), printer in London, Aldersgate Street, 1670-8. In I670 he, with E. Cotes, printed for Henry Brome The History of the Duke of Espernon. 
[Haz. I. 147.] He was also the printer of the Term Catalogue of Hil. 1675 [T.C. I. 202], and he is mentioned in the 1675 list of printers in London [S.P.D. Car. II. vol. 369, 97], but his name rarely appeared in an imprint except in the form of the initials A. C. He is last mentioned in the Term Catalogue of Easter 1677 [T.C. 1. 279], but he published in 1678 The Death and Burial of Mistress Money, sold by T. Vere and J. Clarke. [Pepys 363 (563); Haz. 1. 492.] Nichols records that he succeeded James Flesher as printer to the City of London in 1672, and that in 1679 Samuel Roycroft was appointed to that office. [I.it. Anecd. III. 57r.] In 1675 he printed a news sheet called The City Mercury or Advertisements concerning Trade. [Burney 75 A.] Clark died about 1677 or 1678 , and was succeeded by his widow Mary (q.v.).

CLARK, or CLARKE (BENJAMIN), printer and bookseller in London, George Yard, Lombard Street, 1674-98. Printer and publisher for the Quakers. In their records at Devonshire House are the following entries: "At a Meeting at Rebecca Travers the 21 st of $y^{\mathrm{e}} 7$ th Month 1674 , Agreed upon that hereafter A. S. [i.e. Andrew Sowle] B. C. [? Benjamin Clark] nor no other print any booke but what is first read and approv'd of in this meeting." A. S. and B. C. appear as the Society's publishers in another minute of the $26 \mathrm{th}$, and Month, 1675. In 1680 he published $A$ Test and Protest against Popery from the conscientious Christian Protestants, called Quakers. [B.M. T. 407. (4**).] Naturally the Quaker books did not find their way into the Term Catalogues, which was confined strictly to authorized publications; but Benjamin Clark dealt in other literature as well, and his name frequently occurs in the Catalogues between the years 1679 and 1698 as a publisher of school-books, \&c. [T.C. I. 342, III. 57.] Dunton [p. 292] refers to him as "Thee and Thou Clarke".

CLARK, or CLARKE (FRANCIS), printer in London, 1687-8. Mentioned by Dunton [p. 249] as having printed his Remains. In 1687 he was surety for Francis Leach the printer, in a plea of debt brought by Thomas Malthus. [C.P.R. $3 \circ 56$ m. $3^{2}$ recto, Easter 3. Jas. II.] In 1688 he printed an edition of Thomas Deloney's Garden of Good Will for G. Conyers. [Haz. H. 154.] His name does not occur in the Term Catalogues, and his address has not been found, but it may possibly have been the same as that of Henry Clark (q.v.). 
CLARK, or CLARKE (HENRY), printer in London, near St. Paul's Wharf in Thames Street, r687-91. Possibly a relative of Francis Clark. This supposition is strengthened by Dunton [p. 249], who speaks of him as chief printer to T. Malthus, with whom Francis Clark had some business transactions. Dunton goes on to say that Henry Clark was diligent and dispatchful in his business. After his death his widow employed Mr. Sedgwick to manage the business and afterwards to better purpose J. Barber. In 1687 he printed a tract entitled Relief of Apprentices woronged by their masters. Amongst other publishers who employed Clark to print for them, may be mentioned Dorman Newman, T. Northcott, and J. Taylor.

CLARK, or CLARKE (JOHN), bookseller in London, (I) Bible in the Old Exchange, or, Bible in the Old Exchange, near St. Paul's; (2) Bible and Crown in the Old Exchange; (3) Bible and Crown in the Poultry, near Cheapside. 1697-1723. Publisher of divinity and also of the translation of Le Clerc's Life of John Locke, r705. [T.C. III. 48r.]

CLARK (MARY), printer in London, Aldersgate Street, 1677-96. Widow of Andrew Clark $(q . v$.$) . She continued the business until I696. In I68I she$ printed for Charles Harper and Jacob Tonson the $4^{\text {th }}$ ed. of pt. 2 of Cowley's Works.

CLARK (s.), bookseller in London, Birching Lane, near the Royal Exchange, I 7 II. Only found in the Term Catalogue for Easter I7II, when he published three books, one being on trigonometry and another on the art of writing. [T.C. III. $673,674,676$.

CLARK, or CLARKE (WILLIAM), bookseller in Winchester, 1684-8. In Trin. I684, his name appears with W. Abington of London, as publisher of the Rev. Henry Anderson's Religion and Loyalty maintain'd; and in 1686 and I688, he published Bishop Ken's Exposition on the Church Catechism and Letter. [T.C. II. 83, 222.]

CLARKE (J.), bookseller in London, Bible and Harp, in West Smithfield, r680. A poetical broadside by William Farthing was printed for him by T. H. in r680. [B.M. C. 40. m. II (92).]

CLARKE (JOHN), bookseller in London, under St. Peter's Church, Cornhill. See Dictionary, 164I-67. 
CLARKE (JoHN), jun., bookseller in London, Mercer's Chapel, 1651-78. See Dictionary, $164 \mathrm{1}-67$, where the terminal date 1690 is probably incorrect. The latest date on which his name appears in the Term Catalogue is Mich. 1678. [T.C.I. 333.]

CLARKE (JOHN), music-seller in London, The Golden Viol, St. Paul's Churchyard, I68I-7. First mentioned in the Term Catalogues in Hil. I68I, and last in Hil. 1687. [T.C. I. 432, II. 187.] He dealt solely in music.

CLARKE (JOHN), printer (?) in Oxford, r7r4. [Madan, p. 32.]

CLARKE (JOSEPH), bookseller in London, Star, Little Britain, r670-3. Published the works of William Walker, master of the school at Grantham in Lincolnshire, notably a Dictionary of English and Latin Idioms. [T.C. I. 50.] His last entry in the Term Catalogue was in Mich. 1673. [T.C. I. 155.]

CLARKE(R.), bookseller at Shafton (? Shaftesbury), Dorset, I 7 I9. Received subscriptions for R. Bradley's Philosophical Account of the Works of Nature, I7 19.

CLARKE (RICHARD), bookseller in London, Rose, St. Paul's Churchyard, 1670-81. Publisher of F. Quarles's Divine Emblems, 1670, and in the following year of a Concordance of the Bible. [T.C. I. 27, 64.] Junior Warden of the Company in 1676 ; senior Warden in $\mathbf{r 6 8 0 - 1 .}$

CLARKE (THOMAS), bookseller in Kingston-upon-Hull and Newcastle-uponTyne, r675-88. Admitted on July 22nd, r675 a freeman of the Company of Upholsterers, Tin-Plate Workers and Stationers of Newcastle-upon-Tyne. [N. \& $Q$. Io S. vi. 444.] In 1688, he was sued by Awnsham Churchill the London bookseller in the Common Pleas, on a plea of assault. [C.P.R. 3068 m. 169.] An advertisement of books on sale by him in 1685 is given in The Way to Good Success, by N. L. [B.M.4478. aaa. 124.] See Clark, or Clarke ( ).

CLARKE (WILLIAM), bookseller in London, Shakespeare's Head under the Royal Exchange, I725 (?). Son of John Clarke, schoolmaster, of York, d. I734. At the end of I. Priest's Sermon in Defence of the Liturgy, n. d., is a list headed "The following books, all by Mr. Clarke, are sold by W. Clarke his son, at Shakespeare's Head," \&c.

CLAVELL (ROBERT), see Dictionary, 1641-67

CLAVELL (ROGER), bookseller in London, Peacock near St. Dunstan's Church in Fleet Street, 1695-8. In the Post-Boy of September 17 th-19th, 1695, is the 
following advertisement : "If any person has any Study of Books, or Library consisting either of Divinity, Law, History, Physick, \&c., to dispose of, If they please to send a catalogue of them to Roger Clavel at the Peacock near St. Dunstan's Church in Fleet Street, they shall have the full value for them, and the cost of Carriage Paid." In I695 he was succeeded by T. Leigh. [T.C. II. 633.]

CLAY (F.), bookseller in London, Bible without Temple Bar, 1721-35. Publisher of ladies' novels by Penelope Aubin, Aphra Behn, Madame d'Aulnoy, and others. [Esdaile, pp. I55, 160, 255, \&c.]

CLAYTON (WILLIAM), bookseller in Manchester, I700 (?)-19. Apprentice to E. Johnson of the same town (q.v.). Succeeded to the business when his master absconded. [Dunton, p. 238.] His name occurs in a list of those who received subscriptions for R. Bradley's Philosophical Account of the Works of Nature, I7 I9.

CLEAVE (ISAAC), bookseller in London, Star in Chancery Lane, 1678-1711. Makes his first appearance in the Term Catalogues in Hil. 1678 as the publisher of a book against Rome. [T.C. I. 306.] In 168I he became the publisher of a news sheet called The Popish Mass Display'd, No. I of which appeared on April 20 (with a misprint of the year as $167 \mathrm{I}$ ). Only two issues are known. [B.M. Burney 8I A.] He was also a publisher of law-books, and Dunton [p. 228] describes him as well known to lawyers of the first rank and having printed several eminent trials. Amongst these latter was The Tryal of Sir William Parkins knt., for . . . conspiracy to assassinate . . King William III, 1696. Cleave was still publishing in I7II, in which year an advertisement in the

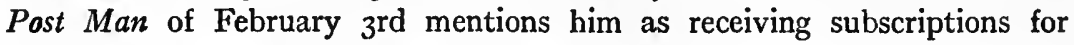
R. Bradley's Treatise of Succulent Plants.

CLEMENT (SAMUEL), bookseller in London, (I) Lute, St. Paul's Churchyard; (2) Swan, St. Paul's Churchyard ; (3) Sun [sic, for Swan ?], St. Paul's Churchyard. I69I-3. Began publishing in I69I, when he issued Guy Miège's English Grammar from the Lute in St. Paul's Churchyard. In the next year he moved to the Swan, and in 1693 he entered in the Term Catalogue the $3^{\text {rd ed. }}$ of John Shower's Serious Reflections on Time and Eternity with the imprint, "Printed for S. Clement at the Sun in St. Paul's Churchyard" (which we suspect to be a misprint for "Swan"). [T.C. II. 458.] 
CLEMENTS (HENRY), bookseller in Oxford, 1684-1721. Apprenticed to Richard Davis, bookseller of Oxford. On May 26th, 168r, he married his master's maid. [Wood, II. 541.] Began publishing in 1684. [T.C. 11. 95.] In $169 \mathrm{r}$, in company with $\mathrm{G}$. West, he published Gerard Langbaine's Account of the English Dramatick Poets [T.C. II. 358], and in 1693 , with West and Crosley, William Somner's Treatise of the Roman Ports and Forts in Kent. [T.C. 11. 476]. On the death of Thomas Bennet, who seems to have been his London agent, Clements took over his business in London at the Half-Moon in St. Paul's Churchyard, in addition to his shop at Oxford. In 1692 Clements was a witness for Clarendon in his libel action against Wood. In his depositions Clements gave his age as about forty-seven. Mr. Clark [ib.] gives the date of Clements's death as 1721 .

CLEMENTS (HENRY), bookseller in London, Half-Moon, St. Paul's Churchyard, 1707-19. It is not clear whether this bookseller was not identical with the bookseller at Oxford of the same name, as the name appears twice in the proposals for printing Corpus Omnium Veterum Poetarum Latinorum in 1709, once for London and once for Oxford. [T.C. III. 656.] Mr. Arber refers to the London man as "the younger". Clements succeeded T. Bennet at the Half-Moon in 1707, and became the publisher of many important books, such as Isaac Littlebury's translation of Herodotus in 1708, Dr. William King's Miscellanies, 1709, Thoresby's Ducatus Leodiensis, 1717, and Bibliotheca Biblica, 1717. With Samuel Keble he was appointed printer of the Votes of the House of Commons. He died August 23rd, 1719, when W. and John Innys stated at the end of a catalogue of their publications that they had secured most of the books printed by Mr. Henry Clements " lately deceased ". [B.M. I21. i. I. (18).]

CLEMENTS (RICHARD), printer (?) in Oxford, 1725. [Madan, p. 32.]

CLIFF (NATHANIEL), bookseller in London, ( $\mathbf{r}$ ) Golden Candlestick in Cheapside, near the Old Jewry; (2) (with D. Jackson) Bible and Three Crowns near Mercer's Chapel, r708-16. Succeeded E. Jaye at the former address in 1708 , when he published $A$ Persuasive to Moderation. [T.C. III. 588.] In the following year with several other booksellers he issued in monthly parts $A$ New Collection of Voyages and Travels. About 17 ro he entered into partnership with D. Jackson, and together they took over the Bible and Three Crowns in Cheapside near Mercer's Chapel, formerly held by Thomas Parkhurst. Both the partners 
seem to have died or given up business by 1716 , as the firm was then S. Cliff and T. Cox, and in $1718, \mathrm{R}$. Cruttenden and T. Cox.

CLIFTON (FRANCIS), printer in London, Old Bailey, c. I720. Printer for the Roman Catholics. His trade consisted largely in printing ballads and broadsides that were obnoxious to the Government. Thomas Gent, the York printer, worked for him for some time and consequently was involved in trouble. [Gent, Life; Davies, History of the York Press.]

COCKERAINE (WILliam), see Cockram.

COCKERILL, or COCKRIL (THOMAS), bookseller in London, (I) Atlas in Cornhill ; (2) Three Legs in the Poultry. 1674-1702. Dealt chiefly in theological and educational works. His first and last entries in the Term Catalogues were in 1674 and I702. [T.C. I. 176, III. 289.] Dunton [p. 214] says of him: "He was always up to the ears among great persons and business (perhaps engaging for a third volume) yet I will do my rival that justice to say he was a very religious charitable man. The printing The Morning Exercise and Charnott's Works brought him into great credit. . . . His kinsman Mr. Thomas Cockril (q.v.) is a living transcript of his uncle's virtues and public spirit".

COCKERILL, or COCKRIL (THOMAS), jun., bookseller in London (?) 1702 ?I705?. Nephew of Thomas Cockerill, sen., whom he survived. See Dunton's account of the latter, written in 1703 . The attribution to him as well as to his uncle of some books of 1690 in the Index to T.C. appears to be an error. [T.C. III. 3,705.]

COCKRAM (WILLIAM), bookseller in Northampton, 1675-7. Published The State of Northampton from the beginning of the Fire, September 20, 1675 to November 5. Licensed November 22nd, r675 [Bodl. Pamph. I35]; and S. Ford's Fall of Northampton, $\mathbf{1 6 7 7 .}$

COGGAN (FRANCIS), bookseller in London, Inner-Temple-Lane, 1699-1707. First mentioned in the Term Catalogues in June I699, as a publisher of law books. [T.C. III. I37.] Dunton [p. 226] says of him, " $\mathrm{He}$ is so cautious and wise that he is noted for it . . . and is as well a judge as a seller of books." In 1707 Bernard Lintot bought of him one half of Love and a Bottle, for $E^{2} 3^{5}$. He was also the publisher of the second part of V. Bowater's Antiquities of Middlesex [Harl. 5961, 128]. He died some time in 1707, and was 
succeeded by his widow Margaret Coggan. Her name appears in the Term Catalogues for the last time in r709. [T.C. III. 644.]

COGGAN (MARGARET), bookseller in London, Inner Temple Lane, I708. Widow of Francis Coggan. She held a share in Dr. John Harris's Lexicon Technicum, was also the publisher of a History of the Reign of Queen Anne, by Abel Boyer, r709. [T.C. III. 600, 6r6, 644.]

COLEBROOKE (JOHN), bookseller in Midhurst, Sussex, I700. In I700 he sold a Sermon preach'd at the funeral of George Payne, Junior . . ., by the Rev. Richard Oliver, curate of Midhurst. [T.C. III. I93.]

COLES (FRANCIS), see Dictionary, I641-67.

COLLEY (JOHN), printer (?) in Oxford, r676. [Madan, p. 30.]

COLLIER, or COLLYER (JOHN), printer and bookseller in Nottingham, ( $\mathrm{r}$ ) Hen Cross ; (2) at the Sheep Pens. I7rI-25. Mentioned in a list of provincial booksellers in Notes and Queries [10 S., vol. v. p. 184], as at work in 1714 and by Allnutt as in r $7 \mathrm{I}$. He was the printer of The Nottingham Mercury and The Nottingham Post. In 1722 he printed a broadside on the method of hiring servants [B.M. I85r. c. ro. (5I)], and in 1725 an ed. of Charles Cotton's Wonders of the Peak.

COLLIER, or COLLYER (JOSEPH), bookseller in London, (I) Angel on London Bridge, a little below the Gate, or, by the Gate; (2) (a) Bible, (b) Golden Bible [under the Gate] on London Bridge. 1679-1724. Is first met with in 1679, in partnership with Stephen Foster, at the Angel, when he published England's Grievances in times of Popery and a sermon preached in St. George's, Southwark, at the funeral of Mrs. Frances Fenn [T.C. I. 366], but shortly afterwards Foster moved to the Sun and Bible on London Bridge. Collier remained at the Angel till after April 10, r680, as on that date his name and address appeared in an advertisement of Bateman's Scurvy-Grass in Smith's Currant Intelligence; but in Michaelmas of that year he is found at the Bible [T.C. I. 42I], where he remained until I700. [T.C. I. 217.] The house was sometimes called The Golden Bible. Treasurer of the Company of Stationers in succession to Benjamin Tooke, r702-24. Died in 1724, [Timperley, p. 629.] Dunton [p. 219] says of him: "He was my fellow apprentice for many years. ... He has a great deal of learning, a discerning judgement, is pleasant in his conversation, and sincere in his piety. He 
writes an excellent hand, is an accurate accomptant and justly merits the honour the company of stationers did him, in choosing him their treasurer."

COLLINS (ARTHUR), bookseller in London, Black Boy in Fleet Street, r709-16. Said to have been born about 1690 , but probably earlier; his father is said to have been gentleman usher to Queen Catherine of Braganza. Collins is first found as a bookseller in partnership with Abel Roper. He is chiefly remembered as the compiler and publisher of the Peerage called after his name. The first edition appeared in 1709 , without the compiler's name, but printed for Abel Roper and Arthur Collins. This was a volume of $47^{\circ}$ pages, but so great was its success that a revised and enlarged second edition appeared in I 7 ro-r I, and a third, sold by Arthur Collins alone, in I7 I4-I6. In expectation of a place under Government, Collins gave up his business in Fleet Street in I 7 r6, but he continued to compile genealogical works, though often " reduced to great straits" for money. At length the king granted him a pension of $£ 400$ a year. Collins died in March 1760 and was buried in Battersea Church "aged 70"; if this is correct he published his Peerage at the age of $\mathrm{r} 9$.

COLLINS (FREEMAN), printer in London and Norwich; Norwich, Red Well. I682-17 I3. In I682 he printed for T. Benskin, London, and C. Yeo, Exon., $A$ True and Impartial Relation of the Informations against Three Witches, viz. Temperance Lloyd, Mary Trembles, and Susanna Edwards, who were . . . convicted at... Exon. [Haz. I. I27.] Between that date and 1697 he printed other books for Exeter booksellers. [J. I. Dredge, Devon Booksellers and Printers, pp. 9, ro.] Dunton says [p. 244] that in r689, he employed Deputy Collins to print for him. But his name does not appear in the Term Catalogues as a printer until 1703, when he printed for J. Nutt Sir H. Mackworth's pamphlet on Conformity [T.C. III. 373], and in the next year he is found printing for Francis Oliver, bookseller in Norwich, the Rev. Thomas Clayton's sermon on Unity of Worship. [T.C. III. 39r.] In 1707 he was elected junior warden of the Stationers' Company. At this time one of his apprentices was Edward Cave, afterwards the founder of The Gentleman's Magazine, who was sent down to Norwich to edit The Norwich Courant. Later Collins seems to have gone to Norwich himself, and in 1712 , to have set up in succession to F. Burgess. His widow Susanna printed till 1724 .

COLLINS (GABRIEL), bookseller in London, at the Middle Temple Gate, r68790. Possibly son of Thomas Collins. Publisher of Thomas Shadwell's Tenth 
Satyr of Juvenal, 1687. He was also a publisher of law books. [T.C. 200, 34r.]

COLLINS (JAMES). See Dictionary, r64r-67. Still in business in $1682-3$, when Adiell Mill brought an action against him for debt. [C.P.R. 3009, $\mathrm{m} . \mathrm{r}_{3} \mathrm{r}$.] In r68r he had a shop under the Temple Church.

COLLINS (THOMAS). See Dictionary, r641-67. Still in business in 1682 . At the end of John Burbury's Relation of a Journey of . . Lord Henry Howard, r67r, published by Collins with J. Ford, is a 24-page list of their publications covering every class of literature. [B.M. 978. b. r.]

COLMAR (JOHN), printer in Edinburgh, in the Grassmarket at the foot of Heriot's Bridge, 1680-5. One of the Dutch workmen brought over by John Cairns about r68o. In 1685 he printed Edinburgh's true Almanack, on his own account ; but the greater part of his time he was in partnership with others. See Lindsay, David. [Aldis, p. rrr.]

COLSON (w.), bookseller at Winchester, r705. Published the Rev. John Horsnell's Sermon . . . at the Cathedral of Winchester, at the Assizes . . . March 8th, $170 \frac{4}{5}$. [T.C. III. 477.]

COMBES (CHARLES), sen., printer in Oxford, r720-8. [Madan, p. 32.]

COMBES (CHARLES), jun., printer in Oxford, $1728(?)-36$. Died in 1736 . [Madan, p. 32.]

CONINGSBY (CHRISTOPHER), stationer and bookseller in London, ( $\mathrm{I}$ ) Golden Key, in Fleet Street, 1687; (2) Golden Turk's Head, Fleet Street, r69r ; (3) Ink-Bottle, against Clifford's Inn Gate, in Fetter Lane, Fleet Street, I 7 I I. I687-r 7 I1. His first entry in the Term Catalogues, in Hil. r687, was W. Elder's Enchiridion Calligraphiae, a series of engraved plates. [T.C. 1I. I87.] He sold legal forms of all kinds, warrants for land-tax, licences for alehouses, and general literature. He was still publishing in $\mathbf{r} 7 \mathbf{r}$.

CONNIBER (JOHN), printer (? or bookseller) in Barnstaple, co. Devon, r682. Mr. Dredge inserts this name in his second supplement on the strength of a note made by Mr. J. R. Chanter, who, he thinks, may have met with it in the Corporation Accounts. [Dredge, Devon Booksellers and Printers. second supplement, p. 59.] 
CONYERS (GEORGE), bookseller in London, (I) Golden Ring, Ludgate Hill; (2) Little Britain, (a) over against the Sugar Loaf, (b) next the Feathers. I686-I7I2. This bookseller had a unique stock, hardly to be found in any other shop in London, for he made a speciality of the publication of cheap practical manuals on every conceivable subject. A glance through the Term Catalogues, of which he availed himself largely, shows him as publisher of books on angling, astrology, building, cookery, drawing, dyeing, gardening, gauging, husbandry, japanning and varnishing, medicine, painting, and perfumery. He also published chap-book abridgements of popular romances, roadbooks, almanacks, \&c. In $\mathrm{I}^{\mathrm{I}} \mathrm{I} 3$ he contributed to the fund for the relief of William Bowyer, sen. [Timperley, p. 600.] Dunton [p. 230] describes Conyers as a "man free from faction, noise, and anger, a diligent man in his shop, a kind neighbour, and a religious master".

CONYERS (JOSHUA), see Dictionary, 164I-67.

COOK or COOKE (JoHN), bookseller in Sherborne, Dorset, I713-16. Publisher of James Lacy's Sermon preach'd at the consecration of a church in the parish of Castleton near Sherborne, I715. [Mayo, Bibl. Dorset., p. 126.] In I716 he also published Shuttleworth's Perswasive to Union.

COOK (wILLIAM), bookseller in London, Green Dragon, without Temple Bar, I676. Recorded by Mr. F. G. Hilton-Price in his articles on 'Signs in the Strand '. [Midd. \& Herts. N. \&o Q., III. I3.]

COOKE (J.), bookseller in London, High Holborn, I 720 (?). He published Life and Character of Mrs. Mary Moders. . . the Famous German Princess, n. d. [Haz. III. 30.]

COOKE (WILLIAM), printer in Chester, I7I8(?)-23. Hazlitt records two books printed by him. (I) Syntax. The Grounds of the Latin Syntax . . Chester : Printed by William Cooke for Jos. Hodgson, and ... sold by Peter Polter. [1720 ?] (2) A Paraphrase on the xxviij Chapter of Deuteronomy. By the Rev. McLindsay. Chester : Printed by Wm. Cooke, for the author, I 723. [Haz. I. 4I 5, 492.] He bought Ince's material in or about I 7I8. [Gent, pp. 83-4.]

COOPER (WILLIAM), bookseller and book-auctioneer in London, (r) Warwick Lane; (2) The Pelican, Little Britain, I668-88. In a volume of astrological tracts called The Philosophical Epitaph of W.C., Esquire, 1673, it appears 
that at an early period of his life William Cooper was a religious enthusiast and a great believer in astrology, and that he either suffered from some physical illness, or that his religious beliefs got him into trouble with the authorities. In the dedication to the Epitaph he speaks of having been "in a living grave" in 1652, and having been "helped from his long troubles" by Elias Ashmole in 1662. His first entry in the Stationers' Register was made on January Ist, 1667 [i. e. 1667] and was an astrological tract called $A$ Chymicall dispensatorie, or, the Treasurie of medicines, written in Latine by John Schroder and Englished by William Rozoland. [Stat. Reg., Roxb. 11. 383.] To his Epitaph he added "A Catalogue of Chemical Books" to which in 1675 he made several additions; this was the first English bibliography of the subject. Cooper was also the first book-auctioneer in England. His first auction was held in 1676 , the library dispersed being that of Dr. Seaman. From that time until his death he shared with Edward Millington the foremost place as an auctioneer, amongst the more important libraries that came under his hammer being those of Dr. Samuel Brooke, I680, Dr. Nathan Paget, M.D., 1681, Walter Rea, 1682, and the stock of Richard Davis, bookseller of Oxford, between 1686 and I688. Amongst Cooper's publications may be noted Spenser's View of the state of Ireland, Ware's De Scriptoribus Hiberniae, Usher's Sylloge veterum Epistolarum Hibernicarum, an edition of Head's English Rogue, and Marlowe's Lust's Dominion. Cooper died before Nov. I689, being succeeded by his widow. [Lawler, p. xxvii.]

CORBET (CHARLES), bookseller in London, Oxford Arms in Warwick Lane, 1683. Does not appear to have been a member of the Company of Stationers, as its records show no sign of his having been an apprentice or taking up his freedom; but he may have been a member of some other company. In 1683 he published a poetical broadside entitled $A$ New Narrative of the Old Plot [B.M. I872.a. I $\left(125^{*}\right)$ ], and in the severe winter of $1683^{-4}$ he published two ballads in commemoration of the frost. In the Term Catalogue for Trin. 1683, in company with J. Crowch, he advertised $A$ Collection of New Songs set within the compass of the Flute. Written and composed by C. F. Gent. [T.C.II. 30.] It seems possible that he was a dealer in music rather than in books.

CORBET (THOMAS), printer (?) at Oxford, I694. [Madan, p. 32.]

CORBETT (BENJAMIN), bookseller in London, I686-17or. Son of Waites or Waties Corbett of Elton, Herefordshire. Apprenticed for seven years from 
November 4 th, 1678 to Robert Everingham, printer. Admitted a freeman of the Company of Stationers on July 5th, r686. [MS. records of Stat. Co.] He was the publisher of the first review entitled Weekly Memorials, or Account of Books, 1688, also of Tooker's Famous Collection of Papers [c. 1700.] On November 2oth, I70r, a Benjamin Corbett who may or may not be identical with the above, wrote to a Mr. Pettiver, saying that he was on the point of sailing for China. [Sloane MS. 4063, f. r28.]

CORBETT (THOMAS), bookseller and book-auctioneer in London, ( $\mathbf{r}$ ) corner of Ludgate Hill, next Fleet Bridge; (2) (a) the Child's Coat, down the Ditch side near Bridewell Bridge ; $(b)$ by Fleet Ditch ; (3) Addison's Head, next the Rose Tavern, without Temple Bar. I715-43. Apparently son of Charles Corbet of the Oxford Arms. Thomas Corbett's name does not appear in the records of the Stationers' Company either as apprentice or freeman. In I 705 he published the fourth edition 'with additions, on a fine paper and Elzevir letter", of New Miscellaneous Poems. [Postman, Sept. 6th-8th, I7I5.] In the same year he also published a sermon called Great Britain's Happiness under ... a Protestant King, by Gershom Rawlins. [B.M. 4474. d. 99.] In I 76 he began selling books by auction at his warehouse, the Child's Coat, down the Ditch side, near Bridewell Bridge. Here on Nov. 7th, I7 16, he sold the library of Thomas Cooke of Fulham, and on October 31st, I7 7 , the library of the Rev. - Kirke of Chester. [Daily Courant, Oct. 29th, I7I7.] In 17 I9 he moved to the Addison's Head without Temple Bar, where he continued until his death in 1743 . Sir Charles Corbett, the famous lottery agent and bookseller, is believed to have been his son.

CORSELEY (w.), bookseller in Bristol, $1721-35$. His name is found in the imprint to a sermon of $172 x$ by J. Harcourt. [B.M. 226. f. I (8).] The dates given above are from a list of provincial booksellers in Notes and Queries [Ioth series, v. I4r.]

CORTNEY ( ), bookseller at Salisbury, I7r6. Son of John Courtney, q.v. (?). Known from an advertisement sheet of prints. [Bodl. Scrapbook, no. 2 (3).]

CORYTON (WILLIAM), bookseller in London, Black Swan on Ludgate Hill. I 7 I I. His name occurs in the imprint to $A$ Short Character of His Ex.T[homas] $E[$ arl $]$ of $W[$ harton] $L[$ ord $] L[$ ieutenant $]$ of $I[$ reland], I III. [B.M. T. 18I5 (3).] 
COSGROVE (HENRY), printer in Norwich, I7II. See Crossgrove.

COTES (ELLEN), see Dictionary, 164I-67.

COTTON (THOMAS), printer in Cork, I 715 (?). See Welsh (Andrew).

COTTRELL (JAMEs), see Dictionary, 1641-67.

COURTENAY (JAMES), bookseller in London, Golden Horseshoe, Saffron Hill, 167 $1-85$. The earliest notice of him is found in the State Papers in the form of a news letter addressed to him from Whitehall, during his absence abroad in $167 \mathrm{I}$. It deals solely with foreign affairs and has no reference to his business. [Calendar of State Papers, Charles II, 167 1, pp. 332, \&c.] In 1679 he published Female Poems on several occasions, written by Ephelia, which was printed for him by William Downing. [T.C. I. 350.] In 1685 Courtenay sued Thomas Young "bibliopolam", of Shaftesbury, for the balance of his account $£ 30$ 6s. [C.P.R., Hil. I Jas. II, Roll 304I, m. 272 v.]

COURTNEY (JOHN), bookseller in Salisbury, 1650-75. See Dictionary, I64 I-67. In 1675 he had printed for him in London, Avona: or, A Transient view of the Benefit of making rivers of this Kingdom navigable. Occasioned by observing the Scituation of the City of Salisbury, upon the Avon ... By R. G. [Haz. II. 695.]

COWLEY (THOMAS), see Diclionary, 1641-67.

COWNLY (GILBERT), bookseller in London, at the Pope's Head in the Lower Walk (or East end of the Lower Walk) of the New Exchange, 1685-9I. Succeeded William Cademan at this house in 1685. [T.C. II. 129.] Cownly published for the Rev. R. Wolley, The Present State of France, 1689 [Haz. III: 270.] The unsold copies were reissued in 1691, with a new title-page, Galliae Notitia, or the present state of France. On the verso of the last leaf of a copy of this edition in the B.M. is a list of Cownly's publications, including Miscellany Poems, with the Temple of Death, by Eminent Hands, and Segrais' romance, Zayde. The latter he apparently took over from Cademan, as Mr. Esdaile notes a copy with the latter's imprint, published in 1678 ; but he does not record any issue by Cownly, who may merely have bought some of the stock of F. Saunders's second edition, 1690. [Esdaile, p. 304.] About I690 J. Knight is found in possession of Cownly's premises, but not before ; and all the references given in the index to the second volume of the Term Catalogues to Knight as at this address should refer to the Blue Anchor in 
the Lower Walk, where he carried on business for several years with F. Saunders.

COWPER. See Cooper.

COWSE (BENJAMIN), bookseller in London, Rose and Crown, St. Paul's Churchyard, 1714-23. In I7I4 Humphrey Wanley approached Cowse and others with a proposal that they should publish Annales de Lanercost, Viscount Weymouth having promised his support; but the Viscount died suddenly and the project fell through. In $172 \mathrm{I}$ he published Laws of British Plantations. [Haz. A. 26r.] Cowse is next heard of in 1723 , in connexion with the publication of certain castrated sheets of Holinshed's Chronicle, which was advertised in the Post Boy of February 16th, $172 \frac{2}{3}$. In this he was associated with Christopher Bateman. [Nichols, Lit. Anec., I. 83, 251.]

COWSEY (J.), bookseller at Exeter, I682. Only known as selling two of W. Crompton's discourses, Sovereign Omnipotency and The Justice of God Asserted, both printed for B. Alsop in 1682. [T.C. I. 504 ; Dredge, Devon Booksellers and Printers, p. 42.]

COX ( ), bookbinder in London, Sherburne Lane, 1670-1700? Referred to by Dunton [p. 259] as "a grave thriving binder for thirty years, but is now retired ... and, for all his misfortunes, is a bright example".

COX (BENJAMIN), bookseller in London, Prince's Arms, Ludgate Street, 1685-9. Succeeded Samuel Smith at this address in 1685. [T.C. II. 138.] His career was a brief one, as the last entry under his name in the Term Catalogues was an edition of Baxter's Dying Thoughts, in Trin. 1689. [T.C. II. 28r.]

COX (GEORGE), stationer in London, St. Botolph without Aldgate, r680-2. Died in or before 1682 , when the will of his widow Elizabeth Cox was proved in the Prerogative Court of Canterbury. [P.C.C. I6 Drax.]

$\operatorname{COX}$ (н.), bookseller in London, Holborn, over against Furnivall's Inn, 1676-9. Successor to Nicholas Cox at this address. Only two entries are recorded in the Term Catalogues, Recreative pastime by card play, in Trin. 1676, and Political and Military Observations, in Hil. I679. [T.C. I. 247, 342.]

COX (NICHOLAS), bookseller in London and Oxford : (I) London, over against Furnivall's Inn, Holborn; (2) Oxford, near Queen's College. 1673-1721. Manciple of St. Edmund Hall. Author of a work called The Gentleman's 
Recreation, 1673. It went through many editions. Cox was also the publisher of some plays and historical works. In 1680 he published a catalogue of plays reprinted and brought up to date from that printed in Nicomede, 1671 . [Wood, I. 20.] In 1685 he appears to have had a shop at Oxford, which Mr. Arber says was near Queen's College. From there he published A. Freyer's Funeral Sermon on the death of Charles 11 , preached at Dort, 1685, and Gerard Langbaine's Momus Triumphans, 1688. [T.C. II. I43, 240.]

COX (THOMAs ?), bookseller in London, Bible and Three Crowns, near Mercers' Chappel in Cheapside, I716-18. In partnership with S. Cliff, and afterwards R. Cruttenden (q.v.). He may be the Thomas Cox referred to by Timperley [p. 684] as an eminent bookseller and exchange broker, who died on February 3 rd, 1754 .

CRAWFURD (THOMAS), printer in Glasgow, 1721. In 1721 he printed an edition of Naphthali, or the Wrestlings of the Church of Scotland. [John McUre, History of Glasgow (1830), p. 371.]

CRAYLE (BENJAMIN), bookseller in London : (1) Bell, St. Paul's Churchyard ; (2) Lamb, Fleet Street, (a) next, (b) near, Whitefriars ; (3) Peacock and Bible, (a) Ludgate Street, (b) West End of St. Paul's Church, (c) St. Paul's Churchyard. 1683-90. Began as a publisher in 1683, when he issued Jo: Quarles's poem, Triumphant Chastity. [T.C. II. 29.] In 1684 he moved to Whitefriars. In 1685 he published Delightful and Ingenious Novels, which ran to four editions. [Esdaile, pp. 2 ro-Ir.] He also dealt in cheap scholastic books. [T.C. II. 232.] In I686 he moved back to St. Paul's Churchyard, and his last entry in the Term Catalogues is Drayton's England's Heroical Epistles, Trin. 1690. [T.C. II. 326.]

CREED (JOHN), bookseller at Cambridge, living opposite Great St. Mary's Church, on ground where now is the lawn attached to the Senate House, 1670-85. We know of seventeen books, chiefly in Latin and Greek, printed for him from 1670-85. [T.C. I. 59-11. 147, and Bowes's Catalogue of Cambridge Books.] He was probably succeeded by Thomas Webster (q.v.).

CRIPPS (SUSAN). See Dictionary, I641-67. She afterwards married Peter Parker. [Stat. Co.'s Register F, p. 595.]

CROFT (EDWARD), bookseller in London, (I) Two Golden Lions, Poultry ; (2) Seven Stars, Little Lombard Street. 1677-8. Was perhaps son of 
Edward Croft, who died in 1667. [See Dictionary, 1641-67.] In 1677 Edward Croft published The Right of Tythes asserted. [T.C. I. 294.] In the following year he moved to Lombard Street, and published there a pamphlet on schism and separation. [T.C. I. 319.] Nothing more is heard of him.

CROOK (ANDREW), bookseller and King's Printer in Ireland, Dublin, r68r-r 731. Son of John Crook (1638-69). In 1681 he was in partnership with his mother Mary Crook $(q . v$.) as a bookseller. In 1685 he took to printing, in partnership with Samuel Helsham. In 1686 he became B. Tooke's assign in the office of King's Printer, and after 1689 was sole King's Printer. He worked till $\mathbf{r}_{73 \mathbf{I}}$, and died in or about $\mathrm{I}_{732}$; his will was deposited in the Dublin Prerog.Court.

CROOK (JOHN), jun., printer in Dublin, r679-84. Son of John Crook, sen. (q.v. Dictionary, 1641-67), King's Printer in Dublin, who died in 1669. Apparently he was not old enough or qualified to get his father's place, and it was filled by B. Tooke, from 1669 to 1678 alone, but in 1679 John Crook shared the office of King's Printer with him and so continued till 1683 . He died intestate in 1684 . Administration was granted to his mother, Mary (or Maria) Crook, widow.

CROOK (MARY), printer in Dublin, 1671-84. Widow of John Crook, sen., King's Printer in Dublin, and mother of John Crook, jun. She was a bookseller in $167 \mathrm{I}$ and also appears as a printer a little later. Her place of business in 1679 was His Majesty's Printing House, and she sold works printed by Tooke, and also by him and her son John when he was Tooke's partner in the office. Her son Andrew joined her in the bookselling business in $\mathrm{r} 68 \mathrm{r}$.

CROOKE (ANDREW), bookseller in London, Green Dragon, in St. Paul's Churchyard, 1630-74. See Dictionary, r641-67.

CROOKE (ELIZABETH), bookseller in London, Green Dragon without Temple Bar, nigh Devereux Court, being the passage into the Middle Temple, r694-6. Succeeded William Crooke, whose widow she probably was, in r694. [Midd. \& Herts. N. \& Q. III. I3.] In Hil. I695 she published a sermon by Thomas Manningham [T.C. II. 537.] In I 696 the firm apparently ceased business, and its stock was remaindered; as in Hil. r696 a notice appeared in the Term Catalogue that "all the books printed for William Crook at the Green Dragon" were to be sold by D. Brown at the Black Swan and Bible without Temple Bar [T.C. II. 575.] 
CROOKE (JOHN), bookseller in London, and King's Printer in Ireland, 1638-69. See Dictionary, 1641-67.

CROOKE (williaM), bookseller in London, Green Dragon, without Temple Bar, 1667-94. See Dictionary, 164r-67. Identical with the bookseller living at the Three Bibles on Fleet Bridge in r664-5. No doubt a son of Andrew Crooke, 1630-74. He printed for Richard Flecknoe and Thomas Hobbes, and published all kinds of literature. Lists of his publications are printed in G. Sibscota, The Deaf and Dumb Man, 1670, and The Moores Baffled, r681. He died some time in 1694, and was succeeded by Elizabeth Crooke (q.v.) [Midd. \& Herts. N. \& Q., III. 13.]

CROOM (GEORGE), printer in London, (x) Bride Lane; (2) Blue Ball in Thames Street, near Addle Hill (over against, or near, Baynards Castle); (3) Blue Ball over against Bridewell; (4) On the Thames. I671-1707. In 1670 or r67r a private press was discovered by the Company of Stationers at the house of George Croom in Bride Lane; who, being sent for, acknowledged the having a press in his house for printing damask boards. The Company ordered that the press should be taken down and brought to the Hall. [MS. records of Stat. Co.] Nothing more is heard of him until 1682 , when he printed The Loyal London Mercury (24 nos., June 14th-November rith). [Timperley, p. 563.] Croom's name appears twice only in the Term Catalogues, first as the printer of The Tryals of Henry Cornish [and others], 1685 [T.C. II. 150], and 2nd ed. 1707; and in 1689, of a Manual of Prayers [T.C. II. 284]. On May 9th, 1688 he issued the first number of The Weekly Test Paper. [Timperley, p. 571.] Dunton [p. 252] says of him: "Some would insinuate as though he favoured the Jacobites, but I take him for a man of more sense. ... Mr. Croom is a fair dealer, understands his business. . . . He ... formerly printed for me The Tigurine Liturgy and of late several sheets of the Post Angel." During the great frost of $1683-4$ Croom set up a printing press on the ice on the Thames, at which he printed a broadside entitled, Thamasis's [sic] Advice to the Painter from her Frigid Zone, or, Wonders upon the water. [B.M. 1875. d. 6 (8).]

CROSKILL (RICHARD), bookseller in London, Lincoln's Inn, New Square, r 706-7. Published A Trip to Leverpoole, by two of Fate's Children, I 706. [Haz. Iv. 58.] 
CROSKILL (THOMAS), bookseller in London, r675. Only known from $A n$ Answer to the Character of an Exchange Wench, printed for him in 1675 . [Haz. H. 84.]

CROSLEY (JOHN), bookseller at Oxford. See Dictionary, r64I-67.

CROSSBY (JOHN), bookseller in Edinburgh, r700. Robert Russel's The sin against the Holy Ghost, I 700, bears the imprint " Edinburgh, printed by James Watson for John Crossby".

CROSSGROVE (HENRY), printer in Norwich, Magdalen Street, I 706-44. Born on August I4th, I683, at Low Leyton, Essex, son of Patrick Crossgrove, an Irishman, and Elizabeth his wife, widow of John Fellows of London and daughter of Harry Gutteridge of Leyton. In a " Chronological Account of Remarkable Accidents and Occurrences to date", given in Francis Burges's True Description of the City of Norwich, ed. I 718 , occurs this note : " I706, Sam. Hasbart a distiller, set up a Printing Office in Magdalen St. and sent for Henry Crossgrove from London to be his journeyman." They separated in I7I8, according to Gent. The first number of the Norwich Gazette was printed by Crossgrove in November I706. In politics it was a Tory and Jacobite paper. [Timperley, p. 626.] In the Weekly Journal for March I 2 th, I $7 \frac{1}{1} \frac{4}{5}$, was inserted a paragraph to the effect that a petition had been signed by the Whigs, calling upon the Government to indict "Mr. Crossgrove the printer" for publishing in the Gazette "A Short Account of the State of England, when King James II intended to call his second parliament" taken from Kennet's History of England, " but we do not hear that the said printer is sent for in custody, or that he keeps out of the way for the same, it having been only reprinted by him after it had sold above ro impressions in London". Crossgrove had some correspondence with Strype. In his later years he became Town Councillor for Mancroft Ward. He died on November I 2 th, 1744 .

CROUCH, or CROWCH (EDWARD), printer in London, 1672. See Dictionary, $1641-67$. Still at work in 1675 , when he is mentioned in a list of printing houses in London. [S. P. Dom. Car. II. vol. 369 (97.)]

CROUCH (NATHANIEL), sen., bookseller in London, (I) Bell, next to Kemp's Coffee House in Exchange Alley (over against the Royal Exchange in Cornhill), I68I-2; (2) Bell (a) in the Poultry, near Cheapside, (b) over against 
Grocers' Alley, in the Poultry, near Cheapside, I683-1708. I663-1725(?). Was born about 1632 ; son of a tailor at Lewes. Apprenticed on May 5 th, $165^{6}$, to Livewell Chapman for seven years, and then took up his freedom in the Company of Stationers. Under the pseudonym of Richard or Robert Burton, he compiled a number of small books of which Dr. Johnson said that "they seem very proper to allure backward readers". The History of the Nine Worthies of the World, 1696, \&c., is perhaps the most celebrated. Dunton [pp. 206, 435-6] says of him, "I think I have given you the very soul of his character when I have told you that his talent lies at Collection. He has melted down the best of our English Histories into Twelve penny Books, which are filled with wonders, rarities, and curiosities ; for, you must know, his Title-pages are a little swelling ". The D.N.B. gives a list of forty-six of his compilations. He is believed to have died before $I_{725}$, when the name of Thomas Crouch (perhaps his son) is found on one of his books. [D.N.B.]

CROUCH (NATHAniel), jun., bookseller in London, Bell, Poultry, 1697. Probably a son of Nathaniel Crouch, sen., at whose shop he published, with T. Crouch, a divinity book in 1697 . [T.C. III. 2.]

CROUCH (SAMUEL), bookseller in London, at the Prince's Arms, a corner shop of Pope's Head Alley in Cornhill, 1674-17rr. Was in some way related to Nathaniel Crouch $(q . v$.) Samuel made his first entry in the Term Catalogue in Mich. 1674 [T.C.I. I87], and became a publisher of school books and cheap literature. In 1679 he started a newspaper called The True Protestant Domestic Intelligence. No. I was issued on July 9th, 1679. Mr. Arber says that Nathaniel Crouch was the writer of it. [T.C. I. 543.] In I69r Samuel Crouch became surety in $£ \mathrm{I}, 000$ for a certain John Gardner, in an action brought against the latter for assault. [C.P.R. Mich. 3 W. and M. Roll, 3 ror m. 140 recto.] His name occurs frequently in the Term Catalogues up to I 7 II. Dunton says of him [p. 2II], "He is just and punctual in all his dealings : never speaks ill of any man; has a swinging soul of his own; would part with all he has to serve a Friend; and that's enough for one Bookseller ".

CROUCH (THOMAs), bookseller in London, (x) Bell in the Poultry, 1697 ; (2) Bell in Paternoster Row, near Cheapside, 1725. 1697-1725? Probably a son of Nathaniel Crouch the elder, at whose shop (above) he published, with $\mathrm{N}$. Crouch jun., a divinity book in 1697 [T.C. III. 2.] In I 725 his name is found on one of "R. Burton's" booklets. 
CROWCH (J.), music-seller in London, Three Lutes in Drury Lane, r683-6. With C. Corbet he published in 1683, A Collection of new Songs, for the flute, by C. F., and in 1686 with N. Thompson The Compleat Dancing-Master. [T.C. II. 30, r68.]

CROWNFIELD (CORNELIUS), printer to the University and bookseller at Cambridge, 1698-I743. "A Dutchman, who had been a soldier, and a very ingenious man" [Ames, p. 462]. He was appointed business adviser to the Curators of the University Press in 1698 at the first meeting of that newly formed body, and seems to have been at once sent to Rotterdam to buy type for the University Press. He often visited Holland on business, and there are several references to him in the Correspondence of Dr. Richard Bentley, and in Hearne's Collections. In a letter from Dr. Barnes to Hearne, May I $5^{\text {th, }}$ I709, "Landlord Crownfield has brought back the frontispiece [to Homer, printed $\mathrm{I} 7 \mathrm{Ir}$ ] rarely designed, from Holland". [T. Hearne, Remarks and Collections, ed. Doble, II. I98.] He was appointed Printer to the University February $\mathrm{I}$ th, $\mathrm{I} 70_{6}^{5}$, but previous to this we find printed for him, A. Tacquet, Elementa Geometriae, cura Gul. Whiston, r703. From the time of his appointment to 1740 , when he was succeeded by Joseph Bentham, a large number of important works were printed by him, amongst which may be mentioned, Dr. Bentley's editions of Horace ( I $_{7}$ II) and Terence ( I $_{726}$ ), the second edition of Sir Isaac Newton's Philosophiae Naturalis Principia Mathematica (17 73 ), Wasse's edition of Sallust (1 7 ro), Sir Thomas Browne's Christian Morals (r 7 r6), Historiae Ecclesiasticae, 3 vols., folio (1720), Dr. Knight's Life of Erasmus (1726), Conyers Middleton's Bibliothecae Cantabrigiensis ordinandae methodus (1723) and his Dissertation concerning the Origin of Printing in England (r735), some being beautifully printed with the new type purchased from Holland, on paper specially purchased from the same source [see a note to Newton's Principia in Gray's Newton Bibliography, p. 7.] On February 25th, 17 $\frac{39}{40}$, a resolution was passed to appoint a new inspector, and to allow the present, now infirm, to continue his full salary, and on March 24th, 1740, Joseph Bentham was appointed in the room of Crownfield [Bowes, Cambridge Printers, $3^{1} 3$. Crownfield died in $\mathrm{I} 743$ and was buried in St. Botolph's parish on

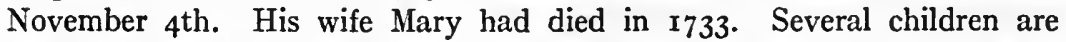
recorded in the parish registers. Two of his sons, Henry and Thomas, were educated at Clare College, and were subsequently ordained. Previous to his appointment as University Printer he lived in St. Edward's parish, but on his 
appointment moved to the house attached to the University Press in Silver Street. Dr. Barnes, writing to Hearne $c$. September 24,1708 , says that he is lodging with Mr. Crownfield at the Printing House [Hearne, Remarks and Collections, II. I35.] He was a bookseller as well as a printer ; Tacquet was printed for him in 1704 and later in various works printed by him he has a list of "Books Printed for and Sold by Cornelius Crownfield at the University Press in Cambridge".

CRUMP (ЈонN), bookseller in London, Three Bibles, St. Paul's Churchyard, 1673-82. Began to publish in 1673 [T.C. I. 149.] In 1675 he published a novel entitled Beraldus, Prince of Savoy. [B.M. 12510. aaa.3.] The last entry under his name occurs in Mich. I682, when he published a political pamphlet called, The True Loyalist. [T.C. I. 503.]

CRUTTENDEN (HENRY), printer at Oxford, I68I-94. Anthony Wood had a Catalogue of books on sale by John Gellibrand of London dated r682(?) which was given to him by Cruttenden the printer on the occasion of the execution of Stephen Colledge at Oxford on August 3 Ist, r68r. [Wood, Ir. 553.] In 1684 he was threatened with proceedings for printing an edition of Cornelius Nepos, which Dr. Timothy Halton the licenser declared contained more than he had licensed. [Ib., III. 86.] In 1687 Obadiah Walker, Master of University College, set up a Roman Catholic press in his house, aided by Cruttenden, who obtained the title of King's printer. [Madan, p. I9.] Cruttenden died in 1694, and Wood notes that he was buried in Holiwell Churchyard on October I2th. [Wood, III. 470.]

CRUTTENDEN (R.), bookseller in London, Bible and Three Crowns near Mercers' Chappel in Cheapside, I718. Perhaps a son or brother of Henry Cruttenden $(q . v$.$) . In partnership with T. Cox, in which he appears to have$ succeeded S. Cliff $(q . v$.$) .$

CULLEN (JoHN) stationer in London, The Buck without Temple Bar, I 7 ro. The shop was bequeathed by Mary Hayes in her will, dated 17 ro and proved I I 3 , and is described as being "heretofore in the occupation of Ephraim Dockwra bookseller decd ... and now in the occupation of John Cullen citizen and stationer of London ", and as having formerly been known as the Pestle and Mortar. The house with this latter sign was occupied in 1694 by Andrew Bell and Jonas Luntley (q.r.). [P.C.C. ${ }^{1} 3^{6}$ Lceds.] 
CUMBERLAND (RICHARD), bookseller in London, Angel in St. Paul's Churchyard, 1693-8. Mathematical and miscellaneous publisher. His first and last entries in the Term Catalogues were in Easter 1693, and Mich. I698. [T.C. II. $45^{8}$; III. IOI.]

CUNYNGHAM (ALEX.), printer in Glasgow, before 1681 . His will was registered February 25th, 168r. [Aldis, p. II2.]

CURLL (EDMUND), bookseller in London and Tunbridge Wells, (I) Covent Garden; (2) Peacock without Temple Bar, I706-1o ; (3) (a) Dial and Bible, against St. Dunstan's Church, $(b)$ next the Temple Coffee House in Fleet Street, I7IO-23; (4) on the Walk, Tunbridge Wells, I712; (5) Paternoster Row, I720 [this and the preceding must be branch shops] ; (6) over against Catherine Street in the Strand, 1723-6 ; (7) next to Wills's Coffee House in Bow Street, Covent Garden, I729; (8) Burleigh Street, Strand, I733; (9) Pope's Head, Rose Street, Covent Garden, 1735-47. I705 (?)-47. Born, according to his own statement [Curliad, p. 14] in 1683, but perhaps in 1675, as the Gentleman's Magazine [xv11. 592] gives his age as seventy-two at his death in 1747. Curll came early from the West of England to London, and was apprenticed to a bookseller, "Mr. Smith by Exeter Change". Having served his apprenticeship he set up first a stall and then a shop in Covent Garden, where he probably carried on a purely retail trade. In I 706 he first appears in an imprint, publishing at " the Peacock, near St. Clement's Church in the Strand ", a " reprint" [D.N.B.], really a reissue of the sheets, of Captain Bladen's translation of Caesar's Commentaries, published in the previous year by Richard Smith, who may be identified with his old master. In 1707 he pirated Prior's Poems on Several Occasions. In I 708 he published, in conjunction with E. Sanger, Dodwell's Explication ... concerning the Immortality of Human Souls, and Boileau's Lutrin. [T.C. III. 595-6.] The latter appears in his list of 1735 as still in stock. Curll declared in 1727 that the former was the first book printed by (i. e. for) him. [Apology for the Writings of Walter Moyle.] On September I3th, I 710, he made the first of his very few entries in Stat. Reg., Some Account of the Family of Sacheverell, and he himself contributed to the controversy a pamphlet, The Case of Dr. Sacheverell, I 10. In this year he left the Peacock for the Dial and Bible close by, previously occupied by $\mathrm{A}$. Boswill, and published there $A$ Complete Key to the Tale of $a T u b$. Two years later he is found subscribing a guinea to the Bowyer 
fund, and had prospered enough to have a branch shop at Tunbridge Wells. In 1716 began his long quarrel with Pope. He had had a hand in the publication by James Roberts of Court Poenis, some of which are attributed in the advertisement to " the laudable translator of Homer". Pope was so annoyed that he arranged a meeting with Curll and Lintot at the Swan Tavern in Fleet Street, and there administered to Curll an "emetic potion"; he then published a satirical account of the affair, A Full and True Account of a Horrid and Barbarous Revenge by Poison on the Body of Mr. Edmund Curll bookseller, which was followed by other pamphlets. In the same year Curll first came under the displeasure of authority, being reprimanded at the bar of the House of Lords for breach of privilege in publishing a piratical edition of An Account of the Trial of the Earl of Wintoun [Lords' Journals, May 1716], and was also tossed in a blanket and beaten by the Westminster scholars for pirating, with many inaccuracies, their Captain's oration over Dr. South. In 1720 he apparently opened a branch shop in the City, in Paternoster Row, but continued to give the Dial and Bible as his address on imprints till at

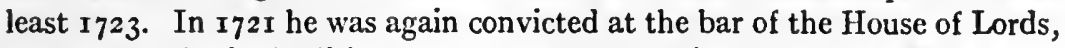
for an unauthorized edition of the Duke of Buckingham's Life and Works; and in 1725 and 1728 he was fined for publishing immoral books; on the latter occasion he was also imprisoned for five months, and used his imprisonment to acquire the copy of the Memoirs of John Ker of Kersland, for publishing which (as being defamatory of the Government) he was in the same year condemned to stand in the pillory at Charing Cross ; the inconveniences of this he skilfully avoided by circulating among the crowd a leaflet stating that he was suffering for vindicating the memory of Queen Anne. He stated that of the most notorious of the indecent books he had been convicted of publishing in 1728 (Venus in the Cloister) he had sold only one chance copy; but this can hardly be true, as it appears, with the rest, in his list of $\mathbf{7 3 5}$. In spite of all these transactions he is found in $1723-4$ and again in 1728 offering his services to the Government. In 1733 his Copy of the Will of Matthew Tindal, one of a large series of wills and memoirs which led Arbuthnot to observe to Swift that Curll was " one of the new terrors of death ", brought him into a violent quarrel with Eustace Budgell. His feud with Pope had continued intermittently since 1716 . In 1726 he printed Pope's Letters to Henry Cromwell, of 1708-12, and Pope accused him in the Dunciad (Notes, ed. 1729) of, among many other things, clandestinely acquiring the copy 
of these letters, a charge which Curll denied. But Pope's attack at large on Curll in the Dunciad is so strong that its victim is now generally remembered only as "dauntless Curll" and "shameless Curll". He replied at length in the Curliad, I729, a valuable source of biographical details concerning its author. In spite of these amenities Pope is known to have secretly arranged the publication by Curll in $\mathbf{1} 735$ of his Literary Correspondence for Thirty Years, and at the same time to have contrived to have the publication stayed by the Lords on a far-fetched and unsuccessful plea of breach of privilege. His object was to give excuse for and advertise his own authorized edition. Curll published his collection, which degenerated into a miscellany, in $1735-7$, and Pope his in I737-4I. Curll had simultaneously moved to Rose Street, Covent Garden, and taken the sign of "Pope's Head", of which sign his device is no doubt a copy. Here he continued to publish, apparently more peacefully, until $\mathbf{1 7 4 7}$, on December IIth of which year he died. His will, which was proved on July 2 Ist, 1748 , contains the following codicil of July 17 th, I 742 :

I have no relatives, my son is dead,

He left no issue, and his wife 's re-wed;

Therefore no legacys at all I leave,

But all I've got to my dear wife bequeathe.

[P.C.C. 209 Strahan.]

The son here referred to as dead by 1742 had a separate shop in 1726 and sold his father's books, while the latter was in conflict with the authorities; he appears to have been with him in Burleigh Street in I733. Curll issued brief select lists of novels and of poems in I7I9 [in The Female Deserters (printed for James Roberts), and Major Pack's Miscellanies], and of theology in 1723 [in Addison's Miscellanies], also a list of forty-three books issued from "over against Catherine Street in the Strand", i.e. not before 1723 [a copy is bound after John Hales's Discourse, I720, B.M. III3. g. I3]. Classified general lists appeared in 1726 [in Ashmole's Order of the Garter, and ed., not in B.M.], and in $\mathrm{r} 735$ [separately, B.M. G. I3457/2]. This last contains nearly two hundred items, including not only some of his earliest publications, but also those on account of which he had suffered fines and imprisonment, and is the basis of any bibliography of his productions. It may be compendiously said of Curll that while he possessed all the vices 
attributed to him, he also possessed virtues which are too commonly ignored. Some of his publications are in the worst style of a bad period; many are libellous. He was pertinaciously defiant of authority, and malicious toward his enemies. But he is generally truthful, and his chief enemy, Pope, was the aggressor and deserved much worse handling than Curll gave him. The accusations against him of starving his hacks are apparently exaggerated, at least, if not quite false. Curll's classified list of 1735 shows that he was a large publisher of almost every sort of literature, especially of memoirs and of local history. A series of county histories, which he advertised as Anglia Illustrata, in 20 vols., and a bibliography of such books, entitled The English Topographer, alone give him a claim to gratitude ; but comparatively few of his publications are worthless. In short, he was a man of considerable intellect, and an excellent man of business, who was troubled by few scruples. A vivid portrait of him is drawn by Amory in John Buncle (ed. 1770, Iv, $\mathbf{r}^{8}$, \&c.): "Curl was in person very tall and thin, an ungainly, awkward, whitefaced man. His eyes were a light grey, large, projecting, gogle and purblind. He was splay-footed, and baker-kneed. He ... was well acquainted with more than the titlepages of books. ... He was not an infidel. . . . He was a debauchee. ... By filling his translations with wretched notes, forged letters and bad pictures, he raised the price of a four shilling book to ten. . . . He died at last as great a penitent ... as ever expired." [W. J. Thoms, Curll Papers (reprinted from N. \& Q.) ; D.N.B. ; and sources quoted.]

CURTEYNE (AMOS), bookseller at Oxford, 1665-90. See Dictionary, 1641-67. Son of Henry Curteyne. Was established as a bookseller as early as 1664 , when Anthony Wood bought books of him. [Life and Times, vols. i, ii.] He began to publish in 1670, when he advertised Edward Leigh's Select and Choice Observations concerning all the Roman and Greek Emperors, and, in partnership with George West and John Crosley, Charles Estienne's Dictionarium Historicum, Geographicum, Poeticum. [T.C. 1. 45, 50, 62.] In 1676 Curteyne published Sir Henry Spelman's De non temerandis Ecclesiis. [T.C. 1. 230.] His name appears in the Term Catalogue for the last time in Easter 1687 , when he advertised Institutio Logicae by John Wallis and a duodecimo entitled Of Education. [T.C. I1. 193-195.] He died in 1690.

CURTIS (JANE), bookseller in London, 1679-90. Wife of Langly Curtis (q.v.). 
CURTIS (LANGLY), bookseller in London, (I) Goat Court, (a) on Ludgate Hill, (b) near Fleet Bridge ; (2) Sir Edmonbury Godfrey's Head, near Fleet Bridge. 1668-90. Apparently all these addresses refer to the same shop. On February 16th, 1668 [i.e. 1668] he entered The Quaker's Spirituall Cort [sic] proclaymed. [Stat. Reg. Roxb., II. 397.] He published several papers in support of Oates and Bedloe, and amongst others $A$ Pacquet of Advice from Rome, a weekly sheet the first number of which appeared on Friday, December $3^{\mathrm{rd}}, \mathbf{1 6 7 8}$. He and his wife Jane were frequently in trouble with the authorities. On February 7 th, $16 \frac{79}{80}$ Jane Curtis was tried for printing a copy of verses reflecting on the Lord Chief Justice entitled Scroggs upon Scroggs, and in April 1683 , Langly Curtis was ordered to pay $£ 500$ and stand in the pillory in Bloomsbury Market for publishing Lord Russell's Ghost, or the Night Walker of Bloomsbury. [London Gazette, April 21-24, 1683.] In this year he also printed an answer to Elkanah Settle's Narrative [Nichols, Lit. Anecd., 1. 43], after which nothing more is heard of him in the Term Catalogues, but Hazlitt traces him until 1690. [Haz. 1. 456.]

CUTLER (ROBERT), see Dictionary, 1641-67.

D. (N.), bookseller (?) in London, Little Britain, 1674. Published a topical pamphlet in 1674. [Haz. I. 264.]

D. (P.), bookseller (?) in London, Little Britain, 1674. Published News from the Exchange, 1674. [Haz. III. 146.].

D. (s.), printer in London, 1695-7. Charles Peter's New Observations on the Venereal Disease, and ed., was printed in 1695 by S. D. and D. N. [Haz.IV. I6o], and in 1697 S. D. alone printed Miscellanies over Claret. [Haz. III. 300 ; Huth.]

D. (w.), bookseller in London. Possibly Walter Davis. These initials are found on many ballads and broadsides during the period of the Popish Plot.

DAGNALI (MATHIAS), bookseller at Aylesbury and Leighton Buzzard, 16581736. Probably son of Stephen Dagnall. [See Dictionary, 1641-67.] A tablet in the Lady Chapel of Aylesbury Church states that he died September 26, 1736, aged 78. His wife Sarah died in August 1736 , aged 76 . They left two sons, Matthias and Deverell. He dealt very largely in ballads.

DAGNEL (STEPHEN), bookseller at Chesham, Bucks, 1720. His name is found with that of a score of other provincial booksellers and chapmen, in the 
imprint to a ballad entitled Roger's Delight ; or the West Country christning \& gossiping, Northampton, r 720. He was probably son of Stephen Dagnall, bookseller of Aylesbury, and brother of Mathias Dagnall (q.v.).

DALTON (ISAAC), printer and bookseller in London, Goswell Street, I7 16 -18. Published a weekly newspaper, The Shift shifted, of which no. 12 appeared on July $215 t, 1716$; in 1718 he is found printing, for W. Boreham, an edition of Skelton's Tunning of Elinor Rumming.

DANCER (NATHANIEL), bookseller and bookbinder in London, Fleet Street, c. I700. Dunton [p. 228] says of him: "He was formerly a binder, but is now a noted bookseller in Fleet-street." His name is not otherwise known, and he was probably only a retail dealer.

DANIEL (M.), bookseller in London, $1671-5$ (?). Possibly widow of Thomas Daniel. Published in partnership with T. Ratcliff, Madame de Villedieu's novel, Love's Journal. [Esdaile, p. 21I.] May be the M. D. who published The Starr-Prophet Anatomiz'd and Dissected, by J. S., 1675. [Haz. II. 529.]

DANIEL (THOMAS), printer in London, 1669-70. Possibly successor to Roger Daniel. In company with Thomas Ratcliffe he printed for Philip Chetwind in 1669 the ninth edition of Earle's Microcosmographie. One T. D., printer, who may have been Daniel, was associated with William Downing about 1670 .

DANVERS ( ), stationer in London, Temple Churchyard, r689. Known from an advertisement of stolen books in the London Gazette of May 6th, I689.

DARBY (JOHN), sen., printer in London, Bartholomew Close, 1662-I704. See Dictionary, I64I-67. In February 1684 he was convicted of printing a libel called Lord Russell's Speech ; but escaped with a fine of twenty marks. [Nichols, Lit. Anecd., viII. 367.] Dunton [p. 247] has this notice of him : "I might call him the religious printer. He goes to Heaven with the Anabaptists but is a man of general charity. He printed that excellent speech of my Lord Russell and several pieces of Colonel Sydney, and is a true assert or of English liberties." Timperley [pp. 589-90] says that he died December I Ith, 1704, in his 8oth year. He was succeeded by his son John. Among his apprentices was Henry Woodfall.

DARBY (JOHN), jun., printer in London, Bartholomew Close, 1704-33. Son of the preceding. Contributed three guineas to the fund raised in 
I713 for the relief of William Bowyer after his fire. In 1719 he printed for booksellers at Bath, Bristol, and Oxford, Arthur Bedford's Serious Remonstrance against the stage. In $\mathbf{1 7 2} \mathrm{I}-2$ he printed for D. Browne the 8-vol. edition of Rushworth's Historical Collections. He died at Islington in the early part of 1733 , his will being proved on February 3 rd, r732 [i.e. r73 $\frac{2}{3}$ ]. He left an only child, Elizabeth, wife of Isaac Clarke, and desired that his executors should be cautious how they disposed of any of his copies of books or shares of copies, in case any of his grandchildren should become or marry a bookseller.

DARKER ( ), printer in London, c. r69o (?). Dunton [p. 247] mentions "Mr. Darker" as having printed much for him, first in partnership with Mr. Newman in Little Britain, and later alone, till his death. His widow married a Mr. Grantham. He probably died too early to be identified with either Samuel Darker (q.v.).

DARKER (SAMUEL), printer in Exeter, r698-r 700. Printed, for Charles Yeo, John Pearce, and Philip Bishop, Richard Dunning's Bread for the Poor, r698. In the same year he entered into partnership with S. Farley, and they printed together till $\mathrm{r} 700$, three pamphlets from their press being known. [Dredge, I0, II, 62, 94.] In I700-1 a bookseller of this name is found in London. See below.

DARKER (SAMUEL), bookseller in London, (r) Jewen Street; and (2) (simultaneously) Three Legs, at the end of the Old Jewry, in Cheapside, r 700-r. Dealt in theological works. [T.C. III. 2rr, 253.] Possibly identical with the Exeter printer.

DARRACK (THOMAs), printer in London, c. r 700-ro. Printed John Dunton's Dissenting Doctors, and ed., and Athenianism, both in r710, the former at least with Tookey. [Dunton, p. 696 ; Nichols, Lit. Anecd., v. 80.]

DAVIDSON (JAMES), printer and bookseller in Edinburgh, 1724-64. Printed in partnership with Robert Fleming; the Acts of the General Assembly from I 724 to 1764 bear their imprint as printers to the Church of Scotland. In 1728 Davidson and Thomas Ruddiman were appointed conjoint printers to the University.

DAVIES: See also Davis. 
DAVIES (ELEANOR), bookseller at Oxford, r683. Sold John Speed's map of Canaan, advertised in Easter 1683. [T.C. II. 22.]

DAVIES (т.), bookseller in London, 168I. Publisher of no. $\mathrm{I}$ of The Observator Observed, or Protestant Observations upon Anti-Protestant pamphlets, $\mathrm{I} 68 \mathrm{r}$; nos. 2 and 3 were printed for J. Gilford (q.v.). Two books sold by him in this same year are recorded by Hazlitt [II. 90, 363].

DAVIES or DAVIS (THOMAS), bookseller in London. See Dictionary, I64I-67. Master of the Company of Stationers, 1668-70.

DAVIS. See also Davies.

DAVIS (R.), bookseller (?) in London, Three Ink Bottles, Castle Alley, near the Royal Exchange, I 709. Dealer in maps. In I 709 he sold H. Moll's Theatrum Historicum. [T.C. III. 647.]

DAVIS (RICHARD), bookseller in Oxford, 1646-88. See Dictionary, I64I-67. A catalogue of over a hundred books of all sorts printed for and sold by him is printed on the second leaf of H. Paleston's Historical Essaies, I664. On June $25^{\text {th }}$, 688 , a portion of his stock was sold by auction. [London Gazette, June II-I4, 1688.]

DAVIS (ROBERT), bookseller in Bridgwater, I7r6. Mentioned in a list of provincial booksellers contributed by W. C. B. to Notes \& Queries [Ioth S., V. I4I].

DAVIS (T.), bookseller in London, Red Lion Street, Whitechapel, r698-г 7זr. Published a divinity book in Hil. 1698. [T.C. III. 50.]

DAVIS (THомAS), bookseller of Denbigh, r6g9. Sold school books which he purchased of John Minshull, bookseller of Chester. [Library, and ser., IV. 373-83.]

DAVIS (WALTER), bookbinder and bookseller in London, Amen Corner, $1676-87$. In 1676 the following advertisement appeared in the Term Catalogue: "I am desired to give notice that, upon the death of Mr. Cutler, Mr. Walter Davis bookbinder, in the Stationers Rents in Amen Corner, is ready to undertake the publishing of new books, in the same manner, and upon the same terms, as Mr. Cutler did. R. Clavell." [T.C. I. 264.] His last entry in the Term Catalogues was made in 1686 [T.C. II. 165], but Hazlitt records a book with his imprint in I687. [II. 285.] 
DAVIS (WILLIAM), bookseller in London, (a) Bull, over against the Royal Exchange ; (b) Black Bull, Cornhill, near the Royal Exchange. 1699-1705. Publisher of Poems on several occasions, said to be by a brother bookseller, Herbert Walwyn, 1699. In 1704 he published a play, The Faithful Bride of Granada, and in 1705 a comedy, The Gamester. [T.C. III. 412, 439.]

DAWES (GEORGE), bookseller in London, Chancery Lane, over against Lincoln's Inn Gate, $166_{5}-85$. See Dictionary, $1641-67$. A list of books printed for and sold by him was inserted at the end of Dr. John Godolphin's View of the Admirall Jurisdiction, and ed., 1685. [B.M. 517. b. 2r.]

DAWKS (ICHABOD), printer in London, (I) Blackfriars ; (2) Wardrobe Court, Great Carter Lane. 1673-1730. Eldest son of Thomas Dawks the younger. Born at Westerham in Kent, September 22nd, r66r. On May r6th, r673, he went with his father to work at Mrs. Maxwell's printing office, but in the following year they transferred their services to Mrs. Flesher. Ichabod Dawks married on August $3 \mathrm{rd}, \mathrm{r687}$. In 1694 he petitioned the Court of Assistants of the Stationers Company, representing the inconvenience of the $e^{3}$ press at Chester, and that it was reasonable to suspect that many of the late pamphlets might be printed there, there being no one to overlook it. The court agreed that a representation be made of it to one of the secretaries of State. [Records of the Stat. Co.] He is chiefly remembered as the founder of the newspaper known as Dawks' Nezos-Letter, which was distinguished from other papers of the time by being printed on writing paper in script type, with a blank space left for correspondences. It continued until I 7 5 5 perhaps later; but copies are rare, and complete sets unknown. Dawks was also the printer of a sheet called The Protestant Mercury, issued in 1697. His name rarely appears in the Term Catalogue. He died February 27 th, I730, and was buried at Low Leyton. [D.N.B., Timperley, p. 660 ; Nichols, Lit. Anecd., I. 3, 72, II8, 373 ; II. I6I ; III. I 76, 290-I ; IV. 9.]

DAWKS (thomas), the elder, printer in London, 1635-70. See Dictionary, I64 $1-67$. Died at Low Layton in Essex on May i 1 th, I670.

DAWKS (THOMAS), the younger, printer in London, ( $\mathrm{I}$ ) Blue Anchor, west end of Paul's; (2) Blue Anchor, Ludgate Street; (3) Blackfriars ; (4) end of Thames Street, next Puddle Dock; (5) His Majesty's British Printer, west end of Thames Street ; (6) on Addle Hill in Carter Lane. I652-96 (?). Son 
of Thomas Dawks, printer [d. 1670]. Born at Kelmscott in Oxfordshire, October 8th, 1636. Admitted at Merchant Taylors' School, April 2nd, I649. Began as a printer at the private press of the Master, W. Du Gard, and from I652 to I657 was employed as a compositor on Walton's Polyglot Bible; he afterwards worked at John Darby's printing house in Bartholomew Close. He married in December 1660, and his son Ichabod was born at Westerham, Kent, on September 22nd, 166r. On May 16th, 1673, Thonas and his son were working in the office of Mrs. Maxwell, from which they went to Mrs. Flesher's printing house on October 5 th, 1673. Thomas Dawks set up as a master printer in Blackfriars in May 1674 ; in Hil. 1680 he and his son printed a Methodical History of the Popish Plot. [T.C. I. 384.] In the previous year, however, his address is given as The Blue Anchor at the west end of Paul's and also as in Ludgate Street. These evidently refer to one and the same house, which was doubtless a warehouse or shop for the sale of books, distinct from the printing houses. In the True Protestant Mercury of June 22-5, 168I, he advertised his removal to Thames Street, near Puddle Dock, and in 1685 his office was in Addle Hill in Carter Lane. His name occurs for the last time in the Term Catalogues in Easter 1689 [T.C. II. 252], but his entries there are few. The date of his death is unknown; but his name occurs as publisher of Dawks' Nezes Letter on August 4th, 1696. His daughter Dorothy married first Benjamin Allport and secondly William Bowyer the elder. [D.N.B. ; Nichols, Lit. Anecd., I. 3, 4; Timperley, p. 660.]

DAWSON (ELIZABETH), bookseller in Cambridge, 1706-28. Widow of Thomas Dawson the younger; she continued to live in the High Street, and died in 1728, her will being, like her husband's, at Peterborough. On October 29th, 1725, the University passed a Grace "for remitting debt for books owed by Elizabeth Dawson".

DAWSON (THOMAS), the elder, bookbinder at Cambridge, 1675-95 (?). Mentioned in the will of Troylus Atkinson (q.v.) of 1675 as living in his freehold tenement the "Nag's Head". [Gray and Palmer, Cambridge Wills, II5.] See next entry.

DAWSON (THOMAS), the younger, bookseller at Cambridge, in the High Street, 1695-1 706. Son of Thomas Dawson the elder. His name appears on five works printed for him at the University Press, 1695-1 706. In this last year he published the Lexicon Novi Testamenti Alphabeticum, by John Dawson. a work 
of renown, frequently reprinted, the sixteenth edition being published in 1822. The author, son of Thomas Dawson, and apparently a brother of his publisher, entered Christ's College, July 7 th, 1693, as sizar. [Peile's Biog. Register of Christ's College, II. 128.] On the title of Censorinus, de Die Natali, 1695, the publisher is styled Thomas Dawson, jun. He died r708, and his will is at Peterborough.

DEACON (в.), bookseller in London, Angel in Giltspur Street, 1699-1704. Dealer in popular literature. In partnership with $\mathrm{J}$. Deacon. Most of their books are undated, but B. Deacon published editions of Richard Johnson's Tom a Lincoln, dated I703, I704, and 1705. [Esdaile, p. 85.]

DEACON (JOHN), bookseller in London, (I) Rainbow, Holborn, a little above St. Andrew's Church ; (2) The Angel in Giltspur Street, without Newgate, 1682-1701. Publisher of all kinds of cheap and popular literature. Made his first entry in the Term Catalogues in Mich. 1682. [T.C. I. 509.] About r694 he moved to the Angel in Giltspur Street, where he continued until r 701 , or perhaps later.

DEACON (M.), bookseller in London, Horse-shoe in Giltspur Street, c. I700. Hazlitt records The Life and Death of Fair Rosamond, with the above imprint. [Haz. I. 364.]

DEACON (s.), bookseller in London, Angel in Giltspur Street, c. I700. Hazlitt records a copy of The Garland of Love with the above imprint. [Haz. I. 266.] Probably the widow of J. or B. Deacon.

DEAN (J.), bookseller in London, ( $\mathrm{I}$ ) Cranbourne Street, in Leicester Fields, near Newport House; (2) at the Queen's Head, between the Royal Grove and Helmet in Drury Lane. 1679-85. A publisher of broadsides. He moved to his second address in 1685 . Among dated sheets by him are The Loyal Conquest, I683 [B.M. 1872. a. I (32)], Song of the Light of the Three Nations turn'd into darkness, 1684 [Haz. II. 43I], Islington Wells, a song [B.M. C. 20. f. 2 (167)], The Royal General, a ballad, r684 [Bodl. Ashm. G. I5I84], and A Song upon the Rondizvous on Hounsley-Heath, 1685 [Bodl. Ashm. G. 15187]. Dean's name does not appear in the Term Catalogues.

DEANE (ROBERT), papermaker, Chelmsford, Essex, I686. Mentioned in a lawsuit in Trin. 2 Jas. II. [C.P.R. 3046, m. 416, verso.] 
DEERE or DEEVE (JOHN), bookseller in London, Barnard's Inn Gate, Holborn, 1700-1. Dealer in law-books [T.C. III. 176]. He is mentioned as taking in advertisements for The State of Europe, r7or [Burney, 99]. He is probably the person spoken of by Dunton [p. 292] as "unfortunate D-ve".

DEGRAVES (E.), bookseller in London, next the Fountain Tavern in the Strand, 1700. His name occurs in the Term Catalogue for Mich. 1700 as selling some divinity books. [T.C. III. 212.]

DEW (R.), bookseller in London, 1682. In $168 \mathrm{I}$ he published $A$ Vindication of the Character of a Popish Successor [B.M. T. 94* (13)], and also Plato Redivivus [T.C. I. 443], and in r682 Mr. Emerton's Cause. [Haz. I. 144.]

DEWALL (JOSEPH), stationer in London, Globe near the New Exchange in the Strand, I7II. Only known from an advertisement of a lost box in the London Gazette, March 17 th, $17 \frac{10}{11}$.

DICEY (WILLIAM), printer at St. Ives, Hunts., near the Bridge, and at Northampton, 1719. Dicey is first heard of at St. Ives, where he began to print the St. Ives Postboy, afterwards called St. Ives Mercury, in I 7 rg, in partnership with Robert Raikes. In 1720 the partners moved to Northampton and there founded (no. I, May and) The Northampton Mercury, and in $\mathbf{1 7 2 1}$ they added (no. I, January 3Ist) The Northampton Miscellany. In 1722 they founded The Gloucester Journal, but Dicey appears to have remained at Northampton, while Raikes became solely responsible for the Gloucester office. Dicey published at Northampton a number of chap-books; the first of these to be advertised in the Mercury was The Force of Nature, or the Loves of Hippolito and Dorinda, 1720. [в.м. 1078. i. 29(2).] He also printed and distributed gratis lists of recent books. [R. Austin, Robert Raikes, in The Library, January 19I5; History of the Northampton Mercury (Mercury Extras, no. 10); P. M. Eastman, Robert Raikes and Northamptonshire Sunday Schools, 1880.]

DICKIE (WILLIAM), bookseller in Glasgow, in the Salt Market, 1695-7. Sold the following books: R. Craghead's Advice to Communicants, 1695; Spiritual Songs [c. 1695], Thomas Hall's Plain ... Explication ... shorter catechism, 1697. [Aldis, p. I12.]

DICKINSON or DICKENSON (HENRY), bookseller at Cambridge, 1672-94. Nine works were printed for him alone or with other booksellers : Sir Isaac 
Newton's edition of Varenius, Geographia, 1672, Lactantius, Opera, 1568 , and with other booksellers his name appears as receiving subscribers' names for Torriano's Italian Dictionary, 1684, and Ray's History of Plants, 1686. His first and last entries in the Term Catalogues were Varenius, 1672, and J. Ellis's Articulorum xxxix Defensio, 1694. [T.C. I. I20; II. 493.] On "7 Feb. $167 \frac{2}{3}$ dyed Mrs. Dickenson, Mr. Wootton's daughter of Malton, the wife of Mr. Dickenson, bookseller ". [Alderman Newton's Diary, ed. Foster, p. 70.] It is probable that he was father of William Dickinson (q.v.).

DICKINSON (WHLIAM), bookseller at Cambridge, 1699-1718. Probably a son of Henry Dickinson (q.v.). Lived in the High Street, at what is now no. I Trinity Street, or next door, from 1699 to his death, and his widow until $173 \frac{2}{3}$. He was one of the Churchwardens of Great St. Mary's, r 706. He died June 26th, 1718, aged 49, and was buried in the churchyard of Great St. Mary's Church. In his will, dated June $24^{\text {th }}, 1718$, he left to his son Nathaniel and daughter Sara "all my houses and estates in the parishes of St. Andrews and St. Buttolphs". His wife Rose, being executrix, proved the will July $3^{\text {Ist }}$ following.

DICKSON (FRANCIS), printer and bookseller in Dublin, 1707-14. In 1707 he printed an edition of Defoe's Caledonia. In 1708 he joined with S. Powell to print The Flying Post, and in I 7 Io with Aaron Rhames to print an edition of The Tryal of Dr. Henry Sacheverell. In I7II and I7I2 he is found alone printing Dr. E. Synge's Defence of himself and a sermon by Berkeley on passive obedience.

DIGHT (WALTER), bookseller at Exeter, over against the Guildhall, r667-93. "Walter Dight's house over against the Guildhall was no doubt the one afterwards occupied by the well-known Gilbert Dyer bookseller." [Dredge, 8.] He published chiefly theological books.

DOBSON (ELIPHAL), sen., bookseller in Dublin, Stationers' Arms, Castle Street, 1682-1 720 (?). His name appears in the imprint in Laurence's Interest of Ireland, I682, as one of the booksellers, and as publisher of Logica Elenctica, by Thomas Goveanus, I683 [T.C. II. I7], and Neal Carolan's Motives of Conversion to the Catholick Faith, as it is professed in the Reformed Church of England. [T.C. 11. 247.] He published many works of value at that time. He was succeeded by his son (q.v.). 
DOBSON (ELIPHAL), jun., bookseller in Dublin, I 720 (?). Son of Eliphal Dobson, sen. (q.v.).

DODD ( ), and Mrs.,printers in London, c. 1 720-4. Dodd married a daughter of Bliss, the Exeter printer. Thomas Gent $(q . v$.) knew and is said to have worked for him. On his death-bed Dodd exhorted his wife to employ Gent as her assistant, which she did. Gent found her printing office in great confusion ; he left her service to go to York, where he married in I724. According to Gent, Mrs. Dodd married again and fell into poverty; it does not appear whether she continued to print or not. [R. Davies, Memoir of the York Press, 1868, p. 1 58 ; T. Gent, Life, 1832, pp. 134, 136-7, 145, \&c.]

DODD (A.), bookseller in London, Peacock without Temple Bar, 1714-31. In I714 in partnership with others he published The Ladies Tales, and in 17 I9 a novel, Charon, or, The Ferry Boat. [Esdaile, pp. 254, 185.] Mr. F. G. Hilton Price mentions this bookseller as living in the Strand in 1723 [Midd. E Herts. N. \& Q. II. 93.] He was still publishing in I731. [Esdaile, p. I9r.]

DODGINS ( ), bookbinder in London, c. 1700. Mentioned by Dunton [p. 258].

DOES ( ), bookseller in Sandwich, Kent, 1699. Advertised in The Flying Post, December 2nd, I699, as selling Edw. Brown's sermon preached at the Kentish Feast, November 16th, 1699; he does not appear in the imprint to the book.

DOLLIF (FRANCIS), bookseller at Oxford, near the Mare-maid Tavern, 168I-90. In 168r he published John Bennion's Assize sermon, Moses' Charge to Israel's Judges [Bodl. Wood $\frac{633}{12}$ ] ; an edition was advertised in 1683 by R. Davis [T.C. II. 2] ; in the index Arber gives this to Dollif. [T.C. II. 636.] In 1690 he gave Anthony à Wood a catalogue of "A curious collection of musick books". [Wood, III. 332.]

DOWLEY ( ), bookbinder in London, c. 1700. Mentioned by Dunton [p. 26r].

DOWNES (GEORGE), bookseller in London, Three Flower de Luces, over against St. Dunstan's Church in Fleet Street, 1676-8r. Publisher of law-books. Made his first entry in the Term Catalogues in Mich. 1676, and his last in Hil. I68 $\frac{1}{2}$. [T.C. I. $\left.263,469.\right]$ 
DOWNING (JOSEPH), printer and bookseller in London, St. Bartholomew's Close, 1670-1724. He may have been some relation of William Downing the printer, whose name appears in the list of printing houses in London in 1675. But there is reason for believing that Joseph Downing was at work as a printer as early as 1670 . Downing was the printer of the piratical edition of Danvers's Treatise of Baptism, complained of to a House of Lords Committee in ${ }^{6} 677$ by Francis Smith [q.v., and Hist. MSS. Comm., Rept. ix, App., p. 78.] In I707 he issued $A$ Nere Catalogue of Books [B.M. I I900. a. I6 (I)]; and in 1708 he printed a broadside, Proposals for erecting Libraries in Wales. [Harl. $595^{8}$ (5I).] In the same year he published Defoe's Account of some Remarkable Passages in the Life of a Private Gentleman. As a bookseller Downing dealt almost entirely in theological literature, and a list of eight of his publications is given at the end of the Rev. John Burrough's Two Sermons, which were printed and sold by him in I7 $_{4}$. [B.M. 4454. b. $3^{8}$ (2).]

DOWNING (w.), printer at Oxford, 1673. Printed in 1673 an edition of Juvenal with the imprint : "Oxford by W. Downing for F. Oxlad Senior." [Haz. II. 323.] Possibly identical with William Downing, of London (q.v.).

DOWNING (WILlIAM), printer in London, ( $\mathrm{r}$ ) Great St. Bartholomew's Close ; (2) George Court, St. John's Lane. I675-1720. Possibly identical with the Oxford printer of the name $(q . v$.$) . First met with in a list of printing houses$ in London, issued in 1675 , when he is referred to as one who had set up since the Act was in force [S.P.D., Car. II, vol. 369, p. 97]. A Reply to . . the D. of Buckingham's Letter, printed by W. D., 1685 , may be from his press. In 1690 he reprinted the Dublin Intelligence. At the time of the fire at W. Bowyer's premises there were two printers of the name of Downing, who contributed to his relief fund [Nichols, Lit. Anecd., I. 62-3.] In I720 Edward Ward's Delights of the Bottle was printed by W. Downing at the second of the above addresses.

DRANT (T.), bookseller in London, Ship in St. Mary Axe, 1675. In company with T. Lacey he published in 1675 Syncrisis, or, the most natural and easie method of learning Latin by comparing it with English [T.C. 1. 219], and Cocker's Morals [ib., B.M. I077. I. 6 (6)]. Another work which he published in this year was Richard Head's Proteus Redivivus. [T.C. I. I97.]

DRAPER (RICHARD), bookseller in London, Golden Ball by Aldgate, r680-2 (?). His name is given as one of those selling Methodical History of the late... 
Popish Plot, 1680. [T.C. 1. $3^{84}$.] He may be the R. D. who published Francis Osborn's Works, 8th ed., r682. [Haz. I. 311.]

DREW (MATTHEW), printer in London, 1673-5. Head's Canting Academy, 1673, was printed for him by F. Leach. [Haz. I. 206.] His name occurs in the List of Printing Houses in London of 1675 , as having " set up since the Act [of I662] was in force". [S.P.D., Car. II, vol. 369, p. 97.] The StarrProphet Anatomiz'd and Dissected, by J. S., was printed in 1675 for M. D., who may be Drew.

DRING (DANIEL), bookseller in London, Harrow and Crown, Fleet Street ; at the corner of Clifford's Inn, 1695-6. Probably a son of Thomas Dring, whom he succeeded at this address. He published two anonymous poems on the death of Queen Mary. [T.C. II. 559.] In Trin. 1696 he advertised Abraham Du Quesne's New Voyage to the East Indies. [T.C. II. 588.]

DRING (THOMAS), bookseller in London, (I) White Lion, Fleet Street, $(a)$ at, (b) next, Chancery Lane ; (2) Blue Anchor, Fleet Street, over against Fetter Lane; (3) Harrow, Fleet Street; ( $a$ ) at the corner of, (b) next, Chancery Lane ; over against the Inner Temple Gate. I668-94. Son of Thomas Dring (1649-68, q.v., Dictionary, I64I-67). Dealer in law-books, plays, romances, and general literature. In 1673 he moved to the Blue Anchor and in 1674 to the Harrow. He died early in 1695 and in the Term Catalogue for Trinity Term in that year is a notice that some of his stock was to be sold by N. Rolls, D. Brown, and J. Walthoe. [T.C. II. 563.]

DRUMMOND ( ), bookseller in London, 1668-9. Only known from a note in the State Papers to the effect " that Mr. Drummond bookseller, now in Holland, can inform where the books, Vox et Lacramentum [Lacrinae] Anglorum and The Painter are printed. [S.P.D., Car. II, vol. 25I, p. I94.]

DRURY (SAMUEL), bookseller in London, Golden Lion and Lamb, Whitechapel, over against the Haymarket, r702-3. Dealer in theological books His first and last entries in the Term Catalogues are in 1702 and 1703 . [T.C. III. $283,366$.

DUCHEMIN ( ), widow, bookseller in London, The Sacrifice of Abraham, over against Somerset House, 1705. Recorded by Mr. Hilton-Price in his Signs of the Old Houses in the Strand in the I7th and 18th Centuries. [Midd. E. Herts. N. \& Q. II. 157.] 
DUFFIELD (EDMUND), printer (?) in Oxford, I683. [Madan, p. 30.]

DUMBAR or DUNBAR (ANDREW), bookseller in Edinburgh, at the Tron-Kirk, I684. His name occurs in the imprint to Certamen mathematicum, betwixt George Liddell and James Paterson (Aberdeen. Printed by John Forbes ... and are to be sold by Andrew Dumbar Book-seller at the Tron-Kirk in Edinburgh). He is believed to have married the widow of William Jaffray, stationer. [Aldis, pp. II2, II 5.]

DUNCAN (JAMES), printer and type-founder in Glasgow, near Gibson's-Wynd, in the Salt-Market Street, I 7 1 7-c. 1750. Up to 1720 he printed in partnership with William Duncan, but after that date he worked alone. In 1718 he is styled a letter-founder, and on October 2 nd, $17 \mathbf{1 9}$, he was appointed printer to the town. [John M'Ure, History of Glasgow, 1830, p. 370.]

DUNCAN (WILliam), printer in Glasgow, in the Salt Market, 1717-c. 1760. Up to I 720 he printed in partnership with James Duncan, but from that date until 1760, or later, he worked alone. [John M'Ure, History of Glasgow, I830, p. 370.]

DUNLOP (JAMES), bookseller in Glasgow, 1676-83. James Durham's The Law Unsealed, Edinburgh, 1676, was sold by him and other Glasgow booksellers. His name occurs among the debtors in the inventory of A. Anderson in 1676. The James Dunlope, one of G. Lithgow's debtors in 1662, was probably the same. Will registered September 22nd, 1683. [Aldis, p. I12.]

DUNMORE (JOHN), bookseller in London, near the sign of the Woolpack in Ivy Lane; (2) Three Bibles in Ludgate Street. 1669-8I. See Dictionary, 164I-67. In 1674 Daniel Elzevir sent him 2,000 copies of Grotius, De Veritate Religionis Christianae, which were seized by the Custom House, but afterwards released. [S.P.D., Car. II, vol. 369, pp. 61, 62.] In I679 he sold the library of Sir Edward Bysshe, the herald. He was the publisher, with Dring, Tooke, Sawbridge, and Mearne of a fine edition of Cicero's Works, I68r, printed by E. Horton from the types of J. Grover. [T.C. I. 455.]

DUNTON (JOHN), bookseller in London, (a) Raven, $(b)$ Black Raven; $(\mathrm{I})$ in the Poultry, $(a)$ at the corner of Prince's Street, near the Royal Exchange, $(b)$ over against the Stocks Market; (2) in the Poultry, over against the Compter; (3) in Jewen Street. I674-I 700 (?). Born at Graffham, Huntingdon, May 4th, I659, son of the Rev. John Dunton, he was at first intended for the Church, but dis- 
appointing his father's expectations was apprenticed in about 1674 to Thomas Parkhurst the bookseller. During his apprenticeship he headed an address of the Whig prentices against one of the Tories, and he seems to have been already somewhat volatile in conduct. After the expiration of his term he set up as a bookseller, at first taking only half a shop. He took to "printing ", i.e. publishing, at once ; his first books being Thomas Doolittle's The Lord's Last Sufferings, 168r [T.C. 1. 458], and Stephen Jay's Daniel in the Den, a sermon by John Shower, and a collection of his father's funeral sermons, entitled The House of Weeping, with a memoir by himself. He made a success with his publications, and opened a shop at the Black Raven, at the corner of Prince's Street, where in 1685 he published Maggots, being the anonymous juvenile poems of Samuel Wesley, father of John and Charles. Dunton had in 1682 married Elizabeth, daughter of Dr. Samuel Annesley, a leading Nonconformist preacher. In 1685 his business received a check by the " universal damp upon trade, occasioned by the defeat of Monmouth in the West" ; he went to Boston in New England to sell a cargo of books and at the same time recover debts to the extent of $£ 500$ owed him there, his business being largely in Puritan theology. Here he visited Elliot, who presented him with twelve copies of his Indian Bible. Dunton returned in 1686 , but having given surety for $£ x, 200$ for a brother-in-law, was compelled to seek refuge in a tour in Holland and Germany. He returned in r688 and opened a new shop opposite the Poultry Compter, with the old sign of the Black Raven, and tells us that he remained there ten years " with variety of successes and disappointments." [Life and Errors, pp. 5 $^{\mathbf{I}-2 .}$ ] But his last entry in the Term Catalogues from this house was in 1694 , after which he only made one more entry, in 1696, from the Black Raven, Jewen Street. After r688 Dunton published copiously, some of his ventures being "projects" of his own, noteworthy among these being the Athenian Gazette, 1689-95, The Post-Boy Robbed of His Mail (a collection of letters), and a laudatory life of Judge Jeffreys. In the course of his career Dunton claims to have printed 600 books (employing a large variety of printers), and to repent of but seven. In 1692 he attained the Livery of the Stationers' Company. His first wife died in r697; in the same year he married Sarah Nicholas of St. Albans, with whom and her mother he quarrelled over the non-payment of his debts. Soon after his second marriage he visited Dublin with a cargo of books, and became engaged in a quarrel with a bookseller there, Patrick Campbell ( $q . v$.$) , which he$ 
set forth at length with much else in his Dublin Scuffle, r699. Dunton was now compelled to hide from his creditors and so to give up his business; he employed his enforced leisure in much writing, in which growing insanity clearly appears. But in 1703 he wrote The Life and Errors of John Dunton (S. Malthus, I 705), in which he gives not only his autobiography, but characters of a vast number of his contemporaries in the book trade, which have been of the greatest value in the compilation of this Dictionary. After this he fell further into poverty. In the notes to the Dunciad Pope calls him " a broken bookseller and abusive scribbler". He lived till I733. [Life and Errors, ed; with memoir by J. B. Nichols, I817;D.N.B.]

DURRAM or DURHAM (MICHAEL), stationer at Newcastle-upon-Tyne, I675. Admitted to the Newcastle Stationer's Company, July 22nd, I675. [Welford, Early Newcastle Typography, p. I28.]

DURSTON (THOMAS), printer in Shrewsbury, I 7r4.

DYER ( ), stationer in London, Rose in Bread Street, c. I700. Partner with Alexander Merreal at the Rose in Bread Street. Dunton [p. 256] says of him : "He was a fair dealer and a pious man. . . . I bought a great deal of paper of him."

DYMOCK (THOMAS), bookseller at Oxford, 168I. In 168I he was defendant in an action for assault brought by Bartholomew Sprint, bookseller, against a number of booksellers and printers. Details are wanting. [C.P.R., Trin. 33, Chas. II, 2992, m. 256.]

EATON (JOSEPH), bookseller in Liverpool, $\mathbf{7}$ ro.

ECKELSTON (EDWARD), bookseller in London, Peacock, Little Britain, r683. Publisher of Dr. John Barnard's Theologo-historicus, r683. [T.C. II. 6.]

EDDOWES (s.), bookseller in London, (I) next the Fleece Tavern, Cornhill, I682 ; (2) Blue Anchor, under the Piazza of the Royal Exchange, Cornhill. I682-93. First entry in the Term Catalogue, a medical book, H. Stubbe's Select Observations in Mich. I682. In 1683 he sold Quevedo's Visions, 6th ed., published by Herringman. Last heard of in I693. [T.C. I. 5I4; II. 34, 473.]

EDLIN (JOHN), printer in London, (1) Dutchy Lane in the Strand, I 7 I9 ; (2). near the Savoy; (3) (?) Prince's Arms over against Exeter Exchange. I719-32. Began as a bookbinder. In The Weekly Packet of April 18-25, I719, it is 
recorded that last Saturday a fire broke out ... at Mr. Edlin's a Bookebinder in Dutchy Lane in the Strand". He printed proposals for Stackhouse's History of the Bible, "got credit of paper, brushed up his old battered letter, picked up a poor compositor or two . . . and began to be very clamorous for copy". [Stackhouse's Bookbinder, Bookprinter and Bookseller, 1732.] Joined by Thomas Edlin. [Mid. \& Herts. N. \& Q. III. I8.]

EDLIN (THOMAS), bookseller in London, r721-8. One of the publishers of Defoe's Moll Flanders, 1721 , and Fortunate Mistress, 1724. [Esdaile, pp. 202-3.]

EDWARDS (DAVID), printer in London, Nevil's Alley in Fetter Lane, r694-1 70I. His imprint is first found on a broadside entitled The Widow Whiterow's humble Thanksgiving, I694. [B.M. T. I762 (7).] He succeeded A. Baldwin as the publisher of The New State of Europe [B.M. Burney I 7 B]. In I696 he was defendant in a suit brought by the Company of Stationers against certain printers and booksellers for printing Primers and Almanacs. In his answer Edwards declared that he printed about thirty or forty gross of black and white Primers for William Spiller. He sold some to a bookbinder named Meade. [Chan. Proc. before 1714, Collins $\frac{486}{100}$, P.R.O.] In I 70r the publication of The New State of Europe was taken over by M. Edwards, probably David's widow, at the same address.

EDWIN (JonathaN), bookseller in London, Three Roses, Ludgate Street, I67I-9. Dealt in all kinds of literature, from sixpenny pamphlets dealing with the lives of pirates and murderers, to folio histories and classics. His first entry in the Term Catalogues was in Mich. I671, of Fifty-one Sermons by Dr. Mark Frank. [T.C. 1. 84.] In the same year he published a novel, Amorous Travellers. [Esdaile, p. I48.] In 1674 he was selling T. Flatman's Poems and Songs, published by B. Tooke. Amongst Edwin's more important publications may be noticed an edition of Caesar's The Welch Common Prayer Book for the use of Churches, I678. He made his last entry in the Term Catalogues in Easter, 1679. [T.C. 1. 348.] He was a staunch Royalist and Churchman, issuing several books against the Presbyterians and Dissenters.

EGLESFIELD (FRANCIS). See Dictionary, r64I-67. He made his last entry in the Term Catalogues in 1676 .

EGLESFIELD (JOHN), bookseller in London, Marigold, Fleet Street, (a) over against the Globe Tavern, (b) near Salisbury Court. I68I-6. In all 
probability related to Francis Eglesfield $(1637-76)$. First heard of in $168 \mathrm{I}$, when he was defendant in an action for assault brought against him by John Jennings. Details are wanting. [C.P.R. Trin. 33 Chas. II, Roll 2992, m. 256.] His name first appears in the Term Catalogues in 1683 [T.C. II. 30], and he was the publisher of Henry Bold's Latin Songs in 1685 and 1686. [T.C. II. II4, I68.]

EGLESFIELD (THOMAS), bookseller in London, (I) Brazen Serpent, St. Paul's Churchyard; (2) Little Britain. 1652-84. Omitted from the Dictionary, 1641-67. In $165_{2}$ he published Major Cosmo Manuche's The Royal Lovers, $A$ Tragi-Comedy, with the first of the above imprints, which had once been the printing house of Reginald Wolfe. In $1683^{-4}$ he became surety for Francis Eglesfield, gent., of St. Mary Cray, Kent, doubtless a relative. [C.P.R. Hil. 35-36 Chas. II, Roll 3020, m. 31 recto.]

EIRES (HENRY), bookseller in Warrington, r 704-I2. [N. \& Q., roth S., v. 242.]

EKINS (NATH.). See Dictionary, I641-67. He made his last entry in the Term Catalogues in 1673. [T.C. 1. I43.]

ELLIOTT (ROBERT), printer (?) in Oxford, r693-6. [Madan, p. $3^{\mathbf{r}}$ ]

ELLIS (c.), bookseller in Mansfield, Notts., r69o. Published in Mich. r69o Religion and Loyalty inseparable (a Nottingham Assize sermon), by a namesake and perhaps a relative, Clement Ellis, Rector of Kirby, Notts, "Printed for W. Rogers at the Sun in Fleet Street; and C. Ellis in Mansfield." [T.C. II. 329.]

ELLIS (EVAN), printer in London, I722. According to Gent [p. I18] he printed " the bellman's verses at Christmas".

ELVIES or ELVIS (THOMAS), stationer in London, Strand, I688. Defendant in an action for the recovery of a debt brought by George Emery. Elvies is also described as a "tanner" of the city of Stafford. [C.P.R. 3068, m. r640, Trin. 4 Jas. II.]

EVANS (SAMPSON), bookseller in Worcester, 1674-91. First appears in an advertisement for a lost book in Trin. 1674. [T.C. I. I83.] His name also appeared in Mich. 1676, as one of the publishers of Графалтаркєа, or the Scripture's Sufficiency [T.C. I. 250], and in I68I he published G. Wall's Sermon preached to the natives of . . Worcester. [Bodl. Sermons, 2I (6).] In Mich. 
3 William \& Mary (169I) an action was commenced against him by Joshua Sharpe and Lucy Singleton for the recovery of a debt. [C.P.R. Mich. 3 W. \& M., Roll 3ror, m. 400 recto.]

EVELEIGH (ROBERT), bookseller at Exeter, 1668-8r. Mr. Dredge [p. 93] only records one book as published by Robert Eveleigh, discourses by Thomas Mall and others, entitled of Holy Living, "London: Printed for William Grantham .. Westminster Hall . . . sold by Robert Eveleigh, Bookseller in Exon." He was still there in $168 \mathrm{r}$, when his name is found in an advertisement of the sale of Dr. W. Outram's library, in the London Gazette, November I 7 th-2 Ist.

EVERINGHAM (ROBERT), printer in London, Seven Stars, Ave Mary Lane, 1680-r700. The earliest notice of this printer that has been found is the imprint of No. 5, \&c., of a news-sheet called Mercurius Civicus, "Printed by R. E. in Ave Mary Lane for the author. I680." On October 7th, I680, he printed a Weekly Advertisement of Books [Timperley, p. 560]; in the same year on April roth there appeared in Smith's Currant Intelligence a notice by Colonel Thomas Blood, repudiating Everingham's editions of The Narrative. In I699 he printed Fruit-Walls Improved. [Haz. III. 58.] See Whitledge (R.)

EVERSDEN (GEORGE), bookseller in London, Adam and Eve, St. John's Lane. See Dictionary, 1641-67.

EVERSDEN (HENRY), see Dictionary, 1641-67.

EVETS (EDWARD), bookseller in London, Green Dragon in St. Paul's Churchyard, 1683-1705. His first and last entries in the Term Catalogues were in 1683 and I 705. [T.C. II. 20, III. 454.]

EWREY (WILLIAM), bookseller in London, Golden Lyon and Lamb over against the Middle Temple Gate in Fleet Street, 1680(?)-9. Possibly identical with the W. E. who published The English Gazette (afterwards The Westminster Gazette), No. I, December 22nd, I680, \&c., to be sold by T. Fox. In I689 he published a sermon by W. Wilson, rector of St. Peter's, Nottingham. [B.M. 226. g. I0 (13).] At the end are advertisements of other books sold by him.

F. (E.), printer in London, 1672. Printed T. Willis's De Anima Brutorum ... for R. Davis of Oxford, 1672. [Haz. III. 268.] These initials may be those of 
the widow of James Fletcher or Flesher the printer (died 1670 ), who was still in business in 1675 .

F. (F.), bookseller in London, 1679. These initials appear on the imprints to An Answer to Blundell the Jesuit's Letter, I679 [B.M. 515.1. 2 (24)], and The Deposition . . of the late ... Plot, [1679.] [Bodl.]

F. (N.), bookseller in London (?) I68I. Hazlitt [II. 343] records $A$ Letter out of Scotland, from Mr. R. Le [Strange] to his Friend H. B. in London. Printed for $N . F$. in the year I68r. Folio, 2 leaves.

F.(w.), bookseller in London, $x 696$. These initials, with those of M. G. (probably Mathew Gilliflower), are found in the imprint to an edition of Quarles's Emblems of 1696 . [Haz. II. 506.] In all probability they stand for William Freeman.

FABIAN (MARY), bookseller in London, Mercers' Chappel in Cheapside, I698I 701. Perhaps widow of Thomas Fabian, some of whose publications were also issued by her. Her first and last entries in the Term Catalogues are in Trin. 1698, and Mich. I701. [T.C. IIr. 87, 276.] She was succeeded at this address by $\mathrm{J}$. Baker.

FABIAN (THOMAs), bookseller in London, Bible in St. Paul's Churchyard, 1676-93. This is perhaps the person alluded to by Dunton [p. 292] as "Lord" Fabian. His name appears for the first time in the Term Catalogues in Easter I676, when with Abel Roper and others he advertised a folio Josephus. [T.C. I. 24I.] He was also the publisher of William Drummond's History of Scotland in I68I. The bulk of his publications were divinity. Fabian's last entry in the Term Catalogues was made in Mich. I693. [T.C. II. 47I.] Mary Fabian may have been his widow.

FAIRBROTHER (s.), printer in Dublin, I7 14-34. In I 720 he printed $A$ Collection of several Statutes relating to His Majesty's Revenue of Ireland, in 1724 the Charter empowering Erasmus Smith to erect Grammar Schools in Ireland, and in I 725 the I 3 th ed. of L'Estrange's version of Seneca's Morals. In I723 he was printer to the Irish House of Commons.

FAITHORNE (HENRY), bookseller in London, Rose, St. Paul's Churchyard, I68I-8. Publisher to the Royal Society. He first appears in partnership with J. Kersey, in Hil. I68 $\frac{0}{1}$. [T.C. I. 426.] He published Weekly Memorials for the Ingenious, a critical account of recent publications. In 1686 he and his partner advertised proposals for a folio edition of John Ray's General 
History of Plants. [T.C. II. I62.] Some time in 1687 Kersey's name disappears, and Faithorne carried on the business alone until Trin. I688 [T.C.II. 232], after which nothing more is heard of him, unless he be the H. F. who appears in the imprint to The Muses' Farewel to Popery and Slavery, I689. [Haz. III. 200.]

FARLEY (SAMUEL), printer at Bristol, St. Nicholas Street, near the Church, 1712-25. There were two printers of this name, one in Bristol and one at Exeter. Samuel Farley of Bristol was the printer of the Bristol Postman, a weekly paper that began to appear in 1712, and was discontinued in 1725 .

FARLEY (SAMUEL), printer at Exeter and Salisbury, 1699-1727. In 1699 Samuel Darker of Exeter was joined by Farley, and together they printed several books of local interest until 1701, when Farley is found printing by himself. He appears to have settled in the parish of St. Paul's, Exeter, some time in 1699 and he continued to print in Exeter until 1715, when he removed to Salisbury. In 1705 he was joined by Joseph Bliss, but the partnership only lasted three years. On September 24th, I7I4, Farley issued the first number of The Exeter Mercury, or Weekly Intelligence of Nezos, but he transferred this to Philip Bishop in I 715, before leaving Exeter. He returned to Exeter in 1723 and started Farley's Exeter Journal. In November 1727, the burial of Samuel Farley is recorded in the register of St. Paul's, Exeter. He was succeeded in business by Edward Farley, probably a son. [Dredge, passim.]

FARNWORTH (B.), bookseller in Newark, $1715-19$. His name is found in an

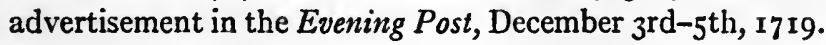

FARY (ROBERT), bookseller in London. The Bell in Gracechurch Street, $17 \mathbf{3} 3$. An octavo edition of Phaedrus's Fables printed in 1713 bears the imprint "London: Printed by H. Meere, for Robert Fary, Druggist, at the Bell in Gracechurch Street, M.DCC.XIII ", and on the back of the title-page three other works, including the Comedies of Terence, were advertised as printed for R. Fary.

FAWCET (FRANCIS), bookseller in London, King's Head and Crown, near Durham Yard in the Strand, r 701. Publisher of the Rev. Tho. Knaggs's Sermon against Atheism, preached I 700. [B.M. 226. h. 3 (18).] 
FAWKNER (J.), bookseller (?) in London, at the Talbot on London Bridge, 1698. Publisher of John Shower's funeral sermon on Mrs. Jane Papillon, who died July I2th, I698. [B.M. I4I8. C. 21.]

FAYRAM (F.), bookseller in London, 1721-9. In conjunction with a number of others he published novels written or translated by Penelope Aubin. [Esdaile, pp. 155-6, 263.]

FELTHAM (ANTHONY), bookseller in London, Westminster Hall, foot of Parliament Stairs, 1691-9. With W. Whitwood he published in 1692 The Experienced Farrier, by E. R. Gent. [T.C. II. 397.] In 1693 they issued Dr. John Archer's Secrets disclosed or a Treatise of Consumptions. [T.C.II. 479.] The last entry under his name in the Term Catalogues was the 3 rd ed. of Thomas Bray's Course of Lectures upon the Church Catechism. [T.C. III. II9.] Dunton [p. 292] nicknamed him "smiling Feltham".

FELTON (ANTHONy), see Feltham.

FELTON (JOHN), bookseller in Newport, Shropshire, 1679-80. William Thackeray ( $q . v$. below and in Dictionary, $1641-67$ ) sold him goods to the value of $£^{200}$ and had to sue him in the King's Bench for the recovery of the money. [C.P.R. Trin. 33 Chas. II, Roll 2995, m. 1876 verso.]

FENNER (ENOCH), bookseller at Canterbury, Bible and Crown behind St. Andrew's Church, I703-29. Son of Rest Fenner I (?) (q.v.). He was in business by himself in I703, when he published The Expert English Schoolmaster, by Thomas Lydal, schoolmaster at Canterbury. [T.C. III. 379.] He died in I 729, his will being proved on September 9th. The contents of his shop he directed to be sold, his wife Margaret to have the interest of the proceeds for life. He left a son, Rest Fenner, who succeeded him in the business, and he nominated as his executors Robert Knaplock, William Mount, and Samuel Birt, all booksellers of London. [Probate Registry, Cant. Arch. Reg. 87, f. 36.] FENNER (REST) I, bookseller and stationer in Canterbury, I663-I7II (?). It is not clear whether there were three or four booksellers of this name. The first appears in 1663 [Dictionary, $1641-67$ ] ; the last is too late for our period. In 1678 the stock of Mercy Browning of Amsterdam (q.v.) was bought by a Rest Fenner of Canterbury, and an action was brought against him by Nathaniel Ponder for the value of part of it supplied by him. [Chanc. Proc. Before 1714, Reynardson, Bundle 428, 132.] In 1687 and 1689 he published 
in conjunction with London publishers a novel, Cynthia [T.C. II. I93], and N. Greenwood's Astronomia Anglicana. [Lond. Gaz. July Ist-4th, 1689.] Fenner's name does not appear in the imprint to the latter. The will of Rest Fenner, senior, of Canterbury, stationer, dated January I6th, 1709, was proved on December 29th, I7II; his executors were his sons Rest and Enoch (q.v.); the position of his house is not stated.

FENNER (REST) II, bookseller in Canterbury, Mercery Lane, I68I-I7II. Son of Rest Fenner I. Apprenticed to his father and took up his freedom as a citizen of Canterbury in I681. In I 702 R. Ferner [sic] jun., Mercery Lane, Canterbury, published with E. Tracy of London, James Brome's sermons, A Seasonable Warning to all hardened Sinners, preached at Newington near Hythe. In I 7 I I he was named executor to his father's will.

FERRABY (GEORGE), bookseller in Hull, 1718-25. His name occurs in the imprint to the York Mercury as one of those by whom advertisements for the paper were taken in. [Davies, Mem. of York Press, p. 133.]

FICKUS (JoHN), bookseller in Oxford, 1682-6. [Madan, p. 31.]

FICKUS (THOMAS), bookseller in Oxford, Holywell, 168I-4. On August Ist, I68I, Anthony à Wood [I1. 549] mentions "Thomas Fickus a stationer newlie set up in Holywell ". In Easter 1682 he advertised Hierocles upon the Golden Verses of the Pythagoreans, and in Hil. 1684, Praecipuorum Theologiae Capitum Enchiridion didacticum, by George Tully, Principal of St. Edmund's Hall. [T.C. I. 486, II. 65.]

FIRTH (ISAAC), stationer in London, Little East Cheap, r707. His name is met with in an advertisement of lost property in Povey's General Remarks on Trade, September 29th to October Ist, 1707. [Burney 140.]

FISH (JOHN), bookseller in London, ( 1 ) Golden Tun in the Strand ; (2) Adam and Eve in Hungerford Market. I68I-1703. He published at the first address given above a broadside entitled The Speech and carriage of Stephen Colledge in I68I [B.M. T. I.* (ro9)], and at the latter he advertised a patent medicine in the Post Man on February 26th-28th, $170 \frac{2}{3}$.

FISH (wILlaM), stationer in London, St. Martin's in the Fields, r686. The sheriffs of London sued to recover against him a debt of $£ 40$, in the Court of Common Pleas, Hil. 2-3 Jas. 2. [C.P.R. 3055, m. I888 recto.] 
FISHER (HENRY), bookseller in Wrexham, I700. Sold school books and devotional works, which he purchased wholesale of John Minshull, bookseller of Chester. [Library, and ser., IV. 373-83.]

FISHER (JOHN), printer in St. Ives, Hunts., Tedd's Lane, r7I6-r8. Printed the first Huntingdonshire newspaper, The St. Ives Post. [H. E. Norris in $N$. \& $Q$. Ioth S. vIIr. 20I.]

FISHER (WILLIAM), bookseller in London, at the Postern Gate, Tower Hill, 1657-90. See Dictionary, 1641-67. Was still in business in I69o. He took R. Mount into partnership between 1684 and I687. [T.C. II. I08, I95, 321.] An entry by Hazlitt [II. 529] of a book printed for an otherwise unknown William Firder in 1684 may be an error for William Fisher.

FLEMING (ROBERT), printer in Edinburgh, 1724-78. One of the printers to the Church of Scotland. From 1724 to 1764 he printed in partnership with James Davidson.

FLETCHER, or FLESHER (MRS.), printer in London, Little Britain, I6708 (?). The widow of James Fletcher. Her name occurs in a list of the printing-houses in London in March 1675. [State Papers Dom., Car. II, vol. $369,97$.$] She may be identical with the E. F. (q.v.) mentioned in some$ imprints between 1670 and 1678 . She was a daughter of Cornelius Bee, bookseller.

FLETCHER (JAMES), printer in London, 1652-70. See Dictionary, r64r-67. The business was continued by his widow (q.v. above).

FLETCHER (STEPHEN), bookseller in Oxford and London, 1714-27. Born in I680 at Salisbury, and apprenticed to F. Oxlad sen. Hearne was one of his customers, and on April ist, I 1 I6, records that Fletcher was a candidate for the place of verger of the university, which the Statutes required should be filled by a stationer, but he withdrew in favour of "one Pottle", who was neither bookseller nor stationer. [Hearne's Collections, Oxf. Hist. Soc. v. I92.] In I7I9 he proposed to print Marmora Oxoniensia, and consulted Hearne, who dissuaded him from the undertaking. [Ib. VII. 6.] In I72I Fletcher bought the library of Dr. John Keil, giving $£ 220$ for it. [Ib. vII. 30r.] On August zand Hearne writes to J. Murray: "Stephen Fletcher (called by some positive Fletcher, and by others pos Fletcher) is gone to Shirbourne in 
Dorsetshire, to get some of Mr. Jo. Pullen's books now selling there." [ 16 . vII. 395.] Fletcher died in London on September 12th, 1727, From Hearne's notice, it appears that Fletcher had a shop at Westminster as well as at Oxford. Hearne's sketch of his character is not flattering. [1b. IX. 347-8.]

FLETCHER, or FLESHER (THOMAS), bookseller in London, (I) Angel and Crown, St. Paul's Churchyard ; (2) Old Change, over against Distaff Lane. 1677-86. In partnership with Jonathan Edwin, he entered in the Term Catalogue of Mich. I677 John Nalson's Common Interest of Kings and People. [T.C. I. 293.] In June 1685 John Noakes recovered against him in the Common Pleas a sum of $\ell^{60}$. [C.P.R. Trin. I. Jas. II, Roll $303^{8}, \mathrm{~m}$. I86 I recto.] Fletcher removed to Old Change about 1685. He published onc or two medical books. His last entry in the Term Catalogues was in Hil. 1686. [T.C. II. I59.]

FORBES (JOHN), the elder and the younger, booksellers and printers at Aberdeen, 1656-r704. See Dictionary, 1641-67.

FORD (JOHN), bookseller in London, at the Middle Temple Gate, Fleet Street, I671-3. Joined Thomas Collins, their first joint entries in the Term Catalogues being The History and Relation of a Journey of . . . Lord Henry Howard from London to Vienna [T.C. I. 73], and John Wilson's comedy, The Cheats, both in Easter 1671. They were also the publishers of Shadwell's comedy The Miser in 1672, and in the same year of the Reliquiae Wottonianae. In 1673 they published John Evelyn's translation from Rapin, Of Gardens, and a miscellaneous Collection of Poems. Nothing further is heard of Ford, though Collins continued the business for some years later.

FORREST (EDWARD). See Dictionary, 1641-67.

FORREST (JOHN). See Dictionary, I641-67.

FORRESTER (ANDREW), bookseller and bookbinder in London, next door to the Mitre Tavern in King's Street, Westminster, I676-80. In 1676 he sold Seller's maps, and in ${ }^{16} 78$ was one of those who sold W. Walgrave's Decimal Arithmetick. [T.C. I. 301.] He reprinted $A$ true Narrative of the reception of their Royal Highnesses... in Scotland, 1680. [B.M. T. 100* (158).] His business was carried on later by $P$. Forrester.

FORRESTER (P.), bookseller in London, King's Strcet, Westminster, 1687. Probably a son or brother of Andrew Forrester. Hazlitt records a Proclama- 
tion by James II as published by him in 1687 . This house seems to have been the recognized agency for the publication of Scottish literature.

FORRESTER (SUSANNA), bookseller (?) in London (?) 1685. Perhaps widow of Andrew Forrester. Hazlitt records A Publication of the Royal Authority of ... James the Second, "Edinburgh, printed ... Reprinted at London by Tho. Newcomb for Susanna Forrester, I685." [Haz. II. 3II.]

FORSTER (JOHN), bookseller in Dublin, Skinner Row, r 704-5. Published in I 704 and I 705 a sermon and a tract by E. Synge. [Bodl. Serm. I9; B.M. 498. a. 28.]

FOSTER (BENJAMIN), bookseller in London, Three Flower de Luces, Poultry, I672. He advertised James Janeway's Token for Children, I672. [T.C. I. I22.]

FOSTER (JOHN), printer (?) in London, Greyhound, Pye Corner, 1697. Only known from the imprint to a ballad about a murderer. [Haz. H. 348.]

FOSTER (MARMADUKE), bookseller in London, Black Swan at Amen Corner, 1685. In partnership with Awnsham Churchill at the above address in r685, when they published the Rev. Samuel Master's Discourse of Friendship. [B.M. 226. g. I2 (17).]

FOSTER (STEPHEN), bookseller in London, (I) Angel on London Bridge; (2) Sun and Bible on London Bridge. 1679-80. Associated with J. Collier, but the partnership was of short duration, as Foster shortly afterwards moved to the Sun and Bible. His last entry in the Term Catalogues was in Hil. I680. [T.C. I. $3^{83}$.]

FOULKES, or FOWKES (EDWARD), bookseller in London, Saracen's Head, Chancery Lane, 1664-75. See Dictionary, 1641-67.

FOWLER (JoHN), bookseller in Northampton, I 7 I4-I9. Subscribed for Walker's Sufferings, I7I4. His name is mentioned in a list of those receiving subscriptions for R. Bradley's Philosophical Account of the Works of Nature, I 7 I9.

FOX (JOSEPH), bookseller in London, Seven Stars, Westminster Hall, I686 (?)I746. The following notice appeared in the General Advertiser of November 25th, 1746: "On Sunday morning [November 23rd] died in the 83rd year of his age, Mr. Joseph Fox, sen. who kept a bookseller's shop in Westminster Hall, upwards of sixty years. He was also eminent for sending written News Letters to most parts of the Three Kingdoms. He is succeeded in both parts of his business by his son, who has been partner with him these Twelve 
Years past." In the Term Catalogue of Hil. 1691, A. Roper and J. Fox entered a play called Sir Anthony Love, or the Rambling Lady, and two satires on Dr. W. Sherlock, The Weesils, and The Weesil Trap'd. [T.C. II. 347.] In I696 he sold for the author James Whieston's Englands Calamities Discover'd ... [Haz. Iv. 176.] Fox also had a shop in Tunbridge Wells during the season there.

FOX (THOMAS), bookseller in London, (I) Angel in Westminster Hall ; (2) White Hart, Fleet Street, over against St. Dunstan's Church. 1679-9I. What relation, if any, this bookseller had to Joseph Fox, is unknown. Thomas Fox appears to have begun business in the Hall in 1679 , when his name appears in the Term Catalogue as one of the publishers of a History of Edward 11 . [T.C. 1. 368.] In the same year he is found selling Cottoni Posthuma [T.C.I. 376], and in 1680 Behemoth, a pamphlet in answer to Hobbes. [T.C. 1. 387.] On Wednesday, December 22nd, 1680, he started The English Gazette. After seven numbers had been issued, the title was altered to The Westminster Gazette, but the venture came to an untimely end in January $168_{1}^{\circ}$. Fox was also one of the publishers of the Proceedings at the trial of the seven bishops in 1688. [T.C. II. 251.] His name appears in the Term Catalogues for the last time in Easter r691. [T.C. II. 361.]

FRANCKLIN, or FRANKLIN (RICHARD), bookseller in London, Sun in Fleet Street, 1720-1. Published N. Amhurst's Familiar Epistle from Tunbridge Wells, r 720. [Wrenn, I. 8.] He also wrote in I72I an answer to Amhurst's Epistle to Sir John Blount. [Bodl. G. Pamph. 2716.]

FREEBAIRN (ROBERT), printer and bookseller in Edinburgh, (I) his shop in the Parliament Close; (2) his printing-house in Forrester's Wynd. 1705-37. A son of David Freebairn, bishop of Edinburgh. He settled at Edinburgh as a bookseller, and in r706, having purchased the printing-house which John Spottiswood had imported for the purpose of printing law books, he began to print. Many important books printed in Edinburgh during the next few years bear his imprint. In I 7 I I he obtained a gift of the office of Queen's printer for forty-one years from the expiration of Andrew Anderson's privilege ; one-third of this gift he made over to John Baskett, and one-third to James Watson. At the Rebellion in 1715 he retired to Perth and printed for the Pretender. [W. J. Cowper, The Pretender's Printer, 19r8, and The King's Press at Perth, I715-16, I919.] For this his gift was declared forfeit, 
but he afterwards returned to Edinburgh and resumed the style of royal printer. His assigns continued printing till $\mathbf{1} 75^{2}$.

FREEMAN ( ), bookseller in Durham, I7I3-I9. Mentioned in the Memoirs of Ambrose Barnes [p. 458] as in business at Durham in 1713. In a list of provincial booksellers printed in Notes and Queries he is given as still there in I 7Ig. [N. \& $Q$. roth Ser. v. I83.]

FREEMAN (WILLIAM), bookseller in London, (I) Artichoke, Fleet Street, (a) next St. Dunstan's Church, $(b)$ over against the Devil Tavern, $(c)$ near Temple Bar ; (2) Bible, Fleet Street, over against the middle Temple Gate. $1682-\mathrm{r}_{7} \mathrm{I}($ (?). Began as a publisher in $\mathrm{r} 682$, and from that time onwards did a large and general business. He moved in 1690 or 1691 . Dunton [p. 215 ] says of him, " $\mathrm{He}$ is of a courteous affable nature, and very obliging to all he has to do withal ; and I found (by that small correspondence I have had with him) he was bred, as well as born, a gentleman." In $\mathrm{I}_{7} \mathrm{I}_{3}$ he contributed five guineas to the Bowyer Fund. [Timperley, p. 600.]

FRITH (JOHN), bookseller in London, Little Eastcheap, r682-94. His name is found as publishing a broadside in 1682 [Haz. II. 346], and in an advertisement of the sale of a shop, in the City Mercury of June Irth, I694. [Burney, II 2 A.]

FURBY ( ), bookseller (?) at Tenterden in Kent, 1699. His name appears in an advertisement of the publication of the Rev. Edward Brown's Kentish Feast sermon, in The Flying Post of December 2nd. It does not appear in the imprint to the book.

FURDER (WILLIAM), bookseller in London, I684. Known from The StoreHouse of Nature expos'd to view, printed for him in r684. [B.M. 546. g. 33.]

FYNDAL ( ), printer at Oxford, I7 6 . A printer at the Theatre in Oxford. There is no evidence that he was a master-printer. Hearne records under date of August roth, r716, that a fellow of St. John's, Whately by name, had married Fyndal's daughter. [Hearne's Collections, Oxf. Hist. Soc., v. 274.]

G. (J.), printer in London, $1650-88$. These initials occur frequently between the dates given. [Haz.] They may possibly stand for J. Grantham (q.v.), whose name appears on books of 1682-4. 
GAIN, or GAYNE (JoHN), printer in London, 1681-7. In Trin. 33. Chas. II (168r) he was sued by the Stationers' Company for illegally printing primers ; but won the case. [C.P.R. 2992, m. 44I.] In 1685 he was defendant in an action for debt brought by Elizabeth Jenning, executrix of the will of Jane Jenning. [C.P.R. Mich. I. Jas. II. 3040, m. 82 I recto.]

GALLOT ( ), printer at Oxford, 1673. A compositor of this name is mentioned by Anthony à Wood [II. 261, 264] in connexion with his Historia et Antiquitates Universitatis Oxoniensis, $\mathrm{I} 673$.

GALT (JAMES), bookseller in Glasgow, 1675. T. Vincent's Catechism, Edinburgh, I675, was sold by him.

GARDINER( ), printer in London, Lincolns Inn Fields, 1 724. Mentioned by Negus as a Roman Catholic printer.

GARDINER, or GARDNER (FINCHAM), bookseller in London, (I) Three Roses, Ludgate Street; (2) White Horse, Ludgate Street. 1682-4. Mainly a publisher of divinity ; but in I682, he was one of the publishers of Sir William Dugdale's Antient Usage of . . . Armes. He is perhaps the person alluded to by Dunton [p. 293] as " prudent" Gardner.

GARDNER (ROBERT), printer in Belfast, $1713-34$. This printer was the third who practised the art in Belfast.

GARRET (JOHN), bookseller in London, $(a)$ at the foot of, (b) going up, the stairs of the Royal Exchange out of Cornhill, 1676-97. Probably the successor of Thomas Jenner ; he dealt in maps, gazetteers, \&c. Dunton [p. 292] has a reference to "Indenture Garret". He may have got the name by selling printed indenture forms. His first and last entries in the Term Catalogues were made in Hil. 1676 and Mich. 1679. [T.C. 1. 227, III. 39.]

GARRETT (WILIIAM), bookseller in London, r622-74. See Dictionary, 164I-67.

GARTHWAITE (MARY), bookseller in London, Golden Lion in St. Bartholomew's Hospital, 1670. Widow of Timothy Garthwaite. Advertised W. Walker's Treatise of English Particles in 1670. [T.C. 1. 6r.]

GASCOIGNE (J.), bookseller in London, Wapping Stairs, 1682. Advertised A new map of Carolina in I682. [T.C. I. $5^{1}{ }^{3}$.]

GAVETT (RICHARD), see Gravett. 
GAYNE (JoHN), see Gain.

GEE (ROBERT), bookbinder in Cambridge, $1675-81$. In 1675 he was living in a tenement adjoining the dwelling-house of Troylus Atkinson in the parish of Great St. Mary. He died in 168r. The inventory of his goods, dated December 22nd, 168r, ccxlvijli. vs. ijd. in total, has items " For all his working tools both, for presses for other, bords, past bords vli." "For all the books and paper ccijli. xviijs. ijd." [Gray and Palmer's Cambridge Wills, 115, 123.] His wife Frances died July r684. Her goods were valued at $£^{29} 9$ s., with no mention of books or shop.

GELIIBRAND (EDWARD), bookseller in London, Golden Ball in St. Paul's Churchyard, 1675-82. Mainly a divinity publisher, but he also published Sir John Temple's Irish Rebellion, 1679, and the 4 th ed. of Sir William Temple's Observations on the United Provinces, 1679 [T.C. 1. 377], and the and ed. of the latter's Miscellanea, r681. His last entry in the Term Catalogues was in Mich. r682. [T.C.I. 503.] He was probably a son of Samuel Gellibrand, who carried on business at this address until 1675 . John Gellibrand (q.v.) may have been his younger brother.

GELLIBRAND (JOHN), bookseller in London, (I) west end of St. Paul's Churchyard ; (2) Golden Ball, St. Paul's Churchyard. I680-4. Mainly a publisher of Latin books. His first and last entries in the Term Catalogues are in 1680 and 1684. [T.C. I. 385, II. 99.] The Golden Ball does not appear in his address till 1683 , and then his name is never found with Edward Gellibrand's in an announcement; but it is reasonable to suppose that they were in partnership, as they used the same address.

GELLIBRAND (SAMUEL), bookseller in London, 1637-75. See Dictionary, I641-67.

GENT (THOMAS), printer in London and York, (I) London, near the Two Fighting Cocks in Fleet Lane ; (2) York, Coffee-Yard. 17ro-78. Only the early part of this printer's career concerns us, as it was not until the close of 1724 that he set up in York. He was born in Ireland on May 4 th, 1693 , and was apprenticed to Powell the Dublin printer (q.v.) about I 706, but was hardly treated by him and ran away. Arriving in London in August 17 ro he at once found employment with Edward Midwinter of Pye Corner, a printer of broadsides and chapbooks, and remained with him till $\times 7 \times 3$, after which 
he worked successively for short periods for Mrs. Bradford, a Quaker printer, and Mears, and then as a "smouter", i. e. casually. On April 2oth, I7I4, he set out on foot for York, and there entered the service of John White (sen.). He remained in this employment a year, and fell in love with White's granddaughter and maid Alice Guy, whom he was later to marry. He is said to have been dismissed by White upon the latter's learning that he had broken his apprenticeship with Powell; but he himself says that his term being over he wished to visit his parents, and was " offered to be continued". He visited Dublin, where he worked for Hume, and was seized by Powell. In I716 he was back in London with Midwinter, and in 1717 was made a member of the Stationers' Company. Leaving Midwinter a second time he worked for John Watts and John Wilkins successively, and in 17 I 8 revisited Dublin, where he was again employed by Hume. On his return to London he took service with Francis Clifton, a Roman Catholic printer, and was engaged in a mysterious piece of illicit printing for Atterbury. Soon after this he was with Midwinter again. Clifton had printed for him a satire, Teague's Ramble, and in 1722 he cut woodcuts to an abridged Robinson Crusoe for Midwinter. In 1722 or 1723 he set up for himself in Fleet Lane and printed $A$ Collection of Songs, and (with Hotham) a book of emblems entitled Divine Entertainments, with ballads and bills for the cockpits. Meanwhile he continued "smouting" for other master-printers. After his departure from York he had kept up a correspondence with Alice Guy, and the news of her marriage to Charles Bourne, his fellow workman under White, was a severe blow. He wrote a poem, The Forsaken Lover's Letter to his former Sweetheart, and gave it to Dodd the printer, who sold thousands of copies. At Dodd's death Gent undertook the management of the press for Mrs. Dodd, but in 1724, on hearing of Bourne's death, he hastened to York and married the widow on December roth, in spite of the younger White's opposition. He thus became a master-printer, the only one in York, and almost the only one in the North of England. The first books he printed were sermons, Thomas Clarke's The True Foundations of a Nation's Greatness, printed for F. Hildyard [r 724 ], and Samuel Johnston's The Advantage of Employing the Poor, printed for R. Mancklin [ 1725$]$. He also issued The Original York Journal, a continuation of The York Mercury. White, who was printing at Newcastle-on-Tyne, set up a branch press in York, in opposition to Gent, and though the latter printed actively for many years, his business gradually failed and he fell into poverty, 
dying in 1778 at the age of eighty-six. He wrote several topographical works of value, including a History of York, I 730, and a life of himself, partially edited in $183^{2}$ by Joseph Hunter, from which most of the known details of his life are drawn. He seems to have suffered from a violent and suspicious temper; the Life is full of abuse of others and praise of himself. [Life ; Davies, York Press ; D.N.B.]

GERARD (J.), bookseller in London, Cornhill, 1692. Known as the publisher of a broadside, $A$ True and Impartial Account of the . . Earthquake . . ., 1692. [Haz. I. 264.]

GIBBS (J.), bookseller in London, 1689. Published a pamphlet called, The Character of a true English Protestant Souldier, I689. [B.M. T. I 702 (6).]

GIBBS (ROBERT), bookseller in London, Golden Ball, Chancery Lane, 1650-75. See Dictionary, 1641-67. Still in business in 1675, when he entered in the Term Catalogue an edition of Richard Baxter's Two Disputations of Original Sin. [T.C. I. 204.]

GIBSON (R.), bookseller in London, Roebuck, between the Two Temple Gates, Fleet Street, I703-4. Advertised in 1703-4 a divinity book, a play, and a political pamphlet. [T.C. III. 366,37 I, 40I.] He may be identical with the subject of the next entry.

GIBSON (ROBERT), bookseller in London, Golden Hat Block in Middle Row, Holborn, I700. Offered a gratuity of one shilling in the pound, to any one who would help him to the buying of any library or parcel of books. His advertisement appeared in a sheet called The Infallible Astrologer, 1700, which also contained a few other booksellers' advertisements. He may be identical with the subject of the preceding entry.

GIFFORD (ANN), bookseller in London, 1722. Possibly widow or one of the daughters of Robert Gifford (q.v.). Her name occurs in the imprint to The Obliging Husband, 1722.

GIFFORD (ROBERT), printer, bookseller and bookbinder in London, in Old Bedlam, without Bishopsgate, I689-1721 (?). Publisher of broadsides, chapbooks, and other popular literature. His shop was in the porch or gateway of Bethlehem Hospital. He is first met with in Easter 1689, when he advertised a Jest Book. [T.C. II. 257.] He is probably the "Mr. Gifford" 
mentioned by Dunton [p. 260] amongst bookbinders that worked for him. "He now keeps a shop in Old Bedlam, and having printed several copies that have sold well he will, if he continues Fair-keeping, get a lumping portion for his daughters." At the beginning and end of England's Witty and Ingenious Jester, by W. W. Gent, published by Gifford in I7I7, are lists of books printed and sold by him.

GILBERT (THOMAS), bookseller in Oxford, r669-77. Published the writings of Theophilus Gale, of Magdalen College. [T.C. I. I4, 21, 56, ro5, 285], and apparently nothing else.

GILBERT (WILLIAM), bookseller in London, Half-Moon, St. Paul's Churchyard, 1672-4. Publisher of popular and cheap literature, amongst which may be noticed a book of songs and catches called Westminster Drollery and $A$ Compendium, containing exact rules to be observed in the composing of two or more parts, either for vocal, or instrumental musick. His first and last entries in the Term Catalogues were made in 1672 and 1674 . [T.C. I. 95, 151, 188.]

GILBERTSON (J.), bookseller in London, Sun and Bible on London Bridge, 1684. Advertised in the Term Catalogue of Hil. I684 an edition of "Joseph ben Gorion's" History of the Jezes. [T.C. II. 65.] At a later date J. Williamson and $\mathrm{H}$. Green held these premises.

GILBOURNE (PERCIVAL), bookseller in London, the Narrow, at the corner of Chancery Lane, in Fleet Street, I697-8. He sold the and ed. of Lassel's Travels in and Through Italy, 1697, and in 1698 he published The Daily Communicant. [T.C. III. 33, 75.]

GILES (EDWARD), bookseller in Norwich, (I) St. Andrew's parish ; (2) near the Market Place. 1678-1703. In 1678 he had on sale the Rev. John Collinges' Several Discourses concerning the actual providence of God [T.C.1.329], and in I680 the same divine's Defensative Armour against four of Sathans most Fiery Darts. [B.M. 4409. d. I9.] From I678 to I69I he published sermons, \&c., by other Norfolk clergy. [T.C. II. 26, 41, 68, 93, I34, 378.] In 1695 a catalogue of books printed for him was appended to Martin Finch's Sermon upon the death of the Rev. John Collinges. In 1696 he published John Stackhouse's Mutual Duties of Elders and People, but the date of the copy in the British Museum is $\mathrm{I} 698$. In the London Gazelle of December 2 nd, $\mathrm{I} 689$, is an advertisement of a sale of books by Edward Millington, the great London auctioneer, 
at Mrs. Oliver's house in Norwich, and catalogues were to be had of E. Giles. Dunton [p. 237] in a brief notice praising his honesty, speaks of him as alive (1703).

GILLIFLOWER (MATTHEW), bookseller in London, Westminster Hall, (I) The Sun ; (2) The Spread-Eagle ; (3) Spread Eagle and Crown or Black Spread Eagle; and in Oxford. I67r-1702. One of the most important of the Westminster Hall booksellers. His name appears for the first time in the Term Catalogue in Mich. 1671, when he published, with Richard Lowndes, Sir Robert Cotton's Cottoni Posthuma. Amongst the many other interesting works he either sold or published were William Harvey's Anatomical Exercises [T.C. I. 123], Sir Henry Spelman's Law Terms, 1683, Montaigne's Essays, 1685-6, and the sixteenth edition of Chamberlayne's Angliae Notitia, r687. In I688, in company with James Partridge and Samuel Heyrick, he was appointed one of the printers to the House of Lords, a contract which they sublet. Gilliflower is last heard of in I702. [T.C. III. 313.] Oxford appears as his place of imprint in 1700 . [Madan, p. 3r.]

GILLWORTH (PETER), bookseller at Newcastle-under-Lyme, 1684. Published Cawdry's Certainty of Salvation, 1684. [B.M. 4902. cc. 2.]

GITTINS (THOMAS), bookseller in Shrewsbury, I 7 I 5-16. Publisher of W. Powell's Ways that lead to Rebellion laid open, 1715-16. [B.M. 225. g. I9 (7).]

GLEN (JAMES), printer and bookseller in Edinburgh, 1656-87. See Dictionary, I64I-67.

GODBID (ARTHUR), printer in London, near the Grate, Little Britain, I680-2. Probably a son of William Godbid ( $q . v$. in Dictionary, $1641-67$ ), and like him printed music. In partnership with J. Playford. Letterpress productions known from their press are : 1680, J. Davies's Instructions for History. [T.C. 1. $3^{82}$ ], and $A$ Seasonable Corrective to the new Project for the Good of England, broadside, for Clavel [B.M. T. I* (93)]; I68I, Daniel Nicols's Sermon preached in the Cathedral of Lincoln, July I8th, 1681, for Joseph Lawson of Lincoln [B.M. 694. d. I I (6)], and an address to the King from the Mayor of Gloucester, broadside. [B.M. T. I* (29).]

GODBID (WILLIAM), printer in London, 1656-77. See Dictionary, 1641-67.

GODDARD (THOMAS), printer and bookseller at Norwich, in the Market Place, $1703^{-19}$ (?) His name first appears in the Term Catalogues in 1703 as selling 
Benjamin Whichcot's Moral and Religious Aphorisms. [T.C. III. 360.] In 1706 he was the publisher of The Norwich Postman, which was printed by S. Sheffield [Timperley, p. 592], and, among other books, of the Rev. J. Chorley's Metrical Index to the Bible, I $7 \mathbf{I}$, which was printed by William Chase of Norwich (q.v.). In I7r3 he printed An Abstract of the several Acts of Parliament relating to Norwich [Bodl. Gough. Norf. 59 (3)], and his name occurs again in the proposals for printing Richard Bradley's Philosophical Account of the Works of Nature, I7 19.

GODWIN (JOSEPH), bookseller and printer in Oxford, upper end of Catstreet, 1637-73. See Dictionary, 1641-67. Mr. A. C. Clark notes that he died in 1673 . He left a son Joseph. [Wood, v. 304.] Mr. Madan [p. 29] enters him as a printer.

GOLDING (EDWARD), bookseller and printer in London, Rainbow Court, Aldersgate Street, $1683-91$. During the years $1683-4$, his name appears in the Term Catalogues as publishing four books, chiefly of divinity. [T.C. II. 50, \&c.] He also printed John Blagrave's Evil Spirit Cast-out, r6gr. [Haz. III. I9.]

GOOD (JAMES), bookseller in Oxford, near the Theatre, r68r-5. Published Effigies Amoris in English, 1681 , and $A$ Sermon before the King, by G. Ironside, 1685. [T.C. I. 465,484 ; the latter is in Bodl., Mar. 187.]

GOODALL ( ), bookseller (?) in London, Golden Cross, Cornhill, near the Royal Exchange, 1679-80. A Mr. Goodall, a neighbour of Benjamin Harris, gave evidence at the trial of the latter in 1679 . In 1680 a pack of cards illustrating the Popish Plot was to be sold by Mr. Goodall at the above address. [T.C. I. $3^{84}$.]

GOODMAN (JOHN), bookseller in London, r688. Publisher of a broadside, A True Copy of a Paper delivered by the Lord De . . . shire to the Mayor of Darby. [B.M. T. 100* (186).]

GOODWIN (JOHN), printer or bookseller at Oxford, I694. [Madan, p. 3r.]

GOODWIN (TIMOTHY), bookseller in London, (I) Maiden-Head, over against St. Dunstan's Church in Fleet Street; (2) Queens' Head, against St. Dunstan's Church in Fleet Street. 1683-1720. This eminent bookseller began publishing in Mich. 1683. [T.C. II. 44.] Dunton [p. 284] has this character of him : " $\mathrm{He}$ is esteemed a very honest man ; and what he engages upon is either very 
useful or very curious. Mr. William Rogers, Mr. Harris, and myself were once partners with him in publishing some Dying Speeches, and I observed a more than ordinary openness and justness in his dealings . . . He is Dr. Sherlock's bookseller, and printed Abp. Tillotson's Works, in conjunction with Mr. Ailmer." It was Goodwin who started the subscription for the relief of William Bowyer the elder, heading the list of subscriptions with ten guineas. [Nichols, Lit. Anecd. I. 60.] In r694 he changed his sign to the Queens' Head. He died in 1720 . [Timperley, p. 622.] The following publications by Goodwin are not recorded in the Term Catalogues: $A$ true copy of a Paper written by Capt. Thomas Walcot at Newgate, r683 [в.м. T. 100* (189)]; The Speech of Sir George Pudsey, r685. [B.M. T. 100* (175).]

GOOLDING (T.), printer in Newcastle-upon-Tyne, on the side, near Henderson's Coffee house, I7 5 . Only known from the imprint to a booklet entitled Honesto Willo. [Welford, Early Nerocastle Typography, p. 24.]

GOSLING (ROBERT), bookseller in London, (I) Mitre (or Mitre and Crown) against St. Dunstan's Church in Fleet Street; (2) at the Middle Temple Gate. r 707-41. Began publishing in 1707. [T.C. III. 555.] Many of his publications are noticed by Nichols. [Lit. Anecd. I. $21 \mathrm{r}$, et seq.] $\mathrm{He}$ is often mentioned by Browne Willis in his correspondence with Hearne. He died on January 4th, I741. Sir Francis Gosling, the banker, was his son.

GOUGE (J.), bookseller in London, Castle, Westminster Hall, r700-7. His name first occurs in Trin. I700, as selling a divinity book. [T.C. III. r96.] In 1707 he advertised a metrical translation from Epictetus. [T.C. IIr. 557.]

GOUGH (EDWARD), bookseller in London, Cow-cross, r682. His imprint is found on William Wood's Bore-Man's Glory, r682. [Haz. I. 467.]

GOVAN (DONALD), printer in Glasgow, I7 $15-19$. Govan had a press within the University, and in $17 I_{5}$ was appointed its printer. On May Ist, I7I9, the Town Council authorized a payment to Govan for printing various papers at "the time of the late rebellion." [Extracts from the records of the Burgh of Glasgow, 17 r8-38, p. 59.]

GRAFTON (GEORGE), bookseller in London, (I) Mitre, Fleet Street ; (2) Middle Temple Lane. r687-99. Made his first announcement in 1687. [T.C. II. 202.] In 1688 he sold a broadside entitled The Speech of Sir George Treby to the Prince of Orange; and in the same year he published Richard Blackbourne's 
Three Novels in one. [T.C. II. 223.] In 1689 Grafton was one of the booksellers selling the 1687 ed. of Chaucer. [T.C. II. 26r.] His last entry in the Term Catalogue was in Hil. 1699. [T.C. III. III.] His two addresses apparently represent the same house ; it was later occupied by Robert Gosling.

GRANGER (MATTHEW), bookseller in London, r69o. An Account of what passed in the House of Commons ... in relation to the Earle of Castlemaine, 1690 , was printed for him. [Haz. IV. I58.]

GRANT (FR.), bookseller in London, 1668. Published $A$ Strange and true relation of one Mr. John Leech, 1668. [Haz. II. 703.]

GRANTHAM (J.), printer in London, New Street, between Shoe Lane and Fetter Lane, I682-4 (?). In 1682 Grantham received advertisements, for insertion in various papers, at the above address. [The Loyal Impartial Mercury, September I 5th-Igth, I682.] He printed for D. Brown, T. Goodwin, and J. Walthoe at various times. He is last heard of in I684 [Haz. III. 258], unless he be identical with a J. G. who printed from 1650 till 1688 . [Haz.]

GRANTHAM (WILLIAM), bookseller in London, Crown and Pearl over against Exeter Change, in the Strand, r684. See Dictionary, r641-67. He sold in r684 an edition of Quarles's Emblems. [Haz. III. 207.]

GRAVES (GOWIN), bookseller at Cambridge, living in the parish of Great St. Mary on a site now occupied by the University Senate House lawn, I684-r 725. Mentioned in the wills of his father, William Graves, $1684(q . v$.$) , his mother,$ Magdalen Graves, I69I, and his brother, William Graves, jun., I686 (q.v.). On his brother's death in 1695 we find him claiming $£ 25$ as owing to him, and he was paid $f_{2}$ os. 9 d. for cataloguing his brother's books for sale. [Gray and Palmer's Cambridge Wills.]

GRAVES (JOHN), bookseller in London, Bible in Salisbury Street in the Strand, I68I-I7I5. He never used the Term Catalogues. Hazlitt records his imprint in the following: r681 : The Character of a Popish Successour Compleat [Haz. III. 284]; 1695: Urania. A Funeral Elegy on the Death of Our Gracious Queen; 1703: Misery is Virtues Whetstone .. Remains of . . Grace, Lady Gethin; I7I5 (with J. Baker): Memoirs of North Britain. [Haz. III. 284, II. $3^{86, \text { I. I } 84, \text { III. } 225 .]}$ 
GRAVES (THOMAS), bookseller in London, next White's Chocolate House in St. James' Street, r683-1 725. In 1683 he published Elkanah Settle's Supplement to the Narrative. [Haz. II. 553.] His name does not appear in the Term Catalogues; but he received subscriptions for the Works of Sir Henry Spelman in I722, and for Francis Mason's Vindication of the Church of England, 1 725. [Nichols, Lit. Anecd. I. 240, 329.]

GRAVES (WILlIAM), sen., bookseller at Cambridge. See Dictionary, 1641-67. Graves married Magdalen Tomlinson, April 6th, 1640, at St. Edward's Church, and died 1686 . His will, made November Ist, 1684, " being infirm and crasy in body, but of sound and perfect [mind] ", was proved September 24th, I686. The inventory of his goods totalled $£_{66} \mathrm{I}_{7} \mathrm{I} 3 s$. $4 d$., and amongst the items is "Hall [stall?] and shop, all the stock of books ccccvli." His widow died 1693 , and her will, proved March Ist, I693, is printed along with her husband's by Gray and Palmer, pp. 124, 125. Sons and daughters are mentioned, including William and Gowin (q.v.).

GRAVES (WILlIAM), jun., bookseller at Cambridge, r680-93. Evidently succeeded to his father's business and continued to live in the same house. He published several works from 1680 to 1693 . [Bowes, nos. $163(\mathrm{~b}), \mathrm{I}_{76} 6, \mathrm{I} 76^{*}, \mathrm{I} 85$, I88, I96; Haz.I. 443,IV. I38.] Mentioned in the wills of his father (q.v.) and his mother, Magdalen Graves, I693 [Gray and Palmer, p. I25.] His will, dated December $25^{\text {th }}$, 1686, proved February ist, I695, by Dr. Wm. Tindall, Fellow of Trinity Hall, contains a curious bequest to Clare College in the event of his wife not having issue which was not executed, for he was bankrupt for twelve weeks before his death, and the administrator, after selling the books and everything else, paid in two instalments $18 s .2 d$. in the pound. The inventory of his goods totalled $647^{\text {li }}$ Ios Iod, but their sale realized $83^{81 \mathrm{i}}$ I $^{\mathrm{s}} \mathrm{I}^{\mathrm{d}}$. A list of the creditors and the dividend, along with the will, \&c., is printed by Gray and Palmer, pp. 128-132.

GRAVETT (RICHARD), bookseller in Bristol, near the Tolzey, 1695-1738. Is first heard of as one of the booksellers in Bristol who in 1695 sold John Cary's Essay on the State of England. In I 7 I his name is mentioned in an advertisement in the Post Boy as receiving subscriptions for a forthcoming book. He was Sheriff of the City in I712-13 and died in 1738. [A. B. Beavan, Bristol Lists, p. 292.] 
GRAY.(s.), printer in London, Amen Corner, near Paternoster Row, 1720. Known from an advertisement for a missing man in The Daily Courant, June 3 oth, 1720 .

GREAVES (J.), bookseller at Cambridge, 1663. Published Ichabod; or, Five Groans of the Church. [Bowes, no. 121.*]

GREEF (н.), bookseller in Bristol, I7I5. Publisher of The Bristol Weekly Mercury (no. I, October Ist, I 7 I5).

GREEN (ABRAHAM), bookseller in London, I682. Only known as a publisher of broadsides in that year.

GREEN (D.), bookseller in London, 1682. Dryden's Satyr to his Muse and Mac Flecknoe were published by him in $\mathbf{1 6 8 2}$.

GREEN (RICHARD), bookseller at Cambridge, living on the site now occupied by the University Senate House lawn, 1682-94. His name appears on books published from 1682 to 1694 , including Mercurius Rusticus of 1685 and Dr. Joshua Barnes's edition of Euripides in folio. [Bowes.] He and Luke Meredith, (q.v.), married grand-daughters of Richard and Margaret Royston, and in 1698 they employed John Reeves to prosecute a commission of lunacy against their grandmother, and Green gave a bond to cover expenses. On the 24th December, 1698 , judgement was given against him for $£ 200$. Green died September 1699, and by will left everything to his wife Mary. [Gray and Palmer, p. 132]. He was apparently indebted to Samuel Smith and Benjamin Walford, booksellers of London, at the time of his death. His wife, before satisfying them, also died ( 1699 or 1700 ), and they took out letters of administration.

GREEN (ROBERT), bookseller in London, (I) near Ratcliffe Cross, London ; (2) Rose and Crown, Budge Row. 1674-85. Dealer in maps and topographical books. His name first appears in Easter 1674, and for the last time in Mich. I685. [T.C. I. I7 I, II. I48.]

GREENWOOD (JOHN), printer in Manchester, 1693. One of the earliest Manchester printers. R. W. Procter [Memorials of Manchester Streets, p. I83] records the following entry in the parish register: " 1693 . March 1. Jonathan, son to John Greenwood of Manchester, printer, baptized ". He adds that in spite of careful search no further information concerning this printer could be found. 
GREENWOOD (JONATHAN), bookseller in London, (I) The Crown, in the Poultry; (2) Black Raven, Poultry, near the Old Jewry. 168I-8. Dealt principally in divinity. Made his first entry in the Term Catalogues in Mich: I68I, with Richard Allen's Instructions about Heart-Work. [T.C. I. 457.] Dunton, who succeeded him at the Black Raven, thus refers to him [p. 227] : "Served his apprenticeship with Mr. Cockril ... Though he had contracted a large acquaintance and had Dr. Annesley's friendship, who helped him to 'Mr. Allen's Heart-Work' and other saleable copies, yet he concluded trading at last with as small a pittance of the world as he had to begin it." $\mathrm{He}$ is last heard of in Mich. r688. [T.C. II. 237.]

GREGORY (J.), bookseller in London, Cornhill, I69o. Published Great News from the Isle of Wight, 169o. [Haz. I. 455.]

GRIERSON (CEORGE), bookseller and printer in Dublin, I709-33(?). Was the first and most distinguished of several generations of a family of printers. He was first a bookseller (i $709-14$ ), but his imprint as printer is found in I 7 I 5 and thenceforth frequently. In 1733 he was appointed King's printer in succession to Andrew Crooke. He was twice married, first to the learned and accomplished Constantia Grierson (her maiden name is not certain) and afterwards to a sister of James Blow, the chief Belfast printer. Grierson's press turned out a variety of books on different subjects, including several editions of the Book of Common Prayer, the Bible, some classics, and the Psalms, \&c.

GRIFFIN (BENNET), bookseller and printer in London, Griffin in the Old Bailey, I67I-I700. Probably son of Edward Griffin II (1638-52). His name is joined with that of his mother Sarah Griffin as a printer; but Bennet Griffin confined himself to bookselling for a time and published several notable works, including Bacon's Sylva Sylvarum, with an epitome of the Novum Organum, 1683 [T.C. II. 34], and James Wright's History and Antiquities of the County of Rutland, I684. He printed Buchanan's Latin Poems, I686 [T.C. II. I73], and an Epictetus for Sam. Keble, I692. [Haz. II. 204.] His. name also appears first among the booksellers selling Chauncy's Hertfordshire, I 700, after which nothing more is heard of him.

GRIFFIN (SARAH), see Dictionary, 1641-67.

GRIGG (G.), bookseller in London, near Charing Cross, I7r7. Sold Jer. Owen's Sermon ... to ... Dissenters, I7I7. [B.M. T. I805 (II).] 
GROINE ( ), stationer in London, Black Horse, between the two Temple Gates within the Bar, r669. Appointed Receiver of Letters for the General Post Office, 1669. [S.P.D. Car. II. 262, 180.]

GROOM (G.), printer in London, r 705-9. He printed editions in $8^{\circ}$ of Sternhold and Hopkins's metrical version of the Psalms for the Company of Stationers in 1705 and 1709.

GROSVENOR (RICHARD), bookseller in Wolverhampton, I685-9I (?) In 1684 or 1685 a broadside entitled The Loyal Speech of George Plaxton . . . upon the Proclamation of ... King James the Second was printed for him at London by J. Leake. [B.M. 8I22. i. I (4I).] Grosvenor is believed to have died in I69r.

GROVE (HUGH), bookseller and printer in Portsmouth, I718. Mr. F. A. Edwards [Early Hampshire Printers (in Papers of the Hampshire Field Club), p. II5 n.] refers to a sermon by the Vicar of Portsmouth, printed by Hugh Grove, bookseller in Portsmouth, in 1718 (communicated to him by a Mr. W. H. Long), as preceding the earliest Portsmouth printing previously known by thirty years; but he does not give its author or title. It appears that Grove was both a printer and a publisher.

GROVER (JAMES) and (THOMAS), printers and type-founders in London, (I) Pelican Court, Little Britain; (I) Angel Alley, Aldersgate. 1676-1 728. James Grover began as a printer about ${ }_{1676}$. [Haz. I. 216.] He probably began as a type-founder at the same time, and in 1679 he cast the types for an edition of Herodotus in Greek and Latin which was printed by E. Horton and published by J. Dunmore, R. Chiswell, B. Tooke, and T. Sawbridge, and they were used again in a fine edition of Cicero in two folio volumes, also published by Dunmore. Later he was joined by his son Thomas, and after Moxon's retirement from business the Grover foundry, with that of Joseph and Robert Andrews, shared between them the whole of the English trade. The most notable founts in their possession were a pica and long primer Roman from the Royal Press at Blackfriars, Day's double pica Roman and Italic, English Samaritan matrices from which the type for Walton's Polyglott Bible had been cast, and a Greek uncial fount, cut for the specimen of the Codex Alexandrinus which Patrick Young proposed to print, but did not live to accomplish. The date of James Grover's death seems to be unknown; but Thomas died 
in 1728 , after which the foundry remained nearly idle in the hands of Nutt, the printer, husband of one of his daughters, till $175^{8}$, when it was sold to John James. [Reed, The Old English Letter Foundries, p. 205.]

GROVER (THOMAS), type-founder in London. See Grover (James).

GUILLIM, see Gwillim.

GUN, GUNN, or GUNNE (MATTHEw), bookseller and printer in Dublin, Bible and Crown, Essex Street, I694-1 710 (?). Described as a bookseller in 1694; in 1695 he published a tract, The Rector's Case. [Bodl. G. Pamph. 2 I94 (1 5).] In 1696 he printed a quarto tract; but he appears most often as a seller or publisher of books and not as a printer. He bought books largely at Dunton's auction at Dublin in 1698. [Dunton, p. 550.] In I7or he published $A$ Full Account of . . . Captain Kidd. [Haz. I. 245.] He was living in 1710 and perhaps later.

GUNTER (LAURENCE), printer in Edinburgh, 1685. In partnership with J. Colmar. Their imprint appears on N. Paterson's Panegyrick to Thomas Kennedie, 1685. [Aldis, p. 69.]

GUY (JOHN), bookseller in London, (I) at the Corner shop of Little Lombard Street and Cornhill ; (2) Flying Horse, Fleet Street, between St. Dunstan's Church and Chancery Lane. I670(?)-I 709. Brother of Thomas Guy (q.v.) and a member of the Haberdashers' Company. He began in partnership with his brother, and in Mich. 1677 their joint names appear as sellers of Elisha Coles' English-Latin and Latin-English Dictionary. [T.C. I. 293.] After the partnership between the brothers was dissolved about 1679, while Thomas continued to occupy the premises in Cornhill, John moved to the Flying Horse in Fleet Street, where he published in Easter Term, r680, L. Maidwell's tragedy, The Loving Enemies. [T.C. 1. 394.] He either gave up business or ceased publishing shortly after this, as nothing more is heard of him. He died in 1709 , his will being proved on July 5 th. In this he mentions his sister Anne Varnam and her son Thomas Varnam, who succeeded his uncle Thomas Guy in his shop in I7II. He also mentions a cousin, Joseph Osborne, and he left the residue of his estate to his brother Thomas. [P.C.C. I70, Lane.]

GUY (THOMAS), bookseller in London and Oxford ; London, at the Corner shop of Little Lombard Street and Cornhill, 1668-1724. This famous bookseller 
was the eldest child of Thomas Guy, lighterman and coalmonger, and was born in 1644 or 1645 in Pritchard's Alley, Fair Street, Horsley Down, Southwark. His father, an Anabaptist, died young, leaving three children, two of whom were boys, Thomas and John. Their mother returned to her native place, Tamworth. Here the children were educated, and the two boys were sent eventually to London and apprenticed to the trade of bookselling, Thomas on September 3 rd, 1660 , to John Clarke. Thomas, being the elder, was probably apprenticed a few years earlier than his brother John. At any rate Thomas took up his freedom in the Stationers' Company on October 7 th, 1668, and shortly afterwards set up in business for himself with a stock worth about $£ 200$. Some time about 1675 he was joined by his brother John. It has been erroneously stated by Nichols [Lit. Anecd. III. 599-600] that Thomas Guy laid the foundation of his bookselling business by engaging in the unlawful importation of foreign printed Bibles: but what he and his brother did was to buy from the Stationers' Company large stocks of Bibles, \&c., which the Company had seized on the wharves. Indeed, the King's printers actually seized these Bibles on the ground that they were illegally imported, then reprinted the first sheet, and issued them again as English Bibles, and thus sought to drive the Universities out of competition. This is made clear by an affidavit by John Guy. [Hist. MSS. Comm., Rept. xi, App. p. 274.] Before 1679 Thomas Guy, Peter Parker and Moses Pitt were called in to assist Oxford University in its attempt to put Bibles on the market at a cheaper rate and in better print than the King's printers were then doing. Consequently Pitt was appointed printer and Parker and the Guys managed the selling, with the result that the price of Bibles, Testaments, and Common Prayer Books was reduced very considerably. At the same time it must be confessed that Moses Pitt's earlier attempts at Bible printing were not much better typographically than those that were on the market before. The statement that Guy imported type from Holland is also misleading. It was Bishop Fell who imported Dutch letter, as is well known, for the express purpose of founding the Oxford Press. The assistance of the Guys was not called in until the opposition of the Stationers' Company became so dangerous that the University felt that it should have the help and guidance of some London booksellers, and choice was made of Parker, Pitt, and the Guys. John Guy dropped out of the partnership about 1679 and moved to the Flying Horse in Fleet Street; Thomas Guy's name appears in the 
Term Catalogues for the last time in 1707. [T.C. III. 576.] According to Dunton [p. 205] Thomas Guy in I 703 occupied a high position among London booksellers and was an eminent figure in the Stationers' Company. A statement that Guy almost starved the bookbinders he employed, may have been only ill-natured gossip. Certainly as early as 1678 Guy had founded at Tamworth an almshouse for six poor women, which he enlarged in 1693 to accommodate fourteen men and women. In I 7or he also built there a town hall, which is still standing. Many of his poorer relations received pecuniary help from him, and in many other ways he showed a generous nature. In 1704 Guy became a governor of St. Thomas's Hospital, and in 1707 built and furnished three new wards. On August 5 th, I7 7 , he offered the Stationers' Company $\ell^{I, 000}$ to enable them to add to the quarterly charity to poor members and widows. Guy had conceived the idea of providing for the many patients who could not be taken into St. Thomas's Hospital or were discharged thence as incurable. In I 721 he leased from the Governors a piece of ground opposite, and, having pulled down a number of small houses, began the erection of a hospital, ever since known as Guy's. The building, which cost

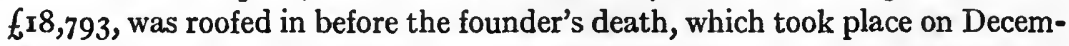
ber 27 th, 1724, in his eightieth year. Guy's will was proved on January 4th, 1724-5. It was afterwards printed and went through three editions in 1725 , being reprinted by the governors of the Hospital in 1732 . It dealt principally with the government of the Hospital. [Works quoted; D.N.B.]

GWILLIM, or GUILLIM (JOHN), bookseller in London, against Crosby Square in Bishopsgate Street, 1684-1707. According to Dunton [p. 224] John Guillim or Gwillim was originally a clasp-maker. He took up bookselling, attended Bristol fair every year and was a thriving man. He is first mentioned in the Term Catalogues in 1684 , when, in company with S. Sprint, he published an astrological work by John Gadbury. [T.C. II. I03.] In $x 707$ he was party to an action brought by the Company of Stationers for the infringement of their patents. [Chan. Proc. before 17 14, Bridges $\frac{270}{21}$ P.R.O.]

GWILLIM (PHIII), printer in London, at his Wharf at the end of Bur Street in East Smithfield, I7I7. Possibly son of John Gwillim. He printed in I7I7 a pamphlet entitled $A$ Believer's Evidences for Heaven. [B.M. 702. f. 2 (5).]

H. (J.), printer in London, 1697-1 710. Perhaps John Humphrys (q.v.). 
HAIGHT (w.), bookseller in London, Bloomsbury, 1689. Only known as publisher of An Answer to the Bishop of Rochester's First Letter to the Earl of Dorset, E॰c. . . . By an Englishman, 1689. [Haz. iii. 126.]

HAIR (J.), see Hare.

HALES (THOMAS), printer in London (St. Omer ?), 1696. A Roman Catholic printer, who printed the Life of the Lady Warner, "London ", 1696. [Haz. ii. 633.]

HALEY or HALY (FRANCIS), bookseller in London, $(a)$ at his shop in Holborn, at the corner of Chancery Lane, (b) Chancery Lane near Holborn. 1670-81. Publisher of works on witchcraft. His name first appears in the Term Catalogue for Hil. 1670. [T.C. 1. 27.] He is last heard of in 1681. Gray's reference to 1690 is a misprint for 1680 . [Index to Haz. ; cf. IV. I35.]

HALEY or HALY (M.), printer in London, 1683-4. Printed with J. Millet a poetical broadside commemorating the great frost of 1683 (sold by Robert Walton and John Seller). [B.M. C. 20. f. 2 (159).] The same pair put their initials only to a ballad, An excellent Example to all Young Men, I684. [B.M. C. 40. m. I I (72).]

HALEY (THOMAS), printer in London, 1677-82. Associated with Ann Purslowe in 1677 . In 1680 he put his initials to a poetical broadside concerning William Farthing, printed for J. Clarke, and his name is also found in the imprint to a romance, The Most Excellent History of Antonius and Aurelia, 1682. [Bodl., Douce A. 271.]

HALL (EDWARD), bookseller in Cambridge, living in the High Street, next [north of] the Green Dragon [on land now occupied by the University Senate House lawn], r688-1 703. His name appears as publisher on books dated 1688-1 700. [Bowes, nos. 194, 203, 339, 2905; T.C. II. 402, 599; III. 40, 173.] He died in 1703 , and his will is at Peterborough. Two years later his premises were occupied by Thomas Webster, bookseller $(q . v$.).

HALL (JOHN), printer at Oxford, I670(?)-r707. After Bishop Fell's death John Hall, " who knew how to influence his new masters, and at the same time to make a good hand of it to his own profit and advantage ", raised the prices of all kinds of printing at the Theatre. [Hearne, II. 90.] On the Coronation of William and Mary he was paid 442 $^{2} 5 \mathrm{~s}$. for printing and binding the verses on the King and Queen, and a further sum of $f_{1} 9$ ros. for 
two large Bibles of imperial paper and for binding eight “ bookes of (Loggan's) College Cutts" which were probably presented to their Majesties at that time. [Wood, IV. 82.] Hall died just before Christmas I 707. [Hearne, II. I2 I.]

HALL (JOSEPH), bookseller and bookbinder on Tyne Bridge, Newcastle-uponTyne, 1683-99. Publisher of Richard Werge's sermons preached in St. Mary's Church at Gateshead during the years 1683-5, now very rare. [Memoirs of Mr. Ambrose Barnes, App., pp. 422, et seq.] In 169I he published a sermon preached by George Tullie, Sub-Dean of York, before the Mayor of Newcastle. [T.C. II. 345.] In 1693 he published the Sermons of John March, Vicar of Newcastle. [T.C. II. 473.]

HALL (w.), stationer (?) in London, Angel in Fleet Street, I684. Sold a "Compendium of Writing, printed on a large Imperial Sheet of Paper".

HALL (WILLIAM), bookseller in Oxford, 1670. See Dictionary, I641-67.

HALSEY (R.), bookseller in London, Cornhill, (a) St. Michael's Church Porch, (b) Plough and Harrow, near the Royal Exchange. I 700 (?)-1 723. Dunton, in 1703 [p. 217], refers to a Mr. Halsey as a "man of good judgement; his great ingenuity and knowledge of the learned Languages have justly entitled him to the friendship of Athens" [i. e. of Dunton's Athenian Society]. In I 7 I he appears in an advertisement as one of those from whom catalogues of a book-sale could be procured [Daily Courant, January Igth], and in the same year he advertised a preparation called " The Britannick Beautifyer". [Postman, February 8th.] In I703 he published the Rev. J. Hancock's Febrifugium Magnum.

HAMMOND (HENRY), bookseller at Bath and Devizes, 1695-1721. Probably in partnership with John Hammond, as their names appear jointly on W. Gough's Four Sermons, 1695. [B.M. 4479. a. 40.] In I697 Henry Hammond published Dr. Pierce's Bath Memoirs, printed at Bristol. [T.C. III. 26.] In I 79 his name occurs as one of the publishers of the Rev. Arthur Bedford's Serious Remonstrance... against ... Play ... Houses, and he was still publishing in I72r. [N. \& $Q$. , roth Ser., V. I4I.] A list of his publications in stock in 1707 is to be found in J. Jackson's Sermon preached at Bathe. [Bodl. Serm. II. (I).]

HAMMOND (JоHN), bookseller at Bath and Devizes, I695-I 719. Apparently in partnership with Henry Hammond $(q . v$.$) . John disappears after I 7 \mathbf{1 9}$, 
when his name is found in the proposals for printing Richard Bradley's Philosophical Account of the Works of Nature.

HANCOCK (JOHN), sen., bookseller in London, 1643-73 (?). See Dictionary, $1641-67$. Still in business in 1673 .

HANCOCK (JOHN), jun., bookseller in London, (a) Three Bibles in Pope's Head Alley, $(b)$ at the first shop in Pope's Head Alley, next Cornhill. 1673-1705. Son of John Hancock, senior. Their joint names are found for the first time in Hil., 1673, as publishing certain sermons by William Bridge [T.C. 1. 126], but the date of his father's death and of his succession to the business is not known. In March $1676-7$ he was committed for selling copies of a pamphlet called The Long Parliament Dissolved, which he said he had received from Mrs. Brewster, paying her a groat for each copy. On promise of amendment he was released. [Hist. MSS. Comm., gth Report, App., p. 70.] The firm published chiefly divinity, and Hancock's name continues to appear in the Term Catalogues until Easter I705. [T.C. III. 458.] In 1679 the name of "John Hannock", probably a misprint for Hancock, is found as selling Capt. W. Bedloe's Narrative of the Burning of London. Dunton [p. 224] refers to him as " an old friend and acquaintance", and states that he "printed" works by Thomas Brooks, and got a considerable estate by bookselling.

HANCOX (THOMAS), bookseller at Hereford, 1674. Publisher of the Rev. T. Good's Firmianus and Dubitantius, or Certain dialogues concerning Atheism, 674 .

HANNOCK (JOHN), bookseller in London, r679. Probably an error for John Hancock, jun. (q.v.).

HARBIN (THOMAS), printer in Dublin, 1724-6. In partnership with Pressick Rider, but on one occasion printed alone in 1726 . Together they printed, in 1725, an edition of Molyneux's Case of Ireland, Lewes' Origines Hebraicae and Young's Poem on the Last Day, and in 1726 Browne's English Expositor Improved.

HARBIN (THOMAS), bookseller in London, (I) Wheatsheaf against the Tun Tavern, near Hungerford Market ; (2) Bible and Anchor in the New Exchange in the Strand. 1693-1737. In 1693 he published for John Whittel, Constantinus Redivivus. [Haz. II. 643.] On June 11 th, 1694, his name occurs in an advertisement of patent medicines in The City Mercury. In $172 \mathrm{I}$ he published Sir Francis Hubert's Life of Edward II, with the imprint of the Bible and 
Anchor. Harbin was also noted as selling ink of good quality. He died November 18th, 1737. [Timperley, p. 660.]'

HARBOTTLE (R.), bookseller in London, r68r. He published Strange Neros from Hicks Hall, r68I. [Haz. II. 395.]

HARDEY (RICHARD), bookseller (?) in London, c. 1677. Mentioned in some legal proceedings. [Plea Roll, Mich. 29 Chas. II, m. I 70.]

HARDING (JOHN), bookseller in London, (I) Bible and Anchor, St. Paul's Churchyard ; (2) Bible and Anchor, Newport Street, near Leicester Fields ; (3) St. Martin's Lane. r678-ryr2. Entered in the Term Catalogue of Mich. 1678 Christopher Nesse's Christian's walk and work on earth . . . Second edition. [T.C. I. 336.] Dunton became acquainted with John Harding at Sturbridge Fair and dealt with him for several years, finding him [p. 223] " a very honest man, an understanding bookseller and a zealous Church of England man, yet no bigot". In I684 he moved to Leicester Fields, and among his apprentices was Bernard Lintot, who had been turned over to him from Tho. Linyard. In I 709, among those who received subscriptions for the Corpus omn. vet. Poetarum Latinorum was-Harding, in St. Martin's Lane, who is probably identical with John Harding. [T.C. III. 657.] In I 7 I 3 he subscribed to the fund for the relief of William Bowyer the elder.

HARDING (JOHN), printer in Dublin, I72I-4. In 1721 he printed a History of the Kings of Scotland, a substantial volume, and in 1724 Swift's Drapier's Letters, for which latter he was prosecuted.

HARE or HAIR (J.), bookseller and musical instrument maker in London, (I) Mutton Court in Maiden Lane, over against Haberdashers' Hall ; (2) Freeman's Yard in Cornhill ; (3) Golden Viol in St. Paul's Churchyard; (4) Viol and Flute in Cornhill. 1680-1718. The first of the above imprints is found on No. I of Mercurius Publicus, February 21st-28th, I6 $\frac{79}{80}$ [Burney, 8IA], and may possibly refer to a different man. J. Hare or Hair was by trade a musical instrument maker, but sold all kinds of music books. His name occurs in the Term Catalogues for the first time in Trin. 1696, when he sold $A$ Collection of Nero Songs set by Mons. Nicola Matteis. [T.C. II. 589.] He was still in business in 1718 , when he published The Compleat Country Dancing Master. [Haz. I. II4.] 
HAREFINCH (JOHN), printer and bookseller in London, Montague Court in Little Britain, $1682-\mathrm{I} 690$ (?). In $\mathrm{I} 682$ he printed for $\mathrm{H}$. Rhodes a novel called The Pastime Royal [Esdaile, p. 282], in 1683 for James Norris, Hac and Hic; Or, The Feminine Gender more worthy than the Masculine [Haz. III. 27I], and in 1684, for the same, Poems and Discourses by John Norris. [Haz. I. 308.] In the Term Catalogue of Trin. I688 [T.C. II. 236] he advertised Chr. Musgrave's Motives. In the following year he printed for William Hensman, the bookseller at the King's Head, Westminster Hall, Nicholas Greenwood's Astronomia Anglicana. This work was not advertised in the Term Catalogue but in The London Gazette, where the further information is given that the book was to be had at the shop of Rest Fenner in Canterbury. The printer's name was not given. Harefinch died about 1690 , and his widow afterwards married a printer named Sharpless. [Records of Stat. Co.]

HARFORD (MRS.), bookseller at Portsmouth, I695 (?)-I 7 Io. Probably widow of Robert Harford, bookseller at Portsmouth (q. ข.).

HARFORD (ROBERT), sen., bookseller in London, Angel in Cornhill, near the Royal Exchange, I677-81. Probably son of Ralph and Elizabeth Harford, see Dictionary, 1641-67. He made his first entry in the Term Catalogues in Trin. 1677. [T.C. 1. 285.] He published a news sheet called Mercurius Anglicus (no. 1, November 20th, 1679). No. 12 appeared as The True Nezos or Mercurius Anglicus; unlike other "Mercuries", which consisted of one leaf, the first eleven numbers consisted of two leaves or four pages; but this was soon found too expensive, and it reverted to the ordinary form in no. I2. It contained a few advertisements, chiefly of books published by Harford. Amongst his varied publications was Edmund Halley's Catalogus Stellarum Australium in Mich. 1678. [T.C. 1. 335.]

HARFORD (ROBERT), jun., stationer and bookseller in London, St. Paul's Churchyard (?), 1685-I714. Defendant in an action for debt brought by William Curtis, judgement being signed against him on November 12th, I Jas. II. [C.P.R., Mich. I Jas. II, Roll. 3039, m. 4I4 recto.] " Harford's shop in the Church Yard" is referred to on p. 8 of a pamphlet entitled The Irish Massacre, I714, as a place where pamphlets were sold.

HARFORD or HARTFORD (ROBERT), bookseller at Portsmouth, 1675-95. His name appears in an advertisement of Dr. Sermon's Pills. The business 
was continued for a long period, the name of Mrs. Harford, bookseller, appearing in x710. [F. A. Edwards, Early Hampshire Printers, 1891.]

HARGRAVE (D.) or (RICHARD), bookseller in London, (I) against Furnivalls Inn Gate ; (2) Fleet Street, 1689-1713 (?). In the Term Catalogues for Hil. and Easter r696, he is mentioned as joint publisher with S. Heyrick of Sir Thomas Raymond's Reports. [T.C. II. 568, 579.] In one of these entries his initial is given as D., in the other R. In $\mathrm{r}_{7} \mathrm{r} 3$ a Richard Hargrave was connected with the publication of a pamphlet called The Art of being Honest for $a$ little Time, which was the outcome of a dispute amongst the parish authorities of St. Dunstan's in the West. It gave the names of all the inhabitants who paid the Scavenger's Rate in I 713-14, and though the trades of the persons named were omitted many stationers and booksellers of that period are named. [B.M. 796. c. 35.] In The London Gazette, October 28th3Ist, r689, "Mr. Hargrave " against Furnivall's Inn Gate is mentioned in an advertisement of a sale as one of those from whom catalogues could be obtained.

HARIS (F.), see Harris.

HARPER ( ), bookseller at Hallaton, Leicester, 1687. Defendant in an action for trespass brought against him by Henry Hitchcock. [C.P.R., Hil. 2-3 Jas. II (1686), Roll 3052, m. I25 verso.]

HARPER (CHARLES), bookseller in London, The Flower de Luce, Fleet Street, r670-r709. His name first appears in the Term Catalogues in Easter 1670. [T.C. I. 40.] He was a prolific publisher of divinity. A list of books printed for him in 1684 will be found at the end of The Laws of Jamaica, I684. Dunton [p. 210] thus describes him: "I believe him an honest man and a warm votary for High Church. He printed Mr. Wesley's 'Life of Christ', and makes a considerable figure in the Stationers Company." Harper was Junior Warden of the Company in 1699-1700. The Flower de Luce was an old building standing at the corner of Fetter Lane and Fleet Street, and in the first quarter of the seventeenth century was occupied by John Hodgets the bookseller. [See Dictionary, I557-1640.]

HARRIS (BENJAMIN), bookseller and printer in London and Boston, New England ; London, (I) Bell Alley, Coleman Street ; (2) (a) Sweeting's Alley, Cornhill, (b) Stationer's Arms, Sweeting's Rents, near the Royal Exchange ; 
(3) Maiden Head Court in Great East Cheap ; (4) Golden Boar's Head in Gracechurch Street, or, at the corner of Gracechurch Street, next Cornhill ; Boston, (I) by the Town Pump near the Change ; (2) over against the Old Meeting House; (3) Bible, over against the Blue Anchor. 1673-1708. The following sketch of this notorious character is chiefly an abridgement of Mr. P. L. Ford's Introduction to his edition of the New England Primer, 1897. Benjamin Harris makes his first appearance as a bookseller in the Term Catalogue for Mich. 1673, when he issued, from Bell Alley in Coleman Street, a work entitled War with the Devil. [T.C. I. 147.] His chief characteristic at this time seems to have been an ardent Protestantism. At the time of the Popish Plot he threw himself actively into the fray and published a large number of ballads, broadsides, and tracts against the Pope and the Jesuits, as well as printing the Domestick Intelligence and other news-sheets with the same object. In 1679 he issued An Appeal from the Country to the City, for the Preservation of His Majesty's person and the Protestant Religion. This gave great offence to the Government, and Harris was brought to trial for "printing and sending it", and he was ordered to find security for his good behaviour for three years. Harris himself printed the account of this trial. Unwarned by his experience, Harris in I68I printed a Protestant Petition and was again prosecuted. This time the judge fined him $£ 500$ and ordered him to be put in the pillory, a sentence that was duly carried out. After this he left England and went to America, and Dunton, writing from Boston, said, "Old England is now so uneasie a place for honest men that those that can will seek out for another country: And this I suppose is the case of Mr. Benjamin Harris and the two Mr. Hows whom [sic] I hear are coming hither". [Dunton, Letters from New England, 1867 , p. 144.] Harris set up a book and coffee, tea, and chocolate shop " by the Town Pump near the Change " in Boston in I686. Here too he was quickly involved with the authorities, for in 1690 he issued without permission the first newspaper printed in America, under the title of Public Occurrences, which was suppressed by proclamation. Sometime between 1687 and 1690 Harris issued the first edition of The Nerw England Primer, of which no copy is known. In Henry Newland's almanac, entitled News from the Stars, "printed by R. Pierce for Benjamin Harris at the London Coffee House in Boston, 169I " (and consequently printed late in 1690), the last leaf advertised a second impression of The New England Primer, enlarged. In 169I Harris 
formed a partnership with John Allen and became Printer to the Governor and Council, and removed his business to a shop "over against the Old Meeting House", making another move in 1694 to "the Sign of the Bible, over against the Blew Anchor". But evidently things did not prosper with him, and towards the end of 1695 he returned to England and opened a printing office at Maiden Head Court in Great East Cheap, and in 1703 Dunton [p. 217] writes, " $\mathrm{He}$ is now both Bookseller and Printer in Gracechurch Street, as we find by his London Post." The last entry under Harris's name in the Term Catalogues was in Mich. I 7or, and his death is believed to have taken place about 1 708. Partridge in his Almanac says that Benjamin Harris and his son had added a supplement of their own to his almanac in 1704 and 1705 .

HARRIS (ELIZABETH), bookseller in London, Harrow in Little Britain, 1699r 7rr. Widow of John Harris. Dunton says [p. 223] that she printed his Panegyrick on the Lord Jeffreys, The Great Historical Dictionary, The Present State of Europe, " and other copies that have sold well".

HARRIS (F.), bookseller in London, I682. A political pamphlet entitled War Horns make room for the Bucks with Green Bowes, bears the imprint, “London, printed for F. Haris, r682". [Haz. I. 288 ; B.M. 1077. h. 33.]

HARRIS (GEORGE), bookseller in London, Queen's Head, St. James's Street, r7o3-21. Published in r7o3 a volume of verse called Poems on Several Occasions. [B.M. Ir633. e. 52.] In I72I he was one of the publishers of Paul Chamberlen's series of novels called Love in its Empire. [Esdaile, p. 183.]

HARRIS (GABRIEL), bookseller in Gloucester, I702-22. Published two sermons preached at Colford, Gloucester, one by William Harrison of Stanton, the other by Humphry Jorden of Newland. [Flying Post, November 5th, 1702.] See Went.

HARRIS (JOHN), bookseller in London, (x) Harrow against the Church in the Poultry ; (2) Harrow in Little Britain, I685-98. This bookseller was the particular friend of John Dunton, who devotes two pages [23I-2] of his Life and Errors to a description of him. Dunton and he were partners in Coke's Detection, The Secret History of Whitehall, Leybourn's Panarithmologia, and "thirty other valuable books". Dunton further says, "from the day I left my shop in the Poultry, I put all I printed into John's warehouse and 
found him always ready to even accompts, and to discharge his trust to a half-farthing". George Larkin the printer is said to have composed the following couplet on Harris :

Of all honest Booksellers if you'd have the Marrow, Repair to King John, at the Sign of the Harrow.

Harris made his first entry in the Term Catalogues in Mich. 1685. A pleasant and compendious History of the first Inventers, 1686, published and probably written by him, has at the end a list of seven books, five religious and all popular, printed for him. [B.M. II37. a. 37.] He moved to Little Britain sometime in 1695 or 1696 , and is believed to have died some time in 1698 , his business being continued for some years by his widow Elizabeth Harris.

HARRIS (s.), bookseller in London, 1703. A novel entitled A Banquet for Gentlemen and Ladies was published by S. Harris in I703. [Esdaile, p. 157.]

HARRIS (w.), bookseller in London, next door to the Turn Stile in the Postern, I69o (?). Published an undated news-quarto, A Full and True Relation of an English vessel newly taken by a Company of French Pyrats, at next Sessions to be try'd for their Lives. [Haz. I. 355.]

HARRISON ( ), bookseller in London, Chancery Lane, r703. Mentioned by Dunton [pp. 229-303].

HARRISON (ISRAEL), bookseller in London, (r) Star, in Chancery Lane ; (2) Greyhound, Chancery Lane ; (3) under Lincoln's Inn Gate, or Lincoln's Inn Fore-Gate. 1673-1706. Publisher of law books and general literature. Partner with B. Southwood (q.v.) in 1673 . In 1675 he either changed the sign of the house from the "Star" to the "Greyhound" or moved to other premises with that sign. He also had a second shop under Lincoln's Inn Gate. Dunton describes him [p. 230] as " a diligent man in his shop, a kind neighbour and a religious master".

HARRISON (RICHARD), bookseller in London, New Inn without Temple Bar, 1701. Published John Cory's comedy, A Cure for Jealousie, r 701, at the end of which is a "Catalogue of Books printed for R. Harrison ... " consisting of only three entries. [B.M. 8I. c. 19.]

HARRISON (THOMAS), bookseller in London, White Swan, West Corner of the Royal Exchange, Cornhill, 1683-r 7rr. Dunton says [p. 225] that he was apprentice with Samuel Crouch. He is first heard of in the Term Catalogues 
in Mich. 1683. [T.C. II. 39.] In that year he published Manger's French Grammar. [T.C. II. 53.] He published several tracts against Sacheverell in I 7r I. [T.C. III. 669-70.]

HART (JAMES), printer in Glasgow, I7I4. He printed within the University in I7I4 An account of a conference betwixt Mr. John Steel minister at Old Cumnock, and John Adamson a disorderly preacher. [John McUre : History of Glasgow (1830), p. 370.]

HART (JONAS), bookseller in Cambridge. His name appears on two works : Dissertationes Academicae a Petro Olivier, 1674, and R. Sheringham's The King's Supremacy Asserted, I682. [Bowes, 151; Haz.Iv. 167.] Hewas probably a relative of William Morden the bookseller (q.v.), who in his will, 1678, mentions "brother Andrew Hart and Susanna his wife" [Gray \& Palmer's Cambridge Wills, II9], Andrew Hart being the executor. He joined with William Morden's son Charles as publisher of Sheringham's work of $\mathbf{1 6 8 2 .}$

HART or HURT (T.), bookseller in Coventry, r 702-20. Publisher of sermons by E. Davies, n.d., and J. Kimberley, I702. [B.M. 225. g. II (4, 14).] In I 7I I he published the Rev. J. Davies's Book for the Aged. [T.C. III. 667.]

HART (WILLIAM), bookseller in Oxford, r686. [Madan, p. $3^{\text {I.] }}$

HART or HURT (WILIIAM), printer in London, Great Carter Lane, near Doctor's Commons, I 11 . Printer of The Flying Post, r711. In March 1712-13 he printed The British Ambassadress's Speech to the French King, "the cursedest libel that ever was seen" on Queen Anne, and was condemned to pillory and fine. [Swift, Journal to Stella, March 21st, I712-13.]

HARTFORD, see Harford.

HARTLEY ( ), bookbinder in London, 1668. The searchers of the Stationer's Company took from "Hartley a binder" 35 Psalters, about the year 1668. [Records of Stat. Co.]

HARTLEY (JOHN), bookseller in London, (I) (a) over against Gray's Inn Gate in Holborn, (b) next Middle Row, Holborn, (c) next door to the King's Head Tavern, Holborn ; (2) Fleet Street, over against St. Dunstan's Church. 1697-1709. On May 1st, 1697, he advertised in The Post Boy J. Gailliard's Blasphemous Socinian Heresie, and Hazlitt records under the same year Regular and Irregular Thoughts on Poets and Orators. [IV. 104.] Hartley was 
the publisher of many important books, including Sacheverell's Account of the Isle of Man, 1698, Sir T. Bodley's Reliquiae Bodleianae, 1703, Bentley's Dissertation upon the Epistles of Phalaris, and an Universal ... Dictionary, in 2 vols., I709. In 1699 Hartley compiled a catalogue of books in all faculties and languages, from the catalogue of the Bodleian and many other libraries. This catalogue was arranged under subjects, and the seventh part consisted wholly of English books. Hartley reissued this catalogue in 1 701, with an index of authors. [B.M. 6rg. b. 4.] His last entry in the Term Catalogues was in 1709. [T.C. III.629.] He moved to Fleet Street about I707, when Robert, probably his son, succeeded him in Holborn.

HARTLEY (ROBERT), bookseller in London, over against Gray's Inn, Holborn, 1 707-9. Probably a son of John Hartley. In I 707 he published The Admirable and Indefatigable Adventures of the Nine Pious Pilgrims. [Esdaile, p. 287.] In 1709 he sold the Nomenclatura Anglo-Latina. [T.C. III. 627.]

HARTLEY (THOMAS), bookseller in London, Black Boy, behind St. Alban's Church in Wood Street, $167 \mathrm{r}$. Published an edition of The King's Psalter in I671. [Haz. IV. 126.]

HARTLEY (WILLIAM), bookseller in London, c. 1703. Dunton [p. 208] has the following description: "He deals much, and has his shop well furnished with ancient books that are very valuable. He prints many excellent translations, and has a good acquaintance among learned men, amongst whom I would reckon the ingenious Mr. Abel Boyer." He did not use the Term Catalogues.

HARTSHORN ( ), bookseller in Leicestershire, I 714. Subscribed to Walker's Sufferings of the Clergy.

HASBERT (SAMUEL), printer in Norwich, Magdalen Street, 1706-18. In partnership, which was terminated in 1718 , with Crossgrove (q.v.). [Gent, p. 77.]

HATLEY (H.), stationer in London, Three Flower de Luces, St. Paul's Churchyard, 1682. In the Term Catalogue for Trin. 1682, appeared the notice of John Ayres's Practical Penman, and a ciphering book, both to be had of this stationer and others. [T.C. I. 497.] This is no doubt the Major Hatley, noticed by Dunton [p. 255] as " well skilled in Military Discipline, and from being a Captain, is advanced to a Major ... I dealt with this Military stationer for six ycars." 
HAWES (WILIIAM), bookseller in London, (x) Rose, Ludgate Street; (2) 'Golden Buck, Fleet Street, over against St. Dunstan's Church ; (3) Bible and Rose, Ludgate Street ; (4) Rose and Crown, next the Dog Tavern on Ludgate Hill. I698-I 709. Publisher of cheap divinity books. Dunton [p. 208] "describes him as "just in Trade, and knows his business very well". In ryo5 he moved to the Golden Buck in Fleet Street, being succeeded at the Rose by J. Bowyer. In I 706 he returned to Ludgate Street, and by I 709 had moved to his last address.

HAWKINS (E.), bookseller in London, near Fleet Bridge, 169I-r702. In I69r he published a rhyming pamphlet entitled $A$ Last Search after Claret in Southwark, and its answer $A$ Search after Wit. [T.C. II. 38r.] Another tract of the same kind, called Bacchanalian Sessions, by Richard Ames, came from the same publisher in 1693 [T.C. II. 454], and in 1702 a broadside elegy on the death of William III. [B.M. C. 20. f. 2 (223).]

HAWKINS (M.), bookseller in London, Angel in St. Paul's Churchyard, r7o9. Publisher of an edition of Hudibras. [T.C. III. 653.]

HAWKINS (s.), and (тHоMAS), see Howkins.

HAYES (JOHN), printer to the University of Cambridge, 1669-r705. Appointed by Grace of October I4th, 1669. He succeeded John Field who died the previous year. His appointment was made under new conditions, the University by Grace of July 7 th, $\mathbf{r} 669$ deciding to lease the printing to him for froo a year. He died November 28th, 1705 , aged $7 \mathrm{r}$. During his period of office he printed many works of importance : several editions of the Bible and Prayer Book; Crashaw's Poemata et Epigrammata, 1670; Ray's Proverbs, 1670, 1678; John Smith's Discourses, 1673; Barclay's Argenis, 1673; J. Lightfoot's Horae Hebraicae et Talmudicae, 1674; Joshua Barnes's Edward III, 1688, and Euripides, 1694 ; the Cambridge Concordance to the Holy Bible, r695, \&c. [Bowes, Cambridge University Printers, 308, and Catalogue of Cambridge Books.]

HAYES (WALTER), bookseller and mathematical instrument maker, in London, Cross Daggers in Moorfields, r673-85. Publisher of Leybourn's Line of Proportion or Numbers, I673. [Haz. I. 257.] He was one of those who sold W. Walgrave's Decimal Arithmetick, advertised in the Term Catalogue for Hil. 1678. [T.C. 1. 30r.] In 168 $_{5}$ he published Dr. John Twysden's Use of the general Planisphere. [T.C. II. I47.] 
HAYHURST (ROBIN), printer in London, 1689, Little Britain [c. 1700]. Dunton has two references [pp. 247, 293] to Hayhurst. In speaking of William Bonny the printer, he says that Bonny would have "printed treble to what he did, had not Robin Hayhurst lived so near him ", and a little further on in a list of persons, whom he had omitted to describe elsewhere, he refers to "Robin Hayhurst, who lived by printing of false news". In 1689 Hayhurst issued a poetical broadside, commemorating the coronation of William and Mary, printed for him by A. M. [B.M. C. 20. f. 2 (180).]

HAZARD (JOSEPH), bookseller in London, Bible in Stationers' Court near Ludgate, 1716. There is a copy of his advertisement in the Bagford Collection. [Harl. 596r (3r4).]

HEAD (GODFREY), letter-founder of London, 1686. Defendant in a plea of trespass brought against him by Charles Fowle. [Hilary 2-3 James II, C.P.R. $3052 \mathrm{~m} .86$.

HEAD (RICHARD), see Dictonary, 164I-67.

HEATHCOTE (J.), bookseller in London, Baldwin's Gardens, 1680-1725. Published An Account of the Proceedings at Guildhall ... for the election of a Sheriff, I682. [Haz. II. 364.] He was afterwards the publisher of a Halfpenny Post, and was described by Negus as a "High Flyer".

HEATHCOTE (WILLIAM), printer in London, 1718. Committed to Newgate for printing treasonable libels. [The Weekly Packet, February 8th-15th, 1718.]

HELDER (THOMAS), see Dictionary, 1641-67.

HELME (w.), printer in Dublin, 1721-4. He printed in 1723 Warren's Abridgement of all the Irish Statutes of the 4th session of the then Parliament, and in 1724 Downes's Lives of the Compilers of the Liturgy.

HELMES (J.), bookseller in London, King's Head, Westminster Hall, I 707-I I. His stall had been occupied till $\mathrm{I} 700$ by William Hensman $(q . v$.). In 1707 he was one of the booksellers selling Sir Hans Sloane's Voyage to ... Madera, soc. [T.C. III. 569.] Sale catalogues of the library of William Popple, March I 7 II, were to be had at his stall.

HELSHAM (SAMUEL), printer and bookseller in Dublin, $168 \mathrm{I}-9$. This printer first appears in $168 \mathrm{r}$, when he printed Archbishop Marsh's Institutiones 
Logicae. He joined Andrew Crook in 1685 and they worked in partnership for three or four years and became assigns of Benjamin Tooke, the King's printer, but Helsham's name appears no more after 1689. In the Term Catalogue for Hil. I686, his name occurs amongst the booksellers inviting subscriptions for a folio edition of Ray's History of Plants. [T.C. II. I62.]

HENCHMAN, see Hensman.

HENDERSON (ALEXANDER), bookseller in Edinburgh, in the upper end of the Lucken Booths, 1692-1709. Amongst the books in which his name appears, are the following : The Pastor and the Prelate, by D. Calderwood, I692; Two Sermons by William Veitch, 1693; Sir T. Craig's Scotland's Soveraignty asserted, 1695; and in 1699 a sermon by Andrew Cant. In I 708-9 The Scots Postman was sold at his shop. [Aldis, p. II4.]

HENSMAN, HENCHMAN, or HINCHMAN (WILLIAM), bookseller in London, King's Head, Westminster Hall, 1671-r700. Succeeded James Collins at this stall. Publisher of general literature. His first entry in the Term Catalogues was, in Hil. 167r, Francis Quarles's Boanerges and Barnabas. [T.C. I. 68.] In 1680 he was agent for a Fire Insurance Office. [True News, May 5th-8th, 1680.] In $168 \mathrm{I}$ in company with Simon Neal he published a newssheet called Mercurius Veridicus (No. I, January $7^{\text {th }}$ ). His name appears for the last time in the Term Catalogues in Easter I 700. [T.C. III. r86.] His stall was occupied some years later by J. Helmes (q.v.).

HEPBURN (ANDREW), printer in Glasgow, I689. Probably a fictitious name. It is found in the imprint to Late proceedings and votes of the Parliament, I689. [Aldis, pp. 77, II4.]

HEPTINSTALL (JOHN), printer in London, I67I-I712. Dunton spoke of him [p. 248] as a " modest humble man, and very ingenious in his calling", and added that he made " the best ink for printers of any man in London". He printed for Edward Giles the Norwich bookseller. He was also a printer of music books, and several of Purcell's works came from his press. In I $7 \mathbf{1} 3$ he contributed four guineas to the Bowyer relief fund. [Nichols, Lit. Anecd. I. 62.]

HERRINGMAN (HENRY), see Dictionary, 1641-67.

HERRINGMAN (JOHN), bookseller in London, next to the Fountain Tavern in the Strand, 1676. Father (?) of the "kinsman" to whom Henry Herringman 
bequeathed all his copies and parts of copies on his attaining the age of twenty-three. He was the publisher of J. Sudbury's Sermon preached before the King . . May 7, 1676.

HEWSON (R.), bookseller in London, Crown in Cornhill, r689. Chiefly memorable as the publisher of Bartholomew de las Casas' Popery truly displayed (not in the British Museum). [T.C. II. 273.]

HEYRICK (R.), bookseller in London, 1686. Probably a relative of (or possibly only a mistake for) S. Heyrick. The name is found in the imprint to Stratagems of War, by M. D. A. B. D., I686. [Haz. II. 238.]

HEYRICK (SAMUEL), bookseller in London, Gray's Inn Gate, Holborn, r6621700. See Dictionary, 1641-67. Elected senior Warden of the Company of Stationers in 1696-7, and again in 1699-1700. From 1684 Richard Sare (q.v.) was with him at Gray's Inn Gate, but each published many books independently.

HICKMAN (SPENCER), bookseller in London, Rose in St. Paul's Churchyard, 1670-2. Publisher to the Royal Society. A list of books on sale by him in 167x fills twenty-four pages at the end of John Burbury's Relation of a Journey. [B.M. 978. b. I.] His last entry in the Term Catalogues was in Hil. 1672. [T.C. I. 96.]

HICKS (FRANCIS), bookseller in Cambridge, 1682-99. His name appears on some seven books of I682-99. [T.C. I. 495 ; II. 336, 559 ; III. 27, 55 ; Haz. II. 281, 672.]

HICKS (M.), bookseller in Cambridge, 1699. Probably widow of the preceding. Published The Sceptical Muse, r699. [T.C. III. I4I.]

HIDE (MICHAEL), bookseller in Exeter, 1663-98. He sold Robert Vilvain's Theoremata Theologica, printed for the author, 1663. [Dredge.] On July Ioth, I688 an advertisement of a sale of books at the New Inn, Exeter, appeared in Public Occurrences, and catalogues were to be had of Michael Hide. In 1691 he was agent for the proposals for printing Synodicon in Gallia Reformata. [T.C. Ir. 388.] Hide probably died in or before 1698 , for his stock was advertised for sale in the Flying Post of November roth-12th in that year.

HILDYARD or HILLIARD (FRANCIS), bookseller in York, Bible in Stonegate, r680(?)-1731. His name is first found in George Meriton's Praise of 
Yorkshire Ale, printed for him by J. White in 1685 (3rd ed. 1697). In this year he printed a sale catalogue ; so that he must have been in business for some years already. In 1695 he was associated with the Churchills in publishing M. Micklethwait's version of Olivaires of Castile. [Haz. III. I59; I. 3 ro.] Ten years later Dunton [p. 237] could speak of him as " the topping man in that city". In the Post Boy of February 2oth, I I I I he advertised for subscriptions to a Corpus omnium veterum Potarum Latinorum. He was succeeded at his death in $173 \mathrm{I}$ by his son John Hildyard, who died in 1757 and was succeeded by Hon[oria ?] Hildyard and Caesar Ward. [Davies, passim; Timperley, p. 841 ; Evening Advertiser, April 7th-gth, I 757.]

HILL (JOHN), bookseller in London, (r) Post Office, Fleet Street ; (2) Black Lion, Fleet Street. r677-8. Published The Clerk's Manual, I677 [T.C. I. 290], and in 1678 Part IV, Book iii. of Theophilus Gale's Court of the Gentiles. [T.C. I. 322.]

HILLAR, see Hillier.

HILLIARD, see HILDYARD.

HILLIER or HILLAR (NATHANIEL), printer and bookseller in London, Prince's Arms, Leadenhall Street, over against St. Mary Axe, r 700-7. Referred to by Dunton [p. 292] as "independent Hiller". Publisher of Cotton Mather's More Wonders of the Invisible World, r700. [T.C. III. 217.] Hazlitt records Youth's Tragedy, $A$ Poem, by T. S. " London, Printed and sold by Nath. Hillier, I707." [Haz. 1. 370.]

HILLS (GILHAM), printer (?) in London, r737. According to Nichols [Lit. Anecd. vIII. r68] Gilham Hills, printer, was son of Henry Hills junior, and died in 1737 . In this case he must be distinguished from his namesake and uncle, son of Henry Hills senior (q.v.). The date of his death makes Nichols's statement probable.

HILLS (HENRY), sen., printer in London, r64I-89. See Dictionary, 1641-67. As considerable confusion and error is found in all the accounts of the later life of this printer, the D.N.B. for example stating that he died in $17 \mathrm{I} 3$, the following additional information about him is now recorded. About the year 1670 Henry Hills, sen., became one of the assigns of John Bill the Second and Christopher Barker the Third in the King's Printing House in Blackfriars. He afterwards became a Roman Catholic, with the result that on December 12 th, I688, a mob attacked the printing house in Black- 
friars, " spoiled his Formes, Letters, \&c., and burnt 200 or 300 reams of paper printed and unprinted." [English Currant, December 12th-14th, r688.] Hills fled for his life to St: Omer, where he died shortly afterwards, his will being proved on January 21st, 1689. Probate was granted to Gilham Hills his son by his first wife; the executors were Elizabeth Hills the widow and Adiell Mill, being one a recusant and the other a bankrupt. His children were Henry Hills jun., Gilham Hills, James Hills, and George Hills, the two latter by his second wife. He also had a son John, who was dead at the time of the making of the will, and a daughter Dorothy, married to a man named Edwin. [P.C.C. 6, Dyke.] Both his sons Henry and Gilham became printers and during his father's lifetime, Henry Hills jun. was so-called, in spite of which he has been confused with his father. One of them, presumably the father, was junior warden of the Company of Stationers in 1682-4, and Master in 1687-9.

HILLS (HENRY), jun., printer in London, $(a)$ on the Ditch-side, $(b)$ near the water-side, in Blackfriars, $1680($ ? $)-1713$. The son of Henry Hills, senior, the King's Printer. His initials "H. H. jun." are found on an undated edition of Julius Caesar, printed about 1680 , and have been taken to stand for Henry Herringman, jun., but Henry Herringman the publisher left no son. (See Dictionary, 164I-67.) In I683 Henry Hills, jun., printed for W. Davis An Elegy upon ... the Lord Capel [B.M. C. 20. f. 2 (157)], and in the same year, The Presentment of the Grand Jury of Bristol [Bodl.]. On the death of his father Henry Hills, jun., succeeded to his father's share in the King's Printing House, and dropped the word " junior", which has been the cause of much confusion. He became notorious for pirating every good poem or sermon that was published, "a circumstance", says Nichols, "which led to the direction in the Act of 8 Anne that fine-paper copies should be presented to the public libraries". [Nichols, Lit. Anecd. virr. 168.] A large number of these pirated duodecimos appeared in 1709 and 1710 . In a poem on Lintot's Miscellanies, ascribed to Dr. King, occur the following lines,

While neat old Elzevir is reckoned better

Than Pirate Hill's brown Sheets and scurvy Letter.

Henry Hills, jun., died in 1713 , and an advertisement appeared in the Evening Post of November I2th to the effect that his stock, "consisting of the most eminent Sermons, Poems, Plays, \&c., is now to be disposed of, 
at the Blue Anchor, Paternoster Row. N.B. There can never be any of the same, or any in the like manner, reprinted after these are gone, there being an Act of Parliament to the contrary". Nichols states that Gilham Hills the printer was his son. [VIII. 168.] Many of his cheap reprints, 1708-10, were reissued in two vols. by $\mathrm{T}$. Warner, in $17 \mathrm{I} 7$, as $A$ Collection of the Best English Poetry, by several hands. [B.M. I1603. d. 14, I5.]

HILLS (JoHN), bookseller in London, Exchange Alley in Cornhill, 1676-90. In Mich. 1676 he advertised a set of grammatical cards [T.C. 1. 256], and in the following year Tables for all Merchants and Shopkeepers. [T.C. I. 275.] In r69o he sold a set of Chronological Tables. [T.C. II. $3^{\mathrm{I}} 3$.]

HILTON (ROBERT), bookseller at Manchester and Ashbourne, 1678-88. Robert Hilton, bookseller, married in 1678 , took the oath of allegiance to Charles II in the following year, had a son baptized in I68I. [R. W. Procter, Memorials of Manchester Streets, p. 182.] Apparently moved to Ashbourne, where he published in 1688 The Gospel-Call in Metre. [T.C. II. 215.]

HINCH (s.), printer in London, 1684. During the Frost Fair held on the Thames in the winter of $168 \frac{3}{4}$, four printers, one of whom was the above, printed a broadside in verse, On the Royal Martyr, King Charles 1., ' Printed on the Frozen Thames, January the 3oth, 1683. By the Loyal Young Printers, viz. G. and A. Melbourn, S. Hinch, and J. Mason.' [Haz. II. 681.]

HINCHMAN, see Hensman.

HINDMARSH (H.), bookseller in London, Golden Ball, Cornhill, over against the Royal Exchange, 1696-8. Succeeded Joseph Hindmarsh. Publisher of anti-Quaker literature. [T.C.II. 599.] In 1698 he was one of the publishers of Collier's Short view of the Immorality and profaneness of the English Stage.

HINDMARSH (JOSEPH), bookseller in London, bookseller to His Royal Highness, (I) Black Bull in Cornhill, over against the Royal Exchange ; (2) Golden Ball in Cornhill. 1678-96. His first entry in the Term Catalogues was Loyaliy and Peace, two sermons by the Rev. Sam. Rolls, Chaplain to the King, in 1678. [T.C. 1. 329.] At the Sessions at the Old Bailey on April I $3^{\text {th, }}$ 1680, Hindmarsh was accused of publishing The Presbyterians' Paternoster and Ten Commandments. In the same year he issued Oldham's Satyrs upon the Jesuits. [T.C. 1. 419.] In 1682 he publishod Buckingham's Essay upon 
Poetry, D'Urfey's New Collection of Songs and Poems, Sir R. Talbor's English Remedy, a translation from Cicero's De Natura deorum, and the Rev. A. Elliot's Modest Vindication of Titus Oates. [T.C. I. 508-9.] In 1684 he published a poetical broadside entitled $A$ Letter to Ferguson. [B.M. 1872. a. I (4I).] Dr. Richard Midgeley conveyed to him and others in 1693 his copyright in the eight volumes of the Turkish Spy. [Nichols, Lit. Anecd. 1. 413.] In 1685 he moved to the Golden Ball in Cornhill and is last heard of in Hil. 1695. [T.C. II. 567.] He was succeeded by H. Hindmarsh.

HINE (R.), bookseller in London, near the Royal Exchange, r 7or. Published $A$ Walk to Sinithfield, or A True Description of the Humours of Bartholonew Fair, 1701. [Haz. H. 31.]

HINTON (THOMAS), printer in Cirencester, in Pye Corner, 1718-24. The first Gloucestershire printer. Probably began printing in 1718 . Hazlitt [H. 230$]$ records The most strangest and unparalleled Account ... to be justified by several persons living in Campden in Gloucestershire, n. d. In I7I9 he began The Cirencester Post, or Gloucestershire Mercury (no. I8, March 16th, I 719) [B.M. P.P. 3424 c.], but the earliest copy recorded by Messrs. Hyett and Bazeley [II. 162] is that of July 25 th, 1720 . They say, however, that Hinton must have established his press two or three years before Raikes came to Gloucester. This paper was published weekly, and the civil year was used in dating it, so no. I must have appeared about the last week of October I $7 \mathbf{1 8}$. His son Thomas was a bookseller at the Talbot in Tetbury in 1720 . [Hyett and Bazeley, 1. 20.]

HIRST (JOHN), printer and bookseller at Leeds, over against Kirkgate-End, I718 (?)-30. He printed and sold The Leeds Mercury (vol. ii, no. 49, April 5th-12th, 1720, vol. I, no. I probably in 1718); and was still at work at Leeds in 1730. [Allnutt, p. 301.]

HISLOP (ARCHIBALD), bookseller and printer in Edinburgh, in the Parliament Yard at the sign of the Bible, I670-8. Watson [p. II] says, "Archbald Hyslop; a bookseller, set up, taking in with him William Carron, a very excellent workman, who advis'd Mr. Hyslop to bring new materials from Holland. They printed Thomas à Kempis very neatly, and some other smali books; to which is prefix'd sometimes the name of the one, and sometimes the name of the other". No book is known bearing Hislop's 
name as printer, but an edition of The Psalms in meeter was printed for him in 1670 by A. Anderson, and he was one of those who sold James Kirkwood's Rhetoricae Compendium in 1678 . There were two bookbinders of this name in Edinburgh. The wi:l of the earlier was registered on July Ioth, 1679, and he may have been identical with the bookseller. The other bookbinder died in 1697 , his will being registered on June 8th. According to Watson [p. 14] this printing house passed into the hands of John Cairns. [Aldis, pp. II4-I5.]

HIVE (T.), bookseller in London, Nag's Head, Jewen Street, I695 (?). The second edition of John Taylor the Water Poet's Verbum Sempiternum, and ed., n.d. (Imprimatur dated October 6th, 1693), has the above imprint [Haz. H. 604], but Hive is otherwise unknown.

HODGES (JOHN), bookseller in Derby, 1716. One of the booksellers named in the imprint to Henry Cantrell's Royal Martyr a True Christian, I716.

HODGKIN (THONAS), printer and bookseiler in London, next door to the Dolphin Inn, West Smithfield, I677-I7I3. This printer is first met with in the proceedings taken by the House of Lords in February $1676-7$ to discover the printers and vendors of certain libellous pamphlets. Hodgkin was called before the Committee as a witness in regard to the tract entitled Some Considerations upon the question whether the Parliament is dissolved by its Prorogation for fifteen months, but all he could say was that he had been unable to find out who printed it. He was probably only a workman at that time. [Hist. MSS. Comm., gth Report, App., pp. 69-78.] In 1686 his name appears as a bookseller, when he sold the Thirty-six Sermons of the Bishop of Lincoln. [T.C.II. I9r.] In 1688 he is recorded as the printer of an edition of Suetonius. [T.C. II. 230.] He was also the printer in 1690 of the seventeenth edition of Chamberlayne's Angliae Notitia, and continued in business until after 1713, when he contributed to the Bowyer relief fund.

HODGKINSON (s.), printer in Derby, near St. Warburg's Church, 1719-27(?). Printer of The Derby Postman (no. 8, January 19th, 1720). The title was changed in I726 to The British Spy, or Derby Postman, and a new series

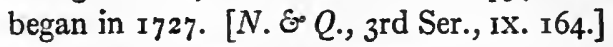

HODGSON (JOSEPH), bookseller in Chester, I712. Only known as the publisher of 'T. Leche's Danger of Bad Principles, I7I2. 
HODGSON (THOMAS), books'ller in London, over against Gray's Inn Gate in Holborn, 1700-2. Noticed by Dunton [p. 215] as a successful bookseller. Amongst his publications was Dr. Sacheverell's Account of the Isle of Man, 1702. [Haz. III. 218.] His name does not appear in the Term Catalogues.

HOLFORD (JOHN), bookseller in London, (a) Pall-Mall, over against St. Alban's Street ; $(b)$ Crown in Pall Mall. 1681-9. Published The Present State of the Protestants in France, 1681. [Haz. IV. 40.] In 1684 he advertised in The London Gazette of November 24th-27th an edition of Lucian. In 1685 he published Edward Eccleston's opera The Calaclysm. [T.C. II. II4.] His last entry was in 1689 . [T.C. II. 275.] He was probably a relative of S. Holford, who published from the same address at the same time. His two addresses probably describe the same house.

HOLFORD (SAMUEL), bookseller in London, Crown in the Pall Mall, I685-8. Began to publish about 1685 with Dr. Nehemiah Grew's Musaum Regalis Societatis [T.C. II. 150], and John Holford appears to have been in partnership with him. He sold books on all subjects, and distributed the sale catalogue of Lord Maitland in I689. He is last heard of in I694, when with J. Taylor of Paternoster Row he published The Swordsman's Vade Mecum. [T.C. I1. 493.]

HOLLAND (ABRAHAM), bookseller in Manchester, Hanging Ditch, I673-90. Born at Crumpsall in March 1640 . In 1673 he married, and he appears in the poll book of I6go. [R. W. Proctor, Memorials of Manchester Streets, p. I82.] HOLLAND (J.), bookseller in Chester, I7I4. Published A General View of Christian Religion, by L. Fogg, I7I4. [B.M. 44IO. f. I7.]

HOLLAND (JAMES), bookseller in London, Bible and Ball in St. Paul's Churchyard, I705-II. Publisher of sermons; he made his first appearance in the Term Catalogues in Trin. 1705. [T.C. III. 463.] He was also the publisher of Nahum Tate's The Triumph, 1705.

HOLMAN (c.), stationer (?) in London, Hare in Southwark, 1692. Dealer in William Jordan's copy-books. [T.C. II. 404.]

HOLT ( ), printer in London, St. John's Lane, I 7 I2 (?)-24 (?). Possibly a son of R. Holt, printer. In 1713 he contributed to the Bowyer Relief Fund, and in Negus's List of Printers in $\mathbf{1 7 2 4}$ he is mentioned among those "well affected to King George ". [Timperley, p. 63r.] 
HOLT (ELIZABETH), printer in London, 1689-90. In partnership with W. Horton. In 1689 she printed W. Ravenhill's Short Account of the Company of Grocers, and in the same year, in partnership with W. Horton, Gazophylacium Anglicanum, Containing a derivation of English words, for Randall Taylor. In 1690 she printed for Thomas Basset, Locke's Essay concerning Human Understanding. She is probably the " widow Holt" who was ordered to lay down the trade of printing, see Holt (R.). Dunton's reference [p. 292] to "virgin Holt" may be to a daughter.

HOLT (R.), printer in London, $1671-88$. In $1671-3$ he and Evan Tyler, sometimes as R. H. and E.T., printed in partnership ; in 1672 their names appear on Thomas Philipott's Brief Historical Discourse of Heraldry. [B.M. 605. b. 7.] In 1686-8 he was in partnership with E. Horton; they printed Sir Roger Manley's Commentaria de Rebellione Anglicana, as well as $A$ Relation of the Conference between William Laud . . . and Mr. Fisher the Jesuit . . . which they printed for J. Mitchell and R. Hughes. [T.C. II. I7I.] E. Horton apparently died soon after, for Holt was in partnership with W. Horton in I688 for the printing of Florio's Italian and English Dictionary, and Torriano's Vocabolario. [Haz. II. 600.] Holt is believed to have died in I688, as an order was made in that year by the Company of Stationers that the widow Holt [see Holt (Elizabeth)] and others should lay down the trade of printing in obedience to the Act of Parliament. [Records of Stat. Co.]

HOMER (SAMUEL), bookseller in London, St. Paul, Little Britain, 167r. Pub lisher of a funeral sermon by W. Yole on Mrs. Martha Walmsly in 1671 ; [T.C. I. 85.]

HOOKE (J.), bookseller in London, Flower de Luce, over against St. Dunstan's Church, in Fleet Street, I718-25. Publisher of the Rev. John Lyly's False Friend and Inconstant Mistress, I7I8. [Haz. 1. 270.] In 1722 he was one of the publishers of a novel called The Adventures of the Prince of Clermont, and was still publishing in 1725 . [Esdaile, pp. 189, 191.]

HOOKE (NATHANIEL), bookseller in London, King's Arms, Little Britain, 1672. Publisher of Richard Cumberland's De Legibus Naturae, 1672 [T.C. I. 99], also of vol. iv of M. Poole's Synopsis [T.C. I. 114], and Dr. Francis Glesson's De Natura Substantiae Energetica. [T.C. 1. 120.] 
HOOKER (JOSEPH), bookseller (?) in Exeter, r688. Advertised catalogues of a book sale at Exeter in Public Occurrences, July Ioth, 1688. Not mentioned by Dredge.

HOOLE (SAMUEL), stationer in London, Crown, next Ludgate Church, r6891712. Received subscriptions for Jean de Launoy's Epistolae Omnes, r689. Dunton [pp. 255, 405] says that he had "traded with him for many years", and praises his charitable disposition. Accordingly he was one of the largest subscribers to the Bowyer Relief Fund in $17 \mathrm{I} 3$. [Timperley, p. 600.]

HOPE (E.), bookseller in London, North Entrance into the Royal Exchange, I680 (?)-84. Succeeded to William Hope between 1672 and 1680 . He advertised Bateman's Scurvy Grass in Currant Intelligence, April Ioth, I680, and in $\mathbf{r} 684$ he published the $4^{\text {th }}$ ed. of C. Sutton's Godly Meditations. [T.C. II. 64.]

HOPE (WILliam), bookseller in London, ( $\mathrm{I}$ ) under St. Martin's Outwich, Bishopsgate; (2) at the North Entrance to the Royal Exchange. 1670-2. See Dictionary, 1641-67. Still in business in 1672. Succeeded by E. Hope.

HOPPER (GEORGE), printer in London, 1683. Mentioned in the will of Robert Pawlett alias Pawley, who died in 1683, as one of his overseers. [P.C.C. 97, Drax.] He may have been only a working printer and not a master.

HORNE (ROBERT). See Dictionary, 1641-67. Still at work in r686. [T.C. II. 162.] Succeeded by Thomas Horne.

HORNE (THOMAS), bookseller in London, South Entrance to the Royal Exchange, I686-17Ir. Successor to Robert Horne. Began as a divinity publisher in 1686. [T.C. II. I75.] In 1694 in company with C. Brome he published Select Novels from Cervantes, Petrarch, \&c. [T.C. II. 505 ; Esdaile, p. 32.] He was still publishing in 7 7rr. [T.C. III. 677.]

HORTON (E.), printer in London, $1671-88$. First met with in 1671 as the printer of a broadside entitled, Great Britain's Beauty, or London's Delight, by George Elliott, Gent. [B.M. C. 20. f. 2 (89).] Between 1679 and 1688, however, Horton was employed to print some notable editions of the classics, and these books may rank with the best work of that period. The first was a folio Herodotus in Greek and Latin, for which the type was cast by James Grover. This was followed by an edition in two folio volumes of 
the Works of Cicero in $168 \mathrm{r}$. From about 1686 he was in partnership with R. Holt $(g . v$.). Neither is mentioned in the list of printing houses of 1675 . Also about 1686 Horton levied an execution on Nathaniel Ponder for a debt, which was settled by Thomas Braddyll. He was succeeded by W. Horton between 1686 and I688.

HORTON (w.), printer in London, 1688 (?)-9o. By 1688 he succeeded E. Horton in the partnership with R. and E. Holt (q.v.); in 1690 Horton alone printed William Walker's English and Latin Dictionary. [Haz. III. 313.]

HOTHAM (MATTHEW), bookseller in London, Black Boy on London Bridge, 1704-25. Successor to John Back. Like all the London Bridge booksellers, he published all kinds of cheap and popular literature, which he circulated up and down the country by chapmen. Hotham died in 1725, and was buried in St. Magnus' Church.

HOW (JOB), printer in London, c. I700. Mentioned by Dunton [p. 250] as " honest Job". Where there is no christian name or address in the imprint it is difficult to distinguish him from John How (q.v.).

HOW or HOWE (JOHN), bookseller and printer in London, (1) Sweeting's Alley in Cornhill; (2) Seven Stars, at the South-West Corner of the Royal Exchange in Cornhill ; (3) Coach and Horses without Bishopsgate ; (4) Ram's Head Inn Yard in Fenchurch Street; (5) Seven Stars, Talbot Court, Gracechurch Street. 1680-I 709. He first appeared as publisher of a satirical news-sheet in the Protestant interest, entitled Catholic Intelligence (nos. I-5, March Ist-29th, I679-80) [B.M. Burney 8I], and in the same year sold E. Clark's Protestant Schoolmaster. [Haz. III. 43.] In $168_{3}$ he published, at the corner of the Royal Exchange in Cornhill, Catastrophe Mundi, or Merlin revived [T.C. II. 7 ; Haz. III. I60], and Rome rhymed to death, a collection of poems by Rochester and others. [Haz. I. 364.] In I684 his address appears as "the Coach and Horses without Bishops-gate" on a sheet, $A$ strange ... Relation of ...the ... Frost. [Haz. II. 238.] After this he is not heard of again till 1699, when he began a paper, The Weekly Comedy (no. 1, May roth). In the next three years he was actively printing numerous pieces for Edward Ward, including The London Spy, and Tutchin's Observator; he was settled in Fenchurch Street, but moved in I 702 to Talbot Court, where he is found in 1707 publishing with M. Hotham Pleasant Intrigues of an English Nobleman 
. . at Venice. [Haz. III. 254.] In I 709 he issued privately a pamphlet entitled Some Thoughts on the present state of Printing and Bookselling [B.M. Irgor. a. 2 (3)], in which he attacks various fellow-printers for piracy while vindicating himself. Dunton says of him [p. 220], " $\mathrm{He}$ was a bookseller for many years, and now follows the trade of printing. ... He is a true lover of his Queen and Country [i. e. a Whig].... He was a great sufferer in King James's reign, and has had the fate of being a traveller. ... He is now settled in Gracechurch Street; and, being a great Projector (as we see by the London Spy and the Observator, \&c.), is likely to increase apace." His sufferings and travels here spoken of, possibly due to his political party, account for the gap in our record of him. See How (Job).

HOWE (JOSEPH), bookseller in Nottingham, 1689. Sold locally an Assize sermon preached at Nottingham by W. Wilson (London, for Awnsham Churchill). [Creswell, p. 6.]

HOWELL (JOHN), bookseller at Oxford, 1686-99. In I686 John Howell published $A$ Collection of Prayers. [T.C. II. I64.] He was still in business in 1699. [T.C. III. I48.]

HOWELL (MARY), Oxford, r698. [Madan, p. 31.]

HOWKINS or HAWKINS (s.), bookseller in London, George Yard, Lombard Street, r694. Probably identical with a Mrs. Howkins who is frequently referred to at this time, and widow of Thomas Howkins. She dealt largely in patent medicines.

HOWKINS or HAWKINS (THOMAS), bookseller in London, George Yard, Lombard Street, 1684-94. Began as a publisher of mathematical books [T.C. II. 98], and also published books on writing and shorthand. His last entry was made in Easter 1693. [T.C. II. 459.] In I694 he was the publisher of The City Mercury [Burney Ir2 A], and in that year S. Howkins, probably his widow $(q . v$.$) , was in business at the same address.$

HOWLETT ( ), printer in London, Lincoln's Inn Fields, r724. Mentioned in Negus's List as a Roman Catholic printer.

HOYLE (SAMUEL), stationer of London, 1685. Defendant in an action for debt brought successfully against him by. Humphrey Brooke, doctor of Medicine, in Trin. I James II. [C.P.R. I Jas. II, Roll 3038, m. 1666 verso.] 
HUBBALD (FRANK), bookseller in London, Duck Lane, c. r700. Noticed very briefly by Dunton [p. 229] as " having been unfortunate in business".

HUD (THOMAS), printer in Manchester, -r692. His burial is recorded in the parish register, September I Ith, I692. [R. W. Procter, Memorials of Manchester Streets, p. 182].

HUDDLESTON (GEORGE), bookseller in London, (I) Strand, near the Savoy ; (2) Black-a-Moors Head, Exeter Change. 1697-8. Publisher in 1697 of Le Comte's Memoires of China [T.C. III. 47], and in r698 of Evelyn's Gardener's Almanack, and Thomas Lyster's Blessings of Eighty-Eight.

HUDGEBUT (JOHN), stationer in London, (I) Harp and Hoboy in Chancery Lane near Fleet Street; (2) St. Paul's Churchyard; (3) Strand, (a) near Charing Cross, (b) near St. Martin's Lane. 1680-99. Dealt chiefly in music. In 1680 he published Youth's Delight, or nezo lessons for the Flageolet. [T.C. I. 432.] In Hil. I686 he was sued by Martha, Lady Atcheson, otherwise Atkins, for forfeiture of a bond. [C.P.R. $3055, \mathrm{~m}$. IgII r.] In this he is described as "Stationer" of St. Paul's Churchyard. He is last heard of in Hil. 1699, when he was in the Strand. [T.C. III. 109.]

HUGHES (R.), bookseller in London, Unicorn, over against the Queen's Head Tavern in Paternoster Row, I684. A Catholic bookseller. In Trin. I684 he advertised Critical Enquiries into the various editions of the Bible, by Father Simon of the Oratory, and in 1686 The Relation of the Conference between Laud and Fisher. [T.C. II. 82, r7r.] In 1692 Viscount Sidney directed the Postmaster-General to stop any letters directed to a Mr. Brett at Mr. Hughes in Paternoster Row and send them to him. [S.P.D., William and Mary, I692, p. I32.]

HUGHS ( ), bookseller of Beaumaris, r700. Sold school books and devotional works, which he bought wholesale from John Minshull, bookseller of Chester. [Library, and ser., IV. 378.]

HUME or HUMES (THOMAS), printer in Dublin, Copper Alley, r715-28. He did a great deal of printing, the principal work from his press being Crossley's Peerage of Ireland, I725. In I7I5 he was in partnership with A. Meres. In this year, or late in 1714 , and again in 1718 , Thomas Gent ( $q . v$.) worked for him in Copper Alley. He spelt his name with an "s" at first, but omitted the " $\mathrm{s}$ " in his later imprints. 
HUMPHERIES (RICHARD), bookseller in London, 1690. He published $A$ Sermon preached at Christ Church, London, Nov. the 2d. 169o, by David Jones. [B.M. 693. f. 19 (9).]

HUMPHREYS (J.), printer in London, Bartholomew Lane behind the Royal Exchange, 1697 (?)-1724. Two references to a Mr. Humpheries or Humfreys are found in the early part of the eighteenth century, one in the list of printers subscribing to the relief fund for William Bowyer in 1713 and the other in Negus's list of $\mathbf{1 7 2 4}$. In the latter Mr. Humpheries is described as being printer to the parish clerks. [Timperley, pp. 601,631-2.] He printed Sternhold and Hopkins for the Company in 1723. J. Humphrys printed for John Lawrence. He may also be identical with the J. H. who printed for J. Sprint in 1697 and for J. Robinson, J. Laurence, and J. Wyat in 1710.

HUNT (RICHARD), bookseller in London, (I) Lute in St. Paul's Churchyard ; (2) Repository in Gresham College. 1683-99. Humphrey Salter's Genteel Companion, 1683, was printed for Richard Hunt and Humphry Salter at the Lute in St. Paul's Churchyard. [Haz. IV. 91.] He may possibly be identical with the bookseller of the name who was at Hereford in $1685(q . v$.$) ;$ he does not appear again in London unless he be the Mr. Hunt who in 1693 was advertised as receiver of contributions to the Philosophical Transactions [T.C. II. 466], and in 1699 published Dr. Edward Tyson's Orang-Outang. [T.C. III. 137-8.]

HUNT (RICHARD), bookseller in Hereford, 1685 . Occurs in a list of booksellers and stationers who sold a patent medicine, given at the end of M. Bromfield's $A$ brief Discovery of the ... Scurvy. [N. E Q., I Ith Ser., XI. 45.] Possibly identical with the London bookseller of the name (q.v.).

HUNT (WILliam), stationer in London, St. Clement Danes, 1688. Defendant in an action for assault brought against him in the Court of Common Pleas. [C.P.R. Trin. 4 Jas. II, 3068, m. I76 verso.]

HUNTER ( ), printer in London, Jewin Street, 1 724. Mentioned in Negus's list as "well affected to King George".

HURLOCK (BENJAMIN), bookseller in London, (a) over against St. Magnus' Church, (b) on London Bridge. $1671-3$. Son or grandson of George Hurlock (q.v. in Dictionary, $164 \mathrm{I}-67$ ). He first appears in the Term Catalogues in 
I67I, but may have been at work much earlier ; his address is very near George Hurlock's, and both published books for sailors. Like other London Bridge booksellers he dealt mostly in schoolbooks and popular literature, often in assoeiation with Passenger. His most important publication was Military and Maritime Discipline, 1672, fol. Succeeded by his widow Elizabeth, q.v. [T.C. I. 73, 75, 76, 86, 88, III, I33, I34, I57.]

HURLOCK (ELIZABETH), bookseller in London, Rose at the West End of St. Paul's, 1673-5. Succeeded her husband Benjamin (q.v.), whose publications she advertised herself as selling in Mich. 1673 . In 1675 she published Thomas Miller's Compleat Modelist, a nautical book. [T.C. I. 157, 224.]

HURT, see Hart.

HUSBAND (RICHARD), stationer in London, Upper Shadwell, near the Market, I680. Sold a pack of cards illustrating the Popish Plot. [T.C. I. $3^{84}$.]

HUSSEY (CHRISTOPHER), bookseller and book auctioneer in London, Flower de luce, over against the Globe in Little Britain, 1678-1705. Began as a publisher of theological and mathematical books in 1678 . [T.C. I. 308.] He added book-auctions to his other business, and copies of his catalogues of $169 \mathrm{I}$ are in the British Museum, among them being that of the library of the Rev. Ph. Mason, January 4th, I69I-2. [B.M. 821. i. 9 (29).] Hussey's name appears in the Term Catalogues for the last time in Easter 1705. [T.C. III. 457.] Dunton [p. 286] speaks of him as " a downright honest man : and has always a large stock of books that are very scarce".

HUTCHINSON (HUGH), bookbinder and bookseller in Durham, I665-84. Probably son of William Hutchinson. [See Dictionary, 1641-67.] Bishop Cosin bought prayer-books and stationery of him in 1665 , and in 1670 had his armorial stamp impressed on the backs of all his books by Hutchinson. [Cosin Correspondence (Surtees Soc.), II. 268-9, 277-8, 284.] In I684 he published a sermon, The Compleat Conformist, by Archdeacon Grenville.

HUTCHINSON (LEONARD), stationer in London, St. Clement Danes, I687. Defendant in a suit for the recovery of $£ 60$ brought by Hugh Waters. [C.P.R. 3056, m. $5^{89}$ recto.]

HUTCHINSON (ROBERT), bookseller in Edinburgh, in the Head of the College Wind, 1696. Publisher of $A$ Satyr against Atheistical Deism by Mungo Craig, 1696. [Aldis, pp. 94, II5.] 
HYTHER (JONAS), bookseller in London, 1682 . Published in 1682 The Speech of ... Sir George Treby. [Haz. ח. 603.]

I. (м.), bookseller in London, I668. Hazlitt [Iv. 107] records The Duke of Buckingham's Speech in a late Conference, "London: Printed for M. I.", I668.

I. (N.), bookseller (?) in London, I680. Hazlitt [11. 583 ] records the following: An Account of a strange and prodigious Storm of Thunder, Lightning and Hail which happened in and about London on Tuesday the Eighteenth of this instant May... "London, Printed for N. I." I680, 40 , four leaves, but does not give any reference as to where it is to be found.

ILIVE (т.), printer in London, Aldersgate Street, 1724. Father of Jacob, Abraham, and Isaac Ilive, printers and letter founders. [Nichols, Lit. Anecd. I. 309.] Described by Negus as a "High Flyer".

ILLIDGE (SAMUEL), bookseller and book auctioneer in London, under Searle's Gate, Lincoln's Inn, New Square, 1716. Publisher of an edition of Brathwaite's Drunken Barnaby's Four Journeys in 1716 . He is also frequently mentioned in the newspapers of this period as holding book auctions.

INCE (E.), printer in Chester, I7I2-18. His only known imprint is that to Lawrence Fogg's Two Treatises, "Chester, Printed by E. Ince for R. Minshull in Bridge-Street," I712. [Allnutt, p. 299.] Gent [pp. 79, 83-4] says that his materials were bought from his executors in 1718 by one Cook.

INGHALL (WILLIAM), senior, bookbinder and bookseller in London, r68I-2. A broadside entitled The Character of a Tory bears the imprint: "London: Printed for William Inghall the Elder, Bookbinder, I681." [B.M. 816. m. 2 (16).] In the next year Inghall is found publishing The Irish Evidence.

INNYS (JoHN), see Innys (William).

INNYS (WILLIAM), bookseller in London, Prince's Arms, St. Paul's Churchyard, I7II-32. One of the leading booksellers in London in the first quarter of the eighteenth century. Succeeded B. Walford at this house. He made his first entry in the Term Catalogues in Easter I 7II. [T.C. III. 659.] In I 7I3 he subscribed five guineas to the Bowyer fund. He was afterwards joined by John Innys. In I 720 they issued an eight-page miscellaneous catalogue of books printed for them, including Clarendon's History of the Rebellion, 6 vols. ; Strype's Life of Archbishop Whitgift; and Le Neve's Monumenta 
Anglicana, 5 vols. In 1722 they were among the booksellers receiving subscriptions for a folio edition of Sir Henry Spelman's Works. [Nichols, Lit. Anecd., 1. 240.] They were also the publishers of many of Sir Isaac Newton's works. They were still at work in 1732 . [Roberts, Cambridge Press, p. 91.]

ISTED (J.), bookseller in London, Golden Ball against St. Dunstan's Church in Flect Street, $17 \mathrm{II}_{\mathrm{I}-25}$. He was advertising books in the news sheets of I7II, and was still publishing in 1725 when he issued the Miscellaneous Works of Dr. William Wagstaffe. [Nichols, Lit. Anecd. 1. 323.]

J. (s.), bookseller in London, I68r. Published in I68I two sheets, Mistris Celiers Lamentation for the loss of her Liberty, and A Dialogue between the Pope and the Devil, about Owen and Baxter. [Haz. II. 88, 174.]

J. (т.), printer in London, 1672-82. These initials, which may be those of Thomas James, are found in A New Help to Discourse, advertised in Hil. I672, as printed by T. J. for Peter Parker. [T.C. I. Ioo.] They recur in an edition of Hannah Woolley's Gentlewoman's Companion, 1682, "printed by T. J. for Edward Thomas ". [T.C. 1. 468.]

JACOB (IVILLIAM), bookseller in London, Black Swan near Bernards-Inn Gate, in Holborn, r670-80. Publisher of law-books and divinity. His first and last entries in the Term Catalogues were made in Easter 1670 and Trin. I680. [T.C. I. 39, 405.]

JACKSON (DAVID), bookseller in London, Bible and Three Crowns, Cheapside, near Mercer's Chapel, I 700-r6(?). Prof. Arber gives under his name in the Index to the Term Catalogues (vol. III) a reference to Parkhurst, whom he apparently succeeded at this address. In $\mathrm{I} 7 \mathrm{ro}$ he joined $\mathrm{N}$. Cliff $(q . v$.$) , and$ disappeared by 17 I6. Dunton [p. 293] has a reference to "candid "Jackson, who may or may not be the same person.

JACKSON (ЈонN), printer in York, Petergate, r707. Printed Catalogus pharmacorum, 1707. [Bodl. 1692. f. 23.]

JACKSON (N.), bookseller in London, in the Strand, 1693. Published The Country Miser, I693. [Haz. I. 148.]

JAFFRAY (GEORGE), printer in Edinburgh, (I) his Shop, at the Tron Church door ; (2) his Printing House within the Head of Peebles Wynd. 1696-ryro. "In 1696 George Jaffray set up a small printing-house ; it is now extinct." 
[Watson, p. I8.] Probably son of William (q.v.). No books have been noted bearing Jaffray's name before 1700 . [Aldis, p. I1 5.] He moved to his second house in 1702 or 1703 .

JAFFRAY (WILLIAM), stationer in Edinburgh, 1695. Will registered December 3oth, 1695; together with those of Margaret Walker, his relict, and Andrew Dunbar, her last husband. [Scottish Record Soc., Index to Edinburgh Testaments.] Probably father of George (q.v.).

JAKIN (ELLEN), stationer (?) in London, at the end of St. Paul's Alley, in St. Paul's Churchyard, 1680 . In 1680 a pack of cards commemorating the Popish Plot was advertised for sale by several dealers, amongst them the above; but she may not have been a stationer. [T.C. I. 384.]

JAMES (GEORGE), printer in London, Little Britain, I712 (?)-35. Author and printer of the Post Boy. Perhaps brother of John and Thomas James, typefounders, but see Reed, p. 212 note. The inter-relationship of the members of the James family engaged in the trade at this time is obscure. Negus in his list of 1724 describes George as a "High-Flyer". In 1724 he succeeded Alderman Barber as City printer. [Nichols, Lit. Anecd. I. 305.] He died in 1735 . His sister Elizabeth married Jacob Ilive the printer.

JAMES (THOMAS), bookseller and mathematical printer to the King, Printing Press, Mincing Lane, 1678-1711. Great-grandson of Thomas James, Keeper of the Bodleian Library. Unless he is to be identified with the T. J. (q.v.) who printed in 1672 , he began printing about 1678 . In 1680 he printed for T. Vile a Weekly Advertisement of Books. James died in $171 \mathrm{I}$ and his books, which he bequeathed to the public, were offered to and accepted by Sion College. In the College is a portrait of James. [Nichols, Lit. Anecd. I. 308.]

JAMES (THOMAS), type-founder in London, Bartholomew Close, 1710-36. Son of the Rev. John James, Vicar of Basingstoke. Served his apprenticeship with Robert Andrews and began business in Aldermanbury, whence he removed to Town Ditch and finally settled in Bartholomew Close. In x 710 he went to Holland, and after considerable trouble returned to England with 3,500 matrices of various founts of roman and italics, as well as sets of Greek and some black letter. William Ged's attempt to introduce stereotype printing failed owing largely to the action of James and his workmen. James's prosperity declined, and he died in 1736 , being succeeded 
by his son John, who had for some time managed the business. [Plomer, Short History of English Printing, 1915, p. 196; Reed, pp. 212-20.]

JANEWAY (ELIZABETH), bookseller in Chichester, 1697. Published $A$ Sermon preached ... at the Assizes held at Horsham ... March 23, 1696/7. By Peter Heald, A.M., Prebendary in the Cathedral Church at Chichester. [T.C. III. I2; Bodl. Sermons, 9.]

JANEWAY (RICHARD), senior, printer, bookseller, and bookbinder in London, (a) Queen's Head Alley, (b) Queen's Head Court, Paternoster Row, I68o98(?). Like Benjamin Harris, Langley Curtis, and Nathaniel Thompson, Janeway became notorious as a fanatically Protestant publisher in the time of the Popish Plot. His first entry in the Term Catalogues is in Easter 1680, and is characteristically entitled The Tryal, conviction and condemnation of Popery for High Treason. [T.C. I. 397-8.] In this year he sold also A Defence of True Protestants, spelling his name "Janua". [Title-page only in Bagford Coll., B.M., Harl. 5927 (504).] Janeway quarrelled with other publishers of Protestant news-sheets and retorted in The Impartial Protestant Mercury and The New Neres Book, both of which he started in 1681. In that year he also brought an action for assault against Thomas Newcombe, John Towse, Randal Taylor, and Michael Foster, all of them stationers. The details of the case are wanting; but it was probably connected with a search carried out on his premises by the Company of Stationers. [C.P.R. 2296, m. 256 r.] His name drops out of the Term Catalogues in Easter 1690. [T.C. III. 318.] $\mathrm{He}$ is probably the "honest Dick Janeway", the binder, described by Dunton [p. 257] apparently as dead in I703. He was probably alive in 1698 , as Richard Janeway junior (q.v.) describes himself as such in that year.

JANEWAY (RICHARD), junior, printer in London, Dogwell Court, Whitefriars, near Fleet Street, I698-1724. Probably son of Richard Janeway, senior. In 1698 The Lancashire Levite Rebuk'd was " printed by Richard Janeway, junr." $\mathrm{He}$ is probably the Janeway given in Negus's list of printers, 1724, as being in White Friars [Nichols, Lit. Anecd. I. 29I], and also the Janeway who printed occasionally for Dunton both before and after the latter's misfortunes, c. 1698 [p. 250]; Negus classes him among the printers "well affected to King George". [Nichols, Lit. Anecd. I. 29r.]

JANUA (RICHARD), see Janeway (Richard), senior. 
JAQUES (JOSEPH), bookseller at Midhurst in Sussex, 1712. Sold the Rev. Charles Bettesworth's Sermon preach'd at Petworth... September 3d, 1712, at a Confirmation, London, r712. [B.M. 4473. aaa. 46 (8).]

JAUNCY (т.), bookseller in London, Angel, without Temple Bar, 1720. He published two books in 1720: (r) A New Miscellany of Original Poems ... by the most Eminent Hands, viz. Mr. Prior, Mr. Pope, \&c. ; (2) Longus, The Pastoral Amours of Daphnis and Chloe . . . The second edition. [B.M. II335. a. 2.]

JAYE (ELIPHAL); bookseller in London, ( $\mathrm{I}$ ) Bible on the north side of the Royal Exchange, 169I ; (2) Golden Candlestick in Cheapside, 1702 ; (3) near Mercer's Chapel, 1703. 1691-1 703. Advertised Sir Edward Sadler's History of the Jacobites in Mich. r69x. [T.C. II. 38I.] He was the publisher of Edward Ward's Writings in 1702 [T.C. III. 300-I], and of two of the Rev. Richard

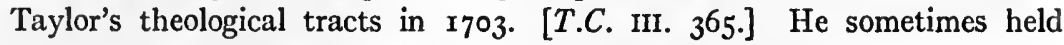
book auctions. [London Gazette, August gth-13th, 1694.]

JEFFERY (EDMUND), bookseller in Cambridge, 1699-1 729, living in the High Street two doors south of the Green Dragon, and later, from 1719 to 1729 , at what is now No. I Trinity Street, succeeding William Dickinson $(q . v$.$) ,$ and being succeeded by Wm. Thurlburn $(q . v$.$) . His publications were princi-$ pally sermons preached before the University. For John Leng's Sermon of I699 we learn that he and R. Clavel of the Peacock in St. Paul's Church-yard, London, paid $16 s$. per sheet for printing the 1,000 copies. [Bowes, Cambridge Books, note to no. 105.] A catalogue of some of his publications is to be found in J. Hughes's edition of Chrysostom de Sacerdotio, 17 ro.

JENKINSON (ROBERT), bookseller in London, 1690. Publisher of The Judgement of the Foreign Reformed Churches concerning . . . the Church of England, by N. S., I690. [B.M. T. I03० (16).]

JENOUR (MATTHEw), printer in London, near St. Sepulchre's Back-Gate in Gilt-Spur Street, 1707-25. Printed Povey's news-sheet, The General Remark on Trade, 1707. [Burney 140 .] In 1724 Jenour was printing The Flying Post and was numbered among those "well affected to King George" by Negus. Later he became "the first establisher of the Daily Advertiser", a paper which for many years stood at the head of all the diurnal publications. 
"Mr. Jenour was a man of very respectable character, and the Daily Advertiser enriched his family". [Nichols, Lit. Anecd., I. 290-1.]

JOHNSON (ANDREW), bookseller in Lichfield and Birmingham, I694 (?)-1 702 (?). Younger brother of Michael and Benjamin Johnson. Apprenticed to the latter at the age of 23 , in 1683 , for seven years, but never made free of the Company. He assisted his brother Michael at Lichfield, and on his own account published the first Birmingham book, $A$ Discourse concerning Churchcommunion [by A. Jeacocke], r jo2, probably at his brother's stall. [Birmingham Pub. Lib., Cat. of the Birmingham Collection, I918, p. 792.] He was a noted boxer, and instructed his nephew Samuel in that art. [Boswell, ed. Hill, V. 229, n. 2 ; A. L. Reade, in Times Lit. Suppl., January 6th, 192 I, p. I I.]

JOHNSON (BENJAMIN), bookseller in London, r683. Brother of Michael and Andrew Johnson. Born at Cubley in 1658-9; apprenticed to Richard Simpson two years later than Michael, in 1675 ; took up his freedom in 1683 , or two years before him. [A. L. Reade, in Times Lit. Suppl., January 6th, I92I, p. II.]

JOHNSON or JOHNSTON (EPHRAIM), bookseller in Manchester, I694-170I. He first appears as one of the publishers of an anonymous work entitled The doctrine of the Church of England concerning the Lord's Day, 1695. [T.C. II. 548.] He published several controversial pamphlets. [R. W. Procter, Memorials of Manchester Streets, p. 183.] In I 700 he sold large numbers of school books and devotional works, which he purchased of John Minshull, bookseller, of Chester. [Library, snd. Ser., IV. 373-83.] He appears to have left Manchester by I703, when Dunton says [p. 238]: "He was apprentice to Mr. Johnson of the same town, but his master thinking it necessary to be a knave, and as the consequence of it to walk off, so Mr. Clayton succeeds him, and has stepped into the whole business of that place, which is very considerable."

JOHNSON (J.), printer in London, I 700 (?). Printer of broadsides, amongst others $A$ full and true discovery of all the Robberies, of that famous English Pyrate Capt. James Kelly . . executed . . . r70o. [B.M. 515.1. 2 (786).]

JOHNSON (JAMES), bookseller in London, ( $\mathrm{I}$ ) Chancery Lane; (2) near Fleet Street. 1689-1703. Began business in 1689, when he sold Selden's Table Talk. [T.C. II. 293.] He also published (r) Reflections on the Petition 
and Apology for the Six Deprived Bishops, 1690 ; (2) Murther upon Murther, printed for J. Johnson, near Fleet Street, r703. His two addresses may describe the same house.

JOHNSON (MICHAEL), bookseller in Lichfield, Uttoxeter, Ashby-de-la-Zouche, and Birmingham, I685-173I. Celebrated as the father of Samuel Johnson. Born in 1656, son of William Johnson, yeoman, of Cubley, Derbyshire, who removed to Lichfield and died there in or soon after 1663 , and brother of Benjamin and Andrew Johnson (q.v.). In 1673 he was apprenticed to Richard Simpson, and in 1685 was made free of the Stationers' Company. The story in Boswell about his apprenticeship at Leek is apocryphal. He remembered in later years the great sale of Absalom and Achilophel. In 6887 he published a

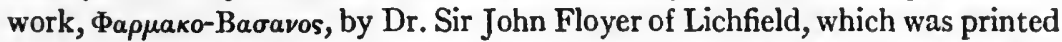
for him in London, " to be sold at his shops at Litchfield and Uttoxiter, in Staffordshire ; and Ashby-de-la-Zouch, in Leicestershire". At Birmingham, and probably at Uttoxeter and Ashby-de-la-Zouch also, he opened his shop on inarket days only. He was a man of much learning, but "wrong headed, positive, and afflicted with melancholy," like his greater son, whom he also resembled in stature; he was moreover unmethodical and kept no accounts. He embarked in the manufacture of parchment and lost his money, so that his later years were spent in increasing poverty. But he served many offices in the City of Lichfield, including Sheriff in 1709 and Senior Bailiff in 1725 . He married, in r 706, Sarah Ford, of a Worcestershire family, and had two sons, Samuel, and Nathanael ; the latter died in early manhood. He died in December I731. His two brothers, Benjamin and Andrew, were also booksellers. [Boswell, ed. G. Birkbeck Hill, I. 34-7; A. L. Reade, Johnsonian Gleanings, and letter, Times Lit. Suppl., January 6th, 1921, p. II.]

JOHNSON (R.), printer in London, r682. Identical with the following? Printed The Tory-Poets, $A$ Satyr, r682. [Haz. III. 249.]

JOHNSON (ROBERT), bookseller in London, Holborn, r 7or. Identical with the preceding? Published in r 701 The Jacobites Lamentation for the death of the late King James. [Haz. III. 126.]

JOHNSON (THOMAS), see Dictionary, 1641-67.

JOHNSTON (JOHN), stationer in Edinburgh, -1692. Will registered January r $3^{\text {th, }}$ r693. [Bann. Misc. II. 296.] 
JOHNSTON (WILLIAM), stationer in Edinburgh, I686-8. In I686 papers of proposals for reprinting the Works of King Charles the First were to be had of him [T.C.II. 185]; and in I688, in partnership with A. Ogston, he published a work entitled : Bibliotheca Universalis. [Aldis, pp. 74 and I I5.]

JOHNSTONE (EPHRAIM), bookseller in Manchester. See Johnson, or Johnston (E.).

JONATHAN (EDWIN), bookseller in London, Three Roses in Ludgate Street, 1672. He published Two Letters to $W$. Prynne, and Letters relating to the present state of Europe, both in 1672 [Bodl. Wood, 4I6; G. Pamph., I678 (9)]. His device bore the motto " Love and Live".

JONES (ARTHUR), bookseller in London, Flying Horse near St. Dunstan's Church in Fleet Street, $1684-6$. His first publication recorded in the Term Catalogues was a work called The Grandeur of the Law, r684. [T.C. II. 71.] He also published a large number of broadsides and in 1686 a pack of cards representing the rebellions of Monmouth and Argyle. [T.C. II. I59.]

JONES (EDWARD), King's Printer in London, the Savoy; and Dublin. 1688-I $70 \frac{5}{6}$. The King's printers, Bill, Hills and Newcombe, having printed the Declaration made by James II against the Prince of Orange, they were, on the accession of William, replaced by Edward Jones. Dunton [p. 324] speaks highly of his character, and adds " $\mathrm{He}$ has got a noble estate 'by authority' and is deservedly famous for printing 'The True News' and publishing the London Gazette". In 1690 he had an office in Dublin. Jones died at his house at Kensington on Saturday the 16th February 1706, and was buried in Hampstead cemetery. Immediately on his decease there was published an elegy on him, The Mercury Hawkers in Mourning. [Nichols, Lit. Anecd., IV. 81.]

JONES (н.), bookseller in London, in the Strand, I68I-9I. Publisher of political broadsides. The following have been found: (I) Loyalty vindicated from the calumnies cast upon it by R. J. [i.e. Richard Janeway], I68I. (2) Englands Choice, by Peter Chamberlen, 1682. [Haz. II. 90.] (3) Elymas the Sorcerer, by Thos. Jones, I682. [Haz. II. 3II.] (4) To the King's Most Excellent Majesty, 1688. [B.M. T. 100* (I9I).] (5) An Exact List of the Royal Confederate Army in Flanders, I691. [B.M. T. I00* (214).] 
JONES (JOHN), bookseller in Worcester and London ; London, (I) Dolphin and Crown, St. Paul's Churchyard ; (2) Bell, in St. Paul's Churchyard. I68I-99. Messrs. Burton \& Pearson in their Bibliography of Worcestershire [II. 52] record Kedarminster Stuff, "London, printed for John Jones bookseller in Worcester, 168r." Jones, about 1697, opened a shop in London at the Dolphin and Crown in St. Paul's Churchyard, and in the following year issued a Sermon of Good Works by J. Jephcott, which has the imprint, "London, Printed for John Jones, Bookseller in Worcester and are to be sold at the Dolphin and Crown in St. Paul's Churchyard, 1698 ". The last two leaves of this volume contain a list of books printed for and sold by John Jones at the Dolphin \& Crown in St. Paul's Churchyard. In I699 his sign was the "Bell" in St. Paul's Churchyard. [T.C. III. 150.] Probably identical with or son of the Jones who was a bookseller at Worcester in 1663. [Dictionary, 1641-67.]

JONES (JOHN), bookseller in Oxford, 1702-25. Perhaps the same as " Jones senior," 1718-25, and also the London and Worcester bookseller of the name. [Madan, p. 3r.]

JONES (RICHARD), bookseller in London, (I) Jermin's Yard, Aldersgate Street ; (2) Golden Lion, Little Britain, near the Lame Hospital Gate ; (3) White Horse, Little Britain. I666-8r. See Dictionary, 1641-67. He was still at work in 1681 .

JONES (THOMAS), bookseller in London; printer at Shrewsbury. 1676-1713. Born at Corwen in 1847 , he first practised the trade of a tailor in London. Hazlitt [II. 90] records The Character of a Quack-Doctor, London, printed for Thomas Jones, 1676 ; also, Ex Nihilo Omnia : or, The Saints Companion, London, printed by J. Orme for Thomas Jones, 1692. In I690 Jones also sold books printed in Welsh. [T.C. II. 298.] In or before 1696 he set up the first press at Shrewsbury. [Allnutt, p. 297.]

JORDAN (J.), bookseller in London, Angel in Giltspur Street, without Newgate, 1680-2. Publisher of several political broadsides at the time of the Popish Plot. He also received advertisements for The Loyal Impartial Mercury in I682.

JOURDAINE (D.), printer in Plymouth, 1696. Set up the first printing-press in Plymouth in 1696 . [Worth, History of Plymouth, 189o, p. 464, mentioning no book from the press.] 
JOYNER ( ), printer in London, Giltspur Street, against St. Sepulchre's Back Gate, near West Smithfield, I715. Advertised, in The British Weekly Mercury, November I6th-23rd, I715, Articles to promote Learning.

K. (J.), bookseller in London, I68I-9. These initials appear on the following publications : (1) A New Years Gift for Plotters (a broadside), I68I [B.M. 1872. a. I. (122)]; (2) $A$ New Poem on the Lord Mayor, I682 [Haz. II. 364]; (3) The Clergy's Late Carriage to the King, printed for H. L. and I. K. [I688] [B.M. T. roo* (194)] ; and (4) The Muses Farewell to Popery and Slavery, I689. [Haz. III. 200.]

K. (J.), printer in Edinburgh, see Kniblo.

KADWELL ( ), bookseller in Milton, Kent, 1699. His name occurs in the advertisement in The Flying Post, December 2nd, I699, of Edw. Brown's sermon preached at the Kentish Feast. It does not appear in the imprint to the book. The name was probably more often spelt Cadwell.

KEAT (HUGH), bookseller in Evesham, 1678. He published in 1678 a "Moral Interlude,' entitled; $A$ Traitor to himself, by William Johns of Evesham, and the imprint runs, " Oxford, Printed by L. L. [i.e. Leonard Lichfield] and are to be sold by Edward Forrest, Booksellour in Oxford, and Hugh Keat, Booksellour in Evesham, 1678." [B.M. 644. e. 54.] R. Clavell was theLondon agent for this book. [T.C. I. 320.] Keat was no doubt a relative of William Keate (q.v.).

KEATE (WILliaM), bookseller in Stratford upon Avon, r68I-2. Evidently a relative of Hugh Keat of Evesham (q.v.). In Hil. 34-35 Charles II, Robert Clavell, the London bookseller, who was also agent for Hugh Keat, brought an action in the Court of Common Pleas, against William Keate of Stratford, to recover various sums of money due to him for goods (presumably books) supplied. [C.P.R. 3009, m. $3^{80,}$ r.]

KEBLE (SAMUEL), bookseller in London, (r) Unicorn, Fleet Street, (a) near Ram Alley, (b) near Serjeant's Inn ; (2) (a) Turk's Head, (b) Great Turk's Head, Fleet Street, over against Fetter Lane. I674-I 7 5 (?). A well-known publisher of divinity. Keble's name appears in the Term Catalogues for the first time in Mich. 1674 as the publisher of a translation from H. Grotius, entitled The Conciliation of Grace and Free-Will [T.C. I. 189], and from that time until I 709 he constantly entered books. In I706 he published John Bowack's Second part of the Antiquities of Middlesex. [Harl. 5961 (128).] 
An engraved broadside catalogue of his publications survives. [B.M. I865. c. 3 (132).] Dunton [p. 297] has the following account of him : "Mr. Keble is a very ingenious, modest, humble man. . . . He printed that useful book called $A$ Week's Preparation for the Sacrament, and other excellent books of devotion." In 1704 he took his son William into partnership. In 1715 he was one of those receiving subscriptions for the third volume of Laurence Howel's Synopsis Canonum Ecclesia, which had been rewritten by the author, after the destruction of the original manuscript in Bowyer's fire in I 7 13. [Nichols, Lit. Anecd. I. ro6.]

KEBLE (WILLIAM), bookseller in London, Turk's Head, Fleet Street, r 704. Son of Samuel Keble (q.v.). In 1704 he was in partnership with his father, and also published, with W. Freeman and J. Knapton, an edition of Euclid [T.C. III. 432], but the later reference to him given in Mr. Arber's Index to that volume is apparently a mistake for Samuel. [T.C. III. 650.]

KEBLEWHITE ( ), bookseller in Newport, Isle of Wight, c. I703. "Mr. Keblewite in the Isle of Wight has a good trade, considering the place, but that is not his whole dependence. He has been twice Mayor of the town, and is not only rich, but a grave and discreet Churchman." [Dunton, p. 237.]

KEBLEWHITE (STEPHEN), see Kibblewhite.

KEBLEWHITE, or KIBLEWAITE (w.), bookseller in London, Swan, or White Swan, St. Paul's Churchyard. 1694-1702. Dunton [p. 292] distinguishes this bookseller as "London (and sober) Kiblewaite". Keblewhite made his first entry in the Term Catalogues in Hil. $169 \frac{3}{4}$ with a book of divinity. [T.C. II. 490.] He was publisher for William King, Bishop of Londonderry. He is last heard of in 1702, when he advertised the second edition of Dr. James Keill's Anatomy of the Human Bodie. [T.C. III. 329.]

KEIMER (s.), printer in London, I7r4. Printed for N. Cliff and D. Jackson.

KEINTON (M.), bookseller in London, Rose, in St. Paul's Churchyard. 1678-82. A bookseller of this name was one of the publishers of a book called $O f$ the Heart and its Right Sovereign. . . By J. T., advertised in 1678 and again in 1682, and of Argumentum Anti-Normanicum. [T.C. I. 302, 496.] This may have been Matthew Keynton, who was at work in 1656 and who was then living at the Fountain in St. Paul's Churchyard. [Dictionary, 1641-67.] But the name may be a misprint for $\mathrm{M}[\operatorname{ary}]$ Keirton (q.v.). 
KEIRTON (MARY), bookseller in London, 1673. In Stat. Reg. 1673, Mary Keirton assigned to Samuel Mearne $15 \mathrm{I}$ copies. See also Keinton (M.).

KELL (RICHARD), bookseller in London, in or near West Smithfield, I684-94. Publisher of ballads, broadsides, and chapbooks. Hazlitt quotes several in the Pepys Library, as Englands Fair Garland ... Songs, r684; Cupid's Court of Salutations, 1687. [Haz. I. 423, 481, 484, 490.] In 1694 he published The Trimmers Confession of Faith. [B.M. C. 20. f. 2 (202).] He may have been a son of R. Kels [q.v. in Dictionary, 1641-67].

KELLINGTON (JOB), bookseller in London, Star in Little Britain, I68I (?)-3. Publisher of the Works of the Rev. Isaac Ambrose in 1682 and of Walker's English Examples of the Latine Syntaxis in I683. [T.C.I.488, II. 3I.] See K.(J.).

KEMP (HOBART), bookseller in London, The Ship in the Upper Walk of the New Exchange, I67I-2. He published $A$ History of Jewels in $167 \mathrm{I}$, and Shadwell's Miser in 1672. [T.C. I. 81, III.]

KENNEDY (ALEX.), bookseller in Scotland (?) 168I. Three books of I681 "printed for A. Kennedy" are mentioned by Aldis, who says that they are probably Scottish. [Aldis, p. II5.]

KENT (HUGH), bookseller in Evesham. An error [Haz. II. 317] for Hugh Keat $(q . v$.$) .$

KERSEY (JOHN), bookseller in London, The Rose in St. Paul's Churchyard, 168I-6. In partnership with H. Faithorne. They were publishers of miscellaneous literature and also of Weekly Memorials for the Ingenious, or, An Account of Books lately set forth in several languages. [T.C. 1. 48I.] This was a rival publication to that published by R. Chiswell, W. Crook, and S. Crouch. [T.C. I. 532.] Kersey either died or gave up business in $\mathbf{I} 686$. and Faithorne continued alone. Their place of business may have been on the site of the house in which George Thomason, the collector of the literature of the Revolution, once lived. See K. (J.).

KETTILBY (WALTER), bookseller in London, (I) Bishop's Head, in Duck Lane ; (2) St. Paul's Churchyard. I669-1 7I I. A noted publisher of divinity books. His first appearance in the Term Catalogues was in Mich. 1669, when his address is given as the Bishop's Head in Duck Lane. [T.C. I. 17.] In I670 he was carrying on business both here and in St. Paul's Churchyard. [T.C. I. 58], but in $167 \mathrm{r}$ he appears to have given up the Duck Lane premises. Dunton 
[p. 209] refers to him as "an eminent Episcopal bookseller", and he published much learned literature, such as Isaac Barrow's Lectiones Octodecim [T.C.I. 105], and Henry More's Remarks upon two ... Discourses. [T.C. I. 228.] A list of his publications is found at the end of Dr. Charles Hickman's Sermon preached before the ... House of Commons ... Igth October I6go. He was still publishing in May I 7 rr. [T.C. III. 66o.]

KETTLEWELL (ROBERT), bookseller in London, (I) Hand and Sceptre over against St. Dunstan's Church in Fleet Street; (2) Hand and Sceptre, King Street, Bloomsbury. r68r-94. Probably a relative of the Rev. John Kettlewell, several of whose writings he published. He began as a publisher in r68r [T.C. I. 448], and was for a time in partnership with R. Wells. Some time between $\mathrm{r} 686$ and $\mathrm{r} 694$ he moved to Bloomsbury; after the latter date nothing more is heard of him. [T.C. II. x66, 508, 519.] In Trin. 1688 he was defendant in a suit for trespass. [C.P.R. Trin. 4 Jas. II, Roll 3068, m. $187 \mathrm{r}$.

KIBBLEWHITE (STEPHEN), bookseller in Oxford, r 7 r4-23. On April rst, I 7 r6, Thomas Hearne recorded that "Kibblewhyte a bookseller" was one of the unsuccessful candidates for the place of verger in the University. [Collections, v. 192.] He was at work in 1723. [Madan, p. 32.]

KIBLEWAITE (w.), see Keblewhite.

KIDGELL (JOHN), bookseller in London. (r) Atlas, Cornhill ; (2) Golden Ball, Holborn, near Gray's Inn Gate. 1680-84. Dealer in law books; publisher of Rights of the Kingdom. He moved to Holborn some time after r682. His last entry in the Term Catalogues was in February 1684. [T.C. II. 63.]

KING (CHARLES), bookseller in London, Judge's Head, Westminster Hall, 1707-25. His name appears for the first time in the Term Catalogues in Trin. I 707 as one of the publishers of Francis Higgins's Sermon preach'd at Whitehall on Ash Wednesday, 1706. [T.C. III. 553.] A list of eight books published by him with Benjamin Barker is found in an Assize Sermon by J. A. Dubourdieu, I7 14. [Bodl. Sermons, 6 (I3).] In $1_{7} 1_{3}$ Lintot bought of him a third share in Geddes's Tracts against Popery. [Nichols, Lit. Anecd. vill. 298.] Charles King was still in business in 1725. The Mr. King mentioned by Dunton [p. 359] as succeeding him at the Black Raven in the Poultry about r698 may have been this man, but is more probably J. King. 
KING (GREGORY), bookseller in London. At the East Corner Piazza House of James Street, Covent Garden, 1677. In Trin. 1677 he advertised a map of England by J. Adams. [T.C. I. 282.]

KING (J.), bookseller in London, (I) The Black Raven in the Poultry ; (2) The Lute in St. Paul's Churchyard. I698 (?)-1703. In Trin. I700 he advertised in the Term Catalogue a sermon preached at Hemel Hempstead by the Bishop of Chester [T.C. III. I93] and in I 703 Dr. William Howel's Elements of History. [T.C. III. 357.] It is doubtful whether he is the Mr. King who succeeded Dunton $[q . v .$, p. 359] about 1698 at his shop in the Poultry.

KINNEIR (D.), printer in Reading. Next door to the Saracen's Head, in High Street, I 723. Printed The Reading Mercury in partnership with William Parks (q.v.).

$\operatorname{KINSEY~(J.),~book-auctioneer~in~London.~At~the~Court~of~Requests,~or~Wards,~}$ over against the Lobby of the House of Commons, I697. The catalogue of an auction held by him in 1697 is in B.M. He is mentioned by Dunton [p. 232].

KIRKHAM (WILLIAM), bookseller in London, I68I. Defendant in an action for assault brought by Bartholomew Sprint. [C.P.R. Trin. 33 Chas. II, R. 2992, m. 256.]

KIRKMAN (FRANCIS), see Diclionary, 1641-67.

KIRKTON (JOSHUA), bookseller in London, c. I679. Will registered in Edinburgh, February 8th, 1679. [Bann. Misc. II. 296.]

KNAPLOCK (ROBERT), bookseller in London, (I) Angel and Crown, St. Paul's Churchyard ; (2) Bishop's Head, St. Paul's Churchyard. I696-I 737. One of the chief London publishers of his time. His first entry in the Term Catalogues was an edition of Juvenal and Persius, translated by Dryden, Congreve, Stepney, and Creech, in Mich. I696. [T.C.II. 602.] Dunton [p. 216] says : "He printed Mr. Wesley's Defence of his Letter, \&c., and then, to be sure, he is no Dissenter. However he is a very sober honest man, and has not one spot in his whole life, except it be the printing that malicious and infamous Pamphlet." He published many works in all classes of literature and held shares in the most important books. In or soon after 1707 he moved or altered his sign to the Bishop's Head in St. Paul's Churchyard ; in that year he appears at the Angel 
and Crown as part publisher with John Nicholson of Hickes's edition of the Works of a Kempis; a list of publications is appended to vol. II. Also in 1707 he bought part of the stock of Thomas Bennett, bookseller at the Half Moon. He died on January Ist, 1737. [Timperley, p. 659.]

KNAPTON (JAMes), bookseller in London, (I) Queen's Head, St. Paul's Churchyard; (2) Crown, St. Paul's Churchyard. 1687-1 738. This noted bookseller began, like many others, as a publisher of theological books, his first entry in the Term Catalogues being in Mich. 1687. Dunton [p. 295] spoke of him as "a very accomplished person ... and shews by his purchasing Dampier's Voyages he knows how to value a good copy". In 1688 he began to publish plays and novels in large numbers. It was in 1696 that he first advertised Dampier's Voyages. [T.C. II. 609.] He held shares in all the most important books that were issued and carried on a flourishing business until his death in 1738. He was Master of the Company of Stationers in 1727 and again in 1728 , and was succeeded in business by two of his brothers, John and Paul. [Nichols, Lit. Anecd. I. 236, III. 607.]

KNIBLO (JAMES), printer in Edinburgh, $1683-4$. In 1683 he printed, in partnership with Lindsay, Solingen, and Colmar, the third part of William Geddes's The Saints Recreation; and in 1684 , in partnership with Solingen and Colmar, Sir Robert Sibbald's Scotia Illustrata and two other books. See also Lindsay (David). [Aldis, pp. 64, 67, 127.]

KNIGHT (JоHN), bookseller in Lincoln, 1696-1716. In 1697 he published Twelve Sermons preached at the Cathedral Church of Lincoln, by Walter Leighton [T.C.III. 23], and in 1699 An Essay on Virtue and Piety, by John Carton, Rector of Branston near Lincoln. [T.C. III. 130.] He is again found in I 7 II as the publisher of a sermon by Sam. Walker, Vicar of Croft, called Reformation of Manners. In $\mathrm{I}^{7} \mathrm{I}_{4}$ he is found among the subscribers to Walker's Sufferings of the Clergy. In I716 he published a sermon by John Clark.

KNIGHT (JOSEPH), bookseller in London, (I) Blue Anchor in the Lower Walk of the New Exchange, Strand ; (2) Pope's Head in the Lower Walk of the New Exchange, Strand. r684-9o. In partnership with F. Saunders. They succeeded to the business of Henry Herringman in 1684 and were chiefly publishers of plays. Joseph Knight's name appears for the last time in the Term Catalogues in Easter 1690. [T.C. II. 312.] 
KNOWLES (THOMAS), bookseller and bookbinder (?) in London, Tower Street, r682-r 700 (?). Published The Protestant Dissenters' Case, a folio leaf. He may be identical with the Mr. Knowles noticed as a bookbinder by Dunton [p. 260]: "He is an ingenious and constant man at his Trade; and bound for me that 'History of Living Men' and 'Athenian Oracle' which I lately dedicated and presented to the Prince of Denmark and Duke of Ormond with my own hand."

KNOX (HENRY), bookseller in Edinburgh. In the Luckenbooths, "e regione insigniorum domini Ross". I696-1716. Probably youngest son of William Knox, bookbinder; baptized May 9 th, I64I ; M.A. Edin., I664; entered burgess and guild brother of Edinburgh, 1678 ; minister of Bowden (transferred from Dunscore) about I68I; ejected by P.C. I689. In 1696 he is found as a bookseller, selling A. Montgomery's Cerasum et sylvestre prunum, and Sébastien Châteillon's Octupla. Henry Knox died at Edinburgh, December 27th, 1716, in his seventy-sixth year. [Aldis, p. I I 5.]

KUNHOULT, or KUNHOLT (GABRIEL), bookseller in London, ( $\mathrm{I}$ ) The King's Head over against the Muse ; (2) St. Martin's in the Fields ; and at Oxford. 1680-5. Mentioned in an advertisement of patent medicines in True Neros, March 6th-10th, 16 $\frac{79}{80}$. In Mich. I Jas. II, Mary Wild, widow, recovered against him a debt of $f 500$. [C.P.R. 3040, m. 692 r.] He appears in Oxford in $\mathbf{6} 68 \mathrm{r}$. [Madan, p. 30.]

L. (A.), bookseller in London, I 7oo. Published the third edition of Joseph Glanville's Saducismus Triumphatus, I 700.

L. (H.), bookseller in London, r688. These initials are found on a broadside, The Clergy's Late Carriage to the King, printed for H. L. and I. K. [I688]. [B.M. T. 100* (I94).]

L. (J.), printer in London, 1702. Printed in this year for Edward Evets (q.v.).

L. (N.), bookseller in London, 1682. A pamphlet entitled The Charge of a ToryPlot maintain'd, r682, was printed for him and sold by R. Janeway.

LACEY, or LACY (THOMAS), bookseller in London, Golden Lion, Southwark, (a) near the Meal Market, $(b)$ near the Market Place, $(c)$ near St. Thomas's Church. 1672-94. Began publishing in 1672, when he was joint publisher with Robert Pask of Edward Cocker's London Writing Master. [T.C. I. I20.] 
In 1678 he published the first edition of the same author's Arithmetick. [T.C. I. 323.] Lacey was one of the agents for Bateman's "Scurvy Grass", which he advertised in The Protestant (Domestick) Intelligence of February 24th, 16 $\frac{79}{80}$. His name is not found in the Term Catalogues after Mich. 1684; but he published England's Golden Treasury in I 694 (license dated 1691). [B.м. 717. b. 55(I).] Hazlitt [I. 9I] records an edition of Cocker's Morals, printed for Thomas Lane, 1675 . This is apparently an entirely different edition from that in the British Museum with the same date, which has the imprint, "London, Printed by W. D. for T. D. at the Ship in St. Mary Axe, and T. L. at the Golden Lyon near the Meal Market in Southwark stationer." The tenant of the Golden Lion in Southwark was Lacy, and we suspect the Thomas Lane referred to by Hazlitt to be a misreading for Thomas Lacy. At the same time it is clear from the collation that Hazlitt's copy of Cocker's Morals belonged to an entirely different edition. The possibility of a misreading of the imprint is strengthened by the fact that in the very next entry Hazlitt records a copy of Cocker's Arithmetick, with the name of Thomas Law, at the Golden Lion in Southwark, where a reference to the book itself shows that it is printed by Thomas Lacy.

LADYMAN ( ), bookseller in London, near the Bars at Aldgate, 1691. His name occurs on a sale catalogue of $169 \mathrm{I}$ as one of those from whom copies might be obtained. [B.M. 82r. i. 9 (26).]

LAMBERT (RICHARD), bookseller at York, Crown, $(a)$ at, $(b)$ within the Minster Gate. See Dictionary, 1641-67. Working in 1686. He was succeeded by Robert Clarke, who married Susannah Lambert, probably his daughter, in 1690.

LANE (JOHN), bookseller in London, Blue Anchor in Wild Street, r688. His imprint occurs in a pamphlet by A. Pulton, Some Reflections upon the Author and Licenser of ... The Missioner's Arts discovered. [B.M. T. 1839 (3).]

LANE (THOMAS), see Lacey.

LARKIN (GEORGE), senior, bookseller and printer in London, (I) Two Swans without Bishopsgate ; (2) Kings Head in Wood Street ; (3) Lower end of Broad Street, next to London Wall ; (4) Coach and Horses without Bishopsgate ; (5) Hand Alley, Bishopsgate Strect. 1666-r 706. The following may be substituted for the brief account of Larkin given in Dictionary, I64r-67. 
George Larkin was born about the year 1642. He began publishing and perhaps also printing in I666, when he issued Bunyan's Grace Abounding, and also many things which gave offence to the Government. In the proceedings which took place before the Committee of the House of Lords in 1676 , Roger Norton deposed that in 1668 he searched Larkin's house and found there copies of two notorious pamphlets, The Cobbler of Gloucester and Advice to a Painter. Larkin's name does not appear in the Term Catalogues until Easter 1683, when he printed two books on Uniformity for Edm. Hickeringill. [T.C. II. 20.] $\mathrm{He}$ afterwards became the intimate friend of Dunton, who makes many effusive references to him in his Life and Errors and other writings. To quote from one [p. 245], “ Mr. Larkin has been my acquaintance for 20 years and was the first printer I had in London ... and has lately published an ingenious essay on the Noble Art and Mystery of Printing ... Mr. Larkin has a son now living of the same name and trade with himself." George Larkin's age is given by Dunton [p. 441] as 64 in 1706 ; but the date of his death is unknown.

LARKIN (GEORGE), junior, printer in London, Bishopsgate Street, I703-24. Son of George Larkin, sen. Mentioned by Dunton [p. 250]; also in Negus's List of Printers, I 724, as one of those well affected to King George.

LAW (THOMAS), see Lacey.

LAWRENCE (JOHN), bookseller in London, Angel in the Poultry, r681-r $7 \mathrm{rr}$. A noted Presbyterian bookseller. His first entry in the Term Catalogues was J. Houghton's Collection of Letters for the Improvement of Husbandry and Trade... Mich. 1681. [T.C. I. 464.] He shared with Dunton the publication of Lord Delamere's Works, Mackenzie's Narrative of the Siege of Londonderry, and Baxter's Life. Dunton calls him " an upright honest Bookseller . . . so exact in Trade as to mark down every book he sells". He married a daughter of the Rev. - Roswell. [Dunton, p. 205.] He was still in business in I 7 Ir. [T.C. III. 673.]

LAWSON (JOSEPH), bookseller in Lincoln, at the Bail, r681-9. Publisher of Selden's Of the Judicature of Parliament; advertised in the Term Catalogue for Easter 168I, a sermon preached in Lincoln Cathedral on July I8th, I68I, by the Rev. Daniel Nicols, and $A$ General Discourse of Simony, by the Rev. J. Metford, r682, John Ineth's Guide to the Devout Christian, 1687, and Dr. Brevint's Christian Sacrament and Sacrifice, I689. [T.C. I. 443, 470, 509 ; II. 205, 263.] 
LAYCOCK (WILLIAM), bookseller in London, 1696 (?)-1703 (?). Married (Susannah ?) daughter of William Miller (q.v.), and carried on the latter's collection of "stitched books". [Dunton, p. 2r3.] A sale catalogue of the collection was compiled for him at an unknown date by Charles Tooker.

LEA (PHIIIP), bookseller in London, (I) Atlas and Hercules, Poultry, (a) in Cheapside, (b) right against the Old Jewry ; (2) Westminster Hall, next the Common Pleas. 1683-99 (?) In addition to selling books Philip Lea was also a maker of globes and dealer in maps. His name first appears in the Term Catalogues in Trin. 1683. [T.C. II. 30.] In 1685 he sold an edition of Euclid [T.C. II. 136], and in 1692 An Epitome of the Whole Art of War. [T.C. II. 394.] His last appearance is a comprehensive advertisement of books, maps, globes, and instruments, in Trin. 1699 [T.C. III. 140-1] ; the date of his death is unknown, but his widow continued to carry on the business until 1703 . [T.C. III. 382.]

LEABOURN (ELIAS), bookseller in London, 1680. His name occurs in the imprint to a broadside on the Popish Plot entitled Reynard's Dozonfall, I680. [B.M. C. 20. f. 6 (8).]

LEACH (DRYDEN), printer in London, Elliot's Court, Little Old Bailey, 1707-24. Son and successor to Francis Leach $(q . v$.$) , and cousin of Swift$ and, presumably, of Dryden. Swift speaks of him several times contemptuously in the Journal to Stella. He procured him the printing of Harrison's Tatler in January $17 \frac{10}{1} \frac{0}{2}$, but a month later Leach lost it. Swift tells us that he was known as printer of the Postman, that he had acted Oroonoko, that he married Mrs. Baby Aires of Leicester, and that he was a coxcomb. [Swift, Prose Works, 11., Journal to Stella, 1900, pp. 40, 99, 103, 112.] In 1713 Leach subscribed three guineas to the Bowyer fund. In $\mathbf{7} 24$ Negus classed him among the printers well affected to King George. [Nichols, Lit. Anecd. I. $62,312$.

LEACH (FRANCIS), printer in London, Elliot's Court, Little Old Bailey, 1673-1707. By some oversight, this printer, who was in all probability a son of the Francis Leach, printer, who died in 1658 , is not mentioned in the list of printers taken in 1675. He was well known to John Dunton, who gives [p. 247] a rather foolish description of him, from which we may extract what follows : " He is ... blest with ... a constant trade ; has printed The Postman, \&c., many years; and I may venture to say, that Francis Lcach is the 
handsomest Printer in London." His son Dryden (q.v.) succeeded him in I 707 , the Postman for July Ist being the first with his imprint.

LEACH (WILliaM), bookseller in London, Crown, Cornhill, near the Stocks Market, $1678-91$. First appears as a publisher in 1678 [T.C. I. 308, 310, 314] with E. Cooke's tragedy Love's Triumph and other books. He made his last entry in 1683 . [T.C. II. 25.] He died intestate in 1691 , administration being granted to his principal creditor, Richard Hewson. [P.C.C. Admons, Jan. r69r.]

LEAKE (JOHN), bookseller and printer in London, Crown, Fleet Street, between the Two Temple Gates, I673-I 7 I 7 (?). Son of William Leake, with whom he was in partnership until 1679, when William's name appears in the Term Catalogue for the last time. [T.C. I. 363.] John Leake then appears to have set up as a printer, and between I68I and I693 printed for Awnsham Churchill, Jonathan Greenwood, Arthur Jones, Luke Meredith, Benjamin Needham, and Abel Swalle. [Haz. 1. 432 ; II. 67, 553, 592, 646 ; III. 125, 233.] $\mathrm{He}$ was in all probability the Mr. Leake who in $17 \times 3$ subscribed to the Bowyer relief fund; he may also be the person mentioned by Dunton [p. 292] as "humble Leek", and the J. L. who printed Sternhold and Hopkins for the Stationers' Company in $\mathbf{I} 7 \mathbf{I} 7$.

LEAKE (WILLIAM), see Dictionary, 164 I-67.

LEE, or LEIGH (CHARLES), bookseller in London, I68I-2. Publisher of many political pieces on the Popish Plot, amongst them Pordage's Medal Revers'd, 1682. [Haz. III. 291.]

LEE (SAMUEL), bookseller in London and Dublin ; London, Feathers, Lombard Street, (a) near Pope's Head Alley, (b) over against the Post House. 1677-95. Began publishing in 1677 , when he brought himself into notice as the compiler and publisher of the earliest known London Directory, $A$ Collection of the names of the Merchants in and about the City of London. It was a small octavo, issued at a shilling, and was entered in the Registers of the Company of Stationers by Daniel Major, stationer, on Lee's behalf, the latter not being a freeman of the Company. Major was joint publisher of the work, which was advertised in the Term Catalogue for Mich., Lee's name appearing first. [T.C.I. 294.] That the copyright was his is proved by the fact that on November 26 th, 1677 , a warrant was passed for a grant to him of the sole rights of publication for fourteen years. [S. P. Dom. Entry Book, 334, p. 439.] At the time of the 
Popish Plot he published several broadsides, and in Trin. 33, Chas. II [1681-2] Henry Hills brought an action against him in the Court of Common Pleas for slander in saying that there was a principal member of the Stationers' Company who had sent for a Dutch printing-press and letters and printed treasonable and seditious books, and upon being pressed declaring it was Mr. Hills the King's Printer. Hills claimed $£ \mathrm{I}, 000$ damages. [C.P.R. 2993, Trin. 33, Chas. II. m. 508 recto.] This is Dunton's character of Samuel Lee [p. 214]: "Such a Pirate, such a Cormorant was never before. Copies, Books, Men, Shops, all was one, he held no propriety, right or wrong, good or bad, till at last he began to be known, and the booksellers not enduring so ill a man among them to disgrace them, spewed him out, and off he marched for Ireland where he acted as felonious-Lee as he did in London." Lee's name is found for the last time in the Term Catalogues in Hil. 1684. [T.C. 11. 65.] In Dublin he issued an edition of The Present State of Europe, 1693, and one of Dionysius Syrus' Explication of the History of Jesus Christ, 1695. [B.M. 3224. b. 18.] He is believed to have died soon after this.

LEIGH (CHARLES), see Lee.

LEIGH (JOHN), bookseller in London, ( $\mathrm{I}$ ) Blue Bell, Fleet Street, by Flying Horse Court ; (2) Stationers' Hall. 1670-85. Chiefly a publisher of law and divinity. He made his first entry in the Term Catalogues in Easter 1670 [T.C. I. 39], was appointed treasurer of the Company of Stationers in 1679 , and died I685-6. [Nichols, Lit. Anecd. III. 607.]

LEIGH (THOMAS), bookseller in London, (I) Peacock near St. Dunstan's Church in Fleet Street; (2) Rose and Crown, St. Paul's Churchyard. I698-r 704. Inserted an advertisement for a lost seal in the Post Boy of July 21 st, I698. His earliest entry in the Term Catalogues was in Trin. 1698. [T.C. III. 74.] Roger Clavell had entered books published at the Peacock in Fleet Street in the Easter Catalogue of the same year. Leigh soon afterwards joined partnership with D. Midwinter at the Rose and Crown in St. Paul's Churchyard; these premises were jointly occupied by them with Richard Chiswell. Leigh's name is not found in the Term Catalogues after 1704 [T.C. III. 418], but Midwinter continued the business for many years later.

LENTHALL (Johs), stationer in London, Talbot, next the Mitre Tavern, against St. Dunstan's Church, Fleet Street, I709. In partnership with IV. Warters (q.v.). Sold packs of cards, maps, and general stationery. 
LESLIE (HENRY), bookseller in Edinburgh, Blue Bible over against Blackfriars Wynd, I677. Sold James Kirkwood's Grammatica delineata . . . editio tertia, printed in London by G. Godbid in 1677. [Aldis, pp. 57, 116.]

LESLY (GEORGE), bookseller in Edinburgh, in the Parliament Yard, 1678. Publisher, with A. Hislop, of James Kirkwood's Rhetoricae compendium, 1678. [Aldis, pp. 58, 116.]

LETT (R.), bookseller in London, I68I. No Protestant Plot was printed for him in r68r. [Haz. II. 344.]

LEVI (J.), bookseller in London, Golden Eagle, near the Fountain Tavern in the Strand, I 7II. Advertised in newspapers of I $\mathrm{I} I \mathrm{I}$ as a dealer in French books.

LEIVIS (G.), bookseller in Bristol, r 7or. Published Dean Hole's Danger of Deism, 1 701. [T.C. III. 268.]

LEWIS (WILlIAM), bookseller in London, Dolphin in Russell St., Covent Garden, I709-25. An old schoolfellow of Alexander Pope's. Published in I 709 the Works of Robert Gould, 2 vols. [T.C. III. 645], and in I7I I Pope's Essay on Criticism. In $\mathrm{I}_{74}$, in company with Lintot, he published a reprint of Miscellanies, in which pieces by Pope appeared. Lewis was still publishing in 1725 .

LICHFIELD (J.), printer in Oxford, 1682-4. Brother of Leonard Lichfield II ? [Madan, p. 3r.]

LICHFIELD (LEONARD), the second, printer in Oxford, Holywell, 1657-86. See Dictionary, 1641-67. Succeeded his father as University Printer in 1657, and was appointed printer of the Oxford Gazette in $166_{5}$. In December 1679 he was a candidate for the yeoman bedelship. He died of a fever February 22nd, I686 [Wood, III. I80], and was succeeded by his son Leonard III.

LICHFIELD (LEONARD), the third, printer and bookseller in Oxford, I687-I 749. Printed for Obadiah Walker (q.v.) Two Discourses of Abraham Woodhead, which some scholars of the University obtained from the printer sheet by sheet, and printed an answer to it within a month. [Wood, III. 209.]

LILLIECRAP (PETER), printer in London, 1647-72 (?). See Dictionary, 1641-67. In the list of printing houses in London of 1675 , his business is stated to have been bought in by the Company of Stationers since 1672 . 
LINDSAY (DAVID), printer in Edinburgh, in the Grassmarket at the foot of Heriot's Bridge, 168I-5. Watson [p. 14] thus relates the history of this press : "Sir Thomas Murray of Glendoick, having carefully digested the Acts of Parliament ... imploy'd John Cairns, Bookseller in Edinburgh, ... and he brought Dutch workmen and materials from Holland for that purpose. The Dutch-men's names were Josuah van Solingen and Jan Colmar. Mr. Cairns dying in a short time after they came here, the Dutch-men kept the house a going, and printed the folio Acts of Parliament in 168I. This printinghouse, becoming at last the Dutch-men's in property ; and Mrs. Anderson endeavouring to stop their working by her gift ; David Lindsay, merchant in Edinburgh obtain'd a gift from King Charles II . . . and for his protecting them with his gift, they give him a share of their printing house; he and they printed several books very neatly, under all their names. . . and at last the Dutch-men purchased Mr. Lindsay's gift, and bought back his share of the printing-house. These Dutch-men falling into very considerable debts, by the purchasing of this printing-house, and the ill payment of most of their employers ; James Watson ... paid money for them ... and they made over the printing-house to him "-and seem to have entered into his employ. The printing privilege prefixed to the Acts of $168 \mathrm{I}$, renews to David Lindsay as undertaker, and John Cairns as printer, the privilege granted to Sir Thomas Murray in 1679; it was confirmed by the Privy Council, March 3Ist, 168I. Lindsay was appointed one of the King's printers November $23^{\text {rd, }} 1682$. The succession of imprints at this house was as follows: 168I-3, Lindsay. 1682-4, Lindsay and his partners. 1682, Solingen. 1682-5, Solingen and Colmar. I683, Lindsay, Kniblo, Solingen, and Colmar. I684, Kniblo, Solingen, and Colmar. 1685, Colmar. 1685, Colmar and Gunter. [Aldis, p. I16.] Lindsay's advertisement, c. I68I, exists. [B.M. Cup. 65I. e. (82.)]

LINDSEY (WILLIAM), bookseller in London, Angel, near Lincoln's Inn, 1694-6. Published weekly an international critical journal, entitled Miscellaneous Letters. If we may believe Dunton [p. 229], Lindsey was born to a good estate, and after trading for a few years, retired into the country.

LINTOT, or LINTOTT (BARNABY BERNARD), bookseller in London, (I) Cross Keys in St. Martin's Lane, 1698 ; (2) Post Office, in the Middle Temple Gate in Fleet Street, $1701-4$; (3) Cross Keys (and Crown), (a) between the two Temple Gates in Fleet Street, $(b)$ next Nando's Coffee House, Temple Bar, 
1709-36. 1698-1736. This eminent publisher was born at Southwater, Horsham, on December Ist, 1675. He was the son of John Lintot yeoman and was probably a nephew of the Joshua Lintot who was printer to the House of Commons between 1708 and I7Io. Bernard Lintot was bound apprentice to Thomas Lingard in December $1690^{\circ}$, was afterwards turned over to John Harding, and became a freeman of the Company in March 1699 . In $x 698$ his name appears on the imprints of Crowne's Caligula and Vanbrugh's Relapse. He married on October $13^{\text {th }}, \mathbf{1} 700$. He very soon became noted as the publisher of poems and plays by Farquhar, Fenton, Gay, Parnell, Pope, Steele, and other famous authors. In 1712 he published Micellaneous Poems and Translations by several hands, in opposition to Tonson's Miscellany ; it contained the first version of The Rape of the Lock. In I7I3 Lintot was the highest bidder for the copyright of Pope's Iliad, and became proprietor. The first volume appeared on June 6th, I715, the last in 1720 . Owing to the appearance in Holland of a pirated duodecimo edition, Lintot was robbed of much of his expected profit, being compelled to issue a similar cheap edition in this country. For the Odyssey, which he published in 1 725-6, Lintot agreed to pay Pope $£ 600$, and to supply free of charge copies for Pope's subscribers. Pope insisted that free copies should also be sent to the subscribers found by Broome. This led to a quarrel, and Pope pilloried Lintot in The Dunciad, and elsewhere. During the severe frost of 17 I $_{5}-16$ Lintot was one of those who set up stalls on the frozen Thames. After the accession of George I he was appointed one of the printers of the Parliamentary votes, and kept this office until 1727. Lintot took his son Henry into business in $173^{\circ}$. He died on February $3^{\text {rd, }} 173^{6}$, and his will, made in $173^{\circ}$, was proved on February 14 th, by his son. Lintot served the office of renter warden of the Company of Stationers in 1715 , and in 1729 and $173^{\circ}$ was under-warden. He is described by Swift as large and fair in person and character; Young says that he was choleric. Pope gives an amusing account [Letter cxx, ed. 1730] of Lintot's conversation, in which the latter reveals his arts in managing translators and correctors and critics of tongues unknown to himself. He was noted for posting up the titles of his new books, printed in red. [D.N.B., T.C., \&c.]

LINTOT (JOSHUA), bookseller in London, New Street, near St. Martin's Lane, in the Fields, I708-9. Probably uncle of Bernard Lintot, with whom he published for the House of Commons William Bohun's Collection of Debates, I 708-9. [T.C. III. 619.] 
LITTLEBURY (ROBERT), bookseller in London, (I) Unicorn, Little Britain ; (2) King's Arms, Little Britain. 1652-85. See Dictionary, 1641-67. Appears in the Term Catalogues for the first time in Hil. 1670. [T.C. I. 64.] On the death of Dr. Edmund Castell in 1685 , Robert Littlebury and Robert Scott were chosen to value his library. [Nichols, Lit. Anecd. Iv. 28-9.]

LLOYD (HENRY), printer in London, 1662-75. See Dictionary, 1641-67. In 1672 he printed, for James Magnes, John Cory's comedy, The Generous Enemies. [B.M. 644. d. 57.] He was still at work in 1675 , for he appears in the list of London printing houses of that year.

LLOYD (o.), stationer and bookseller (?) in London, near the Cliurch in the Temple, I 7 Ir. Sold copy books. [Post Boy, February I 7 th, $17 \frac{10}{11}$.]

LLOYD (SIMON), bookseller in Mold, 1699. Sold school books, which he purchased of John Minshull, bookseller of Chester. [Library, and Ser., IV. 373-83.]

LOCK (J.), printer in London, in the Long Walk, near Christ Church Hospital, over against the sign of the Drawers, 1673-5. His imprint is found in Strange and Wonderful News from Ytaly, or, $a$. . relation of the Travels, Adventures and Martyrdoms of four eminent Quakers of York-shire, 1673. [Haz. II. 306.]

LONGFORD (WILLIAM), bookseller in Warminster, 1694. [List of Provincial Booksellers, N. \& Q., I I th Ser., I. p. 364.]

LONGMAN (THOMAS), bookseller in London, Ship and Black Swan, Paternoster Row, 1724-55. Son of Ezekiel Longman of Bristol, and founder of the great publishing house; was apprenticed to John Osborn, bookseller of Lombard Street, on June 9th, I716. Just at the expiration of his term, William Taylor, bookseller, of the Ship and Black Swan in Paternoster Row, died, and Osborn, who was one of the executors, persuaded Longman to purchase the business, which he reopened there soon after, having previously married Osborn's daughter Mary. His subsequent career lies outside the scope of this Dictionary, but an excellent history of the house of Longmans appeared in The Critic in 1860 [new ser. xx. 366, \&c.].

LORD (HENRY), bookseller in London, Duke of Monmouth, Westminster Hall, I680-2. First heard of in I680 when with many other booksellers he sold A methodical History of the ... Popish Plot, made in a pack of cards. [T.C.I. 
384.] In partnership with Thomas Fox he published in 1682 The Novels of Geo. Francesco Loredano. [B.M. I073. a. 40.]

LORD (THOMAS), bookseller in London, 1681. In 168I he was defendant in an action for assault brought by Bartholomew Sprint, bookseller, against a number of booksellers and printers in London and Oxford. Details are wanting. [C.P.R. Trin. 33, Chas. II., Roll 2992, m. 256.]

LOVE (JOHN), bookseller in Dumbarton, before $1695^{-1725}$. His son John was born in 1695. He died in 1 725. [G. Chalmers, Life of Thomas Ruddiman, p. 135.]

LOVEDAY ( ), bookseller in Dartford, 1699. His name appears in the advertisement of Edward Brown's Sermon preached at the Kentish Feast, November 16th, 1699. [Flying Post, December 2nd, 1699.] It does not appear in the imprint to the sermon.

LOVEDAY ( ), bookseller in Evesham, 1714. One of the subscribers to Walker's Sufferings of the Clergy.

LOVELL (T.), bookseller in London, Bible, in St. James's Street, 1689-97. His name occurs in Mich. 1689 as one of the publishers of Richard Stafford's Of Happiness [T.C. II. 282], and again in Hil. 1697 as one of the publishers of Dr. Adam Littleton's True Method of learning the Latine Tongue. [T.C. III. 7.]

LOWNDES (RICHARD), see Diclionary, I641-67.

LOWNDES (SAMUEL), bookseller in London, $(a)$ over against Exeter House, Strand, near the Savoy; (b) over against Exeter Exchange, by the Savoy Gates. I669-I700. One of the leading publishers of the period. Dunton [p. 2I3] has the following notice of him: "He was Dr. Horneck's bookseller for many years. He printed his 'Great Law of Consideration', his 'Sermons of Judgement' and Discourse on the Sacrament, entituled "The Crucified Jesus, \&c.'-Mr. Lownds was a sincere honest dealer . . ." Lowndes also published for Meric Casaubon, and held shares in all the best copyrights. He is last mentioned in the Term Catalogue in 1700 [T.C. III. I86]; and Dunton in 1703 speaks of him in the past tense.

LUCAS (CENTURION), printer in London, 1686-7. Defendant in a suit for trespass brought by Andrew Meeyer in Trin. 2. James II, Adjournment to Mich. [C.P.R. 3046. m. 267 , verso.] He may have been only a workman and not a master printer. 
LUMISDEN, or LUMSDEAN (CHARLES), bookseller in Edinburgh, in the Lucken-Booths, over against Warristan's Land, 1678-90. "Bought the 15 of Aprill 1678, from Mr. Charles Lumsdean thir six books ". [Sir John Lauder, Lord Fountainhall, Journals, 296.] A Charles Lumsdean, probably the same, was cautioner for Solingen and Colmar in 1687. [Fountainhall, Historical Notices, Bann. Club, II. 804 ; Aldis, p. II 7.]

LUMISDEN (THOMAS), printer in Edinburgh, 1723-48. In 1722-3 Lumisden bought part of the types belonging to the printers to the Church of Scotland (the successors of Andrew Anderson), and the Acts of the General Assembly for 1723 were printed by Thomas Lumisden and Company. In 125 he petitioned the Commissioners of the General Assembly to take off his hands an Irish [Gaelic] translation of the Confession of Faith and Catechism which he had printed. From 1725 to 1748 he printed in partnership with John Robertson.

LUNTLEY (JONAS), bookseller in London, Pestle, over against the Horse-shoe Tavern in Chancery Lane, 1694. Only known from the imprint to Sir George Mackenzie's Institutions of the Laws of England, which he published in partnership with Andrew Bell in 1694. [Haz. II. 376.]

LUTTON (JOHN), bookseller in London, (a) Blue Anchor, (b) Anchor, Poultry. 1672-4. He published in 1672 an edition of Sir George Downing's Discourse (ist ed., 1664). In 1673 he published Norfolk Drollery, a small volume of verse by M. Stevenson, and in 1674 he issued Dr. J. Smith's Grammatica Quadrilinguis. [T.C.1. 11 2, 127, 155; Haz. 1. 390.]

LYFORD (J.), bookseller in London, I689. Hazlitt [II. 646] records a sheet printed for him in 1689: The Form of the intended Coronation Oath agreed upon by the Committee.

M. (B.), bookseller in London, c. 1680-82. These initials, when followed by a manifestly fictitious address, stand for R. Bentley and M. Magnes (q.v.).

M. (B.), bookseller in London, I716. Published a sheet, The Oxford Tragedy, 1716. [Bodl. Fol. @. 662 (7).]

M. (N.), bookseller in London, 1679. Published a broadside in verse entitled $A$ Consultation between the Pope and a Jesuit, concerning the way how to introduce Popery into England, 1679. [B.M. C. 20. f. 2 (122).] 
M. (т.), bookseller in London, 1678 . These initials, which are found in conjunction with T. B. in 1678 , may perhaps be those of Thomas Moore.

MCEUEN (JAMES), bookseller and printer in Edinburgh, on the north side of the Cross, I718-32. He printed in partnership with William Brown and John Mosman; and the Edinburgh Evening Courant, which in 1718 he obtained an exclusive privilege to publish, bears his name from that year to 1732. McEuen had also an establishment in London. He was succeeded by Alexander Kincaid, whom he had assumed as a partner. [J. W. Couper, The Edinburgh Periodical Press, I908.]

MACKIE (JOHN), bookseller in Edinburgh, in the Parliament Close, I69I-I722 (?). In I69I he published $A$ vindicatory schedule . . . cure of fevers, by Andrew Brown; in 1695 he was one of several booksellers who sold Sir T. Craig's Scotland's Soveraignty asserted, and in 1699 , in partnership with J. Wardlaw, he published $A$ Letter giving a description of the Isthmus of Darian. His will was registered on April 13th, I 722. [Aldis, p. I 7 7.]

MCLEAN (ARCHIBALD), printer in Glasgow, "I 706 " [? I 756]. Keach's The Travels of Godliness, 2oth ed., bears the imprint: "Glasgow, printed by Archibald McLean, for Alexander Weir, bookseller in Paisley, MDccvi." This date is most probably a misprint for MDCCLvi. An Archibald McLean printed several books in Glasgow between 1753 and 1757 .

MACOCK (JoHN), see Diclionary, 1641-67.

MAGNES (H.). An error for J. Magnes. [Haz. I. 224.]

MAGNES (JAMES), see Dictionary, 1641-67.

MAGNES (M.), see Bentley (R.).

MAGNES (s.), see Bentley (R.).

MAJOR (DANIEL), bookseller in London, (I) Flying Horse, Fleet Street ; (2) Hand and Sceptre, near St. Dunstan's Church. 1677-80. In 1677 he entered in the Stationers' Register the first London directory, The Collection of the names of the Merchants living in and about London. The work was, however, the copyright of Samuel Lee $(q . v$.$) . Major was also one of the publishers of a$ broadside on heraldry, entitled Le Blazon, 1679. [T.C. I. 360.] In that year he moved to the Hand and Sceptre, previously occupied by T. Orrell. His last entry in the Term Catalogues was made in Easter 1680. [T. C. I. 393.] 
MALLET (A.), bookseller in London, near Fleet Bridge, 1704. Published An Account of the Behaviour, Confession and last Dying Words of Thomas Sharp, 1704. [Haz. 1. 264.] Other references given to A. Mallet in Gray's Index to Hazlitt should be to D. Mallet (q.v.).

MALLET (DAvID), printer in London, (I) Half-Moon Court, adjoining to Ludgate; (2) next door to Mr. Shipton's Coffee House, near Fleet Bridge. $1677-89$ (?). One of the lesser London printers. In 1677 he reprinted a scurrilous ballad called The Four-Legg'd Elder, originally issued in 1647. [Haz. II. 192.] In 1680 he printed for Elkanah Settle, The Life and Death of Major Clancie, which was on sale at his house in Half-Moon Court [T.C. I. $3^{82}$ ], and in 1687 Sir Charles Sedley's Bellamira came from his press. Mallet also printed many broadsides and Narratives of the Proceedings at the Old Bailey. His work was very rough, and his type poor. In 1686 he was forbidden by the Company of Stationers to print any more [Records of Stat. Co.], and his name disappears in 1687 , but the initials D. M., which may be his, are found as late as 1689 in England's Happiness Restored. [B.M. I872. a. I (9).]

MALLET (ELIZABETH), bookseller and printer in London, ( 1 ) Black Horse Alley near Fleet Bridge ; (2) Hat and Hawk in Bridle Lane ; (3) Next door to the King's Arms Tavern by the Ditch-side near Fleet Bridge. 1685-1702. Probably related to D. Mallet, with whom she was associated in the printing business. She was the publisher of The New State of Europe (no. I, September 20th, I701). [Burney II 7 B.] In 1702 she published a novel, $A n$ Historical Account of the Amours of the Emperor of Morocco. [T.C. III. 320.]

MALTHUS (SARAH), bookseller in London, London House Yard, at the West End of St. Paul's, I700(?)-I 706. Widow of Thomas Malthus. Her only entries in the Term Catalogues were made in 1704: The Royal Diary (William III's) and Dunton's New Practice of Piety. [T.C. III. 397-8.] She was then at London House Yard. Dunton speaks of her kindly in 1703 in his Life and Errors, and as if she was then newly set up in business, and she published the book two years later; but by 1706 he had quarrelled with her. He accuses her of slandering him in The Wandering Spy; she attached his goods for debt, and he abused her violently in The Whipping Post, I 706, calling her "a hedge-publisher", "the famous publisher of Grub-street News", \&c. He says that she was a bookseller's daughter. [Dunton, pp. 220, 447, 459, 462-3.] 
MALTHUS (тHомas), bookseller in London, Sun, in the Poultry, I682-I 700 (?). Appears for the first time in the Term Catalogue of Mich. 1682, as the publisher of a Life of the Duke of Monmouth. [T.C. I. 506.] During 1684 he issued many books, including a cheap abridgement of Exquemelin's History of the Bucaniers and several medical works. In 1685, when Dunton was setting out on his voyage to America, he met Malthus at Gravesend, on his way to Holland, " his circumstances being something perplexed". In another passage Dunton refers to Malthus as "very unfortunate". His name appears in the Term Catalogues for the last time in I686. [T.C. II. I69.] But Dunton in 1703 speaks of him as if recently dead. After his death, his business was continued by his widow Sarah (q.v.). [Dunton, pp. 86, 220, 447, \&c.]

MAN (SAMUEL), see Dictionary, 1641-67.

MANHOOD ( ), bookbinder in London, r684 (?). Mentioned as a bookbinder by Dunton, with whom he did business until Dunton went to Boston. Manhood afterwards gave up business and "went to the Garter Coffee House by the Royal Exchange" [Dunton, pp. 259, 260].

MANKLIN, or MANCKLIN (RICHARD), bookseller in York, 1697-1 725. Only known as the publisher (with Hildyard and Baxter) of George Barker's Sermons, 1697 [T.C. III. 23], and Sam. Johnston's Advantage of employing the Poor, 1725 , the latter printed for him by Gent. [Davies, pp. 123, 162.]

MANSHIP (SAMUEL), bookseller in London, (I) Black-Bull, over against the Royal Exchange ; (2) Ship, Cornhill, near the Royal Exchange. I687-17 I3. Made his first entry in the Term Catalogue in Mich. 1686. [T.C. II. I77.] Dunton [p. 206] describes him as "Mr. Norris's Bookseller". In 1687 he published a novel called The Gallant Hermaphrodite. [Esdaile, p. 185.] He was still in business in I7I3, when he contributed to the Bowyer relief fund. [Nichols, Lit. Anecd. I. 6I.] About 1694 he moved to the Ship. Lists of his books are appended to H. Hills's Dialogue between Timotheus and Judas, 1696, and John Norris's Practical Treatise concerning Humility, I707; Cotton's Montaigne is the most important book there advertised.

MAPLESDEN, or MAPLISDEN (PETER), bookseller in Newcastle-upon-Tyne, 1676-89. Admitted to the freedom of the city of Newcastle in 1676. [Memoirs of Mr. Ambrose Barnes, App., p. 414.] Between 1677 and 1689 he 
published several sermons for John March, Vicar of Newcastle. [T.C. II. I3 ; Bodl. Sermons 13.] Maplesden was also one of the publishers of Richard Gilpin's Daemonologia Sacra, 1677. [T.C. I. 287.]

MARCH (JOHN), bookseller in Exeter, (a) near the Conduit, (b) Bible, a little below St. Martin's Lane in the Fore Street. I 7 13-26. First met with in 17 13, when he published Francis Squire's Brief Justification of a reputed Whigg; in 17 I $_{4}$ he was a subscriber to Walker's Sufferings of the Clergy. In I7I6 he printed the same writer's Brief Exhortation to Protestant Liberty. [B.M. 225. h. 8 (8).] In I7I9 his name occurs in the proposals for printing Richard Bradley's Philosophical Account of the Works of Nature. In 1724 he published, with E. Score, Richard Izacke's Remarkable Antiquities of Exeter, and ed., which was printed for them in London. March died in 1726, and was succeeded at the same house by Aaron Toyer, jun. [Dredge, pp. 22, 65, 100.]

MARLOW (JOHN), printer in London, Vine, at the upper end of Aldersgate Street, 1674-88. This printer was called before the Committee of the House of Lords in $1676-7$, and admitted having printed for Thomas Sawbridge The Earl of Shaftesbury's Speech, part of the Letter from a Person of Quality, and the pamphlet entitled The Naked Truth, the last written by Herbert Croft, Bishop of Hereford, and published in I675. [Hist. MSS. Comm., Report 9, App., pp. 77-8.] Marlow was also the publisher and printer of the first number of Mercurius Infernus, 1679. In Easter 3 Jas. II, he was defendant in an action for debt brought against him by Richard Jeff. [C.P.R. $3056, \mathrm{~m} .573 \mathrm{v}$.

MARRIOT (GEORGE), bookseller in London, Temple, Fleet Street, by the Inner Temple Gate, $1674-77$. Makes his first appearance in the Term Catalogues in 1674 as a publisher of law books. [T.C. I. I80.] In 1677 he published R. Izacke's Antiquities of the City of Exeter [T.C. I. 266], and in the same year an edition of Beaumont and Fletcher's Elder Brother. [T.C. I. 296.]

MARRIOT (RICHARD), see Dictionary, I64I-67.

MARRIOTT (ANNE), bookseller in London, I687-9. The London Intelligence of I689 was printed for Anne Marriott by John Wallis. [Burney, 97 A.] Was she one of the "Mercury women" of whom we hear so much at that time? The initials $A$. M. on a broadside, $A$ Speech spoken by $M r$. Hayles, 1687, are probably hers. 
MARRIOTT (JOHN), stationer in London, r 700 (?)-1 742. Only known from his will, which was proved in the Prerogative Court of Canterbury on November r2th, r742. [P.C.C. Tremley 33r.] He left property in Essex and London and two sons, John and William.

MARSH (JOHN), bookseller in London, Red Lion in Cateaton Street, r688. In partnership with Lawrence Baskerville he issued an English and Welsh Dictionary under the title of The British Language in its Lustre. [Haz. I. 240.]

MARSHALL (JOHN), bookseller in London, Bible in Gracechurch Street, I695-I725. Probably a relative of William Marshall (q.v.), with whom he was associated in $x 695$ in the publication of a divinity book. [T.C. II. 547.] Dunton refers to him as "industrious and thriving John Marshall", and adds, "I heartily wish him success in his new purchase of "The Western Martyro$\operatorname{logy}$ " ". [Dunton, pp. 216, 292, 355.] In addition to the works of the Rev. Thomas Beverley, John and William Marshall were publishers for Dr. Owen. John Marshall was still publishing in 1725 .

MARSHALL (JOSEPH), bookseller in London, Bible in Newgate Street, 1707-25. Son of William Marshall. Was taken into the business about 1707 , and was still publishing in 1725 . [T.C. III. $5^{81}$.]

MARSHALI (WILIIAM), bookseller and bookbinder in London, (x) Butcher's Hall Lane, 1676 ; (2) Bible in Newgate Street, $1679-1725$; (3) Bible in Gracechurch Street, r685. I676-r725. He advertised in Mich. 1676 The Tomb of Semiramis, hermetically sealed, " to be sold by W. Marshall Bookbinder in Butcher's Hall Lane ". [T.C. 1. 257.] He dealt chiefly in divinity, and at the time of the Popish Plot published several pamphlets on the Protestant side. In 1695 John Marshall ( $q . v$.$) , a relative, opened a shop at the Bible in Grace-$ church Street; but William Marshall also had an interest in that business as early as 1685 , as at the end of John Collins's Doctrine of Decimal Arithmetick, published by Nathaniel Ponder in that year, is a r2-page catalogue of books newly printed and sold by William Marshall at the Bible in Gracechurch Street. About $\mathrm{r} 700$ he took into business his son Joseph Marshall, and they were still at work at the Bible in Newgate Street in 1725 .

MARSTON (JOHN), bookseller in Bury St. Edmunds and Sudbury, r683-5. In a list of provincial booksellers $[N$. \& $Q$., roth Ser., v, February 24th, 
1906], John Marston is given as being at Bury St. Edmunds in 1683. In 1685 Dorman Newman, the London stationer, brought an action against John Marston, bookseller, of Sudbury, co. Suffolk, in the Common Pleas, to recover a debt of $£_{166} 6 s$. $6 d$., probably for books supplied. The action was adjourned. [C.P.R. Trin., I Jas. II., Roll 3038, m. 1862 r.]

MARTEN, see Martin.

MARTIN (BRIDGET), bookseller in Bristol, at the Cross [in Temple Street], 1697. In the Post Boy of January 6th-8th, 1697, she advertised for sale, "at the Cross in the same street during the Fair ", copies of W. Wynne's edition of Powel's History of Wales.

MARTIN, or MARTYN (JOHN), see Dictionary, r641-67. He was at the Bell without Temple Bar till 1670, when he moved to the Bell in St. Paul's Churchyard.

MARTIN (JOHN), bookseller in Edinburgh, 1718-24. Britannia Triumphans, I 7 18, bears the imprint: "Edinburgh, printed by John Mosman and William Brown for the Author, and sold by the said William Brown and John Martin." Martin is also mentioned in the Acts of the General Assembly for 1720 and I724.

MARTIN, or MARTEN (sIMON), bookseller in Leicester, 1705-14. In 1705 he published S. Carte's Cure of Self-conceit, a sermon preached at Leicester [Bodl. Sermons 4]; and in I 706 A Faithful Account of the Lamentable State of a young Man, and his immediate recovery ... at Cropston in Leicestershire, was printed for him in London. [Haz. II. 340.] In I7I4 he was one of the subscribers to Walker's Sufferings of the Clergy.

MARTYN, see Martin.

MASON (J.), printer in London, 1684. One of four partners who printed a broadside in verse, On the Royal Martyr King Charles I, "printed on the frozen Thames, January the 3 oth, $168_{3}$, by the loyal young printers, viz. E. and A. Milbourn, S. Hinch and J. Mason." They were very likely not masterprinters.

MASON (JоHN), bookseller in Edinburgh, 1672. Published Two Prayers to be taught unto Children, 1672 . [Aldis, pp. 53, 117.$]$ 
MATHIE (ALEXANDER), bookseller in Glasgow, I718. His name occurs in the imprint of William Forbes's $A$ methodical Treatise concerning Bills of Exchange, and ed., Edinburgh, I7 18.

MATTHEWS (EMANUEL), printer and bookseller in London, Bible in Paternoster-Row, I 700-I7. Perhaps a son of John Matthews, printer, of Little Britain. In I 700 a sermon by H. Matthews of Chester was printed for E. Matthews in Paternoster Row. [Bibliotheca Cestriensis.] In I7I3 he was among the printers subscribing to the Bowyer relief fund, and in 1716 he printed the Rev. J. Owen's Sermon to Dissenters. [B.M. T. I805 (I I).]

MATTHEWS (GEORGE), see Matthews (John) senior.

MATTHEWS (JoHN), senior, printer in London, (a) Pelican, (b) Pilkington Court, Little Britain, I68I-I 166 (?). In I68I John Matthews was defendant in an action for assault, brought against him by Bartholomew Sprint. [C.P.R. Trin. 33 Chas. II., Roll 2992, m. 256 r.] In I 701 he printed for Elizabeth Mallet a sheet called The New State of Europe. He was also the printer of Defoe's History of the Union, I707. [T.C. III. 562.] He contributed three guineas to the Bowyer fund in $\mathrm{I}_{7} \mathrm{I} 3$, and in the next year appears among the subscribers to Walker's Sufferings of the Clergy. He died about I $7 \mathbf{1 6}$, three years before the execution of his son John $(q . v$.$) , and his business passed$ to his widow, who was then its proprietor. [Gent, p. 9r.] A son George is said to have carried it on later. Emmanuel Matthews $(q . v$.) may also have been one of the family.

MATTHEWS (JoHN), junior, printer in London, (a) Pelican, (b) Pilkington Court, Little Britain, I 719. Son of John Matthews, sen. This unfortunate young man, who was only an apprentice, was in I 7 rg apprehended and tried for printing a tract entitled Ex ore tuo te iudico, Vox Populi Vox Dei, said to be written in support of the Pretender. In the printed account of his trial he is spoken of as a " poor youth" and a "young man"; copies of the libel were found at the printing house of his mother in Little Britain. He was found guilty and executed at Tyburn in I7I9, in his eighteenth year. [Howell's State Trials, XV. I327; Weekly Packet, October 31st-November 7th, I719; Timperley, p. 623 ; Gent, p. 9I.]

MAXFIELD ( ), bookseller in London, c. I700. Dunton refers [p. 293] to a bookseller of this name as " conscientious and dutiful Maxfield". 
MAXWELL (ANNE), see Dictionary, 1641-67.

MAY (GEORGE), bookseller in Exeter, 1680-86. First heard of in r680, when he published Thomas Long's Sermon against Murmuring. [T.C. I. 403.] In 1686 he published God in the Creature . . a Poem ... London, Printed for George May, and are to be sold at the Peacock in St. Paul's Churchyard, I686 [Haz. I. I92] ; and N. Kendall's Sermon preached at the Assizes at Launceston, I8 March 1685 .

MAYO, MAYOR or MAYOS (JOHN), printer in London, (I) Golden Cross in Thames Street near Queenhithe ; (2) over against Water Lane, Fleet Street. 1697-1714. In 1697 he printed and sold Ezekiel Polsted's Excise-Man (in the imprint to which his name is spelt Mayos). In The Postman of October 25th-27th, 1698, he advertised An Essay concerning Adepts. Again, in The Postman of January 2oth, $17 \frac{1}{2} \frac{0}{1}$, he is found advertising vol. I of The British Apollo, and Nichols records that in 17r3-14 he printed for F. Burleigh a periodical called The Balm of Gilead. [Lit. Anecd. vir. 494.]

MEAD (DANIEL), bookseller in London, Bible, Snow Hill, by the George Inn Gate, r707-32. Possibly related to the Rev. Matthew Mead, for whom he published two Discourses in 1707 and a sermon in I 7II. [T.C. III. 54I, 662.] Hazlitt records a book printed by him in I 7 I 5. [1. 472.] He was probably alive in $173^{2}$, for Thomas Norris, the London Bridge bookseller, left him a bequest in his will, proved in that year. [P.C.C. Bedford 174. ]

$\operatorname{MEAD}(\mathrm{M}$.$) , bookseller and printer (?) in London, Gutter Lane, I697 (?)-$ 1703. He is probably the M. M. who printed three divinity books in 1697 . [T.C. III. 3.] In I 7or he put his name with others to two very similar books. [T.C. III. 253.] Dunton [p. 252] mentions as then living a Mr. Mead, who printed for him A Step to Oxford.

MEAD (RICHARD), bookseller in London, I684. Only known from the imprint to a broadside entitled Speech of Hadgi Giafer Aga, I684. [B.M. T. I00* (167).]

MEADE ( ), bookbinder in London, Honey Lane Market, r696. Mentioned by David Edwards as having bought a quantity of primers in I695. [P.R.O. Chanc. Proc. before I 7 44, Collins 486/roo.]

MEADOWS (w.), bookseller in London, $1719-25$. In 1719 he was the publisher of a novel called Charon, or the Ferry Boat, and in $\mathrm{I} 72 \mathrm{r}$ he was one of the 
publishers of Paul Chamberlen's series of novels called Love in its Empire. [Esdaile, pp. 185, 183.] He was still publishing in 1725.

MEARNE (A.), bookseller in London, Little Britain, 1683. Probably Samuel Mearne's widow. See Mearne (C.).

MEARNE (CHARLES), bookseller in London, (I) Little Britain ; (2) the King's Arms, near Charing Cross. 1680-6. Son of Samuel Mearne. In r680-8r he was one of several publishers advertising a handsome Cicero. [T.C. I. 390, 455.] In the next year he appears in partnership with his father in Little Britain, and in 1683 with A. Mearne, probably his mother, advertising the two volumes of John Nelson's Impartial Collection of the Great Affairs of State. [T.C. I. 47 I, II. 27.] By I 686 he had moved to Charing Cross, where he then took subscriptions for Ray's General History of Plants. In the same year he was one of the partners in the works of Sir Thomas Browne, and this is his last appearance. He seems never to have published alone, but always to have taken shares in large ventures. He has often been held to be a binder, like his father; but Mr. Gordon Duff [Edinb. Bibl. Soc. Trans. xi. 47] shows that no bindings can be attributed with any probability to him.

MEARNE (SAMUEL), see Diclionary, 1641-67.

MEARS ( ), printer in London, 1713-14. See Meere (H.).

MEARS (w.), bookseller in London, Lamb, without Temple Bar, I71 $3^{-27}$. In I7I3 he issued a catalogue of plays. [Bodl. $4^{\circ}$, Rawl. I4I.] In I7I4, in company with D. Brown, he published The Persian and Turkish Tales, translated from the French of Pétis de la Croix, and in 1725 Defoe's Nero Voyage Round the World. [Esdaile, pp. 286, 209.] In I723 he appended a miscellaneous list to T. Salmon's Chronological Historian. He was one of the publishers of Defoe's Tour through Great Britain, I 724-7, in copies of vol. III. of which appears a list of twenty-four books, many of an historical character, printed for him.

MEERE (H.), printer in London, (I) Black Friar, in Blackfriars ; (2) Old Bailey. 1 708-24. In the $O b$ rvator of February 7 th, I 708, he inserted the following advertisement, pri.." $d$ in the type advertised: "Scriptographia ; or, Written Print Hand, (which can't be imitated by any other printer) fit for Bills of Lading, Bills of Sale, Bonds of all Sorts . . . or any other blank LawForms. Such as have occasion for any of these, may have them printed on 
this, or larger characters of the like, by H. Meere, Printer, at the Black-Fryar, in Black-Fryars, London." In I7I3 he printed The Innocent Epicure for R. Gosling, and some school-books, including Terence and Phaedrus, for Robert Fary; he was also the printer of The Daily Post and The British Journal. In 1724 he was living in the Old Bailey, and is mentioned in Negus's list as a "high-flyer". He is probably identical with the "Mears" in whose printing-office in Blackfriars Gent worked in $17 \mathbf{I}^{3-14}$.

MEIN (JAMES), bookseller in Edinburgh, on the North-side of the Street at the Cross, 1684-6. In 1684 he issued $A$ true Relation of the great Victory . . by . . . Prester John, against the Turks, by Jo. Miles, and in $1686 \mathrm{~A}$ Relation of the Procession ... enjoyn'd by Mahomet Solyman. [Aldis, p. II7.]

MELLETT (THOMAS), printer in London, r681. Defendant in an action for assault and trespass brought by Bartholomew Sprint. [C.P.R. Trin. 33 Chas. II, R. 2992, m. 256 r.] Perhaps not a master printer.

MENSON (JOHN), bookseller in Edinburgh, I67I. One of the six booksellers

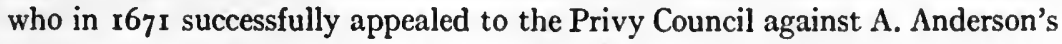
attempted enforcement of his monopoly. [Aldis, p. II 7.]

MERCER (THOMAS), bookseller in London, Half-Moon, near the Exchange in Cornhill, 1679-84. His name first appears in Easter 1679 as publisher of Henry Brett's History of Jesus Christ. [T.C. I. 350.] He figures again, in an advertisement of lost property, in The Protestant (Domestick) Intelligencer, March 19 th, $16 \frac{79}{80}$, and is last heard of in 1684 , when he published John Jones's Great Duty of Conformity. [T.C. II. 68.]

MEREDITH (LUKE), bookseller in London, ( $\mathrm{r}$ ) King's Head, West end of St. Paul's Churchyard, I684-6; (2) Angel, Amen Corner, $1687-92$; (3) Star, St. Paul's Churchyard, I692-I700. 1684-I700. Began in Trin. I684. [T.C. II. 8r.] The greater part of his publications were in divinity, but he was the publisher of Langbaine's Account of the English Dramatick Poets, I69r. [T.C. II. 358.] He married a daughter of Richard Royston, and some time during r686-7 moved to the Angel, the premises of his father-in-law, who had died in r686. Meredith succeeded to many of Royston's books, and after his own death in I 700 some were printed for John Meredith in trust for Luke's children, Royston and Elizabeth. [T.C. III. 725.] An 8-column list of Royston's copies, as set out in the Stationers' Register and certified by the 
Clerk to the Company as now the property of the children of Luke Meredith deceased, is appended to Jeremy Taylor's Antiquitates Christianae, printed in $1702-3$ for the trust.

MERES (A.), bookseller in Dublin, White Hart, Copper Alley, 1715. In partnership with Thomas Hume.

MERREALL (ALEXANDER), stationer and bookseller in London, Rose in Bread Street, 1662-r703. See Dictionary, 1641-67. Living in 1703, when Dunton [p. 254] wrote of him thus : "Mr. Merreal at the Rose in Bread Street. $\mathrm{He}$ is rich, yet very humble. He has been put up for Sheriff ... He was the first Stationer I ever dealt with [i. e. about I68I] ; and in trading with him for twenty years I ever found him just and kind. It is a question whether he is more his Chapman's Friend, or his own." See Sheafe (S.).

METCALFE (THOMAS), bookseller in London, over against the Red Lion Court, Drury Lane, 1694-I 7II. First appears in I694 as the publisher of a translation of Essays supposed to be written by Monsieur [Nicholas] Fouquet. [T.C. II. 512.] In I709 he was one of many booksellers who took subscriptions for the Corpus Poetarum Latinorum. [T.C. III. 657.] He was still in business in I 711 .

MIDWINTER (DANIEL), I., bookseller in London, (I) Rose and Crown St. Paul's Churchyard; (2) Three Crowns, St. Paul's Churchyard. I698-1725. In partnership with Thomas Leigh. They shared the premises formerly occupied by Richard Chiswell, and made their first entry in the Term Catalogues in Mich. 1698. Leigh dropped out of the partnership in 1704, and Midwinter moved to the Three Crowns between 1706 and 1708. Dunton speaks of them as doing a "topping business", and there is no doubt that they were two of the largest booksellers of the day, holding shares in most of the chief undertakings. The date of Midwinter's death is unknown. He was still publishing in 1725 , and was succeeded by his son Daniel II.

MIDWINTER (EDWARD), bookseller and printer in London, Star, Pye Corner, y 7 ro-25. His first known publication is The Northamptonshire Wonder, "printed and sold by Edward Midwinter", I 7ro. [Haz. 11. 710.] When Thomas Gent first came to London, and again about 1722, he was employed by Midwinter. Midwinter was a printer and publisher of ballads and chapbooks, amongst which may be mentioned an abridgement of Defoe's Robinson 
Crusoe, 1722 [Gent] and in 1724 [Esdaile, p. 208 ; Haz. 11. 362, 710]; but his circumstances were so poor that Gent records that on one occasion, apparently in 1723 , he was obliged to remove himself and family to a place called the Mint, a district in Southwark which was then a sanctuary for insolvent debtors. [Davies, York Press, p. $15^{8}$.] Midwinter is mentioned in Negus's list of printers as a "high-flyer". [Nichols, Lit. Anecd.1.3I I.] He married as his second wife, about 1720 , Elizabetl daughter (or perhaps daughterin-law) of Thomas Norris (q.v.). [Gent, Life, passim, and sources quoted.]

MILBOURN (ALEXANDER), printer in London, 1684-93. Son of Thomas Milbourn (?). With E. Milbourn (a brother ?), S. Hinch, and J. Mason (q.v.) he printed a broadside in the Thames Frost Fair of 1684 . At the sessions held at the Old Bailey in April 1693 he was bound over to come up for judgement at the next sessions, for printing a libel. [B.M. 5 I 5.1 .2 (I48).]

MILBOURN (E.), printer in London, 1684. See Milbourn (A.).

MILBOURN (THOMAS), printer in London, Jewin Street, 1659-86. See Dictionary, 164I-67. Dunton [p. 244] says that he was married four times, that he had lived in Jewin Street for forty years, and died at the age of 74. By an order of the Company of Stationers made in 1686 , he and others were forbidden to carry on the trade of printing. [Records of the Company.]

MILES (E.), printer in London, 1674. Printed a news-tract, Treason and Murther [1674]. [Haz. III. 76.]

MILL (ADIEL), stationer of London, Peacock in Amen Corner, 1687-90. First heard of in 1687 , when he purchased the business of Robert Scott the bookseller (q.v.), "near £ro,00o deep", and issued a catalogue of the books in February $168 \frac{7}{8}$ [B.M. 821. i. I3 (I)] ; but he, " with his auctioneering, atlases, and projects, failed " for $£ 30,000$ or more in 1690 , and ruined Scott, to whom he could not pay the purchase money, and also his relative, Moses Pitt. He became a debtor in the Fleet. [Roger North, Lives of Francis North, E'c., III. 290-1 ; Moses Pitt, Cry of the Oppressed, p. 153.] See Hills (H.) sen., and Roberts (R.)

MILLER (J.), bookseller in London, Rose, West End of St. Paul's, 1677. Publisher of an Alphabetical Martyrology, compiled by N.'T., in I677. [T.C. 1. 299.] 
MILLER (JAMES), bookseller in Edinburgh, 1665-72. See Dictionary, 1641-67.

MILLER (JOHN), bookbinder in Edinburgh, c. I674. Will registered January 2 Ist, I675. [Bann. Misc. II. 296 ; Aldis, p. 117 .]

MILLER (JOHN), bookseller in Sherborne and Yeovil, I69I-I709. Local publisher or agent for the sale of sermons, \&c., by Dorsetshire and Somersetshire divines, also published in London. His name appears in seven such entries between the dates given, a shop at Yeovil being also mentioned in one of 1697 . [T.C. II. 379 ; III. $35,210,386,425,582,611$; the last is B.M. 225 . h. $3(3) \cdot]$

MILLER (SIMON), see Dictionary, I64I-67.

MILLER (susannaH), bookseller in London, The Acorn, in St. Paul's Churchyard, I698 (?)-I 700. Probably daughter of William Miller (q. v.).

MILLER (WILliaM), bookseller in London, Gilded Acorn, St. Paul's Churchyard, 166r-96 (?). See Dictionary, 164I-67. Dunton [p. 213] says of him: " $\mathrm{He}$... was blessed with a great memory, which he employed for the good of the publick ; for he had the largest collection of stitched books of any man in the world, and could furnish the Clergy (at a dead lift) with a printed sermon on any text or occasion. His death was a public loss, and will never be repaired unless by his ingenious son-in-law, Mr. William Laycock, who I hear is making a general collection of stitched books ; and as Mr. Miller's stock was all put into his hands, perhaps he is the fittest man in London to perfect such a useful undertaking." A sale catalogue (without date) of this stock of pamphlets was afterwards compiled by Charles Tooker for Laycock. [B.M. 620. a. I (I).] Miller advertised largely in the Term Catalogues, and also generally added an advertisement at the end of his imprints. For example, the imprint to the second edition of Captain GeorgeSt. Lo's England's Safety, 1693, runs thus : "London: Printed for W. Miller, at the Gilded Acorn in St. Paul's Churchyard, where gentlemen and others may be furnished with Bound Books of most sorts, Acts of Parliament, Speeches and other sorts of Discourses, and State Matters ; as also Books of Divinity, Church Government, Humanity, Sermons on most occasions, \&c." A list of his books is to be found in this book. It is the last entered in his name in the Term Catalogues. The exact date of his death is unknown, but his business was 
carried on for some time by Susannah Miller, probably the daughter mentioned by Dunton, who married William Laycock.

MILLET (JOHN), printer in London, 1683-92. In partnership with M. Haley. They printed large numbers of ballads, broadsides, and chap-books for various booksellers.

MILLINGTON (EDWARD), bookseller and book-auctioneer in London, ( 1 ) Pelican, Duck Lane ; (2) Bible, Little Britain; and in Cambridge. I670-1703. Made his first entry in the Term Catalogues as a publisher of books in Easter 1670, when he published William Seaman's Grammatica linguae Turcicae. [T.C.I. 3I.] It was, however, as a book-auctioneer that he became famous. Dunton [pp. 235-6] calls him "the famous Mr. Edward Millington", and " a man of remarkable elocution, wit, sense, and modesty", and adds : " He was originally a bookseller, which he left off, being better cut out for an auctioneer ; he had a quick wit, and a wonderful fluency of speech. There was usually as much comedy in his 'Once, 'Twice, Thrice,' as can be met with in a modern play : 'Where', said Millington, ' is your generous flame for learning ? Who but a sot or blockhead, would have money in his pocket, and starve his brains?' Though I suppose he had but a round of jests. Dr. C. once bidding too leisurely for a book, says Millington, "Is this your Primitive Christianity?' alluding to a book the honest Doctor had published under that title. ... He died in Cambridge, and I hear they bestowed an elegy on his memory and design to raise a monument to his ashes." Ned Ward, in $A$ Step to Stirbitch-fair, gives a similar description of Millington's humour as an auctioneer. He was the chief auctioneer of the time. [B.M. Catalogue of Sale Catalogues.] He was holding auctions at Cambridge, in the town itself, at the Eagle and Child, opposite St. Benet's, and at Stourbridge Fair, as early as I686. [Mayor, Cambridge under Queen Anne, pp. 249, 492.] He died in 1703 . [Timperley, p. 588.]

MILLION (HENRY), bookseller in London, ( 1 ) Bible, Fleet Street ; (2) Bible, Old Bailey. 1670-79. Believed to be the son of John Million,q.v., Dictionary, 1641-67. His first entries in the Term Catalogues were Cornelius Agrippa's Female Pre-eminence and Herbert Palmer's Memorials of Godliness and Christianity, Mich. 1670, and his last Moses Rusden's Full Discovery of Bees, 1679. [T.C. 1. 57, 60, 373.] He was in Fleet Street in 1675 [T.C. I. 203], and had moved to the Old Bailey by 1679. All his few books were cheap. 
MILLS (F.), bookseller in London, Rose and Crown without Temple Bar, 1696. In partnership with $\mathrm{W}$. Turner. Their names are found in the imprint to Le Maire's Voyages to the Canary Islands, 1696.

MILLS (RICHARD), see Diclionary, 164I-67.

MILNER (JACOB or JAMES), bookseller in Dublin, Essex Street, 1692-1 701. The name "Jacob Milner" is first met in 1692 and again in 1693 . In 1697 "J. Milner" published Bishop John Stearne's Tractatus de Visitatione Infirmorum. [T.C. III. 27.] The will of "James Milner" was proved in I701. All these probably relate to the same man.

MILWARD (EDWARD), bookseller in Lichfield, I680. He sold John Brinley's Discovery of the Impostures of Witches and Astrologers, London, printed for John Wright, r680. [Haz. II. 62.]

MINIKIN (GEORGE), (?) stationer in London, King's Head in St. Martin's, I676. Sold a pack of cards representing the counties of England. [T.C. I. 237.]

MINSHULL (JOHN), bookseller in Chester, Bridge Street, 1674 (?)-1712. Doubtless related to the William Minshall or Minshull who was carrying on business in Chester in the days of the Commonwealth. [Dictionary, 1641-67.] From certain Chancery Proceedings we learn that John Minshull was apprenticed to a London bookseller, Peter Bodvell, and afterwards purchased his freedom from the Company of Stationers of Chester and set up in business for himself about the year 1674 . Books published by him in 1682 and 1698 are recorded in J. Cooke's Bibliotheca Cestriensis. He sold school-books wholesale to booksellers and stationers in various places, amongst his customers being Ephraim Johnson of Manchester. According to Timperley he died in r 7x 2.

MINSHULL (R.), bookseller in Chester, Bridge Street, r 712. Son of John Minshull. In 1699 he was a student at Trinity College, Dublin, where Dunton visited him [p. 625]. He probably joined his father soon after this, and succeeded him in 1712 . He is given in a list of provincial booksellers in $N$. $\&$. [Ioth Ser., v. 142.]

MITCHELL (J.), bookseller in London, Threadneedle Street, 1686. Sold the $4^{\text {th }}$ ed. of the Conference between Laud and Fisher. [T.C. II. I II.]

MONCK'TON (PHILIP), bookseller in London, Star, in St. Paul's Churchyard, 1 701-7. A publisher of divinity, which is probably why Dunton. [p. 292] 
refers to him as "Church-Unity Monckton". Made the first and last of his many entries in the Term Catalogues in r7or and 1707. [T.C. III. 263,537 .]

MONCUR (JOHN), printer in Edinburgh, his printing house at the foot of the Bull Close, opposite to the Tron, r jog-r 2 ; his house and shop at the Head of the Bank-Close, in the Lawn-market, I 726. I 707-26. In I 709 he printed The Scots Postman, and in 1712 The Evening Post. On page viii of the edition of Guthrie's Christian's Great Interest which Moncur published in 1726 is a list of twenty-nine books printed and sold by him.

MONEY (JOHN), bookseller in London, I68I. Defendant in an action for assault brought by Bartholomew Sprint. [C.P.R. Trin. 33, Chas. II., Roll 2992, m. 256.] He is not known as a publisher.

MONTAGU (RICHARD), bookseller in London, the Book-Warehouse at the corner of Great Queen-street, near Drury Lane, I 7 18 (?). A list of books and pamphlets sold by him occupies the last leaf of $A$ Warning-piece for English Protestants, n.d.

MONTEATH (JOHN), printer in Edinburgh, c. I674. Will registered July 2oth, 1674. [Bann. Misc. II. 295 ; Aldis, p. II7.]

MONTFORD (JOHN), see Mountford.

MONTGOMERY (HUGH), bookseller in London, Cornhill, 1703. Only known from Dunton, who says [p. 269], "He was born a Scotsman and served his time with Andrew Bell," and tells us that he was " of a low stature" and that he himself thought so highly of him that he entrusted him with the sale of the whole impression of his Idea of a New Life, i. e. Life and Errors.

MOORE, or MORE (THOMAS), bookseller in London, Maidenhead, over against St. Dunstan's Church in Fleet street, 1678-84. Publisher of John Wallis's Defence of the Royal Society, 1678. [B.M. 740. c. 21 (8).] In 1684 he was defendant in a suit brought by Anthony Trethway in the Court of Common Pleas for the recovery of $£ 300$. [C.P.R., Hil. 35/6, Chas. II, 1683-4, Roll $3020, \mathrm{~m} .35^{2}$ verso.]

MOORE (THOMAS), printer in London, 1685. Printed Thomas Wright's Glory of God's Revenge against Murther and Adultery for Benjamin Crayle, 1685. [Haz. I1. 663.] 
MORDEN (CHARLES), bookseller in Cambridge, 1678-89. Son of William Morden, bookseller ( $q . v$.) who in his will, March 4 th, 1678, left him “ all books bound and in quires which I have in Cambridge and those in London and also all my debts " as well as the "Freehold tenement . . . wherein I now dwell ... in the parish of St. Michael's," \&c. We find his name on two works, the third edition of R. Sheringham's The King's Supremacy Asserted, 1682, along with Jonas Hart (q.v.) a relative, and on Beaufrons, 1684. He was buried February 28th, I68\%. [Gray \& Palmer, I18, II9.]

MORDEN (ROBERT), engraver, printer, and bookseller in London, near the Royal Exchange, 1671-1702. An engraver of maps, charts, prints, playing cards etc., who not only printed his productions but sold them. [T.C. I. IO.] His advertisement first appeared in the Term Catalogue of Trin. I67 I [T.C. 1. 80], and he was still in business in I 702 .

MORDEN (WILLIAM), bookseller in Cambridge, 1652-79. See Dictionary, $1641-67$. In his will dated that year [Gray \& Palmer, p. I18] he leaves his business, the freehold house he lived in, along with other bequests, to his son Charles (q.v.). In $166 \mathrm{I}$ he subscribed $f_{4}$ towards the Free and Voluntary Gift to his Majesty, being the largest amount given by a bookseller. Amongst the books published by him are the Philosophical Works of Henry More, 1662, editions of J. Ray's Proverbs, 1670, 1678, John Smith's Select Discourses, I673, \&c.

MORPHEW (JOHN), bookseller in London, near Stationers' Hall, 1706-20 (?). Publisher of political pamphlets, State trials, news-sheets and novels, and one of the principal booksellers of the period. Morphew made his first entry in the Term Catalogues in Mich. I 706, with a shilling book on the war. [T.C. III. 522.] He appears to have set up in the premises previously occupied by John Nutt. On October I2th of that year he issued the first number of The CountryGentleman's Courant. He issued the first number as an advertisement without charge. [Nichols, Lit. Anecd. IV. 82.] Early in 1707 he issued Mercurius Oxoniensis, or, The Oxford Intelligencer, by M. G., and in the same year The Monthly Miscellany. Apart from novels and ephemeral tracts he published much interesting literature. In the Journal to Stella, December I3th, I 7 I , Dean Swift wrote, "I forgot to tell you that the printer told me yesterday that Morphew the publisher was sent for by that Lord Chief Justice [the Earl of Macclesfield], who was a manager against Sacheverell, 
he showed him two or three papers and pamphlets, among the rest mine of the Conduct of the Allies, threatened him, asked him who was the author, and has bound him over to appear next term." Morphew was still publishing in 1720 , when he issued a second volume of novels by Mrs. Manley. [Esdaile, p. 266.]

MORTIER (DAVID), bookseller in London, Erasmus's Head, in the Strand, I70I. Published, with John Smith and Edward Cooper, C. Le Brun's Conference upon Expression, a work illustrated with many engraved plates. [B.M. I403. d. 48.]

MORTLOCK, or MORTLAK (G.), bookseller in London, 1670-1717. See Mortlock (Henry).

MORTLOCK, or MORTLACK (HENRY), bookseller in London, (1) Phoenix, in St. Paul's Churchyard; (2) White Hart, in Westminster Hall. 1660-1 709. See Dictionary, 1641-67. The first of the above addresses was undoubtedly Henry Mortlock's principal place of business, as the stalls in Westminster Hall were only open during term time and were liable to be cleared away in the event of a State trial or other public function. Henry Mortlock is first met with as a publisher in the Term Catalogue of Easter 1670 , when he advertised Phineas Fletcher's Father's Testament as on sale at the White Hart in Westminster Hall. [T.C. I. 29.] At this time he had a relative, G. Mortlock, in partnership with him, and a list of books sold by them at both their shops is found at the end of Joseph Glanvill's Essays, 1676. Dunton has [p. 286] the following note upon Henry Mortlock : "Mr. Mortlack has been Master of the Company of Stationers, and the most indefatigable shop-keeper I have known. He is very exact in trade. He was much assisted by the great Doctor Stillingfleet Bishop of Worcester, and printed [i. e. published] most of his works. He is now pretty much up in years, speaks slow, but speaks seldom in vain." He was one of the most prolific publishers of the time. The last entry under his name in the Term Catalogues is in I 709. [T.C. III، 356.] The date of his death is unknown. G. Mortlock was still in business in 1717, when he published Anthony Blackwall's Introduction to the Classics. [Nichols, Lit. Anecd. I. 133.] John Mortlock, of Nottingham and Newark (q.v.) was no doubt a relative.

MORTLOCK (JOHN), bookseller in Nottingham and Newark, 1695. Doubtless a relative of $\mathrm{H}$. and G. Mortlock of London $(q . v$.), as amongst the books sold 
by him was An Explanation of the Additional Rules for the Genders of Nouns in the Oxford Grammar, "by John Twells, Master of the Free School in Newark. London, Printed for Hen. Mortlock . . . and sold by John Mortlock bookseller in Nottingham, and at his shop in Newark, 1695."

MORY (EDWARD), bookseller in London, Three Bibles in St. Paul's Churchyard, 1695-9. Chiefly a publisher of divinity. He made his first entry in the Term Catalogues in Mich. 1691, and his last in Easter I699. [T.C. II. 378 ; III. 128.]

MOSMAN (GEORGE), bookseller and printer in Edinburgh, $(a)$ his shop on the South Side of the Parliament Close ; $(b)$ his printing house in Hart's Close, over against the Trone-Church. I669(?)-I707 or I708. May be identical with the George Mosman, merchant, who was fined $f_{200}$ (Scots) by the Privy Council on March 8th, 1669, for being at a conventicle, and who in 1685 was again before the Privy Council for a similar offence. In 1690 George Mosman acquired the printing house of the Society of Stationers, in which he had been a partner, and commenced printing on his own account. In this year he published sermons preached before the King's Commissioner by Gilbert Rule and David Williamson; the latter has a list of ten books printed for him. By Act of the Privy Council dated November 21st, 1690, he was appointed Printer to the Church of Scotland and her Assemblies, in spite of Mrs. Anderson's opposition. He died in 1707 or 1708 , and was succeeded by his widow, who printed the Acts of Assembly from I708 to I 7II. [Aldis, p. II8.]

MOSMAN (JOHN), printer in Edinburgh, I 7 7 $7-30$. Printed in partnership with William Brown, and also as John Mosman and Company. In 1724 Mosman and Brown succeeded as assigns of the deceased James Watson, and thereafter they assumed the style of King's Printers.

MOTTE (BENJAMIN), printer and bookseller in London, (I) Aldersgate Street ; (2) Middle Temple Gate, Fleet Street. 1693-1738. Began as a printer in Aldersgate Street, and is first mentioned in the Term Catalogues in 169.3. [T.C. II. 469.] In 1694 he described himself as printer to the Company of Parish Clerks [T.C. II. 520]. He afterwards added publishing to his business, and was the publisher of Gulliver's Travels, which Swift sent to him from Twickenham, where he was staying with Pope, by the hands of Charles Ford. Swift then asked the publisher to deliver a bank-bill of $£ 200$ to his friend Erasmus Lewis, on undertaking publication, but Motte preferred to get back some 
of his money first, and deferred payment for six months. Notte was also the publisher of Miscellanies in Prose andVerse by Swift,Pope, Arbuthnot, and Gay, 1727. Swift maintained friendly relations with Motte, who acted as his London agent. Motte apparently did not give up his printing-office when he took to publishing, as he was included in Negus's list of printers in 1724, as a " high-flyer ". He died on March 12th, 1738, and was succeeded by Charles Bathurst, who had been his partner.

MOUNT (RICHARD), bookseller in London, Postern on Tower Hill, I684-1 722. Believed to have come of a Kentish family. His name appears in the Term Catalogues for the first time in Trin. 1684 as one of the publishers of a work on geometry. [T.C. II. 84.] Dunton mentions him as dealing chiefly in paper and sea books. In 1697 he was one of those from whom tickets for the Kentish Feast in that year could be obtained. Mount was Master of the Company of Stationers for the three years I7I7-19, and Nichols further states that he gave the Clock in the Court Room. He died June 29th, 1722, aged about 70. [Lit. Anecd. III. 599.]

MOUNTFORD, or MOUNTFORT (JOHN), bookseller in Worcester, r690-1 7 Io. In 1690 he published Admiration of Angels at the Salvation of men [T.C. II. 33I], and in 1706 G. Wall's Sermon upon the death of Mrs. Mary Bromley [Bodl. Sermons, 21 (7)] ; in The Post Boy of February 20th, r710, his name occurs in a list of booksellers from whom proposals for the Corpus Poetarum Latinorum could be obtained; the abbreviated list in T.C. [III. 656-7] does not mention him. In I $_{7}{ }_{5}$ he was one of the subscribers to Walker's Sufferings of the Clergy.

MOXON (JAMES), bookseller in London, Strand, Charing Cross, 1668-77; in Edinburgh, in Low Ord's Close at the foot of the Cannongate, r689. 1647-89. See Dictionary, 1641-67. The last entries under his name in the Term Catalogues are in Easter 1677 [T.C. I. 273, 274], when he was still in partnership with Joseph Moxon. George Walker's True Account of the Siege of LondonDerry, Edinburgh, r689, contains an engraved plan with his imprint as given above. [Aldis, p. I18.]

MOXON (JOSEPII), see Dictionary, 164I-67.

MOXON (MORDECAI); bookseller in Manchester, 1679-93. In 1683, Adam Martindale arranged with "Mr. Moxon, bookseller in Manchester", for the 
publication of a pamphlet. [Life, Chetham Soc., 1845, pp. 230-I.] The date of Moxon's decease does not appear, the latest entry referring to the family being the burial of his daughter, March I693. [R. W. Procter, Memorials of Manchester Streets, p. 182.]

MUNNS ( ), bookseller (?) in Cranbrook, Kent. r699. His name appears in the advertisement in the Flying Post, December and, r699, of the Rev. Edward Brown's sermon at the Kentish Feast. It does not occur in the imprint of the book.

MUSDEN (WILLIAM), stationer and bookseller (?) in London, Hen and Chickens, Cheapside, I680. Sold a pack of cards representing the Popish Plot. [T.C. I. 384.]

N. (c.), bookseller in London, 1675-7. An unknown bookseller who sold the lives of criminals, etc., such as The Holborn Hector, "printed for C. N. and are to be sold in the highway to Tybourn ", I675. [Haz. I. 217.]

NEAL (sIMON), bookseller in London, ( $\mathbf{I}$ ) Three Piggeons in Bedford Street, $(a)$ in Covent Garden, (b) over against the New-Exchange, I674-87; (2) Angel Court, St. Martin's Lane, near the Church, r687-9I ; (3) in the Long Walk, near Little Britain, r69r-4. 1674-94. Published several plays and romances as well as some historical works. He also dealt in cheap manuals of devotion and Church politics ; but his output is of a secular character to an extent very unusual for the time. His first and last entries in the Term Catalogue are in 1674 and 1694 . [T.C. I. 163, Ir. 527.]

NEEDHAM (BENJAMIN), bookseller in London, (r) Black Raven, Duck Lane ; (2) Crown, Duck Lane. I674-85. Known from the imprints to three books : (1) B. Pererius, The Astrologer Anatomiz'd, I674; (2) Il Putanismo di Roma, translated by I. D., I678 ; (3) Elkanah Settle, Heroick Poem on the Coronation of James II, 1685. [T.C. I. 165,332 ; II. I27.] He had moved to the Crown by 1678 .

NEEDHAM (GWYN), printer in Dublin, Crane Lane, I718-25. Most of his extant production consists of single sheets.

NEEDHAM (RALPH), bookseller in London, Little Britain, I665-72. See Dictionary, 1641-67. In the Term Catalogue for Trin. 1672, his name occurs as joint publisher with Joseph Clarke of a manual of divinity, compiled by the Archbishop of York. [T.C. I. I09.] 
NEGUS (SAMUEI), printer in London, Silver Street near Wood Street, 1701 (1722)-24. Chiefly remembered as the compiler in 1724 of a list of the various printing houses in London, classified by their political principles, as "Known to be well affected to King George", "Nonjurors", "Highflyers", \&c. He also gave a list of the various newspapers appearing in London, with the names of their publishers or printers. In the introductory epistle he states that he had been a printer for twenty-three years, but a master only two, and that he found great difficulty in making a living. He was rewarded by a carrier's place in the Post Office. Nichols [Lit. Anecd. 1. 288-312] reprints the whole document.

NEILL (PATRICK), printer in Belfast, 1696 (?)-1702. Said to have come to Belfast in 1696 , but his carliest extant imprint is dated 1699 , and appears as Patrick Neill \& Co., in that year and in 1700 , and in 1701 and 1702 as Patrick Neill alone. All the output of his press was Puritan divinity.

NELME, or NELMES (HENRY), bookseller in London, (a) Royal Exchange, (b) Leg \& Star, Cornhill, r696-7. Apprentice to P. Parker, who left him his business. Dunton [p. 229] says that Nelme came to "an untimely end". He published Evangelium Medici, by Dr. Bernard Connor, I697 [B.M. Ir70. c. $20(\mathrm{I}, 2)]$, and two other religious books, also An Impartial History of the Plots

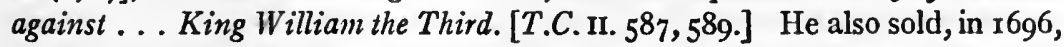
"Setts of Cutts for Bibles in Folio, Quarto and Octavo, curiously engraven on copper, containing near 200 in number ... somewhat cheaper than usually, viz. the Folio at 9 s. the Quarto $7 s$. and $6 d$., the Octavo and Small Quarto at 6s. perfect." [T.C. II. 597.]

NELSON (NORMAN), bookseller in London, Gray's Inn Gate in Holborn, I680. Publisher of and dealer in law books. Also described as a "vintner" in an action for debt brought against him in 1680 by Robert Turner. [C.P.R., Mich. 33, Chas. II, 2996, m. 353.] This seems to be a very late survival of a mixture of trades that was common enough in the sixteenth century.

NEVILL (JOSEPH), bookseller in London, Greyhound in St. Paul's Churchyard, 1660-72. See Dictionary, 1641-67.

NEVILL (SARAH), bookseller in London, Archimedes in St. Paul's Churchyard, 1677. Possibly the widow of Joseph Nevill (q.v.). Published The Judgement of Mr. Francis Bampfield. [T.C. I. 270.] 
NEWBOLT (WIIIAM), printer in London, 1684-17r4. This is no doubt the person described in the London Gazette of September Ist-4th, 1684, as "William Newbolt, aged 22 years, or thereabouts, a well set middle sized man ... run away from his master on Monday the Ist instant ; and is supposed to be lurking about the City of London. Whoever shall apprehend the said William Newbolt, and bring him to Nat. Thompson, Printer at the Entrance into the Old Spring Garden, near Charing Cross, shall have a Guinea reward, and their Charges born." In I69o he was indicted for printing His Majesty's most gracious Declaration to all his loving Subjects, a Jacobite broadside found scattered about the streets of London. One Edward Buttler was associated with him and both were described as printers. The printing press was said to have been kept at one Douglas's at Westminster. [MS. Harl. 6846, fol. 37r-9.] He subscribed in I 7 44 for Walker's Sufferings of the Clergy.

NEWBOROUGH (M.), bookseller in London, Golden Ball, St. Paul's Churchyard, r707. Probably the widow of Thomas Newborough (q.v.). Appears to have taken Maurice Atkins into partnership, and they, with J. Nicholson of the King's Arms in Little Britain, published the third edition of Boyer's Wise and Ingenious Companion, French and English, a school book, which they advertised in Easter, r 707. [T.C. III. 548.]

NEWBOROUGH (THOMAS), bookseller in London, (I) Star, St. Paul's Churchyard; (2) Golden Ball, St. Paul's Churchyard. r686-r707. One of the leading men in the book-trade, and concerned in many of the more important publications of the time. Dunton spoke of him [p. 229] as a good Churchman, " a thoughtful just man, and knows how to encourage a good Author, for none can think that the 'Supplement to the Historical Dictionary', written by the learned Collier, is made at a small charge." Newborough's name is found in the Term Catalogues for the last time in Easter, I707. He was succeeded by M. Newborough, possibly his widow (q.v.), and Maurice Atkins. [T.C. III. 537.]

NEWCOMB, or NEWCOME (RICHARD), bookseller and printer in London, Wine-Office Court, Fleet Street, I69I-I 7I3. In r69r he published $A$ Voyage round the World, or a Pocket Library, 3 vols., the translation or editorship of which is ascribed to John Dunton. [T.C. II. 338.] His name is also found in I 7 I3 as the printer of a pamphlet entitled, What sort of a Peace is this? [B.M. I8 8 ०. C. $6\left(20^{*}\right)$.] 
NEWCOMB (THOMAs). See Dictionary, $164 \mathrm{r}-67$. He printed numbers of plays for Herringman.

NEWMAN (DORMAN), bookseller in London, (r) King's Arms in the Poultry, near Grocers' Alley; (2) Surgeons' Arms, Little Britain; (3) Ship and Anchor $(a)$ at the Bridge-Foot, (b) near the Bridge Gate, on Southwark Side. 1665-94. See Dictionary, 1641-67. One of the largest publishers of his day; but owing to speculation he went bankrupt in 1694. [London Gasette, September 24th-27th, r694.]

NEWMAN (HUGH), bookseller in London, (I) Kings Arms, Poultry ; (2) Grasshopper in the Poultry. 1692-1703. Served his time with Dorman Newman (q.v.), and was nearly related to him. [Dunton, p. 2I5.] His first entries in the Term Catalogues appear in Easter 1692, when he published The Life of Richard Baxter and a poem called The Jacobite Conventicle. [T.C. II. 402-3.] He continued publishing until Trin. I 703. [T.C. III. 355.]

NEWTON (ELIZABETH), bookseller at Portsmouth, r 708.

NEWTON (JoHN), bookseller in London, ( 1 ) Three Pigeons in Fleet Street, 1688 ; (2) near the Sugar Loaf in Bell Alley, Coleman Street, r689-96. I688-96. Began business in 1688, by the publication of Religio Laici and an edition of Don Quixote. [T.C. II. 233-4.] His second address is found on a poetical broadside of 1689 on the coronation of William and Mary. [B.M. C. 20. f. 2 (I8I).] He is described by Dunton [p. 233] as a man "full of kindness and goodnature and affable and courteous in trade". His name is not found in the Term Catalogues after Hil. I698. [T.C. III. 55.]

NEWTON (w.), bookseller in London, (a) Little Britain, over against Bartholomew Close Gate, $(b)$ near the Pump. 1694-I 7 Ir. Newton's name first appears in the Term Catalogues as the publisher of a divinity pamphlet in Easter 1694. He also sold Dutch editions of the Classics. [T.C. II. 500 ; III. 494.] In I III his name occurs as one of the publishers of R. Bradley's Treatise of Succulent Plants, in an advertisement in The Post-Man of February 3 rd. He appears to have been in partnership then with Thomas Shelmerdine. Their address is given as in Little Britain; the two addresses given above therefore probably refer to the same house. 
NEWTON (wILlIAM), bookseller in Blandford, Dorset, 1670. Publisher in I670 of the Rev. John Straight's Sermon . . . at the Assizes held at Dorchester in I669. [Mayo, Bibl. Dorset. p. 52.]

NICHOLSON (ANTHONY), bookbinder in Cambridge, Six Bells, I667-80. Son of Anthony Nicholson [see Dictionary, $164 \mathrm{I}-67$ ], who died in April 1667 [see his will in Gray \& Palmer, p. I04], at which date Anthony jun. was living at the "Six Bells". The inventory of his goods, dated February 2nd, I680, mentions " his tooles in the shop x." (Gray \& Palmer, p. 12I). Robert Nicholson, the bookseller, was his brother.

NICHOLSON (JOHN), bookseller in London, (I) King's Arms, Little Britain ; (2) Queen's Arms, Little Britain. I686-I 7 I5. First heard of in the year I686, when he advertised a pack of heraldic cards. [T.C. II. I8I.] Ten years later he was associated with $\mathrm{T}$. Newborough in the publication of a Latin Testament for the use of scholars [T.C. II. 603], but his place of business is not mentioned until 1697 . From that date he was a prolific publisher of works of all kinds and made frequent use of the Term Catalogues. Dunton [p. 209] has this record of him : "His talent lies at projection, though I am thinking his Voyages and Travels will be a little posthumous. He is usually fortunate in what he goes upon. He is a man of good sense. . . . He purchased part of my stock, when I threw up all concerns in trade ; and I ever found him a very honest man." Amongst Nicholson's more notable publications may be mentioned Thomas Gage's New Survey of the West Indies, which he shared with Newborough, and advertised in Easter I699 [T.C. III. I30], and The Index Villaris, published with Newborough and others in 1700 . [T.C. III. I 77.] He also shared in most of the large ventures of the time. He did not change his sign to the "Queen's Arms " in 1 702, as might be supposed ; for he still called it the " King's Arms" in I 707, when he published, with Robert Knaplock, Hickes's edition of the Works of à Kempis; there is a list of books at the end of vol. II of this. In I715 William Bowyer printed for him Pearson's Exposition of the Creed. [Nichols, Lil. Anecd. I. 109.]

NICHOLSON (ROBERT), bookseller in Cambridge, I662-89. [See Dictionary, I64I-67.] Son of Anthony Nicholson (d. 1667) and succeeded to his father's business a few years before his death. Alderman Newton's Diary, ed. J. E. Foster, under I687 has "I I Sept. Sunday, Sarah Nicholson, daughter of Robert Nicholson of Cambridge stationer, marryed at Trinity College Chapell by 
Dr. Wolfran Stubb unto Robert Dawney of the Citty of Norwich worsted weaver son of Anne Keeling of Norwich widow". With others he drew up the inventory of the goods of John Field, r668, Robert Gee, r68r, William Graves, 1686, and E. Beeching, 1689. [Gray \& Palmer, p. 107.] A Poem attempting something upon the Rarities of the renowned University of Cambridge was printed for him in London in r673. [Bowes, Cambridge Books, no. Iro (b).]

NICKS(JoHN), bookseller in London, White Hart in St. Paul's Churchyard, 1722. Published William Burscough's sermon, The Revolution recommended to our memories, preached at St. Peter's Westminster on Nov. 5 th I7 $_{5}$, I 722. [B.M. 694. f. 7 ( 17$)$.]

NICOL (JAMES), printer in Aberdeen, his printing house in the north side of the Castle Gate ; his shop in the end of the Broad Gate. I710-32. In December I 7 Io Nicol succeeded to the widow of John Forbes, younger, whose daughter he had married, as printer to the town and University. On his retirement from business in $173^{6}$ he was succeeded by James Chalmers. [See J. P. Edmond, The Aberdeen Printers.]

NISBETT (HENRY), bookseller in Derby, I704-II. In I 704 he published a sermon preached at St. Mary's, Nottingham, by Anthony Blackwall, and in 1706 an edition, also by Blackwell, of Theognis. The latter was printed by J. Heptinstall and sold by Henry Mortlock in London. [T.C. III. 535.] Blackwall was "Moderator" at Derby School. In I I I he printed a sermon preached by H. Harris at Derby on July 9th, I 7 Io.

NOBLE (THOMAS), printer in Edinburgh, 1686. In the employ of James Watson. [Aldis, p. Ir8.]

NORCOTT, see Northcott.

NORMAN (s.), bookseller in London, 1682. New News from Tory-Land and Tantivy-Shire was printed for S. Norman in 1682. [B.M. 8122. aaa. 20 (12).]

NORMAN (THOMAs), bookseller in London, Pope's Head in Fleet Street, (a) near Fleet Bridge, $(b)$ near Salisbury Court. 1679-80. Dealer in plays. His name appears in Mich. 1679, and again in Hil. 1680. [T.C. 1. 370, 385.]

NORMAN (WILLIAM), bookseller and bookbinder, in Dublin Dame's Street, r682-r703. In 1682 he sold $A$ Judgement of the Comet. In 1683 he is described as " bookbinder to the Duke of Ormond ". Publisher of Sir James 
Ware's Hunting of the Romish Fox in r684. [T.C. II. 74.] In 1686 he is mentioned in a list of those booksellers from whom prospectuses of a reprint of the works of King Charles I could be obtained. [T.C. II. I85.] He was printer of the Votes of the House of Commons in Ireland in r692. [Burney, I04 A.] In 1694 he published a sermon by St. George Ashe, printed by Joseph Ray. He was Master of the Booksellers' Company in Dublin, and was a great amateur gardener. [Dunton, pp. 238, 565-6.]

NORRIS (JAMEs), bookseller in London, King's Arms, without Temple Bar, I682-4. Appears to have been related to the Rev. John Norris, Fellow of All Souls, Oxford, and Rector of Aldbourne in Wilts. Issued a broadside entitled Erra Pater's Prophesy, or Frost Faire, 1682 ; the whole of this is engraved. [B.M. C. 20. f. 2 (158).] His last advertisement in the Term Catalogues appeared in Mich. 1694, when he issued a translation of Xenophon's Cyropaedia. [T.C. II. 96.]

NORRIS (THOMAS), bookseller and bookbinder in London, (r) St. Giles without Cripplegate; (2) Looking Glass on London Bridge. 1695-1732. In the course of an action heard in the Court of Chancery Thomas Norris, bookbinder, admitted having bought about five or six hundred psalters and the same number of primers in 1695 , but declared that they were printed at Oxford. Some of these he sold to a Mr. Gandy, haberdasher in Milk Street. [P.R.O. Chan. Proc. before I $_{14}$, Collins 486/roo.] In I 1 I Thomas Norris moved to the premises on London Bridge previously occupied by Josiah Blare. There he carried on the joint trades of bookbinder and bookseller, publishing many chapbooks and ballads as well as all kinds of nautical books. He is more than once mentioned in the Churchwardens' Accounts of St. Magnus. In I 720 he was paid three shillings for a Bible, and in $\mathrm{r}_{\mathbf{7 2 2}-3}$, being then one of the churchwardens, he made the following entries: "paid myselfe for a large Folio Bible for the Church, very finely bound. Delivered Decr. 24th, I720 $f^{6}$ I Is. $3^{d}$. Paid ditto for five large common prayer, 4 for the churchwardens, and $\mathrm{I}$ for the clerk, and new binding two old Bibles $f_{3} \mathbf{I}_{3}$ s. 9d." Norris retired from business soon after this and settled at Highgate, where he died in I732, his will being proved on June 7 th. He left a son William, and bequests to the following stationers of London, Daniel Mead of Snow Hill, Richard Ware and John Wilford. [P.C.C. I74, Bedford.] Gent [p. II3] says that Norris's daughter (or perhaps daughter-in-law) Elizabeth married, as her 
second husband, in about 1720 , Edward Midwinter, the printer in Pye Corner. Gent calls Norris " a very rich bookseller on London Bridge, whose country seat was at Holloway".

NORRIS (w.), printer and bookseller in Taunton, 17 r8. Set up the first press at Taunton; the first piece printed and sold by him there was a sermon by F. Squire entitled The Lawfulness of taking Oaths, I 7 18. [Allnutt,p.301 ; Bodl.]

NORTH (JOHN), bookseller in Dublin, r682. Sold $A$ Judgement of the Comet, I682.

NORTHCOT (RICHARD), bookseller in London, next Peter's Alley in Cornhill ; and at the Mariner and Anchor upon Fish Street Hill, near London Bridge, I677-91. May have been related to Thomas Northcott or Norcott (q.v.). Richard was chiefly a publisher of theological works between the years named. NORTHCOTT, or NORCOTT (THOMAS), printer in London, George Yard, Lombard Street, 1684-90. Printer of George Fox's Journal. First mentioned in the Monthly Meetings on June 25th, 1684. Dunton [p. 292] refers to him as "friend " Northcot. In addition to Quaker literature, he printed in 1686 Patrick Ker's Grammatista [T.C. II. I80], and in 1690 Mankind displayed. [T.C. II. 304.]

NORTON (ROGER), see Dictionary, 1641-67.

NOTT, see also Nutt.

NOTT (WILlIAM), bookseller in London, Queen's Arms, Old Pall Mall, 1687-9o(?) See Dictionary, x641-67. A copy of The petition of the Irish Bishops to Lord Tyrconnell was addressed "For Mr. William Christopher", to be left with Nott, in r687. [Bodl. MS. Clar. 89, f. r05.] His last entry in the Term Catalogues was in I689. [T.C.II.274.] For a possible reference to him in 1690 see Nutt (J.).

NOWEL (N.), bookseller in London, Duck Lane, r681-1703. In 1681 he published Rome's Follies or, the Amorous Fryars, A Comedy. Dunton describes him [p. 2II] thus: "Mr. Nowel is a first-rate Bookseller in Duck-Lane, has a well furnished shop and knows books extraordinary well, which he will sell off as reasonably as any man. I have always reckoned him among our ingenious Booksellers." He does not appear in the Term Catalogues, and was probably a retailer only.

NUTT (ELIZABETH), printer in London, in the Savoy, r720-3r. Printed T. Cox's Magna Brilannia, 6 vols., 1720-31. She was joined by R. Nutt in 1724, having 
printed vols. I and 2 alone in 1720 . These two volumes were sold by M. Nutt (q. v.). "Nutt, in the Savoy," is classed by Negus as a " high-flier".

NUTT (JOHN), printer and bookseller in London, (I) (a) near Stationers Hall, or Juxta Basilicam Stationariorum, (b) in Stationers' Court ; (2) in the Savoy. 1690 (?)-1710 (?). The Rev. Rowland Davies, Dean of Ross, records in his Diary under date April 3rd, r69o: "Then I went to my brother and with him into the City, having at Nott's bought this book and a case for sermons for three shillings." [Camden Soc. Pub. no. 64, 1857, p. 97.] This entry may possibly refer to William Nutt, the bookseller of Pall Mall, although the latest reference to him in the Term Catalogues is r688-9. On the other hand, if the Dean really made his purchase in the City, then the reference must be to John Nutt, who is not otherwise known to have been established there until 1698. [T.C. III. 95.] Dunton again has added to the confusion. He says of "Mr. Nutt" : "He was originally a printer, and lived with Mr. Jones in the Savoy for many years . . . and now gives as great content to those that employ him as any publisher whatever." This was written in 1703 , but John Nutt, the printer in the Savoy, is not mentioned in the Term Catalogues as a printer until 1 708. The fact seems to be that Nutt gave up bookselling about 1708 to resume his earlier trade as a printer. His last entry in the Term Catalogues is Moll's Atlas, I709, printed by him. [T.C. III. 651.] He was apparently succeeded by Elizabeth Nutt $(q . v$.$) , probably his widow. His most famous$ publication was Swift's Tale of a Tub, I704 and reprints to I 7 Io.

NUTT (M.), bookseller in London, in Exeter Exchange in the Strand, I 720. See Nutt (Elizabeth).

NUTT (R.) See Nutt (Elizabeth).

NUTT (WILliaM), see also Nott.

OAKES (EDWARD), printer and bookseller in London, Well-Yard, near West Smithfield, $1663-72$ (?). See Dictionary, 1641-67. In 1670 he printed (as E. O.), for Francis Haley, The Opinion of Witchcraft Vindicated, by R. T., and in I67 $\mathrm{I}$ he published with Haley Dean Lloyd's Legend of Captain Jones. [B.M. 1077. b. $3^{8 .]}$ In the 1675 list of Printing Houses, it is stated that this house had been "bought in " by the Company of Stationers, "since I672."

OGILBY (JOHN), see Dictionary, 1641-67.

OGSTON (ALEXANDER), bookseller in Edinburgh, in the Parliament Close, I685-8. In 1688 he was threatened for selling anti-popish books, and in the 
same year Mrs. Anderson seized some octavo Bibles he had imported from London. Amongst his publications were G. Scot's Model . . Government . . . East-New-Jersey, I685, S. Colvill's Mock-poem, or whigs supplication, 1687, and Bibliotheca Universalis, 1688. He was succeeded by his widow Martha Ogston (q.v.). [Aldis, p. I18.]

OGSTON (JAMES), bookseller in Edinburgh, c. I 7 I4. Will registered August 3Ist, I7I4.

OGSTON, afterwards STEVENSON (MARTHA), bookseller in Edinburgh, in the Parliament Close. 1688-1738(?). Widow of Alexander Ogston, whom she succeeded. Her will, under the name of "Martha Stevenson, relict of Alexander Ogston, bookseller in Edinburgh ", was registered on January 2oth, 1738. [Aldis, p. I8.]

OKES, see Oakes.

OLIVER ( ), Mrs., bookseller in Norwich, I7II-25. Perhaps the widow of Francis Oliver, who ceased publishing in 1712 ; if so, her publishing in the last year of his activity might be accounted for by his illness. [N. \& $Q$., Ioth Ser., v. 184.] It seems very improbable that this Mrs. Oliver is identical with Mrs. Elizabeth Oliver (q.v.). No address is given in $N$. \& $Q$.

OLIVER (ELIZABETH), bookseller in Norwich, Cockey Lane, I689-I704. William Oliver $(q . v$.$) was succeeded in 1689$ by his widow, at whose house and for whose benefit Edward Millington of London held an auction, probably of Oliver's stock, on December 16th. [London Gazette, November 28thDecember 2nd, I689; B.M. 82 I.i. 2 (4).] Three sermons, by J. Brett, J. Jeffery, and J. Robinson, all of $\mathrm{I}_{704}$, bear her imprint [Quinton, Bibl. Norf., pp. 54, 235 ; Bodl. Sermons, 17], after which she disappears. Francis Oliver, presumably her son, began business at the same address in 1704 .

OLIVER (FRANCIS), bookseller in Norwich, Cockey Lane, I704-I2. Probably a son of William Oliver, whose widow he succeeded in 1704 , between which year and 1712 he is known to have published five books, at least four of them being sermons; most of them were printed for him by Freeman Collins. [T.C. III. 391 ; Quinton, Bibl. Norf., pp. 94, 528-9, 65, 71, 2.] His relationship to the Mrs. Oliver (q.v.) who was in business in Norwich from 17 I 1 is obscure.

OLIVER (SAMUEL), bookseller in Norwich, I692-3. Probably a son of William Oliver. His publications are confined to two years, and consist of Peter 
Choavin's De Naturali Religione, 1693 , and four sermons, one of which was printed for him by John Russell, printer to the University of Cambridge. [Quinton, Bibl. Norf., pp. 444, 548; T.C. II. 408, 45I, 455.]

OLIVER (WILlIAM), bookseller in Norwich, 1663-89(?). See Dictionary, 1641-67. Publishing at least as late as 1680 , when he had Three Sermons by C. Robotham printed for him in London [Quinton, Bibl. Norf., p. 440], and perhaps as late as 1689 , at the end of which year the widow Oliver had an auction, probably of her husband's stock. His son John was admitted to St. John's College, Cambridge, on July 8th, r681. [Admissions to St. John's College, II. 84.]

ONELY, see Onley.

ONLEY (WILlIAM), printer in London, (I) Little Britain ; (2) Bond's Stables, near Chancery Lane. I697-I 709. A printer of ballads, broadsides, and chapbooks for various London publishers. But one of his first productions was a more literary work, the second edition of D'Urfey's Cinthia and Endimion, which he printed in 1697 for S. Briscoe and R. Wellington. Dunton's character-sketch of him [p. 248] lays stress on the rapidity of his work and his popularity with the journeymen printers, and tells us that " being very ingenious, by his own projections he keeps two printing houses constantly at work ; one in Little Britain, and the other in Bond's stables, near Chancery Lane". John How, I 709, asks : "How many copies of other mens has Mr. Onely printed, and whether the booksellers of London, particularly those on the Bridge, were not his customers for the said books? What Mr. Keble recovered of Mr. Onely when he sued him for printing 'The Week's Preparation'? " [Some Thoughts on the Present State of Printing and Bookselling, p. 10.] Onley frequently used his initials only, and very rarely dated his books.

ORME (JAMES), printer in London, 1692-8. This printer was employed by several London publishers, including R. Basset, R. Bentley, A. Bosvile, Thomas Jones, Randal Taylor, and R. Wellington. He printed in 1692 Elkanah Settle's Triumphs of London, in 1697 Edward Filmer's tragedy, The Unnatural Brother, in the same year Mary Pix's comedy, The Innocent Mistress, and in 1698 Crowne's tragedy, Caligula.

ORME (JOHN), bookbinder in London, 1681-2. In Mich. 33 Chas. II he brought an action in the Court of Common Pleas against William Hare for false imprisonment. [C.P.R. 2997 , m. 448 r.] 
ORREL (THOMAS), bookseller in London, Hand and Scepter, Fleet Street, I678. In 1678 he published (I) a play, The Rambling Justice, (2) a miscellany of verse, Oxford Drollery, and (3) Words made Visible. [T.C. I. 320, 330, 332.]

OSBORN, or OSBORNE (JOHN), bookseller in London, (I) Oxford Arms in Lombard Street ; (2) Paternoster Row. 17 I I-39. First met with in partnership with T. Varnam, who succeeded to the business of Thomas Guy [T.C. III. 667], and in 1725 he is found publishing with his son-in-law, T. Longman, at the Ship in Paternoster Row. Nichols says that he became Master of the Company of Stationers in 1735 and died on March 13th, r739. [Lit. Anecd., III. 6or.]

OSBORN, or OSBORNE (ROBERT), bookseller in Exeter, near the Bear, r693-6. He was local agent for the sale of two sermons: (r) The Pastor's Care and Dignity, and the peoples Duty. A sermon preached ... at Taunton, by G[eorge] T[rosse], r693. [Gilling, Life of Trosse, p. I27; Dredge, Io.] (2) IIoเ $\mu v \eta$ Фudakiov, The Pastor's Charge and the Peoples Duty, A Sermon, by Samuel Stoddon, 1694. [Dredge, Io.] In 1696 he issued $A$ Sermon preached in ... Exeter on the Thanksgiving Day. [Dredge, 94.] This had a leaf with a list of books printed for him.

OSBORNE (THOMAS), bookseller in London, Gray's Inn, near the Walks, I 702-43. In Trin. I702 he sold an edition of Glanvil's translation of Fontenelle's Plurality of Worlds. [T.C. Im. 313.] Osborne died in 1743 , and was succeeded by his son Thomas. It was the latter who bought the Harleian Library and employed Oldys and Johnson to catalogue it; his relations with the latter have made him much better known than his father, who was nevertheless one of the leading publishers of his time. [D.N.B.]

OSWALD (ANDREW), bookseller in London, Oxinden Street, I686. Thomas Newcomb printed for him His Majesties . . Letter to the Parliament of Scotland, r686. [B.M. T. I00* (173).]

OVENS (MARY), bookseller at Kannershmead (?) in Wales, r699. Sold schoolbooks, which she purchased of John Minshull, bookseller in Chester. [Library, and ser. IV. $373^{-83}$.]

OVERTON (HENRY), bookseller and printseller in London, White Horse without Newgate, 1707 -9. Son of John Overton. His father sold him his stock of maps, prints, and engravings on his marriage in 1707 ; he is mentioned in the 
Term Catalogue of 1709. [T.C. III. 647.] He had taken his brother Philip (q.v.) into partnership 1709.

OVERTON (JOHN), bookseller and printseller in London, (I) White Horse in Little Britain next door to Little St. Bartholomew's Gate; (2) White Horse without Newgate. 1667-1707. See Dictionary, 1641-67. In 1671 he moved to the White Horse without Newgate, the shop previously occupied by Henry Overton ( $q . v .$, Dictionary, $164 \mathrm{I}-67$ ), who was perhaps his father. John Overton established a good business in prints, maps, and engravings of all kinds, and was the principal vendor of mezzotints of his day. In 1707 , on the occasion of his son Henry's marriage, he sold him his stock-in-trade and retired in his favour. He died in $\mathrm{I} \mathrm{I} 3$, his will being proved on April and. Besides Henry $(q . v$.) he left three other sons: Thomas, who went to America, James, and Philip (q.v.).

OVERTON (PHIII), bookseller and printseller in London, White Horse without Newgate, 1709. Stated in Arber's index [T.C. III. 728] to have sold G. de L'Isle's map (Theatrum Historicum); the entry of it on the page referred to [III. 647] does not contain his or his brother's name, but the map does.

OWEN (JOHN), bookseller in Oxford and Cambridge, 1 yor-10. On October 4th, I 701 , the University of Cambridge entered into an agreement with John Owen of Oxford, stationer, for the production of an edition of Suidas's Lexicon in three volumes folio; Owen to pay $\ell^{1}$ Ios. $6 d$. per sheet, paying for the first roo copies when the second roo were ready for delivery, and so on, six months credit being given for the last 200, the whole stock to remain at the Press as security till paid for. Owen being unable to fulful his part of the engagement, on April 16th, 1 703, a Grace was passed for a new contract with Sir T. Jannson in place of John Owen, insolvent. Owen's failure placed the University in difficulties with regard to the work, and correspondence and negotiations respecting it went on for a period of forty years. The work was published by the University Press in 1705, when the degree of LL.D. was given to the editor. Correspondence concerning the work will be found in the Correspondence of Dr. Richard Bentley. Other works were arranged for by Owen between r 7or-ro, and some bear his name as "typographus", which may only mean "publisher". In one of these, Simon Ockley's Introductio ad Linguas Orientales, 1706, is a long dedication to Elias Abenaker of London, Gent., in which he speaks of his having been induced, by "specious promises", 
apparently by Bentley, ("a Person of an high Character, and a pretending Encourager of Arts and Sciences, and Printing in particular ") to leave Oxford for Cambridge, and acknowledges the "noble assistances you have supplied me with, to raise my Fortune in the World, and put my Affairs into a prosperous and flourishing Condition." In 1703 he published volume 1 of C. Cellarius' Notitia Orbis Antiqui, sive Geographia Plenior, but volume in bears the imprint "Amstelaedami Casparus Fritsch", and was issued in r7o6. He was in Holland in 1706, and was entrusted with books and letters from Rheland and L. Kuster to Dr. Bentley and others. The last book to bear his imprint is a Sallust of 17 ro. [R. Bowes's Cambridge Printers, p. 312, Cambridge Books, and Notes on the Cambridge University Press, 17or-7, in Camb. Antiq. Soc. Communications, vi., 362-7 ; Bentley's Correspondence, ed. Chr. Wordsworth, 1842 ; S. C. Roberts, Hist. of the Camb. Univ. Press, pp. 87-9.]

OXLAD (FRANCIS), senior, bookseller and bookbinder in Oxford, I665-73. See Dictionary, 1641-67. Still publishing in 1673 , when he published a folio edition of Juvenal. [Haz.II.323.] Stephen Fletcher was one of his apprentices. [Hearne, Collections, IX. 348.]

P. (G.), bookseller in London, 1687. A true Relation of the Great Thunder . . . at Alvanley was printed by D. Mallet for G. P., I687. [Cooke, Bibliotheca Cestriensis, p. 24.] G. P. may be George Pawlett or G. Powell, or less probably George Parker, who is only known to have been in business in 1683 .

PAGE (DIXY). See Dictionary, 1641-67. He was still publishing in 1672 , when in company with T. Passinger and B. Hurlock he issued a chap-book, The History of the Five Wise Philosophers. [Haz. 1. 325.]

PAGE (HUMPHREY), bookseller in Nantwich and Chester, r685-r711. In 1685 his name occurs in a list of booksellers who sold a patent medicine, given at the end of M. Bromfield's Brief Discovery of the ... Scurvy. [N.\& Q., I I ser. XI. 45.] He was then at Nantwich. He was still in business in I I I I, when he published at Chester a sermon by J. Oliver. [B.M. 225. h. I (I 5).]

PALMER (EDMUND), bookseller in Stamford, r 706. His name occurs in a list of provincial booksellers. [N. E $Q$., Io ser. v. 242.] He had a son Benjamin, who was entered at St. John's College, Cambridge, on July 8th, 1704, and took his D.D. degree in 1725 . [Mayor's Admissions to St.John's College, Pt. II, p. I 72.]

PALMER (GEORGE), bookseller in London, Black Spread Eagle, without Temple Bar ; [(2) King and Duke of York's Head, Strand, near Arundel House (?) 
r670.] Published at the Black Spread Eagle in 1670 The Lovers' Logick, an English translation of de Callières' l'Amant Logicien. [Haz. II. I62; T.C. I. 21.] The second address is given by Arber in the index to vol. $i$ of the Term Catalogues, but without apparent reason, as he gives only the one reference.

PALMER (R.), bookseller in London, Crown, without Temple Bar, I7r6. Publisher of a chap-book called Love's Perpetwal Almanack, . . . by Amorous Gay. [Haz. I. 266.]

PALMER (SAMUEL), bookseller in London, 1685-6. Apprentice to John Dunton and went with him to America. He was "very honest and diligent", but "preferred shooting to bookselling", so about 1686 he gave up the trade, and obtaining a post in the Army, met his death by drowning. [Dunton, pp. 87, II2, I29-130.]

PALMER (SAMUEL), bookseller in Gloucester ; and in Tewkesbury, near the Tolsey, 1685. Probably a relative of Thomas Palmer, stationer, of Tewkesbury, who died in March $16 \frac{79}{80}, q . v .$, Dictionary, $1641-67$. His name occurs in a list of booksellers selling a patent medicine given at the end of M. Bromfield's Brief Discovery of the Scuryy, 1685. [N. \&० Q., II ser. XI. 45.]

PALMER (SAMUEL), printer in London, Bartholomew Close, I723(?)-32. The exact date at which Palmer set up is unknown. He was probably at work in 1700 , but we first hear of him as printing Sternhold and Hopkins for the Stationers' Company in 1723. Franklin, when he came to England at the end of 1724 , was employed in Palmer's printing house, which he calls famous. [Autobiography, ed. J. Bigelow, I909, p. 91.] He is chiefly remembered as part author of a very bad $H$ istory of Printing. Originally his intention was to write a book about the practical part of the art; but he was deterred by the fears of the trade that he would betray secrets, and turned his work into a history of printing, which was issued in parts but was not completed at the author's death. Although his business was a large one, Palmer eventually became bankrupt, and died on May 9th, 1732. His History was continued by George Psalmanazar. The work as a whole was published in 1732 . This History was worthless, and has been treated with contempt. J. Lewis, writing to Ames, described Palmer as " a good printer, but a bad historian, ignorant, careless and inaccurate". [Nichols, Illustr. of Lit. IV. 174.] His merits as a printer caused him to be selected to supervise a private press set up by some 
of the Royal Family at St. James's in r731. The following notice of his death appeared in The Norwich Gazette, May 6th-13th, 1732 : " Last Thursday died the learned and ingenious Mr. Samuel Palmer, printer of the Grub Street Journal, and author of the History of Printing. He has not left his equal, either as a printer or as a scholar." He printed the Grub Street Journal in $173^{1}$ and 1732 , in partnership with J. Huggonson. [B.M. Burney.]

PALMER (THOMAs), see Dictionary 1641-67.

PARDOE (MARK), bookseller in London, Black Raven, Strand, over against Bedford House, $1677-86$. Hazlitt records a book as published by him in 1677 . The earliest reference to him in the Term Catalogues is in 168 o. [T.C. I. $3^{85}$.] A short list of books, several of them scientific, printed for him by 1680 is to be found in The Novels of Elizabeth, by Madame d'Aulnoy. [B.M. G. 1516.] In 1682 he published a Latin edition of Hobbes's Leviathan. [T.C. I. 473.] His last entry in the Term Catalogues was in 1686. [T.C. II. I72.]

PARK (JOHN), newsvendor in Edinburgh, at the Fountain Well, 1712. The Evening Post, no. 225, May 13th-15th, 1712, has the imprint : "Edinburgh : printed by John Moncur, and sold . . . by John Park at his stand at the Fountain Well, where advertisements are taken in, 17 I2." [W. J. Couper : The Edinburgh Periodical Press, I. 253.]

PARKER (ANDREW), printer in London, Goswell Street, 1724. Parker, of Goswell Street, is included by Negus among printers "known to be wellaffected to King George". His Christian name is supplied by Nichols in his Index. [Lit. Anecd. vil. 308.]

PARKER (EDMUND), bookseller in London, ( $\mathrm{I}$ ) Bible and Crown in Lombard Street, (a) near St. Mary Wolnoth's Church, (b) near the Stocks Market ; (2) under the Royal Exchange. r704-23. His name first occurs in the Term Catalogue of Hil. 1704, with two books of divinity. [T.C. III. 385.] He contributed to the Bowyer relief fund in $\mathrm{I}_{7} \mathrm{I}_{3}$ [Nichols, Lit. Anecd. 1. 6I], and was still in business in 1723. [Haz. 1. 62.]

PARKER (EDWARD), printer in London, (a) Salisbury Court, (b) Salisbury Street, 1723-4. Nichols records that "Mr. Parker" printed four sheets of the "Castrations of Holinshed's Chronicle" in 1723 . [Lit. Anecd. 1. 252.] Negus in I 724 includes among the printers "known to be well-affected to King George", " Parker Senior, Salisbury Street, and printer of a Half-penny Post". 
PARKER (G.), bookseller in London, $168_{3}$. Published a poetical broadside entitled Thompson Tell-lyes, or an answer to Titus Tell-Truth. This was doubtless a satire on Nathaniel Thompson, the printer of a news-sheet called The True Domestick Intellizerce at the time of the Popish Plot. [B.M. C. 20. f.6(13).]

PARKER (PETER), senior, bookseller in London, ( $r$ ) At the end of Pope's Head Alley next Lombard Street, 1665; (2) under Creed Church near Aldgate, $1667-72$; (3) Leg and Star, Cornhill, over against the Royal Exchange, $1673-1703 ; 1665-1703$. See Didionary, 1641-67. In partnership with John and Thomas Guy (q.v.), and Moses Pitt was one of the publishers of Oxford Bibles. His removal to Cornhill is dated by entries in the Term Catalogues. [T.C. II. 100, 126.] Dunton [pp. 228-9] states that he left his business to his apprentice H. Nelme or Nelmes. This was in 1696 ; but Nelme " came to an untimely end", and disappears after 1697. Dunton says of Parker, "this bookseller lives by the Royal Exchange", so that it seems that he resumed the business after the failure of Nelmes.

PARKER (PETER), junior, bookseller in London, 1707 . Defendant in an action brought by the Company of Stationers, for printing and selling books against their monopoly. Parker pleaded that the Master and Wardens could not claim a benefit apart from the Commonalty of the Company, and that what copies he sold bore the imprint of the Company. [Chanc. Proc. before i7r, Bridges, 270/21.]

PARKER (RICHARD), bookseller in London, Unicorn, under the Piazza of the Royal Exchange, Cornhill, r692-1725(?). A publisher of plays and historical works. He made his first entry in the Term Catalogue in 1692. [T.C. II. 393.] Dunton [p. 2 ro] speaks of him as "fortunate in all he prints . . . universally known and beloved by the merchants that frequent the Royal Exchange". He subscribed to the Bowyer Fund in 1713 .

PARKHURST (THOMAs), bookseller in London, ( $\mathrm{r}$ ) George in Little Britain, 1653-6 ; (2) Three Crowns (a) at the lower end of Cheapside, (b) near the Conduit, (c) near Mercers' Chapel ; (3) Golden Bible upon London Bridge, r66 7 (?)7 I ; (4) Bible and Three Crowns at the lower end of Cheapside, near Mercers' Chapel, 1670; (5) Bible and Three Crowns in the Poultry; 1679. 1653-1711. See Dictionary, 1641-67. As the bulk of Parkhurst's life-work was done between 1667 and 1711 , the notice previously given may be incorporated with 
this. Thomas Parkhurst was bound apprentice to John Clarke, bookseller in London, in 1645, and was made a Freeman of the Company of Stationers on July 3 rd, 1654. He began to publish theological books about that date, and a list of twenty-five publications on sale by him in 1657 is found at the end of S. Purchas's Theatre of Political Flying Insects. [B.M. 452. a. 37.] Another and longer list, arranged under sizes, was issued with W. Secker's Nonsuch Professor, 1660. About 1667 opened the Golden Bible upon London Bridge, in addition to his other shop in Cheapside near Mercers' Chapel, both imprints being given on T. Wadsworth's Immortality of the Soul explained [T.C. 1. 64], but he apparently gave up the London Bridge shop before the end of the year 1671. In 1679 he published for Capt. W. Bedloe The Excommunicated Prince ... being the Popish Plot in a play, the imprint to which was "The Bible and Three Crowns in the Poultry". Probably all his imprints, except the Little Britain and London Bridge ones, refer to one house. Dunton was one of Thomas Parkhurst's apprentices, and spoke well of him as a master. He calls him the most " eminent Presbyterian bookseller in the Three Kingdoms", and adds, "He has printed more practical books than any other that can be named in London." [Dunton, pp. 39, 42, 205, 224, 699.] In 1689 Parkhurst served the office of Under Warden, and in 1703 was chosen Master of the Company of Stationers. He gave up business in 1711 , his stock being sold by auction by Thomas Ballard at the Black Boy Coffee House, in Ave-Mary Lane on February $5^{\text {th }}$ and following evenings.

PARKS(WLLLAM), printer in Ludlow, $1719-20$; in Hereford, 1721 ; in Reading, 1723. 1719-23. At Ludlow he printed two sermons by Samuel Jones. [Allnutt, pp. 301-3; information kindly given by Mr. G. P. Mander.]

PARRY (RICHARD), bookseller in Bangor, 1699. Sold schoolbooks and prayerbooks which he purchased wholesale of John Minshull, bookseller of Chester. [Library, and ser. Iv. 373-83.]

PARSHAM ( ), bookseller in Northampton, 1704. An Assize sermon preached at Northampton on July 26 th, 1704 , by John Pierce, was sold by him. [T.C. III. 424.] Possibly identical with James Pasham (q.v.).

PARSLOWE, see Purslowe.

PARSON, or PARSONS (HENRY), stationer in London, Three Bibles and Three Ink Bottles near St. Magnus' Church on London Bridge, 171 1-18. His name 
occurs in an advertisement of the sale of playing cards in the Post Man of February $3^{\text {rd, }}$ 1711. He was also defendant in an action brought against him by John Baskett the printer, judgement being given for the plaintiff on July 8th, I 7 I8.

PARSONS (WILLIAM), stationer in London, $168 \frac{6}{7}$. Defendant in plea of trespass brought against him by John Smith. [C.P.R. Hil., 2-3 Jas. II, 3052, m. 49 v.]

PARTRIDGE (JAMES), bookseller in London, Post Office, between Charing Cross and Whitehall, 1683-94. There seem to have been two stationers in partnership at this address, James and Jo. Partridge. James was sometimes described as "Stationer to Prince George of Denmark", and published several medical works; while three books, two of which are medical and the third a novel, are advertised on the last leaf of An Historical Account of the Late Troubles, during the wars of Paris, published by Henry Chapman in 1686, as for sale by "Jo. Partridge" at the above address. But "Jo." may be a misprint. James Partridge's name appears in the Term Catalogues for the last time in I694. [T.C.II. 525.] James Partridge, Matthew Gilliflower and Samuel Heyrick termed themselves Printers to the House of Lords in $168 \frac{8}{9}$; but as none of them were printers by trade, they must have farmed out the office.

PARTRIDGE (Jo.), see Partridge (James).

PASHAM (JAMES), printer in Northampton, 1721. Printer of a short-lived Tory newspaper, The Northampton Journal, in opposition to Raikes and Dicey (q.v.). Possibly identical with Parsham (q.v.).

PASK, or PASKE (ROBERT), stationer and bookseller in London, (I) Stationers' Arms and Ink Bottle, under Pinners Hall, $(a)$ Broad Street, $(b)$ Winchester Street by Gresham College, 1669; (2) Stationers' Arms and Ink Bottle, Lombard Street, near Sir Robert Vyners, $1670-72$; (3) (a) under the Royal Exchange, Threadneedle Street, $(b)$ in the Piazza on the North Side of the Royal Exchange, 1676-8. 1669-78. Publisher of some plays, and also the maps and surveys of John Ogilby. His name is found in an advertisement of lost property in The London Gazette of November 2nd, 1676, in which the last of the above addresses is found; his removes can be dated from the Term Catalogues.

PASSINGER (SARAH), bookseller in London, Three Bibles on London Bridge, r689-92. Widow of Thomas Passinger the First (q.v.). She was, before 
her marriage with Passinger, the widow of Charles Tyus, bookseller. In 1689 she advertised a book entitled Abstractum Chirurgiae Marinae in The London Gazelte of July Ist. She died in 1692, and was buried in the south aisle of St. Magnus, the business passing to her nephew Thomas Passinger the Second.

PASSINGER (THOMAS), the First. See Dictionary, 1641-67. A list of books sold by him is given at the end of Forde's Montelion, 1687. [Bodl. Douce D. 225.]

PASSINGER (THOMAS), the Second, bookseller in London, Three Bibles and Star, on London Bridge, 1692-5. Nephew of Thomas Passinger the First ; succeeded to the business on the death of the latter's widow Sarah.

PATON (JOHN), bookseller in Edinburgh, in the Parliament Close, 1716-54. Many issues of The Acts of the General Assembly between the years 1716 and 1754, as well as several books printed by Ruddiman, bear his name in the imprint.

PAWLETT (E.), bookseller in London, Bible in Chancery Lane, 1692. Possibly the widow of George Pawlett. Advertised a theological work in 1692. [T.C. II. 404.]

PAWLETT (EDWARD), bookseller in Grantham, 1686 . Timperley [p. 641] says : "The earliest known sale of books by auction in this country, out of London, is the following: 'A Catalogue of choice books ... . will be sold [sic] by auction at Mr. Edward Pawlett's house, bookseller in Grantham, on Wednesday the 4th Day of August 1686." "'

PAWLETT (GEORGE), bookseller in London, Bible in Chancery Lane, 1683-90. Son of Robert Pawlett or Pawley. He was one of the publishers of Sir Henry Spelman's Glossarium Archaiologicum in 1687. [T.C. 1I. 189.] He died in I690; his executors were Abraham Chambers and Jacob Tonson. [P.R.O. Chancery Decree Roll 1356.]

PAWLETT (ROBERT). See Dictionary, 1641-67. He died in 1683, leaving to his son George all his copyrights. Roger Norton, printer, was nominated overseer. [P.C.C. 97 Drax.]

PAWLEY, see Pawlett.

PEACOCK (JOHN), bookseller in London, 168I. In 1681 he published an edition of the Proceedings of the House of Commons in the Parliament held at 
Oxford from the 2 Ist to the 28th March, in which he referred to the exorbitant rates paid by booksellers for copyrights. [B.M. T. $94^{*}$ (1 7).]

PEARCE (JOHN), bookseller in Exeter, 1697-8. In the Term Catalogue of Hil. I69 $\frac{6}{7}$ is entered a work entitled $A$ Religious Conference between a Minister and Parishioner, which was to be sold by J. Pearce in Exeter. [T.C. III. I.] Dredge does not mention this, but has the following [ff. ro, 62, 94]: (1) $A$ Practical Treatise concerning Evil Thoughts ... By William Chilcot, 1698; (2) A Sermon preached in St. Saviour's Church in Dartmouth, by Humfry Smith, 1698; (3) Bread for the Poor, by R. D., 1698. The last three were printed for Pearce, Charles Yeo, and Philip Bishop by Samuel Darker.

PEARSE (FRANCIS), bookseller in London, 1685. Gave a bill for $£$ ro to Thomas Symmons, which afterwards came into the hands of Robert Turner, who sued upon it. The proceedings were adjourned. [C.P.R. Mich., I Jas. II, Roll 3039, m. $3 \circ 9 \mathrm{v}$.] In the same year he published a small book, The Honourable State of Matrimony made comfortable, by $\mathrm{D}$. B.

PEARSON (WILIIAM), printer in London, over against Wright's Coffee House in Aldersgate Street, I 700-25. A printer of music. He printed for John Cullen, Henry Playford, D. Brown, and other noted music publishers. In I723 he printed R. and J. Barber's Book of Psalmody for Josiah Rathbone, bookseller at Macclesfield in Cheshire, giving the above address. [J. H. Cooke, Bibliotheca Cestriensis, p. 31.]

PEARTREE (OWEN), bookseller in Yarmouth, 1703-6. Publisher of the following books : (1) A Sermon preach'd at the Cathedral Church of Norwich, ... by a priest of the Church of England, printed for O. Peartree in Yarmouth, and J. Sprint at the Bell in Little Britain, 1703. [T.C. III. 354.] (2) The Church Catechism resolved into Questions and Answers, By B. Love, A.M., the third edition . . . Norwich, Printed by F. Burges and sold by the booksellers of Norwich and Owen Peartree in Yarmouth, I706. [B.M. 3505. df. 50.]

PEELE (JOHN), bookseller in London, Locke's Head in Paternoster Row, 1722-71. Referred to by Nichols as "a very considerable bookseller". He died on September 8th, I771. [Lit. Anecd. III. 737.] In I722 he published a sermon by George Stubbes.

PEISLEY, or PIESLEY (ANTONY), bookseller at Oxford, near St. Mary's Church, 1692-1724. Hearne, writing to Dr. T. Smith on February 1st, 1709, 
informs him that " Peisley the bookseller has bought the whole impression of Ignatius" [Collections, 11. 166], and in the following year he tells Thorpe that Peisley has bought Leland De Scriptoribus. [Ib. III. 88.] In I 7 I I he started a newspaper called The Surprise, which Hearne characterized as a "silly paper". The author was believed to be T. Tickell, then Professor of Poetry. In December 17 I9 Peisley bought the remainder of the library of Dr. Hudson, after the University had taken what they wanted [Ib. VII. 85], and in I 721 some books of Dr. Yates, for which he gave $£^{80}$. [Ib. vir. 277.] He died suddenly on August I Ith, I 724. Hearne records that he "used to have auctions frequently in Oxford, in the Old Convocation House at the N. East End of St. Marie's Church, and he talked of having one next Lent. . . . He hath one Son of the same trade, about twenty-two years of age, and six Daughters, the eldest of which is married to Mr. Beaver, M.A. and Steward of Corpus Xti College ; the other five are unmarried. Mr Peisly had several houses in Oxford and an Estate of about six score Pounds per annum at Clifton, near Dorchester. ... He died in the fifty-seventh Year of his Age, and was buried in St. Marie's Church this day." [Ib. vIII. 252.]

PEMBERTON (J.), bookseller in London, (a) Golden Buck, (b) Buck and Sun, against St. Dunstan's Church in Fleet Street. 1709-12. One of the publishers of Whitelocke's Memorials. [T.C. III. 643.] Hazlitt records a work on the Hertfordshire witch, Jane Wenham, published by him in 17 12. [11. 280.]

PENDLEBURY (ADAM), bookseller in Oxford, r684. [Madan, p. 3r.]

PENN (JOSEPH), bookseller in Bristol, behind the Rose Tavern, r709-22. Published Sermons, \&c., by Strickland Gough, minister in Bristol, in 1709-14. [B.M. 4475. de. $5 ; 4478$. e. 90 (3).] Some books bearing dates 17 19-22 are said to have been printed by him.

PENNOCK ( ), printer (?) in London, Paternoster Row, r 709. Referred to as a piratical printer by J. How in Some Thoughts on the present state of Printing and Bookselling, 1709, p. 12.

PENROSE (JOHN), bookseller in Leeds, 1712. Known from a list of provincial booksellers printed in Notes \& Queries. [N. \& Q., ro ser. v. 183.]

PEPYAT (JEREMY), bookseller in Dublin, Skinner Row, 17 I1-15. Published three tracts by E. Synge, Bishop of Raphoe, between 1711 and I7I5. [B.M. 4165. c. $26(4,5)$; 4474. aa. 95 (I).] 
PERO (JOHN), bookseller in London, (a) Black, (b) White, Swan, Little Britain, 1694-1703. Made his first entry in the Term Catalogues in Easter 1694. [T.C.II. 500.] He was the publisher of Memoires of the Reign of King Charles I, by Sir Philip Warwick, 1702 [T.C. III. 292], and in 1703, with I. Cleave and E. Tracy, he published an abridgement of La Calprenède's Cassandra. [Esdaile, p. 192.] Pero is praised by Dunton [p. 215].

PETERS (FRANCIS), bookseller in London, r681. Published a pamphlet, Vox Patriae, 1681. [B.M. 8I6. m. 2 (13).]

PEYTE ( ), printer in London, 1717. Gent, under this year [p. 75], speaks of "an old printer, called Father Peyte". Perhaps he was not a master printer.

PHILIPS (JоHN), bookseller in Worcester, 1685 . Occurs in a list of booksellers and stationers who sold a patent medicine, given at the end of M. Bromfield's Brief Discovery of the Scurvy. [N. \& Q., I I ser. XI. 45.]

PHILLIPPS (JOHN), bookseller in Exeter, 1681. In 33 Chas. II Trinity (C.P.R. 2995) he was sued by George Saffin, sheriff of Exeter, for a debt of $£^{276}$, and judgement was signed on July 15 th, 33 Chas. II.

PHILliPS (JoshUA), bookseller in London, (I) Atlas in Cornhill, 1680 ; (2) Seven Stars, St. Paul's Churchyard, 1680-93 ; (3) King's Arms, St. Paul's Churchyard, I694-1706; (4) Black Bull, Cornhill, 1707-9. 1680-1709. First mentioned in the Term Catalogues in Mich. 1680 (the Atlas in Cornhill appearing here only, combined with the Seven Stars). [T.C. I. 416.] Published books in various classes of literature. Between Mich. 1693 and Mich. 1694 he altered his sign or moved to fresh premises in St. Paul's Churchyard [T.C. II. 487, 527]; he moved to the Black Bull in Cornhill between Easter 1706 and Trin. 1707. [T.C. III. 505, 555.] The latest mention of him in the Term Catalogues is in 1709 . He often shared copies with H. Rhodes and other booksellers.

PHILPOT, or PHILPOTT (JAMES), printer in Gosport, Middle Street, 1 708-36. In 1708 he printed the Gosport Churchwardens' Accounts, and in 1710 Essex Waller's farce, $A$ Trip to Portsmouth. [Cotton, II. 86.] Noticed by Mr. F. A. Edwards in a list of Hampshire booksellers and printers in Notes $\&$ Queries. [10 ser. v. 481.] He suggests that this John Philpott may have been the father of James Isaac Philpot of Winchester $(q . v$.). 
PHILPOT (JAMES ISAAC), bookseller and printer in Winchester, 1725-32. Son of James Philpot of Gosport (q.v.)? Gave 2Is. to use the trade of printer and bookseller at Winchester, 1725. [N. \& $Q$., ro ser. v. 482.] A sermon, dated 1732 , is known from his press. [Allnutt, p. 303.] In 1732 he had a free loan from the city fund to assist young tradesmen.

PICARD (BENJAMIN), bookseller in London, Three Bibles in the Minories, 17 I I. Sold J. Davis's Seaman's Speculum, and also John Darling's Carpenter's Rule made Easie in 1711. [T.C. III. 672-4.] Possibly the same as the following.

PICKARD ( ), printer in London, Salisbury Court, 1724. Mentioned by Negus as "well-affected to King George". Possibly the same as the preceding.

PIERCE (THOMAS), bookseller in London (?), 1676. Published in $1676 \mathrm{~A} \mathrm{Sad}$ Relation of a Dreadful Fire at Cottenham. [Haz. III. 29.]

PIESLEY, see Peisley.

PIKE (JoHN), bookseller in Shaftesbury, 1675. Published in 1675 a religious tract entitled $A$ Cluster of Worcestershire Fruit, by J. P.; printed in London. [Bodl. Pamph. 135.]

PIKE, or PYKE (THOMAS), bookseller in London, (I) Bread Street End, Cheapside; (2) Pall Mall. 1688-94. Publisher of Elkanah Settle's Insignia Bataviae ... 1688. His name is also found in an advertisement of patent medicines in The City Mercury, June IIth, I694. [B.M. Burney, II 2 A.]

PINDAR (JOHN), bookseller in Cambridge, r663 (?)-r 703 (?). Published The Tablet of Cebes, Done out of Greek into English by Robert Warren, I699. [Haz.II. 88.] He may be the John Pindar who witnessed the last will and testament of Jonathan Pindar, r663 [Gray and Palmer, p. roo], and is mentioned in the will of William Morden, 1678 , as living in the parish of St. Michael's in a tenement adjoining that of Morden's. [ $I b$. I18.] A John Pindar in 1689 gave $£ \mathrm{I} 5$ towards buying a bell for St. Michael's Church. [Cooper, Memorials of Cambridge, III. 342.] As no record of his death appears in the Church Registers it may be that he moved to Great St. Mary's parish to a house by the side of the Market Place, where we know a John Pindar was living from r699 to his death in 1703 , when his widow continued to live there until $17 \mathrm{r} 4$. 
PINDAR (JONATHAN), the First, printer and bookbinder (?) in Cambridge, r680 (?)-98. Appointed University Printer June $r \mathrm{rth}, \mathrm{r686}$, but in March r693 another Printer was appointed, and on October roth, r698, a Grace was passed for an annuity of $£_{5}$ each to Hugh Martin and Pindar, "formerly elected printers". [Bowes, Cambridge Printers, p. 3 ro.] No books printed at the University Press bear his imprint. Probably a relative of Jonathan Pindar, d. r663 [Gray and Palmer, p. roo], and of John Pindar (q. v.). A Jonathan Pindar appraised the goods of Anthony Nicholson (q.v.) r680, Rose Browne r687, Robert Gee $(q . v$.) r68r, William Graves $(q . v$.$) r686, and E. Beeching$ (q.v.) r689. [Gray and Palmer.] John Pindar, Gent., in his will, dated June 25th, proved September 30 th, 1680 , left property and money to Jonathan Pindar and his wife, and $\ell_{\text {ro }}$ to apprentice their son Jonathan $(q . v$.$) and \ell_{\text {ro }}$ to be paid to him when twenty-one years of age ; also to another son John property and reversion of property. In the University Audit Books for 1692-4 are entries for payments made to a bookbinder of this name, who may be the same person. [Bowes, Cambridge Printers, p. 3rr.]

PINDAR (JONATHAN), the Second, printer at Cambridge, r699-I730. Appointed University Printer September 8th,1699. "On 28 August 1730, there is a Grace declaring the voidance of the office of Printer to be necessary before certain proposals for printing Bibles and Prayer-Books can be settled, and offering Pindar the continuance of his full salary after his resignation." [Bowes, Cambridge Printers, p. $3^{\mathrm{Ir}}$.] This must be the son of Jonathan Pindar the First, mentioned in John Pindar's will.

PITT (MOSES), bookseller and printer, London and Oxford ; London, (r) White Hart, Little Britain, 1668-73; (2) (a) Angel, in St. Paul's Churchyard, (b) over against the Little North Door of St. Paul's Church, 1673-86; (3) Duke Street, Westminster, r688; Oxford, The Theatre, r680-82. r668-96. Son of John Pitt, yeoman, of St. Teath, Cornwall. On October rst, r654, Moses Pitt was bound apprentice to Robert Littlebury, citizen and haberdasher of London, and was made free of the Haberdashers' Company on November 8th, r66r. His first publication was Thomas Brancker's Introduction to Algebra, r668. He continued to publish copiously. Shortly before 1679 , when Dr. Fell was looking for some London men to manage the printing and bookselling business on which the University of Oxford was embarking at his suggestion, he chose Moses Pitt as one of them, and it is interesting to read Pitt's own narrative of the transaction as set out in his pamphlet, The Cry of 
the Oppressed. He there says: "Having undertaken the printing of an Atlas or Description of the Whole World, which will be about Twelve volums in Folio ... and being much incouraged by Dr. Fell, then Bishop of Oxford, I took of him the Printing House at Oxford called The Theatre, where I have finished four of the volums ... and have Two volums more almost finished ... and did also purchase of the Bishop a great quantity of Books, to the value of many thousands of pounds. And did in the latter end of King Charles Time, print great quantities of Bibles, Testaments, Common Prayers \&c. in all volums, whereby I brought down the price of Bibles \&c. more than half, which did great good at that time (Popery then being likely to over-flow us)." $\mathrm{He}$ continued to publish in London throughout these years, and till 1688 . The published volumes of the Atlas appeared in 1680-82. Had he confined himself to bookselling Pitt might have completed the publication of The English Atlas, and retired a rich man; but he launched out into building speculations, chiefly in Westminster, over which he lost large sums of money and weakened his credit to such an extent that his partners in the bookselling business and Bible trade [see Guy (Thomas)] cut themselves loose from him. In Pitt's own words, "they pretended that I ow'd them some hundreds of pounds, and they lock't up my Oxford-warehouse". But it was a relative, Adiel Mill (q.v.), who, taking advantage of Pitt's difficulties, advanced him money on exorbitant terms for his building schemes and induced the unfortunate bookseller to hand over to him his "stock of books, atlases, Atlas paper, Copper Plates, Pictures, Printing Press, letters \&c.", afterwards forcing him to become a prisoner in the Fleet Prison for debt. Whilst there Pitt wrote a graphic account of the miseries suffered by the prisoners, which he entitled The Cry of the Oppressed, r69r. At the same time he endeavoured to raise money for them in various ways. Pitt remained a prisoner from April 2oth, 1689, to May I6th, I69I. He married a Miss Upman, perhaps a relative of the Rev. Upman, to whom he refers in his Cry. After his release Pitt wrote An Account of one Ann Jefferies .. who was fed for six months by ... fairies, 1696.

PLACE (JoHN), see Dictionary, 1641-67.

PLACE (WILLIAM), see Dicitonary, 1641-67.

PLAYFORD (E.), bookseller in London, Little Britain, 1685. Part publisher of D. Newhouse's Whole Art of Navigation, I685. [T.C. II. 146.] Successor of John Playford the Younger (?).

PLAYFORD (JoRN), the Elder, see Dictionary, 1641-67. 
PLAYFORD (JOHN), the Younger, printer in London, Little Britain, 1679-85. Son of Matthew Playford, rector of Great Stanmore, and nephew of John Playford the elder. [See Dictionary, 164I-67.] From 1679 to 1683 he was in partnership with Ann, widow of William Godbid, the music printer. [See Dictionary, I64I-67.] In 1684 and 1685 Playford carried on the business alone; he died in 1685 . He printed the sixth and seventh editions of The Dancing Master, 1679 and 1686, the latter issued posthumously. [D. N. B.]

PONDER (NATHANIEL), bookseller in London, ( 1 ) Peacock in Chancery Lane ; (2) Peacock, Poultry, (a) near Cornhill, (b) over against the Stocks Market. 1669-1700(?). Publisher of Bunyan's Pilgrim's Progress. He was the son of John Ponder, a Nonconformist mercer, of Rothwell, in Northamptonshire. On June 2nd, 1656 Nathaniel Ponder was bound apprentice to Robert Gibbs, bookseller, of Chancery Lane, and, at the expiration of his term, set up as a bookseller at the sign of the Peacock in Chancery Lane. His first entry, in the Term Catalogue for Easter 1669, was Dr. Owen's Brief Declaration and Vindication of the doctrine of the Trinity [T.C.I.8], and he became the publisher of most of the writings of that Nonconformist leader. Another of his patrons was Sir Charles Wolseley, a Cromwellian. In 1676 Ponder opened a second shop in the Poultry; but shortly afterwards gave up the premises in Chancery Lane, and on August roth in that year he was committed to prison for publishing Andrew Marvell's Rehearsal Transpros'd. [S.P.D. Chas. II, vol. 174, f. 161.] The first edition of Bunyan's Pilgrim's Progress was advertised by Ponder in the Term Catalogue for Hil. $1677-8$, as an octavo, to be sold for the sum of eighteenpence. Probably no one was more surprised than the publisher at the success achieved by this publication. Three editions were called for within twelve months. Ponder found it difficult to keep pace with the everincreasing demand for the book, and was obliged to get it printed where and how he could, so that misprints crept in and were not rectified, while the whole production steadily deteriorated with every fresh edition, and surreptitious and unauthorized editions were put on the market by unscrupulous publishers. Ponder did not publish only Nonconformist divinity; in 1685 he published the English translation of Le Vayer de Boutigny's Tarsis et Zelie, a romance in folio. About 1680 Ponder consigned to a certain Mercy Browning, a bookseller at Amsterdam, a large parcel of books, for sale on commission. It seems highly probable that she was a connexion of Thomas Browning of Rothwell, a Nonconformist minister for whom Nathaniel Ponder made appli- 
cation for a licence to preach in 1672 . This transaction between Mercy Browning and Ponder became the subject of a lawsuit in 1692, Mercy Browning, as Ponder alleged, having sold her stock to a certain Rest Fenner (q.v.) without having paid for the books consigned to her by Ponder. A curious point about this lawsuit is that Ponder stated that the consignment was made in 1678 , and included two copies of Whitelock's Memorials of Affairs of State, which was not published until r682. [Chancery Proc. before 1714, Reynardson, Bundle 428, 132.] In 1681 Ponder was one of a number of London printers and booksellers against whom a mysterious action for assault was brought by Bartholomew Sprint. [C.P.R. 2992, m. 256 r.] The fourth edition of the Pilgrion's Progress had appeared in the previous year, and a part of the impression bore, on the back of the portrait, an " Advertisement", in which in bitter terms Ponder accused Thomas Braddyl of printing unauthorized editions of the work; yet in r 688 he was employing this same printer to print an edition of ten thousand copies, as well as an edition of five thousand copies of the second part, and five thousand copies of Bunyan's Grace Abounding. All this we learn from a lawsuit begun by Ponder against Braddyl in the Court of Chancery in 1697. From this we further learn that Ponder was a prisoner in the King's Bench Prison for debt in r688, and that Braddyl, in addition to settling an execution with which Ponder was threatened, had also supplied Ponder's son with clothes to the value of $f_{14}$. After this little more is heard of Ponder. Mr. Arber states [T.C. III. 730], that he published the 3 rd edition of Bunyan's $M r$. Badman in I 700 from "London Yard, at the West End of St. Paul's Church", but the edition in question is dated 1696 , not 1700 ; the edition of 1700 was issued by the Churchills. Ponder sold an edition of Bunyan's Holy War in 1696 [Bodl. Arch. Bodl. A. I. 48] ; the last editions of Pilgrim's Progress issued by him were Pt. I. edd. I I and 12,1688 and n. d. Pt. II. ed. 3 was issued in 1690 , and Pt. I. ed. 13 in 1693, by R. Ponder, i. e. presumably his son Robert. One W. P., who may be a relation, figures in Bunyan imprints from r695 to I702. He left, besides Robert, who married Mary, the daughter of Robert Guy of Isham, Northants, three daughters, Mary, Susannah, and Hannah. [Chan. Proc. before ryr4, Collins $\left.\frac{461}{31} \frac{461}{33}\right]$. An interesting article on Nathaniel Ponder, written by Mr. W. Perkins, appeared in The Wellingborough News, October 2nd, 1903.

PONDER (ROBERT), see Ponder (Nathaniel).

PONDER (w.), see Ponder (Nathaniel). 
POOL, see Poole.

POOLE (EDWARD), bookseller in London, (I) Ship, Cornhill, (a) next door to the Fleece Tavern, (b) over against the Royal Exchange ; (2) Exchange Alley. (3) At the Half Moon, (a) near, (b) under, the Royal Exchange, I685-1702. Noticed by Dunton [p. 226] chiefly for his religious opinions. His name appears in the Term Catalogues for the first time in Mich. I685, with a translation of Heliodorus. [T.C. II. 145.] He was the publisher of some of Richard Head's works, and in 1692 was one of the publishers of $A n$ Epitome of the whole art of War. He moved to Exchange Alley between 1690 and 1692 , and to the Half Moon by I700. [T.C. III. I96.] He is last heard of in I702. [T.C. III. 3Io.]

POOLE, or POOL (JOHN), bookseller in London, Clements Inn Gate, I670-9. This bookseller held shares in various law-books during this period. [T.C. I. 39, 53, 359.]

POOLE (JOSEPH), bookseller in London, Blue Bowl, in the Long Walk, by Christ Church Hospital, 1682. Publisher of A True History of the Captivity and Restoration of Mrs. Mary Rowlandson, in New England, 1682. [Haz. III. 2I4.]

POPE ( ), bookseller in Salisbury, I 7 I5. Publisher of The Necessity of Grace, a sermon by R. Eyre, I7I 5. [B.M. 225. h. 2 (IO).]

POPE (WALTER), bookseller in Edinburgh, Roxburghe Close, over against St. Giles's Steeple, 1683. In that year a broadside by N. Paterson entitled Obsequies ... Alexander, late Lord Bishop of Rosse were sold by him. [Aldis, p. II8.]

POPPING (SARAH), printer and bookseller in London, Raven, Paternoster Row, I713-23. Printer and publisher for a time, of the Observator (I III, \&c.) In I7r6 Mrs. Popping was one of the publishers of Pope's satire on Edmund Curll. [Esdaile, p. 289.] In this year she also published Dennis's True Character of $M r . P[o p e]$ and his Writings. Her name was in the imprint to Curll's pirated edition of An Account of the Trial of the Earl of Winton, also in 1716 , for which she was taken into custody for breach of privilege, but was discharged. [W. J. Thoms, Curll Papers, pp. 37-9.] In 1723 she advertised Dunton's Upon this Moment depends Eternity, but it is believed not to have appeared. [Nichols, Lit. Anecd. v. 83.] 
PORTEOUS (JOIrN), bookseller in Edinburgh, on the south side of the High Street, a little above the Court of Guard, 1699. The Edinbargh Gazette, nos. 44 and 50 , contain advertisements of books printed for and sold by him.

POTBURY (EDWARD), stationer in Exeter, $168 \mathrm{I}$. Defendant in a suit brought by George Saffin, sheriff of Exeter, for the recovery of a debt. Judgement was signed for the plaintiff on July 12th. [C.P.R. Trin. 33 Chas. II, Roll 2995, m. 1872.] Not mentioned by Dredge, and perhaps only a retailer.

POWELL ( ), Mrs., bookseller in Flint, r700. Bought one dozen Psalters from John Minshull, bookseller of Chester, for seven shillings. [Library, and ser. Wv. 373-83.]

POWELL (EDMUND), printer and bookseller in London, Blackfriars, I708-Ir. In 1708 his name appears in the Term Catalogue as the printer of The Improvement of Human Reason (Hai Ibn Yokdan, translated by Simon Ockley) [T.C. III. 595], and he published other works by the translator. Lists of his publications appeared from time to time in The Female Tatler in 1709. In I $7 \mathrm{rr}$ he is mentioned in a list of persons receiving subscriptions for a work entitled The Grand Curiosity. [Daily Courant, September 29th, 171r.]

POWELL (EDWARD), bookbinder in London, Little Britain, I698. In the London Gazette of December r2th-r 5 th, 1698, is an advertisement of John Brown's work on muscular dissection, with a notice that any subscribers who had not reccived their copies might have them at Mr. Edw. Powell's, Bookbinder in Little Britain.

POWELL (G.), bookseller in London, Chancery Lane, over against Lincolns Inn Gate, 1685-6. Sold the Coronation Service book used at the crowning of James II. [T.C. II. 129.] He was associated with William Powell, who lived at Holborn Court in Grays Inn, in the production of a miscellany entitled A Memorial for the Learned, in r686. [T.C. II. r 7o.] One of these two is probably the man referred to by Dunton [p. 293] as "grave" Powel.

POWELL (STEPHEN), printer in Dublin, r697-1 724. This printer is first found in 1697 in partnership with John Brent and John Brocas. In 1698, I699, and 1700 he appears under his initials in partnership with one J. B. In r699 his full name occurs alone in one imprint again. Besides poems, sermons, \&c., he printed in 1717 Hugh McCurtin's Brief Discourse in vindication of the Antiquity of Ireland. 
POWELL (WILLIAM), bookseller in London, Holborn Court, Grays Inn, r686. Associated with G. Powell (q.v.).

POWNEY (ROBERT), stationer in London, Ship and Star, against Katherine Street in the Strand, I705-25. [Hilton-Price, Signs of the Old Houses in the Strand in the r7th and I8th Centuries, in Midds. E० Herts. N. \& Q., II. I $5^{8 .]}$

PRATT (DANIEL), bookseller in London, Bible against York Buildings in the Strand, I715. Published with D. Mead an edition of The History of George a Green. [Haz. I. 472.]

PRESTON ( ), bookseller in Faversham, 1699. His name appears in the advertisement in The Flying Post, December 2nd, I699, of the publication of the Rev. Edw. Brown's sermon preached at the Kentish Feast. It does not appear in the imprint of the book.

PRICE (c.), bookseller in London, next the Fleece Tavern in Cornhill, I706. Associated with John Senex in publishing Miscellanea Curiosa. [T.C. III. 513, 523.]

PRICE (THOMAS), bookseller in London (?), 1684. His name is found in the imprint to a pamphlet entitled $A$ Pair of Spectacles for $M r$. Observer, I684. [B.M. T. 100* (I66).]

PRICKE, or PRYKE (ROBERT), book and print seller in London, (I) in White Cross Street, over against the Cross Keys, 1669-72 ; (2) Golden Lion, at the corner of New Cheapside, next Bethlehem, in Moorfields, 1669-72; (3) adjoining to Cripplegate within, $1674-6$; (4) Golden Ball in St. Paul's Churchyard, I677-85; (5) Bow Lane, 1698. He translated, engraved, and published a number of foreign architectural and similar books, and also issued Cocker's Penna Volans in 1685 . He had frequent entries in the Term Catalogues from 1669 to 1672 of books published simultaneously from his first two addresses, but afterwards his entries are only occasional. His copies seem to have passed to $S$. and J. Sprint, for whom he reissued some in I698. [T.C., D.N.B.]

PRING (JANE), bookseller in Exeter, near St. Martin's Lane, r 723-30(?) The widow of Thomas Butter (q.v.). She married again, on August 3Ist, I 723, Daniel Pring jun., but she continued to carry on the bookselling business herself until her death, which took place before I723. [Dredge, ff. 67: 98-9.] 
PROCTER (wILLIAM), stationer in London, Bread Street, 1705. In 1704 he received subscriptions for Richard Blome for the latter's History of the Holy Bible [T.C. III. 396.] Dunton describes him [p. 256] as a fortunate man, who had drawn a sum of $£ 500$ per year in the Parliament Lottery; and as a generous creditor.

PROSSER (ENOCII), bookseller in London, Rose and Crown (a) in Swithins Alley, $(b)$ in Sweeting's Rents, at the East End of the Royal Exchange in Cornhill, 1681. Publisher, in partnership with J. Hancock, of Memoirs of the Life and Death of Sir Edmund Bury Godfrey, and The Plot in a Dream, by Philopatris, both in 1681. [T.C. I. 461, 464.] He was perhaps the E. P. who published a broadside Elegy on the Death of the Plot, I68 I. [B.M. I872. a. I (30).] PRYKE (ROBERT), see Pricke.

PULLEYN, or PULLEN (CAVE), bookseller in London, Angel in St. Paul's Churchyard, 1681-5. Published (I) A . . History of the Succession of the Crown of England, 1681, and (2) An Apology for the Builder, I685. [B.M. T. $94^{*}$. (15) ; T. 2029 (3).]

PULLEYN (OCTAVIAN), junior, stationer in London, King's Head in Little Britain, 1664-8. See Dictionary, 1641-67. An advertisement of his appeared in the London Gazetle on March 12 th, 1667.

PURSLOWE, or PARSLOWE (ANNE), printer in London, 1675-77. Possibly widow of G. Purslowe [See Dictionary, 1641-67.] May be identical with the Mrs. Purslowe whose name occurs in the List of London Printing Houses of 1675. Printer of Poor Robin's Intelligence (no. 1), March 23rd-3oth, 1676. In the number for April Ioth-1 7 th, 1677, T. H. (i.e. Thomas Haley) joins A. P. as printer.

PYKE, see Pike.

PYMAN (JAMES), stationer in London, Gracechurch Street, 1692. In Mich. 1692 , he became surety in a sum of $£ 50$ for one James Daggett. [C.P.R. Mich. 3. W. \& M. Roll 3102, m. 757, v.]

RAE (PETER), printer in Kirkbride, $1711-14$, and in Dumfries, 1715-20. Peter Rae was minister at Kirkbride and Dumfries, and was the real printer of fourteen books and pieces, mostly theological, but including Rae's own History of the Late Rebellion, 1718 , which all bear the imprint of Robert Rae, probably his son. Rae is said by Watson [p. 19], to have made his own press, and to be 
" making some advance towards the founding of letters". In youth he had followed his father's trade of a clockmaker. [William Stewart, The Rae Press, Edinb. Bibl. Soc. Publ. vi. 107-I5.]

RAE (ROBERT), see Rae (Poter).

RAIKES (ROBERT), printer in St. Ives, Huntingdonshire, Northampton, and Gloucester ; St. Ives, I718-20 ; Northampton, over against All Saints' Church, I720-22 ; Gloucester, (I) against the Swan Inn [in Upper Northgate Street ?], $1722-3$; (2) in Southgate Street, 1723-43; (3) Black-Friars, 1743-57. 1718-57. Born in 1690, son of a Yorkshire clergyman. Mr. R. Austin states that he was in the employ of Thomas Gent of York in I7I8 ; but Gent did not set up for himself till 1724. In this year Raikes established a press at St. Ives, where he printed the St. Ives Post Boy. In I7 99 William Dicey $(q . v$. set up The St. Ives Mercury, and in the following year the pair went into partnership, and moving to Northampton, produced the Northampton Mercury. In 1722 Raikes and Dicey founded yet another paper, The Gloucester Journal, and, to print it, the first Gloucester press. Both names occur on all issues of it till recent times; but Dicey remained at Northampton and Raikes took charge of the Gloucester business. A few popular books, like those published by the firm at Northampton, came from the Gloucester Press ; of these the earliest known is John Blanch's History of Great Britain, from the Tower of Babel, 1722. Raikes was summoned to the Bar of the House of Commons in 1728 for printing reports of its proceedings. He died in 1757 , and was succeeded by his son Robert, the philanthropist and promoter of Sunday Schools. [Roland Austin, Robert Raikes, the Elder, and the Gloucester Journal, in The Library, 3rd ser., VI. January 1915 (see also Notes and Queries I2th ser., x. 26I-4); History of the Northampton Mercury (Mercury Extras, no. 10), r9o1. See also Dicey (William).]

RAINY (THOMAS), bookseller in Doncaster, 1693. Only known from Henry Higden's comedy, The Wary Widdow, "London, Printed for Abel Roper at the Mitre near Temple Bar, and Tho. Rainy, Bookseller in Doncaster, 1693." [B.M.644.h. 4I.]

RAMSAY (ALLAN), bookseller in Edinburgh, (I) The Mercury in The High Street ; (2) in the Luckenbooths. 1716(?)-58. About 1716 he took up the business of bookselling at his house in the High Street, where he had previously carried on the trade of wig-making. In 1726 he removed to a shop in the 
Luckenbooths, and there established the first circulating library in Scotland. His Poems (1721) and The Ever-Green (1724) were printed for him by Thomas Ruddiman. He continued in business to within about three years of his death, which took place in 1758 .

RAMSAY (PATRICK), printer in Edinburgh, c. 1660-80. See Dictionary, 1641-67, and also below, Reid (John).

RANCE (JOHN), printer in Oxford, 1 7 1 2-19. In a letter from Hearne to Browne Willis, dated May Ist, 17 15 , he speaks of " Rance the printer " as "going on " with the remainder of the Index to "Collectanea". [Collections, v. $54 n$.; Madan, p. 32.]

RANDALL, or RANDEL (RICHARD), bookseller at Newcastle-upon-Tyne, 1676-1714. Admitted a freeman of the Newcastle Stationers' Company, December 20th, 1676. [Welford, p. I 28.] In partnership with Peter Maplesden he published in 1676 Richard Gilpin's Daemonologia Sacra [T.C. I. 287], and in 1677 a sermon preached at Newcastle by John March. [Bodl. Sermons, 13.] In 17 I4 he appears among the subscribers to Walker's Sufferings of the Clergy.

RANEW (NATHANIEL), bookseller and book-auctioneer in London, (I) Angel, in Jewin Street; (2) King's Arms in St. Paul's Churchyard, 1663-94. See Dictionary, 1641-67. In partnership with Jonathan Robinson (q.v.). In 1670 they moved to the King's Arms in St. Paul's Churchyard. The partnership was dissolved in $1671-2$, when Robinson moved to the Golden Lion, Ranew remaining at the King's Arms. They published a book together in 1674, however. [T.C. 1. 166.] In 1678 he sold by auction " at the Harrow, over against the Colledge of Physicians, in Warwick Lane", the libraries of Lord Warwick and Dr. Gabriel Sanger. It appears to have been the only book auction he conducted. [Lawler, Book-Auctions in England, p. 124.] His name occurs for the last time in the Term Catalogues in Hil. 1694. [T.C. II. 495.] His widow Hannah's will was proved in 1713. See Robinson (Ranew).

RATCLIFF (THOMAS), see Diclionary, 1641-67.

RATHBONE (JosiaH), bookseller in Macclesfield, r723. Published $A$ Book of Psalmody, by R. T. Barber. [J. Cooke, Bibl. Cestr.]

RATTEN (CALEB), bookseller in Market Harborough, I708-x6. Mentioned in a list of provincial booksellers in Notes \& Queries. He was evidently the successor to Thomas Ratten. [N. \& $Q$. I Ith ser., XI. 45.] 
RATTEN (GEORGE), bookseller in Coventry, r 7or. Only known as the publisher of a sermon by the Rev. M. Heynes, printed in I701. [B.M. 225. i. 16 (I).] Perhaps father of W. Ratten $(q . v$.$) .$

RATTEN (THOMAS), bookseller in Lutterworth, Kettering, and Market Harborough, 1685 . His name occurs in a list of booksellers and stationers at the end of M. Bromfield's Brief Discovery of the . . Scurvy, 1685, as agent for a patent medicine. [N. E. $Q$. I I th ser., XI. 45.]

RATTEN(w.), bookseller in Coventry, I 7 I6. Perhaps son of George Ratten (q.v.) He sold Joseph Cattell's sermon, The Destroying Angel recalled, preached at Rothwell on July I7th, I7I5. [B.M. 4474. d. 32.]

RAVEN (JOSEPH), bookseller in London, Searle's Square, Lincoln's Inn, r 700. Published a ballad, The Welshman's praise of Wales, r7oo. [B.M. C. $40 . \mathrm{m}$. I I (87).] He also sold a patent medicine called "Elixir Febrifugium Martis".

RAVENSHAW (SAMUEL), bookseller and book-auctioneer in London, Old Palace Yard, Westminster, r69r. Catalogues of book-sales held by him are in the British Museum. [B.M. 82r. i. 9, i. 5 (3I).]

RAW, or RAWE (T.), bookseller in London and Bath; London, (I) Bible, St. Paul's Alley, r679 ; (2) London Yard, near St. Paul's r681 ; Bath, r685. In Mich. 1679 , he advertised $A$ Full Narrative, or a discovery of the Priests and Jesuits, but his name did not appear in the imprint. [T.C. 1. 373.] In 1681 he published in London Yard a poetical broadside, The Bane to the Devonshire Cant. [C. 20. f. 6 (19).] In $\mathrm{r}_{58}$ he published William Leybourn's Platform for Purchasers, $A$ guide for builders, which bears his Bath imprint. [T.C.II. I36.]

RAWLINS (JоHN), printer and bookseller in London, Anchor in St. Paul's Churchyard, 1674 (?)-1 703 (?). The W. and J. R. who printed in 1674 a translation of La Calprenède's Cleopatra for P. Parker and T. Guy may be William and John Rawlins. In 1684 John printed an edition of John Wilson's Cheats for J. Wright, and in 1686 W. de Britaine's Humane Prudence for R. Sare. In 1692 he published An Account of the great Victory obtained at sea against the Frenck. Dunton [p. 25I] says "Mr. Rawlins, near Paternoster row, has printed several Books for me. ... He is an honest and thriving man, and has an excellent choice of good letter". This might apply to either John or William. 
RAWLINS (WILLIAM), printer in London, near Paternoster Row (?), I674 (?)I 703 (?) See Rawlins (John). William was one of the assigns of Richard and Edward Atkyns for printing Reports des Cases in 1678. [T.C. 1. 321.$]$

RAWSON ( ), stationer in London, Paul's Chain, by Doctors' Commons, 1694. Advertised a patent medicine in the City Mercury, June IIth, 1694. [B.M. Burney, I1 2 A.]

RAY (ELIZABETH or ELIZA), printer in Dublin, r 708(?)-13. Only known as the printer of The Church Catechism Explained, I713. She was the widow of Joseph Ray and died some time in 1713 .

RAY (JOSEPH), printer and bookseller in Dublin, (I) College Green ; (2) in Skinner Row, opposite to the Tholsel, 1676-1 708. This printer's name is given in an imprint of 1676 , but not till 1681 does it occur again. From then till 1708 it is often found. The output from his press was large and included some notable works such as the first ed. of Molyneux's Case of Ireland stated, 1698. In 1694 he printed Sir George Ashe's Sermon preached in Trinity College Chappell, giving College Green as his address. [Bodl. Sermons, I (r9).] He printed the Newsletter for some months, and later the Dublin Intelligence. In 1702 he published Thomas Everard's Stereometry. [T.C. III. 292, 301.] He died in or about 1708 , and his will was proved that year in Dublin. Ray was never the King's printer, but he printed (besides many theological and controversial works for leading divines of the established church) some of the votes of the House of Commons. He was succeeded by his widow Elizabeth (q. v.).

REA (FRANCIS), bookseller in Worcester, 1651-85. See Dictionary, 1641-67. Still in business in 1685 , when he was defendant in a suit brought by William Daniels for payment for certain timber. [C.P.R. Trin. I Jas. II, Roll $303^{8}$, m. 1777.$]$

READ (E.), bookseller in London, at the corner of Duke Street, near Lincoln's Inn Fields, 1707. Published $A$ Supplement to the First Part of The Gentleman instructed, 1707. [T.C. III. 572.]

READ (J.), printer in London, White-Fryers, near Fleet Street, I709-24. A jobbing printer of broadsides, \&c. He was also the printer of a Half-Penny Post and a Weekly Journal. He is referred to by J. How in Some Thoughts on the present state of Printing and Bookselling, 1709, p. 12, as a printer of other 
men's copies. Negus mentions him in $\mathbf{1 7 2 4}$, as a "well-affected" printer. READ (R.), bookseller in London, 1682. Publisher of a pamphlet, London's Liberties, 1682. [Haz. II. 364.]

REDDISH (w.), bookseller in London, in Griffith's Buildings, near the Royal Cock-Pit, 1697. One of several booksellers selling three theological tracts in I697. [T.C. III. 3.]

REDMAYNE (JOHN). See Dictionary, 1641-67.

REDMAYNE (SAMUEL), printer in London, Jewin Street, 1722-4. Possibly a son of William Redmayne. On December 2 nd, 1722 he was fined for printing a libel. He is mentioned by Negus in 1724 as a "high-flyer". [Nichols, Lit. Anecd., vill. 368 ; I. 3 II.]

REDMAYNE (WILlIAM), printer in London, Addle Hill, 1674-1719. Probably successor to John Redmayne. He did a great deal of work for the booksellers, amongst others for D. Brown, S. Coggan, S. Keble, A: Roper, and R. Smith. In 17 I9 he was imprisoned for printing a libel on the Government. In the Weekly Packet of April 4th-11th, I719, was the following item of news: "Mr. Redmayne the printer is very ill of a fever in Newgate." He died on April Irth. [Nichols, Lit. Anecd., viII. 368.]

REDWOOD (JOHN), bookseller and printer in Cork, (I) near the Exchange I 7 I 5 (?)-21 ; (2) Castle Street, 1723. I71 5-23. He appears as a bookseller in Cork in 1716 , or perhaps even in 1715 . He so continued till 1721 , but is found as a printer in 1723 , when his imprint is found in The Spiritual Week, and in another devotional book, and in Steele's Conscious Lovers.

REEVE (MRS. LITTLE), bookseller in Norwich, I707. Her name occurs in an advertisement of "Golden Snuff" in the Daily Courant of May 3oth, I707.

REEVE (THOMAS), printer in Canterbury, 1717. The first printer in Canterbury. He printed "for the proprietors" the early numbers of the Kentish Post, or Canterbury Newos Letter. [F. W. Cock, in The Library, July, 1913, 3rd ser., IV. 285-7.]

REID (JOHN), bookseller in Glasgow, 1676 . One of the debtors in A. Anderson's inventory of 1676 . [Bann. Misc. II. 283.]

REID (JOHN), I, printer in Edinburgh, in Bell's Wynd, at the head of the Court of Guard, I680-I716 (?) Watson says [p. 13] that Reid set up with Patrick 
Ramsay about $\mathbf{6 8 0}$. This is confirmed by a broadside, Serenissimo . . Jacobo, Albaniae et Eboraci Duci .. . Congratulatio ... XIII Kal. Mart. 1680, which has the imprint, "Has praeli sui primitias, ut in publica Gratulatione micam, excuderunt Typographi tyrones, Pat. Ramsaeus, Jo. Rhedus." [Adv. 24 (1 5a).] In September 1683 Mrs. Anderson gave in a complaint against him to the Privy Council for setting up a printing house in contravention of her privilege ; but the Council allowed Reid to print anything not in Tyler's gift, to the terms of which Mrs. Anderson's gift was restricted. In November of the same year Mrs. Anderson brought a further action against him for stealing types from her office. On September 23rd, r7or, he was ordered by the Privy Council to be imprisoned in the Tolbooth till further order, for printing a treasonable paper by a certain Capt. Donaldson, on the death of James II, and the proclaiming of the Prince of Wales in France [Acts of Privy Council.] In 1704 his imprint is found on a chap-book, The New Glous-siershire [sic] Garland. He died about 1716 , his will being registered on the I Ith May of that year.

REID (JоHN), II, printer in Edinburgh, in Liberton's Wynd, I699 (?)-1712. Son of the preceding. Watson [p. 18] says that he set up about 1699, but no book of his bearing that date has been found. Reid was connected, as printer, with several of the newspaper enterprises of his time : The Edinburgh Gazette (1702); The Edinburgh Courant (1707), The Scots Postman (17 10); and others. After his death in August 1712 his widow, Margaret Reid, carried on business for a short time.

REID (JOHN), III, printer in Edinburgh, in Pearson's Close, a little above the Cross, I 7 I 4-2I. Son of John II, and Margaret Reid (?) In I 7 I4 Reid printed some numbers of the Edinburgh Gazette; and The Last Speech and Confession of Nicol Muschet, who was executed on January 6th, 1721, bears his imprint.

REID (MARGARET), printer in Edinburgh, at the foot of the Horse Wynd, I714-16. Widow of John Reid II ( $\left.f_{17} 12\right)$. In $1714^{-15}$ she printed some numbers of the Edinburgh Gazette, and An Abstract of an Account of the Proceedings at Perth was also printed by her, probably in 1716.

REYNOLDS (ROWLAND), bookseller in London, (I) Sun and Bible, Postern Street, near Moorgate, 1667-9; (2) King's Arms, Poultry, 1670 ; (3) Sun and Bible, Poultry, $1672-5$; (4) near Arundel Gate, in the Strand, 1676 ; (5) Henrietta Street, Covent Garden, 1677 ; (6) (a) next door to the Golden Bottle in the Strand, at the Middle Exchange Door, (b) near Salisbury 
Exchange, Strand, 1681-4, 1667-91. See Dictionary, 1641-67. Publisher of miscellaneous literature, last mentioned in the Term Catalogues in Easter I684 [T.C. II. 76.] In Mich. 3. W. \& M. (169I) he was sued by Timothy Hart for debt. [C.P.R. 3ror, m. 440.] His frequent removals may perhaps have the same origin.

RHAMES (AARON), printer in Dublin, 1700-34. One of the leading Dublin printers of his time; his descendants continued in Dublin for about two centuries. In 1714 he printed the first extant complete English Bible printed in Ireland. He also printed the earliest heraldic work printed in Ireland. He died in 1734 ; his will was registered in the Dublin Diocesan Court.

RHODES, or RODES (HENRY), bookseller in London, next door to the Bear Tavern, Fleet Street, near Bride Lane; (2) next door to the Swan Tavern, Fleet Street, at the corner of Bride Lane ; (3) Star, Fleet Street, at, or near the corner of Bride Lane, or near Fleet Bridge. 1681-1709. Possibly a son of Matthew Rhodes (1642) a prolific and miscellaneous publisher. He shared with Joseph Hindmarsh and Richard Lane the copyright of The Turkish Spy. Rhodes was dead before 1725, when his widow married Sir Thomas Masters, knight. [Nichols, Lit. Anecd. viIl. 356.] His various addresses may describe the same house.

RIBOTEAU (H.), bookseller in London, Crown, over against Bedford House, Strand, 1702. Publisher with the widow Mariet of French literature. His name is also found in an advertisement of a book auction in the Post-man of November 7 th, 1702 .

RICHARD (w.), bookseller in London, 1682. Publisher of a political broadside in verse on the Popish Plot entitled A Letany for St. Omers. [B.M. C. 20. f. $6(15) \cdot]$

RICHARDS (GODFREY), bookseller in London, Golden Ball, Cornhill, over against the Royal Exchange, 167I. Published a book on tonnage and poundage for merchants. [T.C.I. 72.]

RICHARDS (HANNAH), bookseller in Nottingham, 1703-4. Probably widow of Samuel Richards (q.v.), whom she succeeded in I703. [Creswell, p. 7.] Published in 1704 the Rev. John Barrett's Discourse concerning Pardon of Sin. [T.C. III. 409.] 
RICHARDS (JOHN), bookseller in Nottingham, 1698-1703. Perhaps a son of Samuel Richards. He published John Ellis's Sermon preached at the Church of St. Mary in Nottingham, January 4, 169\%9. [T.C. IIr. 106 ; Creswell, p. 6.]

RICHARDS (SAMUEL), bookseller in Nottingham, 1669-1703. First met with in 1669. In 1674 he published, with T. Guy, Goodwill tonoards Men [T.C. I. I85], and in 1686, with L. Meredith, Rest for the heavy laden, by Clement Ellis, Rector of Kirkby, Notts. [T.C. II. 156.] Dunton says in I703 [p. 237] that "he pursues his business very closely and is a person of great integrity." He died in this year and his widow or daughter, Hannah Richards (q.v.), succeeded him. [Creswell, pp. 5-7.]

RICHARDSON (EDMOND), bookbinder and bookseller in London; (I) Scalding Alley ; (2) Naked Boy, Blowbladder Street, over against St. Martin-le-Grand, 1698; (3) Naked Boy, Newgate Street, 1699-1 703 ; (4 ?) near the Poultry Church. I680 (?)-1 703. Dunton says [pp. 257-8] that Richardson "was my kind neighbour in Scalding Alley for many years, bound most of my Calves Leather Books whilst I lived in the Poultry.... Having thrived by his binding trade, he is now a flourishing bookseller in Newgate Street". In I69I he published Islington-Wells, but his first entry in the Term Catalogues was a theological book, in Easter Term 1698. [T.C. III. 63.]

RICHARDSON (J.), bookseller in Leeds and Wakefield, r 700-5. Published a volume of sermons in 1705 . [T.C. III. 462-3.]

RICHARDSON (JOHN), printer in London, near the Mitre Tavern, Fenchurch Street, $1675^{-1} 703$. His name is first met with in the list of London printing houses of 1675 as one of those who had set up since the Act was in force. He printed the ${ }^{6} 685$ edition of Cocker's Arithmetick for Passinger and Lacy. He also printed for Dunton, who speaks of him [p. 250] as being then (in 1 703) a man "pretty much up in years; however his young inclinations are not altogether dead in him; for I am informed his son and he have married two sisters". He was Under-Warden of the Company in 1696-7.

RICHARDSON (STEPHEN), printer at Oxford, Holywell, I7I5-55. First mentioned by Hearne in July $17 \mathbf{I}_{5}$ as the printer of certain verses on Dr. Radcliffe. He was elected Architypographus, much to Hearne's chagrin. Richardson had two sons, Stephen and John. [Hearne, Remarks and Collections, V. 79, IX. 403 ; Madan, p. 32.] 
RICHARDSON (w.), printer in London, r zor. Printed for Eben. Tracy an edition of Wits Academy, r 7or. [Haz. II. 653.]

RIDER (PRESSICK), printer in Dublin, I724-5. In partnership with Thomas Harbin he printed in 1725 a new edition of W. Molyneux's Case of Ireland.

RILEY (WILLIAM), bookseller in London, next door to the Queen's Head, without Temple Bar, r67o. Sold an edition of T. Clarke's Phraseologia Puerilis in r670. [T.C. 1. 62.]

RIVINGTON (CHARLES), bookseller in London, (r) Bible and Crown, St. Paul's Churchyard, $\mathrm{I} 7 \mathrm{I} \mathrm{I}-42$. Born in $\mathrm{I} 688$, the second son of Thurston Rivington, of Chesterfield, he was apprenticed to Matthews, bookseller $(q . v$.$) , and took$ up his freedom in I III. He must have already had considerable capital, though his father did not die till I734, as he in the same year bought the business of Richard Chiswell, the large bookseller and publisher in St. Paul's Churchyard, who was just dead. He announced Pierre Jurieu's Practice of Devotion in Easter I Y I [T.C. III. 659] from the Bible and Crown in St. Paul's Churchyard (Chiswell's sign had been the Rose and Crown). The D.N.B. states that his first house was in Paternoster Row, and Mr. S. Rivington says that he moved in $I_{7} \mathrm{I}_{4}$ to the Bible and Crown at no. 62 on the north side of St. Paul's Churchyard ; but he would naturally have succeeded to Chiswell's house in the Churchyard in $\mathrm{r} 7 \mathrm{rr}$, instead of going to another in Paternoster Row. He kept up the religious character of Chiswell's business, and later published for the Wesleys and Whitefield. He also did a large business in publishing sermons on commission. He is the hero of the story of the country vicar who ordered 35,000 copies of a sermon to be printed. Rivington agreed after a protest, and, having sold 17 , sent him a bill for some $£ 784$, but reassured him a day or two later by confessing that he had only printed roo. A list of some of Rivington's early publications is given in Fénelon's Pastoral Letter, I 7 15. He was one of the founders in 1736 of the new "Conger" or booksellers' club for buying and selling shares in copies. He and Osborne share the credit not only of publishing Pamela, but of having suggested to Richardson the idea of a collection of letters, which developed into it. He died on February 22nd, 1742, and was succeeded by two sons, John and James, out of a large family ; Richardson acted as guardian to his children and trustee for the business till John's majority. [S. Rivington, The Publishing Family of Rivington, I9r9; D.N.B.] 
ROBERTS (J.), bookseller in Bridgwater, r698-1700. In I698 he published, with S. and J. Sprint, A Sermon preached at Bridgwater, by J. B., and in 1699-1700, with J. Sprint, Religion justified in a sermon preached before . . the Mayor... of Bridgwater, by J. H., Minister. [T.C. III. 90, 167.]

ROBERTS (JAMES), printer and bookseller in London, ( $\mathrm{I}$ ) near Stationers' Hall, 1706; (2) Warwick Lane, 1713-54. 1706-54. In I706 J. Gilbert's Reflections on Dr. Fleetwood's Essay upon Miracles was printed for J. Roberts near Stationers' Hall. [T.C. III. 508, 521.] It is not clear whether he was identical with the printer James Roberts, of Warwick Lane, who was able to subscribe five guineas to the Bowyer Fund in I7 13 , was classed by Negus as "well-affected", was Master of the Stationers' Company in 1729, 1730, and r731, and died, aged 85, on November 2nd, r754, and whom Nichols, in giving these facts [Lit. Anecd., III. 737] calls " a printer of great eminence". He also published books.

ROBERTS (R.), printer in London, I679 (?)-99. He may be the R. R. who with A. M. printed in $1679 A$ True Relation of the ... Cruelties lately acted by the Rebels in Scotland. [Haz.III. 224.] He is first mentioned in the Term Catalogues in Mich. 1685, as printer of The Mirror of Martyrs. The advertisement states that it was printed "for R. Roberts" ; but in this as in many other cases, it does not imply that he was a regular bookseller. In I690 one R. R., with M. C., printed for Adiel Mill a folio ed. of the Letters of Gerard Vossius. In I692 Roberts printed the Votes of the House of Commons in Ireland. [Burney, $104 \mathrm{~A}]$, and in 1699, for J. Nutt, Dr. W. Harris's Description of the King's Palace and Gardens at Loo. [T.C. IIr. 154.] Dunton says of "Mr. Roberts" (no doubt this man): "In twenty books that he printed for me he never disappointed me once ... so that what he left to his Widow will wear well "; which shows that he was dead before 1703 .

ROBERTSON (JOHN), printer in Edinburgh, 1725-48. Dr. John Lee, in his Memorial for the Bible Societies, records several editions of the Psalms in Metre and Confession of Faith printed at Edinburgh by T. Lumisden and John Robertson between $\mathrm{I}_{725} 5$ and 1748 .

ROBINSON ( ), bookseller in Great Marlow, r7rr. Publisher of the Rev. Richard Millechamp's Sermon ... at the Funeral of Mr. James Harman . . . Augt. Igth, I7Ir. His name does not appear on the title page, but was mentioned in a newspaper advertisement of the publication. 
ROBINSON (EDWARD), bookseller in Ludlow, 1678-r 7 ro. Published William Smith, Rector of Bitterley's Just Account of the horrid contrivance of John Cupper ... in poysoning his wife, r684. [Bodl. Ashm. 739 (27). ; T.C. II. 103.] Mentioned in a list of provincial booksellers as publishing in 17 ro. $[N . \mathcal{E} Q$., Ioth ser., V. I83.]

ROBINSON (JONATHAN), bookseller in London, (I) Angel in Jewin Street, r667-70; (2) King's Arms, St. Paul's Churchyard, r670-7I ; (3) Golden Lion, St. Paul's Churchyard, I672-I7Ir. I667-I7Ir. Publisher for the Nonconformists. Till $167 \mathrm{I}$ he was in partnership with $\mathrm{N}$. Ranew $(q . v$.$) . There are$ numerous entries by him in the Term Catalogues. In the London Intelligence of January 29th, I68\%, he offered ten shillings reward for a lost MS. of The Life and Death of Nathaniel Mather of Boston in New England. He was still publishing in $\mathrm{r}$ IIr, but was perhaps dead by $\mathrm{I}_{713}$, when Ranew Robinson ( $q . v$.), almost certainly his son, was in business as a bookseller.

ROBINSON (JOSIAH), bookseller in London, Lincoln's Inn Gate, next Chancery Lane, 1672. Published an astrological tract by Thomas Trigge, The Fiery Trigon Revived, 1672. [T.C. I. I12.]

ROBINSON (RANEW), bookseller in London, I7I3. Presumably a son of Jonathan Robinson. Mentioned in the will of Hanna Ranew, widow of Nathaniel Ranew, proved April I5th, I713. [P.C.C. 89 Leeds.] In the same year he contributed three guineas to the Bowyer Fund.

ROBINSON (ROBERT), bookseller in London, near Gray's Inn Gate, Holborn, I672-82. He entered a few books in the Term Catalogues in 1672-4, and was still in business in 1682 , when his name is found as publisher of The Moderate Intelligencer. [Timperley, p. 563.]

ROBINSON (U.), printer in Milton-Ernis, near Bedford, I7r9. Printed John Hunt's Vindiciae verae pietatis. [Allnutt, p. 302.] A private press?

RODES (HENRY), see Rhodes.

ROE (JEREMIAH), bookseller in Derby, (a) Upper end of Sadler Gate, (b) near the Market Heads, I725. About $\mathbf{I}_{725}$ he issued an advertisement that he sold books and stationery " as cheap as in London ", and that he bought libraries. [Wallis, Sketch of the Early History of the Printing Press in Derbyshire (Derbyshire Arch. E Nat. Hist. Soc. Journal, III. 142).] 
ROGERS (GABRIEL), bookseller in Shrewsbury, 1695. Published a sermon by T. Dawes in 1695. [B.M. 226. f. 21 (8).] He was succeeded by John Rogers.

ROGERS (HENRY), bookseller in London, $(a)$ Bible, $(b)$ Crown, in Westminster Hall, 1678. With W. Crooke he announced in 1678 Rawlins's comedy Tunbridge Wells [T.C.1. 310]; his name alone occurs on the British Museum copy [643.d.64]. His sign appears as the Bible in the Term Catalogue, and as the Crown on the book.

ROGERS (JOHN), bookseller in Shrewsbury, High Street, 1708-13. Perhaps a son of Gabriel Rogers. Given in a list of provincial booksellers in $N$. $E Q$. as publishing in 1713 . [ $N$. E。 $Q$., Ioth ser., v. 242.] He sold $A$ Sermon proving Sloweness to Anger the truest Gallantry, printed for T. Varnum and J. Osborne, London. [n. a. 1713, owner's note in Mr. G. P. Mander's copy.]

ROGERS (WILLIAM), bookseller in London, ( 1 ) Maiden's Head in Fleet Street, 1678-9; (2) Sun, against St. Dunstan's Church in Fleet Street, r680-1 7 Ir. 1678-171r. He became one of the largest publishers of his day, chiefly of theology. One of his chief patrons was Archbishop Tillotson. Dunton [p. 208] was associated with Rogers in publishing some dying speeches.

ROLLS (NATHANIEL), bookseller in London, at his Auction House, Petty Canons Hall, in Petty Canons, (a) near the North End, $(b)$ on the North Side, of St. Paul's Churchyard, r692-5. Publisher of schoolbooks. His first entry in the Term Catalogues, in Mich. 1692, was an edition of Eusebius. Another of his publications was Milton's History of Britain. His last entry was in 1696. [T.C. II. 430, 531, 595.]

ROOKES, or ROOKS (THOMAS), see Dictionary, 164I-67.

ROPER (ABEL) I, see Dictionary, 164I-67.

ROPER (ABEL) II, bookseller in London, (I) Bell, Fleet Street, $(a)$ over against the Middle Temple Gate, (b) near Temple Bar, r688-9; (2) Mitre, Fleet Street, 1690-3; (3) Black Boy, Fleet Street, over against St. Dunstan's Church, 16941 707. 1688-r 726. Nephew of Abel Roper I, who in a will by which he left him all his copies, expressed a hope that the young man might serve his apprenticeship under him. This wish was not fulfilled, as Abel Roper I died within a year of making his will, on March 4th, 1679. Abel Roper II is first met with in the Term Catalogue of Trin. 1688. [T.C. II. 229.] In I69I he was sued by Thomas D'Urfey for payment in respect of the latter's comedy Love for Money. [C.P.R. 
3ro2, m. 541, r.] In 1694 he joined E. Wilkinson at the Black Boy. [T.C. II. 501.] The latter disappears after 1696. Arthur Collins had succeeded Roper at this house in $170 \frac{8}{9}$. In 1707 Roper was the proprietor of the Post Boy, and he employed A. Boyer to translate news for the paper. In August I 709 Boyer was discharged and at once set up a rival sheet called The True Post Boy. [Post Boy, August r6th-18th, ryog.] Dunton [p. 210] says of him: "He rises in the world . . . prints 'The Post Boy', 'The Life of King William', 'The Annals of Queen Anne', and several excellent Abridgements. I have formerly been a Partner with him." He was still in business in 1726 when Bowyer printed Alexander Innes's Trelve Sermons for him. [Nichols, Lit. Anecd., I. 348.]

ROSE (GEORGE), bookseller in Norwich, $1675-86$. In 1675 he published a sermon preached in Norwich Cathedral by Robert Conold [B.M. 226. g. Io (4)], and in 1676 The Divine Physician, by J. H., M. A. [T.C. I. 245.] He was still publishing in $\mathrm{r} 686$.

ROUND (JAMES), bookseller in London, Seneca's Head, Exchange Alley in Cornhill, r702-45. Began publishing in r702 [T.C. III. 297], chiefly history and school-books, such as W. Willymot's English Examples to Lilly's Grammar Rules, with the Proprieties, for the use of Eaton School, and ed., I7II. Round became one of the most important booksellers in London, and was Master of the Company. He died on December 17 th, 1745 . [General Evening Post, December r 7 th-rgth, r 745.]

ROYSTON (RICHARD), see Dtctionary, I64I-67. See also Green (Richard), and Meredith (Luke). RUDDIMAN (THOMAS), printer in Edinburgh, in Morocco's Close, r724; in the Parliament Close, 1729-57. I715-57. Ruddiman, who was born in 1674, en tered the Advocates' Library as assistant librarian in 1702 , and from 1730 to I $75^{2}$ held the office of Keeper of the Library. In I 707 he added the business of book auctioneer to his other occupations, and from about this time was associated, chiefly in an editorial capacity, with several works printed by Robert Freebairn. He also gave assistance to Ames in the preparation of the Typographical Antiquities. His Rudiments of the Latin Tongue was first published in $\mathrm{I}_{7} \mathrm{I}_{4}$, and in the following year his edition of Buchanan's works, in two folio volumes, came from Freebairn's press. In the same year (I 715) Ruddiman commenced printer, and took into partnership his younger brother Walter $(q . v$.$) . As his first undertaking he printed half the second volume of$ 
Patrick Abercromby's Martial Atchievements of the Scots Nation, which was published by Freebairn. In 1728 Ruddiman and James Donaldson were appointed conjoint printers to the University of Edinburgh. In 1729 he became proprietor of the Caledonian Mercury which he had printed since I 724 and which continued in the family until 1772 , when, together with the printing house and materials, it passed into the hands of John Robertson. He died in 1757. [G. Chalmers, The Life of Thomas Ruddiman, I794.]

RUDDIMAN (WALTER), printer in Edinburgh, I715-70. Younger brother of Thomas Ruddiman (q.v.). Born in 1687 . From 1706 he worked with Robert Freebairn, printer, and in 1715 was taken into partnership by his brother. Died in 1770 .

RUMBALL (E.), bookseller in London, Post House, Russell Street, Covent Garden, 1701. In partnership with $\mathrm{R}$. Wellington he published the second edition of Five Love Letters from a Nun to a Cavalier, 1701. [B.M. 10909. a. 9.]

RUMBALL, or RUMBOLD (RICHARD), bookbinder and bookseller in London, Bell and Coffin, Old Change, 1679-84. Published The Grand Question concerning the Bishops' right-to vote in Parliament in cases capital, 1679, and $A$ Seasonable Discourse against Toleration, 1684. [T.C. I. 374, II. 9I-2.]

RUMBALL, or RUMBALD (WILLIAM), bookseller in London [Bell and Coffin(?)], Old Change, r680. Probably related to Richard Rumball. He published in I680 Don Tomazo, or The juvenile rambles of Thomas Dangerfield. [B.M. I26r4. b. I9.]

RYLES (THOMAS), bookseller in Hull, I 707-16. John White of York printed for him an Assize sermon preached in Lincoln Cathedral by Christopher Hildyard on March 17 th, $170 \frac{6}{7}$, n. d. [Bodl. Sermons, 10 (1).] In I7ro he sold one of the pamphlets produced by the arrest and impeachment of Dr. Sacheverell [B.M. III. b. 28.] In I7 I4 he subscribed to Walker's Sufferings of the Clergy. He is met with last in $17 \mathrm{r} 6$, when his name is found in the imprint to a sermon, preached on July 22nd, by John Clark.

SACKFIELD (JOHN), bookseller in London, Lincoln's Inn Square, 1717. Publisher of Sir Stephen Fox's Memoirs, I 7 I 7 . [Haz. II. 225.]

SADLEIR (ELIZABETH), printer in Dublin, I715-22. Apparently succeeded Sarah Sadleir. In 17 I 5 and 1716 she printed (for Geo. Gunson) the fourth and fifth editions of Puffendorf's Whole Duty of Man. In 1716 she printed Matthew 
Henry's Communicant's Companion, and in 1721 Burnet's Exposition of the Thirty-nine Articles and a large folio edition of Hooker's Works.

SADLEIR (SARAH), printer in Dublin, I712-14. In I 712 she printed a sermon by Peter Hanny, and in I 7 I 4 a "twenty-eighth edition" of Cocker's Arithmetic, edited by John Hawker.

SADLER (THEODORE), bookseller in London, Little Britain, 1660-9. See Dictionary, 1641-67. In 1669 he was examined before Lord Arlington for selling a work called The Brief Method. Sadler said the copies were brought to him by a Frenchman in the name of the Superintendent of Somerset House ; but that person denied all knowledge of it. [S.P.D. Chas. II, 26I, f. 37.]

SALUSBURY (JOHN), printer and bookseller in London, (I) Atlas, Cornhill, near the Royal Exchange ; (2) Rising Sun, Cornhill, over against the Royal Exchange ; (3) Angel, in St. Paul's Churchyard. 1685-98. Began as a publisher of theological books at the Atlas in Cornhill, about Easter, 1685 . [T.C. II. I23.] In 1687 he was selling medical books. [T.C. II. 206.] In I689 he moved or changed his sign to The Rising Sun in Cornhill. In I692 he published the Rev. Thos. Doolittle's Earthquakes explained and practically improved. In 1694 he printed a weekly paper called The Flying Post, which he sold at $2 d$. and in which he advertised that he was prepared to buy books. He died between August and September 1698, as recorded in The Flying Post of October I5th. Salusbury was also the publisher of The Weekly Memorial. [Burney, I04 A.] At the time of his death his imprint was The Angel in St. Paul's Churchyard. Dunton calls him "a desperate hypergorgonic Welshman", and "a silly, empty, morose fellow", and adds [p. 2ro] that he went to law with the Stationers' Company.

SALUSBURY (T.), bookseller in London, ( $\mathrm{r}$ ) (a) Black Lion, Post Office, Fleet Street, between the two Temple Gates, (b) Temple, Fleet Street, $(c)$ next the the Inner Temple, (d) near Temple Bar, I685-92; (2) King's Arms, Fleet Street, 1693-4. 1685-94. His name first appears in the Term Catalogue for Hil. 1685. Publisher of some important works. He is last heard of in Hil. 1694. [T.C. II. 494.]

SAMPSON (JACOB), bookseller in London, next door to the Wonder Tavern in Ludgate Street, 1680-2. One of the booksellers who became publishers at the time of the Popish Plot. He published in 1679-80 one book, John Flavell's 
Sacramental Meditations, and, with T. Simmons, two pamphlets and a broadside on the Plot: (1) The Narrative of Lawrence Mowbray, (2) The Narrative of Robert Bolron, (3) A Full and Final Proof of the Plot. [T.C. I. 381-3; B.M. T. I* (62).] He also published engraved portraits of celebrities, and he is possibly the person referred to by Dunton [p. 292] as "Card" Sampson. SANDERS, see also Saunders.

SANDERS (RICHARD), bookseller in London, 1681. Publisher of $A$ New Ballad of London's Loyalty. [B.M. C. 38. i. 25 (I2).]

SANDERS (ROBERT), the Elder, see Dtctionary, 1641-67.

SANDERS (ROBERT), the Younger. Printer and bookseller in Glasgow, (I) his shop a little above the Grammar School Wynd; (2) his shop a little below Gibson's Wynd; (3) his house in the Salt Mercat a little below the Well. 1695-1730. Son and successor of the preceding. Usually designated "of Auldhouse ". One of the King's printers, printer to the City and University. Died January 1730. [Aldis, p. 120.]

SANDYS (EDWIN), printer in Dublin, 1705-18. He printed in 1705 the famous sermon of the Rev. Francis Higgins, and reprinted some English editions; in 1709 he printed Remarks upon Partiality detected for T. Servant. In $\mathrm{I} 7 \mathrm{I} 3$ he reprinted for 'George Grierson ' Waller's Peace on Earth, in 1715 Phillips's Cyder, and Pope's Temple of Fame, \&c., and in 7 18 a Miscellany of Poems, \&c. SANGER (EGBERT), bookseller in London, Post House, Middle Temple Gate, Fleet Street, 1707-1 I. Publisher, in 1707, of Mercurius Oxoniensis and of Mrs. Centlivre's comedy, The Platonick Lady. In the next year he published, with Curll $(q . v$.$) , Rowe's translation of Boileau's Lutrin and a book by$ Dodwell. His other publications include William Taverner's comedy, The Maid the Mistress, and some historical works. He was still in business in I III. [T.C. III. 669.]

SARE (RICHARD), bookseller in London, Gray's Inn Gate, Holborn, 1684-1723. The son of a clergyman; he was apparently in partnership with S. Heyrick, of this address, but each published independently. Sare's first publication was, with D. Brown, the eleventh edition of Bacon's Sylva Sylvarum, in 1684. [T.C.II. 105.] He prospered, and published many books. In 1693 he published L'Estrange's translation of Josephus ; while it was in the press T. Basset and the other owners of the copyright of the older translation printed an advertisement in protest, and Sare another in reply. [B.M. 806. k. $15\left(20^{*}, 20^{* *}\right)$.] 
He supported the Government, and was generally careful in what he published as well as personally blameless; but the casual sale of a copy of The Rights of the Christian Church Asserted exposed him to a frivolous prosecution by Samuel Hilliard, Prebendary of Lincoln, which resulted in his acquittal. [S. Hilliard, A Narrative of the Prosecution of Mr. Sare, 1709, B.M. 702. f. 2 (3); $A$ Defence of the Rights of the Christian Church, 1709, B.M. 858. d. 9.] According to Nichols, Sare was one of the oldest and steadiest friends of the elder Bowyer, and after the fire at his printing-house in $\mathbf{I}_{7} \mathrm{I}_{3}$ collected over $£ 66$ for his benefit. [Lit. Anecd. 1. 61, 63.] Sare died on February 2nd, $172 \frac{3}{4}$. His funeral sermon, from which much of what we know of him is derived, was preached by Dean Stanhope ; it was printed by Bowyer for Richard Williamson, who succeeded to Sare's business. Both the Dean and Dunton [p. 218] warmly praise Sare's amiability and high character.

SARE (THOMAS), bookseller in London, right over against the Black Prince in Duck Lane, 1673. His imprint occurs in the Rev. Richard Steele's Antidote against Distractions, $3^{\text {rd }}$ ed., 1673. [T.C. I. 137.]

SAUNDERS, see also Sanders.

SAUNDERS, or SANDERS (E.), bookseller in London, Crown in the Pall Mall, 1683-92. Associated with S. Holt in publishing an English translation of J. Commelin's Belgick or Netherlandish Hesperides, 1683. [T.C. II. I9.] In 1692 he was the publisher of $A$ Collection for the Improvement of Husbandry and Trade. [B.M. Burney, I05 A.]

SAUNDERS (FRANCIS), bookseller in London,Blue Anchor on the New Exchange in the Strand, 1684-99. Partner with Joseph Knight. They succeeded to the business of Henry Herringman in 1684, and were therefore the leading publishers of plays. The partnership was dissolved about I688, when Knight moved to the Pope's Head in the New Exchange. Saunders is last met with in the Term Catalogues in Trin. 1699. [T.C. III. 149.] Dunton says [p. 214], "He lived in the New Exchange and had the honour to be personally known to very many of the Nobility and Gentry of the first rank in England," and adds that he "lived long a bachelor, being too busy to think of Love".

SAVILE (GEORGE), bookseller in London, 1674. Published Defensio Legis, by Fabian Philips, 1674 [Haz. II. 473], which, however, was advertised by William Cooper. [T.C. I. 155.] 
SAWBRIDGE (GEORGE), the Elder, see Dictionary, 1641-67. George Sawbridge, the Younger $(q . v$.), was probably not son of this man but of Thomas Sawbridge, whom he succeeded.

SAWBRIDGE (GEORGE), the Younger, bookseller in London, Three Golden Fleur de Luces, Little Britain, 1692-1711. Succeeded Thomas Sawbridge (q. v., Dictionary, 1641-67) at this address in 1692. He published many scientific books. In 1705 he was convicted of printing or publishing a pamphlet entitled The Case of the Church of England's Memorial, and sentenced to pay $£ 200$ to the Queen and to appear in all the Courts in Westminster with a paper upon his head denoting his offence and to find security for his good behaviour for two years. Dunton [p. 2Ix] has this notice of him: "Mr. George Sawbridge succeeds his father in the trade, and prints many valuable copies. He has good skill in military discipline, and made a very handsome figure in Captain Robinson's company." As Dunton has just described the elder George Sawbridge, he seems to imply that the younger George was his son. If we do not take the words "succeeds his father in the trade " literally, this is possible, and in that case George the elder and Thomas must have been near relatives. But Dunton may have been in error, or have expressed himself confusedly.

SAWBRIDGE (HANNAH), bookseller in London, Bible on Ludgate Hill, r682-6. Widow of George Sawbridge, the Elder, who died in r68r. Her name occurs in the Term Catalogues as continuing the business till 1686 . [T.C. II. I60.]

SAWBRIDGE (THOMAS), bookseller in London, (I) next the Anchor, Duck Lane; (2) Three Flower de Luces, Little Britain, 1669-92. For the relationship between George and Thomas Sawbridge see above. Thomas Sawbridge began to publish in 1669, with William Leybourn's Art of Dialling. [T.C. I. I8.] He quickly rose to a high position in the trade, and between 1678 and $168 \mathrm{I}$ was associated with John Dunmore, T. Dring, Charles Mearne, and Benjamin Tooke in the publication of a series of classics which may rank amongst the finest examples of book production of that period. The type for this series came from the foundry of J. Grover. Sawbridge was a prolific publisher. He made his last entry in the Term Catalogues in Mich. 1692 [T.C. II. 430], and was succeeded by his son (?) George Sawbridge, the Younger (q.v.). 
SAYES (w.), printer and bookseller in London, Lovel's Court, Paternoster Row, 1707-14. 'In 1707 he took in subscriptions for L. Howell's Synopsis Canonum, which was advertised in the Daily Courant of September 3oth. In that he was described as the printer. It appeared in I708, and was printed for Clavel and others. In I II he published the Rev. Charles Palmer's Danger of a total ... Neglect... of the Lord's Supper. In I7I4 he was one of the subscribers to Walker's Sufferings of the Clergy.

SAYWELL (J.), printer at Gateshead, I7ro. Founded in this year The Newcastle Gazette, or Northern Courant. [Allnutt, p. 298; copy in Advocates' Library.]

SAYWELL (WILLIAM), bookseller in London, Red Lion in Winchester Street, 1670. Perhaps a son of John Saywell (q. v., Dictionary, 164I-67). He published The Mystery of Mysteries, 1670. [T.C. I. 47.]

SCORE (EDWARD), bookseller in Exeter, High Street, 1704-24. First appears as publishing, with P. Bishop, Joseph Pitts's True and Faithful Account of the Religion and Manners of the Mahommetans, printed by Farley, 1704 . [Dredge, p. 13.] In I 714 Score subscribed to Walker's Sufferings of the Clergy, and in 1724 he published Richard Izacke's Remarkable Antiquities of Exeter, and ed., 1724, which was printed for him in London. The firm was still in existence in 1779, when an Edward Score of Exeter is mentioned by Nichols as selling libraries by auction. [Lit. Anecd. vII. 686.]

SCOTT (JAMES), bookseller in Glasgow, 1676 . One of the debtors in Andrew Anderson's inventory, I676. [Bann. Misc. II. 283 ; Aldis, p. 120.]

SCOTT (ROBERT), bookseller in London, Prince's Arms, Little Britain, $166 \mathbf{I}-87$. See Dictionary, 1641-67. Scott had a large connexion amongst the literary men and aristocracy of his day. Dr. John Cosin, Bishop of Durham, writing to his librarian on December 23rd, 1669, says, "Mr. Scott is now return'd out of France and Holland with a great many good books." [Cosin, Correspondence, II. 218.] In 1670 Scott was in correspondence with Viscount Conway over some books. [S.P.D. Car. II, 277, f. I86.] Another of his customers was Sir Joseph Williamson, and among the State Papers is a bill of Scott's amounting to $f^{6} \mathbf{r}$ for books supplied to Sir Joseph. Eleven of these had chains attached to them, for which and fixing $14 s$. was charged. But the best biographical notice of this bookseller is that written by Roger North, who says: "Now he [i. e. Dr. John North] began to look after books, and to lay 
the foundation of a competent library. He dealt with Mr. Robert Scot of Little Britain, whose sister was his grandmother's woman; and, upon that acquaintance he expected, and really had from him useful information of books and the editions. This Mr. Scott was, in his time, the greatest librarian in Europe ; for, besides his stock in England, he had warehouses at Franckfort, Paris and other places and dealt by factors. After he was grown old and much worn by multiplicity of business he began to think of his ease and to leave off. Whereupon he contracted with one Mills [i.e. Adiel Mill, q.v.] of St. Paul's Churchyard, near $f_{10,000}$ deep, and articled not to open his shop any more. But Mills, with his auctioneering, atlases, and projects failed, whereby poor Scott lost above half his means. .. . He was not only an expert bookseller but a very conscientious good man, and when he threw up his trade Europe had no small loss of him. Our doctor, at one lift, bought of him a whole set of Greek classics, in folio, of the best editions." [Lives of the Right Hon. Francis North . . . the Hon. Sir Dudley North . . a and Dr. John North, III. 290-t.] His brother-in-law was William Wells, bookseller, with whom he was in partnership for a time. On January 3 rd, $167 \frac{6}{7}$, Scott wrote to Williamson, stating that Sir Roger L'Estrange had ordered Wells's shop to be shut up, because he had sold some copies of L'Escole des Filles, which he had purchased of Lucas, a bookseller of Amsterdam. Scott considered Sir R. L'Estrange's action as "illegal, unjustifiable, and uncivill ". [S.P.D. Car. II, 390, f. 9.] In 1680 Scott commenced a suit against the Company of Stationers in respect of the share in the English stock held by William Wells at the time of his death; Wells's widow had died two years before, leaving Scott her executor. The Company had elected Thomas Rawe in her place, and refused to admit George her son, or to return the $€ 80$ originally paid by Wells. [Chan. Proc. before 1714, Bridges 552/10.] Adiel Mill sold off Scott's stock in 1687 , and advertised the sale in the London Gazette for January 5 th- 9 th. He failed in 1690 . The date of Scott's death is unknown. His last appearance is in 1691 , when he had a share in the seventeenth edition of Chamberlayne's Angliae Notitia. [T.C. II. 385.] His last entry before this was of Dr. John

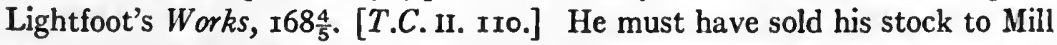
soon after this. His publications are not very numerous, and he was mainly a learned second-hand retailer.

SEAR (THOMAS), bookseller in London, Swithin's Alley, near the Royal Exchange, 1676. Only known from a broadside entitled Bethlehems Beauty, 
London's Charity, and the City's Glory. A Poem on .. New Bedlam. [B.M. C. 20, f. 2 (106).]

SEARCH (DANIEL), bookseller in London, near Whitefriars' Gate in Fleet Street, 1689. Publisher of The Harlem Currant, I689. [B.M., Burney, 97.]

SEDGWICK ( ), printer in London, c. 1691. Dunton tells us [p. 249] that Sedgwick managed the business for the widow of Henry Clark (who died in I69r), but that he was not very successful, and was succeeded by John Barber. SEILE (ANNE), see Dictionary, 1641-67.

SELFE (s.), bookseller in Norwich, Bible and Crown, Cockey Lane, 1 jor-4. The second edition of Humphrey Prideaux's Directions for Churchwardens was printed for him in 1704 by F. Burgess. [T.C. III. 395.]

SELL (JOHN), bookseller in London, over against the East India House in Leadenhall Street, ${ }^{6}{ }_{76}$. Advertised $A$ practical Discourse of Gods Sovereignty in Trin. 1676. [T.C. 1. 248.]

SELLER (JOHN), senior, bookseller in London, (I) Mariner's Compass, at the Hermitage Stairs in Wapping, 1669-91 ; (2) Exchange Alley in Cornhill, 1671-3; (3) (a) Pope's Head Alley in Cornhill, $(b)$ on the west side of the Royal Exchange, 1679-85. 1669-91. Hydrographer to the king, compassmaker, compiler and publisher of maps, charts, and nautical books. In 1667 he makes his appearance in the Royal Society's Philosophical Transactions. [1. $478 ; D . N . B$.$] In 167$ I he set up a second shop, in Exchange Alley; his advertisements of mathematical instruments in 1672 , and of a book in 1673, give this address only. [T.C. I. 100, 151.] In 1676 and 1677 he published from Wapping only; his publications being sold in Exchange Alley, probably at his former shop, by John Hills. [T.C. 1. 256, 267.] But in.1679 he sold his Atlas Minimus both at Wapping and in Pope's Head Alley, Cornhill. [T.C. 1. 350.] His last appearance in the Term Catalogues [II. I14] is with his Nere System of Geography, 1685. In 1691 he sold his Sea-Gunner, printed for him by H. Clark, at the Hermitage in Wapping; he then called himself John Seller, senior. [B.M. 8806. aa. 12.] His chief work was The English Pilot, 1671, \&c. John Seller, junior (q. v.), was probably his son.

SELLER (JOHN), junior, book and map-seller in London, (r) West End of St. Paul's Church ; (2) Star, near Mercers' Chapel in Cheapside. 1689. In 1689 he was one of those selling Petty's Geographical Description of Ireland. 
[T.C. II. 289.] He was then at the West End of St. Paul's; the Star near Mercers' Chapel in Cheapside is given as his address in D.N.B. Probably son of John Sellers, senior.

SELLERS (R.), bookseller in London, I683. Only known from his imprint on Sphinx Lugduno-Genevensis, 1683. [Haz. III. 237.]

SERVANT (тHOMAS), bookseller in Dublin, Bible, Castle Street, I709. In that year a book entitled Remarks upon ... Partiality detected was printed for him by E. Sandys.

SEYMOUR (JOHN), printer at Putney, I669-77. On October 7 th, 1669 , a patent was granted by King Charles II to Captain John Seymour, in consideration of "services to us and to our Royal Father from the beginning to the end of the late troubles and since the restoration, for making several voyages and journeys beyond the seas " to print Latin books, almanacs, \&c., for forty-one years. [Patent Roll, 21 Charles II, Pt. vi. I5.] During the proceedings before the Committee of the House of Lords, in 1677 , in the matter of seditious publications, Samuel Mearne, Warden of the Company of Stationers, declared that John Seymour had set up two or three presses at Putney, and that there was no one who was obnoxious to the Company but fled to Seymour. [Hist. MSS. Comm., Report 9, App., pp. 75-8.] In the same year there is a record in the archives of the Stationers' Company to the effect that " certain members of the Company, with Randall Taylor the beadle, standing indicted in the Crown Office, for breaking Mr. Seymour's presses, letters and cases, and counsel having advised that the safest way will be to submit to a fine and not to plead against the King ; ordered that Randall Taylor do attend the Court of King's Bench, and submit to a fine for himself and the rest, in which the table will bear them all harmless. [Records of Stationers' Company.] Seymour transferred his patent in 167 I to the University of Oxford. [S.P.D. Chas. II, 292, ff. II6, II 7.]

SHAD (J.), bookseller in London, 1653 . He published one of the many poetical broadsides commemorating the great frost of $1683-4$ and the fair on the frozen Thames. [B.M. C. 20. f. 2 (I65).]

SHARP (SIR JOSHUA), stationer in London, I68I (?)-r $7 \times 8$. Youngest brother of Archbishop Sharp. He is thus noticed by Dunton: "The next I dealt with was Mr. Sharp (brother to the Archbishop of that name) . . . Mr. Sharp is 
a person of great honesty-very obliging in his conversation-and thrives so fast in his shop, that 'tis very likely we may see him riding the great horse [i.e. as Lord Mayor]." The prediction of Dunton was in some degree verified. In 1713 Sharp was elected Sheriff of London and knighted. He married Rebecca Harvey, and died December 22, 17 I8. [Nichols, Lit. Anecd. vill. 354.] Sharp does not appear to have been a publisher. He is just possibly identical with the following.

SHARP (s.), stationer in London, Crooked Lane, 1692. His name occurs in the Term Catalogue of Easter 1692 as one of those who sold William Jordan's copybook. [T.C. II. 404.] "S. Sharp" is possibly an error for J. Sharp (q.v.).

SHARP (THOMAS), bookbinder and bookseller in London, Blackfriars, 1679. In 1679 he advertised The Politicks of France by Mr.P[aul] H[ay], Marquis du $\mathrm{C}$ [hastelet], and $A$ Letter ... shewing that the Bishops are not to be Judges in Parliament in Cases Capital. Arber says in his index that Sharp was a bookbinder, but does not give his authority for the statement. [T.C. I. 373, $375,567$.

SHARP (THOMAS), printer in London, Ivy Lane, 1722 (?)-4 (?). In partnership with Thomas Wood, printer of The Freeholder's Journal. On June 19, I722, he was tried and convicted at the Guildhall for printing a supplement to no. ro of that paper. [Timperley, p. 628.] Negus described him as a HighFlyer. [Nichols, Lit. Anecd. 1. 31 I-12.]

SHARPE, see Sharp.

SHARPLESS ( ), printer in London (?), 1690 (?). Married the widow of John Harefinch (q. v.), who died about 1690. [Records of Stat. Co.]

SHAW ( ), bookseller in Newcastle-on-Tyne, at the Bridge Foot, r723. He sold, for the anonymous author, in 1723, Copies in verse for the use of Writing Schools and Hymns for Charity Schools. [Memoirs of Mr. Ambrose Barnes, Surtees Soc., 1867, App., p. 469.]

SHAW (GIDEON), stationer in Edinburgh, in the Parliament Close at the sign of the Blue Bible, 1670-87. Served on the jury at Major Weir's trial in April 1670. One of the six booksellers who in 1671 successfully appealed against Andrew Anderson's monopoly. He married Marion Marshell and had a son, William. Died in 1687. Inventory printed in Bann. Misc. II. 292. [Aldis, I20.] 
SHEAFE (SAMUEL), stationer in London, Bread Street, 17 1 2-32. Partner with Alexander Merreal (q.v.), whose daughter he married and to whose business he succeeded. In $\mathrm{I}_{7} \mathrm{I}_{3}$ he contributed five guineas to the Bowyer fund. $\mathrm{He}$ died August 4th, 1732. [Timperley, p. 646.]

SHEARES (MARGARET). See Dictionary, 1641-67. Still publishing in I671. [T.C. I. 75.]

SHEFFIELD (s.), printer in Norwich, 1706. Printed The Norwich Postman in that year.

SHELL (G.), bookseller in London, Stonecutter Court, Shoe Lane, I684. Published a licentious book in 1684. [T.C. II. 62-3.]

SHELMERDINE (RALPH), bookseller in Manchester, I66I-73. See Dictionary, 1641-67. Still publishing in 1673, when he issued The Mystery of Rhetorick unveiled, by John Smith, Gent. [T.C. I. 157.]

SHELMERDINE (THOMAS), bookseller in London, Rose Tree, Little Britain, I698-17 II. In Easter 1698 he advertised the third edition of Counsellor Manners his last Legacy to his Son, by J. D. [T.C. III. 69.] He was still there in 1711 . [Postman, February $3 \mathrm{rd}, 17 \frac{10}{11}$.]

SHELTON (JOSEPH), bookseller and book auctioneer in London, Peacock in the Poultry, I69I-6. In I69I he conducted a book auction. [B.M. 821. i. 9 (14).] In 1694 he held a sale of books in Coventry, co. Warwick, at the house of Samuel Withers $(q . v$.$) . In partnership with W. Chandler. They issued the$ English translation of Jean Mocquet's Travels in 1696. [T.C. 11. 589.]

SHEPHERD (F.), bookseller in London, I682. His imprint occurs on a broadside, The Last Words and Sayings of the True Protestant Elm Board. [Haz. III. 243.]

SHERLOCK (RICHARD), bookseller in Oxford, I684. [Madan, p. 31.]

SHIRLEY (BENJAMIN), bookseller in London, Fleet Street, under the Dial of St. Dunstan's Church, 1676-80. Began to publish in Hil. 1676, with a medical work by James Cooke. [T.C. 1. 230.] In the following year he issued a Life of Sir Walter Raleigh [T.C. I. 28I], and was one of the publishers of Sir Edward Coke's Reports. He is last heard of in 1680 . [T.C. I. 407.]

SHREWSBURY, or SHROWSBURY (WILIIAM), bookseller in London, Bible in Duck Lane, 1672-1703. His name appears for the first time in the Term 
Catalogue of Mich. 1672 as the publisher of J. Smith's Stereometrie, or, the Art of Practical Gauging. [T.C. I. Ir8.] He published many scientific and medical books, also a Life of Sir Matthew Hale, Lord Chief Justice, of whose treatise, Contemplations, Moral and Divine, he published several editions down to 1695 . [T.C. II. 562-3.] Dunton speaks of him as alive, and says [pp. 22r-2] : "He merits the name of 'Universal Bookseller'..... He keeps his Stock in excellent order, and will find any Book as ready as I can find a word in the Dictionary. ... He is a constant frequenter of Sturbridge Fair."

SIMMONS (B.), bookseller in London, Three Golden Cocks, $(a)$ at, $(b)$ near the West End of St. Paul's, r68r-4. Relative of Nevill Simmons (q. v., Dictionary, I64I-67), and succeeded to his business. His first and last entries in the Term Catalogues were made in r681 and 1684. [T.C. 1. 457, II. ro5.] He was apparently succeeded by Thomas Simmons, who published in 1685 from the Three Cocks in Ludgate Street, an address which probably represents the same house. [T.C. II. II2.]

SIMMONS or SYMONS (MARY), printer in London, 1656-75. See Dictionary, r64I-67. She must be the Mrs. Simmons in the ${ }^{6} 675$ List of London Printers.

SIMMONS (NEVILL), the Elder, see Dictionary, 164I-67.

SIMMONS (NEVILL), the Younger, bookseller in Sheffield, 1697-1702. His relationship to the elder Nevill Simmons is obscure. Publisher of the Rev. N. Drake's Sermons, also of Thomas Jollie's Vindication of the Surrey Demoniack, $\mathbf{1 6 9 8}$, as well as the writings and sermons of the Rev. Timothy Manlove. [T.C. II. 600, III. 92.] Hazlitt [III. 12] records his imprint in a book of 1702 . SIMMONS (SAMUEL), see Dictionary, 1641-67.

SIMMONS, SYMONDS, or SYMMONDS (THOMAS), bookseller in Bury St. Edmunds, 1676-8 ; and in London, (r) (a) Prince's Arms, St. Paul's Churchyard, (b) Prince's Arms, Ludgate Street, 1679-84 ; (2) Three Cocks, Ludgate Street, r685. 1676-85. Son of Nevill Simmons, and, like him, published for Baxter. He began business at Bury St. Edmunds, where he published a school book, called English Examples to be turned into Latine, in r676 [T.C. 1. 237] ; in the same year and in 1678 he published editions of a grammatical work by Vossius, and of Lucian's Dialogues, both by Edward Leeds, one of the masters of Bury School. [T.C. I. 238, 308.] Simmons left Bury St. Edmunds very shortly after this and settled in London at the Prince's Arms in 
St. Paul's Churchyard, by 1679, when he published Dr. W. Simpson's History of Scarborough Spaw, I679 [T.C. I. 358], and other interesting books. He was also the publisher of several broadsides and pamphlets on the Popish Plot, some with Jacob Sampson (q.v.). In I68I he was defendant in a suit for assault brought against him by Bartholomew Sprint in the Court of Common Pleas. [C.P.R. Trin. 33 Chas. II, 2992, m. 256r.] Again, in Hil. 34-5 Chas. II, he stood bond for the appearance of Katherine Kirkman, widow [C.P.R. $3009, \mathrm{~m} .45$ r.], and in 1685 he had some commercial transaction with Francis Pearse, bookseller, which was afterwards the subject of an action in the same court. [C.P.R. Mich. I Jas. II, 3039, m. 309 v.] Dunton [p. 224] calls Simmons " a most accomplished bookseller" and praises his domestic virtues. In 1685 Simmons moved to the Three Cocks in Ludgate Street, probably the shop previously occupied by B. Simmons (q.v.); but nothing more is heard of him after that date.

SIMPSON ( ), bookbinder in London, c. 1690. Dunton [p. 258] says that Simpson, a " grave and antient binder ", was recommended to him by Roberts the printer, as "a curious workman and a very honest man". He supposes him to be nearly related to Simpson the bookseller.

SIMPSON (ANDREW), see Symson.

SIMPSON (JAMES), bookbinder in Edinburgh, 1670. His wife Anne was one of the witnesses at Major Weir's trial in 1670. [Ravillac Redivivus, London, 1678, p. 65 ; Aldis, p. 120.]

SIMPSON (RALPH), bookseller in London, Harp in St. Paul's Churchyard, 1680-1704. Ralph and Richard Simpson were in partnership at the Harp, and one of them is mentioned in the Term Catalogue for Hil. 1680; but as the imprint to that and several other books is simply R. Simpson, it is impossible to say which of them it was. They were the publishers of some of the works of Sir William Temple, and the first definite mention of Ralph is as joint publisher with Richard of that author's Miscellanea, the Second Part, 1690. [T.C. II. 337.] In 1692 Richard moved to the Three Trouts in the Churchyard and is last heard of in 1698 [T.C. III. 57], but Ralph continued to publish until r704. [T.C. III. 395.] The Simpsons were also publishers of a series of controversial tracts on the siege of Londonderry, one of which, A Narrative of the Siege of Londonderry, 1690, is not mentioned in the Term Catalogues, but is in the British Museum. [B.M. T. r 707 (r).] 
SIMPSON (RICHARD), bookseller in London, ( $\mathrm{r}$ ) Harp, in St. Paul's Churchyard, r690-92 ; (2) Three Trouts in St. Paul's Churchyard, 1692-8. 1690-98. See Simpson (Ralph).

SIMPSON or SYMPSON (SAMUEL), bookseller at Cambridge, living on the site now occupied by the Senate House lawn, r670-r702. His name appears on books from 1670 to 1702 . [Bowes, Cambridge Books, nos. 142, 150, 193, 290, 314, 354; T.C. II. I3r.] He probably died before March $170 \frac{2}{3}$, when his house was occupied by another person.

SIMS (JOHN), bookseller in London, King's Head at Sweeting's Alley end of Cornhill, 1656-77. See Dictionary, 1641-67. Continued in business until 1677. Dunton [p. 295] alludes to him as "liberal" Sims. He dealt in school books. [T.C. I. $127-8,295$.] $\mathrm{He}$ was at the address given here, his third, by r673. He was succeeded by S. Tidmarsh.

SKEGNES (CHRISTOPHER), bookseller in London, Golden Ball in St. Paul's Churchyard, $1686-7$. In 1686 and 1687 he entered, either alone or with other booksellers, four books, of which the most important was Thévenot's Travels. [T.C. II. 175, 182, 193, 198.]

SKINNER (EDWARD), bookseller in Oxford, r697. [Madan, p. 3r.]

SLATER (J.), bookseller in London, on the west side of the Royal Exchange, 1684. In that year he sold a broadside, "curiously cut in copper ", of the Fair held on the frozen Thames. [T.C. II. 72.]

SLATER, or SLATTER (J.), bookseller at Eton, r696-r709. Dealer in schoolbooks. In 1696 he advertised an edition of Aesop for use in the school at Eton, and he was still there in I709. [T.C. II. 603, III. 627.]

SMALL (MRS.), bookseller in Deal, Kent, r 7 rr. She was one of those who sold John Davis's Seaman's Speculum. [T.C.III.672; Post Man, March roth, $17 \frac{10}{1}$.]

SMELT (MATTHEW), see Dictionary, 1641-67.

SMITH (CHARLES), bookseller in London, (I) Black Swan, over against the Horn Tavern in Fleet Street, $167 \mathrm{r}$; (2) Angel, Fleet Street, near the Inner Temple Gate, r675-8r. 1671-8r. Made his first entry in the Term Catalogues in Easter r671. [T.C. I. 7r.] Publisher in 1675 of Edward Phillips's Theatrum Poetarum. [T.C. I. 212.] In 168r he issued a translation of Rousseau de la Valette's novel Casimir, King of Poland. [T.C. I. 450.] In that year he was 
defendant in an action for trespass and assault, brought against him by Lemuel Bradley. [C.P.R. 33 Chas. II, 2992, m. 242 v.]

SMITH (CHARLES), bookseller in London, Buck, between the two Temple Gates in Fleet Street, 1707-9. [T.C. III. 567, 613, 652.]

SMITH (E.), bookseller in London, Bible $(a)$ under the Piazza, $(b)$ in the South Portico, of the Royal Exchange, Cornhill, r686-9. Publisher, with others, of G. de Malynes' Consuetudo vel Lex Mercatoria in 1686. [T.C. II. 184.] He made his last entry in 1689. [T.C. II. 277.]

SMITH (E.), bookseller in London, 1707 (?)-9. [T.C. III. 576, 654.] Possibly, but not probably, identical with the preceding.

SMITH (FRANCIS), bookseller in London, ( $\mathrm{I}$ ) Elephant and Castle, without Temple Bar; (2) Elephant and Castle, Cornhill, near the Royal Exchange, I659 (?)-1688 (?). See Dictionary, 1641-67. Commonly called "Elephant" Smith. This bookseller became notorious for his strong political and religious views, for which he was persecuted without mercy by the Government. There is little doubt that he was the Francis Smith who in 1659 published Captain W. Bray's Plea for the Peoples Good Cause [B.M. E. 763 (7)], and he has left on record two pamphlets, in which is recorded his subsequent history. The first of these is entitled An Account of the injurious Proceedings of Sir George Jeffreys ... against Francis Smith, bookseller ... Sept. I6, 1680; upon an Indictment then exhibited against the said Francis Smith, for publishing a pretended Libel, entituled, An Act of Common Council for Retrenching the Expenses of the Lord Mayor and Sheriffs of the City of London, Eoc. [1680?]. [B.M. 1872. a. I (36).] The second was called An Impartiall Account of the Trial of Francis Smith ... for printing and publishing ... [Clod-Pate's Ghost, by] Tom Ticklefoot. As also of the Tryal of Jane Curtis ... for publishing ... a Satyr upon Injustice, or Scroggs upon Scroggs, I68o. [B.M. 6495. i. 32.] Briefly summarized these are the facts which Smith records: In the year 1659 his windows were broken and his lodgers frightened away, because he was suspected of being disaffected to General Monk and the Royalists. In 1660 he was three times a prisoner in the Messenger's hands about a book called The Lord's Loud call to England, and his charge and damage were £5०. At the time of Venner's rising (1657) the mob broke into his house and destroyed his property, threatening to kill him and using him so badly that for some time afterwards he was not able to turn himself in his bed. In August 
r66r he was thrown into the Gatehouse for printing Mirabilis Annus, and by that he lost his shop and trade for two years, amounting to upwards of f30o. On another occasion he was " so often and dayly harassed too and fro by Mr. L'Estrange's order " that he became dangerously ill and delirious. During the plague (of 1665 ) he was living with his family at Dorking. In r666 Lilliecrap, a printer and one of L'Estrange's spies, went to his shop and warehouse near Temple Bar, and took away as many books as two porters could stand under, few of which he ever recovered. In r67r Smith was persecuted under the Conventicles Act, and lost his shop and trade for more than six months. Altogether he reckoned he had lost at least $£^{1}, 400$ during the previous twenty years. Smith stated before a Committee of the House of Lords in $\mathrm{r}_{77}$ that Samuel Mearne and Robert White, acting presumably for the Company, had seized an impression made for Smith of Danvers' Infant Baptism, and, in spite of an order by Lord Arlington, refused to give it up ; a large edition was meanwhile printed by Joseph Downing for Thomas Sawbridge and Randal Taylor, with Smith's name and sign; Mearne knew of this piracy, but took no steps to seize the edition. [Hist. MSS. Comm., Report 9, App., p. 78.] Smith was the publisher of Smith's Protestant Intelligence, Domestick and Foreign. The first number appeared on February Ist, 1680.0 . It recorded the publisher's indictment for publishing a pamphlet entitled $A$ Speech lately made by a noble Peer of the Realm. The Grand Jury threw out the bill. This news-sheet contained very little foreign news and only occasionally inserted advertisements. Smith's last entry in the Term Catalogues was in Mich. 1679; but we know that he was in business as late as r683. Obediah Smith (q.v.), probably his son, published at the Elephant and Castle in r672-3. See also Downing (Joseph). A Francis Smith, stationer, was buried at Farnham in Surrey on July 6th, 1688, and was probably the notorious "Elephant" Smith.

SMITH (J.), bookseller in London, Aldersgate Street, I IIo. Publisher of a broadside on the Sacheverell controversy entitled $A$ Rod for a Fool's back, r 7 ro. [B.M. T. 100* (233).]

SMITH (J.), printer in London, Fleet Street, r715. Printed $A$ short Account of the state of England when King James design'd to call his second Parliament, I 7 $\frac{14}{15}$. [B.M. T. IOO* (235).]

SMITH (JOHN), printer in London, Great Queen Street, 1679-83. Chiefly known 
as the printer and publisher of The Currant Intelligence, begun in 1679 . He was also the publisher of The Jockey's Intelligencer of Horses and Coaches in 1683.

SMITH (JOHN), bookseller in London, Lion and Crown in Russell Street, in Covent Garden, ryor. One of three booksellers publishing C. A. Brun's Conference... upon Expression, I701, a book with many engravings.

SMITH (JOHN), bookseller in Coventry, 1683. Publisher of Jonathan Kimberley's Warwick Assize Sermon, Of Obedience for Conscience sake. . . . [T.C. II. 37.]

SMITH (OBEDIAH), bookseller in London, (r) Elephant and Castle, without Temple Bar, I672-3; (2) BlackSwan, FleetStreet, 1673-80(?); and in Daventry, I684-1704. 1672-I 704. Probably a son of Francis ("Elephant") Smith, who also lived at the Elephant and Castle without Temple Bar. In 1673 Obed. Smith moved to the Black Swan in Fleet Street. [T.C. 1. 102, 157.] Somewhere about $\mathrm{r} 680$ he appears to have left London and settled at Daventry; in $169 \frac{4}{5}$ he published there C. Allestrec's sermon, The Desire of All Men [Bodl. Serm. I (8)], and he was still living there in 1704. [T.C. III. 424.]

SMITH (RALPH), bookseller in London; 1642-84. See Dictionary, 1641-67. Still in business in r684. [T.C. II. ro8.]

SMITH (RICHARD), bookseller in London, (I) Angel and Bible, (a) near the May-Pole, Strand, (b) without Temple Bar ; (2) Fore-walk of Exeter Change in the Strand ; (3) Bishop Beveridge's Head in Paternoster Row. 1698-1 720. Began business as a publisher in 1698 , and issued several of the writings of William Beveridge, Bishop of St. Asaph. He moved to Exeter Change in I 708, and afterwards opened a shop in Paternoster Row, which he named, after his patron, Bishop Beveridge's Head. At the time of the fire at the elder Bowyer's printing office, Richard Smith had in that press Bishop Bull's Important Points of Primitive Christianity as well as an edition of Bishop Bull's Works; all of which were destroyed. Bowyer made good the paper, although Smith had released him from any obligation to do so, and also paid Smith the same dividend as other sufferers received. [Nichols, Lit. Anecd. 1. 55-6.] Smith died before 1721 , and was succeeded in the business by his widow Mary Smith. [Nichols, Lit. Anecd. I. 219.] Dunton has two references to a Mr. Smith, but there is nothing to show to whom they apply. 
SMITH (SAMUEL), bookseller in London, St. Paul's Churchyard, r681-r703. Apprentice with Moses Pitt. Afterwards in partnership with Benjamin Walford, and bookseller to the Royal Society. Dunton declared that Smith dealt in foreign books and spoke French and Latin with fluency. Smith is said by Moses Pitt in his Cry of the Oppressed [p. 153] to have gone down to Portsmouth with Pitt's oppressor, Adiel Mill, and taken possession of certain property there.

SMITH (w.), bookseller in Cambridge, r706-3r. His name appears on Poor Law Overseers' Forms (in the Great St. Mary's Church Books), 1708-3r. A Mr. Smith, bookseller, appears in the Rate Book of St. Botolph Church, March $172 \frac{5}{6}$, for ros. In 1706 there appears to have been a charge against him "for selling books and strong drinks", and depositions of Cambridge stationers were made February 4th and March 23 rd concerning this charge.

SMITH (WILLIAM), see Dictionary, 1641-67.

SMITHURST (BENJAMIN), bookseller, in Launceston, r693-1700 ; (?) and in Plymouth, I 714. 1693-1714(?). It seems highly probable that the Benjamin Smithurst who compiled a Peerage and Baronetage in 1689 , under the title of Britain's Glory, was none other than the Benjamin Smithurst who in 1693 and 1700 published sermons by John Hill and J. R., Cornish clergy. [T.C. II. 475, III. 169.] Smithurst, bookseller in Plymouth, subscribed in 1714 for Walker's Sufferings of the Clergy. His identity with Benjamin is not more than probable.

SNOWDEN (THOMAS), printer in London, 1678 (?)-1680. Probably the T. S. who printed for Thomas Moore in 1678 . His full name is only known fron An Account of the New Sheriffs holding their Office, r680. [B.M. 816. m. 9 (6r).]

SOLINGEN (JOSHUA VAN), printer in Edinburgh, 1680-5. One of the Dutch workmen brought over by John Cairns about 1680. Afterwards in partnership with Lindsay (q.v.), Kniblo, and Colmar. [Aldis, p. 120.]

SOLLERS (J.), bookseller in London, Cornhill, r684. His name appears in r684 as a publisher of an elementary work on Geometry. [T.C. II. 84.]

SOLLERS (ROBERT), bookseller in London, (I) Flying Horse, St. Paul's Churchyard, 1677 ; (2) King's Arms, Ludgate Street, 1678 ; (3) King's Arms and Bible, St. Paul's Churchyard, 1679-82. 1677-82. His name appears first in the Term Catalogue for Easter 1677 . He dealt in plays, novels, poems, and 
divinity. Dunton [p. 292] refers to him as "Country Sollars ", perhaps implying that he supplied the chapmen or else that he went to country fairs himself. It is possible that he had a shop at Rochester in Kent, as Edward Brown's sermon at the Kentish Feast of November 16 th, 1699 , was advertised in the Flying Post of December 2nd, to be sold, amongst others, by "Mr. Sollers in Rochester ". His name, however, does not appear in the imprint to the book.

SOUTHALL (RICHARD), bookseller in Stafford, 1722. Publisher of a sermon by W. Jervis entitled The duty of praying for Princes, 1722, 8vo. [B.M. 225. h. 10 (3).]

SOUTHBY (ЈонN), bookseller in London, (1) The Plough in Cornhill ; (2) The Harrow in Cornhill, $x 684-91$. Began as a publisher of theology in Trin. 1684 [T.C. I1. 80], in which year he either moved, or changed his sign from the "Plough " to the "Harrow". In 1690 he issued The Great Question, or, how" Religion, Property and Liberty are to be best secured. [B.M. T. 1707 (2).] The announcement of this in Trin. 1691 [T.C. II. 37r] is the last that is known of him.

SOUTHBY (RICHARD), bookseller in London, Golden Fleece in Fleet Street, 1693. Advertised a set of tables of the sovereigns of Europe, and also a treatise on the law of bankruptcy. [T.C. II. 440, 478.]

SOUTHWOOD (BENJAMIN), bookseller in London, ( 1 ) Star, next to Serjeant's Inn in Chancery Lane, 1673-5; (2) New Inn Gate, without Temple Bar, 1679. 1673-9. Began business as a publisher in 1673 when, in partnership with Israel Harrison, he reissued J. Smith's England's Improvement Reviv'd of 1670. Harrison dropped out of the partnership after this, and Southwood continued alone as a publisher of a few divinity books and political pamphlets. He gave evidence before the Committee of the House of Lords in $1676-7$ that he had received from Dr. Carey the MS. of The Long Parliament Dissolved, which he gave to Nathaniel Thompson to print. [Hist. MSS. Comm., Report 9, App., p. 72.] His last entry in the Term Catalogues was in 1679. [T.C. I. 356.]

SOWLE (ANDREW), see Dictionary, 1641 67.

SOWLE (TACE, or TACY), printer and bookseller in London, next door to the Meeting House in White-Hart Court in Gracious [Gracechurch] Street; and at the Bible in Leadenhall Strect, 1695-1746. Printer for the Quakers. 
Daughter of Andrew Sowle; born January 29th, 166 6 . She succeeded her father, who died in 1695. Dunton [pp. 222-3] says : "She is both a Printer as well as a Bookseller, and the daughter of one; and understands her Trade very well, being a good Compositor herself. . . . She keeps herself .unmarried." Three years later, however, in 1706, she married Thomas Raylton. Her mother, Jane Sowle, and from I 7 I 5 the latter's assigns, continued the business. Tace survived her husband twenty-three years and died in 1746.

SPEED (ANNE), bookseller in London, Three Crowns in Exchange Alley, over against Jonathan's Coffee House in Cornhill, I 705-II (?). Probably wife of Thomas Speed (q.v.). Her chief publications were sermons and theological tracts. Her first entry in the Term Catalogues was made in Mich. 1705. [T.C. III. 476.]

SPEED (SAMUEL), bookseller in London, 1658-7o. See Dictionary, 1641-67. Still in business in 1670 , when a catalogue of books sold by him occurs at the end of D. Lloyd's State Worthies. [B.M. 6r5. b. 2.]

SPEED (тномAS), bookseller in London, (I) Crown, Poultry, I689; (2) Three Crowns, Cornhill, near the Royal Exchange, I69o-I7I4 (?). I689-I7I4. He was probably son or brother of Samuel Speed. His name first appears in the Term Catalogue for Easter 168g, when he advertised two books on shorthand by Thomas Shelton, and Thomas Farnaby's Index Rhetoricus. [T.C. II. 263.] Dunton [pp. 218-9] says: " He has the honour to print for Sir William Dawes, Dr. Smith and other eminent churchmen. He is a very modest quiet man." His name occurs in the Term Catalogues for the last time in Mich. I707. [T.C. III. 577.] A list of eleven books printed for him is to be found at the end of L. Smith's Knowledge and Virtue, 1702. [Bodl. Serm. I9 (4).] In I7I4 he was among the subscribers to Walker's Sufferings of the Clergy. Anne Speed (q.v.) published at the second of Thomas's addresses in his lifetime.

SPENCER (JOHN), printer in London, 1684. He appears as defendant in an action for debt brought by Sara Reeve, widow. [C.P.R. Trin. I Jas. II, 3036, m. 195 r.] He was probably not a master.

SPICER (JoHN), bookseller in London, r682. Only known from a poem, The Conspiracy of Aeneas and Antenor against the State of Troy, printed for him in 1682 . [B.M. I 1631 . bbb. 3.] 
SPILLER (WILLIAM), bookseller in London, 1696. David Edwards, a printer, in the course of some Chancery proceedings, stated that he had printed about thirty or forty gross of black and white primers at the instigation of William Spiller. [Chan. Proc., before 17 14, Collins 486/100.]

SPOTTISWOOD (JOHN), printer(?), Edinburgh, I706. “In 1 706, Mr. John Spotiswood Advocate, and professor of the Law, brought home a neat little house [sic] for printing his law books : But in a little time after, dispos'd of it to Mr. Robert Freebairn bookseller." [Watson, p. 18.] No books bearing Spottiswood's name in the imprint have been noted.

SPRINT (BARTHOLOMEw), bookseller in London, I681. Only known as plaintiff in an action for assault, brought by him against a number of booksellers and printers in London and Oxford. The details are wanting, and nothing is known of his relation to the other Sprints, booksellers of London. [C.P.R. Trin. 33 Chas. II, 2992, m. 256.]

SPRINT (BENJAMIN), bookseller in London, Blue Bell, Little Britain, 1 709-37. Son of Samuel Sprint, who left him half his books, bound and unbound, and half his copyrights, desiring him to continue with his brother John; he was in the business by 1709 , and the brothers were in partnership till 1727 at least, when they issued the fourth edition of the Works of Scarron. [Esdaile, p. $3^{\circ}$.] Benjamin Sprint died September 2oth, I737. [Timperley, p. 660.]

SPRINT (JOHN), bookseller in London, Blue Bell, Little Britain, 1698-1727. Son of Samuel Sprint. Entered the business in 1698 . In I $73_{3}$ he contributed three guineas to the Bowyer fund. He was joined by his brother Benjamin (q.v.) in 1709 , and they were still together in 1727. Dunton [p. 230] praises him highly.

SPRINT (SAMUEL), bookseller in London, ( $\mathrm{r}$ ) Golden Ball, Duck Lane; (2) Bell, Little Britain; (3) Blue Bell, Little Britain. 1670-1 707. Began business in Duck Lane in 1670 , in partnership with George Calvert. [T.C. I. 35.] In 1672 he set up for himself at the Bell, in Little Britain, and in 1676 his sign became the Blue Bell in Little Britain. In 1698 he took his son John into partnership. They were the publishers of the Index Villaris, and in 1700 a translation of the Works of Scarron, "illustrated with copper cuts." Samuel Sprint died in 1707 , his will being proved on April 28th. He left three sons, John, Benjamin, and Samuel. To his son Benjamin he left half his books, 
bound and unbound, and half his copyrights, and desired him to continue in partnership with his brother John. [P.C.C. 94, Poley.] He served the office of Under Warden of the Company in 1700-1, and Upper Warden in 1704-5. Dunton [p. 209] says of him : "Mr. Samuel Sprint, senior, thrives much in trade, and is punctual and honest: he has been very fortunate in several engagements. He printed 'Mr. Fox of Time', 'Mr. Doolittle on the Sacraments,' and was engaged the same way for Mr. Steele, and other eminent authors."

STAGG (JOHN), bookseller in London, Westminster Hall, I716 (?)-46. The following notices in the General Advertiser of September 2oth and 27th, 1746, contain all the information met with concerning this bookseller: "Yesterday morning [September 19th], died, at his house in Old Palace Yard, Westminster, after a long and tedious indisposition in the 52nd year of his age, Mr. John Stagg, who has been near 30 years an eminent bookseller in Westminster Hall." "Last night [September 26th] the corps of Mr. John Stagg, . . was interr'd . . . in the Cloysters belonging to Westminster Abbey."

STANDFAST (RICHARD), bookseller in London, Westminster Hall, 1711-25. Published $A$ Caveat against Seducers in I 71 , by Richard Standfast, Rector of Christchurch, Bristol, possibly his father.

STARKEY (JOHN), bookseller in London, 1658-89. See Dictionary, 1641-67. Still at work in 1689 . A list of books printed for him appears at the beginning of Jesuitical Aphorismes, 1679. G. Grafton was at Starkey's house, the Mitre in Fleet Street, by 1687 [T.C.II. 202] ; Starkey at this time appears to have been in partnership with Chiswell. [T.C. II. 248, 255, 274.]

STATIONERS, Society of, in Edinburgh, see Dictionary, 1641-67.

STEPHENS (ANTHONY), bookseller in Oxford, near the Theatre, 1685. Miscellany Poems and Translations by Oxford Hands was printed for him in this year. [B.M. I1641. bbb. $3^{8}$.]

STEPHENS (J.), bookseller in London, Hand and Star, between the Two Temple Gates in Fleet Street, 1722. Published a sermon by George Parry in I722.

STEPHENS (JOHN), bookseller in Oxford, 1704-9. On June $13^{\text {th, } 1709 \text {, his }}$ goods and effects were seized by his brother. John Stephens is described by Hearne as "a careless, negligent prating fellow", who had several things 
printed for him at the "Theater-Press", but paid no University dues. [Collections, II. $211-12$; Madan, p. 31.]

STEPHENS (PHILEMON), see Dictionary, 1641-67.

STEPHENS, or STEVENS (ROBERT), printer in London, 1668 (?)-1 700 (?). This man, who does not appear to have exercised his trade as a printer, was appointed "messenger" and "constable" by the Company of Stationers and was in consequence cordially hated by his brother printers, who gave him the nickname of "Robin Hog". He was employed to hunt out secret presses, and figures in nearly all the prosecutions of that period. He sometimes met with resistance. Francis Smith states that in December 1679, "Mr. Stevens and a constable came to his shop with a general search warrant, but as it did not state his name or crime, he dared them at their peril to touch him or anything in his shop." In r681 Stephens was defendant in an action for assault brought against him by S. Lee. [C.P.R. 2994, m. 1093 v.] In 1692, having discovered a private press at the house of Thomas Topham, in Shoreditch, Stephens was allowed $£ 4$ for his expenses and service, with liberty to prosecute the landlord of the house for the $£ 5$ due by the Act for his own benefit. [Records of the Stationers' Company.] Moses Pitt, in his Cry of the Oppressed, also mentions the activities of Robert Stephens.

STEWART (GEORGE), bookseller in Edinburgh, 1716-34. The Freeholder of April roth, 1716, was printed for and sold by him ; and in 1722, 1724, and 1734 he sold books printed by Ruddiman.

STEWART (ROBERT), bookseller in Glasgow, 1662 (?)-76. One of the debtors in A. Anderson's inventory of 1676 . The Robert Stewart in Glasgow, debtor to G. Lithgow in 1662 , is probably the same. [Aldis, p. I21.]

STOKOE (LUKE), bookseller in London, ( 1 ) Golden Key and Bible at Charing Cross ; (2) Golden Key, against the Mews Gate, Charing Cross ; (3) Coventry Court, Haymarket, I700 (?)-27. In I700 " L. Stoley" is recorded by Arber [III. 182] as publishing a divinity book at the first of the addresses given above. This appears to be an error for L. Stokoe. In conjunction with George Harris he published a small volume of verse called Poems on Several Occasions. Together with some Odes in Imitation of Mr. Cowley's Stile and Manner in 1703 . In 1725 he took subscriptions for Francis Mason's Vindication of the Church of England, and in 1727 he issued two sale catalogues. [Nichols, Lit. Anecd. 1. 329, III. 664.] 
STOLEY (L.), see Stokoe (L.).

STONE (AMY), bookseller in Nantwich, 1699-1 7 ro. In 1699 she sold grammars and devotional books, which she purchased wholesale of John Minshull of Chester. [Library, and ser. IV. 373-83.] In the same year and again in 1710 her name appears in the imprints to sermons by J. Oliver, Prebendary of Chester. [Cooke, Bibl. Cestr., p. 26 ; B.M. 226. g. 13 (8).]

STORY (EDWARD), bookseller in Cambridge. See Dictionary, $1641-67$. To that notice should be added that he was buried in Great St. Mary's February $5^{\text {th }}$, $169 \frac{2}{3}$. By his will he bequeathed his real and personal estate to his son Edward Story (M.B. and Fellow of Magdalene College), and, if he should die without issue, to trustees to erect ten almshouses in the town of Cambridge. The son died without issue about I710, and the almshouses were erected about 1729. These almshouses, like those founded by bequest of another bookseller, Henry Wray (q.v., Dictionary, I 557-1640) are still in existence, and used for the object for which they were founded. [Cooper's Memorials of Cambridge, III. I75, 310.]

STORY (JOHN), bookseller in Newcastle-on-Tyne, 1685-6. Took up his freedom in the Newcastle Stationers' Company on July 25th, 1685. [Welford, Early Newcastle Typography, p. I28.] In the following year he issued George Stuart's Joco-Serious Discourse. [T.C. II. 178.]

STRAHAN, or STRACHAN (GEORGE), bookseller in London, Golden Ball, Cornhill, over against the Royal Exchange, 1699-1 740 (?). Began publishing in 1699 [T.C. III. 128], and became one of the leading publishers in London. Nichols [Lit. Anecd.] notes several of the important books which Strahan published. In or about 1740 he was one of six booksellers contracting with the Society for the Encouragement of Learning. [Nichols, Lit. Anecd. II. 96.]

STREATER, or STREATOR (JOHN), see Dictionary, 1641-67.

STREATER (s.), printer in London, 1677. Only known from Giles Fletcher's Israel Redux, 1677. [Haz. II. 222.] Possibly a misprint for J(ohn) Streater.

STREATOR (JOSEPH), printer in London, 1688. Only known from the imprint to Sylvia's Revenge, 1688. [Haz. II. 7x 5.] Perhaps successor to John Streator, who disappears in the previous year.

STURTON (JOHN), bookseller in London, at the Post Office at the Middle 'Temple in Fleet Street, 1696-8. Publisher, with A. Bosvill,' of The Delights of 
Holland, by William Mountague, 1696. [Haz. III. 173.] Sturton advertised Timoleon, or the Revolution, in the Post Boy, March 2nd-4th, 169 ?

SULLEY (GERVAS), bookseller in Nottingham, 1703. Published in 1703 A Sermon Preached before the Mayor ... of Nottingham, December 3 rd, 1702. [Creswell, p. 7 ; Bodl. Serm. 4.]

SWAFFIELD (J.), bookseller, Lion and Lamb, Whitechapel, 1703-4. His name appears in the Term Catalogue for Hil. $170 \frac{3}{4}$, as publishing divinity books. [T.C. III. $385,395$.

SWALE (JOHN), bookseller in Leeds, 1714. One of the subscribers to Walker's Sufferings of the Clergy.

SWAYLE, or SWALLE (ABEL), see Dictionary, 1641-67.

SWINTON (PETER), printer and bookseller in Knutsford, 1684 . In 1684 he printed the funeral sermon on Sir Robert Leicester of Tabley. [Cooke, Bibl. Cestr. p. $23 ; N$. \&. Q., roth ser. v. 183.]

SWINTOUN (GEORGE), printer and bookseller in Edinburgh, 1649-83. See Dictionary, 1641-67. Swintoun appears to have continued till at least 1683 . His name is found on the title page of a Confession of Faith of that date in the British Museum. [Ames III. 643.]

SWINTOUN (JOHN), printer in Edinburgh, 1675-81. Printed several books between these dates. In 1679 he was joined with Thomas Brown in printing two books. Swintoun was " one of His Majesties printers ". [Aldis, p. 121.]

SYMMONDS, SYMMONS, see Simmons.

SYMON (EDWARD), bookseller in London, corner of Pope's Head Alley, in Cornhill, 1720. Published the sixth edition of H. Phillip's Purchaser's Pattern, 1720.

SYMONDS, SYMONS, see Simmons.

SYMSON (ANDREW), printer and bookseller in Edinburgh, in the Cowgate, near the Foot of the Horse-Wynd, 1699-1706. Published the second edition of Sir George Mackenzie's Laws of Scolland, 1699. " In 1700 Mr. Matthias Simpson, a student in divinity, set up a small house ; but he, designing to prosecute his studies, left the house to his father, Mr. Andrew, one of the Suffering Clergy, who kept up the house till about a year ago [1712], that he died." [Watson, p. 18.] His Tripatriarchicon; or, the lives of ... Abraham, Isaac and 
Jacob, which appeared in 1705 , bears the imprint " Edinburgh : Printed by the Author" ; and in 1706 Some just Reflexions on a . . Pasquill came fron! his press with the date misprinted 1606. [Aldis, p. 121.]

T. (A)., printer in London, 1681. Printed a broadside in verse, $A$ Diaologue [sic] between the E. of Sh-and L. Bell- in the Tower, concerning the Plot, 1681. [B.M. C. 20. f. 6 (20).]

TABB (L.), see Bixou.

TAILER (THOMAS), bookseller in Oxford, r684-91. [Madan, p. 31.]

TANNER (PETER), stationer in London, Middle Temple Lane, 1691-9. In 169r he was sued by the Rev. Roger Rogerson for a debt of $£ 33$. [C.P.R. Mich. 3 W. \& M. 3ror, m. II 7 r.] His name occurs in connexion with a moneylending office in the Post Boy of March 4th, 1699.

TAYLOR, see also Tailor.

TAYLOR ( ), bookseller of Whitchurch, Salop, 1700-19. Sold school books and devotional works, which he bought wholesale from John Minshull of Chester (q.v.). [Library, and ser. IV. 373-83.] He subscribed to Walker's Sufferings of the Clergy in 1714 , and in 1719 he was one of those who received subscriptions for R. Bradley's Philosophical Account of the Works of Nature.

TAYLOR (JOHN), bookseller in London, Globe, ( 1 ) at the West End of St. Paul's Churchyard, 1683-7; (2) Ship, St. Paul's Churchyard, 1687-1713. 1683-1713. One of the largest publishers of the period; the references under his name in the Term Catalogues, beginning in Mich. 1683 [T.C. II. 55], are very numerous. In 1687 he moved to Benjamin Tooke's premises, the Ship in St. Paul's Churchyard. About 1700 he took his son William into partnership, but in I7II William set up for himself in Paternoster Row. John Taylor was a contributor to the Bowyer fund in $\mathrm{I}^{7} 3 \mathrm{3}$; but the date of his death is unknown. Dunton [p. 207] wrote of him : "Mr. John Taylor deals very much and is very honest. . . . His principles are moderate." Timperley [p. 588] says that he instituted an annual sermon at the Baptist Church in Lincoln's Inn Fields, to commemorate his escape from death in the great storm of 1703 .

TAYLOR (RANDAL), see Dictionary, $1641-67$. Still in business in 1700 . [T.C, III. I 70.] 
TAYLOR (THOMAS), bookseller in London, ( $\mathrm{I}$ ) next door to the Beehive on London Bridge, 1671 ; (2) Hand and Bible in the New Buildings on London Bridge, 1673-6. 1671-6. In Mich. 1671 he advertised Hodder's Arithmetick. [T.C. I. 91.] In Easter 1673 he used his second address, which may describe the same house. [T.C. I. 235.] He dealt chiefly in theology. He is referred to by Dunton [p. 292] as "Bridge" Taylor.

TAYLOR (WIILIAM), bookseller in London, (r) Ship in St. Paul's Churchyard; (2) Ship in Paternoster Row. 1700-23. Son of John Taylor. Joined his father in the business in St. Paul's Churchyard about 1700 . Made his first entry in the Term Catalogue in r 7ro. He moved to the Ship in Paternoster Row in $17 \mathrm{r}$, and afterwards took the adjoining premises. He is best remembered as the publisher in 1719 of Defoe's Robinson Crusoe, by which he is said to have cleared $\ell_{\mathrm{r}, 000}$. He died in 1723 , and appointed as one of his executors John Osborne ; the latter induced his son-in-law Thomas Longman (q.v.) to purchase the business, which is still flourishing, and still uses the device of the Ship.

TEBB (THOMAS), bookseller in London, Duck Lane, near Little Britain, r 708-r 5. In the Daily Courant for November roth, 1707, Tebb advertised an edition of Lilly's Grammar, and in 1708 he published for John Jackson a translation of Aesop, with cuts from the Frankfort edition. [T.C. III. 597.] Hazlitt [I. 5] records a book with his imprint, dated 1715 .

TERRY (JOHN), bookseller in London, Three Swans, Paternoster Row, I689. Only known from an advertisement of Dr. Manton's Three Volumes of Sermons, published in this year by Thomas Parkhurst and J. Robinson.

TERRY (ROBERT), bookseller in London, r 710-1 r. Advertised a sale of books by auction in the Daily Courant of January 13 th, $17 \frac{10}{1}$.

TERRY (SAMUEL), printer at Liverpool; Dale Street, Cork; and Limerick. 1712-25. First heard of in 1712 as printing Charles Owen's Hymns for Birchall at Liverpool. In the same year he commenced The Liverpoole Courant. He was still in Liverpool in 1720 [Allnutt, p. 299], but he is found printing in Cork in 1721 and perhaps in 1722 . He is then found at Limerick in this latter year, and in 1723 , probably printing two works in partnership with L. Bixou alias Tabb, and again alone in 1725 , when he printed a sermon by the Bishop of Limerick. The principal items from his Cork press were Pietas Corcagiensis, 
or a view of the Green-Coat Hospital, with plates [Bodl. Ireland, I4I], an edition of Dr. Bisse's Beauty of Holiness in the Common Prayer, and an edition of Puckle's Club.

TERRY (T.), bookseller in London, without Newgate, I687. Published John Smith's Compendium of Fair Writing in that year. [T.C. II. 200.]

THACKERAY (THOMAS), bookseller in London, I693. One of four booksellers publishing a chapbook, John Booker's Dutch Fortune-Teller, in I693. [T.C. II. 487.] In Arber's Index the entry is given in error to W. Thackeray. He also published two ballads, $A$ Warning for Married Women and Doctor Faustus, with A. M[ilbourn] and W. O[nley]. [B.M. C. 22 f. $6(24$, 132).] Son of W. Thackeray (?).

THACKERAY (WILLIAM), bookseller in London,(3) Angel in Duck Lane, 1664-92. See Dictionary, 1641-67. Still publishing in I692. [T.C.II.4I5.] He moved to this (his third) address some time between 1669 [T.C. I. I 5] and 1675 [T.C. I. 218]; in the intervening years he gives his address in the Term Catalogues simply as "in Duck Lane". The mass of his publications consisted of ballads and other chapbooks; they were published by a syndicate in which he was a partner, and were not advertised in the Term Catalogues. T. Passenger, F. Coles, T. Vere, J. Wright and J. Clarke were the other regular members; W. Whitwood appears more seldom. An advertisement of books sold by Thackeray appears at the end of Forde's Montelion, 1687. Succeeded by T. Thackeray $(q . v$.$) ?$

THOMAS (EDWARD), see Dictionary, 1641-67.

THOMAS (HUGH), bookseller of St. Asaph, 1699. Sold grammars and devotional works which he purchased wholesale of John Minshull of Chester. [Library, and ser. IV. 373-83.]

THOMAS (JOHN), printer in London, I68r. Defendant in an action for trespass and assault brought by Bartholomew Sprint. [C.P.R. Trin. 33 Chas. II, 2992, m. 256 r.]

THOMPSON, see also Tompson, and Tomson.

THOMPSON (J.), bookseller at Mansfield, r703. Published an edition of Cynthia, a novel. [T.C. III. 376.]

THOMPSON (J.), printer in London, in the Strand, 1725. Printed a series of broadsides relating to the trial of Jonathan Wild. [Haz. 1. 455.] 
THOMPSON (MARY), printer in London, 1688. Widow of Nathaniel Thompson (q.v.). Printed for the Roman Catholics A. Pulton's Reflections upon the anonymous Author and the Licenser of ... The Missioner's Arts Discovered, 1688. [B.M. T. 1839 (3).]

THOMPSON (NATHANIEL), printer and bookseller (?) in Dublin and London, (I) next the Cross Keys in Fetter Lane ; (2) at the entrance into the Old Spring Garden, near Charing Cross. I666-88. See Dictionary, 164I-67. Printer for the Nonconformists, and also for the Roman Catholics. In 1673 he is found in London printing a Romanist book in partnership with T. Ratcliffe. [T.C. I. 136.] He was constantly in trouble with the Company. In I676 he was committed to Newgate for printing seditious pamphlets. In I677 the Company ordered that he should be indicted at the next Quarter Sessions for printing part of a Mass Book in French. [Records of the Stationers' Company.] In the Report of the Proceedings of the House of Lords Committee in February $167 \frac{6}{7}$ it was stated that Thompson had printed a pamphlet, The Long Parliament Dissolved, the type having been examined with Thompson's types and found to agree in everything. [Hist. MSS. Comm., Report 9, App., pp. 69-78.] He next started a news-sheet called Domestick Intelligence, but in 1679 he altered the title to The True Domestick Intelligence. It was a rival sheet to that issued by Benjamin Harris, with whom Thompson was always at war. In 1680 he was committed to the Gatehouse for being privy to the conspiracy of the apprentices to levy war against the King [Protestant Domestic Intelligence, April 2, 1680], and in 1684 he was again in trouble for printing The Prodigal Returned Home. An account of the proceedings against him on that occasion was published as a broadside by A. Banks. [B.M. 515. 1. 2 (94).] In I686 The Compleat Dancing Master was announced [T.C. II. $567-8$ ] as printed for him; it is doubtful whether this implies that he was a bookseller. Thompson was dead in 1688, when the Stationers' Company ordered his widow to lay down the trade of printing in obedience to the Act of Parliament. [Records of the Company of Stationers.] THOMPSON (SAMUEL), see Dhctionary, 1641-67.

THOMPSON (WILLIAM), printer in Stamford, $17 \mathrm{I} 7$; and in Bury St. Edmunds, 1719. 1717-19. With Thomas Bailey he printed the Stamford Mercury. [Allnutt, pp. 299, 303.]

THOMSON (PETER), bookbinder in Aberdeen, 1698-9. A payment to him is 
recorded in the Marischal College accounts for 1698-9. [J. P. Edmond, Aberdeen Press, Lv ; Aldis, p. 12r.]

THORN (NATHANIEL), bookseller in Exeter, St. Peter's Churchyard, I 7 I 7 (?)-7I. Began to publish about the year I7I7, when he issued $A$ Sermon Preach'd in Ely Chappel at the Consecration of . . Lancelot, Lord Bishop of Exeter, ... February 24, I $7 \frac{16}{17}$, by William Rayner. [Dredge, p. 45.] In 1722 he was one of the publishers of Izacke's Remarkable Antiquities of the City of Exeter. He married Mary Simpson by licence dated February ist, $172 \frac{7}{8}$. [Dredge, p. ror.] He was still in business in $\mathbf{7 7 7} \mathrm{x}$.

THORNCOMB (ANDREW), bookseller in London, 1685 . In 1685 he printed Rochester's Poems. [Haz. II. 520.] In 1686 he was in Boston, Mass. Dunton met with him there and has recorded [pp. 97-8] a favourable impression of him. He is probably also the same person mentioned by Dunton [p. 293] as "musical" Thorncomb.

THORNICROFT (THOMAS), bookseller in London, Sun, St. Paul's Churchyard, $1663-72$. See Dictionary, $1641-67$. In business till 1672 ; in this and the preceding year he advertised two books from this third address. [T.C. I. $89,98$.

THORNTON (JETHRO), bookseller in Derby, 1675. Only known from the appearance of his name in an advertisement of a stolen horse. [London Gazette, January 6th-1oth, $167 \frac{5}{6}$.]

THORNTON (ROBERT), bookseller and printer in Dublin, r682-r70r. First appears as a stationer or bookseller in Dublin in 1682 , where the Dublin edition of Dryden's Medal was printed for him. He published in September to December ${ }^{6} 685$ The Neros Letter, and in 169r The Dublin Intelligence. In I692 he appears as a printer, with The Civil Articles of Lymerick. In I693 he was "stationer to their Majesties".

THORP, or THORPE (GEORGE), bookseller in Banbury, x703-6. Successor to William Thorpe. His first entry in the Term Catalogues was a sermon by

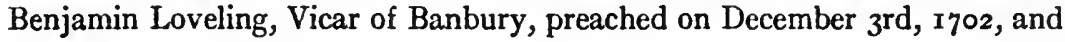
published early in 1703 .

THORP, or THORPE (WILLIAM), bookseller in Banbury, 1682-95. In 1682 he published a sermon by J. Knight called The Samaritan Rebels Perjured [B.M. I358. c. 3], in I686 Edward Pocock's translation of Hai Ebn Yockdan 
[T.C. II. 166], and in 1694 The Husbandman's Manual. [T.C. II. 517.] He was succeeded by his son George.

THOURSTON, see Thurston.

THRALE (BENJAMIN), bookseller in London, Bible, (a) Poultry, near Cheapside, (b) at the lower end of Cheapside, 1677-9. Perhaps son of Richard Thrale. In 1677 and 1679 he advertised two cheap and ephemeral books. [T.C. I. 292, 345.]

THRALE (RICHARD), bookseller in London, in Bishopsgate, 1650-73. See Dictionary, $1641-67$. Is found still in business in 1673 in Bishopsgate, where he had published before 1668 with James Thrale ( $q . v$. in Dictionary, 1641-67). [T.C. $1.60, \mathrm{I} 33,138$.

THURLBURN, or THURLBOURNE (RICHARD), bookseller in Cambridge, 1707-24. His name appears on Robert Cannon's Sermon before the Queen at Newmarket, Cambridge, 1707; and S. White's Commentary on Isaiah, 1708, and as receiving subscribers' names for Corpus Omnium Veterum Poet. Lat., in 1709. [Bowes, Cambridge Books, no. 375 ; T.C. II. 6r 3, III. 659.] He was witness to a conveyance of property in 1724 , now preserved in the University Registry.

THURLBURN, or THURLBOURNE (WILLIAM), bookseller in Cambridge, 1724-68. His name appears on books from 1724. [Bowes, Cambridge Books, no. 419.] In 1729 he succeeded Edmund Jeffery, bookseller (q.v.), at what is now No. I Trinity Street, and moved in 1757 to No. 2, where he remained until his death in 1768 . He was succeeded at No. $\mathrm{x}$ by William Woodyer, bookseller. Both houses were purchased by Thurlburn in 1737 . One of his daughters married James Essex, jun., the architect and builder. [See D.N.B.] THURSTON, or THOURSTON (JAMES), bookseller in Nantwich, 1684 . His name appears in the imprint to Zachary Cawdrey's funeral sermon on Lord Delamer, entitled The Certainty of Salvation, 1684. [B.M. 4902. cc. 2 ; T.C. II. 93.]

THURSTON (MATHIAS), bookseller in Nantwich, 1682-8. In 1688 he was sued by Lawrence Baskervile, for a debt for goods supplied to him in 34 \& 35 Chas II. [C.P.R. East. 3 Jas. II, 3056, m. 409 v.]

TIDMARSH (SAMUEL), bookseller in London, King's Head in Sweeting's Alley End, next house to the Royal Exchange in Cornhill, 1679-89. Made 
his first entry in the Term Catalogues in Trin. 1678. [T.C. I. 322.] Chiefly a publisher of the usual divinity, but in I68I he published Dr. J. Peter's treatise on certain mineral springs near Lewisham. [T.C. I. 450.] In 1689 he published a third edition of Peter's Artificial Versifying, a new way to make Latin verses. [T.C. II. 280.] Referred to by Dunton [p. 292] as "travelling" Tidmarsh, no doubt because he attended country fairs.

TILLET (THOMAS), bookbinder at Cambridge, 1695-1702. In 1695 he bound copies of Lachrymae Cantabrigienses in Obitum . . . Reginae Mariae, printed at Cambridge by John Hayes, $169 \frac{4}{5}$, the fine paper copies in velvet, satin, and vellum, the ordinary copies in vellum or merely stitched. He also bound the University Verses of 1698 , also printed by Hayes, and the Verses of 1702, printed by Crownfield.

TILLIER (T.), printer (?) and bookseller in Chester, 1688. Randle Holme, Chester Herald, published in 1688 his Academy of Armory, in which appear certain verses signed "T. Tillier, Typog." Holme [III. 484] gives the arms of Tillier as " a Talaria or Mercuries Shooe Sable, Winged Argent, in a Field Azure." A broadside entitled An Account of a late Horrid and Bloody Massacre in Ireland has the imprint "London : Printed for T. Tillier, 1688." [Allnutt, pp. 293-4; Bodl.]

TILLOTSON (J.), bookseller in London, I69o. Only known as having published two sermons by Archbishop John Tillotson in that year. The relationship, if any, between the bookseller and the archbishop has not been traced.

TODD ( ), printer in London, Fleet Street, r724. Classed by Negus as a " highflier".

TOMLINS (RICHARD), bookseller in London, (3) in Giltspur Street, 1670; (4) Bible, St. Paul's Churchyard, 1672. 1637-72. See Dictionary, 1641-67. Was still publishing in Easter 1672. [T.C. 1. 106.]

TOMLINSON ( ), widow, bookseller in Liverpool and Warrington, 1685. Her name occurs in a list of booksellers and stationers at the end of M. Bromfield's $A$ Brief Discovery of the ... Scurvy, 1685 , as agent for a patent medicine. [N. \& Q. IIth ser. XI. 45.]

TOMPSON, see also Thompson.

TOMPSON ( ), bookseller in London, Westminster Hall, 1689. His name occurs in an advertisement of patent medicines in the London Gazette of December 26th, 1689 . 
TOMPSON (DANIEL), printer in Dublin, Coles Alley, Castle Street, I714-15. Four or five books printed by him are extant, one being Thomas Sheridan's Latin Grammar.

TOMPSON (RICHARD), bookseller in London, Sun, Bedford Street, 1669. See Dictionary, 164r-67. Sold Alexander Browne's Ars Pictoria. He may be identical with - Tompson, bookseller, who had a stall in Westminster Hall some years later. The second address given by Arber [T.C. I. Index] is evidently a confusion with R. Tonson, who carried on business under Gray's Inn Gate.

TOMSON, or THOMPSON (WILLIAM), bookseller in [Market] Harborough, 1655-69. See Dictionary, r641-67. In 1669 he published Joseph Bentham's Disswasive from Error much Increased.

TONGE (GEORGE), bookseller in Warwick, r682. In this year Evan Tyler of London (q.v.) left him $£ 5$.

TONSON (JACOB) I, bookseller in London, (I) Judge's Head in Chancery Lane, near Fleet Street, 1678-98; (2) in Gray's Inn Gate, next Gray's Inn Lane, 1700-10; (3) Shakespeare's Head, opposite Catherine Street in the Strand, 1710-20. 1677-1720. Younger brother of Richard Tonson (q.v.) and second son of Jacob Tonson, "a barber-surgeon in Holborn". He served his apprenticeship with Thomas Basset, to whom he was articled in 1670 , and took up his freedom on December 2oth, 1677 . He settled at once at the Judge's Head, and in Hil. 1678 shared with his brother and with Bentley and Magnes the publication of Préchac's novel, The Heroin Musqueteer, his name only appearing on the third and fourth volumes. [T.C.1. 300, 320, 330; Esdaile, p. 29r.] He soon began to publish plays, and in 1679, with Abel Swalle, of whom a probably fabulous tradition asserts that he borrowed the purchase money, he published his first book for Dryden, Troilus and Cressida. In 1684 he started the celebrated Miscellany Poems, edited and largely written by Dryden, and commonly called Tonson's Miscellany. Another very important acquisition by Tonson was Paradise Lost, which he purchased in two instalments in 1683 and 1690 . Between 1698 and $\mathrm{r} 700$ [T.C. III. $57, \mathrm{r} 7 \mathrm{r}$ ] he moved from Chancery Lane to Gray's Inn Gate, no doubt succeeding his brother, whose name disappears from the Term Catalogues in r689. The latter's son Jacob probably joined his uncle now ; he had possibly been latterly keeping up a retail business at Gray's Inn Gate. Tonson followed up his earlier successes by publishing for the rising school of literary men. In 1705 he 
published Remarks on Several Parts of Italy for Addison, whom he had met in Holland; Steele seems to have acted for him as a "publisher's reader". He also published Cato, 1713. In I 709 he secured Pope's Pastorals for his sixth Miscellany. From about 1700 he was secretary to the newly founded literary Kitcat Club, and it shortly took to meeting at his house. In I 7 ro he made his second move, to the Strand. [Tatler, October I4th.] He retired about 1720 , in favour of his nephew, and lived till 1737 at Ledbury. Tonson was accused by Dryden of meanness, and is caricatured by him in the wellknown lines :

With leering look, bull-fac'd, and freckled fair

With two left legs, with Judas-coloured hair,

And frowzy pores, that taint the ambient air.

Dunton comments [p. 216] on the harshness of Tonson's critical judgements. [D.N.B. ; Nichols, Lit. Anecd. I. 292-5.]

TONSON (JACOB) II, bookseller, bookbinder and printer in London, (I) Gray's Inn Gate ; (2) Shakespeare's Head, opposite Catherine Street in the Strand, 1700 (?)-35. Nephew of Jacob Tonson I (q.v.), and probably son of Richard. He may have succeeded his father soon after $r 689$, but is first known as in partnership with his uncle after I700. It was Jacob II who in I712 bought half the rights in the Spectator, vols. i-vii, from Addison and Steele. In or about 1720 he succeeded his uncle, and continued to publish important literary works for Steele, Pope, Theobald, \&c. From his will it appears that he was a bookbinder, a stationer and a printer, as well as a bookseller; his printing business was in partnership with John Watts, in Covent Garden they are given as " well-affected " by Negus in 1724. He died on December 2nd, 1735, and was succeeded by his son Jacob III. [D.N.B.; Nichols, Lit. Anecd. 1. 295-7.]

TONSON (RICHARD), bookseller in London, Gray's Inn Gate, 1675-89 (?). Elder brother of Jacob Tonson I. Made his first entry in the Term Catalogues in Hil. 1675 with a duodecimo, The Courtiers Calling. [T.C. I. 198.] In 1676 he published Otway's tragedy Don Carlos, and in the following year the same author's Titus and Berenice and Charles Davenant's Circe, a Tragedy. In 1678 in company with his brother Jacob he published Mrs. Behn's comedy Sir Patient Fancy. He also published several law-books. In 1683 a list of the brothers' joint publications is found in An Account of De Quesne's Expedition. He is last heard of in Easter 1689. [T.C. II. 263]. Jacob Tonson took over 
the shop between 1698 and 1700 ; possibly Richard had only left publishing to his brother and confined himself to retail bookselling.

TOOK ( ), printer in London, Old Bailey, 1724. Classed by Negus as a " highflier".

TOOKE (BENJAMIN) I, printer in Dublin, 1669-85 (?); bookseller in London (1) Anchor, Duck Lane, 1669 ; (2) Ship, St. Paul's Churchyard, 1670- ; (3) Middle Temple Gate, Fleet Street. 1669-1716. According to Timperley, this celebrated bookseller was born about 1642 , and is supposed to have been the son of the Rev. Thomas Tuke, vicar of St. Olave's, Old Jewry; but the bookseller always spelt his name as Took or Tooke. He served his apprenticeship with John Crooke, and was admitted a freeman of the Company of Stationers in February 1665. He succeeded Crooke in 1669 as King's Printer in Dublin, and, like him, combined the office withibookselling in London. The last entry in the Term Catalogues of a book printed by him in Dublin was made in 1685 . He began as a London bookseller by advertising two books, one in partnership with George Sawbridge, from the Anchor in Duck Lane, in 1669 ; in the next year he moved to St. Paul's Churchyard, where his business rapidly throve. He is best remembered as Dean Swift's bookseller, and through Swift's good offices he obtained several offices of profit, including that of Printer to the Queen in 1713. He also published for other leading men of letters in Ireland. In 1689 he was junior warden of the Company of Stationers, and was for some years Clerk of the Company and Treasurer from 1677 to 1702 , when he resigned in favour of Joseph Collyer. He was one of the largest publishers of the time, and held shares in all the most important undertakings. He died in 1716 , leaving a son Benjamin to carry on the business.

TOOKE (BENJAMin) II, bookseller in London, Middle Temple Gate, Fleet Street, 1703-23. Son and successor to Benjamin Tooke I. Dunton [p. 212] speaks well of him, and adds "near Temple Bar" to his name; he was therefore probably already in partnership with his father. "He died May 24th, 1723, leaving a considerable estate to his younger brother Andrew Tooke, who was for many years Master of the Charterhouse Schools." [Nichols, Lit. Anecd., III. 627.]

TOOKER (ARTHUR), bookseller in London, Globe and Half Moon, Strand, a) near the New Exchange, $(b)$ over against Salisbury House, (c) over against 
Ivy Bridge, 1669-80. Associated with R. Tompson in the publication of Alexander Browne's Ars Pictoria in r669. (в.M. copy has his engraved trade label.) In 1680 he was selling a Travelling Map of England. [T.C. I. 405.]

TOOKEY (R.), printer in London, behind the Royal Exchange, I695 (?)-1 724. Dunton [pp. 250,696] referred to him as a "pretty modest obliging Printer". He contributed one guinea to the Bowyer fund in $\mathrm{I}_{713}$, and is mentioned by Negus in 1724 as "well-affected".

TOOTH (BARBER), bookseller in London, near York House in the Strand, 1673. Published The Citizen's Companion, 1673. [T.C. I. I53; Haz. I. 96.]

TRACY (EBENEZER), bookseller in London, Three Bibles on London Bridge, 1695-1719. Successor to Thomas Passinger the Second. Began publishing in 1695. [T.C. II. 547.] Published many ballads, chapbooks and nautical manuals. He was also the proprietor of a patent medicine called the "Balsam of Chili", the virtues of which he set out in a pamphlet published in 1696 . [T.C. II. 579.] In $17 \frac{14}{15}$ he paid a fine of $f_{12}$ for exemption from serving the office of churchwarden of St. Magnus. He was succeeded by his sons H. and J. Tracy. There was another house called the Three Bibles, "the corner house of the square, about the middle of London Bridge", occupied by John Stuart, stationer, who dealt in playing cards and wall-papers, and who also sold a "Balsam of Chili ", in rivalry with the Tracys.

TRENCH (DAVID), see Dictionary, 1641-67.

TUCKYR (ROGER), bookseller in London, Golden Leg, the corner of Salisbury Street, in the Strand, I 700. Published the third edition of Joseph Glanvil's Saducismus Triumphatus, I 700.

TURNER (JOSEPH), bookseller in Sheffield, I70I-15. Published The Silvan Dream or, The Mourning Muses, a Poem, I 701. The author is believed to have: been John Philips, who was probably a Sheffield man. [B.M. I1631.h.4.] In I7I5 he published for J. and J. Green the third edition of $A$ Collection of choice Psalm Tunes; it was printed for him by W. Ayscough at Nottingham. [Creswell, p. 14.]

TURNER (MATTHEW), bookseller in London (a) near Turnstile, in Holborn, $(b)$ Holy Lamb in Holborn, (c) near Turnstile, 1673-93. His name first appears in the Term Catalogue for 1673 . In 1678 he is found publishing Ravenscroft's King Edgar and Alfreda. His name is mentioned in the course of the trial 
of Francis West for selling a book called The Errata to the Protestant Bible, or the truth of the English Translation examined. [Proceedings . . . in the Old Bayly, on ... the I2th ... of October I693; B.M. 515. b. 2 (152).] His three addresses probably refer to the same house.

TURNER (ROBERT), bookseller in London, Star, St. Paul's Churchyard, I676. Sold a pack of cards representing the counties of England and Wales. [T.C. I. 247.]

TURNER (WILLAM), bookseller in London, (I) Rose and Crown, without Temple-Bar ; (2) White Horse, without Temple Bar ; (3) Angel at Lincoln's Inn Back Gate. 1696-1 705. In partnership with F. Mills. Their names are found in 1696 in the imprint to the English translation of Le Maire's Voyages to the Canary Islands. In 1703 he published two plays, The Stolen Heiress and Cibber's She wou'd and She wou'd not. [T.C. III. 336.] In 1705 Dr. Samuel Cobb's poem on the Duke of Marlborough's victories, entitled Honour Retrieved, was published by Turner as well as several plays. His last entry in the Term Catalogues was a comedy called the Basset Table, in 1705. [T.C. III. 482.] He was at the Angel by 1703 .

TUTHILL (J.), bookseller in Great Yarmouth, 1678. Publisher of The Victory of Faith over Satan ... in ... the Life and Death of Hannah Purgal. [T.C. 1. 309.] Probably the John Tuthill of 1661 (See Dictionary 1641-67).

TWYFORD (HENRY), see Dictionary, 164I-67.

TYLER (EVAN), printer and bookseller in Edinburgh, Leith and London, 1633-82.

See Dictionary, 1641-67. At the Restoration Tyler once more returned to Edinburgh, and printed there from 1660 to 1672 , when he finally left Scotland, and A. Anderson succeeded him as Royal Printer. He returned to London and was Master of the Company of Stationers in 1671 . He died December $5^{\text {th }}$ 1682 ; in his will, proved December 29 th, he left $£ 50$ to George Tonge of Warwick, bookseller. Tyler is there described as "printer and bookseller".

TYTON (FRANCIS), see Dictionary, 1641-67.

UNETT (ANN), bookseller in Wolverhampton, I714. Widow and successor of George Unett.

UNETT (GEORGE), bookseller in Wolverhampton, 169I(?)-1714. Succeeded R. Grosvenor, and succeeded by his widow, Ann Unett (q.v.). [Information kindly supplied by Mr. G. P. Mander.] 
UNETT (RICHARD), bookseller in Ridware Hamstall, Staffordshire, I68I. Had a son Richard, born at Hamstall Ridware or Ridware Hamstall, and admitted to St. John's College, Cambridge, on June 2nd, 1681. [J. E. B. Mayor, Admissions to St. John's College, Cambridge, II. 83.]

UNSWORTH (ANN), bookseller in Manchester, I696. Henry Pendlebury's series of sermons entitled Invisible Realites, 1696, was printed for her in London. [B.M. 4453. b. I8 (I).]

UNWIN (MATTHEW), printer in Birmingham, $1716-17$; and in Leicester, 1741 . I 716-4I. [Allnutt, pp. 300, 303.]

VADE (JAMES), bookseller in London, Cock and Sugar Loaf, Fleet Street, 167781. Began publishing in 1677 . [T.C. I. 296.] For Edward Ravenscroft he published a comedy called The English Lawyer in 1678 and in the next year no less than eighty pamphlets on the Popish Plot. In I68I Vade was defendant in the action for assault brought by Bartholomew Sprint, bookseller, against a number of printers and booksellers in London and Oxford. [C.P.R. Trin. 33 Chas. II, 2992, m. 256.]

VAILLANT (PAUL), bookseller in London, over against Bedford House in the Strand, I686(?)-I739. "Paul Vaillant was of a respectable Protestant family at Samur in the French province of Anjou. At the time of the Revocation of the Edict of Nantes he escaped and in 1686 settled as a foreign bookseller in the Strand, opposite Southampton Street, where himself, his sons Paul and Isaac, his grandson [Paul II died February Ist, I802], and Mr. Elmsly successively carried on the same trade in the same house till nearly the end of the eighteenth century." [Timperley, p. 8Ir.] As Timperley is also the authority for the statement that Paul Vaillant died on October 14th, I739, aged 67 years, and as Vaillant would only have been 14 in 1686 , it seems more likely that 1696 was the date at which he opened his shop in the Strand. He began to use the Term Catalogues in Trin. 1707, when he was one of the publishers of John Mill's Greek Testament. [T.C. III. 557.]

VALLANGE, or VALLANCE (JOHN), bookseller in Edinburgh, (I) at the PlainStones ; (2) on the North Side of the High Street a little above the Cross, I69I-I7I3 (?). In I69I he was one of the publishers of J. Cockburn's Eight Sermons. Macqueen's The Magistrate's Dignity, Duty and Danger, 1693, was also to be sold by him, and his name appears in several other books down to at least I 708. He changed his house in or before 1701 . The will of John 
Vallance of Chesters, bookseller, burgess of Edinburgh, was registered April 9th, 1713. [Aldis, p. 122.]

VAN HAEGHEN (FRANCIS), bookbinder and printer (?) in Aberdeen, before 1669. "Issobell Spens relict of the deceased Francis Vanhaggan, bookbinder in Aberdeen." [Register of Privy Council, Scotland, I669, p. 45.] This may

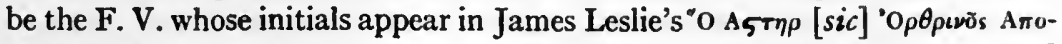
$\lambda а \mu \pi \pi^{-i}$, printed at Aberdeen in 166r. [J. P. Edmond, Aberdeen Printers, p. 214.]

VARENS ( ), bookseller in London, Seneca's Head, near Somerset House in the Strand, I 71 . Sold the "True Cephalick and Head Snuff ", and other patent medicines, according to an advertisement in The Post Man, January I Ith, I $7 \frac{1}{1} \frac{1}{2}$

VARNAM (THOMAS), bookseller in London, Lombard Street, I711-25 (?). Was a nephew of John and Thomas Guy, and is mentioned in the will of the former. In partnership with J. Osborne he succeeded to Thomas Guy's business in Lombard Street, and his name is first found in the Term Catalogue of Easter I7rr. [T.C. III. 675.] He subscribed to Walker's Sufferings of the Clergy in 1714 .

VAUGHAN (CHARLES), bookseller in Bella (?) Wales, 1700 . Sold grammars and devotional books, which he bought wholesale of John Minshull, bookseller of Chester. [Library, 2nd ser. Iv. 373-83.]

VAUGHAN (ROGER), bookseller in London, (1) Little Britain, (2) Bishop's Court in the Old Bayly, 1673-7. In 1673 he sold with J. Williams, jun., The Pope Shut out of Heaven's Gates; he also published a pamphlet, entitled The Northumberland Monster. [B.M. 551. d. 18 (30).]

VERE (THOMAS), see Diclionary, 1641-67.

VEZEY (LAWRENCE), printer in London (?), 1 720. Is mentioned in The Original Weekly Journal of June $25^{\text {th, }} \mathbf{1 7 2 0}$, in connexion with the execution of John Matthews (q.v.). Two journeymen printers, William Phelps and Richard Riley, are also mentioned.

VINCENT (ROBERT), bookseller in London, Clifford's Inn Lane, Fleet Street, 1691-1713. Hazlitt records a book as published by Vincent in 1691. [Haz. III. 160.] In 1693 he published Wright's comedy, The Female Virtuosos. He was also a publisher of law-books. In I713 his name occurs in the list of contributors to the Bowyer fund. 
W. (H.), printer in London, 1699. He printed an edition of the New Testament for the Company of Stationers in I699. [T.C. III. 142.]

WADE (s.), bookseller in London, Bible, under the Piazza of the Royal Exchange, Cornhill, 1693. His name appears in the Term Catalogue for Easter 1693 as one of those who sold John Shower's Sacramental Discourses. [T.C. II. 450.] The house was previously in the occupation of Ralph Smith.

WALBANCK (ELIZABETH), bookseller in London, (I) Southampton Court, Old Southampton Buildings, Gray's Inn, Holborn; (2) near the Three Tuns 'Tavern, Holborn. In Hil. 1674 she published March's Actions for Slander. [T.C. I. 165.] In 1677 she is mentioned in an advertisement of a house to let in The London Mercury of March 7 th. [B.M. Burney, 99.] These two addresses may represent the same house as that occupied by George Walbanck.

WALBANCK (GEORGE), bookseller in London, near Gray's Inn Gate in Holborn, 1669. Possibly son and successor to Matthew Walbanck (1618-67). In Easter 1669 he advertised An Address to the hopeful young Gentry of England. [T.C. I. 10.] He was succeeded by Elizabeth Walbanck, perhaps his widow, in 1674. [T.C. I. 164.]

WALE (JEFFREY), bookseller in London, Angel, St. Paul's Churchyard, I 703-7. His name first appears in 1703 as publisher of the works of the Rev. J. Forbes. [T.C.III.37I.] He became bankrupt in 1707 . [London Gazette, November $13^{\text {th, }}$ I 707.]

WALFORD (BENJAMIN), bookseller and book-auctioneer in London, (I) The Bear in Ave-Mary Lane; (2) The Prince's Arms, St. Paul's Churchyard. 1689-1 7ro (?). Apprenticed to Robert Scott. When Scott sold his business to Adiel Mill, Walford continued in his service. In 1689 he began to sell books by auction at the Bear in Ave-Mary Lane; one of the largest libraries which came under his hammer is believed to have been that of Lord Maitland. [Nichols, Lit. Anecd. III. 665-6.] In r69r he held a sale of books for the creditors of Adiel Mill (of whom Scott $(q . v$.) was probably the largest). [B.M.82r.i. 9 (I6).] His name does not appear in the Term Catalogues until 1693, when he became publisher, with others, of The Counter Scuffle. He had then joined partnership at the Prince's Arms with S. Smith, publisher to the Royal Society, to which office Walford succeeded on Smith's death. They were among the leading publishers of the day. Walford retired from business 
or died between 1709 and I7II, being succeeded at the Prince's Arms by W. Innys. Dunton states (p. 207) that Walford "was a very ingenious man and knew books extraordinary well".

WALFORD (J.), bookseller in London, St. Paul's Churchyard, I 710. Publisher of a broadside for Sacheverell in 1710. [B.M. T. 100* (232).] This may be a printer's error for B. Walford.

WALKER (MATHIAS), bookseller in London, under St. Dunstan's Church in Fleetstreet, 1672. Only known as the publisher of Sir Christopher Wyvill's Pretensions of the Triple Crown examined in 1672 . [T.C. 1. 120.]

WALKER (OBADIAH), printer in Oxford, University College, 1687-8. The Roman Catholic Master of University College. Shortly before Bishop Fell's death in I686 Walker asked him for the control of the University Press, but Fell replied that "he would first part with his bed from under him ". In spite of this, Fell bequeathed his patent for printing to Walker and two others. In May of that year Walker procured a Royal licence to print some forty Romanist books. According to Wood he had Abraham Woodhead's Two Discourses, 1687, " printed at Lichfield's, and some scholars . . . getting the book sheet by sheet ... [there] came out an answer to it in a month following. Whereupon Mr. Walker being sensible that he was falsly dealt with, he set up a press in his owne lodgings (the back part of Univ. Coll.) and there printed Church Government (part 5)." The practical printer who worked this press was Henry Cruttenden (q.v.). At the Revolution Walker fled, but was arrested before leaving England. He died in 1699. [Wood, 1II. 198, 209, 218-21, 282, \&c. ; Hist. MSS. Comm., Report 7, App., pp. 69I 2 ; Madan, p. $19 ;$ D.N.B.]

WALKER (R.), bookseller in London, under Gray's Inn Gate, Holborn, 1676. Only known as the publisher of Modus transferendi Status, 1676. [T.C. I. 259.]

WALL (FRANCIS), bookseller in Bristol, on the Tolzey, I721. Probably son or grandson of Thomas Wall. Only known from his name appearing in W. C. B.'s list of provincial booksellers. [N. \& Q., I Ith ser. 1. 304.]

WALL(THOMAS), bookseller in Bristol, (a) Tolzey, (b) Corn Street, near the Tolzey, 1660-79. See Dictionary, 1641-67. In 1673 he published a map of Bristol. [T.C. I. 135.] Dunton [p. 236] says, " He is well accomplished for his trade, which is very considerable. He was first a Goldsmith but made an exchange 
of that way for this of bookselling. ... For those two years that I kept Bristol Fair, I was treated very kindly at his house."

WALLIS (JOHN), printer in London, (a) near the Green Dragon in Fleet Street ; (b) Whitefriars, 1682-I 700. Printer of broadsides and news-sheets. In 1682 he printed for Randal Taylor a sheet headed $A$ Description of His Majesties True and Loyal Subjects scandalously called Toreys [Haz. II. 600], and in 1683, for Joanna Brome, Remarks on the Preface to the Protestant Reconciler. [B.M. T. I030 (7).] In 1688 he appears as printer of $A$ New Fairing for the merrily disposed or, the Comical History of . . .W. Phill-_. [Bagford (Harl. 596I) ; Haz. 11. 458.] In the same year he became the printer of The Universal Intelligence (no. I, Tuesday, December IIth, I688) [Burney, 96], and for Anne Marriott he printed about the same time The London Intelligence.

WALLUP (G.), bookseller in London, I69o. Only known from the imprint to a poem, Caesarem E. Fortunam vehis, I69o. [B.M. C. 40. m. II (I).]

WALSALL (SAMUEL), bookseller in London, ( $\mathrm{I}$ ) Golden Frying Pan, Leadenhall Street, $1680-4$; (2) Heart and Bible, near the West-end of the Royal Exchange in Cornhill, I684-5. I680-5. Began to publish in 1680 with $A$ Translation of the Sixth Book of Mr. Cowley's Plantarum. [T.C. 1. 394.] His later books were chiefly in divinity. His last entry in the Term Catalogues was in Mich. 1685. [T.C. II. I42.]

WALTER (J.), bookseller in London, ( $\mathrm{r}$ ) Hand and Pen, next the White Hart Inn, in High Holborn, near Drury Lane; (2)Golden Ball in Pye Corner. 1 700 (?). Publisher of chap-books, e.g. The New Year's Garland, The Merchant Lady's Garland [Bodl. Douce PP. 183], and The ... History of Titus Andronicus.

WALTHOE (JOHN), bookseller in London, (I) Black Lion, Chancery Lane, (a) over against, or near, Lincoln's Inn, $(b)$ over against St. John's Head Tavern, $1683-8$; (2) Vine Court, Middle Temple, adjoining to the Cloisters, r690- ; (3) Pump Court, Middle Temple Cloister; and in Stafford. 1683-1733. Began publishing in Mich. I683. [T.C. II. 50.] In 1684 he published two novels from the French entitled The Triumph of Friendship and The Force of Love [T.C. II. 96], and from that time onward he continued to be a prominent publisher of similar books. Dunton, however [p. 208], who speaks very well of him, does not mention these, but notes that " he prints and deals much in Law Books". Walthoe contributed five guineas to the Bowyer 
fund, and was in business as late as the year 1733 . He moved from Chancery Lane to Vine Court between 1688 and 1690. [T.C. II. 238, 342.] As he gave very vague and abbreviated descriptions of his quarters in the Temple it is difficult to decide when he made his second change.

WALTON (ROBERT), printer in London, Globe (and Compasses) in St. Paul's Churchyard, 1647-87. See Dictionary, 1641-67. He was still in business in 1687. [T.C. II. 200.] An advertisenent of "several things made and sold" by him is in Bodl. [Gough Maps, 46, fol. 169.]

WALWYN (HERBERT), bookseller in London, Three Legs in the Poultry, $(a)$ over against, $(b)$ in, the Stocks Market, $(c)$ at the corner of the Old Jewry, I6981702. First appears in 1698 , as one of the publishers of John Conant's Sermons. [T.C. III. 62.] He was the author of Poems on several Occasions, 1699. [в.M. I 1633. df. 20.] Dunton [p. 218] praises Walwyn's poetical powers in extravagant terms, and adds that he was well informed on many subjects and clever at "forming of titles".

WARD (JOHN), bookseller in Leicester, I7II-19. In company with William Ward, bookseller in Nottingham, perhaps his father or brother, he sold Henry Felton's funeral sermon on the Duke of Rutland,preached February 23 rd, 1711 . [T.C. III. 662.] He was still there in 1719 .

WARD (ROBERT), printer in York, 1725 . With John White he set up a press in opposition to Gent's, and printed a rival newspaper, The York Courant. [Gent, pp. 160-3.]

WARD (THOMAS), bookseller in London, Inner Temple Lane, I7II-20. Published a History of the reign of $Q$. Anne, I $7 \mathrm{II}$, and also was one of the booksellers who sold the second edition of John Brightland's Grammar of the English Tongue in that year. [T.C. III. 675.] In 1720 he was one of the publishers of the Works of Machiavelli. [Esdaile, p. 264.]

WARD (WILLIAM), printer and bookseller in Nottingham, 1710-38. His first known publication was $S$. Berdmore's Assize sermon of 1710 ; between that year and 1738 he is found publishing several more sermons of local interest by the same and other divines. In 1717 his name occurs as printer on a single imprint, that to Sir Thomas Parkyns's Practical ... Introduction to the Latine Tongue; but in 1735 and $173^{8}$ he had his printing done in London, 
WARDLAW (JAMES), bookseller in Edinburgh, on the North-side of the Street, opposite to the middle of the Lucken-Booths, 1691 ; (2) in the Parliament Close, at the South door of the New Kirk, $6_{67-9}$; (3) on the North side of the Street a little below the Cross, at the sign of the Bible, I699; (4) the first Stair below the Post Office, a little below the Cross, I70r. I69I-I70r. In I69r he published the defence of James Clark, in 1695 a medical work by Archibald Pitcairne entitled Apollo staticus, and in 1697 A Poem upon the . . Royal Company of Scotland trading to Africa. In 1699 he was joint publisher with J. Mackie of the Letter giving a description of the Isthmus of Darian. [Aldis, p. 123.]

WARNE, or WARN (R.), bookseller in Chippenham, 1707-r4. In the Observator of April 12th, 1707, is an advertisement of B. Fox's Agrippa almost Persuaded, published by Warne. In I $7 \mathrm{I}_{4}$ he subscribed for Walker's Sufferings of the Clergy.

WARNER (JAMES), (?) printer in Edinburgh, r688-9. A Dutch book, with a title beginning Crimineel proces, has the fictitious imprint, "Gedrukt tot Edenburg in Schotland, by James Warner, Drukker van 't hoge Hof des Parlements, r688." Two other quarto tracts, entitled Crimineel-Proces . . ., printed in 1688 and 1689 respectively, bear similar imprints. These were in all probability printed in Holland. [Aldis, p. 123.]

WARNER (WILLIAM), bookseller in London, 1687. Defendant in an action for assault brought by Sir John Coel. [C.P.R. East. 3 Jas. II, 3056, m. 42 V.]

WARREN (THOMAS), printer in London, r693-8. Doubtless a descendant of either Francis or Thomas Warren, who were printers in Foster Lane between r663 and 1668. [Dictionary, 1641-67.] He printed, for N. Rolls, John Lewkenor's Metellus his Dialogues, pt. I, r693, and a number of reprints of plays by Dryden and others in 1697-8, "for Henry Herringman " (i. e. for his widow, see Herringman), and for others.

WARTER (WILLIAM), stationer in London, Talbot, (a) under the Mitre Tavern, Fleet Street, over against Fetter Lane, $(b)$ next the Mitre Tavern, against St. Dunstan's Church, Fleet St., r684-I 709. Son of John Warter, gent., and Jane his wife. In partnership with J. Lenthall $(q . v$.$) . His first entry in the Term$ Catalogues was An exact and lively Map or Representation of the Booths ... upon the Ice on the River of Thames ... in . . I683. [T.C.II. 62.] In I689-90 
he was defendant in a suit in the Court of Common Pleas for the recovery of a sum of money lent or entrusted to him. [C.P.R., I W. \& M., 3082, m. $495 \mathrm{v}$.

WATERS (EDWARD), printer in Dublin, I 708-36. Printed a considerable variety of books at four or five addresses in Dublin. A reprint in 1712 of Swift's Conduct of the Allies and three books by Peter Brown, Bishop of Cork, were among his most notable productions.

WATERTON (RICHARD), bookseller in London, next door to the Blue-Anchor, 169r. Publisher of An Impartial Account of the Late Famous Seige . . of the City of Mons [I69I]. [B.M. T. I707 (II), the imprint partially cut away by the binder.]

WATSON (J.), printer in Maidstone, High Street, near the Conduit, r 725. Printed The Maidstone Mercury (no. 25, May 27th, 1725).

WATSON (JAMES), the Elder, printer in Edinburgh, ( $\mathrm{I}$ ) in the Grassmarket at the foot of Heriot's Bridge ; (2) Holy-Rood-House. 1685-7. Originally an Aberdeen merchant. In $1685^{-6}$ he acquired the printing house of van Solingen and Colmar [see Lindsay (D.) and his partners], and occupied the same premises in the Grassmarket, though no book of Watson's with this imprint has been found. In February 1686, his premises having been broken into by the populace and his workmen (including Thomas Noble) ill-treated, he was taken under Royal protection and his press set up in the precincts of Holyrood Palace. He was also appointed Printer to the Royal Family and Household, and granted other privileges. Watson died in 1687 , his will being registered on December 2 ist. He left a son, James Watson the Younger, and was succeeded by Peter Bruce. [Aldis, p. 123.]

WATSON (JAMES), the Younger, printer in Edinburgh, ( $\mathrm{I}$ ) in Warriston's Close, over against the Luckenbooths ; (2) in Craig's Close on the North-side of the Cross; (3) his shop next door to the Red Lion, opposite to the Lucken Booths. $1695^{-1722}$. Son of the preceding. Commenced printing in 1695 . Imprisoned in I 700 for printing Scotland's Grievance respecting Darien. Mrs. Anderson in 1701 attempted to shut up his office, but was defeated on Watson's appeal to the Privy Council. In I 7 I I, on the expiry of Mrs. Anderson's gift, he was appointed Queen's printer in conjunction with Freebairn and Baskett; this gift was forfeited in 1716 , and a new one issued in favour of Baskett and Mrs. Anderson. In $\mathbf{I}_{7} \mathrm{I}_{3}$ he published his History of the Art of Printing. The 
Preface is the only valuable part of this work; it contains notices of many contemporary Scottish printers, and has been edited separately by Mr. W. J. Couper (I913). Died September 24th, 1722. His widow, afterwards Mrs. Heriot, died in August I731. [Aldis, p. I23 ; W. J. Couper, "James Watson, King's Printer", Scot. Hist. Rev., April 1910, and "Watson's History of Printing ", Library, October I910.]

WATSON (RALPH), senior and junior, booksellers in Bury St. Edmunds, r686r 7 I4. The elder is in W.C. B.'slist of provincial booksellers asin businessin 1686. [N. \& Q. I Ith ser. I. 304.] His name occurs in an advertisement in The Post Man, February 26th-28th, I70 $\frac{2}{3}$, as selling a plaster. He published schoolbooks for the use of Bury school in 1705 , and in Easter 1707 Francis Hutchinson's sermon preached at the Assizes in that town on March 25th, 1707 . [T.C. III. 468, 543.] "Ralph Watson junior" subscribed in 17 I4 for Walker's Sufferings of the Clergy. It is not clear when he succeeded his father.

WATTS (JOHN), printer in London, Little Queen Street, Lincoln's Inn Fields, 1700 (?) -63 . This was one of the most important printing houses in London in the first half of the eighteenth century, and was the school in which many eminent printers learnt the art. Nichols says : "The fame of Mr. John Watts for excellently good printing will endure as long as any public library shall exist. 'The duodecimo editions of Maittaire's Classicks 'ex officinâ Iacobi Tonson et Iohannis Watts' would alone have been sufficient to have immortalized his memory, both for correctness and neatness. But there are many works of still higher importance ; Clarke's Caesar for example ; and several beautiful volumes of English Classicks." [Lit. Anecd. 1. 292.] Among those who worked in this office was Thomas Gent $(q . v$.$) and Chalmers, the father of$ James Chalmers, printer to the City of Aberdeen ; but the best known of all was Benjamin Franklin, who on finding himself stranded in London, first entered the printing office of Palmer and afterwards that of Watts, where he acted as compositor during the remainder of his stay in London. John Watts was one of the patrons of William Caslon the first, and lent him $£$ roo to make a start. He died September 26 th, ${ }_{7} 6_{3}$, aged 85 . [Nichols, Lit. Anecd. III. 739.]

WATTS (JOSEPH), bookseller in London,(r) Gilded Acorn, St.Paul's Churchyard, I685 ; (2) Half-Moon, St. Paul's Churchyard, I685; (3) Angel, St. Paul's Churchyard, 1686 -92. r685-92. Began to publish in 1685 , when he issued Sir 
William Davenant's Gondibert, bk. II1, canto vii. [T.C. II. I14.] He made entries fairly frequently in the Term Catalogues between this and 1692 , when he disappears.

WAVER ( ), bookseller in Oxford, 1677 . Sold a map of England, designed by J. Adams. [T.C. I. 282 ; Madan, p. 30.]

WAYTE (тномAs), bookseller at York, 1653-95. See Dictionary, 1641-67.

WEALE (J.), bookseller in Bedford, I 721. Only known from a list of provincial booksellers in Notes \& Queries [Ioth ser., V. I4I].

WEBB (WILLIAM), bookseller in Chichester, I700-r4. Sold the funeral sermon on George Payne, junior, of Midhurst, preached by Richard Oliver on March 6 th, 1699/1700. [T.C. III. 193.] In I 7 I2 he sold a sermon preached at Petworth by Charles Bettesworth. [Bodl. Sermons, 2 (17).] He was still in business in I 7 I4, when he published a sermon by M. Woodford. [B.M. 225. h. 3 (15).]

WEBSTER (THOMAS), bookseller in Cambridge, I $70 \mathrm{I}-22$. His name appears on a sermon by Dr. John Cornwall, preached May I8th, Ijor. [Bowes I, Cambridge Books, no. 349.] He lived (I) on the site of what is now the Senate House lawn, moving in I704 to (2) a house in the High Street facing Great St. Mary's Church, two doors to the right of the "Green Dragon" (previously occupied by John Creed, bookseller), where he died in 1722 .

WEEKS ( ), bookseller (?) at Maidstone, 1699. His name appears in an advertisement in The Flying Post, December 2nd, I699, of the publication of Edward Brown's sermon preached at the Kentish Feast on November I6th, I699. It does not appear in the imprint to the book.

WEIR (ALEXANDER), bookseller in Edinburgh, r670. His wife Margaret was sister[-in-law ?] of Major Weir, and a witness at his trial in 1670. [Aldis,p.123.]

WEIR (JOHN), bookseller in Edinburgh, I68I. Published in $168 \mathrm{I}$, in partnership with T. Brown and J. Glen, a translation of Scudéry's Les Femmes Illustres. [Aldis, pp. 62, I23.]

WELBURN (CHRISTOPHER), bookseller at York, I691. Published George Halley's Sermon preached at the Castle of York, to the condemned prisoners on March 30, 1691. [T.C. II. 357.]

WELD (JOHN), bookseller in London, Crown, betwixt the two Temple Gates in Fleet Street, 1685-1 700. Began to publish in 1685 , with a copy-book by John 
Chalmer and Dr. Abercromby's Discourse of Wit. [T.C. II. 137.] In I686 he published an anonymous work on witchcraft. [T.C. II. 159.] At the end of R. Adams's Earthly and Heavenly Building, 1690 , is an advertisement of four books printed for him. The last entry under his name in the Term Catalogues was Bishop Burnet's The Life of God in the Soul of Man, I700. [T.C. III. 203.] WELLINGTON(M.), bookseller in London, 17 18-22. See Wellington (Richard)I. WELLINGTON (RICHARD) I, (I) Lute, St. Paul's Churchyard, I693-9; (2) Dolphin and Crown, St. Paul's Churchyard, I699-1 709 (?). I693-I 709 (?). Made his first entry in the Term Catalogues in 1693. [T.C. II. 475.] In 1704 the Company of Stationers brought an action in Chancery against him and John Minshull of Chester, for importing and selling The Psalms in Metre. Wellington professed ignorance of the Company's privilege. [Chan. Proc. before I 7 14, Hamilton 320/40, 319/77; Library, 2ndser.,IV.373-83.] Wellington was the publisher of many plays, romances, and the like. He was publishing in 1709. [T.C. III. 654.] He moved to the Dolphin and Crown between Trin. and Mich. I699. [T.C. III. I4I, I 54.] Edd. 2 (?)-5, 1696-1 705, of Mrs. Behn's collected Histories and Novels were printed for R. Wellington; ed. 6, I7 18 , printed by J. D. for M. Wellington; ed. 7, I722, printed by J. D. for M. P. ; and ed. 8, 1735, for R. Wellington among others. [Esdaile, p. I60] Nichols [Lit. Anecd. II. 304] mentions Richard Wellington as the publisher in I740 of Edward Spelman's translation of Xenophon. From these facts it would seem probable that there were three booksellers of the name: (I) Richard I, who died between 1709 and 1718 ; (2) "M." (perhaps his widow, and subsequently wife of some bookseller with a surname beginning with $P_{\text {.), }}$ who published the sixth and seventh editions of Mrs. Behn in 1718 and 1722 ; and (3) Richard II, who was at work in I 735-40. Dunton [p. 212] says that Wellington " has the intimate acquaintance of several excellent pens, and therefore can never want copies ; and trust him for managing and improving them. He has a pretty knack at keeping his word and I expect to see him master of the Company at least, if not a gold chain about his neck, before he dies".

WELLS (GEORGE), bookseller in London, Sun, St. Paul's Churchyard, 1677-87. This bookseller published some interesting books. He is first met with in 1677 as selling a French Liturgy. In 1678 he published the second edition of Paul Festeau's Nouvelle Gramaire [sic] Anglois. [T.C.1.323.] In the following 
year (1679) he was joint publisher with J. Robinson of Dr. A. Tuckney's Praelectiones Theologicae, and in 1680 they were also the publishers of a French and English vocabulary, compiled by Jacob Villiers, master of a French school in Nottingham. [T.C. I. 386.] In r682 Wells alone published Antiquitates Ecclesiae Orientalis, by Cardinal Barberino and other writers [T.C. I. 473], and shared with Littlebury and Scott in the publication of Chamberlayne's Angliae Notitia. Wells was also the publisher of Isaac Barrow's Lectiones and of a French version of a sermon of Calamy's [T.C.II.6o], and held a share in Torriano's Italian Dictionary, I684. [T.C. II. 66.] In I686, in company with Abel Swalle, he published a translation from the French of Varrilas' History of William de Croy. [T.C. II. I77.] Another work of considerable value published by Wells was The Universal Historical Bibliotheque, or an Account of most of the considerable books, printed in all languages, in ... January and February, I68 $\frac{6}{7}$. This work ran to three issues and then ceased. Finally, in Mich. I687, he was part-publisher of Florio's Vocabolario Italiano e Inglese. [T.C. II. $2 \mathrm{I} 4$.]

WELLS (JoHN), bookseller and bookbinder in London, St. Paul's Alley, r687I716 (?). Defendant in an action for trespass brought by - Gardner, widow. In this he is described as bookbinder. [C.P.R. Hil. 2-3 Jas. II (1686-7), $3052, \mathrm{~m} .49 \mathrm{v}$.] In Easter $169 \mathrm{I}$ he entered in the Term Catalogue The Title of a Thorough Settlement examined. [T.C. II. 36r.] Perhaps identical with the John Wells who in I7I6 published The Case of the Five Rioters. [Bodl. Fol. $\theta .662$ (3I).]

WELLS (R.), bookseller in London, Hand and Sceptre, Fleet Street, over against St. Dunstan's Church, 1686. In partnership with Robert Kettlewell in June 1686, when they published several theological pamphlets. [T.C. II. 166.]

WELLS (WILIIAM), bookseller in London, see Dictionary, $164 \mathrm{I}-67$; also T.C. I. IO-r 20.

WELLS (WILLIAM), bookseller in Oxford, i 719-32. [Madan, p. 32.]

WELSH (ANDREW), printer in Cork, Castle Street, $\mathrm{I}_{715}$ (?)-25. This printer's name is first found, jointly with Thomas Cotton's, upon a folio sheet, probatly of I7 5, The Freeholder's Answer to the Pretender's Declaration. It was sold by John Redwood (q.v.). Welsh printed alone a similar sheet in 1722 [Bibl. Lind. Broadsides, 122I] and John Knapp's Cork Almanack for 
1723 and again for 1724 . He was then in Castle Street. In 1725 he printed a stout 4 to in French, M. Laval's Les Veritez Éc. de la Religion Chretienne. WENT (SAMUEL), bookseller in Stroud, I 722. He and G. Harris sold J. Blanch's History of Great Britain from the Tower of Babel, printed at Gloucester by Raikes and Dicey.

WEST ( ), bookseller in London (?), 1703. Mentioned disparagingly by Dunton [p. 356], who says that he had been apprenticed to Samuel Manship, but "sued out his indentures".

WEST (GEORGE), bookseller in Oxford, c. 1650-r 707. Mr. Madan [p. 32] says that West died in 1695; but he and Antony Peisley were Oxford agents in 1697 and 1699 for two auction catalogues, Bibliotheca selectissima (M. Harding's) and Bibliotheca Andertoniana. [B.M. 821. i. 2 (1 I, 12).] In 1700-1 Bullord, for whom he sold the latter, was employing Dollive ; but West was in business as late as 1707 , for on September 17 th of that year Hearne [11. 46] speaks of a book being "bought of old George West the bookseller".

WHALLEY, or WHALEY (JOHN ?), printer in Dublin, r7oo-24. He was an almanac maker in Dublin in 1691 , but in 1700 he had become, in addition, a printer, and printed his own almanac for that year. He continued to print occasional broadsides till 1 7 7 . He has been described, not unreasonably, as a quack. He died in or about 1724 , and his will is lodged in the Dublin Diocesan Court.

WHISTLER (EDWARD), bookseller and bookbinder in Oxford, 17ro-22. In March 1716 he was elected Inferior Beadle of Arts. Hearne refers to him [v. 189] as a "very silly conceited Fellow, but fit enough for some dull Heads of Houses", and further records that he was University Verger and a bookbinder. He was still living in I722. [Madan, p. 32.]

WHITE (GRACE), printer in York, Coffee House Yard, near the Star in Stonegate, I716-21. Second wife and widow of John White, senior. Besides books she founded and printed the York Mercury (no. 1, February 23rd, I 7 I $\frac{8}{9}$, which was edited and sold by $T$. Hammond, the Quaker bookseller, till Gent quarrelled with him. Mrs. White died in January I 721 , and was succeeded by Charles Bourne, her husband's grandson. [Davies, pp. 132-9.]

WHITE (HENRY), bookseller in London, Three Bibles, Minories, 1677-80 (?). In $167 \frac{6}{7}$ he advertised John Ryther's Looking Glass for the Wise and Foolish, Godly and Ungodly. [T.C. 1. 265.] Succeeded in 1680 by John White (q.v.). 
WHITE (JOHN), bookseller in London, Three Bibles, Minories, 1680. Probably identical with the John White who on Bulkley's death went to York and settled there as a printer. He may have been the son of Henry White, but all that is known of his business in London is the publication of J. Ryther's Hue and Cry of Conscience in $16 \frac{79}{80}$. [T.C. I. 380.] Dunton [p. 292] mentions "Presbyterian (alias Minories) White" and, after a number of other names, "Hue and Cry White"; he may be thus distinguishing Henry and John.

WHITE (JohN), senior, printer at York, Coffee-House-Yard, over against the Star in Stonegate, r680-1716. The year that Stephen Bulkley died (r680) John White, "late of London," settled at York. He was perhaps the John White who is found at the Three Bibles in the Minories in 1680 ; but he must have had some previous acquaintance with York and the family of Thomas Broad the printer, as the first thing he did upon his arrival was to marry Broad's daughter Hannah on November 9th, 1680, upon which Alice Broad, the widow, retired from business in favour of White. In November 1688 , soon after the landing of William of Orange, White had the boldness to print at York the Prince's famous manifesto, which had been refused by all the printers in London, King James having issued a proclamation threatening with severest punishment all who should circulate or even dare to read it. For this daring act White was sent prisoner to Hull Castle, where he was confined until the town surrendered. He was afterwards rewarded by William III with the appointment of "Their Majesties Printer for the City of York and the five Northern Counties ", dated May 26th, 1689. In I 7 I4 he was elected one of the City Chamberlains. He died January Ioth, $17_{1}^{1 \frac{5}{6}}$, aged 80 , and was buried in the church of St. Michael le Belfrey. He was twice married; his son by his first wife was the John White $(q \cdot v$.) who became a printer and bookseller at Newcastleupon-Tyne. His second wife Grace survived him and carried on the business until her death in 1 721. Thomas Gent, who afterwards carried on White's business at York, was in $17 \mathrm{I}^{-1} 5$ a workman under him. [Davies, pp. 131.] WHITE (JOHN), junior, printer in Newcastle-upon-Tyne,( $\mathrm{x}$ ) in the Close, 1 708 (?) $-I 1$; (2) on the Side, I712-69; and in York, in Stonegate, near St. Helen's Church, 1725-35. 1708(?)-69. Son of John White, senior; born about 1689. In 1708 , according to Davies, and in any case by 1711 , he set up by himself the second permanent press at Newcastle. In 1711 he began to print The Newcastle Courant (no. 1, August), perhaps a continuation of The Newcastle Gazette, or The Northern Courant, which Saywell had printed for Button, and which disappears 
about this time. His output consisted, besides the usual local sermons and pamphlets, in chap-books and ballads, of which he was a large producer; one of these, The Second Part of Jack and the Giant, is dated I7II. [B.M. 1076. 1. 8 (23).] Woodcuts soon became a feature of his books, and he printed two handsome works of local interest, Henry Bourne's Antiquitates Vulgares, 1725, and History of Newcastle-upon-Tyne, 1736. In 1739 White found presses and pressmen to print off the Sallust, and Scougal's Life of God in the Soul of Man from the stereotype plates made by Ged $(q . v$.$) , which had been refused$ by other printers. White apparently disliked his niece Alice Bourne's marriage with Gent, by which she took his father's York business out of the family, and was on bad terms with Gent, who calls him "our unmerciful uncle". In 1725 , the year following the marriage, whether or not, as Gent supposed, out of animosity, he set up a rival press in York, with the aid of one Robert Ward, who was probably its practical manager. They printed a newspaper, The York Courant (no. I calculated to be for August or September 1725), and some books. In September 1734 White was elected sheriff of the city of York ; but in 1735 he sold his business to Alexander Staples. He continued to print at Newcastle ; in $r 76 \mathrm{r}$ he took a partner, and in $r 769$ he died, in his eightyfirst year, "the oldest master printer in England". [Welford, pp. 18-23; Davies, pp. 233-6, \&c. ; Nichols, III. 688 ; Gent, pp. 160-3.]

WHITE (LAWRENCE), bookseller in London, White Cross Street, r679. His name is found in the imprint to a broadside on the Popish Plot in 1679. [Haz. II. 486.]

WHITE (MARGARET), bookseller in London, r683. She published in 1683 Crossing of Proverbs, by B. R., Gent. [Pepys ; Haz. 1. 477.]

WHITE (ROBERT), printer in London, r639-77. See Dictionary, r641-67. He was still at work in 1677 .

WHITLEDGE (ROBERT), printer, bookseller, and bookbinder in London, (r) Bible in Creed Lane within Ludgate ; (2) Bible and Ball in Ave Mary Lane. c. I695 (?)-1713. A publisher of Welsh books. In The Post Man of January 25th, r7Ir, he advertised The Welsh Common Fold at Bristol Fair. Dunton [p. 250] tells us that he was a printer and in partnership with Everingham, and that the pair "loved themselves into two Journeymen printers again". Perhaps he had by I 7 II set up afresh as a bookseller. He contributed to the Bowyer fund in $17 \mathbf{1} 3$. 
WHITLOCK (ELIZABETH), bookseller in London, near Stationers' Hall, 1695-9. Duubtless widow of John Whitlock. Her name first appears in the Term Catalogues in Hil. 1696. [T.C. II. 567.] She published several theological pamphlets and $A$ Compleat List of the Knights, Citizens and Burgesses of the New Parliament, 1698. [B.M. 1850. c. 6 (16).]

WHITLOCK (JOHN), bookseller in London, near Stationers' Hall, 1683-95. His name first appears in the Term Catalogue for Mich. 1683. [T.C. 11. 39.] In 1684 he advertised a novel, The Grand Vizier [T.C. II. 96], and then he disappears from the Catalogue for ten years. In 1694 he reappears as selling The Parish Clerk's Vade Mecum. [T.C. II. 520.] In 1695 he issued Solon Secundus: or, some defects in the English Laws [B.M. 8122. aaa. 20 (I5)]; and in the same year An exact Journal of the victorious Expedition of the Confederate Fleet ... under ... Admiral Russell. [T.C. II. 557.] Whitlock appears to have died shortly after this, and he was succeeded by Elizabeth Whitlock, presumably his widow.

WHITWOOD (WILLIAM), bookseller in London, (I) Swan, Duck Lane; (2) Golden Lion, Duck Lane, next Smithfield ; (3) Golden Bell, Duck Lane ; (4) Middle Exchange, Strand ; (5) next the Cross Keys, Strand, near Ivy Bridge ; (6) next the George Inn, Little Britain ; (7) Angel and Bible, near the George Inn, Little Britain; (8) next to the Bible, Duck Lane ; (9) Golden Dragon, next door to the Crown Tavern, Duck Lane, near West Smithfield ; (10) Rose and Crown, Little Britain. 1666-99. This bookseller, who started business in 1666 and was therefore only briefly noticed in the Dictionary, $1641-67(q . v$.$) , was chiefly remarkable for the number of times in which he$ changed his place of business. He was at the Golden Bell in 1676 , and in 1680 had moved into the Strand, where he published Richard Izacke's Remarkable Antiquities of the City of Exeter. [T.C.1.419.] In 1682 he was back in Little Britain, and his last entry in the Term Catalogues shows that between 1697 and 1699 he once more altered his sign to the Rose and Crown. He was a miscellaneous and prolific publisher and used the Term Catalogues freely. Dunton [p. 292] calls him "rolling and honest Whitwood", a phrase which may imply that he was a "rolling printer", i.e. a printer of engravings, but which may merelyallude to his constant removals, though some of his addresses given above probably refer to the same house.

WHITWORTH (JOHN), bookseller in Manchester, Smithy Door, 1697(?)-1 727. Successor to Zachary Whitworth. According to the inscription on the family 
gravestone at Cross Street Chapel, John Whitworth died August 2nd, 1727, aged sixty-four. [R. W. Procter, Memorials of Manchester Sireets, p. 183.] His son Robert, born in July I 707, was the printer of The Manchester Magazine, and eventually became a bankrupt.

WHITWORTH (ZACHARY), bookseller in Manchester, Smithy Door, 1690-7. In the Poll Book of 1690 Zachary is accredited to the amount of one shilling. On November 30th, 1697, he was buried. He was succeeded by John Whitworth. [R. W. Procter, Memorials of Manchester Streets, p. 183.]

WIAT. See Wyat.

WICKER (TOBIAS), stationer in London, 1683. In Hil. 34-5 Chas. II (1682-3) he was sued by George Bradshaw for debt. [C.P.R., 3009, m. 50 r.]

WICKINS (JOHN), bookseller in London, (1) White Hart, Fleet Street, over against St. Dunstan's Church, 1679-84 ; (2) Mitre, Fleet Street, 1684-95 (?). 1679-95. Began to publish in 1679 , when he issued a translation of Mervault's History of the Siege of Rochel. [T.C. 1. 369.] In 1680, in company with T. Basset, he published William Petyt's Miscellanea Parliamentaria. [T.C. 1. 42I], and also, with Heyrick and Dring, A Collection of Letters, relating to the Popish Plot, and published by order of the House of Commons. [T.C. I. 425.] Hazlitt [III. 189] records his imprint in 1695 .

WIDDOWES (GILES), bookseller in London, (1) Maiden's Head, Aldersgate Street, 1669; (2) Green Dragon, St. Paul's Churchyard, 1670-5. 1669-75. His name first appears in the Term Catalogue for Mich. 1669, when, with Cademan of the Pope's Head, he published Frances Boothby's tragicomedy, Marcelia. Amongst his publications at this time was John Josselyn's New England's Rarities discovered ... Illustrated with cuts, 1672 [T.C. I. I 12], and the same author's Account of two Voyages to New England, 1674. Both these books contain lists of his publications. [T.C. I. 177.] Widdowes used as his device a dragon with the letters G. W. above it. His last book entry was made in Trin. 1675 , and his death occurred soon afterwards. He was succeeded by his widow, Margaret Widdowes ( $q . v$.).

WIDDOWES (MARGaRET), bookseller in London, Green Dragon, St. Paul's Churchyard, $1676-80$ (?). Widow of Giles Widdowes ; her name appears for the first time in the Term Catalogue for Hil. 1676 , and is met with up to Easter. 1679. The Complete Catalogue of all the stitcht Books and single sheets printed 
since the first discovery of the Popish Plot, 1680, was sold at the Green Dragon in St. Paul's Churchyard. [T.C. I. 228, 354, 386, 406, 419.] She encouraged Dunton, while still an apprentice, in his amour with Rachael Seaton.

WILCOX $\left(\mathrm{J}_{i}\right)$, bookseller in London, $1721-62(?)$. He sold the sixth edition of N. Cox's Gentleman's Recreation in $\mathbf{1 7 2 1 . ~ B e n j a m i n ~ F r a n k l i n , ~ w h i l e ~ w o r k i n g ~}$ in Palmer's office, lodged next door to Wilcox's shop, and was allowed, for a fee, to use the stock as a lending library. [Franklin, Autobiography, ed. J. Bigelow, 1909, p. 9r.] This bookseller may perhaps be identical with the John Wilcox, Gent., who in 1762 took part in a certain insurrectionary movement in the Company of Stationers. [Timperley, p. 709.].

WILDE (ALLINGTON), printer in London, Aldersgate Street, 1722-31. Son of John Wilde. In 1722 he printed an edition of Mandeville for Conyers, Norris, and Bettesworth. He died in $\mathbf{1 7 3}$. His daughter Martha was the first wife of Samuel Richardson.

WILDE (JAMES), bookseller in Hereford, 1714. Subscribed to Walker's Sufferings of the Clergy.

WILDE (JOHN), printer in London. Aldersgate Street, 1693-1;09. Samuel Richardson was bound apprentice to John Wilde in 1706. Dunton thus writes of him [p. 252]: "He has a very noble Printing House in Aldersgate Street. Whilst I employed him, he was always very civil and obliging, I brought him to be concerned in printing 'The Present State of Europe', in which he is yet employed." Wilde printed many almanacs for the Company of Stationers. He was succeeded by his son Allington Wilde. [Timperley.]

WILDE (JOSEPH), bookseller in Dublin, Castle Street, 1672-83. In 1672 Benjamin Tooke printed for him Dr. John Stearn's De Obstinatione, edited by Henry Dodwell, Fellow of Trinity College. [T.C. I. I13.] In the same year he published Dudley Loftus's translation of Dionysius Syrus on St. Mark. [B.M. 3227. C. 13.] His imprint occurs on a few books for the next four years, and then again in 1682 and 1683 . Perhaps related to Richard Wilde, of London and Dublin.

WILDE, or WILD (JOSEPH), bookseller in London, Elephant (a) near, (b) at, Charing Cross, 1698-r7oo. He sold Daniel Baker's Poems upon Several Occasions, 1698, and Charles Hopkins's poem, The Art of Love, 1700. [T.C.III. 55, 173.] 
WILDE, or WILD (RICHARD), printer, bookseller, and book-auctioneer in London and Dublin ; London, (r) Bible and Crown, Ludgate Hill, r686-8 ; (2) Map of the World, St. Paul's Churchyard, 1689-90 (1696-7?); Dublin, 1694-5, 1698. 1686-98. First known as London publisher of Grammatica Anglo-Romana, by Sam. Shaw of Ashby-de-la-Zouch; Michael Johnson of Lichfield shared this publication with him. [T.C. II. r8o.] He dealt specially in anti-Quaker pamphlets. He did not use the Term Catalogues after r69o. [T.C. I1. 33r.] In 1694 and 1695 he appears as a printer at Dublin, printing in the latter year an Act of Parliament (6 W. \& M. cap. 2), though not King's Printer. He was again in London between that year and 1698 , when he followed Dunton to Dublin and conducted his auction there for him. Dunton gives, in the Dublin Scuffle, a long and laudatory account of Wilde, in the course of which he tells us that he was "descended from an antient family in Herefordshire, and brought up to Learning . . . was bound apprentice to George Sawbridge ", that he remained a bachelor, had met with losses but preserved his integrity, that he was a "great Williamite", and was therefore called in derision "Protestant Dick". [Life and Errors, \&c., pp. 550, 617-r9, \&c.] He was perhaps related to Joseph Wilde of Dublin.

WILDE (w.), printer in London, $1687-96$. A jobbing printer. He was probably the W. W. who, with one J. R., printed in 1687 an edition of Forde's Montelion for Thackeray and Passenger [Bodl. Douce D. 225], as in 1696 his full name is found on the imprints of the same author's Parismus [B.M. 12450. f. 5], and Deloney's Gentle Craft [Bodl. Douce D. 237], and also of the undated fourteenth edition of Deloney's Jack of Newbury, printed for Passinger and Thackeray. [B.M. 1077.g. 35 (r).]

WILFORD (JOHN), bookseller in London, Three Flower de Luces, Little Britain, 1722-32. Perhaps a descendant of George Wilford, bookseller in Little Britain in $165^{2}$; see Dictionary, $1641-67$. Hazlitt mentions one or two books published by him between 1724 and 1727 . He is mentioned in the will of Thomas Norris, the London Bridge bookseller, who died in 1732 . [P.C.C. Bedford, I74.]

WILKIN (RICHARD), bookseller in London, King's Head in St. Paul's Churchyard, 1693-1 720. Referred to by Dunton [p. 234] as a "bookseller of good reputation". He began to publish in 1693 [T.C. II. 475], and from that time until 1720 he published much, chiefly in theology. 
WILKINS (FRANCIS), printer in London, near Fleet Street, 1 700. Only known from the imprint to a broadside, Act anent the Aliment of poor prisoners (October 9th, 1696, Scotland), I 700. [B.M. T. 100* (22I).]

WILKINS (JoHN), bookseller in London, (I) Maiden's Head, New Cheapside, in Moorfields, 1670; (2) Exchange Alley, by the Exchange Coffee House, over against the Royal Exchange, 1672. 1670-72. Publisher in 1670 of a small History of the Administration of Cardinal Ximenes, and in 1672 of Index Biblicus Multijugus, and ed., and George Scortreth's Warning Piece for the Slumbering Virgin. [T.C. I. 56, 122-3.]

WILKINS (JONATHAN), bookseller in London, Star in Cheapside, next Mercers Chappel, 1680-1 703 (?). With Nathaniel Ponder and Samuel Lee he issued a broadside illustrating the mock procession of the Pope, \&c., which paraded the streets of London on November I 7 th, 1680 , in commemoration of the Fire of London. [B.M. C. 20. f. 6 (26).] He was also the publisher of other broadsides. He is perhaps the person referred to by Dunton [p. 292] as "Apprentice Wilkins (commonly called so from his being a good servant and a bad master)."

WILKINS (MATTHEW), printer in Great Milton, Oxfordshire, I7 15 (?). [Allnutt, p. 299.]

WILKINS (RICHARD), bookseller in Limerick, c. 1660-c. I680. In 1686, being then fifty, he was Dunton's landlord at Boston, whither, the latter tells us, he had fled for conscience' sake. He is not included by Dunton in his list of the Boston booksellers, so he had apparently adopted some other trade. [Dunton, pp. I31, I36.]

WILKINS (WILLIAM), printer in London, Little Britain, 1700-51. The favourite printer of the Whig party. He printed The Whitehall Evening Post and several other London newspapers. Gent was employed by him for a time. [Davies, p. 148.] He died in 1751 , and bequeathed a portrait of Dr. Benjamin Hoadly to the Stationers' Company. [Timperley, p. 68o.]

WILKINSON (CHRISTOPHER), bookseller in London, Black-Boy in Fleet Street, 1669-93. Began publishing with T. Basset in 1669, their first entry in the Term Catalogues being Peter Heylyn's Help to English History. [T.C. 1. 24.] Wilkinson became one of the most important publishers in London, issuing books on all subjects. The last entry under his name was in Easter 1693. 
He was succeeded by E. Wilkinson, probably his widow. [T.C. II. 458, 486.] Robert Newberry, Wilkinson's apprentice, being then about thirteen, ran away from him on January 2 nd, $16 \frac{79}{80}$, and was described in an advertisement; he is not otherwise known.

WILKINSON (E.), bookseller in London, Black Boy in Fleet Street, over against St. Dunstan's Church, 1693-6. Successor and probably widow of Christopher Wilkinson. Made a first book entry in the Term Catalogue for Mich. I693, and carried on the business until 1696, when it was taken over by Abel Roper, who had been a partner in the business for some time.

WILKINSON (JAMES), bookseller and printer(?) at Portsmouth, near the [Point] Bridge, I7II-55. Publisher of J. Davis's Seaman's Speculum. [Post Man, March 1oth, 17 $\frac{10}{1} \frac{0}{1}$; T.C. III. 673.] In 1755 Archibald Maxwell's Portsmouth was "printed and sold by W. Horton, J. Wilkinson and R. Carr; but this may mean only that the book was sold by them. [F. A. Edwards, Early Hampshire Printers (Hampshire Field Club Papers, 1891), p. 126.]

WILLIAMS (JOHN), senior, bookseller in London, (I) Crown, St. Paul's Churchyard, 1636-66 ; (2) Blue Anchor in Little Britain, 1667; (3) Crown, Cross Keys Court, Little Britain, I670-6; (4) Crown, St. Paul's Churchyard, 1676-83. 1636-83. See Dictionary, 1641-67. His later career can be traced in the Term Catalogues. [T.C. 1. 27-406.] He died in $168 \frac{2}{3}$, for his will, to which Benjamin Tooke was one of the witnesses, was proved on March 14th. He was succeeded by his son John Williams, junior.

WILLIAMS (JOHN), junior, bookseller in London, ( 1 ) Crown, Cross Keys Court, Little Britain, 1672-4; (2) Crown, St. Paul's Churchyard, 1684. 1672-84. Between 1672 and 1674 he published several books from the house in Little Britain at which his father was in business, but apparentlyon his own account. [T.C. 1. 96, \&c.] In 1684 his name, without the "junior", is found as publishing at the house in St. Paul's Churchyard where his father had latterly published till his death in the previous year. Nothing is known of his career for the intervening decade.

WILLIAMS (JOHN), bookseller in Ruthin, 1699. Sold school-books which he purchased of John Minshull, bookseller of Chester (q.v.). [Library, and ser., IV. $373-83$.

WILLIAMS (T.), printer at Oxford, 1718. Printed a broadside on Edward Biss. [Bodl. Fol. Ө. 662 (9).] 
WILLIAMS (тномAS), bookseller in London, (1) Bible, Little Britain, 1662-70; (2) Golden Ball, Hosier Lane, 1672-5 (-8 ?). 1662-78. See Dictionary, 1641-67. He continued to publish until 1678 . His last and perhaps most substantial publication was Wilson and Bagwell's Complete Christian Dictionary, 1678. [T.C. I. 323.] In 1679 his assigns were Chiswell, Tooke, and Sawbridge. He married the daughter of Richard Cotes, printer; his eldest son Thomas died in 1671. [Smyth, Obituary, pp. 79-91.]

WILLIAMS (w.), bookseller (?) in London, White Swan, Blackfriars, 1677. Published Poetical Piety, apparently his own composition. [T.C. 1. 281-2.]

WILLIAMSON (GAVIN), bookbinder in Edinburgh, 1681. Will registered December 27th, I68r. [Bann. Misc. II. 296 ; Aldis, p. I24.]

WILLIAMSON (JOHN), bookseller in London, (r) Sun and Bible, or Bible, next the Golden Cock, on London Bridge, 1670-8; (2) Cannon Street, 1677. 1670-78. Began to publish in 1670, when he issued Wingate's Arithmetic. [T.C. 1. 60.] He was also the publisher of Hans Bloome's Description of .... Architecture in 1674. [T.C. I. I66.] He was succeeded at the house on London Bridge by Stephen Foster in 1679 . The Cannon Street address appears with the other on one imprint of 1677 . [T.C. I. 279.]

WILLIS (J.), bookseller in London, Three Crowns, Henrietta Street, Covent Garden, r7or. Published The Beau in a Wood, A Satyr. [T.C. III. 245.]

WILLIS (wILlaM), bookbinder in London, King Street, Westminster, 1684. Defendant in a suit for trespass. [C.P.R. Trin. I Jas. II, 3036, m. 346 r.]

WILLSON (H.), bookseller in Boston, Lincolnshire, r72r. [W. C. B.'s list of provincial booksellers in $N$. \& $Q$., roth ser., v. 14I.] See Wilson (Henry).

WILMER (THOMAS), printer in London, I709. Printer of Richard Gibson's almanac, Astrologus Britannicus, I 709, for the Company of Stationers. He also printed in $\mathrm{I}_{7} \mathrm{I}_{4}$ for William Webb, bookseller in Chichester, a sermon by Matthew Woodford. [B.M. 225. h. 3 (1 5).]

WILMOT ( ), printer in London, Fenchurch Street, I 724. Included by Negus among the "well-affected " printers. Possibly identical with William Wilmot, the Dublin printer.

WILMOT (JOHN), senior and junior, booksellers and stationers in Oxford, in St, Mary's parish, near Lincoln College, 1637-1718. See Dictionary, 1641-67. 
This name is found in Oxford at intervals during this period. It must obviously describe two, and possibly three, generations. [Madan, pp. 29-3r.] Wood frequently dealt at the shop, and in 1676 made notes for a catalogue from books bought by Wilmot of a Dr. Lockey. His references to Mr. John Wilmot cover the years 1659-81. [I. 295, IV. 9.] The name is found in the Term Catalogues in $167 \mathrm{r}$ and 1705 . [T.C. r. 79-80, III. 482.] Hearne's "Mr. Wilmot bookseller in Oxford " [vir. 257, \&c.] probably means Samuel, who may have been another son of "old Mr. Wilmot". [VII. 174.]

WILMOT (SAMUEL), bookseller in Oxford and in London (?), I7 55 (?)-33. Hearne has many references to this bookseller. In one of these he notes the prices (some excessive) which Wilmot was asking for secondhand books. [Hearne, v., \&c.] Possibly identical with the Samuel Wilmot who published some sermons in London in 1729.

WILMOT (WILLIAM), printer in Dublin, I724-7. He printed in 1724 two books, two pamphlets against Wood's halfpence, an almanac, and other pieces, and in $\mathrm{r}_{72}$ Whalley's Advice from the Stars, \&c. He died intestate in this year. He may be the - Wilmot whom Negus mentions as printing in London in 1724.

WILSON (GEORGE), printer in Wolverhampton, 1724 (?)-48. His name does not appear till 1744 ; but he may have been the anonymous printer of some tracts by Edward Elwall in $1724-6$, and of advertisements in 1734-6 of an annual Charity Sermon preached at Wolverhampton. He died in 1748 , and was succeeded by his widow Mary Wilson. [Information kindly given by Mr. G. P. Mander.]

WILSON (H.), printer in Maidstone. See Wilson (R.)

WILSON (HENRY), bookseller in Boston, Lincolnshire, r7r9. A Strange and Wonderfull Account of . . . a Fiery Meteor . . seen at . . Boston was printed at Stamford for him. [Bodl. Arch. Bodl. A. II. I52,35.] Presumably identical with $\mathrm{H}$. Willson, r $72 \mathrm{r}$.

WILSON (JOHN), bookbinder in Glasgow, r696-1726. His name occurs as a subscriber of $f_{1} 100$ to the Darien Company in the list published in 1696. [Aldis, p. I24.] John Wilson, bookbinder, is also mentioned in the Records of the Burgh of Glasgow under date February r4th, r726.

WILSON (R.), printer (?) and bookseller at Maidstone, r yor (?)-7. Published the Life of James II, by F. Brettoneau, in 1704, and Gods Providence the 
support of Government, by J. Bernard, Vicar of Ospring in 1707. The "H. Wilson", given by Cotton (2nd ser.) as a printer and bookseller at Maidstone in $r$ gor is probably an error for this R. Wilson.

WINDSOR (JOSIAH), printer in Dublin, r667-9. He printed an Oratio for Peter Butler in 1667 , and a poem in 1669.

WINGFIELD (JOHN), bookseller in London, Crutched Friars, near the Church, I669-7I. Publisher of nautical and mathematical books during these years. [T.C. 1. 19, 80.]

WINTER (JOHN), printer in London, 1668 (?)-72 (?). He was examined in 1668 for printing Roman Catholic books; and he was further prosecuted by the Company of Stationers for working as a printer without licence. His press was thereupon partly demolished. Upon the Queen's intercession it was afterwards returned to him, but in the list of printing houses of 1675 his business was said to have been "bought in by the Company since 1672 ". [S.P.D. Chas. II, 26r (37) ; Records of the Stationers' Company; Haz. I. II4, II. 58r.]

WINTER (WILLIAM), bookseller in Dublin, r682. One of those selling $A$ Judgement of the Comet, $\mathrm{x} 682$.

WITHERS (SAMUEL), bookseller (?) at Coventry, Trinity Churchyard, I694. In the London Gasette of May roth-r4th, I694, is the following advertisement : "In the City of Coventry at the House of Mr. Samuel Withers in or near Trinity Church Yard on Wednesday the 23 rd Inst. will be sold by auction a Catalogue of English Books ... by Joseph Shelton. Catalogues may be had gratis at Bemford's Coffee House in Coventry, and at the place of sale." It seems probable that Samuel Withers was a Coventry bookseller. The auctioneer, Joseph Shelton, was a London bookseller.

WOLLASTON (јонN), bookseller at Bishop's Castle, Salop, r 7 I3. Only known from W. C. B.'s list of provincial booksellers. [N. \& $Q$., roth ser., v. 14r.]

WOOD (THOMAS), printer in Oxford and in London, I 7 I 5-42. [Madan, p. 32.] The Oxford and London imprints with this name seem to refer to the same man. He is probably the T. W. who in 1720 printed in London for a number of booksellers the works of Machiavelli. [Esdaile, p. 264.] Negus enters him as "well-affected"; and Nichols notes that he was the printer of the fifth volume of Thuanus' Historiae for Samuel Buckley in 1733. [Lit. Anecd. II. 26.] He was for a time in partnership with T. Sharpe. 
WOODEN (JOHN), bookseller in Oxford, 1698. [Madan, p. 31.]

WOODFALL (HENRY), printer in London, without Temple Bar, 1724- . Mentioned in Negus's list as " well-affected". Nichols adds this note: "This was the first, I believe, of a name which has now for almost a century been conspicuous in the Annals of Typography. That the more immediate subject of this note was a man of wit and humour, is evident from the famous old ballad of Darby and Joan which he wrote when an apprentice to the printer of that name. At the age of forty he commenced master, at the suggestion, and under the auspices of Mr. Pope, who had distinguished his abilities as a scholar whilst a journeyman in the employment of the then printer to this admired author. Of his personal history I know little farther, except that he carried on a considerable business with reputation; and had two sons, Henry, a printer in Paternoster Row, and George a bookseller at Charing Cross, both of whom I well remember". [Lit. Anecd. I. 300.] Woodfall was apprentice to one John Darby: as he was forty by 1724, this must have been to the elder Darby, who died in 1704 .

WOODWARD ( ), bookbinder in London, c. 1680-95 (?). Dunton [p. 262] tells us that he bound for him, and suggests that he specialized in binding folios; he also says that Woodward was related to one Mitchel, a bookbinder of St. Christopher's Alley, probably J. Mitchell, of Threadneedle Street ( $q . v$.). It may be noticed that James Woodward lived in St. Christopher's Alley rather later.

WOODWARD (JAMES), bookseller in London, (I) (a) St. Christopher's Alley, Threadneedle Street, near St. Christopher's Church, (b) St. Christopher's Churchyard, behind the Royal Exchange, r707-9; (2) Scalding Alley, near the Royal Exchange. 1707-23. First met with in Mich. 1707, when he advertised The Mathematical and Philosophical Works of John Wilkins, Bishop of Chester. [T.C. III. 57I.] In 708 he published Motteux's Rabelais. [T.C. III. 600.] He was still in business in 1723 . [Nichols, Lit. Anecd., I. 256.]

WOOLFE (NICHOLAS), bookseller in London, $(a)$ end of Bread Street in Cheapside, (b) next the Red Lion in Cheapside, 1676-8. In Easter 1676 he advertised Poems, by T. Duffet [T.C. I. 236], and in 1678 New Songs and Poems à la Mode, by P. W. [T.C. I. 303.] His two addresses may well refer to the same house. 
WOTTON (MATTHEw), bookseller in London, (I) Three Pigeons, Fleet Street, 1687; (2) Three Daggers, Fleet Street, 1687-1 725 (?). 1687-1725 (?). This well-known publisher is first met with in Hil. 1687 , when, in company with George Conyers, he advertised Thomas York's Practical Treatise of Arithmetick. [T.C.II. I87.] From that time his output of books increased rapidly. He published law-books, histories, travels, and medical works, and also romances and chap-books, such as The History of the Seven Wise Masters, Greene's Dorastus and Favnia, and A Thousand Notable Things. A list of books printed for him is given at the end of Richard Willis's Sermon before the Lord Mayor, 1702. [Bodl.Sermons 21.] In most of his later publications he only held a share with Chiswell, Tooke, Sawbridge, Conyers, and others. Writing in 1703 Dunton [p. 210] spoke of Wotton as "a very courteous, obliging man. His trade lies much among the lawyers ... I hear he is a rising man". He was still publishing in 1725 , and was succeeded by his son Thomas.

WRIGHT ( ), bookseller in Nantwich, 1699. Sold grammars and books of devotion which he bought wholesale from John Minshull, bookseller of Chester (q. v.). [Library, and ser., Iv. 373-83.]

WRIGHT (JOHN), junior, bookseller in London, ( 1 ) King's Head, Old Bailey, -1667 (?); (2) next door to the Globe in Little Britain, 1667 ; (3) Globe in Little Britain, 1667-77; (4) Crown, Ludgate Hill, 1678-93. 1634-93. See Dictionary, 164I-67. He must surely also be identical with the J. Wright there given as publishing " next door to the Globe in Little Britain" in $166_{7}$. He succeeded his father in $165^{8}$, and carried on and increased a large business. It was mostly in ballad-stock and chap-books, in partnership with Coles, Vere, and others, and he therefore did not use the Term Catalogues much, but made a certain number of entries in them between 1669 and 1693 . [T.C. I. 23, II. 458.] In $\mathrm{r} 68 \mathrm{I}$ he was with Chiswell defendant in an action for debt. [C.P.R. Mich. 33 Chas. II, 2996, m. 260 r.] In the Parish Register of Leeds is recorded the death on March 6th, $167 \frac{5}{6}$ of "Mary daughter of Mr. John Wright bookeseller in London", which may refer either to his sister or daughter. [Thoresby Soc. Publ. x. 160.]

WRIGHT (JOHN), bookseller in Chatham, I 7 II. One of those selling J. Davis's Seaman's Speculum, I7I1. [T.C. III. $672 ;$ Postman, March roth.]

WRIGHT (ONESEPHORUS), bookseller in Kammershmead, in Wales, 1699. 
Sold school-books and psalters which he purchased wholesale of John Minshull, bookseller of Chester (q.v.). [Library, and ser., IV. 373-83.]

WRIGHT (THOMAS), stationer in London, Fore Street, near London Wall, I683-4. He became surety for William Hitch, in the Court of Common Pleas in Hil. 35-36 Chas. II [i. e. I68 3 ]. He is not known to have been a publisher.

WYAT, or WYATT, or WIAT (JOHN), bookseller in London, (r) Golden Lion, St. Paul's Churchyard, 1690-r ; (2) (a) Rose, (b) Rose and Crown, St. Paul's Churchyard, r691-17rr(-20?). I690-1720(?). Publisher for the Nonconformists. Dunton [p. 207] says of him: "Mr. Wiat, if Trim Tram have any truth in it, is an honest and ingenious Bookseller ; but, indeed it is character enough for him, that he was Mr. Robinson's [Robert Robinson's] Apprentice. He prints Mr. Dorrington's Books." In I7I 4 he subscribed for Walker's Sufferings of the Clergy. He used the Term Catalogues fairly regularly.

WYER (ENOCH), bookseller in London, (r) White Hart, St. Paul's Churchyard, 1677-8; (2) Westminster, 1686. 1677-86. Began to publish in 1677 [T.C. I. 274], but he does not seem to have made much use of the Term Catalogues, and his name does not appear in it after Mich. 1678. [T.C. I. 334.] Amongst his publications was a novel called Capello and Bianca, 1677. [T.C. 1. 289.] In some proceedings brought against him in 1686 he is described as of Westminster. [C.P.R. 3052, m. 88.]

YATES ( ), bookseller in London (?), Duck Lane, 1686-1 703 (?). Catalogues of a book-auction held at Grantham by Edward Pawlett (q.v.), in 1686, were to be had of him. Dunton [p. 217] says that Yates had had losses, but was again (in 1703 ) deservedly prosperous.

YEO (CHARLES), bookseller in Exeter, High Street, r682-r 706. First appears as publisher or local agent for the sale of $A$... Relation of . . three witches, viz. Temperance Lloyd . . . convicted at . . Exon, August 14 th, I682. In the previous year he had married Margery Hooper, who survived him. His latest known imprint is of 1704 ; but there is extant a letter of 1706 from $\mathrm{R}$. Clavell to Walker, author of The Sufferings of the Clergy, speaking of Yeo as then very ill. [Walker MSS., Bodl.] He must have died between this date and I709. [Dredge.]

YEO (MARGERY), bookseller in Exeter, over against St. Martin's Lane, in the High Street, 1709-28. Widow and successor of Charles Yeo (q.v.). She is 
first found publishing in partnership with her son Philip in I 709. The last record of her is on April 19th, 1728 . [Dredge.]

YEO (PHIIIP), bookseller in Exeter, against St. Martin's Lane, in the High Street, 1709-16. Son of the preceding. In these years he published a few books from the same house as his mother, at first being in partnership with her.

YOUNG (THOMAS), bookseller in Shaftesbury, 1685. Sued by James Courtney, bookseller, of London, for the balance of his account, $£ 3^{\circ}$ os. 6d. [C.P.R. Hil. I. Jas. II, 304I, m. 272 v.] 


\section{ADDENDA}

ATKINS (GEORGE), bookseller in Chester, 1682. See Atkinson (G.).

BAILEY (THOMAS), printer in Stamford, 17 10-19 (?) and in Bury St. Edmunds, I 716-19 (?). [Allnutt, p. 299.] Probably the printer of the Stamford Mercury ( 7 I5, \&c.) and of the Bury St. Edmunds Mercury (I7I6, \&c.) [Times Tercent. Handlist], and of $A$ strange ... account of . . a fiery Meteor .. at . . Boston, which was printed anonymously at Stamford, and "sold by the printers in Stamford and at their printing office at Bury St. Edmunds in Suffolk". [Bodl. Arch. Bodl. A. II. 152 (35).] His partner was W. Thompson.

BAKER (CHARLES), bookseller in London, c. r690-1 700. Published a ballad, The Seamans Complaint for his Unkind Mistress of Wapping. [B.M. C. 22. f. 6 (175).]

BALDWIN (EDWARD), stationer in London, near Ratcliff Cross, I7I4. Subscribed for Walker's Sufferings of the Clergy.

BENTLEY (к.) A misprint in Etherege's Comical Revenge, 1697. See Bentley (R.)

BISSEL (JAMES), bookseller in London, Bible and Harp, near the Hospital Gate in West Smithfield, c. 1690-1700. Published a ballad, The Victualar's Wifes Kindness. [B.M. C. 22. f. 6 (202).]

BLITHE (JAMES), bookseller in Colchester, I7I4. Successor to Francis Blith. He subscribed for Walker's Sufferings of the Clergy in $17 \mathbf{I} 4$,

BODINGHAM ( ), widow, printer in London, I722. Gent [p. I19] bought a fount of pica from her.

BOUCHIER ( ), bookseller in Peterborough, 1714. Subscribed for Walker's Sufferings of the Clergy in I7I4.

BROWN (JONAH), bookseller in London, I7I4. Subscribed for Walker's Sufferings of the Clergy in I 714 . 
BULLINGER (JоHN), bookseller in London, in Clifford's Inn Lane, 1677. Published A Touchstone for Gold and Silver Wares, by W. B., of London, Goldsmith.

BURGES (EDWARD), bookbinder and bookseller in Canterbury, the Precincts, 1690-1714. He married Mary Page in 1690, and is then described as a bookbinder. In 1700 he was a widower and married Martha King. [Canterbury Marriage Licences, col. 92. Kindly communicated by Dr. F. W. Cock.] He subscribed for Walker's Sufferings of the Clergy in 1714.

CADWELL. See Kadwell.

CAMPBELL (ALEXANDER), printer in Dublin, I 7 18. In that year he was working for Hume. [Gent, p. 82.] Perhaps he never became a master printer.

CLEMENTS (HENRY), booksellers in Oxford and London. See above. These two appear respectively as "senior" and "junior" in the subscription list to Walker's Sufferings of the Clergy, 1714. They were therefore probably father and son.

CONYERS (JOSHUA), see Dictionary, 164I-67. He was at work in 1689. From 1686, and perhaps earlier, he was at the Black Raven, above or near St. Andrew's Church in Holborn, also described as the first shop in Fetter Lane, Holborn. [T.C. II. 178, 269; ballad of Sir Walter Raleigh sailing in the Lowlands, B.M. C. 22. f. 6 (76).]

COOKE (WILLIAM), printer and bookseller in Chester, the Bishop of Canterbury, near the Eastgate, 1718 (?)-25. In 1725 he started The Chester Weekly Journal. [Cooke, p. 31.]

COOPER (EDWARD), book or print seller in London, Three Pigeons, Bedford Street, 1701. With John Smith and David Mortier he published C. Le Brun's Conference . . upon Expression, a book with many plates.

CULLIMORE (LUKE), bookseller in Portsmouth, on the Point, c. 1702-14. Temp. Queen Anne. [N. E。 Q. Ioth S. v. 242.]

DAVIS (s.), printer in Coventry, 1721. [Allnutt, p. 302.]

DENNISSON (c.), bookseller in London, Stationers' Arms within Aldgate. c. I690. A publisher of ballads and chap-books.

EXELL (JOHN), printer in Wotton-under-Edge, 1 704. Cotton, and ser., p. 304. 
FIRDER (william). See Fisher.

FREER (JOHN), bookbinder in London, 1714. Subscribed for Walker's Sufferings of the Clergy in I7I4.

GAMMON (WILliam), bookseller in London, Smithfield, c. 1690-1700. Published a ballad, Newes from More-Lane. [B.M. Rox. III. 212.]

GAYLARD (ROBERT), bookseller in Dorchester, 1714. Subscribed for Walker's Sufferings of the Clergy in $17 \mathrm{I} 4$.

GILBERT (STEPHEN), printer in London, 17 76 . Printed Sternhold and Hopkins for the Company.

GUNNE (RICHARD), bookseller in Dublin, I 714. No doubt the successor of Matthew Gun. He subscribed for Walker's Sufferings of the Clergy in I 714.

GUNSON (GEORGE), bookseller in Dublin, 1715-16. Elizabeth Sadleir printed for him in three years the 4 th and 5 th editions of Puffendorf's Whole Duty of Man.

HAMMOND (THOMAS), bookseller in York, opposite the Market Cross in the Pavement, I719-25. Described as "junior". A Quaker. Joint founder with Grace White of the York Mercury. He apparently wrote the paper; and Gent, who speaks very disparagingly of him, turned him off.

HINTON (THOMAS), junior, bookseller in Tetbury, the Talbot, 1720. He sold E. L. Griffin's Some Copies of Original Instruments and Papers, 1720 , published by his father at Cirencester. [Hyett and Bazely, I. 20.]

HODGSON (JOSEPH), bookseller in Chester, I7II-12. See above. He also published John Cowper's Assize sermon of I 7 I I, presumably in the same year. [Cooke, p. 29.]

HYDE (JoHN), bookseller in Dublin, Dame Street, 17 r9. Published E. Synge's sermon, The Reward of Converting Sinners.

$\mathrm{J}$. (K.), printer in London, $\mathbf{I}$ 702. In that year he printed Sternhold and Hopkins for the Stationers' Company.

KELL (RICHARD). See above. His address, the Blue Anchor, near Pye Corner, occurs on a ballad, The Farmers Reformation. [B.M. C. 22. f. 6 (118).]

KENRICK (WILLIAM), bookseller in London, Black Spread Eagle in the Old Bailey, c. 1690-I 700. Published a ballad, Loves Mistery. [B.M. Rox. III. 254.] 
KENT (E.), printer in Plymouth, in Southside Street, near the New Key, I 7 I (?)-25. Printed The Plymouth Weekly Journal, or General Post (no. 36, August 29th-September 5th, 1718-February 28th, 1725). [Times Handlist.]

LAWRENCE (MARY), bookseller in Dublin, on the Merchants' Quay, near the Old Bridge, I 700 . Aaron Rhames printed a book for her in this year.

MARIET ( ), widow, bookseller in London, r 702. With H. Riboteau, dealt in French books.

MITCHELL (J.). Also a binder. See Woodward ( ).

NEWBERY (ROBERT), bookseller (?) in London, c. 169o (?). See Wilkinson (c.).

OLIVER (E.), bookseller in London, Golden Key on Snow-hill, over against St. Sepulchre's Church, near the Saracen's Head, c. I6go. Dealer in chapbooks and ballads; known from the imprint to a ballad, The Country Miss now come in Fashion. [B.M. C. 22. f. 6 (100).]

PASSINGER (CHARLES), bookseller in London, Seven Stars on London Bridge, I695 (?). Perhaps successor to Thomas Passinger the Second. He published ballads.

READ (G.), printer in Gateshead, I7I3-I4. Printed two sermons in these years, the earlier being without his name. [Welford, p. 24.]

RICHARDSON (SAMUEL), printer in London, I 724 (?)-6I. The famous novelist. His work lies almost entirely outside our period, and he will be dealt with in a future volume. He was at work in 1724 , and was classed by Negus as a " highflier".

SHERMERDINE. See Shelmerdine.

SOWLE (JANE), printer in London, r 706-I 5. See Sowle (T.).

TRACY (H.) and (J.), booksellers in London, 1719-(?). See Tracy (E.).

UNETT (RICHARD), bookseller in Wolverhampton, (?)-r 739. Son of George and Ann Unett, and succeeded his mother. He died in 1739 and was succeeded by his sister Sarah, who carried on the business till 1767 .

WENTBRIDGE (v.), bookseller in London, Duck Lane, c. 169o. Known as publishing a ballad, The Maid's Complaint. [B.M., C. 22. f. 6 (148).] 


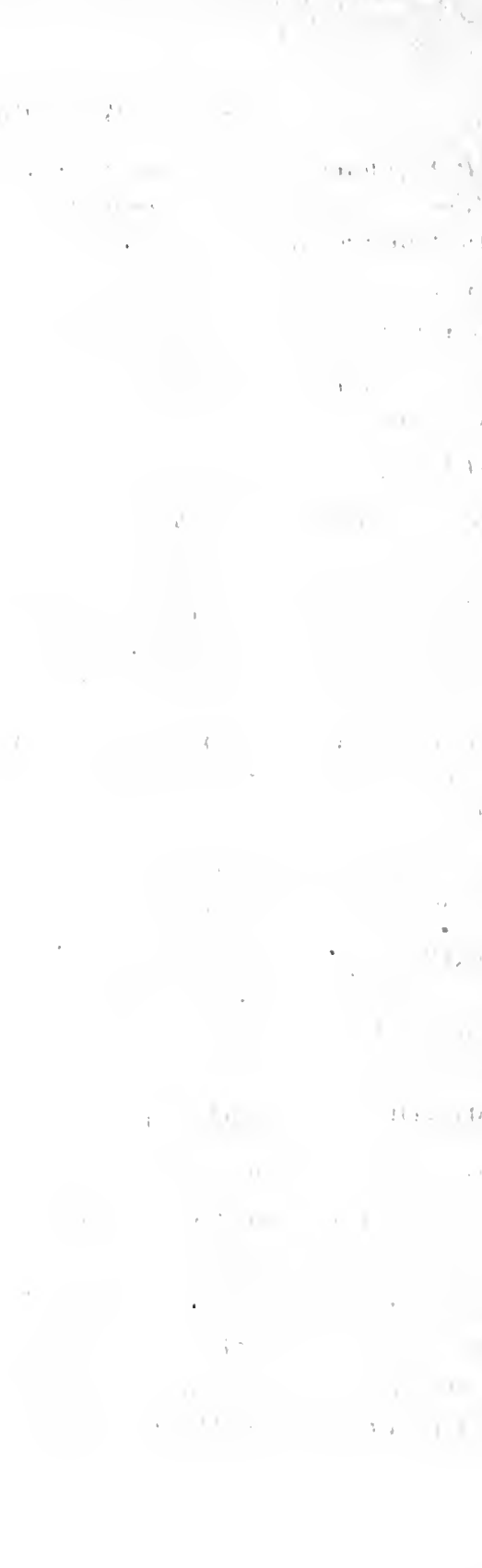


INDEX OF

\section{PLACES OTHER THAN LONDON}




\section{INDEX OF PLACES OTHER THAN LONDON}

For the convenience of users of the Bibliographical Society's Dictionaries I have included in this index the names of all the provincial printers and booksellers given in Mr. Plomer's Dictionary, I64I-I667, except such as were already included in the index to the earlier Dictionary, I557-1640. The index of the latter and the present one taken together should therefore, so far as the provinces are concerned, cover the whole period from 1557 to 1725 . The few men who traded in the provinces before the earlier date may conveniently be found in Mr. Gordon Duff's English Provincial Printers .. to 1557, Cambridge, 1912. Names occurring in the 1641-1667 Dictionary alone, or in the present work merely as cross-references, have been distinguished by an asterisk. The few persons mentioned, for various reasons, in the two Dictionaries as trading abroad have been listed on page 342 ; but it must of course be understood that neither this Dictionary nor Mr. Plomer's earlier one is intended to include foreign printers or publishers of English books as such.

For the sake of brevity many non-significant variations of spelling. such as "Clark or Clarke", have been ignored and only that form given which is placed first in the text. The dates are added merely for convenience of reference. When the period during which a man worked at a particular place is clear from the text I have given this as his date. Otherwise the date is that of his total activity. I have omitted all query-marks as the index is not intended to be used apart from the text of the Dictionary.

R. B. Mck. 


\section{INDEX OF \\ PLACES OTHER THAN LONDON}

A.-ENgland, Scotland, Ireland, and Wales.

ABERDEEN : * J. Brown, 1650-6I ; * J. Forbes, 1656-1704 ; * D. Stranghan, 1659; F. Van Haeghen, 1669; P. Thomson, 1698-9; J. Nicol, 1710-32.

Ashbourne, Derby : R. Hilton, 1688.

ASHBY-DE-LA-ZOUCHE : M. Johnson, 1685-1731.

ASHFord, Kent : Bull, r699.

AYLESBURY : *S. Dagnall, 1650-1 ; M. Dagnall, 1658-1736.

BALA, Wales, Qy. see Bella?

BANBURY : W. Thorp, 1682-95; J. Ball, 1685; G. Thorp, 1703-6.

BANGoR: R. Parry, 1699.

BARNSTAPLE, Devon: J. Conniber, 1682.

BAtH : T. Raw, 1685; J. Hammond, 1695-1719; H. Hammond, 1695-1 721 .

BEAUMARIS: Hughs, 1700 .

BEDFORD: J. Weale, $172 \mathrm{I}$.

Belfast : P. Neill, 1696-1702; J. Blow, 1706-58; R. Gardner, 1713-34.

BeLLA (Bala), Wales: C. Vaughan, 1700.

BIRMINGHAM : *T. Simmons, 1652; M. Johnson, 1685-1731; A. Johnson, 1694-1 702; M. Unwin, 1716-1 7 .

BiSHOP's CASTLE, Salop: J. Wollaston, 1713 .

BLANDFORD, Dorset: W. Newton, 1670 .

Boston, Lincolnshire: G. Barton, 1710 ; H. Wilson, 1719-21.

BRIDGWATER, Somerset : J. Roberts, I698-1 700 ; R. Davis, 1716 . 
BRISTOL: ${ }^{*}$ R. Hassell, $1643 ; *$ W. Ballard, 1651-3; T. Wall, r660-79; *R. Moone, 1661-3; * Teage, 1662-3; *M. Thomas, 1664-7; *S. Moore, 1667 ; C. Allen, 1674-8I ; J. Alexander, 1682 ; J. Ainge, 1693-7 ; W. Bonny, 1695-1714; R. Gravett, 1695-1738; B. Martin, 1697; G. Lewis, I701 ; J. Penn, 1709-22 ; S. Farley, 1712-25; H. Greef, 1715; F. Wall, 1721; W. Corseley, 1721-35.

BURTON-ON-TrENT: W. Bailey, 1685.

Bury St. Edmunds : T. Simmons or Symonds, 1676-8; J. Marston, 1683 ; J. Chamberlain, 1685-90 ; R. Watson, sen. \& jun., 1686-1 714 ; T. Bailey, I716-19 (see add.); W. Thompson, I719.

CAMbridge: T. Atkinson, c. 1626-75; W. Graves, sen., 1631-65; *W. Armstrong, 1647 ; * B. Ridley, 1647 ; * N. Smith, 1647 ; * A. Nicholson, 1648-52; W. Morden, I652-79; E. Story, 1653-74; *W. Nealand, I655-60; * J. Field, I655-68; E. Beeching, 1655-89; R. Nicholson, 1662-89; J. Greaves, 1663 ; J. Pindar, 1663-1703 ; A. Nicholson, 166780 ; R. Brown, 1667-81 ; J. Hayes, 1669-1705 ; S. Simpson, 1670-1 702 ; J. Creed, $1670-85$; H. Dickinson, 1672-94 ; J. Hart, 1674-82 ; R. Gee, 1675-81; W. Atkinson, 1675-94; T. Dawson, 1675-95; C. Morden, 1678-89; T. Bentley, 1679; A. Atkinson, 1680; W. Graves, jun., 1680-93; J. Pindar, 1680-98; R. Green, 1682-94 ; F. Hicks, 1682-99 ; G. Graves, 1684-1 725 ; E. Millington, 1686-1703 ; E. Hall, 1688-1703 ; W. Bertram, 1693; T. Tillet, 1695-1702 ; T. Dawson, 1695-1706; C. Crownfield, 1698-1743; M. Hicks, 1699; W. Dickinson, 1699-1718 ; E. Jeffery, 1699-1729; J. Pindar, 1699-1730; J. Owen, 1701-10; T. Webster, 1701-22 ; E. Dawson, 1706-28; W. Smith, 1706-31 ; R. Chapman, I7II; R. Thurlburn, I707-24; W. Thurlburn, 1724-68.

CANTERBURY: R. Fenner I, I663-17II; R. Fenner II, 168I-I7II; E. Burges, 1690-1714 (see add.); E. Fenner, 1703-29; T. Reeve 1717; J. Abree, 1717-68.

CARLISLE : * R. Scott, 1656-9.

Chatham : Mrs. Brissenden, 1699; J. Wright, 1711.

Chelmsford, Essex : R. Deane, 1686.

Chesham, Bucks. : S. Dagnel, 1720. 
Cilester : * W. Minshew, 1655; * W. Thorpe, 1664; * P. Bodvell or Bodrell, 1666-70; J. Minshull, I674-1712; G. Atkinson, I682 ; G. Atkins, r682 (see add.); H. Page, I685-I7II ; T. Tillier, I688; J. Hodgson, I 7 I I-I 2 (see also add.); R. Minshull, I712; E. Ince, I712-18; J. Holland, I 714 ; W. Cooke, I718-25 (see also add.); R. Adams, 1730-3.

Chesterfield : J. Bradley, 1725-98.

Chrchester : E. Janeway, I697; W. Webb, r700-r4.

Chippenham : R. Warne, r707-14.

Cirencester : J. Barksdale, I678-98; T. Hinton, 1718-24; J. Ballinger, I 723-42.

Colchester : *W. Hall, 1663; *W. Warwick, I663; F. Blith, I 702-II ; J. Blithe, 1714 (see add.).

CoRk : *P. de Pienne, r649; *W. Smith, r657-90; J. Brent, I691 ; G. Bennett, I714-34; T. Cotton, I 715；J. Redwood, I 715-23；A. Welsh, I 715-25; S. Terry, I721-2.

CoVEnTRY : J. Brooke, I67I ; J. Smith, I683; S. Withers, 1694; G. Ratten, r701 ; T. Hart or Hurt, I702-20; W. Ratten, 1716; S. Davis, r72I (see add.).

CranbrooK, Kent : Munns, I699.

DARTFORD : Loveday, I699.

DEAL, Kent : Mrs. Small, r 7 r.

DENBIGH : T. Davis, I699.

DERBY : J. Thorton, I675; T. Cadwell, r685: H. Nisbett, I704-I I ; J. Hodges, I7I6; W. Cantrel, I718-27; S. Hodgkinson, 1719-27; H. Allestree, I719-32; J. Roe, I725.

Devizes : J. Hammond, r695-1719; H. Hammond, I695-1721.

DONCASTER : T. Rainy, 1693 .

DORCHESTER : W. Churchill, I659-88 ; J. Churchill, I688-1 728 ; R. Gaylard, I7I 4 (see add.).

DOVER : * R. Barley, 1654 ; *S. York, 1654. 
Dublin: *R. Hughes, I648-51; * J. Crooke, I660-9; *S. Dancer, 1662-8; * J. Leach, 1666; N. Thompson, 1666-88; J. Windsor, 1667-9; B. Tooke, 1669-85; M. Crook, 1671-84; J. Wilde, $1672-83$; J. Ray, I676-r 708; J. Crook, 1679-84; S. Helsham, r68I-9; A. Crook, r68II731; J. North, 1682; W. Winter, I682; R. Thornton, 1682-1 701 ; W. Norman, 1682-1703; E. Dobson, sen., r682-1720; P. Campbell, 1687-1720; E. Jones, I690; J. Brent, I691-I 700 ; J. Milner, I692-I 701 ; S. Lee, 1693-5; R. Wilde, 1694-5, I698; M. Gun, I694-1710; J. Brocas, 1696-1707; C. Carter, 1696-1 727 ; S. Powell, 1697-1 724 ; M. Lawrence, I700 (see add.); J. Whalley or Whaley, 1700-24; A. Rhames, 1700-34; J. Forster, 1704-5; E. Sandys, 1705-18 ; F. Dickson, 1707-14 ; E. Ray, I708-13 ; E. Waters, 1 708-36; T. Servant, 1709 ; G. Grierson, 1709-33; J. Pepyat, I7II-I5; S. Sadleir, I712-14; J. Carson, I713-59; R. Gunne, 1714 (see add.) ; D. Thompson, 1714-15 ; S. Fairbrother, 1714-34 ; A. Meres, 1715; G. Gunson, 1715-16 (see add.); E. Sadleir, 1715-22; T. Hume or Humes, $1715^{-28}$; A. Campbell, 1718 (see add.); S. Needham, I718-25; J. Hyde, I 719 (see add.) ; E. Dobson, jun., 1 720 ; J. Harding, I721-4; W. Helme, I72I-4; P. Rider, I724-5; T. Harbin, I724-6; W. Wilmot, $1724-7$.

DUMBARTON: J. Love, 1695-1725.

DUMFRIES : P. Rae, I715-20.

DuRham : *W. Hutchinson, 1655 ; H. Hutchinson, $1665-84$; Ashworth, 1696; Freeman, 1713-19.

EdINBURGH : * J. Harrower, 1600-54; *Widow Hart, 1621-42; E. Tyler, 1633-72; *A. Wilson, 1641-54; *P. Wilson, 1643; * J. Lindesay, 1643-9; * T. Lawson, 1645; * G. Lithgow, 1645-62;* Heirs of R. Bryson, 1646; * J. Gray, 1647; * Heirs of G. Anderson, 1649-53; G. Swintoun, $1649-83$; * R. Brown, $1649-85$; *D. Mond, c. 1650; *Company of Stationers, $165^{\circ}$; * J. Hill, 1652; A. Anderson, 1653-7, 166I76 ; *C. Higgins, 1655-60; * J. Glen, 1656-87; P. Ramsay, c. 1660-80; * Society of Stationers, 1660-90; *W. Paterson, 1662; *D. Trench, 166271 ; * J. Miller, 1665-72 ; G. Mosman, 1669-1707; I. B., 1670; W. Brisbane, 1670 ; J. Simpson, 1670 ; A. Weir, 1670; A. Hislop, 1670-8 ; G. Shaw, $1670-87$; J. Menson, 1671 ; A. Anderson and partners, $1671-5$; 
J. Cairns, 1671-80; T. Brown, 1671-99 (-1722 ?); J. Mason, I672; J. Miller, c. 1674; J. Monteath, c. 1674; J. Swintoun, 1675-81 ; J. Anderson, $1676-$; J. Bell, 1676 ; J. Calderwood, 1676-82 ; Heir of A. Anderson, 1676-94; Mrs. Anderson, 1676-1717; H. Leslie, r677; G. Lesly, 1678 ; C. Lumisden or Lumsdean, 1678-90; J. Anderson, c. I679; W. Carron, 1680; J. Colmar, r680-5; J. van Solingen, I680-5; Heirs of A. Anderson, 1680-1700; J. Reid I, 1680-1716; J. Alexander, I681 ; Relict of A. Anderson, 168I ; J. Weir, I68I ; C. Williamson, I68I ; D. Lindsay, 168r-5; W. Pope, 1683; J. Kniblo, 1683-4 ; W. Auld, r684 ; A. Dumbar or Dunbar, 1684; J. Mein, 1684-6; L. Gunter, 1685; J. Watson, sen., I685-7; A. Ogston, 1685-8; T. Noble, I686; W. Johnston, I686-8 ; W. Aitken, 1687; R. Bowter (=Boulter ?) I687; P. Bruce I687-8 ; J. Warner, 1688-9 ; A. Chalmers, 1688-91 ; M. Ogston, afterward Stevenson, 1688-1738; J. Wardlaw, 1691-1701; J. Vallange or Vallance, I691-I713; J. Machie, 1691-1722; J. Johnston, -1692;A. Henderson, 1692-1709; Successors of A. Anderson, 1693-1722; Heirs and Successors of A. Anderson, 1694-1717 ; W. Jaffray, 1695; R. Allan, 1695-6 ; T. Carruthers, I695-1700 ; J. Watson, jun., 1695-1722 ; Mrs. Beiglie, 1696 ; R. Hutchinson, 1696; G. Jaffray, 1696-1 710 ; H. Knox, 1696-1716; J. Porteous, 1699; A. Symson, 1699-1706; J. Reid II, 1699-1712; J. Crossby, I700; R. Freebairn, 1705-37;A. Banks, 1706; J. Spottiswood, I 706 ; J. Moncur, 1 709-12 ; J. Baskett, 17 I I-42 ; J. Park, 1712；J. Ogston, c. 1714；M. Reid, 1714-16; R. Brown, 1714-18; J. Reid III, I7I4-2I ; W. Brown, I7I4-3I; T. Ruddiman, I7I5-57; W. Ruddiman, I7I5-70; G. Stewart, I716-34; J. Paton, 1716-54;A. Ramsey, I716-58 ; W. Adams, I717-25; J. Mosman, 1717-30; J. Martin, 1718-24; J. McEuen, I718-32; T. Lumisden, 1723-48; J. Davidson, I724-64 ; R. Fleming, I724-78 ; J. Robertson,1725-48.

ETON : J. Slater or Slatter, I696-1709.

Evesham : H. Keat, 1678 ; Loveday, 1714.

EXETER: A. Brocas, I655-74; M. Hide, I663-98; W. Dight, 1667-93; R. Eveleigh, I668-81 ; G. May, r680-6 ; J. Phillips, I681 ; E. Potbury, I68I ; J. Cowsey, 1682 ; C. Yeo, 1682-r 706 ; J. B., I688; J. Hooker, 1688; P. Bishop, 1688-1716 ; R. Osborn, 1693-6 ; J. Pearce, 1697-8 ; S. Darker, I698-1700; S. Farley, I699-1727; E. Score, 1704-24; 
J. Bliss, I705-19; P. Yeo, 1709-16; M. Yeo, 1709-28 ; J. March, I 713-26;

T. Butter, I $7 \mathrm{I}_{4-20}$; A. Brice, $17 \mathrm{I}_{4}-73$; M. Bishop, 1717 ; N. Thorn, 1717-71 ; G. Bishop, 1718-20; J. Pring, 1723-30.

Faversham, Kent : Preston, r699.

Flint : Mrs. Powell, r 700.

Gateshead : *T. Rowlandson, c. r664; J. Saywell, r7ro; E. Read, x7 13-14 (see add.).

Glasgow : * J. Sanders, $1625-42$; * J. Neill, r642-5 ; *Heirs of G. Anderson, I648;* R. Sandersonne, I654; A. Anderson, 1657-6r ; * J. Falconer, I659-62 ; * J. Morison, I659-62;* M. Paterson, I659-62; R. Sanders, r66I-96; R. Stewart, r662-76; J: Brown, I662-85; J. Galt, r675; J. Andrew, I676; G. Brown, 1676; J. Reid, 1676; J. Scott, 1676; J. Dunlop, I676-83; A. Cunyngham, -r681; A. Hepburn, I689; W. Dickie, 1695-7; J. Wilson, I696-1726; A. McLean, "1 706"; H. Brown, I712-30; J. Hart, $x_{7} \mathrm{I}_{4} ;$ D. Govan, I7 $15-19 ;$ J. Duncan, $17 \mathrm{I}_{7}-c .1750 ;$ W. Duncan, $1717-c .1760$; A. Mathie, 1718 ; T. Crawfurd, 1721 .

Gloucester : *T. Jordan, I644-64; *T. Langford, I646; S. Palmer, r685 ;

G. Harris, I702-22; R. Raikes, 1722-57.

GosPort : J. Philpot, I 708-36.

GranthaM : E. Pawlett, I686.

Gravesend : Mrs. Appleby, r 7 Ir.

Great Marlow : Robinson, I 7 Ir.

Great Milton, Oxfordshire: M. Wilkins, I 7 I5.

GREAT YARMOUTH : see Yarmouth.

HALIFAX : F. Bentley, r695.

Hallaton, Leicestershire : Harper, r687.

Hamstall Ridware, see Ridware Hamstall.

HARBOROUGH, see Market Harborough.

HEREFORD : T. Hancox, I674 : R. Hunt, r685: J. Wilde, I7 14 ; W. Parks, I 721 .

HoRsham: W. Browne, 17 I2. 
HULL: T. Ryles, 1707-16; G. Ferraby, 1718-25.

IPSWICH: *W. Weekly, I657-9.

KANNERShMEAD (?), Wales: M. Ovens, r699; O. Wright, I699.

KENDAL : *M. Harrison, 1660 .

KETTERING : T. Ratten, 1685.

KIDDERMINSTER : *N. Simmons, 1655-81.

KILKENNY : *T. Bourke, I645-48; *W. Smith, 1649 .

KInGSTON-UPON-Hull : T. Clarke, 1675-88; Clark, r68I-91.

KIRKBRIDE, Cumberland: P. Rae, $17 x \mathrm{I}-\mathrm{I}_{4}$.

KNUTSFORD: P. Swinton, I684.

LAUNCESTON : B. Smithurst, 1693-1700.

LEEDS: J. Richardson, 1700-5; J. Penrose, I712; J. Swale, 1713; J. Hirst, 1718-30.

LEICESTER: * F. Ward, I66I-3; *S. Lincoln, 1663; W. Atkins, I684; S. Martin, 1705-13; J. Ward, I711-19; M. Unwin, 1741.

LEICESTERSHIRE : Hartshom, I 7 I4.

LEIGHTON BUZZARD : M. Dagnall, 1658-1736.

LEITH : E. Tyler, 1651-2 ; ${ }^{*}$ C. Higgins, 1652-54.

LiCHFIELD : E. Milward, 1680 ; W. Bailey, I685; M. Johnson, I685-1731 ;

A. Johnson, 1694-1702.

LIMERICK : R. Wilkins, c. I660-c. 1680; L. Bixou, alias Tabb, 1722-3; S. Terry, I722-5.

LINCOLN : J. Lawson, 168ז-9; J. Knight, I696-1716.

LIVERPOoL: Tomlinson, I685; J. Eaton, I710; S. Terry, I712-20; D. Birchall, 1712-22.

LudLow: E. Robinson, 1678-1710; W. Parks, 1719-20.

LUTTERWORTH : T. Ratten, 1685 .

MACCLESFIELD: J. Rathbone, 1723.

MAIDSTONE : Weeks, I699; H. Wilson, x701; R. Wilson, r701-7; J. Watson, I725. 
MANCHESTER : * B. Hayward, I643; *T. Smith, 1643-9; R. Shelmerdine, r66I-73; A. Holland, $1673-90$; R. Hilton, I678-8I ; M. Moxon, I679-93; Z. Whitworth, 1690-7 ; T. Hird, -1692 ; J. Greenwood, I693 ; E. Johnson or Johnston, I694-1701 ; A. Unsworth, I696; E. Johnstone, 1697-8; J. Whitworth, I697-I727; W. Clayton, I700-I9; R. Adams, I719-33.

MANSFIELd, Notts : C. Ellis, I690; J. Thompson, I703.

MARKET HARBoROUgh, Leicestershire: W. Tomson or Thompson, $1655^{-69}$; T. Ratten, I685; C. Ratten, I708-I6.

MARLBOROUGH : J. Buckridge, I704.

MARLOW, see Great Marlow.

Melton (i. e. Melton Mowbray) : Carver, I720.

MidhuRst, Sussex : J. Colebrooke, I jo0; J. Jaques, I712.

MiLton, Kent : Kadwell, I699.

MiLton, Oxfordshire, see Great Milton.

MITTON-ERNis, near Bedford: U. Robinson, I719.

MOLD : S. Lloyd, 1699.

NANTwich : M. Thurston, I682-8; J. Thurston or Thourston, r684; H. Page, I685-I7II ; Wright, I699; A. Stone, I699-I 7 IO.

NEWARK : J. Mortlock, I695; B. Farnworth, 1715-19.

NEWCASTLE-UNDER-LyME : P. Gillworth, $\mathbf{1 6 8 4}$.

NewCAStle-UPon-TyNe: * J. Chantler, 1653-8; *W. London, I653-60; M. Durram or Durham, I675 ; T. Clarke, I675-88 ; P. Maplesden, I676-89;

R. Randall, $1676-1714$; J. Hall, $1683-99$; J. Story, $1685-6$; S. Burton

or Button, I700-4; J. Button, I704-I4; J. White, I708-69; T. Goolding, 1715 ; M. Bryson, c. 1722-55; Shaw, 1723 .

NEWPORT, Isle of Wight: Keblewhite, I703.

NEWPORT, Shropshire : J. Felton, 1679-80.

Northampton : T. Collins, 1651 ; W. Cockram, r675-7; R. Chown, r684; Parsham, I704; J. Fowler, I7I4-19; W. Dicey, I719; Fowler, I719; R. Raikes, I720-22; J. Pasham, I72I. 
NoRwICH : * E. Martin, I646; *W. Franklin or Franckling, 1646-55;*W. Nowell, 1660-1 ; W. Oliver, I663-89 ; G. Rose, 1675-86 ; E. Giles, 16781703; F. Collins, 1682-1 713; E. Oliver, 1689-1 704; S. Oliver, 1692-3; S. Selfe, r 701-4; F. Burges, 1 701-6; R. Allen, 1 702; T. Goddard, 1 703-19; F. Oliver, 1704-12 ; S. Sheffield, 1706; S. Hasbert, 1706-18; H. Crossgrove, I 706-44; Mrs. L. Reeve, 1707 ; Mrs. Oliver, 1711-25;W. Chase, 1711-27; T. Chapman, 1722.

NotTingham : S. Richards, 1669-1 703; J. Howe, I689; J. Mortlock, I695 ; J. Richards, 1698-1 703 ; G. Sulley, I 703 ; H. Richards, 1703-4 ; W. Ayscough, 1710-19; W. Ward, 1710-38; J. Collier, I 711-25.

OxForD : * J. Adams, I6ro-71 ; J. Godwin, 1637-73; J. Wilmot, sr. and jr., I637-I 718 ; *T. Robinson, I640-63 ; R. Davis, I646-88 ; * E. Benington, I647; * H. Hills, 1647; * J. Harris, 1647-69; G. West, c. 1650-1707; * Alice Curteyne, I651 ; * E. Thorn, $1652-63$; * R. Blagrave, 1656-62 ; * W. Hall, 1656-72 ; * A. Lichfield, 1657-69; L. Lichfield II, 1657-86; * J. Forrest, 1660-69; R. Royston, 1660-86; *S. Pocock, I662; T. Bowman, I664-78; * J. Crosley, I664-1703; * R. Gascoigne, I665; W. Nott, 1665; F. Oxlad, sen., 1665-73; Amos Curteyne, 1665-90; * F. Oxlad, jr., 1667 ; T. Gilbert, 1669-77; J. Hall, 1670-1707 ; J. Adams, I673; W. Downing, I673; Gallot, 1673; R. Bartlet, 1674-82 ; J. Colley, 1676 ; T. Bartlett, 1677 ; Waver, 1677 ; T. Guy, c. 1679; R. Beckford, 1680 ; M. Pitt, 1680-82 ; Beckford, 1681 ; T. Dymock, 1681 ; T. Fickus, r68I-4; J. Good, 168I-5; F. Dollif, 168I-90; H. Cruttenden, 168I-94; J. Lichfield, 1682-4 ; J. Fickus, 1682-6 ; E. Davies, 1683 ; E. Duffield, I683; A. Pendlebury, I684; R. Sherlock, I684; T. Tailer, I684-9I ; H. Clements, 1684-1 721 ; A. Stephens, 1685 ; N. Cox, 1685-8 ; W. Hart, I686; J. Howell, I686-99; O. Walker, I687-8; T. Bennet, I687-1 706 ; L. Lichfield III, 1687-I 749 ; A. Peisley or Piesley, 1692-1 724 ; R. Elliott, 1693-6 ; T. Corbet, 1694; J. Goodwin, 1694; E. Bush, 1696-1 705 ; E. Skinner, 1697 ; M. Howell, I698; J. Wooden, I698; J. Owen, I 701-10 ; J. Jones, 1 702-25 ; J. Stephens, I 704-9; J. Baskett, 1 709-42 ; E. Whistler, 1710-22; J. Rance, 1712-19; J. Clarke, I 714; S. Kibblewhite, 1714-23; S. Fletcher, I714-27; S. Wilmot, I715-33; T. Wood, 1715-42; S. Richardson, 1715-55; Fyndal, 1716; T. Williams, 1718; W. Wells, 1 719-32 ; C. Combes, sen., 1720-8; R. Clements, 1 725 ; C. Combes, jr., $1728-36$. 
Peterborough : A. Atkinson, I680; Bouchier, I 744 (see add.).

Plymouth : D. Jourdaine, 1696; B. Smithurst, I714; E. Kent, 1717-25 (see add.).

PoRTSMouth : R. Harford or Hartford, 1675-95; Mrs. Harford, 1695-1710;

L. Cullimore, c. 1702-I4 (see add.) ; E. Newton, I708; J. Wilkinson, 1711$55 ;$ H. Grove, I7I8.

Preston, Lancashire : P. Burton, 1678 .

PutNey : J. Seymour, I669-77.

READING : D. Kinneir, r723; W. Parks, I723; W. Carnan, I723-37.

RIDWARE HaMstall, Staffordshire: R. Unett, I68I.

Ruthin, Flint : J. Williams, 1699.

ST. Albans : * R. Williains, I649-56.

ST. ANDREws : * J. Drennane, I645; * G. Dradoun, I654.

ST. ASAPH : H. Thomas, 1699.

ST. IvES, Huntingdonshire: J. Fisher, I716-18; R. Raikes, I718-20; W. Dicey, 17 19.

SAlisbury : J. Courtney, I650-75; Pope, I715; Cortney, I7I6.

SANDWICH, Kent : Does, 1699.

Scotland (town unknown): A. Kennedy, r68I.

SevenoAKs : Mrs. Allen, I699.

Shaftesbury : J. Pike, 1675; T. Young, 1685. See Shafton.

Shafton (i. e. Shaftesbury ?), Dorset : R. Clarke, I 799.

SHEFFIELD : N. Simmons, I697-1702; J. Turner, I 70I-I 5.

SHERBORNE : J. Miller, I69I-I709; J. Cook, I713-16.

SHREwSBURY : *Watkis, I663; G. Rogers, I695; T. Jones, 1696-1713; J. Rogers, I708-13; T. Durston, 1714; T. Gittins, I715-16.

SOUTHWARK : T. Alldridge, 1697 .

StAFFord : * J. Felton, 1658 ; J. Walthoe, 1683-1733; R. Southall, 1722.

STAMroRd, Lincolnshire : Caldecot, I690; E. Palmer, I706; T. Bailey, I7roI9 (see add.); W. Thompson, I 7 I7. 
StOURBRIDGE, Worcester : * J. Malpas, 1661.

STRATFORD-ON-AVON : W. Keate, r68I-2.

STROUD : S. Went, 1722.

SUDBURY, Suffolk : J. Marston, 1685.

TAMwORTH, Stafford: W. Bailey, 1685 .

Taunton : *G. Treagle, I646-53; * E. Rosseter, 1658 ; H. Chauklin or Chalkin, 1695-1701; W. Norris, 1718.

Tenterden, Kent : Furby, 1699.

TETBURY, Gloucester: T. Hinton, 1720.

Tewkesbury : S. Palmer, 1685.

Trverton, Devon : H. Burton, r696-r701.

TOTNES, Devon : * Teage, r662-3.

UTTOXETER, Stafford : M. Johnson, 1685-173I.

WAKEFIELD : A. Barber, I700-3 ; J. Richardson, 1700-5.

WARMINSTER, Wilts. : W. Longford, I694.

WARRIngton : * P. Milner, c. I641 ; * J. Tonge, c. I653; Tomlinson, I685; H. Eires, I 704-I2.

WARWICK : G. Tonge, I682.

WATERFord : *T. Bourke, I643-5; * P. de Pienne, r652.

Whrtchurch, Salop : Taylor, r 700-r9.

WinchсомвE, Glos. : * N. Hyett, 1653 .

Winchester: * Taylor, I663; W. Clark, I684-8; W. Colson, I705; J. I. Philpot, I725-32.

WOLVERHAMPTON : W. Bailey, I685; R. Grosvenor, 1685-9I ; T. Unett, I69rI 714 ; Ann Unett, I7I4; G. Wilson, 1724-48; R. Unett, -I 739 (see add.). Worcester : *F. Ash, I644-51 ; F. Rea, 1651-85 ; * Jones, I663; S. Evans, I674-91 ; J. Philips, I685; J. Mountford, I690-1710 ; J. Jones, I698 ; J. Butler, I702-8; S. Bryan, I706-48. 
Wotron-UNDER-EDGE : J. Exell, I704 (see add.) ; J. Bence, (? date).

WREXHAM, Denbigh : H. Fisher, I 700 .

YARMouth : * J. Tuthill, I66I ; J. Tuthill, 1678; O. Peartree, I 703-6.

YEOVIL : J. Miller, I697.

YoRk : * M. Foster, I642; *T. Broad, I644-6o;* R. Brocklebank, I647; *T. Wayte, I653-95; * R. Foster, I659; *A. Broad, 1660-67; R. Lambert, 1660-86 ; * L. Campleshon, 166r; * F. Mawborne, 1662-6; R. Ashburn, 1676; J. White, 1680-1716; F. Hildyard, or Hilliard, 1680-I 73I ; Clark, I68I-91 ; C. Welburn, I69I ; T. Baxter, I697 ; R. Manklin, I697I725; J. Jackson, I707; T. Gent, I710-78; G. White, 1716-21; T. Hammond, I719-25 (see add.); C. Bourne, I72I-4; R. Ward, I 725 ; J. White, I725-35.

B.-FOREIGN.

AMSterdaM : * J. Crosse, 1646 ; M. Browning, 1675-87.

Hague, The : * S. Browne, I643-I660; * J. Ramzey, I659.

St. OMer (?) : T. Hales, 1696. 

Uriversily of Cultomia FACIUTY

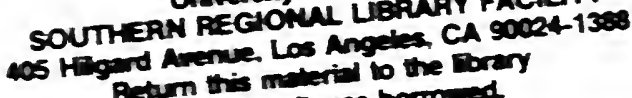

Return this mich borrowed.

B OCT17 199 


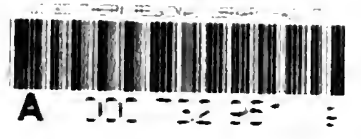

\section{For Reference}

Not to be taken from this row 


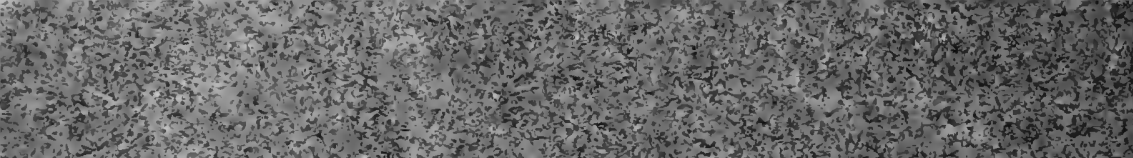
간.

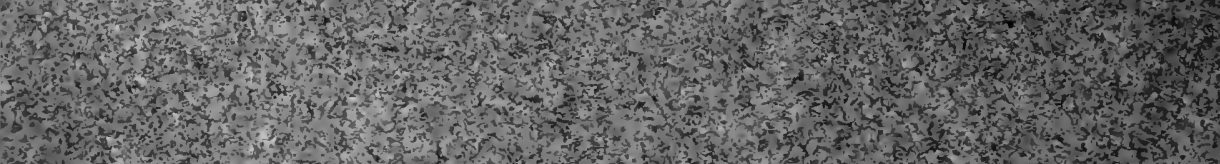

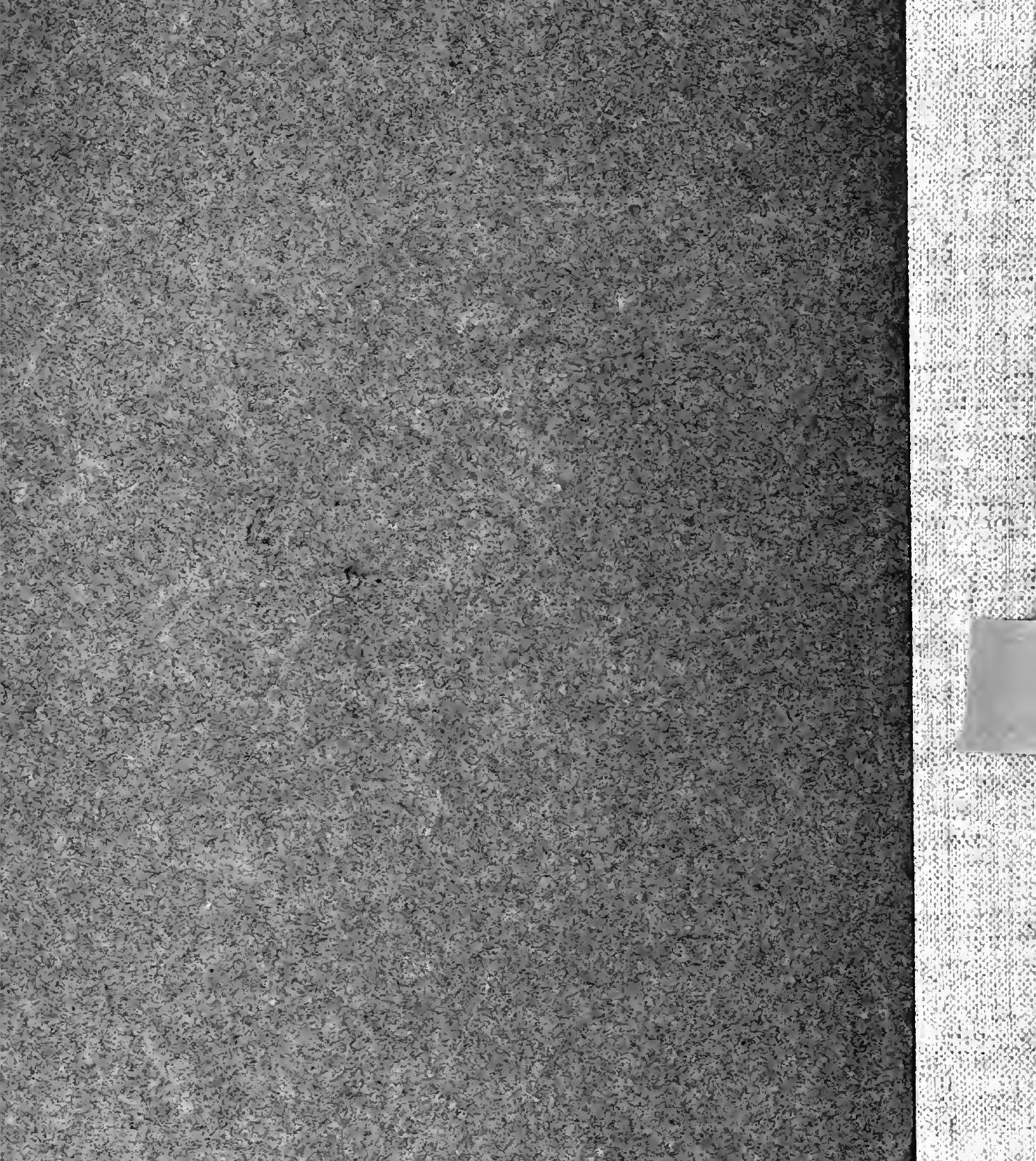

